UNIVERSIDADE DE SÃO PAULO

FACULDADE DE ECONOMIA, ADMINISTRAÇÃO E CONTABILIDADE DE RIBEIRÃO PRETO DEPARTAMENTO DE ADMINISTRAÇÃO

PROGRAMA DE PÓS-GRADUAÇÃO EM ADMINISTRAÇÃO DE ORGANIZAÇÕES

\author{
JONAS FERREIRA
}

Boas práticas administrativo-pedagógicas que colaboram para o desempenho dos alunos de escolas municipais do ensino fundamental do estado de São Paulo no IDEB

ORIENTADOR: PROF. DR. ALEXANDRE PEREIRA SALGADO JUNIOR 
Prof. Dr. Marco Antônio Zago

Reitor da Universidade de São Paulo

Prof. Dr. Dante Pinheiro Martinelli

Diretor da Faculdade de Economia, Administração e Contabilidade de Ribeirão Preto

Profa. Dra. Sonia Valle Walter Borges de Oliveira

Chefe do Departamento de Administração 


\section{JONAS FERREIRA}

Boas práticas administrativo-pedagógicas que colaboram para o desempenho dos alunos de escolas municipais do ensino fundamental do estado de São Paulo no IDEB

Dissertação apresentada ao Programa de PósGraduação em Administração de Organizações da Faculdade de Economia, Administração e Contabilidade de Ribeirão Preto da Universidade de São Paulo, para obtenção do título de Mestre em Ciências. Versão Corrigida. A original encontra-se disponível na FEA-RP/USP.

ORIENTADOR: PROF. DR. ALEXANDRE PEREIRA SALGADO JUNIOR

RIBEIRÃO PRETO 
Autorizo a reprodução e divulgação total ou parcial deste trabalho, por qualquer meio convencional ou eletrônico, para fins de estudo e pesquisa, desde que citada a fonte.

\section{FICHA CATALOGRÁFICA}

Ferreira, Jonas

Boas práticas administrativo-pedagógicas que colaboram para o desempenho dos alunos de escolas municipais do ensino fundamental do estado de São Paulo no IDEB.

394 p. : il. ; $30 \mathrm{~cm}$.

Dissertação de Mestrado, apresentada à Faculdade de Economia, Administração e Contabilidade de Ribeirão Preto/USP - Área de concentração: Pesquisa Operacional

Orientador: Salgado Junior, Alexandre Pereira

1. Ensino Fundamental. 2. Gestão Escolar. 3. IDEB. 4. Investimento em Educação. 5. Análise Envoltória de Dados (DEA) 


\section{DEDICATÓRIA}

À minha esposa Giovana, ao meu filho Vitor e a toda minha família, de modo especial ao meu avô Lauro e à minha avó Dirce. 


\section{AGRADECIMENTOS}

Gostaria de agradecer primeiramente a Deus pelo dom da vida e por ter me dado força e coragem para seguir em frente nos momentos de dificuldades com a esperança de que no final daria tudo certo.

Ao meu orientador Prof. Dr. Alexandre Pereira Salgado Junior, que me orientou ao longo destes anos com muito respeito e profissionalismo, contribuindo significativamente para o meu desenvolvimento acadêmico.

À minha amada esposa Giovana, pelo apoio nos momentos difíceis, pela compreensão nas ausências, pelo incentivo na busca de meus objetivos e por todo amor dedicado a mim e ao nosso filho Vitor.

A todos os integrantes do GREFIC, pelas contribuições durante a realização deste trabalho, de modo especial aos integrantes do grupo de estudos em educação: Eduardo Regalo, Felipe Soriano, Ornella Pacifico e Maurilio Benite.

À Prof ${ }^{a}$. Dr. Irene Kazumi Miura, pelas significativas contribuições a esta pesquisa e pelos diversos ensinamentos acadêmicos.

Ao Prof. Dr. Antônio Carlos Pacagnella Junior, pelas relevantes sugestões feitas a esta pesquisa.

Aos funcionários da Pós-Graduação: Thiago Saran de Carvalho Sasso, Matheus Carlos da Costa, Érika de Lima Veronezi Costa e Silvio Bezerra de Noronha, que sempre foram muito solícitos, me dando todo o suporte necessário para a realização do mestrado.

À FAPESP pelo apoio dado para realização desta pesquisa.

A todos os prefeitos, Secretários municipais de educação, Diretores, Professores e funcionários dos municípios e escolas visitadas, onde fui muito bem recepcionado.

À Credicitrus, que me deu todo o apoio possível para a realização desse mestrado.

Aos meus grandes amigos: Ruéverton César Cardoso, Rodrigo Viana, Flavio Americano de Freitas, Marcelo Fernandes, André Gomes Crespo e Fabio Luiz Cabral, pelo apoio na realização desta pesquisa e pelos momentos de descontração e alegria que passamos juntos.

Aos meus amigos de trabalho: Carlos Eduardo Guizziline, Matheus Vitorino de Souza, Fabricio Amancio Vieira, Vanessa Daniela Hilário, Thaizi Conde Trigo e Joyce Sanches Lopes, pelo apoio ao longo desse mestrado, e de modo especial ao Gilberto, que sempre foi muito compreensível em todos os momentos.

A todos os meus irmãos da loja maçonica União e Trabalho do Oriente de Viradouro-SP, que foram compreensivos com a minha frequente ausência aos trabalhos, ao longo destes últimos anos.

A todos os amigos e Professores da UNIFAFIBE, que me incentivaram a realizar esse mestrado, de modo especial ao Prof. Luciano Pimentel, Prof. Willy de Góes, Prof. Randal Farago, Prof. Jair Ferreira de Lima, Prof. Luciano Mendes, Prof. João Paulo Leonardo, Prof. Lucas Seren, Prof ${ }^{a}$. Amanda Vieira e o Prof. Denio Arrais.

E por fim, a todos aqueles que contribuíram direta ou indiretamente para a realização deste trabalho, o meu mais sincero agradecimento. 


\section{RESUMO}

FERREIRA, JONAS. Boas práticas administrativo-pedagógicas que colaboram para o desempenho dos alunos de escolas municipais do ensino fundamental do estado de São Paulo no IDEB. Dissertação de Mestrado - Faculdade de Economia, Administração e Contabilidade de Ribeirão Preto da Universidade de São Paulo, Ribeirão Preto, 2015

Este estudo teve como objetivo compreender a influência das práticas administrativopedagógicas que podem colaborar para o desempenho dos alunos de escolas públicas municipais do ensino fundamental do estado de São Paulo no IDEB. Para isso foi realizado uma adaptação da metodologia proposta por Salgado Junior (2013) que envolveu a realização de uma pesquisa de abordagem quali-quantitativa, dividida em duas etapas. A primeira etapa consistiu na aplicação da técnica DEA em 1.298 escolas públicas municipais do estado de São Paulo, cuja finalidade foi identificar as escolas eficientes em transformar investimento financeiro, nível socioeconômico e infraestrutura em desempenho no IDEB. A segunda etapa consistiu na realização de um estudo de múltiplos casos, por meio de entrevistas semiestruturadas, análise documental e observação assistemática nas cinco escolas eficientes identificadas pela técnica DEA e em cinco escolas ineficientes (com escore DEA inferior a 0,80 ) escolhidas por possuírem características semelhantes e estarem localizadas nos mesmos municípios das escolas eficientes. A análise dos resultados, apresentados nos estudos de caso, revelou a existência de 23 práticas administrativopedagógicas que apresentam evidências de ter influenciado o desempenho dos alunos no IDEB. Os resultados indicam que a participação da família na vida escolar do filho, assim como a cobrança da comunidade perante o Diretor pode contribuir para melhoria no desempenho dos alunos no IDEB. A preparação específica para a Prova Brasil, a rotatividade de Professores nas disciplinas de Português e Matemática e o sistema disciplinar também foram práticas identificadas nesta pesquisa que podem contribuir para $o$ desempenho dos alunos. Por fim, os resultados encontrados nessa pesquisa podem ser utilizados para definição sobre a destinação dos recursos financeiros por parte da SME e orientar os Diretores na gestão dos processos administrativo-pedagógico da escola, a fim de promover uma melhoria no desempenho dos alunos no IDEB.

Palavras-chave: Ensino Fundamental, Gestão Escolar, IDEB, Investimento em Educação e Análise Envoltória de Dados (DEA). 


\begin{abstract}
FERREIRA, JONAS. Good administrative and pedagogical practices that contribute to student performance of municipal elementary schools in the state of São Paulo in IDEB. Master's thesis - Faculty of Economics, Administration and Accounting of Ribeirão Preto, University of São Paulo, Ribeirão Preto, 2015
\end{abstract}

This study aimed to understand the influence of administrative and pedagogical practices that may contribute to the performance of students in public schools of primary education in the state of São Paulo in IDEB. To this was accomplished an adjustment of the methodology proposed by Salgado Junior (2013) involving the use of a qualitative and quantitative approach to research, divided into two stages. The first step was the application of DEA in 1,298 public schools of São Paulo, whose purpose was to identify the efficient schools in turning financial investment, socioeconomic status and performance in infrastructure in IDEB. The second stage consisted of a study of multiple cases, through semi-structured interviews, document analysis and systematic observation in the five efficient schools identified by the DEA and five inefficient schools (with DEA score less than 0.80) selected for having similar characteristics and located in the same municipalities of effective schools. The results presented in the case studies revealed the existence of 23 administrative and pedagogical practices that show evidence of having influenced the performance of students in IDEB. The results indicate that family participation in school life of the child, as well as pressure of the community before the principal can contribute to improvement in student performance in IDEB. The specific preparation for the Prova Brasil, the turnover of teachers in the disciplines of Portuguese and Mathematics and the disciplinary system were also identified in this research that may contribute to student performance. Finally, the results found in this research can be used for the definition on the allocation of financial resources by the SME and guide the directors in the management of administrative and pedagogical processes of school in order to promote an improvement in student performance in IDEB.

Keywords: Elementary School, School Management, IDEB, Investment in Education and Data envelopment analysis (DEA) 


\section{LISTA DE ABREVIATURAS E SIGLAS}

ABA

ANEB

ANRESC

APR

$\mathrm{BCC}$

BID

CACS

CAPES

CCR

CEPAL

$\mathrm{CF}$

DEA

DMU

ECA

EDUCACENSO

FAL

FINBRA

FIPE

FNDE

FUNDEB

FUNDEF

FUNDESCOLA

GAME

IDEB

IEE

INEP

INSS
Taxa de Abandono

Avaliação Nacional da Educação Básica

Avaliação Nacional do Rendimento Escolar

Taxa de Aprovação

Modelo de retornos variáveis de escala desenvolvido por Banker, Charnes e Cooper

Banco Interamericano de Desenvolvimento

Conselho de Acompanhamento e Controle Social do Fundeb

Coordenação de Aperfeiçoamento de Pessoal de Nível Superior

Modelo de retornos constantes de escala desenvolvido por Charnes, Cooper e Rhodes

Comissão Econômico para América Latina e Caribe

Constituição Federal

Data Envelopment Analysis (Análise Envoltória de Dados)

Decision Making Unit (Unidade Tomadora de Decisão)

Estatuto da Criança e do Adolescente

Censo Escolar

Taxa de Falecimento

Finanças do Brasil

Fundação Instituto de Pesquisas Econômicas

Fundo Nacional de Desenvolvimento da Educação

Fundo de Manutenção e Desenvolvimento da Educação Básica e de Valorização dos Profissionais da Educação

Fundo de Manutenção e Desenvolvimento do Ensino Fundamental e de Valorização do Magistério

Fundo de Fortalecimento da Escola

Grupo de Avaliação e Medidas Educacionais

Índice de Desenvolvimento da Educação Básica

Indicador de Efeito Escola

Instituto Nacional de Estudos e Pesquisas Educacionais Anísio Teixeira

Instituto Nacional do Seguro Social 
LDB

MDE

MEC

NSE

OBMEP

OCDE

OREALC

PCN

PDE

PIB

PISA

PME

PNE

REP

SAEB

SIR

SISTN

SME

STN

UFMG

UNDIME

UNESCO

UNICEF
Lei de Diretrizes e Bases da Educação Nacional

Manutenção e Desenvolvimento do Ensino

Ministério da Educação

Nível Socioeconômico

Olimpíada Brasileira de Matemática das Escolas Públicas

Organization for Economic Co-operation and Development

Oficina Regional de Educación para América Latina y el Caribe

Parâmetros Curriculares Nacionais

Plano de Desenvolvimento da Educação

Produto Interno Bruto

Programme for International Student Assessment

Plano Municipal de Educação

Plano Nacional de Educação

Taxa de Reprovação

Sistema Nacional de Avaliação da Educação Básica

Sem Informação de Rendimento, Falecimento ou Abandono

Sistema de Coleta de Dados Contábeis

Secretaria Municipal de Educação

Secretaria do Tesouro Nacional

Universidade Federal de Minas Gerais

União Nacional dos Dirigentes Municipais de Educação

United Nation Educational, Scientific and Cultural Organization

United Nations International Children's Emergency Fund 


\section{LISTA DE TABELAS}

Tabela 1 - Estabelecimentos por dependência administrativa (2011) ............................................ 20

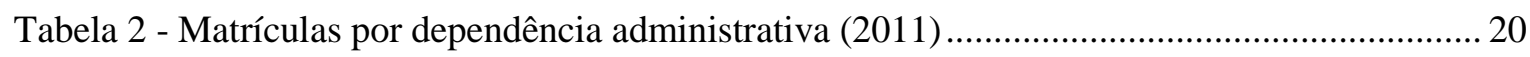

Tabela 3 - Investimento Público Total em Educação em relação ao PIB, por Nível de Ensino...... 52

Tabela 4 - Escala de proficiência Língua Portuguesa ................................................................... 70

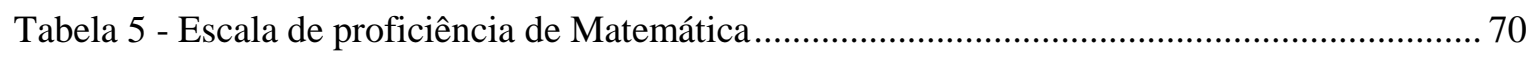

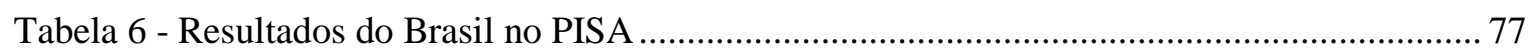

Tabela 7 - Estatística descritiva das variáveis relacionadas às escolas ........................................... 102

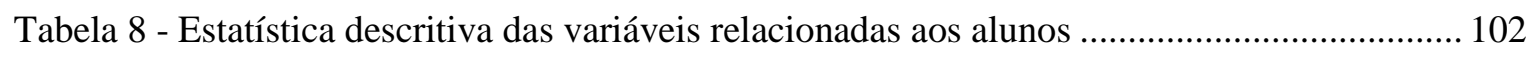

Tabela 9 - Estatística descritiva das variáveis relacionadas aos Professores e funcionários.......... 103

Tabela 10 - Estatística descritiva das variáveis relacionadas ao modelo teórico ............................ 103

Tabela 11 - Caracterização das cinco escolas eficientes selecionadas pela técnica DEA .............. 119

Tabela 12 - Caracterização das cinco escolas ineficientes selecionadas pela técnica DEA ........... 120

Tabela 13 - Correlação de Spearman para identificar as variáveis que formam o instrumento de pesquisa

Tabela 14 - Correlação de Pearson para identificar as variáveis que formam o instrumento de pesquisa. 390

\section{LISTA DE QUADROS}

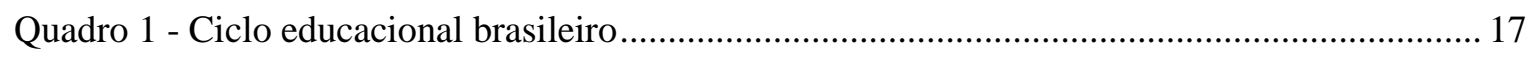

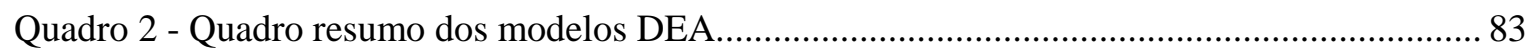

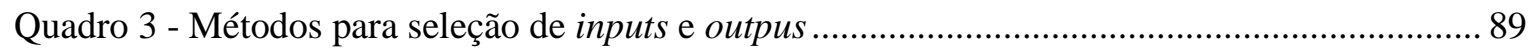

Quadro 4 - Classificação das variáveis utilizadas no modelo teórico .............................................95

Quadro 5 - Autores que relacionam positivamente cada variável com desempenho educacional .. 96

Quadro 6 - Descrição das variáveis utilizadas nas correlações de Spearman e Pearson ............... 101

Quadro 7 - Instrumento de Pesquisa - Secretário Municipal de Educação ...................................... 106

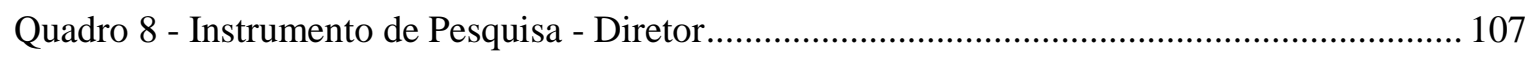

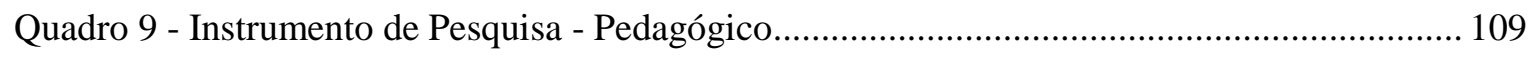

Quadro 10 - Domínios possíveis da aplicação da análise de conteúdo ......................................... 113

Quadro 11 - Justificativa das variáveis utilizadas no modelo DEA ................................................ 118

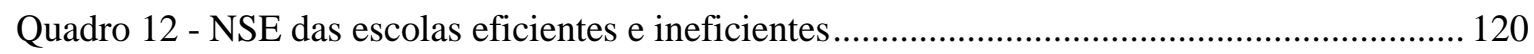

Quadro 13 - Contribuição de cada escola na composição da frequência de cada atividade que compõe o instrumento administrativo aplicado ao Diretor das escolas eficientes ......................... 270 
Quadro 14 - Contribuição de cada escola na composição da frequência de cada atividade que compõe o instrumento pedagógico das escolas eficientes

Quadro 15 - Contribuição de cada escola na composição da frequência de cada atividade que compõe o instrumento administrativo aplicado ao Diretor das escolas ineficientes

Quadro 16 - Contribuição de cada escola na composição da frequência de cada atividade que compõe o instrumento pedagógico das escolas ineficientes.

Quadro 17 - Comparação entre as escolas eficientes e ineficientes pelo indicador administrativo do Diretor

Quadro 18 - Autores que corroboram ou divergem dos resultados encontrados no estudo de caso em relação às práticas administrativas do Diretor

Quadro 19 - Comparação entre as escolas eficientes e ineficientes pelos indicadores pedagógicos

Quadro 20 - Autores que corroboram ou divergem dos resultados encontrados no estudo de caso em relação às práticas pedagógicas da escola...

Quadro 21 - Comparação entre as práticas administrativas do SMEs dos cinco municípios ..........320

Quadro 22 - Escala de frequência de avaliação dos indicadores administrativos da SME.

Quadro 23 - Escala de frequência de avaliação dos indicadores administrativos do Diretor .

Quadro 24 - Escala de frequência de avaliação dos indicadores pedagógicos da escola 394

\section{LISTA DE GRÁFICOS}

Gráfico 1 - Porcentagem de crianças de 0 a 3 anos que frequentam escola ...................................... 17

Gráfico 2 - Porcentagem de crianças de 4 e 5 anos que frequentam escola ..................................... 18

Gráfico 3 - Porcentagem de estudantes de 7 a 14 anos que frequentam escola................................ 19

Gráfico 4 - Porcentagem de estudantes de 15 a 17 anos que frequentam escola.............................. 19

Gráfico 5 - Classificação dos estudantes em níveis de leitura na avaliação PISA 2009 ...................77

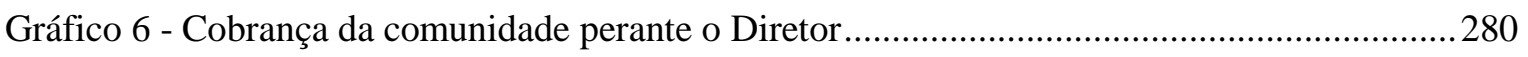

Gráfico 7 - Quantidade de refeições e orientação nutricional ......................................................281

Gráfico 8 - Características da alimentação dos alunos .................................................................282

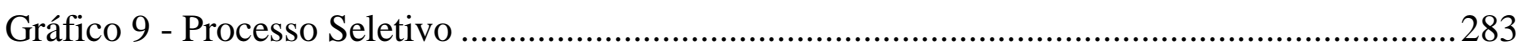

Gráfico 10 - Formação e cursos complementares do Diretor ..........................................................28

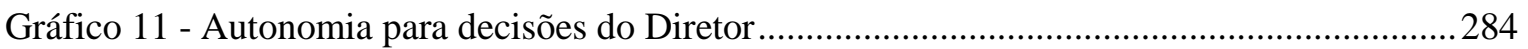

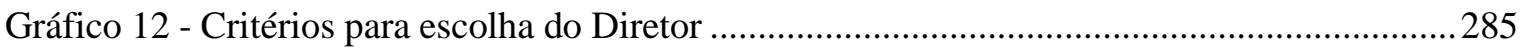

Gráfico 13 - Compatibilidade do salário com a função do Diretor .................................................286

Gráfico 14 - Capacidade do Diretor na captação de recursos financeiros .......................................287

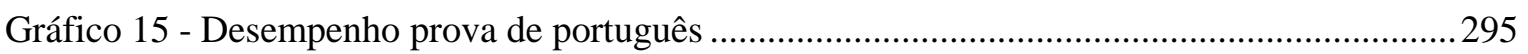


Gráfico 16 - Desempenho prova de português (outros) ................................................................. 296

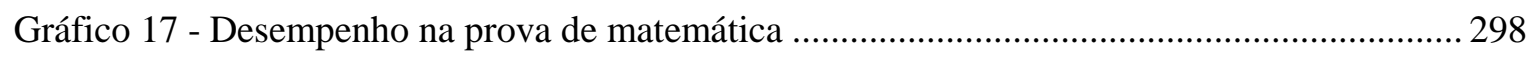

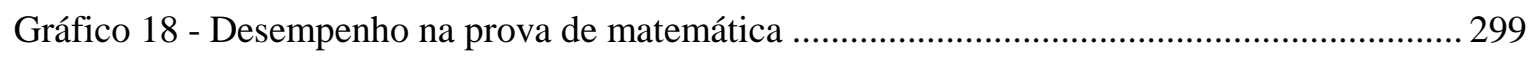

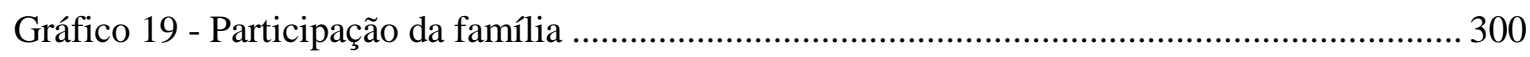

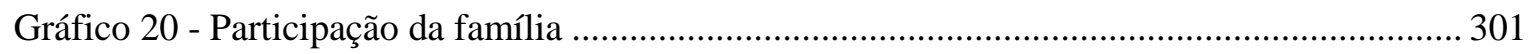

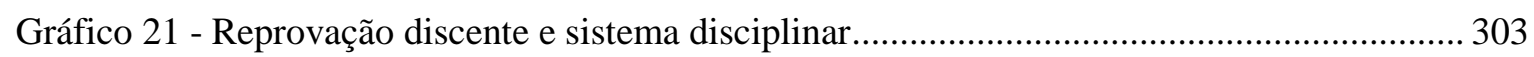

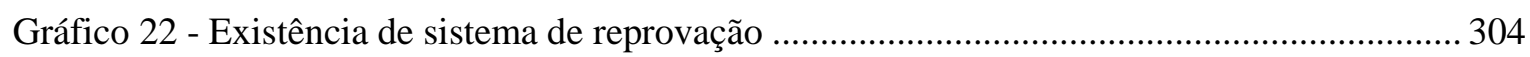

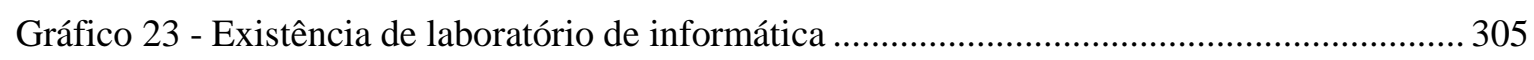

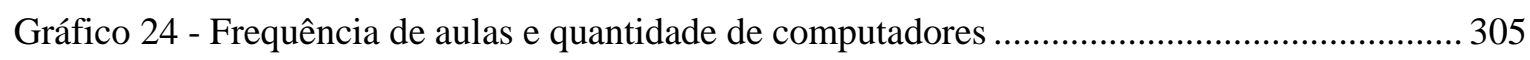

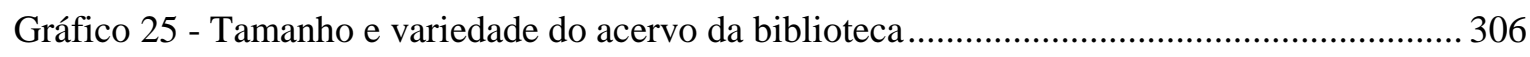

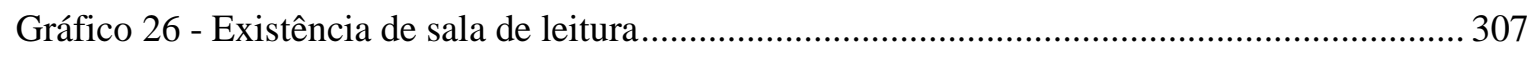

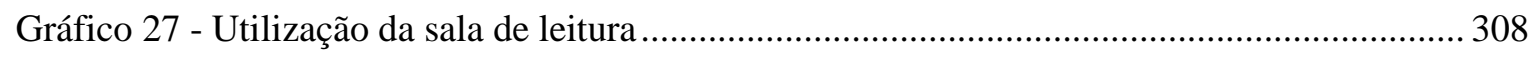

Gráfico 28 - Frequência de utilização do transporte público para ir à escola ................................ 308

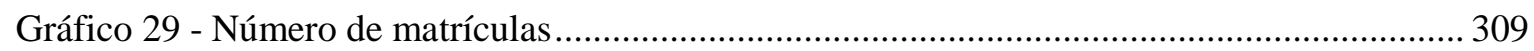

Gráfico 30 - Docentes por gênero, magistério e cursos de licenciatura ……….............................. 310

Gráfico 31 - Percentual de Docentes com curso superior e especialização..................................... 311

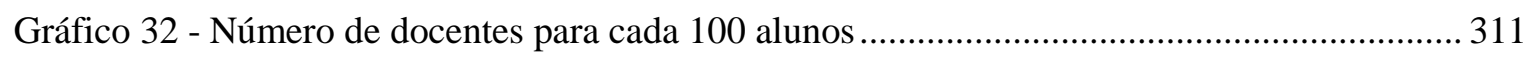

Gráfico 33 - Incentivo financeiro, plano de carreira e salário dos docentes .................................... 312

Gráfico 34 - Número de funcionários para cada 100 alunos ........................................................... 313

Gráfico 35 - Constituição da Secretaria Municipal de Educação....................................................... 321

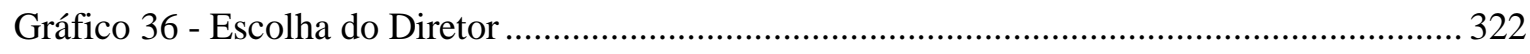

Gráfico 37 - Formação do Secretário Municipal de Educação....................................................... 323

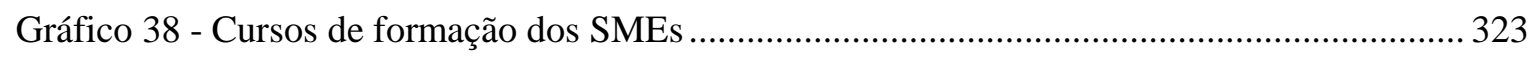

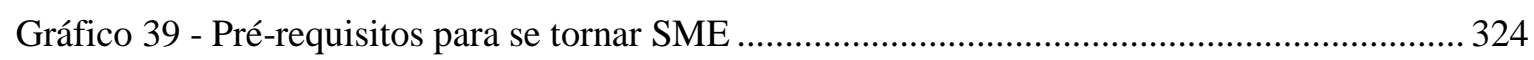

Gráfico 40 - Autonomia e análise crítica do município .................................................................... 325

Gráfico 41 - Capacidade da SME na captação de recursos financeiros ......................................... 326

Gráfico 42 - Destinação do recurso financeiro descentralizado e centralizado............................... 327

Gráfico 43 - Transição de novo Secretário e nova equipe …………………………........................ 327

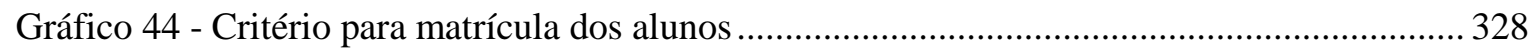

Gráfico 45 - Exclusividade da oferta do ensino fundamental pela rede pública ............................ 328

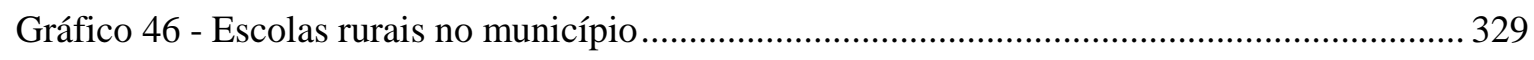

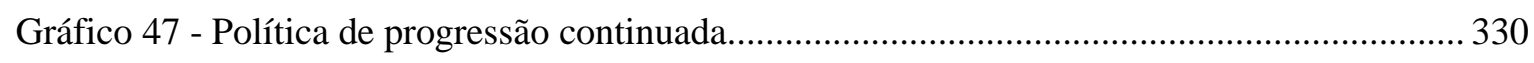

Gráfico 48 - Incentivos para participação em olimpíadas custeadas pelo município ...................... 330 


\section{LISTA DE FIGURAS}

Figura 1 - Organograma das técnicas de avaliação de eficiência ....................................................... 80

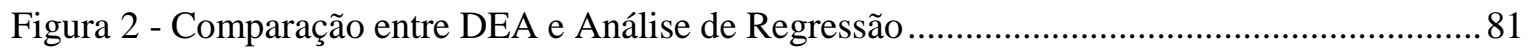

Figura 3 - Elementos de uma unidade tomadora de decisão (DMU).............................................. 82

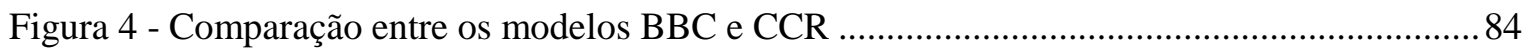

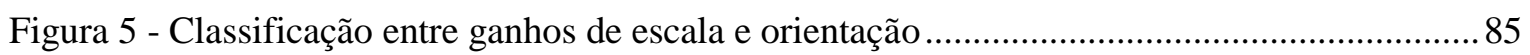

Figura 6 - Comparação do modelo FDH com o modelo BCC …………………........................... 86

Figura 7 - Regiões gráficas da influência da escala de produção .................................................... 87

Figura 8 - Fronteira eficiente em um modelo DEA do tipo de retorno de escala constante (BCC) 88

Figura 9 - Fluxograma para desenvolvimento de uma aplicação DEA …………….........................90

Figura 10 - Método de pesquisa adaptado da metodologia proposta por Salgado Junior (2013)....92

Figura 11 - Inputs e Outputs utilizados no modelo .........................................................................93

Figura 12 -- Representação gráfica da escolha e orientação do modelo DEA …………………......94

Figura 13 - Processo de construção do instrumento e roteiro semiestruturado ................................105

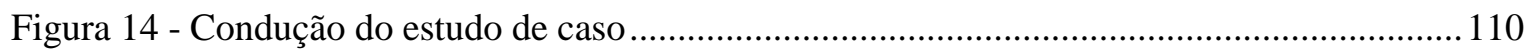

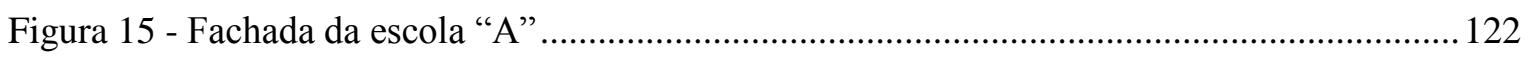

Figura 16 - Fachada da SME do município de Cerquilho ..............................................................123

Figura 17 - Itens adquiridos pela SME que serão enviados às escolas ...........................................125

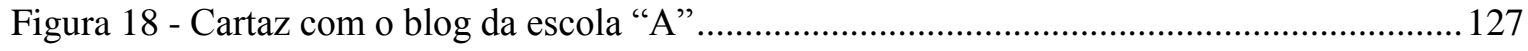

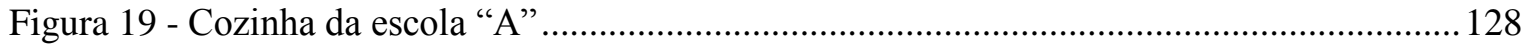

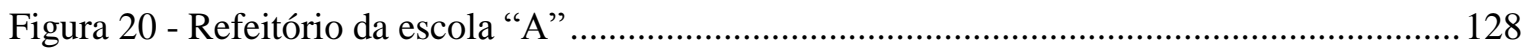

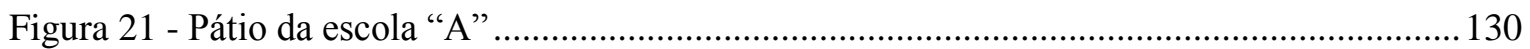

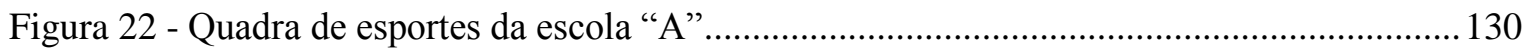

Figura 23 - Escala das aulas de xadrez oferecida aos alunos pela escola "A"..............................133

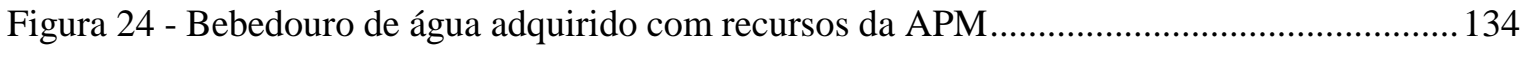

Figura 25 - Cartaz promocional da $1^{\text {a }}$ festa do pastel realizada pela escola com apoio dos pais .. 134

Figura 26 - Regras escolares fixada na entrada das salas de aula...................................................136

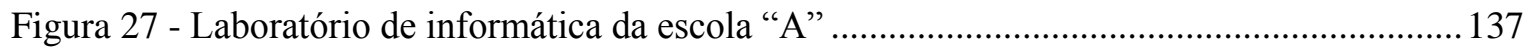

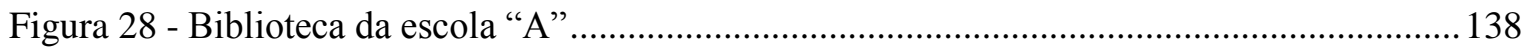

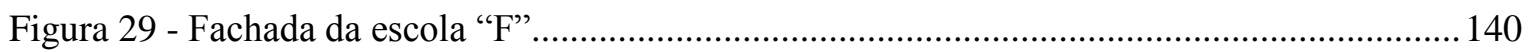

Figura 30 - Refeição oferecida aos alunos no dia da visita à escola............................................... 141

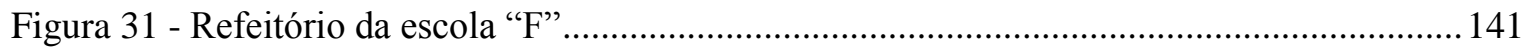


Figura 32 - Quadra de esportes da escola "F"

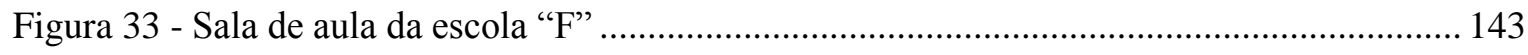

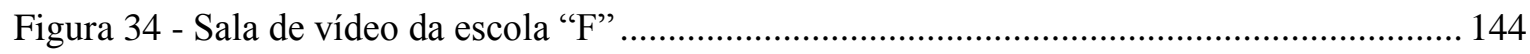

Figura 35 - Mapa dos lugares onde os alunos devem se sentar na sala de aula ........................... 147

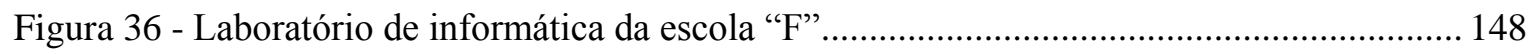

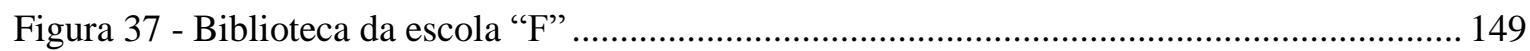

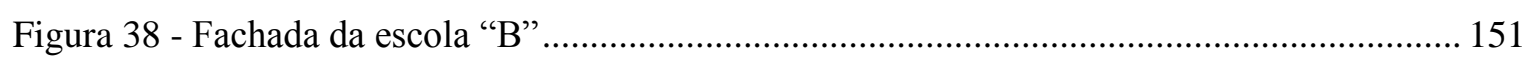

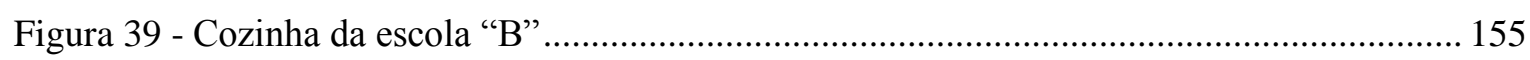

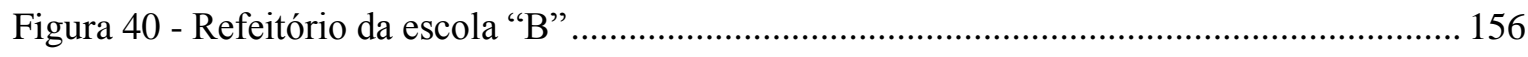

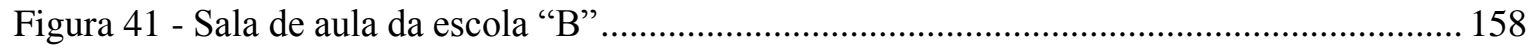

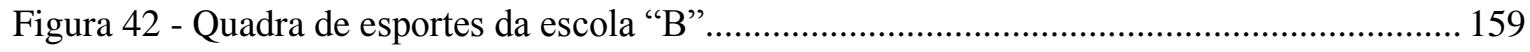

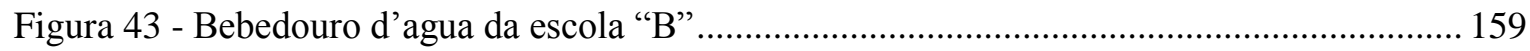

Figura 44 - Cartaz contendo a Lei nº 2.848/40 sobre desacato a funcionário público .................... 162

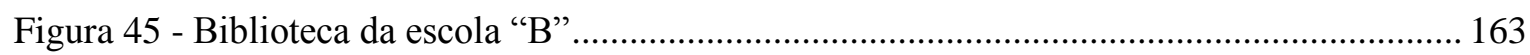

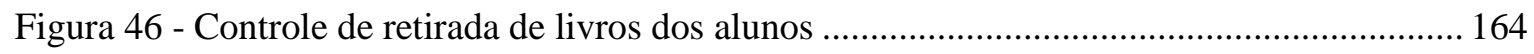

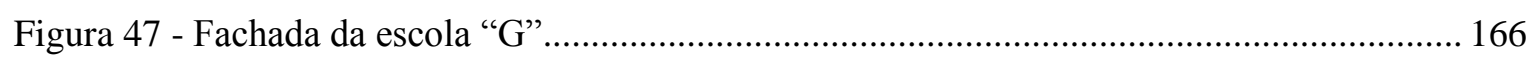

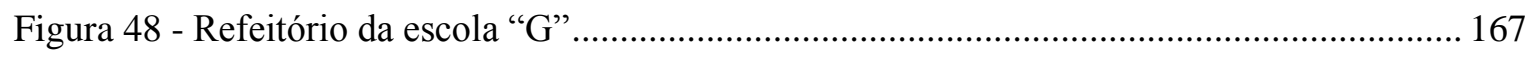

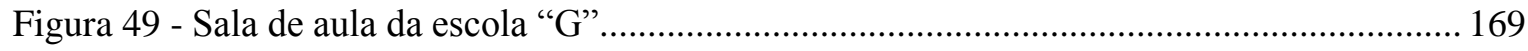

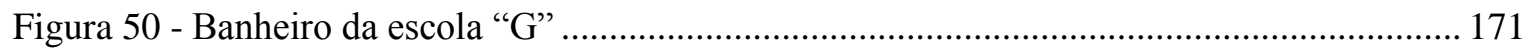

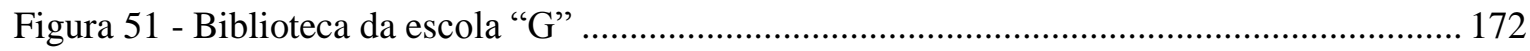

Figura 52 - Fachada da SME de São José dos Campos................................................................. 174

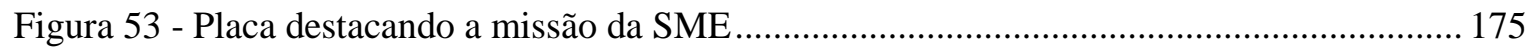

Figura 54 - Departamento Financeiro da SME de São José dos Campos ....................................... 176

Figura 55 - Organização da SME de São José dos Campos........................................................... 177

Figura 56 - Fachada da escola "C"

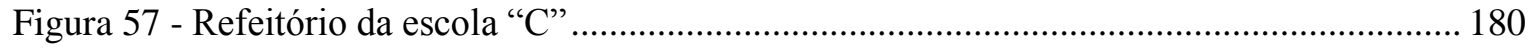

Figura 58 - Horta cultivada pelos alunos da escola "C"'................................................................... 181

Figura 59 - Frase de incentivo aos Professores ........................................................................ 182

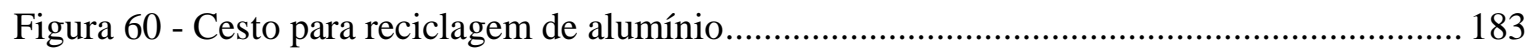

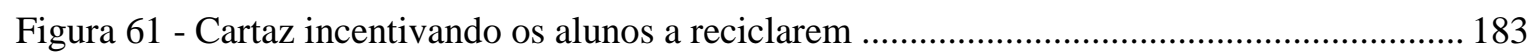

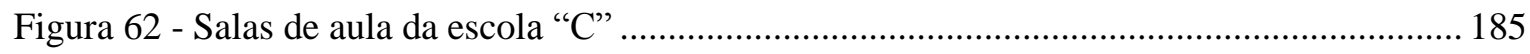

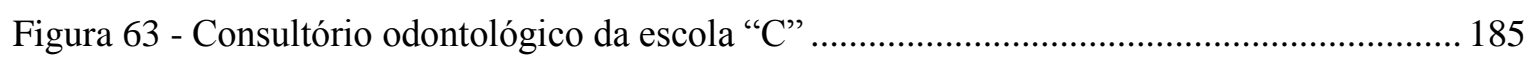

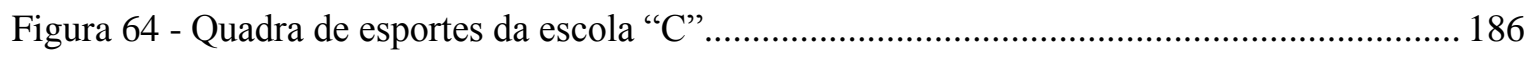

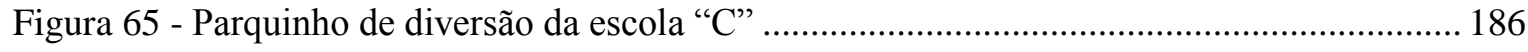




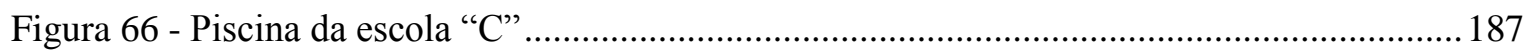

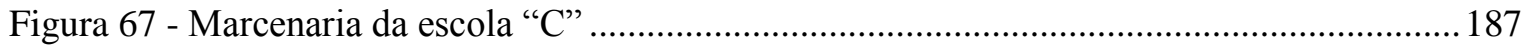

Figura 68 - Sala de recuperação intensiva da escola "C" ................................................................ 189

Figura 69 - Cartazes incentivando a participação dos alunos em olimpíadas e concursos .............189

Figura 70 - Cartazes incentivando a participação dos alunos em eventos de matemática...............191

Figura 71 - Troféu de tabuada vanguarda conquistado pelos alunos da escola.............................191

Figura 72 - Campanha de arrecadação solidária realizada pela escola com apoio dos pais ........... 192

Figura 73 - Cartazes de conscientização e combate ao bullying na escola.....................................193

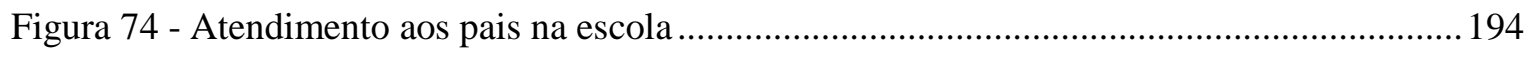

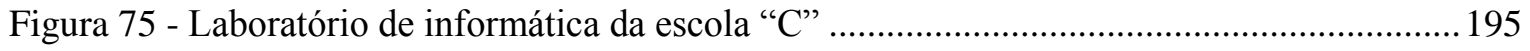

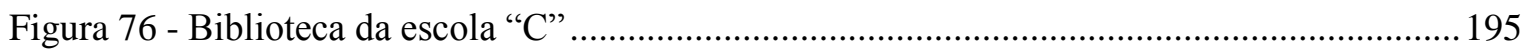

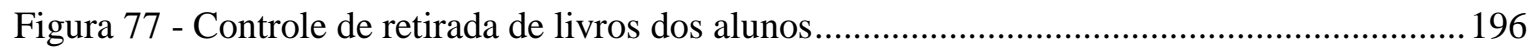

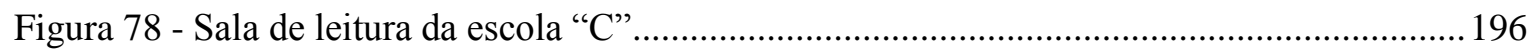

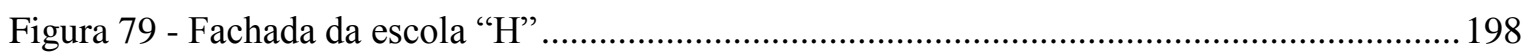

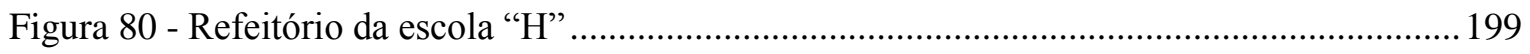

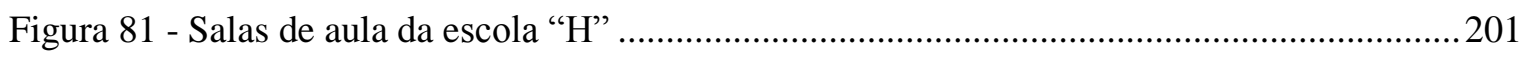

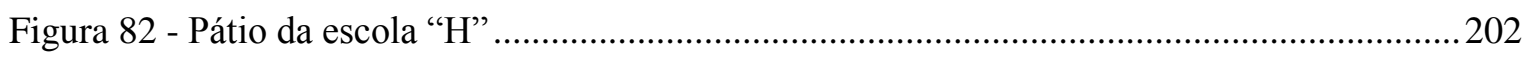

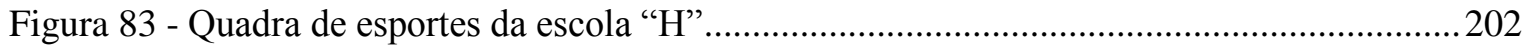

Figura 84 - Desenho de lendas folclóricas feito pelos alunos .........................................................2203

Figura 85 - Cartazes de incentivo a criação de charges .................................................................203

Figura 86 - Atividade de acompanhamento feita pelo docente de matemática ..............................204

Figura 87 - Frase que destaca a importância da matemática ............................................................205

Figura 88 - Modelo didático da tabuada desenhado na sala de aula ..............................................205

Figura 89 - Cartaz contendo a Lei $n^{\circ}$ 2.848/40 sobre desacato a funcionário público ....................206

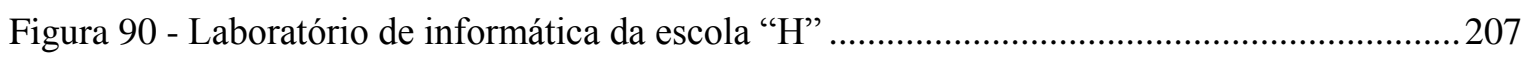

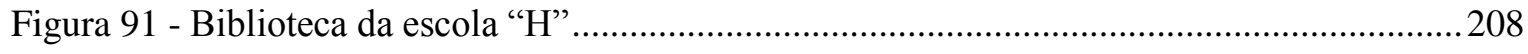

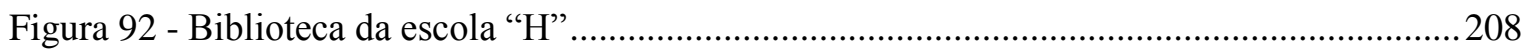

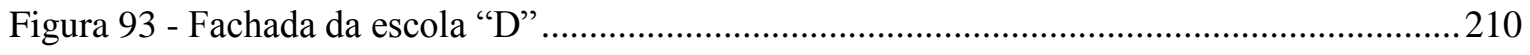

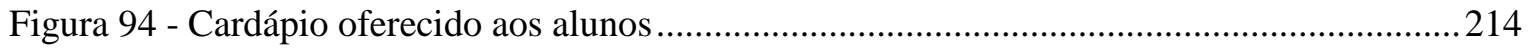

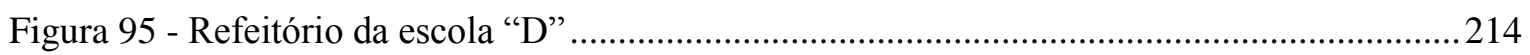

Figura 96 - Comunicado do Diretor aos docentes sobre abono e prazos de entrega de documentos

Figura 97 - Comunicado do Diretor aos docentes sobre o prazo de entrega da folha de substituição 
Figura 98 - Comunicado do Diretor aos docentes sobre os horários de entrada e saída da escola 216

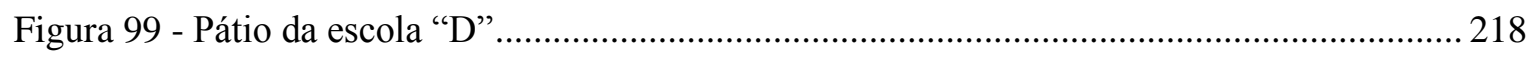

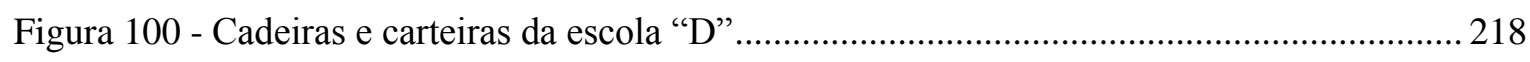

Figura 101 - Ginásio de esportes utilizado pela escola "D" .......................................................... 218

Figura 102 - Alunos da escola "D" classificados para a $2^{\mathrm{a}}$ fase da OBMEP ................................ 220

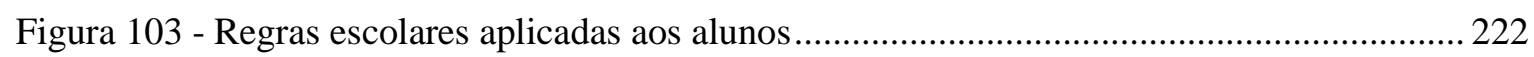

Figura 104 - Regras de comportamento em sala dos alunos do $2^{\circ}$ ano ........................................ 223

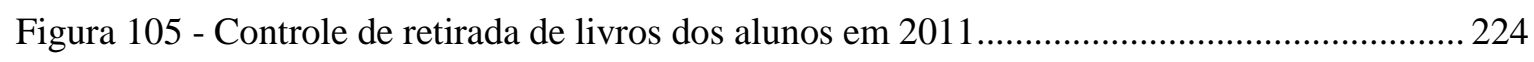

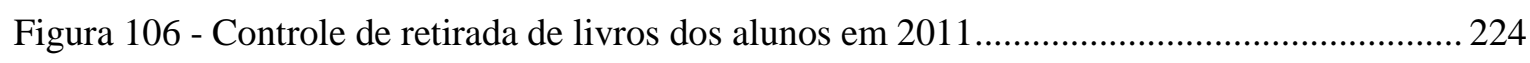

Figura 107 - Controle de retirada de livros dos alunos em 2011 .................................................. 225

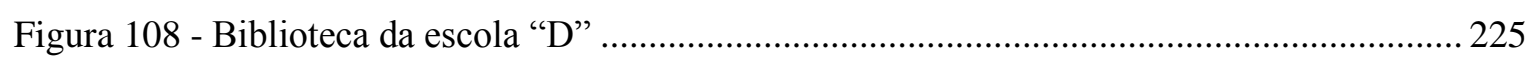

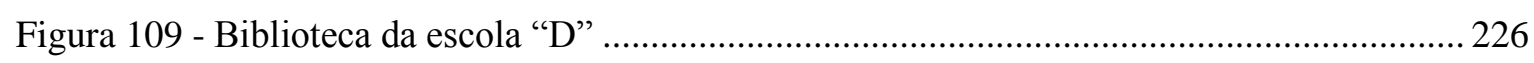

Figura 110 - Ônibus escolares aguardando a saída dos alunos ..................................................... 227

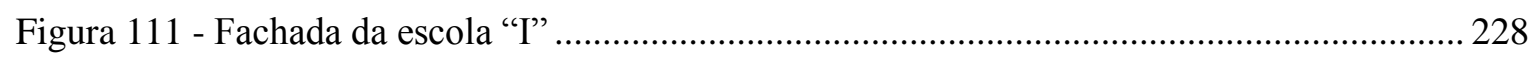

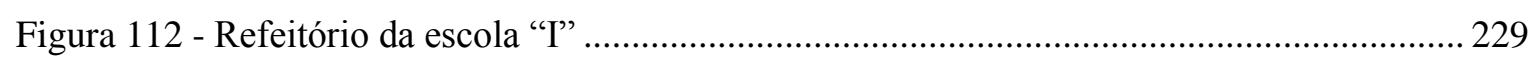

Figura 113 - Acompanhamento do Diretor nos resultados e metas do IDEB da escola................. 230

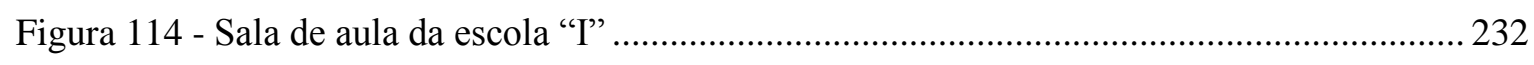

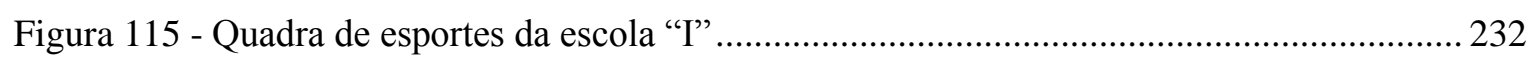

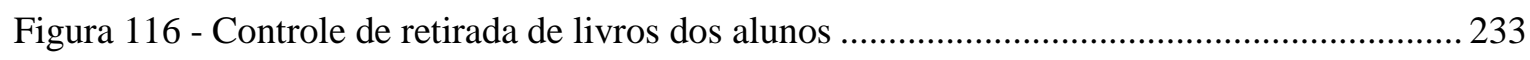

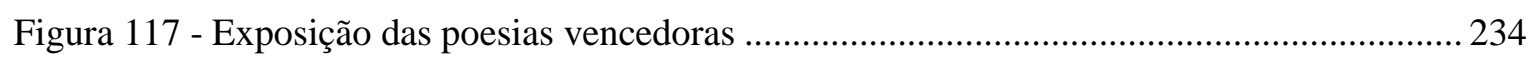

Figura 118 - Alunos da escola "I" classificados para a $2^{\mathrm{a}}$ fase da OBMEP ................................... 235

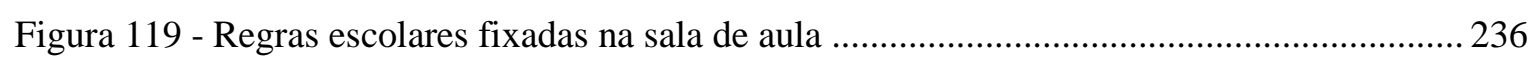

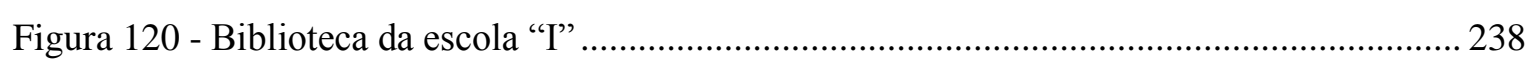

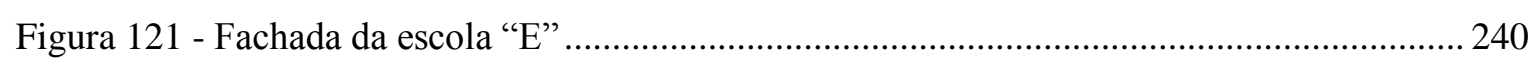

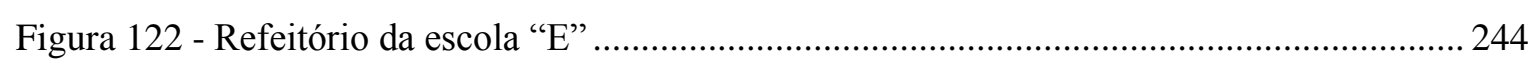

Figura 123 - Datashow e televisor adquirido com recurso descentralizado .................................. 245

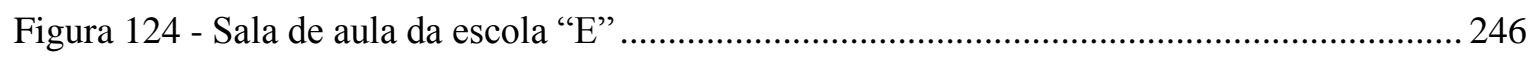

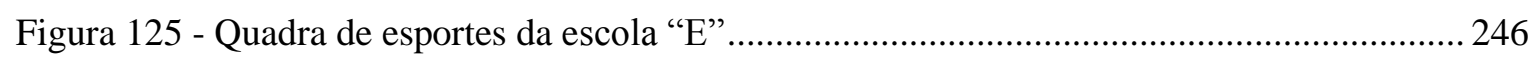

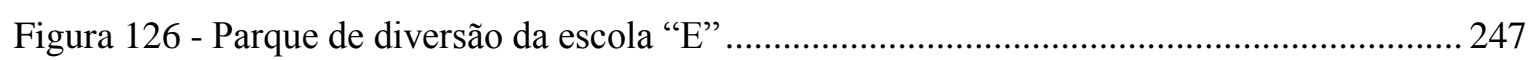

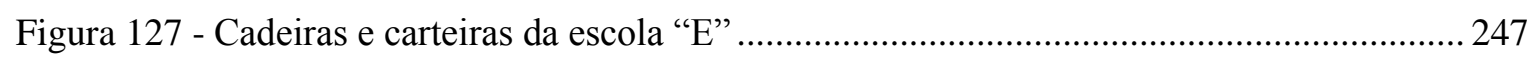

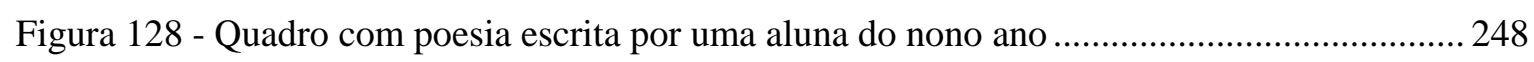

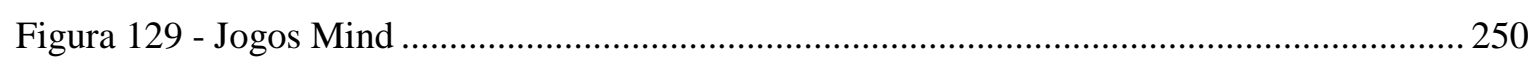

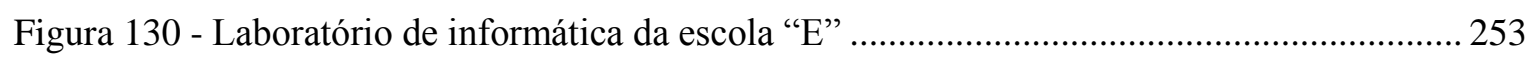

Figura 131 - Controle de retirada de livros dos alunos da escola "E" "........................................... 254 
Figura 132 - Controle de retirada de livros dos alunos da escola "E"

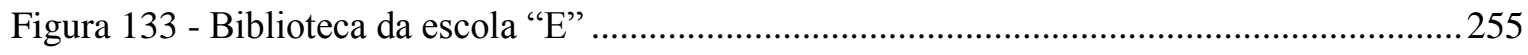

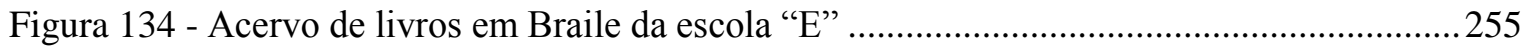

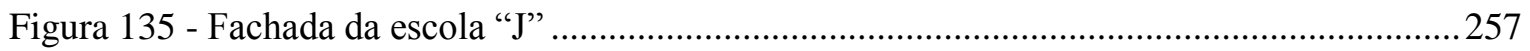

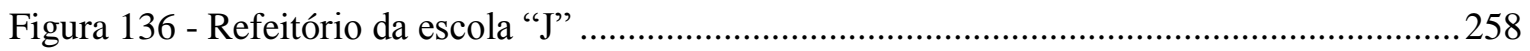

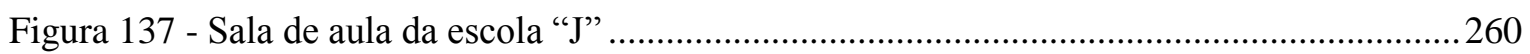

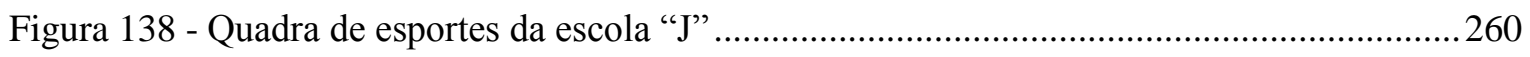

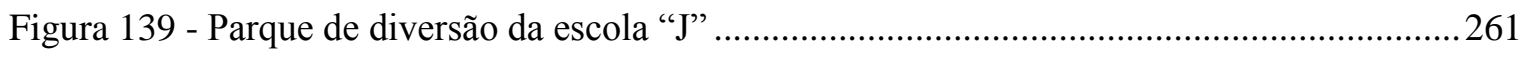

Figura 140 - Produção de texto sobre o meio ambiente elaborado pelos alunos .............................262

Figura 141 - Concurso de frases promovido pela escola "J" ............................................................263

Figura 142 - Avaliação realizada pela docente de matemática..........................................................264

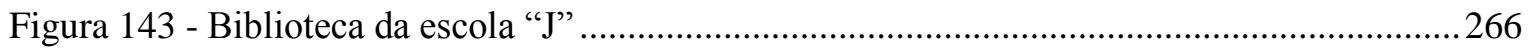

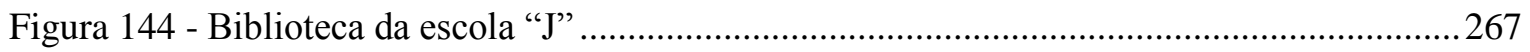




\section{Sumário}

$1 \quad$ Introdução............................................................................................................................... 1

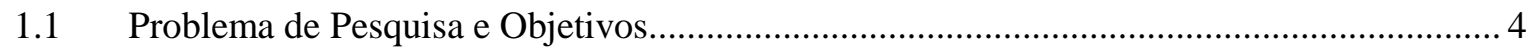

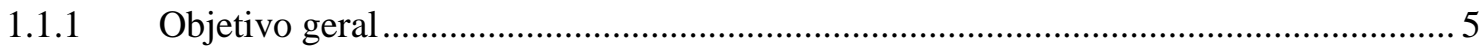

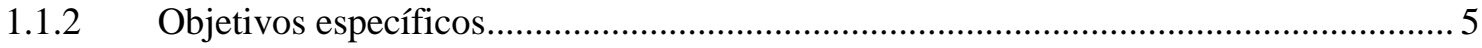

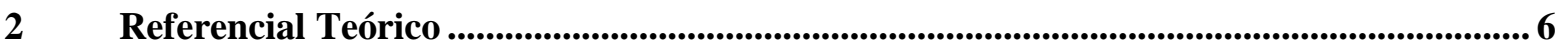

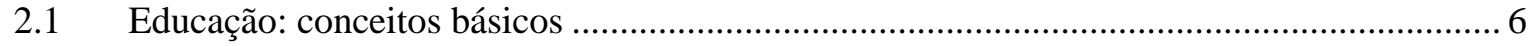

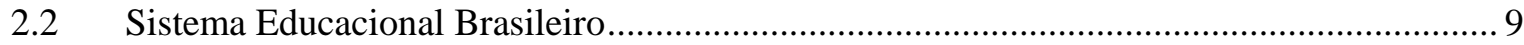

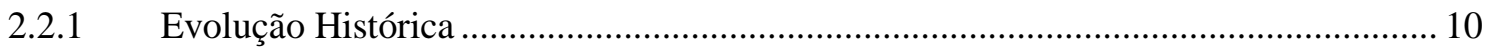

2.2.2 Características da Educação no Brasil............................................................................ 16

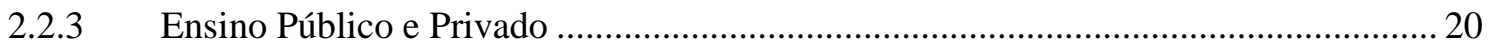

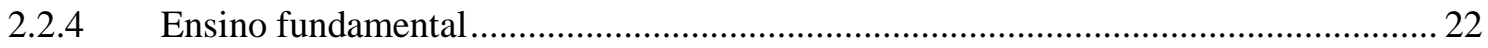

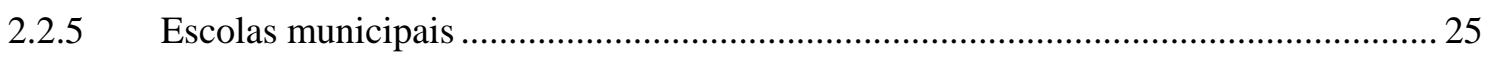

2.2.6 Secretaria Municipal de Educação (SME) ............................................................... 28

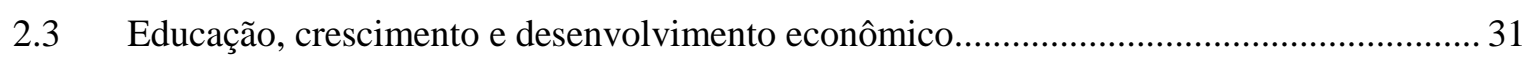

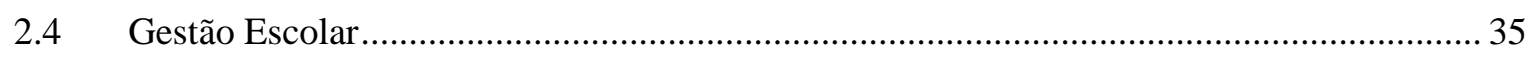

2.4.1 Formação em gestão dos Secretários municipais de educação .................................... 38

2.4.2 Formação em gestão dos Diretores escolares .............................................................. 41

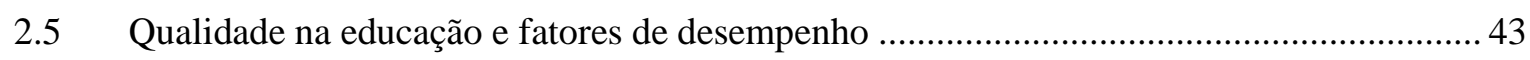

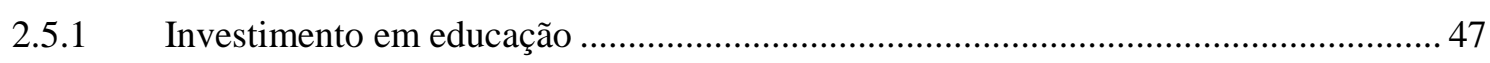

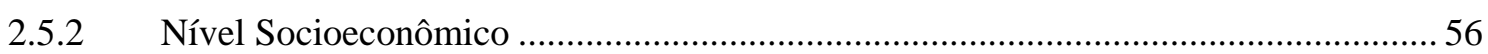

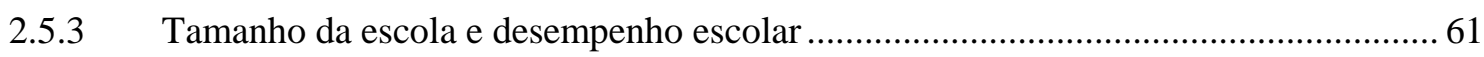

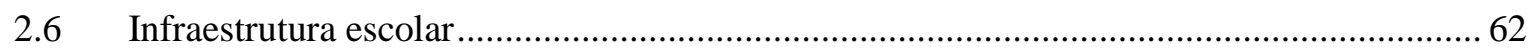

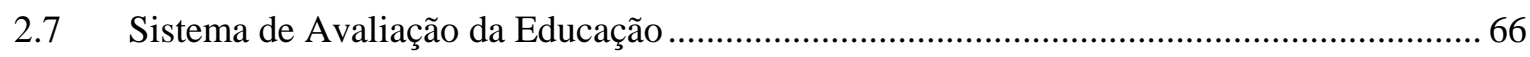

2.7.1 Sistema Nacional de Avaliação da Educação Básica (SAEB) ...................................... 67

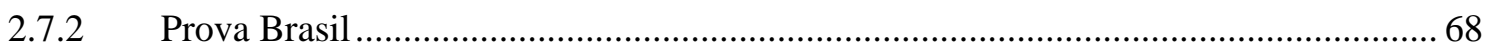

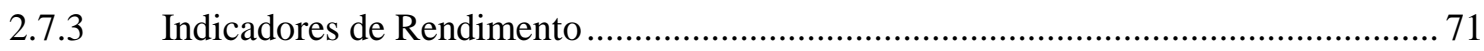

2.7.4 Índice de Desenvolvimento da Educação Básica (IDEB) ............................................ 73

2.7.5 Programa Internacional de Avaliação de Estudantes (PISA) ....................................... 76

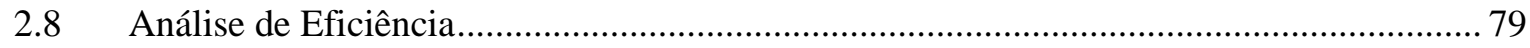

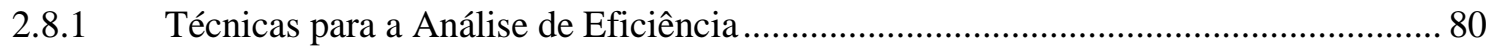

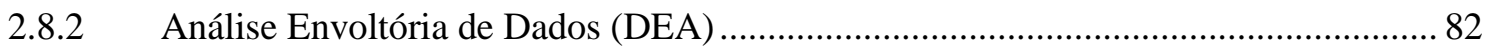

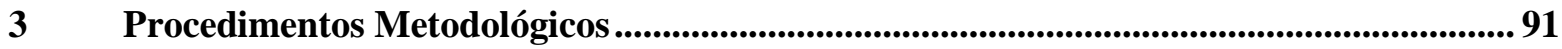

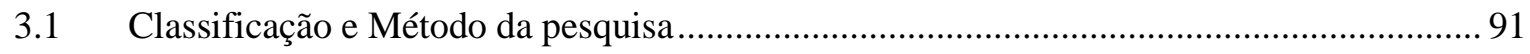

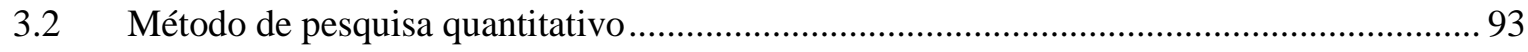




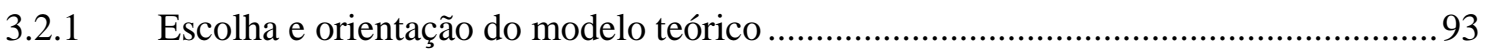

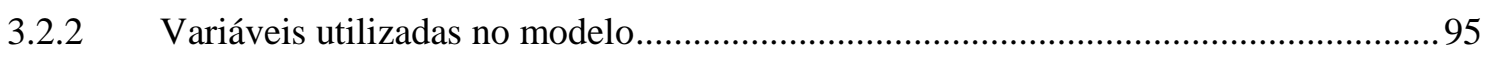

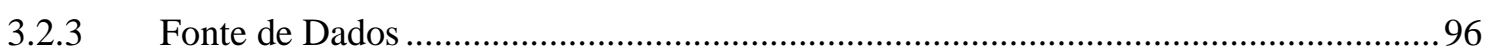

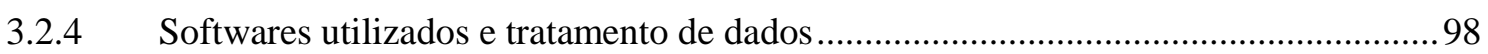

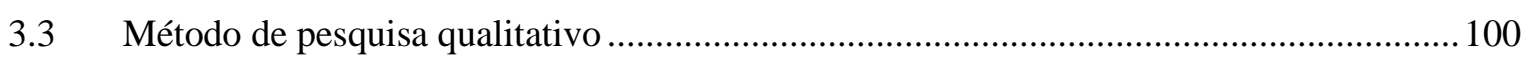

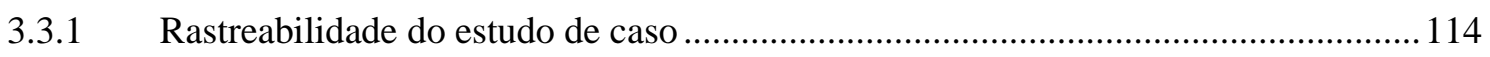

$4 \quad$ Apresentação e Análise de Resultados........................................................................................117

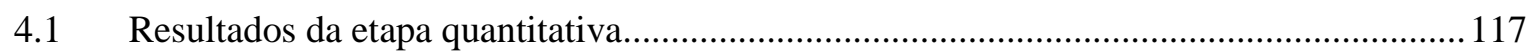

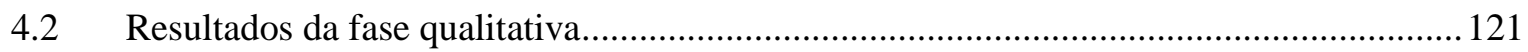

4.2.1 Descrição dos estudos de casos realizados nas escolas eficientes e ineficientes e em

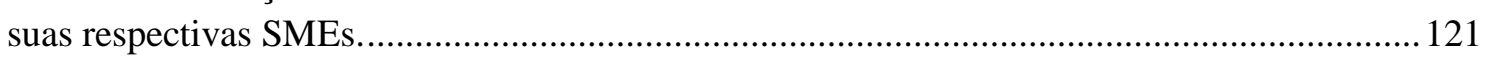

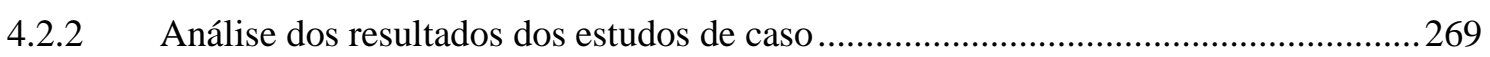

4.3 Avaliação dos fatores identificados frente a estudos encontrados na literatura...................331

4.3.1 Atividades com diferença expressiva (e pouco expressiva) relacionada ao instrumento

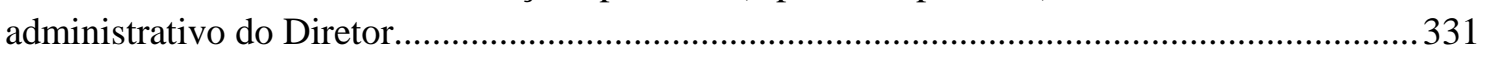

4.3.2 Atividades com diferença expressiva (e pouco expressiva) relacionada ao instrumento

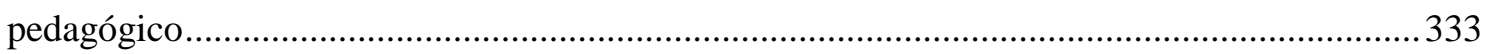

5 Considerações Finais ..........................................................................................................348

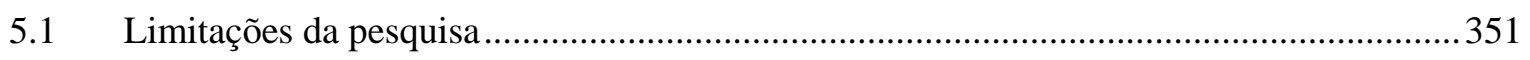

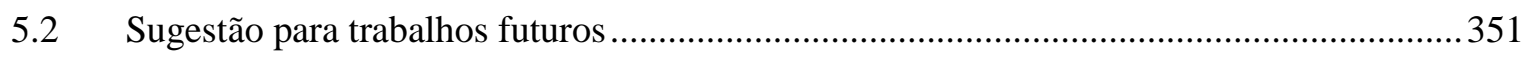

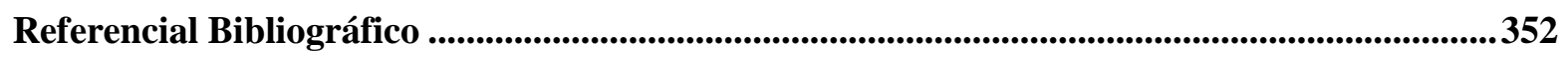

Apêndice A - Roteiro de entrevista - Secretário(a) Municipal de Educação.................................372

Apêndice B - Roteiro de entrevista com Diretor ...........................................................................................375

Apêndice C - Roteiro de entrevista com os Professores ...............................................................379

Apêndice D - Roteiro de Entrevista com os alunos..................................................................382

Apêndice E - Roteiro de Entrevista com os pais ...........................................................................................385

Apêndice F - Roteiro de entrevista sobre Infraestrutura......................................................................387

Apêndice G - Correlação de Spearman das variáveis do instrumento de pesquisa .....................389

Apêndice H - Correlação de Pearson das variáveis do instrumento de pesquisa .........................390

Apêndice I - Escala de frequência de avaliação dos indicadores administrativos da SME .......391

Apêndice J - Escala de frequência de avaliação dos indicadores administrativos do Diretor..392

Apêndice K - Escala de frequência de avaliação dos indicadores pedagógicos da escola ..........393 


\section{Introdução}

A educação é um tema de grande interesse dos países, principalmente por impactar diretamente no seu crescimento e desenvolvimento econômico, bem como garantir a manutenção das instituições democráticas (FRANCO, 2008; BARRO, LEE, 2010). Na esfera econômica, ela contribui com a formação de profissionais mais qualificados, que promoverá maiores ganhos de produtividade e consequentemente será refletido no crescimento da economia (RESENDE; WYLLIE, 2006). No aspecto político e social, a educação permite a inclusão social e profissional dos cidadãos, além de promover a redução das desigualdades, por meio do aumento na renda e no padrão de vida das pessoas (BENEVIDES; 1996; HÖFFE, 2004; VIRGINIO; 2012; CUNHA et. al, 2009). Neste sentido, a educação, com destaque para o ensino fundamental, passa a ser um tema de grande importância no meio acadêmico, sendo alvo de estudos de pesquisadores em diversas regiões do mundo.

O interesse pelo ensino fundamental, que tem como objetivo a formação básica do cidadão (SAVIAN; BEZERRA; MELO, 2012), é justificado pela representatividade que esta etapa do ensino possui sobre a educação básica. Os dados divulgados pelo INEP (2013) corroboram com tal constatação ao demonstrar que o ensino fundamental possui 29,7 milhões dos 50,5 milhões de alunos matriculados na educação básica no ano de 2012, onde 68,2\% deles estudam (se encontram) nas redes municipais.

O interesse pelo estado de São Paulo também é justificado por sua representatividade. Segundo os dados do INEP (2013), esse mesmo estado possuía em 2012 uma concentração de matrículas com $19,4 \%$ do total de matrículas no ensino fundamental do país, seguido pelo estado de Minas Gerais (9,5\%), Bahia (7,8\%), Rio de Janeiro (7,6\%) e Paraná (5,2\%), enquanto os outros estados juntos representavam 50,5\% do total de matrículas do ensino fundamental.

A significativa participação do ensino fundamental na educação básica é fruto de grandes transformações ocorridas na educação brasileira, iniciadas em meados da década de 1990, onde o Brasil conseguiu promover a universalização do acesso ao ensino fundamental e uma significativa expansão do ensino médio (OLIVEIRA, 2007; VELOSO, 2011; BRASIL, 2012). Entretanto, o aumento no acesso à educação não foi acompanhado por melhorias na qualidade 
da educação oferecida aos alunos da rede pública (OLIVEIRA, 2007; LEMES, PAREDES, SOUZA, 2009; CONTE; DONIN, 2013).

Corroborando com esta afirmação, os resultados de avaliações internacionais mostram que o desempenho dos alunos brasileiros precisa melhorar, ainda mais quando comparado a outros países (MENEZES-FILHO, 2007), como apontam os relatórios do Fórum Econômico Mundial (BILBAO-OSORIO; DUTTA; LAVIN, 2013) e da Organização para a Cooperação e Desenvolvimento Econômico (OECD, 2010).

Ao discorrer sobre o avanço da educação no Brasil, cuja principal conquista foi a universalização do ensino fundamental, Andrade (2011) ressalta que é importante ter em mente que a qualidade e não a quantidade da educação é o fator mais importante para explicar o crescimento econômico. Deste modo, é evidente a necessidade de avanços na busca por uma educação de maior qualidade. A qualidade da educação, por sua vez, é considerada um fenômeno complexo, abrangente e que envolve múltiplas dimensões (DOURADO, SANTOS, OLIVEIRA, 2007). Dentre as ferramentas que podem contribuir para a melhoria da qualidade da educação estão os testes de avaliação em larga escala, que mesmo existindo divergências entre alguns estudos e pesquisadores sobre o seu verdadeiro impacto na qualidade da educação (OLIVEIRA; ARAUJO, 2005; CARVALHO, 2008; SILVA, 2008; CURY, 2010), ainda constituem uma forma de se avaliar o desempenho dos alunos do ensino fundamental no Brasil (FERNANDES; GREMAUD, 2009; FREITAS, 2012).

Os resultados dos testes padronizados funcionam como um termômetro da educação básica mostrando o nível da qualidade do ensino oferecido no país (HANUSHEK 2005). Deste modo, seus resultados são utilizados para ampliar a gama de informações e subsidiar a implementação de políticas públicas educacionais (HADDAD, 2008; KUSIAK, 2012) que quase sempre esbarram na limitação dos recursos destinados as escolas públicas brasileiras (ZOGHBI et al., 2009; DIAZ, 2012).

Nesse sentido, torna-se essencial o desenvolvimento de pesquisas que busquem identificar as principais práticas escolares que podem colaborar para um melhor desempenho dos alunos nos testes de avaliação em larga escala, pois elas contribuem para que os Secretários Municipais de Educação, escolas e os Diretores possam planejar e utilizar os recursos 
disponíveis de forma eficaz. "Diante deste cenário, pesquisadores brasileiros intensificam a busca pelos fatores que constituem escolas de qualidade e que influenciam no ensino" (TEIXEIRA, 2009, p. 232).

A abordagem dos principais estudos envolvendo a busca por fatores que impactam o desempenho dos alunos são em sua maioria de caráter quantitativo e qualitativo. Segundo GAME (2002), as pesquisas quantitativas aplicam como metodologia o modelo input-output (entrada-saída) procurando perceber se os recursos humanos, materiais e financeiros e as características dos alunos (as entradas) são capazes de acrescentar algo aos resultados escolares dos alunos (saídas). Para os autores, tal perspectiva possui como limitação o fato das escolas serem consideradas como "caixa-preta", na medida em que seus trabalhos internos, ou seja, os processos que levam aos resultados dos alunos e a organização de suas estruturas e esses fatores serem ignorados. Enquanto as pesquisas de caráter qualitativo buscam abrir a "caixa-preta" das escolas, por meio de estudos de caso, com a finalidade de conhecer seus processos internos e os fatores que impactam o desempenho dos alunos (GAME, 2002). A principal limitação desta abordagem é a impossibilidade de generalização dos resultados, dado pelo tamanho da amostra.

Com base neste contexto, Salgado Junior (2013) adotou uma metodologia quali-quantitativa que buscou fazer uso das características positivas das duas abordagens, de forma integrada e colaborativa. De acordo com esta metodologia, o autor utiliza a Análise Envoltória de Dados (DEA) para escolha e seleção das escolas eficientes e ineficientes em transformar investimento financeiro em desempenho na Prova Brasil. Após a seleção das escolas, o autor realiza um estudo de múltiplos casos nessas escolas a fim de conhecer seus processos internos e identificar as práticas que melhor contribuem para o desempenho dos alunos.

De maneira semelhante este trabalho fará uma adaptação da metodologia proposta por Salgado Junior (2013), ou seja, uma pesquisa de abordagem quali-quantitativa, a fim de estudar as escolas públicas municipais do ensino fundamental do estado de São Paulo. Este estudo é composto por duas etapas: a primeira corresponde à aplicação da técnica DEA, cuja finalidade é identificar as escolas eficientes e ineficientes em transformar investimento financeiro, nível socioeconômico (NSE) e infraestrutura em desempenho no IDEB, a segunda consiste na realização de um estudo de múltiplos casos nessas escolas, com o objetivo de 
compreender a influência das práticas administrativo-pedagógicas que melhor contribuam para o desempenho dos alunos.

Dada a importância econômica, social e política da educação para um país, ela se tornou um dos temas mais relevantes no meio acadêmico. As mudanças ocorridas na educação, a partir de 1990, não refletiram em melhoria na qualidade do ensino público, o que evidencia a necessidade de identificação dos fatores que contribui para a melhoria da qualidade da educação nas redes públicas de ensino.

Com foco no ensino fundamental e em escolas públicas municipais do estado de São Paulo, essa dissertação estuda a capacidade das escolas eficientes e ineficientes em transformar investimento financeiro, NSE e infraestrutura em desempenho no IDEB, a fim de identificar e compreender, por meio de estudo de múltiplos casos, a influência das práticas administrativopedagógicas que colaboram para um melhor desempenho dos alunos no IDEB.

\subsection{Problema de Pesquisa e Objetivos}

Conforme apresentado anteriormente, a educação é um fator importante para o crescimento e desenvolvimento no país em diversas esferas e, no caso do Brasil, o desempenho dos alunos e a qualidade de ensino são comparativamente inferiores a outros países. Desta forma, este estudo busca responder ao seguinte problema de pesquisa: Quais práticas podem influenciar, de maneira expressiva, o desempenho escolar dos alunos em escolas públicas municipais do ensino fundamental no estado de São Paulo no IDEB?

Para a obtenção da resposta do problema de pesquisa, são definidos o objetivo geral e os objetivos específicos deste trabalho. Segundo Richardson (2007), os objetivos, geral e específicos, devem ser extraídos diretamente do problema de pesquisa. Para o autor (2007, pp. 62-63), os objetivos gerais descrevem "o que se pretende alcançar com a realização da pesquisa" enquanto os objetivos específicos definem as "etapas que devem ser cumpridas para alcançar o objetivo geral”. 


\subsubsection{Objetivo geral}

Compreender a influência das práticas administrativo-pedagógicas no desempenho dos alunos de escolas públicas municipais do ensino fundamental do estado de São Paulo no IDEB.

\subsubsection{Objetivos específicos}

No intuito de atingir o objetivo geral foram definidos dois objetivos específicos, por meio dos quais se podem obter as informações necessárias a presente pesquisa.

- Identificar as escolas públicas municipais de ensino fundamental do estado de São Paulo eficientes em transformar investimento financeiro, NSE e infraestrutura em desempenho no IDEB para o ano de 2011;

- Realizar um estudo em profundidade em escolas eficientes e ineficientes, escolhidas por julgamento e conveniência, e localizadas no mesmo município das eficientes, dentre as que apresentaram características de NSE, tamanhos e investimentos financeiros similares às escolas eficientes. 


\section{Referencial Teórico}

Para a realização deste trabalho acadêmico é importante que sejam esclarecidas as bases teóricas necessárias para fundamentá-lo. Nesse sentido, foram definidas as seguintes bases teóricas: (1) conceituação básica sobre educação; (2) análise do Sistema Educacional Brasileiro, considerando sua evolução histórica, as características da educação no Brasil, fazendo uma comparação entre o ensino público e o ensino privado, além de destacar as características do ensino fundamental, bem como das escolas municipais e suas respectivas secretarias municipais de educação; (3) o impacto da educação no crescimento e desenvolvimento econômico dos países; (4) a importância da gestão escolar para a escola e desenvolvimento dos alunos; (5) a qualidade na educação e fatores de desempenho; (6) os aspectos relacionados à infraestrutura escolar; e (7) o sistema de avaliação da educação envolvendo a descrição de inúmeros indicadores como o SAEB, Prova Brasil, Indicadores de Rendimento, IDEB e PISA.

A análise de eficiência e desempenho, abordando em especial a técnica de Análise Envoltória de Dados (DEA) é apresentada na seção seguinte. Feitas tais considerações, as seções a seguir discorrem sobre os principais conceitos teóricos abordados nesta dissertação.

\subsection{Educação: conceitos básicos}

Um dos fenômenos mais significativos dos processos sociais contemporâneos é a ampliação do conceito de educação e a diversificação das atividades educativas (LIBÂNEO, 2001, p.3). Diante de tal importância se faz necessário conhecer as diversas definições da prática educativa encontrada na literatura, haja visto que a discussão acerca da conceituação da educação não pode ser compreendida a partir de uma definição simplificada e única (MACHADO, 2000, p. 3). O autor justifica sua posição afirmando que a busca por uma explicação única, que pudesse clarear a compreensão geral do fenômeno educacional, contraria a própria dinâmica científica e filosófica que há tanto tempo discute o tema.

Segundo Machado (2000), as diferentes definições sobre educação estão sendo discutidas no Brasil e em diferentes países do mundo a partir de estudos realizados por educadores, sociólogos, economistas, entre outros interessados. Nas pesquisas internacionais destacam-se 
os trabalhos de Calleja (2008) e Delors (2010), enquanto que no Brasil se sobressaem os estudos de Caria (1992), Libâneo (2001) e Silva e Santana (2007).

Libâneo (2001) em seu estudo sobre o papel fundamental da pedagogia, na discussão dos rumos da educação brasileira, define a educação como:

O conjunto dos processos, influências, estruturas e ações que intervêm no desenvolvimento humano de indivíduos e grupos na sua relação ativa com o meio natural e social, num determinado contexto de relações entre grupos e classes sociais, visando à formação do ser humano. A educação é, assim, uma prática humana, uma prática social, que modifica os seres humanos nos seus estados físicos, mentais, espirituais, culturais, que dá uma configuração à nossa existência humana individual e grupal (LIBÂNEO, 2001, p. 7).

Calleja (2008), de maneira semelhante, define a educação como uma ação desenvolvida sobre as pessoas que formam a sociedade, com a finalidade de capacitá-las de maneira integral, consciente, eficiente e eficaz, de modo que lhes permita formar um valor dos conteúdos adquiridos, relacionando diretamente com seu cotidiano, para atuar consequentemente a partir do processo educativo assimilado. Segundo o autor, o objetivo da educação é:

Preparar as pessoas para a vida, para desenvolver-se e contribuir para o desenvolvimento da sociedade em que vivem, e isso significa muito mais que possuir um acúmulo de conhecimentos de cultura geral, científica e técnica ou ser capaz de desenvolver um sistema de habilidades manuais e intelectuais; significa, sobretudo, ser capaz de adotar uma correta atitude diante da vida, com as melhores convicções humanas, com altos valores éticos, estéticos, morais e os mais puros sentimentos (CALLEJA, 2008, p. 113).

Dentro do contexto sociológico, Caria (1992) destaca que o conceito de educação mais atribuído a esta área é o de Émile Durkheim (1984), no qual a educação consiste em uma socialização metódica da nova geração pelas gerações adultas, tendo em vista realizar um certo ideal de homem que é, em certa medida, o mesmo para todos os cidadãos, pois a sociedade somente poderá viver se entre os seus membros existir uma suficiente homogeneidade. Para Caria (1992), esta abordagem está em contradição com o que é mais valorizado atualmente, pelo menos no campo científico, enquanto ação educativa: onde se busca uma ação não centrada no Professor e sim na diferenciação dos processos e estratégias com a finalidade de estimular a atividade e não a passividade do aluno, a heterogeneidade de experiências e percursos de aprendizagem e não a homogeneidade de aprendizagens. Entretanto, o autor afirma que são inegáveis as várias e relevantes contribuições, no campo da sociologia educacional, atribuídas a Durkheim, como por exemplo: (1) o ideal de cidadão que 
a escola pretende promover (ao dar autonomia para todos intervir, escolher e decidir de maneira autônoma sobre o seu presente e futuro, dando igualdade de oportunidades a todos), (2) o poder de impor o modo como esse ideal de homem se realiza através da escola e (3) o poder de repensar esse ideal de cidadão a ser formado, procurado e realizado. Caria (1992) finaliza destacando o papel fundamental da sociologia ao contribuir para a conceitualização da educação, pois a sociologia da educação não deve ser entendida apenas como um ramo especializado da sociologia, mas também como uma das ciências constitutivas de um projeto referente a uma ciência da educação.

Em relação à pedagogia tradicional, Silva e Santana (2007) destaca que o conceito de educação é extremamente subordinado à rígida formação moral, na qual a ignorância figura o ápice de desescolarização. Para os autores esse fato nos remete a ideia de que a educação se define como um processo exclusivo de superação da marginalidade por meio da escola, com seus rígidos métodos de disciplina e o conhecimento focado exclusivamente no Professor.

A maioria dos Professores por sua vez define que a educação corresponde a duas ideias centrais (embora nem sempre associadas): “ensinar, no sentido de transmitir informações e conhecimentos escolares disciplinares, e socializar, no sentido de demonstrar normas de conduta de bom comportamento no trato com os adultos" (CARIA, 1992, p.172). Silva e Santana (2007) também afirmam que é bastante usual ouvirmos dos Professores que a educação se resume à escola e se limita apenas a seus muros, ou que a educação vem de casa e é obrigação exclusiva dos pais. Os autores contrariam esta ideia, de modo que a educação não se limita nem ao ensino escolar e muito menos à educação familiar, e sim a um conjunto de fatores dentro das diferentes situações encontradas no cotidiano. Mizukami (1986) corrobora com tal conclusão ao afirmar que:

Há várias formas de conceber o fenômeno educativo. Por sua própria natureza, não é uma realidade acabada que se dá a conhecer de forma única e precisa em seus múltiplos aspectos. É um fenômeno humano, histórico e multidimensional. Nele está presente tanto a dimensão humana quanto a técnica, a cognitiva, a emocional, a sócio-política e cultural. Não se trata de mera justaposição das referidas dimensões, mas sim, da aceitação de suas múltiplas implicações e relações (MIZUKAMI, 1986, p. 01).

Dentro deste contexto, que envolve a complexidade de conceber o fenômeno educativo, Silva e Santana (2007) afirmam que a reflexão acerca do conceito de educação deve ser contínua e 
alentada, de modo a preceder uma elaboração sólida dos seus objetivos e valores, conforme o momento histórico e político em que está inserido.

Calleja (2008) ressalta que, embora haja inúmeras definições sobre educação, geralmente existem muitos pontos em comum entre elas, especialmente aquelas que colocam o indivíduo como sujeito no centro da atividade, e caracterizam a educação como um processo de influência sobre o desenvolvimento das pessoas, a fim de conduzi-las a sua transformação e capacitação para interagir com a sociedade.

Diante de tais considerações, é evidente o papel da educação sobre o desenvolvimento dos indivíduos e consequentemente da sociedade. Delors (2010) corrobora com tal constatação ao destacar que mais do que nunca a educação parece, como papel essencial, conferir a todos os seres humanos a liberdade de pensamento, discernimento, sentimentos e imaginação do que necessitam para desenvolver os seus talentos e permanecerem, tanto quanto possível, donos do seu próprio destino.

\subsection{Sistema Educacional Brasileiro}

A educação no Brasil é um direito constitucional assegurado pelo art. 205 da Constituição Federal de 1988 que garante a educação como um direito de todos e dever do Estado e da família e será promovida e incentivada com a colaboração da sociedade, visando ao pleno desenvolvimento da pessoa, seu preparo para o exercício da cidadania e sua qualificação para o trabalho (CURY, 2002).

Com base na Constituição Federal de 1988, e apoiado por grandes mudanças na década de 1990, o Brasil conseguiu promover a universalização do acesso ao ensino fundamental e a expansão do ensino médio (OLIVEIRA, 2007; VELOSO, 2011; BRASIL, 2012). Contudo, anteriormente a este período, o acesso à educação sempre foi restrito, beneficiando em alguns momentos da história, apenas determinadas classes sociais.

Deste modo, para melhor compreender o sistema educacional brasileiro, esta seção está dividida nas seguintes subseções: 2.2.1 Evolução Histórica (da educação no Brasil); 2.2.2 
Características da Educação no Brasil; 2.2.3 Ensino Público e Privado; 2.2.4 Ensino

Fundamental; 2.2.5 Escolas Municipais e 2.2.6 Secretaria Municipal de Educação.

\subsubsection{Evolução Histórica}

A educação no Brasil apresenta características específicas em seus diversos momentos históricos. Em grande parte da história do Brasil, o acesso à educação era restrito e concentrava-se apenas em uma pequena elite latifundiária, aristocrata e escravocrata. De acordo com Ribeiro (1993),

o período colonial brasileiro, baseado na grande propriedade e na mão-deobra escrava, contribuiu para o florescimento de uma sociedade altamente patriarcal caracterizada pela autoridade sem limite dos donos de terras. [...] Uma sociedade latifundiária, escravocrata e aristocrática, sustentada por uma economia agrícola e rudimentar, não necessitava de pessoas letradas e nem de muitos para governar, mas sim de uma massa iletrada e submissa. $\mathrm{Na}$ primeira metade do século XVIII, Portugal era administrado com "mão de ferro" pelo Marques de Pombal, que fez uma série de reformas educacionais que repercutiram no Brasil. Tirou o poder educacional da Igreja e colocou-o nas mãos do Estado, criando assim, um ensino pelo e para o Estado (RIBEIRO, 1993, pp. 15-16).

Com a vinda da família real para o Brasil em 1808, foram verificadas mudanças no quadro das instituições educacionais da época, contudo mantendo as intenções aristocráticas de D. João VI, pois o ensino primário foi esquecido e a população em geral continuou iletrada e sem acesso ao conhecimento, o que os tornaria mais fáceis de governar (RIBEIRO, 1993).

As instituições políticas no Brasil durante o período colonial restringiram a participação política para poucos políticos eleitos de maneira não democrática. Assim, embora no papel independente, em 1821, o Brasil adotou uma monarquia constitucional com uma clara divisão de poder, um parlamento eleito, um imperador, eleições indiretas com parlamentares (senadores e deputados) eleitos pelos colégios eleitorais estaduais. A participação eleitoral foi restringida por uma exigência de renda, que era a renda de um ano para a maioria das profissões qualificadas (MUSACCHIO; MARTINEZ-FRITSCHER; VIARENGO, 2012).

Após a independência em 1822, a oferta de ensino fundamental no Brasil foi descentralizada. Segundo Ribeiro (1993) e Chaudhary et al. (2012), a Constituição de 1824 e o Ato Adicional de 1834 transferiram para os estados a obrigação de fornecer educação primária, financiado publicamente com algumas transferências provenientes do governo central. Na Monarquia, 
contudo, deu-se muito valor ao ensino superior, refletindo a necessidade de pessoal capacitado para preencher os quadros administrativos do país, que tinha acabado de ficar independente politicamente. Assim, com relação às mudanças legislativas no período, Ribeiro (1993) aponta que,

[...] o ato Institucional de 1834 descentralizou a responsabilidade educacional. Às províncias, caberia o direito de legislar e controlar o ensino primário e médio, e ao poder central se reservou a exclusividade de promover e regulamentar o ensino superior. A preferência dos estudantes por Direito e as duas escolas existentes, uma em São Paulo e outra em Recife, fizeram com que o currículo do nível médio se submetesse ao currículo destas faculdades. [...] No século XIX, uma das caraterísticas do ensino secundário, era a de se voltar totalmente para o preparo dos alunos para o ingresso na escola superior, devido à pressão exercida pela classe dominante que desejava que seus filhos fossem reconhecidos rapidamente como "os homens cultos do país" (RIBEIRO, 1993, p. 17).

Ainda que o governo central enviasse recursos para os Estados, estes recursos, no entanto, eram relativamente baixos (devido ao direcionamento de recursos do governo para o ensino superior), fazendo com o que os Estados também fossem responsáveis pelo financiamento da educação. Como consequência, o nível global dos gastos e matrículas se manteve baixo entre 1824 e 1891, favorecendo a elite oligárquica de cada região. Neste sentido,

[...] a oferta de educação foi limitada durante o período imperial (1821-1889) porque, apesar da centralização da tributação e gastos, os membros do Congresso que elaboraram a Constituição de 1824 optaram por descentralizar a oferta de educação. Portanto, a partir de 1824 em diante, o governo imperial estava focado principalmente na oferta de educação na capital do país e em subsidiar algumas universidades pelo país, enquanto os governos provinciais ficaram responsáveis pelo ensino fundamental e médio em seus próprios territórios (MUSACCHIO; MARTINEZ-FRITSCHER; VIARENGO, 2012, p. 5).

Os primeiros dados sobre educação, publicados no início da década de 1870, mostram que os gastos com criança em idade escolar eram inferiores à US\$ 0,30 e as taxas de inscrição foram de aproximadamente $12 \%$ da população em idade escolar (CHAUDHARY et al., 2012). Segundo Musacchio, Martinez-Fritscher e Viarenho (2012), a adoção de um modelo em que os governos provinciais pudessem direcionar seus recursos para o ensino fundamental e médio fez com que as elites provinciais direcionassem os recursos para educação beneficiando principalmente os filhos das elites, o que explica em parte o elitismo e o baixo índice de alfabetização no período. 
Em 1879, Leôncio de Carvalho, Ministro da Administração Interna, enviou um projeto de lei para reformar o sistema de educação do país para o Congresso, que introduziu a educação secular e determinou a criação de escolas de educação para formar Professores. Os resultados da educação melhoraram gradualmente na maioria dos estados depois destas reformas, mas mudanças significativas na infraestrutura escolar, número de Professores, e o currículo não ocorreram até que os partidos Republicanos assumissem os governos estaduais na década de 1890, financiando a difusão de escolas de ensino fundamental em todos os estados (MUSACCHIO; MARTINEZ-FRITSCHER; VIARENGO, 2012).

De acordo com Martinez-Fritscher, Musacchio e Viarengo (2010), com o fim do império e o início do período republicano, ocorridos em 1889, e a adoção da nova Constituição (em 1891), houve uma significativa descentralização das finanças públicas brasileira, fazendo com que os estados aumentassem significativamente suas receitas. Segundo os autores, a Constituição deu autonomia para os municípios organizar as finanças públicas, cobrar impostos e direcionar os gastos (como por exemplo, em educação). Com estas mudanças, o sistema de ensino fundamental no Brasil melhorou progressivamente ao longo das quatro décadas da República (1889-1930), sendo que, com a descentralização e maior autonomia dos estados, a maior parte dos investimentos em educação veio dos governos estaduais. Chaudhary et al. (2012) destacam que:

[...] os estados usaram sua nova autoridade fiscal para aumentar o financiamento da educação e a alfabetização aumentou de menos de $20 \%$ para $40 \%$, e as taxas de escolarização passaram de $12 \%$ para $23 \%$ em 1930 , 23 níveis de educação, no entanto, ainda eram baixos em comparação com outros países, e os gastos por população em idade escolar eram pequenos (CHAUDHARY et al., 2012, p. 229).

Os primeiros anos da República caracterizaram-se por várias propostas educacionais, visando à inovação do ensino, a maioria das propostas não foi colocada em prática, como a reforma proposta por Benjamin Constant que, dentre outras mudanças, propunha a inclusão de disciplinas científicas nos currículos e dava maior organização aos vários níveis do sistema educacional. As principais mudanças e reformas na educação, tanto em nível superior quanto no ensino secundário são realizadas apenas com a chegada de Getúlio Vargas no poder, em 1930 (RIBEIRO, 1993). Segundo Ribeiro (1993),

Em 1930, é criado o Ministério da Educação e Saúde, cuja pasta é ocupada por Francisco Campos. A 11 de abril de 1930 tem lugar uma reforma no ensino superior, quando é organizado o sistema universitário, sendo logo em seguida a vez da reforma do ensino secundário. Mas estas reformas não são 
tão amplas e sente-se, ainda, a falta de medidas mais abrangentes. A reforma do secundário teve o mérito de dar-lhe organicidade, estabelecendo definitivamente o currículo seriado, a frequência obrigatória, dois ciclos, um fundamental de cinco anos e outro complementar de dois anos, e a exigência de habilitação neles para ingresso no curso superior. No superior, a reforma foi mais a nível administrativo. Criou órgãos, tais como reitoria, conselho universitário, assembleia universitária e direção de cada escola (RIBEIRO, 1993, p. 21).

Segundo Schwartzman e Brock (2005), corroborando com Ribeiro (1993), a educação no Brasil se tornou prioridade nacional apenas com a revolução de 1930 e a chegada de Getúlio Vargas ao poder. De acordo com os autores, o novo governo foi o responsável pela criação do primeiro Ministério da Educação, a criação do primeiro centro brasileiro de estudos e pesquisa sobre a educação, o Instituto Nacional de Estudos Pedagógicos (INEP) e o desenvolvimento do Manifesto dos Pioneiros da Nova Educação, que tinha como principal objetivo ditar as prioridades para o ensino nos anos posteriores, com propostas que tratavam tanto da maneira como deveria ser o ensino, através da participação ativa do aluno no processo de aprendizagem, quanto da maneira de organizar a educação, por meio da abertura de universidades públicas e do ensino básico gratuito, universal e obrigatório, e da formação de Professores em instituições em nível universitário.

Redigido por Fernando de Azevedo e assinado por conceituados educadores, como Anísio Teixeira, o Manifesto dos Pioneiros da Nova Educação, de 1932, propunha que o Estado organizasse um plano geral de educação e definisse a bandeira de uma escola única, pública, laica, obrigatória e gratuita. No entanto, foi apenas com a nova Constituição, promulgada em 1934, que a educação passa a ser vista como um direito de todos, devendo ser ministrada pela família e pelos poderes públicos.

De 1934 a 1945, o Ministério da Educação e Saúde promove uma gestão marcada pela reforma dos ensinos secundário e universitário, implantando as bases da educação nacional e, em 1953, com a autonomia dada à área da saúde (com a criação do Ministério da Saúde), surge o Ministério da Educação e Cultura (MEC, 2014). Segundo Ribeiro (1993),

A Constituição de 1934 dedica um capítulo à Educação e atribui à União, a competência privativa de traçar as diretrizes educacionais do país. Criam-se os Conselhos Nacionais e Estaduais de Educação, determina-se um mínimo de verbas a serem aplicadas para o ensino, reconhecimento da Educação como direito de todos, obrigatoriedade do ensino primário, assistência social e bolsas de estudo aos alunos (RIBEIRO, 1993, p. 22). 
Na década de trinta a educação foi estruturada de forma que o ensino primário, que deveria ser obrigatório e universal, durava quatro anos, dos sete aos dez anos de idade. Era seguido do ginásio, considerado como ensino secundário na época e que também durava quatro anos. Chegava-se, por fim, ao nível colegial, que durava de dois a três anos, concebido como curso preparatório para as universidades. As concepções, os formatos institucionais e as práticas estabelecidas durante o regime de Getulio Vargas representaram um grande avanço para a educação no Brasil e iriam moldar o ensino brasileiro por muitas décadas (SCHWARTZMAN; BROCK, 2005).

De acordo com o MEC (2014), o sistema educacional brasileiro até 1960 era centralizado e o modelo era seguido por todos os estados e municípios. Com a aprovação da primeira Lei de Diretrizes e Bases da Educação (LDB), em 1961 durante o regime parlamentarista, os orgãos estaduais e municipais passaram a ganhar mais autonomia, diminuindo a centralização do Ministério da Educação e Cultura (BRASIL, 1961; HORTA NETO, 2007). De acordo com Costa (2010), a LDB, Lei 4.024 de 1961, foi criada com o objetivo de oferecer uma educação de qualidade e igualitária como direito de todos, bem como integrar toda a legislação sobre educação escolar no Brasil, que até então era fragmentada em diversas leis.

Entre os diversos temas de que tratava a LDB de 1961, Lei 4.024/61, destaca-se a primeira referência de um instrumento legal ao termo: qualidade da educação. No seu artigo 96, a Lei determinava que o Conselho Federal de Educação e os conselhos estaduais de educação desenvolveriam esforços para melhorar a qualidade e elevar os índices de produtividade do ensino em relação ao seu custo: promovendo a publicação anual das estatísticas do ensino e dados complementares, para serem utilizados na elaboração dos planos de aplicação de recursos para o ano subsequente e estudando a composição de custos do ensino público e propondo medidas adequadas para ajustá-lo ao melhor nível de produtividade (BRASIL, 1961).

Para Castro e Duarte (2008), a LDB reconhece a autonomia dos estados e municipios como unidade federada, atribuindo-lhes importantes responsabilidades na área educacional. De acordo com os autores cada esfera do governo possui suas competências, onde, a união é responsável por assegurar anualmente, em seu orçamento geral, recursos suficientes para manutenção e desenvolvimento das instituições de educação por ela mantidas. Enquanto que 
os estados devem definir, com os municípios, formas de colaboração na oferta do ensino fundamental, as quais devem assegurar a distribuição proporcional das responsabilidades, de acordo com a população a ser atendida e os recursos financeiros disponíveis em cada uma das esferas do poder público. Já aos municípios cabem organizar, manter e desenvolver os orgãos e instituições oficiais dos seus sistemas de ensino, integrando-os às políticas e planos educacionais da união e dos estados.

De acordo com Cerqueira et al. (2009) a LDB $\mathrm{n}^{\circ} 4.024 / 61$ foi reformada pela LDB $\mathrm{n}^{\circ}$ 5.692/71 e posteriormente substituída pela LDB n ${ }^{\circ}$ 9.394/96 ${ }^{1}$. Para os autores todo esse processo de transformação no texto regulamentar e legislatório da lei 4.024/61 ocorreu para atender as modificações das necessidades educacionais que foram surgindo ao longo do tempo e marcaram o progresso das diretrizes e bases nacionais da educação.

Em 1971, foi estabelecida a $\operatorname{LDB} \mathrm{n}^{\circ}$ 5.692, que correspondia a uma nova versão da $\mathrm{LDB}$ anterior, com a intenção de transformar a formação educacional num cunho profissionalizante, reforçando os princípios da constituição (COSTA 2010). Já Cerqueira et al. (2009), destacam que para atender as demandas do ensino primário e médio foi necessária uma nova reforma, instituída pela Lei 5.692/71, que alterou a sua denominação para ensino de $1^{\circ}$ e $2^{\circ}$ graus (BRASIL, 1971). Desta forma, as disposições previstas na Lei de Diretrizes e Bases da Educação Nacional $n^{\circ} 4.024 / 61$, relativas ao primário, médio e superior foram revogadas e substituídas pelo disposto na nova lei sancionada pelo congresso.

Segundo MEC (2014), a nova reforma na Lei $n^{\circ}$ 9.393/96 trata-se da mais recente LDB, que trouxe diversas mudanças às leis anteriores, com a inclusão da educação infantil (creches e pré-escola) e a formação adequada dos profissionais da educação básica. De acordo com Costa (2010), a LDB aprovada em 1996 norteia a educação básica no Brasil, define e regulariza o sistema de educação brasileiro com base nos princípios presentes na constituição. Dentre eles está o que prevê a garantia de padrão de qualidade da educação. A LDB ainda traça os princípios educativos especificando os níveis e modalidades de ensino, regulando a estrutura e o funcionamento do sistema de ensino nacional.

\footnotetext{
${ }^{1}$ Com a reformulação da lei em 1996 (Lei 9.394/96), a responsabilidade da qualidade do ensino passou a ser da União que revogou vários artigos da primeira LDB de 1961, sendo que, segundo os artigos $8^{\circ}$ e $9^{\circ}$ desta nova lei a organização dos respectivos sistemas de ensino serão feitas em regime de colaboração pela União, os Estados, o Distrito Federal e os Municípios (BRASIL, 1996).
} 
Segundo Cerqueira et al. (2009), a LDB n 9.394/96 não impossibilita adaptações de melhoria para a educação nacional, mesmo sendo a mais completa legislação em favor da educação já redigida. Para os autores, tal característica proporcionou à educação importantes avanços, como a criação do Fundo de Manutenção e Desenvolvimento do Ensino Fundamental e Valorização do Magistério (FUNDEF) e a instituição de alguns programas do governo federal visando à promoção do acesso ao ensino superior.

Segundo Oliveira (2011), a prática da avaliação educacional sistêmica tornou-se uma tarefa estatal somente por meio da LDB $\mathrm{n}^{\circ}$ 9.394/96, sendo realizada com o intuito de garantir a melhoria da qualidade do ensino e a avaliação educacional. Mesmo sendo vista por muitos autores como a mais importante Lei sobre a educação, a LDB não está imune a críticas. Segundo Cerqueira et al. (2009), a Lei 9.394/96, apesar de propor inovações, não gerou efetivo acesso a uma educação de qualidade a uma expressiva parcela da população que fica excluída também de outros processos sociais. Os autores ainda afirmam que permanecem inconclusos os temas relacionados à busca pela melhoria da qualidade educacional, formação e aperfeiçoamento dos docentes, autonomia universitária e universalização do ensino fundamental.

\subsubsection{Características da Educação no Brasil}

A educação no Brasil é caracterizada por um sistema de ensino misto, com instituições mantidas pelo poder público, pela iniciativa privada e por órgãos de educação, com um ciclo formado por quatro etapas: educação infantil, ensino fundamental, médio e o ensino superior (BRASIL, 1996), sendo que o conjunto composto da educação infantil, fundamental e média é denominado como educação básica.

Também complementam o ciclo educacional os cursos de alfabetização e educação continuada de jovens e adultos (EJA) e os cursos técnicos e técnicos de nível médio (BRASIL, 2012). O Quadro 1 apresenta dados do ciclo educacional brasileiro. 


\begin{tabular}{|c|c|}
\hline Nível Escolar & Faixa Etária \\
\hline Creche & 0 aos 3 anos. \\
\hline Ensino Infantil & 4 e 5 anos. \\
\hline Ensino Fundamental & De 6 a 14 anos. \\
\hline Ensino Médio & De 15 a 17 anos. \\
\hline Ensino Superior & A partir dos 18 anos. \\
\hline
\end{tabular}

\section{Quadro 1 - Ciclo educacional brasileiro}

Fonte: BRASIL (2012)

O Brasil possui grandes números em se tratando de educação. O total de alunos na educação básica em 2012 foi de 50,5 milhões, sendo que 83,5\% desse total de alunos (42,2 milhões) estudam nas redes públicas e 16,5\% (8,3 milhões) em escolas privadas (INEP, 2013). Além disso, o Brasil tem o maior programa de merenda escolar e de distribuição gratuita de livros didáticos do mundo (BRASIL, 2012).

Referente aos níveis de ensino no ano de 2012, o ensino fundamental possui 29,7 milhões de alunos matriculados, sendo que as redes municipais detêm $68,2 \%$ desses alunos, enquanto as redes estaduais atendem $16,3 \%$ e as privadas $15,5 \%$. Já o ensino médio totalizou o montante de 8,3 milhões de alunos, onde a rede estadual é responsável por $85 \%$ desse total de estudantes, enquanto que a rede privada atende $12,7 \%$ e as redes federal e municipal atendem juntas 2,3\% do total de alunos (INEP, 2013). O Gráfico 1 apresenta a evolução de crianças matriculadas em creches (idade entre 0 e 3 anos).

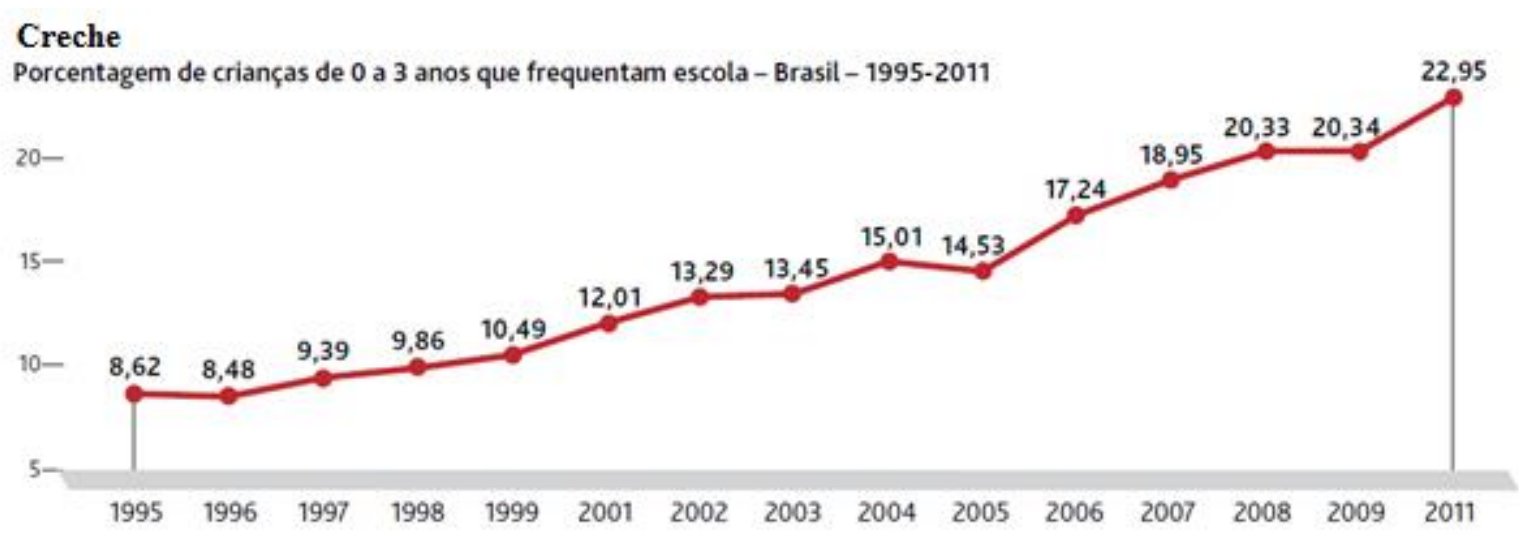

Gráfico 1 - Porcentagem de crianças de 0 a 3 anos que frequentam escola

Fonte: IBGE/PNAD, elaborado por Cruz e Monteiro (2014) 
Conforme apontado anteriormente, a partir da década de 1990 houve uma universalização do ensino, que refletiu no aumento do número de estudantes matriculados em escolas, tanto no ensino infantil, quanto no ensino fundamental e médio.

De acordo com o Gráfico 2, Cruz e Monteiro (2014) apontam que entre 1995 e 2011 o percentual de crianças entre 4 e 5 anos (Ensino Infantil) que frequentam escola aumentou cerca de 69,9\%, sendo que em 2011 o número de crianças matriculadas representavam $81,69 \%$.

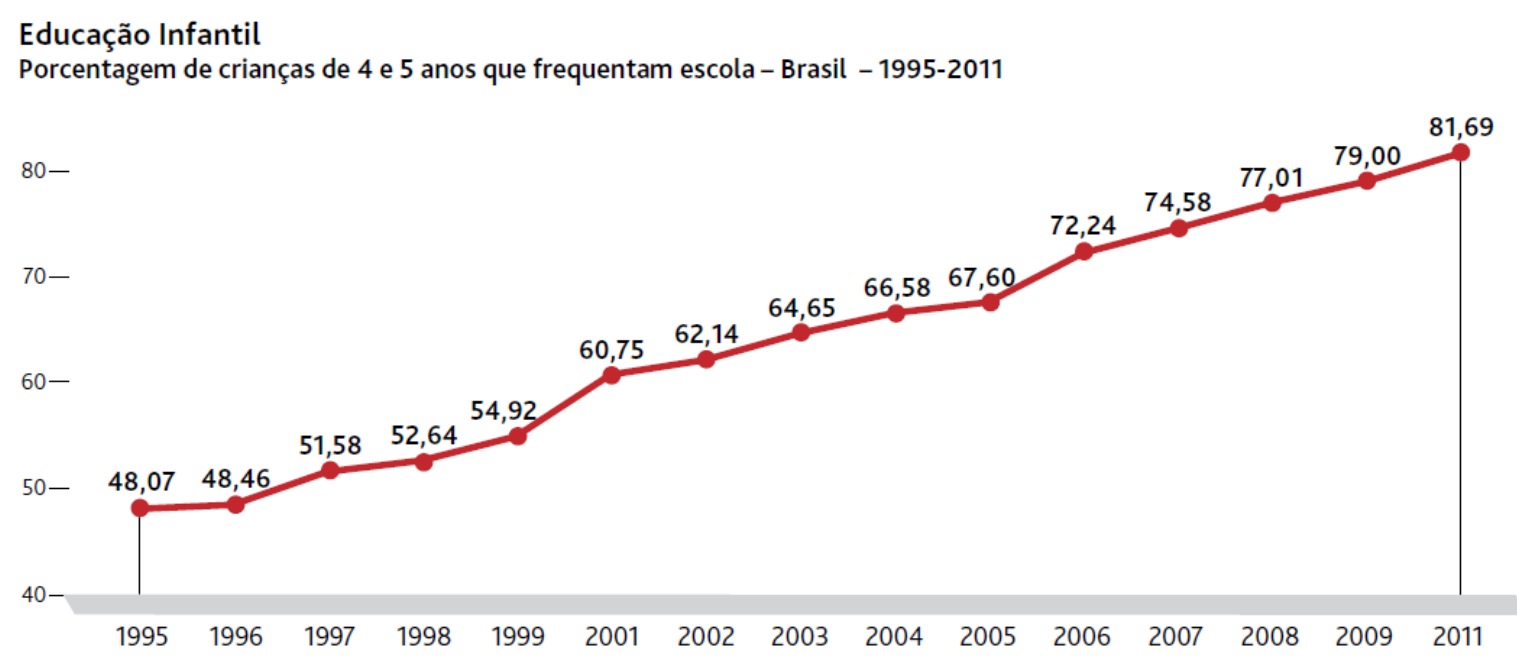

Gráfico 2 - Porcentagem de crianças de 4 e 5 anos que frequentam escola Fonte: IBGE/PNAD, elaborado por Cruz e Monteiro (2014)

No ensino fundamental o crescimento também foi constatado, fazendo com que o número de estudantes matriculados (de 7 a 14 anos) atingisse o patamar de 94,6\% no ano de 2011, conforme é apresentado pelo Gráfico 3. 
Ensino Fundamental

Taxa de matrícula líquida no ensino fundamental - Brasil - 1992-2011

7 a 14 anos $\multimap 6$ a 14 anos

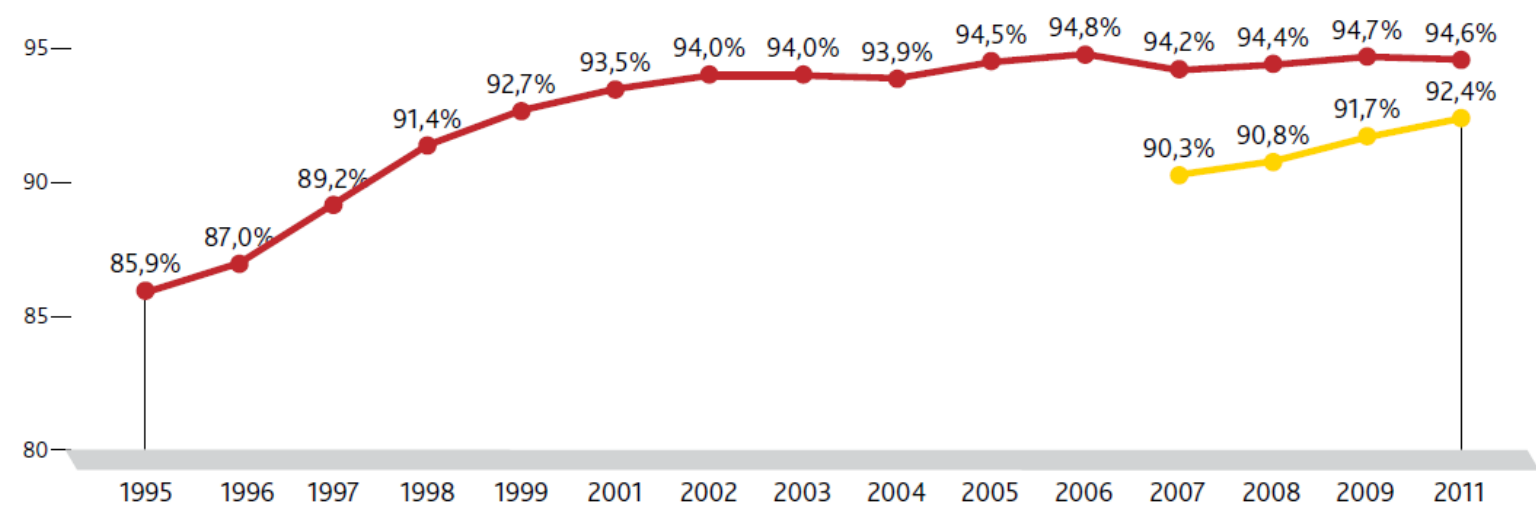

Gráfico 3 - Porcentagem de estudantes de 7 a 14 anos que frequentam escola

Fonte: IBGE/PNAD, elaborado por Cruz e Monteiro (2014)

Os dados do ensino médio (estudantes de 15 a 17 anos), no entanto foram os mais significativos. Entre 1995 e 2011 o aumento da taxa de matrícula foi de 122,4\%, refletindo a universalização do ensino ocorrida a partir de 1990, conforme apresentado no Gráfico 4.

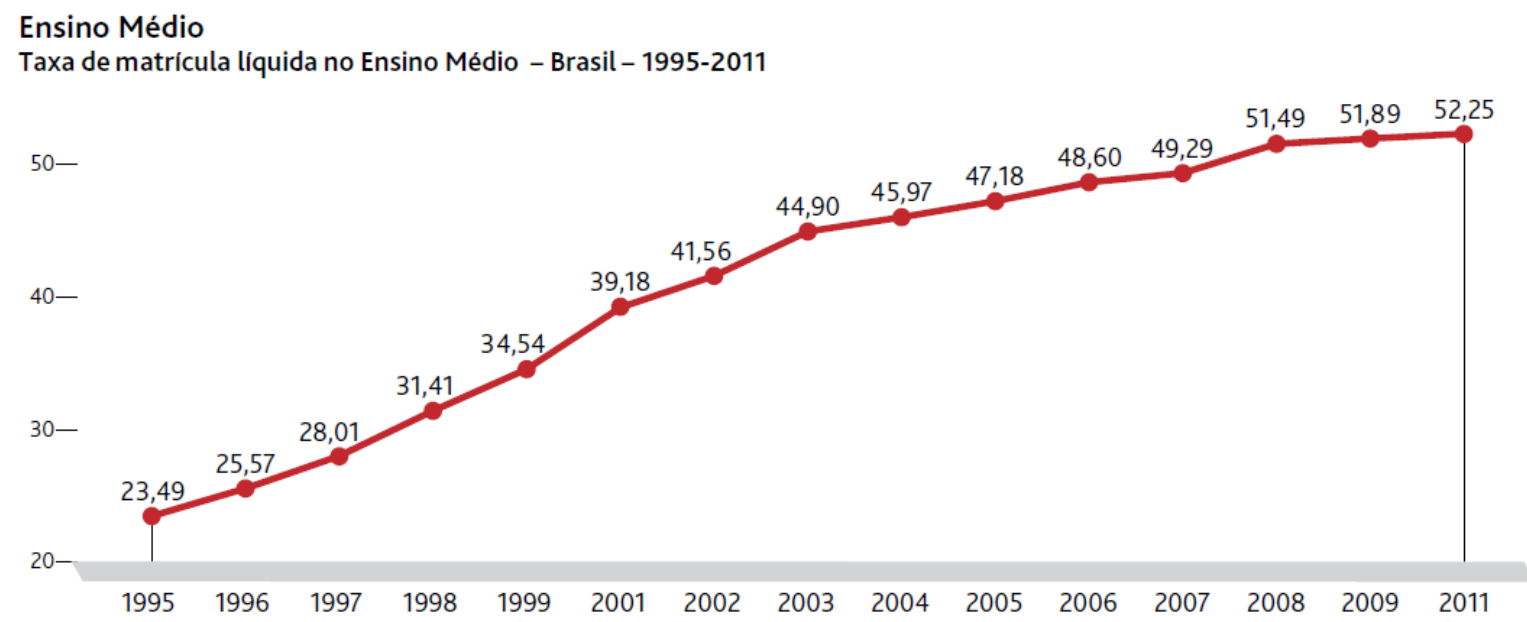

Gráfico 4 - Porcentagem de estudantes de 15 a 17 anos que frequentam escola Fonte: IBGE/PNAD, elaborado por Cruz e Monteiro (2014)

Ao analisar os estabelecimentos por dependência administrativa, nota-se uma maior concentração de estabelecimentos municipais destinados à educaçao infantil $(73,78 \%)$ e ao ensino fundamental $(67,31 \%)$, enquanto no ensino médio as escolas estaduais representam $68,22 \%$ do total de instituições de ensino. A Tabela 1 apresenta os dados dos estabelecimentos por dependência administrativa. 
Tabela 1 - Estabelecimentos por dependência administrativa (2011)

\begin{tabular}{lccccc}
\hline & Federal & Estadual & Municipal & Privada & Total \\
\hline Educação Infantil & 23 & 1.216 & 85.012 & 28.972 & 115.223 \\
Ensino Fundamental & 46 & 26.595 & 98.440 & 21.160 & 146.241 \\
Ensino Médio & 328 & 18.381 & 444 & 7.791 & 26.944 \\
\hline
\end{tabular}

Fonte: IBGE/PNAD, elaborado por Cruz e Monteiro (2014)

Com relação aos alunos matriculados por dependência administrativa, observa-se que as escolas municipais representam 70,98\% das matrículas na educação infantil e que as escolas públicas representam $86,49 \%$ das matrículas do ensino fundamental, sendo que as instituições municipais representam 54,44\% das matrículas enquanto as instituições estaduais representam $31,97 \%$. No ensino médio, as instituições estaduais absorvem cerca de 85,5\% das matrículas. As instituições de ensino privado, com menor participação, detêm 28,06\% das matrículas da educação infantil, $13,51 \%$ do ensino fundamental e 12,17\% do ensino médio. Os dados das matrículas por dependência administrativa são apresentados na Tabela 2.

Tabela 2 - Matrículas por dependência administrativa (2011)

\begin{tabular}{lccccc}
\hline & Federal & Estadual & Municipal & Privada & Total \\
\hline Educação Infantil & 2.552 & 64.652 & 4.954 .341 & 1.958 .507 & 6.980 .052 \\
Ensino Fundamental & 25.096 & 9.705 .014 & 16.526 .069 & 4.102 .461 & 30.358 .640 \\
Ensino Médio & 114.939 & 7.182 .888 & 80.833 & 1.022 .029 & 8.400 .689 \\
\hline
\end{tabular}

Fonte: IBGE/PNAD, elaborado por Cruz e Monteiro (2014)

Considerando que o ensino público e privado apresentam características diferentes, a subseção a seguir discute a comparação entre os dois tipos de dependência administrativa: público (Federal, Estadual e Municipal) e privado.

\subsubsection{Ensino Público e Privado}

Como no Brasil existe a possibilidade de se estudar tanto no ensino público quanto no privado, a todo o momento surgem questionamentos sobre qual sistema de ensino é melhor, ou seja, qual consegue oferecer uma educação de melhor qualidade aos seus alunos. MenezesFilho (2007) mostra em seu trabalho os resultados da comparação de desempenho dos alunos das escolas públicas e privadas sobre várias condições e conclui que, sem levar em conta as 
diferenças de background familiar e infraestrutura, os alunos das escolas privadas obtêm em média um desempenho 50\% superior aos alunos de escolas públicas. O desempenho, por sua vez é alterado quando são levadas em conta as diferenças socioeconômicas entre as famílias e controles para variáveis escolares, tais como infraestrutura e características dos Professores e dos Diretores. Segundo o autor:

[...] quando levamos em conta as diferenças socioeconômicas entre as famílias, esta diferença cai para $17 \%$. Quando adicionamos os controles para variáveis escolares, tais como infraestrutura e características dos Professores e dos Diretores, o diferencial aumenta ligeiramente. Quando controlamos pela educação média dos pais dos alunos (para tentar capturar um efeito de ambiente, também chamado "peer effects") o diferencial retorna para o nível de $18 \%$. Assim, parece que os alunos das escolas privadas têm um desempenho $18 \%$ superior em média aos das escolas públicas, mesmo levando-se em conta todas as características observáveis que poderiam explicar esta diferença, ao nível dos alunos, famílias, infraestrutura, Professores, Diretores e ambiente escolar. Uma hipótese explicativa para esse resultado é que as escolas privadas teriam um sistema de gestão mais efetivo (MENEZES FILHO, 2007, pp. 10-11).

Soares e Alves (2003) também corroboram com tais resultados ao destacar em seu estudo, sobre as desigualdades raciais no sistema brasileiro de educação, que mesmo após equalizar as diferenças socioeconômicas dos alunos ainda se observa um melhor desempenho dos alunos da rede privada em relação aos da rede pública.

Soares (2004) ao tentar explicar as diferenças existentes no desempenho das escolas públicas e privadas afirma que as escolas públicas não conseguem atrair Professores adequadamente preparados em várias disciplinas, principalmente nas áreas de ciências e matemática, e têm de conviver com pessoas que não querem ou não deveriam ficar naquela escola. Para o autor, tais restrições são difíceis de serem contornadas nos sistemas públicos de ensino, enquanto são resolvidas facilmente nos sistemas privados. Para Menezes-Filho (2007), uma das hipóteses explicativas para tais diferenças é que as escolas privadas possuem um sistema de gestão mais efetivo do que as escolas públicas. Soares (2004) ainda destaca que uma das maiores disparidades entre escolas públicas e privadas está na quantidade dos recursos financeiros aplicados em cada rede de ensino, pois o valor anual gasto com cada aluno de escola pública é frequentemente menor do que uma mensalidade de escola particular.

A disparidade entre as duas redes de ensino (pública e privada) contribui para que o Brasil tenha uma educação pública de baixa qualidade, livre de um lado, e uma privada de melhor qualidade de ensino em outro (OLIVEIRA, BELLUZO, PAZELLO, 2013). 
Sacavino (2006) de maneira semelhante afirma que no Brasil há uma tendência de manter um sistema público de ensino deficiente de maneira extensiva para os pobres, e um sistema privado paralelo, cada vez mais sofisticado para os ricos. Segundo o autor, esse processo vem acarretando a formação de uma nova forma de exclusão social não mais marcada pela falta de vagas, mas sim pela baixa qualidade do ensino oferecido, afetando principalmente a formação de parte da população menos favorecida.

Para o Grupo de Avaliação e Medidas Educacionais (GAME) da Universidade Federal de Minas Gerais (UFMG), as escolas públicas tornaram-se o espaço das classes menos favorecidas social e economicamente e as escolas privadas passaram a receber as classes no topo da pirâmide social (GAME, 2002).

Dado as diferenças existentes entre os alunos das escolas públicas e privadas, Akkari (2001) afirma que no Brasil o mercado educacional não é concorrencial, uma vez que cada rede de ensino tem seu público e clientes próprios. O autor ainda destaca que é comum, como estratégia familiar, que muitas famílias de classe média alta matriculem seus filhos em escolas públicas no ensino fundamental, transferindo-os para escolas privadas no ensino médio, buscando uma formação mais sólida na preparação para o vestibular, o que tende a não ocorrer em famílias de classe média baixa em que os alunos tendem a estudar durante o ensino médio em escolas públicas. A mobilidade entre as escolas públicas e privadas é determinada, principalmente, pelo poder aquisitivo das famílias, sendo que no Brasil grande parte das famílias com baixa renda depende, como única alternativa, de escolas públicas estaduais e municipais (AKKARI, 2001).

\subsubsection{Ensino fundamental}

O ensino fundamental corresponde a uma das quatro etapas que compõe o ciclo educacional brasileiro. Conforme destacado anteriormente a educação brasileira é composta pela educação infantil, que atende crianças de quatro e cinco anos; ensino fundamental ${ }^{2}$, com crianças de seis a quatorze anos; ensino médio, com alunos de quinze a dezessete anos e o ensino

\footnotetext{
${ }^{2}$ No Brasil a organização do ensino fundamental é dividida em dois ciclos, o primeiro é chamado de anos iniciais do ensino fundamental e corresponde a educação do $1^{\circ}$ ao $5^{\circ}$ ano, enquanto o segundo é chamado de anos finais e envolve a educação do $6^{\circ}$ ao $9^{\circ}$ ano (BRASIL, 2012)
} 
superior, com alunos acima de dezoito anos, sendo que a educação infantil, o ensino fundamental e o ensino médio são denominados como educação básica (BRASIL, 2012).

A educação básica tem por finalidade, de acordo com o artigo 22 da LDB nº 9.394/96, desenvolver o educando, de modo a lhe assegurar a formação comum indispensável para o exercício da cidadania e fornecer-lhe meios para progredir no trabalho e em estudos posteriores (BRASIL, 1996).

Para Soares e Alves (2003), a educação básica, principalmente no ensino fundamental, é crucial para o desenvolvimento das competências de leitura e o domínio de habilidades básicas em matemática. Nesse mesmo sentido, Libâneo (2001) afirma que a democratização da sociedade e a inserção dos alunos no mundo da produção exigem do ensino fundamental uma necessidade imperativa de proporcionar às crianças e aos jovens os meios cognitivos e operacionais que atendam tanto as necessidades pessoais como às econômicas e sociais.

Outro fator de destaque, que gera interesse em diversos pesquisadores (LIBÂNEO, 2001; SOARES, ALVES, 2003; FRANCO, 2008; AMARAL, MENEZES-FILHO, 2008; CONTE, DONIN, 2013) pelo ensino fundamental é a grande representatividade que esta etapa de ensino possui sobre a educação básica. Os dados divulgados pelo INEP (2013) corroboram com tal constatação ao demonstrar que o ensino fundamental possui 29,7 milhões dos 50,5 milhões de alunos matriculados na educação básica no ano de 2012, ou seja, o ensino fundamental corresponde a aproximadamente $60 \%$ do total de alunos da educação básica.

A relevância do ensino fundamental também pode ser evidenciada, segundo Cury (2002), pela política educacional de focalização nesta etapa de ensino, que consiste na prática, em sua priorização. Tal priorização é concretizada pela garantia constitucional e a presença de inúmeros instrumentos de estímulo ao ensino como sua obrigatoriedade, controle de faltas e proteção jurídica assegurada pelo Estatuto da Criança e do Adolescente, além do Governo Federal ter decretado em 2005 uma Lei que obriga todas as escolas públicas brasileiras a aumentarem, até o ano de 2010, a duração do ensino fundamental de 8 para 9 anos (FRANCO, 2008).

A crescente preocupação do governo brasileiro com o ensino fundamental nas últimas décadas acabou culminando em sua universalização, que foi caracterizado como um processo 
de ampliação do acesso a esta etapa do ensino (OLIVEIRA, 2007). Para Setúbal (2010), a universalização do ensino fundamental gerou um novo contorno de escola, com enormes desafios, principalmente em relação a qualidade da educação. Conte e Donin (2013) corroboram ao afirmar que a universalização do ensino fundamental apenas deslocou o problema da frequência escolar para o nível da qualidade do ensino.

Para Oliveira (2007), um dos principais problemas ocasionados pela universalização do ensino fundamental foi o impacto negativo causado pelo aumento do número de matrículas na qualidade do ensino oferecido pelas instituições educacionais. Marchelli (2010) corrobora com o autor acima ao concluir em seu estudo que o aumento do número de matrículas durante a universalização do ensino fundamental gerou uma redução nos recursos provenientes do estado, uma vez que os investimentos públicos não acompanharam o mesmo ritmo do aumento de matrículas, deste modo, a redução dos recursos contribuiu diretamente para o aumento da baixa qualidade do ensino. Enquanto que para Leme, Paredes e Souza (2009) a baixa qualidade da educação foi consequência de uma expansão rápida e desorganizada do acesso ao ensino fundamental nas duas últimas décadas.

Schwartzman e Brock (2005) alertam sobre os reflexos negativos que a baixa qualidade da educação no ensino fundamental pode ocasionar nas etapas posteriores, contribuindo inclusive para um aumento da evasão escolar, pois "sem aprendizado e a consequente percepção de sua utilidade, dificilmente o aluno continua a frequentar a escola, o que impossibilita, por exemplo, a desejada universalização do ensino médio" (SOARES, 2007, p. 138). Cury (2002) justifica tal relação ao afirmar que a educação deve ser vista como um todo composta por partes interdependentes que se compõe, de modo que, a educação infantil é a base da educação básica, o ensino fundamental é o seu tronco e o ensino médio é o seu acabamento. Deste modo, o autor conclui que a baixa qualidade do ensino fundamental pode comprometer a qualidade da educação básica como um todo.

Para Soares (2007), no ensino fundamental, já universalizado e com o seu papel consolidado no contexto da formação escolar dos alunos, o desafio passa a ser com sua qualidade e nas formas de atingi-la, pois para Schwartzman e Brock (2005) não há dúvida de que o ensino fundamental universal de qualidade é um requisito e uma exigência moral de todas as 
sociedades modernas, pelo bem da equidade social, dos valores culturais e da funcionalidade econômica.

Dentro deste contexto, as escolas municipais possuem um papel de destaque, pois segundo Leme, Paredes e Souza (2009) elas são as principais responsáveis pela gestão desta etapa do ensino que é considerada decisiva na formação educacional. Deste modo, o tópico abaixo tratará sobre as características das escolas municipais.

\subsubsection{Escolas municipais}

As escolas municipais surgiram com a descentralização do ensino e o reconhecimento da Constituição Federal (CF) de 1988 e da Lei de Diretrizes e Bases da Educação Nacional (LDB) de 1996, da autonomia dos municípios como unidades federadas, atribuindo-lhes importantes responsabilidades na área educacional (CASTRO, DUARTE, 2008).

De acordo com Leme, Paredes e Souza (2009) a descentralização no Brasil está associada à transferência, total ou parcial, do controle do ensino fundamental dos estados para os municípios, e ocorreu com o objetivo de melhorar a gestão e o desempenho escolar. Ainda segundo os autores, o processo de descentralização é visto por muitos como um modelo de gestão mais flexível e transparente, capaz de promover a participação da família e da comunidade no processo educativo dos seus filhos.

Para Castro e Duarte (2008), a Constituição Federal de 1988 (BRASIL, 1988), em seu artigo 30, inciso VI, foi a primeira iniciativa concreta que objetivou transferir ao município a competência de manter programas de educação pré-escolar e do ensino fundamental, com a cooperação técnica e financeira da união e do estado. Both (1997) ao discorrer sobre a municipalização do ensino no Brasil destaca a importância de três períodos marcantes e suas contribuições fundamentais para o surgimento das escolas municipais;

[...] a municipalização do ensino no Brasil passou por três períodos: 1- 1946 a 1971, marcado por iniciativas particularizadas, sem expressão prática, mas importante impulso ao pensamento municipalista em educação; 2- 1971 a 1988, há ocorrência de experiências expressivas na área; 3- 1988 a 1991, caracterizada por ser uma fase de transição, através da qual se espera uma definição mais precisa sobre os rumos, sobretudo a partir da constituição de 1988, considerada ponto de apoio para a municipalização do ensino fundamental (BOTH; 1997, p.109-110). 
A descentralização tem proporcionado as escolas municipais cada vez mais importância e participação na educação dos alunos brasileiros. Os dados divulgados pelo INEP (2013) corroboram com essa afirmação ao destacar que a rede municipal de ensino abrange quase metade das matrículas do ensino público com $(45,9 \%)$ dos alunos, o que equivale a 23.224.479 alunos, acompanhado pela rede estadual, que atende 37\% do total, 18.721 .916 alunos. Enquanto a rede federal atende 0,5\% do total, ou seja, 276.436 alunos. Devido à expressiva participação do município no total de matrículas realizadas no ensino público, a gestão da educação municipal passou a representar um fator imprescindível na busca de uma educação de melhor qualidade no país.

Lück (2009) corrobora com tal constatação ao apontar a gestão da educação como um fator determinante para o desempenho educacional. Segundo a autora, uma gestão escolar eficiente busca solucionar problemas educacionais e promover a qualidade no ensino com a finalidade de proporcionar aos alunos aprendizagem efetiva, capacitação e desenvolvimento de competências. Neste sentido, as escolas públicas municipais enfrentam um problema de gestão, pois devido à falta de políticas públicas educacionais no município, a qualidade do ensino fica comprometida com as mudanças de gestão por prefeitos e Secretários de educação (LÜCK, 2009).

Mesmo com esses problemas e limitações peculiares, as escolas municipais ainda apresentam resultados positivos em relação a outras redes de ensino público. Menezes-Filho (2007) conclui em seu trabalho que as escolas municipais possuem resultados que indicam ter um desempenho melhor que os alunos das escolas estaduais. Segundo pesquisa realizada pela revista Veja (VEJA, 2013), as razões do bom desempenho de Novo Horizonte, município localizado no interior de São Paulo, que possui a melhor rede municipal do ensino fundamental do país (Baseado no desempenho da Prova Brasil), não são fruto de métodos milagrosos, caros ou irreproduzíveis, ao contrário, o bom desempenho é consequência de atitudes simples como o comprometimento de gestores, Professores, pais e a sequência de políticas públicas educacionais. A participação da família é um dos pilares da educação em Novo Horizonte, os pais são incentivados a participarem da formação dos filhos e cobrados quando algo não vai bem. 
O bom desempenho de Novo Horizonte também é atribuído a características do município, como o tamanho, por exemplo, ele conta com 3.500 alunos matriculados do $1^{\circ}$ ao $9^{\circ}$ ano. Isso facilita ao Secretário acompanhar de perto o desempenho dos estudantes, Professores e unidades, além de fiscalizar o trabalho dos Diretores e manter contato com os pais. A revista conclui que se a cidade é pequena, com uma população de até 50.000 habitantes, é preciso tirar proveito disso e oferecer uma educação de qualidade a seus alunos, como fez a gestão de Novo Horizonte (VEJA, 2013).

Ao discutir medidas para melhorar o desempenho e a qualidade da educação, Leme et al. (2012) corroboram com a ideia de que a utilização de métodos estruturados (estruturação de conteúdos curriculares, o desenvolvimento de Professores e alunos, livros didáticos, bem como a formação e supervisão de Professores e instrutores) pode gerar resultados positivos no desempenho dos alunos. Os autores obtiveram como resultado, em um estudo feito nas escolas municipais do estado de São Paulo, que as redes municipais que adotaram os métodos estruturados depois de 2005 obtiveram maiores ganhos de proficiência entre 2005 e 2007 na Prova Brasil, comparativamente às redes que não adotaram estes métodos estruturados.

Para Soares (2004), a maior restrição para o bom funcionamento da escola e uma consequente melhoria da qualidade da educação está relacionada à limitação dos recursos financeiros. Tal constatação traz novamente em pauta a necessidade imprescindível das escolas municipais gerirem de maneira eficiente os recursos disponíveis.

A União Nacional dos Dirigentes Municipais de Educação (UNDIME), ao abordar esse tema é categórica ao afirmar que a garantia ao acesso, permanência e aprendizagem de qualidade as crianças, jovens e adultos nas escolas municipais depende, entre outros fatores, da permanente melhoria da gestão administrativa e organizacional na área da educação. Pois a gestão administrativa e organizacional da educação nos municípios promove a capacidade de respostas rápidas e eficientes às necessidades e aspirações da comunidade educativa, sobretudo da comunidade escolar, pois ela não se encerra na dimensão pedagógica, mas estendem-se à administração geral, as finanças, ao orçamento e à busca de resultados efetivos na prestação de serviços para a melhoria da educação. 
Dentro deste contexto, as Secretarias Municipais de Educação, principais responsáveis pelas políticas educacionais e gestão das redes municipais, necessitam ser pensadas continuamente na perspectiva do cumprimento de suas atribuições, que consiste como finalidade principal a oferta de uma educação de melhor qualidade (UNDIME, 2012).

\subsubsection{Secretaria Municipal de Educação (SME)}

A SME é a grande responsável pela gestão da educação no município sendo uma de suas atribuições à criação de condições adequadas para o desenvolvimento educacional dos alunos. Segundo Cerqueira et al. (2009), os municípios e as SMEs passaram a ganhar autonomia na gestão educacional a partir da LDB n ${ }^{\circ}$ 9.393/96 com a descentralização do poder de decisão da União, podendo desta forma, definir as ações a serem realizadas e os objetivos a serem atingidos, de acordo com as peculiaridades nas diferentes localidades do país. Dentro deste contexto, as SMEs se tornaram fundamentais na construção de uma educação de qualidade, principalmente devido as suas atribuições no que se refere à gestão das políticas públicas educacionais do município.

A SME deve desenvolver um planejamento estratégico detalhado que implica em estabelecer objetivos e metas para produzir decisões e ações fundamentais com foco no futuro (UNDIME, 2012). Entretanto, esse é um grande desafio para a SME, vendo que, projetar o futuro exige um planejamento que parta de um diagnóstico atual e do estabelecimento de estratégias que venham a intervir no presente e na tomada de decisões que assegurem o fim maior da educação: que é o acesso, a permanência e a aprendizagem de todas as crianças da sua rede ou sistema de ensino. O Fundescola et al. (2006) afirma que a SME deve se estruturar e oferecer condições adequadas para o bom funcionamento de todo o sistema municipal de educação, para isso:

[...] As secretarias municipais de educação devem se estruturar para proporcionar às escolas condições adequadas de funcionamento. Cabe às secretarias, por exemplo, estabelecer padrões educacionais de desempenho que mostrem o que o aluno deve saber ao concluir cada série ou ciclo; desenvolver um sistema de avaliação que permita avaliar a implementação desses padrões; desenvolver mecanismos que permitam às escolas ter mais autonomia e responsabilidade pelos serviços que prestam; fortalecer os profissionais do magistério, capacitando-os e proporcionando-lhes condições adequadas de trabalho e desenvolver medidas que promovam a equidade (FUNDESCOLA et al. 2006, p. 10). 
A UNDIME (2012) destaca que, de maneira resumida, o trabalho de uma SME deve objetivar a melhoria da qualidade do ensino em seu território de abrangência, recorrendo à indicadores de desempenho para medir os resultados obtidos a partir da execução de seu planejamento.

\subsubsection{Critério para matrícula de alunos}

No Brasil, a escolha do estabelecimento de ensino que o aluno será matriculado é definida pelo sistema público e pela família, dependendo da rede de ensino (privada ou pública). Segundo Resende, Nogueira e Nogueira (2011), na rede privada a escolha é feita exclusivamente pelos pais, baseado nas leis de mercado (oferta e demanda), em que as famílias com maior poder aquisitivo tendem a matricular seus filhos nas escolas com maior prestigio e qualidade. Enquanto no sistema público, a escolha está relacionada ao desejo dos pais e a proximidade da residência familiar à escola (DELGADO; MACHADO, 2007). Entretanto, segundo Setúbal (2010), no estado de São Paulo, não são os pais, mas as secretarias que possuem o poder final sobre as matrículas, ou seja, a SME pode mudar a localização de matrícula dos alunos de acordo com os seus próprios critérios.

Para Resende, Nogueira e Nogueira (2011), a escolha da escola em que o filho irá estudar está relacionada diretamente com o perfil da família, de modo que:

\footnotetext{
Os pais menos escolarizados e de nível socioeconômico mais baixo tendem a privilegiar critérios práticos ou funcionais, tais como: proximidade da residência, facilidade de transporte, infraestrutura física, presença de outros filhos na escola. Em contrapartida, as famílias socialmente mais bem posicionadas tenderiam a utilizar critérios internos ao processo educativo, tais como o desempenho do estabelecimento nas grandes avaliações sistêmicas, a filosofia e os métodos pedagógicos adotados, as atividades complementares oferecidas e, de modo geral, o clima da escola (RESENDE; NOGUEIRA; NOGUEIRA, 2011, p. 956).
}

Resende, Nogueira e Nogueira (2011) destacam ainda que os pais de menor poder aquisitivo não possuem muitas alternativas para matricular seus filhos, pois os custos que envolvem a escolha da escola, que vão desde o gasto financeiro que pode significar o deslocamento da criança a uma escola um pouco mais distante, até o tempo que se precisa investigar 
pesquisando e visitando diferentes escolas, contribuem para que os pais matriculem seus filhos em escolas indicadas pelo poder público.

Setúbal (2010) corrobora com os autores acima ao destacar que os pais dos alunos com menor poder aquisitivo tendem a colocar seus filhos nas escolas mais próximas de sua casa, pois o conjunto de instabilidades que envolvem sua vida impossibilita uma preocupação que lhes exija mais tempo para levar seus filhos a uma escola localizada distante da sua residência.

Deste modo, para a maioria das escolas o seu local de instalação acaba determinando o tipo de aluno que será atendido, criando assim, uma desigualdade de condições entre as escolas localizadas nas periferias e as escolas localizadas na região central das cidades. Soares (2004) corrobora com essa constatação ao afirmar que as escolas situadas nas periferias urbanas e que, portanto, atendem predominantemente alunos de NSE mais baixo, apresentam frequentemente piores condições materiais, corpo docente menos qualificado e experiente do que as escolas públicas localizadas na região central das cidades.

Dentro deste contexto, o NSE das famílias acaba sendo um fator determinante na escolha das melhores escolas, o que contribui ainda mais para o aumento da desigualdade social, de modo que:

A escolha do estabelecimento de ensino pelas famílias revela-se, assim, como um fenômeno por meio do qual se pode observar, de forma bastante clara, o peso das desigualdades sociais na determinação das trajetórias escolares. As famílias que possuem recursos econômicos e culturais mais elevados detêm melhores condições de escolher, são mais propensas a fazêlo, serve-se de critérios academicamente mais relevantes, obtêm mais informações e são mais aptas a utilizá-las. Essas famílias tendem, assim, a escolher a melhor escola possível para os filhos, o que constitui uma vantagem adicional para eles, comparativamente aos alunos oriundos de meios socialmente desfavorecidos (RESENDE; NOGUEIRA; NOGUEIRA, 2011, p.957).

Desta forma, a esperança de uma educação de qualidade mais equitativa encontra-se, de acordo com Setúbal (2010), na preocupação prioritária de alguns pais pertencentes às camadas médias e pobres da sociedade, com a educação de seus filhos, que sabe qual é a melhor escola do bairro e se esforçam para assumir os custos e os trabalhos implicados no deslocamento diário entre o local de sua moradia e a escola. 


\subsection{Educação, crescimento e desenvolvimento econômico}

Nesta seção são analisadas as relações entre educação, crescimento e desenvolvimento econômico, reforçando a importância da educação para o desenvolvimento socioeconômico dos países.

O papel da educação para os países é um tema recorrente no meio acadêmico, em especial quando está relacionado com o crescimento e desenvolvimento econômico. O interesse pelo tema aumenta ainda mais dado à importância inquestionável da educação para o desenvolvimento socioeconômico de um país (GREMAUD, FERNANDES, ULYSSEA, 2006). Nesse sentido vários estudos têm sido realizados relacionando investimentos em capital humano e crescimento econômico. Gremaud, Fernandes e Ulyssea (2006) afirmam que a acumulação de capital humano e, portanto, o nível educacional da força de trabalho tem um papel determinante no crescimento econômico. Deste modo, a grande parte da motivação das políticas de incentivo ao capital humano nos países em desenvolvimento está relacionada com a possibilidade de proporcionar maior crescimento econômico, que contribuirá para uma elevação dos níveis de renda nesses países, com foco na redução da pobreza em longo prazo (HANUSHEK, 2013).

A partir da década de 1950 surgiram importantes estudos sobre os efeitos do capital humano e da educação no crescimento e desenvolvimento econômico, com destaque para os trabalhos feitos por Schultz (1961), Denison (1974) e Psacharapoulos (1981; 1985). Nestes estudos são relacionados os efeitos positivos da educação sobre o crescimento econômico e o aumento da renda familiar. Barro (1999), ao analisar dados de 100 países entre 1960 e 1995, destaca que o crescimento econômico está relacionado principalmente ao desempenho dos alunos em ciências, assim como a quantidade de anos de estudos no segundo grau e níveis superiores. Para o autor, se mantida a qualidade, o aumento quantitativo da educação (número de alunos e quantidade de anos de estudo) favorece a melhoria do desempenho econômico do país. Barro e Lee (2010), em um estudo com 146 países utilizando dados de 1950 a 2010, reforçam os achados anteriores de que a escolaridade tem um efeito positivo sobre o nível de renda de um país e que a educação também produz importantes efeitos econômicos e sociais.

Pereira e Albyn (2009), ao avaliarem os efeitos da educação no crescimento econômico em Portugal, também apontaram a escolaridade como um fator determinante no crescimento 
econômico do país entre 1960 e 2001 sendo que, pela análise de causalidade, impulsos na média do número de anos de escolaridade levam a aumentos indiretos no PIB por trabalhador. Resende e Wyllie (2006) corroboram com os resultados acima ao apontarem que países com alto nível de investimento em educação obtiveram altos níveis de crescimento econômico.

Franco (2008) ao destacar os reflexos da educação sobre o crescimento econômico destaca que a qualidade da educação oferecida pelas escolas, mensurada pelo desempenho dos alunos em testes padronizados, tem forte relação positiva com a produtividade e o crescimento econômico dos países. Neste sentido, Solmon (1985) avaliou o impacto da qualidade da escola sobre os resultados dos alunos, principalmente o desempenho no trabalho e, posteriormente, sobre o crescimento econômico. Para o autor, a melhoria da qualidade do ensino fornecido pelas escolas em países em desenvolvimento pode ser mais importante para as futuras perspectivas econômicas dessas nações no longo prazo do que ampliar o acesso à educação de má qualidade. De maneira semelhante, Cadaval (2010) aponta que a qualidade da educação (mais do que quantidade) é um fator importante para o crescimento econômico do país e da renda das famílias.

Por estar relacionada a aspectos sociais, como a melhoria do padrão de vida, a educação também é utilizada como um importante indicador de desenvolvimento humano. Criado por Amartya Sen e Mahbub ul Haq em 1990, o Índice de Desenvolvimento Humano (IDH) vem sendo utilizado pela Organização das Nações Unidas desde 1993 como forma de classificar os países, comparativamente, pelo seu nível de desenvolvimento humano. Em seu cálculo são utilizados dados relativos à renda, longevidade e educação, que envolve a taxa de alfabetização, que corresponde ao número de pessoas, com quinze anos ou mais, que já concluiu o ensino fundamental e a taxa de escolarização, que considera o número de pessoas matriculadas em algum curso de nível fundamental, médio ou superior (SEN, 2000; PNUD, 2014).

Deste modo, maiores níveis de educação tendem a gerar maior rendimento para os trabalhadores no mercado de trabalho, fazendo com que esse aumento da renda reflita em melhores padrões de vida para esses beneficiários. Desta forma, indivíduos com maior nível de escolaridade tendem a ter renda superior aos indivíduos com menor grau de instrução educacional. Essa diferença de renda entre os cidadãos, causada em parte pela diferença do 
nível educacional, corrobora para a manutenção de uma distribuição desigual de renda, como ocorre em países como o Brasil.

Menezes Filho (2001) defende que a desigualdade de renda no Brasil, reflexo da má distribuição educacional, é percebida por diversos aspectos como etnia e diferenças regionais. Em um país como o Brasil, onde a maioria da população situa-se nos limites da pobreza, o direcionamento de recursos do estado para a área educacional, visando sua ampliação e qualidade, não só é fator essencial para promover o desenvolvimento econômico e social, como pode constituir em um importante instrumento para diminuir a excessiva desigualdade da distribuição de renda (BATALHA; MIRANDA; LIRIO, 2012). Cunha et al. (2009) também defendem a ideia de que é possível reduzir as desigualdades por meio da educação. Segundo os autores (2009),

[...] parece haver consenso de que a educação é um dos fatores que contribui para a redução da desigualdade. As escolas são, portanto, essencial na criação de oportunidades, especialmente para as crianças de famílias de baixa renda. Escolas poderiam contribuir para a minimização dos efeitos de segregação social, que é uma característica importante das cidades brasileiras (CUNHA et al., 2009, p. 882).

Ao considerar que a educação é um dos fatores que permite que um país tenha maiores níveis de crescimento e melhores condições de vida para a população, o desenvolvimento da área educacional se torna ponto fundamental para que o país atinja essas metas, o que em termos práticos significa (1) reduzir a evasão ${ }^{3}$ escolar no ensino fundamental, em especial entre a população mais carente e (2) aumentar o número de estudantes que concluem o ensino médio e iniciam o ensino superior.

Segundo Moran (2007), para enfrentar tais desafios é necessário repensar a escola brasileira, pois da maneira como se apresenta hoje ela é pouco atraente. O autor aponta que além das limitações escolares o desinteresse e a necessidade de trabalhar são os principais motivos que estão levando muitas crianças do $5^{\circ}$ ao $8^{\circ}$ ano a abandonarem as escolas. Baseado em uma pesquisa realizada pelo INEP, produzida em 2005 e publicada em 2007, o autor destaca que,

[...] o que afasta as crianças entre a $5^{\mathrm{a}}$ e a $8^{\mathrm{a}}$ série é mais o desinteresse $(40 \%)$ do que a necessidade de trabalhar (17\%). A escola, principalmente a partir da quinta série, fica fragmentada, compartimentalizada. As disciplinas estão soltas, falam de assuntos sem ligação direta com a vida do aluno. Muitos Professores estão desmotivados. A infraestrutura está bastante

\footnotetext{
${ }^{3}$ Evasão é a condição do educando que, matriculado em determinada série/ano letivo, não se matricula na unidade de ensino no ano seguinte, independentemente de ter sido aprovado ou reprovado (SEDU, 2010)
} 
comprometida, o acesso real da maior parte dos alunos à Internet é muito insatisfatório. No ensino superior, metade dos alunos não termina o seu curso, não se formam. Com uma escola assim e, ao mesmo tempo, com o rápido avanço da sociedade rumo à sociedade do conhecimento, o distanciamento entre a escola necessária e a real vai ficando dramático (MORAN, 2007, p.1).

As causas da evasão escolar são variadas, partindo da falta de motivação dos alunos e despreparo dos Professores à falta de infraestrutura da escola (MENDES, 2013). Além destas questões, a evasão também está ligada à entrada do estudante precocemente ao mercado de trabalho (LEME; WAJNMAN, 2000; CORSEUIL; SANTOS; FOGUEL, 2000; KASSOUF, 2002). Segundo Akkari (2001), muitas crianças acabam abandonando os estudos para trabalhar e contribuir na renda familiar. Desta forma, as causas da evasão estão ligadas tanto à perspectiva do aluno, quanto da instituição. De acordo com Rumberger (2006),

No que se refere à dimensão institucional, não apenas a escola, como também, outras instituições - como a família e a comunidade -, podem influenciar tanto na permanência quanto na saída dos alunos da escola. Especificamente no contexto escolar, os recursos que esta instituição oferece ou deixa de oferecer podem tanto influenciar na efetivação do engajamento e desempenho acadêmico, quanto contribuir para o processo de desengajamento e evasão do estudante (RUMBERGER, 2006).

Costa (2010), baseado na Lei n. ${ }^{\circ}$ 9.394/1996 (BRASIL, 1996), que estabelece as diretrizes e bases da educação nacional e ajusta os princípios da Constituição, aponta que a garantia do direito de educação deve ser relacionada a um padrão de qualidade que possa prover aos estudantes condições de aprendizado. Moran (2007) corrobora com esta observação ao considerar que a educação universal e de qualidade é uma condição necessária para o ser humano evoluir, ser competitivo, superar a desigualdade, oferecer melhores perspectivas, empreendedorismo e empregabilidade. Desta forma, a garantia ao direito à educação não é condição suficiente para aumentar o nível de escolarização, sendo necessária, além do aumento de número de matrículas e democratização do ensino, a provisão de meios para evitar a evasão e proporcionar condições de permanência e continuidade para os estudantes (MEC, 2006). A permanência do aluno na escola é determinante para a sua renda futura. Rodrigues (2010) colabora com tal constatação ao concluir em seu estudo, sobre o impacto da educação no rendimento salarial, que obter um ano a mais de escolaridade tem impacto significativo sobre a renda futura.

Com base na literatura pesquisada ficou evidente que quanto maior o nível educacional, maior será o redimento salarial médio das pessoas e melhores serão suas condições e oportunidades 
de trabalho. Dentro deste contexto, Menezes-Filho (2001) destaca a necessidade eminente de se formular políticas voltadas para as pessoas com baixo nível educacional, de modo que elas possam ser inseridas ou readaptadas no mercado de trabalho e consigam ter melhores condições de vida, contribuindo assim para o crescimento e desenvolvimento econômico do país.

\subsection{Gestão Escolar}

O conceito de gestão empregado em educação está relacionado com a utilização racional dos recursos disponíveis para a realização de determinados objetivos educacionais (PARO; 2002). Segundo o autor, a gestão escolar é um processo muito semelhante à gestão empresarial, pois

[...] diante da necessidade de se promoverem a eficiência e a produtividade da escola, não há razão para que esta, entendida também como organização, não possa pautar-se, na consecução de seus objetivos, por procedimentos administrativos análogos aqueles que tanto êxito alcançou na situação empresarial (PARO, 2005, p. 11-12).

GAME (2002), também associa o conceito de gestão escolar com a gestão administrativa, pois, segundo o grupo, ambas, buscam utilizar de forma correta e eficiente os recursos disponíveis, a fim de se atingir objetivos previamente estabelecidos. O grupo ainda destaca que a gestão escolar consiste em um elemento fundamental que pode diferenciar de forma significativa a qualidade da educação oferecida pelas instituições de ensino. Essa constatação é corroborada pelo INEP (2007) ao afirmar que, estudos e pesquisas indicam haver uma forte relação entre a melhoria da qualidade da educação nas escolas públicas brasileiras e a gestão escolar.

A melhoria da qualidade da educação promovida pela gestão escolar é destacada por Fipe (2007) ao afirmar que um simples aumento do investimento em educação sem a devida preocupação do aprimoramento da gestão, não traria resultados positivos no desempenho dos alunos, pois de nada vale o incremento do investimento, se ele for mal aplicado, ou seja, mal gerido.

O INEP (2007), também corrobora com os estudos apontados acima ao destacar que a melhoria na qualidade do ensino esta intimamente ligada à dimensão da gestão nas unidades escolares, capaz de sustentar e dinamizar ações conjuntas, associadas e articuladas às 
condições materiais e humanas disponíveis no contexto escolar, de modo a atingir a efetiva e significativa aprendizagem dos alunos.

Dentro desse contexto, a gestão escolar constitui uma área de atuação fundamental para a melhoria da qualidade da educação oferecida pelas escolas públicas brasileiras. A sua importância é destacada por Luck (2009) ao afirmar que ela é responsável por realizar todo o planejamento, organização, liderança, orientação, mediação, coordenação, monitoramento e a avaliação dos processos necessários à efetividade das ações educacionais orientadas para a promoção da aprendizagem e formação dos alunos.

Nesse mesmo sentido o INEP (2007), afirma que a gestão escolar tem como dimensão e enfoque de atuação, a mobilização e a articulação das condições materiais e humanas para garantir o avanço dos processos socioeducacionais, priorizando o acesso ao conhecimento e o aperfeiçoamento das relações internas e externas da escola.

Ao discorrer sobre as dimensões da gestão escolar, Luck (2008) as dividiu em duas áreas, conforme sua natureza, sendo elas: a organização e a implementação. De acordo com a autora, as dimensões de organização dizem respeito a todas aquelas que tenham por objetivo a preparação, a ordenação, a provisão de recursos, a sistematização e a retroalimentação do trabalho a ser realizado. Segundo ela, essas dimensões objetivam garantir uma estrutura básica necessária para a implementação dos objetivos educacionais, pois elas não promovem diretamente os resultados desejados, mas são imprescindíveis para que as dimensões capazes de fazê-lo sejam realizadas de maneira mais efetiva. Segundo Luck (2009), as competências da organização envolvem a fundamentação conceitual e legal da educação, o planejamento, o monitoramento e a avaliação das ações promovidas na escola.

Em relação às dimensões de implementação, Luck (2008) destaca que são aquelas desempenhadas com a finalidade de promover, diretamente, mudanças e transformações no contexto escolar. Pois, segundo a autora, elas se propõem a promover transformações das práticas educacionais, de modo a ampliar e melhorar o seu alcance educacional. De acordo com Luck (2009), as competências de implementação envolvem a gestão democrática e participativa, gestão de pessoas, gestão pedagógica, gestão administrativa, gestão da cultura escolar e gestão do cotidiano escolar. 
Desta forma, a gestão escolar caracteriza-se pela contextualização da ação política, organização, articulação e mobilização dos atores envolvidos nos processos educativos da escola e da comunidade, atuando e construindo, coletivamente, o projeto político-pedagógico que norteia toda ação efetiva da escola (INEP, 2007).

Para Soares (2004), a gestão escolar só será bem-sucedida se os objetivos forem claramente definidos, conhecidos por todos e para cuja implementação todos possam trabalhar. Obter essa unidade de propósito na escola em torno de objetivos que reconheçam a centralidade do processo de ensino/aprendizado é determinante para a sua efetividade e talvez constitua a maior tarefa do gestor escolar (SOARES, 2004). Deste modo, abrir as portas da escola para a comunidade e todos os atores envolvidos no processo educacional, por meio de uma gestão democrática, pode ser considerado um fator imprescindível para uma gestão escolar eficiente, que segundo Libâneo (2001), deve ter como foco central a capacidade cognitiva de aprendizagem dos alunos.

A gestão democrática é um princípio definido inicialmente pela Constituição Federal de 1.988, Art. 206, inciso VI (BRASIL, 1988), e pela LDB nº 9.394/96 (Art. $3^{\circ}$. Inciso VIII) como pressuposto de que a educação é um processo social colaborativo que demanda a participação de todos da comunidade interna da escola, assim como os pais e a sociedade em geral, pois é dessa participação conjunta e organizada que resulta a qualidade do ensino para todos, sendo este, o principio da democratização da educação.

Luck (2009) corrobora com tal constatação ao definir a gestão democrática, como sendo o processo em que se criam condições e se estabelecem as orientações necessárias para que os integrantes de uma coletividade, não apenas tomem parte, de forma regular e contínua, de suas decisões mais importantes, mas assumam os compromissos necessários para a sua efetivação.

Segundo Paro (2002), a democratização da gestão escolar se dará na medida em que a administração na escola básica, tanto em suas atividades-meio quanto em suas atividades-fim, se fizer de fato como mediadora para a busca de fins democráticos e educativos. Deste modo, a finalidade da gestão escolar é propiciar um ambiente de formação e aprimoramento da 
educação, sem discriminação de espécie alguma, para que a escola cumpra sua função social, que é formar cidadãos com valores e opiniões que saibam viver em sociedade (SILVA, 2009).

Dentro desse contexto, os gestores possuem um papel fundamental, pois eles são os profissionais responsáveis pela organização e orientação administrativa e pedagógica da escola, da qual resulta a formação da cultura e de um ambiente escolar democrático e favorável ao aprendizado dos alunos (LUCK, 2009).

Nesse mesmo sentido, Silva (2009) destaca que o gestor educacional é o principal responsável pela escola, por isso deve ter visão de conjunto, articular e integrar setores, vislumbrar resultados para a instituição educacional, que podem ser obtidos se embasados em um bom planejamento, alinhado com comportamento otimista e de autoconfiança, com propósito macro bem definido, além de comunicação realmente eficaz.

Segundo Medeiros et al (2011), os rumos apontados por parte dos estudiosos da gestão escolar salientam a necessidade de competências administrativas por parte dos gestores escolares. Deste modo, as duas subseções seguintes tratará da importância do Secretário municipal de educação e do Diretor escolar possuir formação em gestão.

\subsubsection{Formação em gestão dos Secretários municipais de educação}

Ao definir as responsabilidades para os municípios, a Constituição Federal de 1988 e a LDB de 1996 destacaram a importância central que os Secretários municipais de educação passaram a ter na gestão das políticas públicas educacionais em nível local e a enorme responsabilidade que receberam no oferecimento de uma educação de qualidade a todo aluno de sua rede (INEP, 2011). A sua importância está intimamente ligada à sua função e missão como Secretário, que consiste em elaborar, implementar e gerir políticas públicas educativas que garantam o desenvolvimento físico, social, econômico, político e cultural de crianças, adolescentes, jovens e adultos como seres ao mesmo tempo únicos e plenos (UNDIME, 2012).

As decisões tomadas pelo Secretário municipal de educação geram efeito impactante no desempenho educacional do município, de modo que para Lück (2009) a qualidade da 
educação passa pela competência de seus profissionais, e desenvolver continuamente essas competências, se torna um grande desafio a ser encarado pelos profissionais, escolas e sistemas de ensino.

A Undime (2012) ainda complementa dizendo que além das competências técnicas, o Secretário municipal de educação deve ter clareza sobre suas responsabilidades administrativas, políticas e sociais com a causa que abraça, isto é, a causa do gestor público, devendo compreender que a educação é um direito humano fundamental.

A competência para o exercício de uma função ou profissão envolve um conjunto sistêmico de padrões mínimos necessários para o bom desempenho das responsabilidades que caracterizam qualquer tipo de atividade profissional (LÜCK, 2009). Dentro desse contexto, a Undime (2012) destaca que é fundamental se atentar para as principais características do perfil do Secretário municipal que assumirá a gestão educacional do município, classificando como requisitos de grande importância à qualificação técnica e a formação adequada. Outra característica exigida do Secretário e que é considerada imprescindível para a realização de suas funções é a formação em gestão.

Entretanto, sabe-se que a formação básica dos Secretários municipais de educação não se concentra sobre essa área específica de atuação (LÜCK, 2000). A constatação feita pela autora acima é corroborada por uma pesquisa realizada pelo INEP (2011), cujo objetivo foi identificar o perfil dos Secretários municipais de educação. A pesquisa aponta que no Brasil uma grande parte dos Secretários municipais de educação possui formação em nível superior, de modo que ao responder sobre seu nível de escolaridade, a maioria dos Secretários $(59,4 \%)$ declarou possuir pelo menos curso de especialização, também teve um percentual significativo de Secretários com escolaridade mínima em nível superior (30,7\%), já o percentual daqueles que declararam ter escolaridade abaixo do nível superior foi mínimo, apenas 4,5\%. Do total de Secretários que possuem graduação, identificou-se que 44,9\% são formados em Pedagogia e 27,9\% possuem especialização na área de educação, o restante se divide nos cursos de Direito, Administração, Ciências Sociais, Biologia, entre outras. A pesquisa também apontou que os Secretários municipais de educação reconhecem a necessidade de possuir formação em gestão, boa parte deles indicou ser imprescindível a 
capacitação em Gestão Financeira (38,1\%), Gestão Estratégica (36,0\%) e Gestão de Pessoas $(27,0 \%)$ para melhor desempenhar sua função.

De acordo com Lück (2000), a formação de gestores escolares passa a ser indispensável e a representar um grande desafio para o sistema de ensino, pois:

\begin{abstract}
Não se pode esperar mais que os Secretários municipais de educação aprendam em serviço, pelo ensaio e erro, sobre como resolver conflitos e atuar convenientemente em situações de tensão, como desenvolver trabalho em equipe, como monitorar resultados, como planejar e implementar o projeto político pedagógico da escola, como promover a integração escolacomunidade, como criar novas alternativas de gestão, como realizar negociações, como mobilizar e manter mobilizados atores na realização das ações educacionais, como manter um processo de comunicação e diálogo abertos, como estabelecer unidade na diversidade, como planejar e coordenar reuniões eficazes, como articular interesses diferentes (LÜCK 2000, p. 29).
\end{abstract}

A autora conclui dizendo que os resultados da ineficácia dessas ações são tão sérios em termos individuais, organizacionais e sociais, que não se pode continuar com essa prática, pois a responsabilidade educacional exige profissionalismo.

Mendonça (2001) destaca outro aspecto de grande importância e que representa um desafio para a melhoria da gestão do ensino público no Brasil, que está relacionado à descontinuidade das políticas públicas educacionais. De acordo com o autor, o poder pessoal do governante acaba permitindo a descontinuidade na sustentação das políticas públicas educacionais, que culmina, entre outros aspectos, na substituição de materiais de ensino e indicação de novos Diretores e Secretários municipais de educação.

A pesquisa realizada pelo INEP (2011), cujo objetivo foi identificar se os Secretários municipais de educação possuem filiação partidária, corrobora com a afirmação do autor ao demonstrar a posição política dos atuais Secretários. Segundo a pesquisa, $67,7 \%$ dos Secretários se manifestaram ser filiados a algum partido político, em que, 46,9\% indicaram ser filiados ao mesmo partido do prefeito e, entre os que não o são (filiados ao mesmo partido do prefeito) $77,4 \%$ indicaram ser filiados a algum partido de coligação que governa o município.

Deste modo Mendonça (2001) afirma que para a construção de uma educação de qualidade se faz necessário o desenvolvimento de um planejamento educacional estratégico de longo prazo 
que seja visto por todos governantes como a meta a ser atingida em educação pelo município e não por governos que vão e vem a cada quatro anos.

Segundo a Undime (2012), o planejamento tradicional, do cálculo racional e imediatista, que diagnostica a educação pública exclusivamente como gastos do governo, sem concebê-la como um investimento necessário e objetivo para melhorar o presente e, mais ainda, o futuro, não atende as necessidades do país.

Dentro desse contexto, o INEP (2011) afirma que os Secretários municipais de educação têm um papel estratégico para que os municípios cumpram suas responsabilidades com a melhoria da qualidade da educação brasileira. Desta forma, eles devem estar sempre preparados para enfrentar os desafios de promover o desenvolvimento humano e um sistema de ensino que precisa responder as aspirações de uma educação de qualidade dos munícipes (UNDIME, 2012).

\subsubsection{Formação em gestão dos Diretores escolares}

O Diretor é tido como o grande articulador das ações administrativas e pedagógicas da instituição escolar, assumindo em função de suas atribuições e responsabilidades um papel de destaque na construção de uma educação de qualidade. A educação de qualidade, por sua vez, se apoia sobre a competência profissional dos Diretores escolares e sua capacidade de organizar, orientar e liderar as ações e processos promovidos na escola, voltados para a promoção da aprendizagem e formação dos alunos (LÜCK, 2009).

A competência profissional do Diretor envolve principalmente a sua capacidade de gerir de modo eficiente os diversos recursos disponíveis na escola, como por exemplo: os recursos físicos, materiais, financeiros e humanos (LÜCK, 2009). Deste modo, a autora afirma que a formação do Diretor em gestão contribui para a melhoria da qualidade do ensino, por meio do desenvolvimento de competências que possibilita ao Diretor assumir de forma efetiva o acervo de responsabilidades inerentes às suas funções. De acordo com o INEP (2007), estudos recentes indicam haver uma forte relação entre gestão escolar e a melhoria da qualidade da educação. A formação do Diretor em gestão permite que esse profissional desenvolva, dentre outras, a habilidade de integrar e motivar as equipes, objetivando garantir as melhorias dos 
processos de trabalho na escola e consequentemente nos resultados esperados dessa instituição (INEP, 2007).

A importância de o Diretor possuir formação em gestão é justificada pelas atribuições inerentes ao seu cargo, que lhe proporcionam grandes responsabilidades sobre a organização e funcionamento da escola em todos os seus aspectos: pedagógico, sócio-político, financeiro e de infraestrutura (MEDEIROS et.al, 2011). Neste contexto o Diretor é visto como uma figura imprescindível para o processo educacional, pois ele:

[...] funciona como um mediador entre o poder burocrático do quadro administrativo e a escola, como conjunto, sofre pressão dos Professores no sentido de alinhar-se com eles, dos alunos para satisfazer reclamos racionais ou não, e dos pais, para manter a escola ao nível desejado pela comunidade. Tem de possuir as qualidades de um político, algum senso administrativo e ser especialista em relações humanas (TRAGTENBERG, 1982, p. 39).

Segundo Lück (2000; 2009), o Diretor, além de ser um gestor da dinâmica social, é um mobilizador de atores, um articulador da diversidade para dar-lhe unidade e consistência na construção do ambiente educacional e promoção segura da formação de seus alunos, sendo então responsável pelo desempenho dos participantes da comunidade escolar, pela realização dos objetivos educacionais e por atingir padrões de qualidade definidos pelo sistema de ensino. Já para Libâneo, Oliveira e Toschi (2003),

[...] o papel do Diretor é coordenar, mobilizar, motivar, liderar e delegar aos membros da equipe escolar, conforme suas atribuições específicas, as responsabilidades decorrentes das decisões, acompanhar o desenvolvimento das ações, prestar contas e submeter à avaliação da equipe o desenvolvimento das decisões tomadas coletivamente (LIBÂNEO; OLIVEIRA; TOSCHI, 2003, p. 355).

Frente à importância que o Diretor escolar possui sobre a melhoria da qualidade na educação, o INEP e o MEC, desenvolveram o Projeto Piloto da Escola de Gestores, que envolveu 400 Diretores de escolas básicas em um curso de 100 horas/aulas, desenvolvido por meio de cinco módulos presenciais e a distância, por intermédio do ambiente colaborativo do MEC eProInfo $^{4}$ (INEP, 2007). Segundo o INEP (2007), o objetivo do projeto era contribuir para a elevação da competência dos Diretores e a sua capacidade de gestão, compreensão e intervenção sobre a realidade da escola que está sob sua direção, considerando a realidade

\footnotetext{
${ }^{4} \mathrm{O}$ Ambiente Colaborativo de Aprendizagem (e-Proinfo) é um ambiente virtual colaborativo de aprendizagem que permite a concepção, administração e desenvolvimento de diversos tipos de ações, como cursos a distância, complemento a cursos presenciais, projetos de pesquisa, projetos colaborativos e diversas outras formas de apoio a distância e ao processo ensino-aprendizagem.
} 
social, política, econômica e cultural na qual está inserida. O INEP (2007) finaliza afirmando que a expectativa é que esse projeto seja o embrião da instalação de uma política de formação de gestores, que é de vital importância para o desenvolvimento da educação brasileira.

Outro aspecto que merece destaque, além da formação de gestores escolares, é o modo como o Diretor é escolhido para o seu cargo. Segundo o INEP (2007), o Diretor pode ser escolhido para o seu cargo por meio de diversas formas, em alguns estados, por exemplo, os Diretores são eleitos pela comunidade, em outros são nomeados como cargo de confiança do Secretário Municipal de Educação ou assumem seus cargos por meio de concurso público (INEP, 2007). Para Lück (2009), a indicação de Diretores por políticos, a partir de interesses partidários demonstra ser em um elemento desvirtuador do princípio de que a educação está acima dos interesses de grupos específicos. Para a autora, tal prática pode ser considerada um entrave para a boa gestão da escola, uma vez que a qualidade da educação deve realizar-se mediante orientação da mais elevada competência e conhecimento profissional.

De acordo com Lück (2009), uma boa gestão escolar exige, pois o exercício de múltiplas competências específicas do Diretor, devido principalmente à dinâmica constante das situações, que impõe ao gestor novos desafios. Deste modo a autora conclui que o movimento pelo aumento da competência da escola exige maior habilidade de sua gestão, em vista que a formação de gestores escolares passa a ser uma necessidade e um desafio para os sistemas de ensino que buscam oferecer uma educação de maior qualidade.

\subsection{Qualidade na educação e fatores de desempenho}

Com o avanço educacional iniciado em meados da década de 1990 o Brasil conseguiu atingir a universalização do ensino fundamental e aumentar significativamente a frequência escolar em todos os outros níveis. Entretanto, Menezes-Filho (2007) aponta que com a universalização do acesso ao ensino o desafio da educação brasileira passou a ser a qualidade da educação oferecida aos alunos da rede pública. De maneira semelhante Dourado, Santos e Oliveira (2007) afirmam que o avanço da educação brasileira em termos de acesso e cobertura implica novas demandas de atendimento que se relacionam mais diretamente com as condições de permanência dos alunos na escola e as possibilidades de uma aprendizagem mais significativa. Ademais, a qualidade da educação é vista por muitos autores (SOLMON, 
1985; FRANCO, 2008; CADAVAL, 2010) como fator determinante para a melhoria dos indicadores socioeconômicos do país. Deste modo, esta subseção tem como objetivo identificar na literatura as principais definições sobre a qualidade da educação e seus possíveis determinantes.

Segundo Dourado, Santos e Oliveira (2007), a qualidade da educação deve ser abordada sobre uma perspectiva polissêmica, uma vez que esta categoria traz implícita múltiplas significações. Para Fernandes e Nazareth (2011), as várias concepções sobre a qualidade da educação existentes na história recente da educação são justificadas, entre outros fatores, por surgirem em contextos políticos e locais diferentes. Entretanto, uma corrente não é suprimida com o fortalecimento de outra, pois elas coexistem na cultura escolar e influenciam de diferentes formas as práticas educativas e a formulação de políticas educacionais (FERNANDES, NAZARETH, 2011).

Dourado, Santos e Oliveira (2007) corroboram com tal constatação ao afirmar que a realidade educacional evidencia que são diversos os elementos que possibilitam qualificar, avaliar e precisar a natureza, as propriedades e os atributos desejáveis ao processo educativo. Ao fazer um levantamento sobre os conceitos e definições da qualidade da educação em estudos realizados nas últimas décadas, os autores identificaram que:

[...] a qualidade da educação é um fenômeno complexo, abrangente e que envolve múltiplas dimensões, não podendo ser apreendido apenas por um reconhecimento da variedade e das quantidades mínimas de insumos considerados indispensáveis ao desenvolvimento do processo de ensinoaprendizagem, e muito menos, pode ser apreendido sem tais insumos. Estes estudos ressaltam, ainda, a complexidade da qualidade da educação bem como a sua medição por fatores e dimensões extraescolares e intraescolares (DOURADO, SANTOS, OLIVEIRA, 2007, p. 6).

Para Moreira e Kramer (2007), os fatores intraescolares estão relacionados, entre outros elementos, ao currículo, formação docente e gestão escolar; enquanto os fatores extraescolares se referem às condições de vida da população e ao capital econômico e cultural das famílias dos alunos.

Dentro desse contexto, inúmeros pesquisadores buscaram contribuir com a identificação de condições, dimensões e fatores fundamentais para o entendimento do que seja uma educação de qualidade. Gusmão (2012), ao fazer uma revisão bibliográfica sobre a qualidade da educação, identificou que o uso da palavra qualidade no contexto educacional remete 
diretamente aos fins da educação, que no sentido absoluto, seria uma educação que cumpre com os seus objetivos. Deste modo, o uso como indicação positiva ou negativa do termo melhorar a qualidade da educação, seria aproximá-la de suas finalidades primordiais (GUSMÃO, 2012).

Para Dourado, Santos e Oliveira (2007), a qualidade da educação oferecida pelas escolas implica a existência de insumos indispensáveis, de condições de trabalho e de pessoal valorizado, motivado e engajado no processo educativo a ser definido em consonância com as políticas e gestão da educação. Nesse mesmo sentido, a Cepal (2000) destaca que para se atingir a qualidade da educação é necessário abastecer as escolas com suporte tecnológico, imprimir maior força e dinamismo aos programas curriculares e à capacitação docente, aumentar as jornadas escolares e dotar as escolas de maior infraestrutura.

Ao discutir a questão da qualidade da educação a UNESCO e OREALC (2002) aponta que ela é composta por quatro dimensões, sendo elas a pedagógica, a cultural, a social e a financeira. Para a UNESCO, a dimensão ou perspectiva pedagógica é vista como essencial e se efetiva quando o currículo é cumprido de forma eficaz. No que se refere à perspectiva cultural, o documento aponta que os conteúdos precisam partir das condições, possibilidades e aspirações das distintas populações a quem se dirige. Já do ponto de vista social, a UNESCO sinaliza que a educação é de qualidade quando contribui para a equidade. Enquanto do ponto de vista econômico, a qualidade refere-se à eficiência da utilização dos recursos destinados à educação (UNESCO; OREALC, 2002).

Para definir a qualidade da educação a UNESCO utiliza o paradigma de insumo-processoresultados (DOURADO, SANTOS, OLIVEIRA, 2007). Nessa perspectiva a qualidade da educação é estabelecida,

[...] com relação aos recursos, materiais e humanos, que nela se investe, assim como em relação ao que ocorre no âmbito da instituição escolar e da sala de aula, seja nos processos de ensino e aprendizagem, nos currículos, e nas expectativas com relação a aprendizagem dos alunos (DOURADO, SANTOS, OLIVEIRA, 2007, p. 10).

Deste modo, UNESCO (2003) aponta que a qualidade da educação pode ser observada a partir dos resultados educativos, representados pelo desempenho dos alunos em avaliações de larga escala. Oliveira (2006) corrobora com tal constatação ao identificar que a proficiência dos estudantes, medida pelos testes de avaliações em larga escala, tem sido apreendida 
atualmente como o principal significado de qualidade da educação. De modo semelhante, Fernandes e Nazareth (2011) afirmam que a avaliação, por meio de exames padronizados como PISA e Prova Brasil, foi colocada no papel de guia na caminhada pela qualidade da educação na última década.

A aceitação dos testes de larga escala como medida de qualidade educacional é justificada por Cury (2010) devido a sua objetividade. Segundo o autor, os seus resultados expressam as habilidades cognitivas dos alunos, como sua capacidade de leitura, escrita e domínio sobre operações aritméticas. Silva (2008) corrobora com tal afirmação ao destacar que o caráter objetivo dos testes em larga escala é um fator que contribui para a sua ampla aceitação como medida adequada de qualidade.

Em função da objetividade com que os resultados escolares são divulgados e discutidos, tem-se a nítida impressão de que se sabe qual é o problema a enfrentar e os valores em que nós devemos pautar para reverter a crise educacional, cujo maior indício parece ser a demanda crescente por avaliações (SILVA, 2008, p. 31).

Ao destacar a ampla aceitação das avaliações em larga escala, como única medida de qualidade da educação, Silva (2008) destaca que o caráter público da educação escolar está esvaziado à custa da veiculação de uma noção de qualidade educacional estritamente instrumental, ligados a supostos efeitos econômicos e interesses privados, característicos de uma sociedade de consumo. Para o autor, o domínio da visão que concebe a qualidade da educação como resultado das provas fortalece um significado de qualidade primordialmente economicista centrado nos supostos ganhos econômico que a educação de qualidade pode trazer para os indivíduos e para o país. Neste mesmo sentido Carvalho (2008) aponta que isso implica em perda do sentido público da educação. Para o autor:

\footnotetext{
À medida que se concebem o valor e a qualidade da educação com base em seu alegado impacto econômico na vida privada do indivíduo, perde-se seu significado ético-político, ou seja, seu sentido público. Assim, objetivos educacionais identificados com a difusão e o cultivo de virtudes públicascomo a solidariedade, a igualdade, a tolerância- passam a ocupar um lugar secundário em relação ao desenvolvimento de competências e capacidades individuais ou àquilo que, com precisão, se convencionou chamar de capital humano (CARVALHO, 2008, p. 413).
}

Para Fernandes e Nazareth (2011), a utilização dos testes de avaliação em larga escala como principal definição de qualidade educacional é limitada por não abordar todos os aspectos que envolvem a educação. Segundo os autores, 
tal perspectiva desconsidera que a qualidade em educação é um termo polissêmico, e que a educação escolar, por ser uma prática social e ter a formação cidadã como uma de suas funções, não pode ser avaliada em sua função social apenas por exames de proficiência e desempenho em disciplinas escolares (FERNANDES; NAZARETH, 2011, p. 63).

Silva (2008) complementa afirmando que seria potencialmente interessante à criação de um índice de qualidade da educação que abordasse não só a proficiência dos alunos, mas também elementos considerados valiosos dos processos educacionais. Segundo o autor, se faz necessário trazer para o centro do debate a compreensão da qualidade em educação como uma prática carregada de significações, e não somente restrita a resultados mensuráveis.

Dourado, Santos e Oliveira (2007) justificam a complexidade envolvendo as várias significações que podem ser atribuídas a educação de qualidade ao identificar na literatura os principais aspectos que impactam de forma positiva ou negativa a qualidade da educação. São eles:

[...] a estrutura e as características da escola, em especial quanto aos projetos desenvolvidos; o ambiente educativo e/ou clima educacional; o tipo e as condições de gestão; a gestão da prática pedagógica; os espaços coletivos de decisão; o projeto político-pedagógico da escola; a participação e integração da comunidade escolar; a visão de qualidade dos agentes escolares; a avaliação da aprendizagem e do trabalho escolar realizado; a formação e condições de trabalho dos profissionais da escola, a dimensão do acesso, permanência e sucesso na escola, dentre outros (DOURADO; SANTOS; OLIVEIRA, 2007, p. 20).

Deste modo, a exigência contemporânea sobre a melhoria da qualidade da educação tem levado os países e os sistemas educativos a reconhecerem a evidente complexidade do fenômeno educacional e a pensarem a questão da qualidade em toda a sua complexidade, o que inclui reconhecer os fatores externos e internos que afetam a aprendizagem das crianças, jovens e adultos (DOURADO, SANTOS, OLIVEIRA, 2007, p. 16).

\subsubsection{Investimento em educação}

O investimento em educação é fundamental na oferta de uma educação de maior qualidade, pois ele pode ser utilizado para diversos fins pedagógicos e de infraestrutura como a obtenção de melhores materiais didáticos, a criação de bibliotecas e a aquisição de instrumentos que incentivem o aprendizado dos alunos (BATALHA; MIRANDA; LIRIO, 2012). 
Para o INEP (2011), a cobertura dos investimentos públicos em educação corresponde à formulação de política, manutenção e desenvolvimento do ensino, a expansão e melhoria das escolas de diversos níveis e modalidades de ensino, dos estabelecimentos de educação, dos programas de assistência ao estudante, entre outras demandas educacionais.

Segundo Resende e Wyllie (2006), os estudos econométricos acerca dos retornos para educação têm sido recorrentes em diversos países. De acordo com os autores, as fontes de crescimento econômico têm sido crescentemente associadas a investimento em capital humano. Em relação ao capital humano, Sousa e Castro (2012) o descrevem como um produto desenvolvido a partir de decisões deliberadas de investimentos em educação ou em treinamento para o desenvolvimento de uma força de trabalho qualificada. Tobing (2011), ao relacionar capital humano e investimento em educação, constata que a qualidade da educação e o crescimento econômico dependem dos investimentos em educaçao. Segundo o autor,

O investimento em educação é utilizado como determinante da qualidade da educação/escola: aumento dos gastos em educação leva a uma melhor qualidade do ensino e para o aumento do capital humano. [...] Os resultados sugerem que [...] o gasto público em educação afeta o crescimento de forma significativa (TOBING, 2011, p.50; p. 57).

Frigotto (2001) corrobora com tal constatação afirmando que maiores investimentos em educação significam aumento na capacitação e no crescimento e desenvolvimento econômico do país, isto ocorre principalmente devido à melhoria da qualidade de vida dos indivíduos. Nessa mesma linha, Barros e Mendonça (1998) afirmam que um aumento no investimento em educação é capaz de promover o crescimento da renda per capta, a redução da taxa de mortalidade, o aumento na expectativa de vida, além de elevar os indicadores de desempenho escolar.

Em relação ao desempenho escolar ${ }^{5}$, são inúmeros os trabalhos que relacionam desempenho educacional com investimento em educação (MENEZES FILHO 2007; CONTE; DONIN, 2013; AMARAL; MENEZES-FILHO, 2008; BATALHA; MIRANDA; LIRIO, 2012; SAVIAN; BEZERRA; MELO, 2012; PUCCINELLI; SLOMSKI, 2010).

\footnotetext{
${ }^{5} \mathrm{O}$ desempenho escolar é medido por testes padronizados que avaliam as habilidades cognitivas dos alunos e geralmente são aceitos como medida de qualidade da educação (AMARAL; MENEZES-FILHO, 2008)
} 
Os estudos de Batalha, Miranda e Lírio (2012) e Conte e Donin (2013) buscaram esclarecer se maiores investimentos em educação resultam em melhor desempenho dos alunos. Os resultados são conflitantes, de modo que o retorno do investimento em educação gera discussões e opiniões diversas nos inúmeros pesquisadores, criando assim duas correntes de pensamentos: a que não relaciona maiores investimentos com melhores resultados e a que atribui à melhoria do desempenho escolar a um aumento dos investimentos.

Batalha, Miranda e Lírio (2012) buscaram analisar se as escolas municipais do estado de Minas Gerais que recebem maiores investimentos do governo possuem melhor desempenho educacional no ensino fundamental. Os resultados indicam a existência de um efeito positivo sobre o desempenho dos alunos quando se eleva os investimentos. Franco (2008) corrobora com tal resultado ao constatar em seu estudo que o aumento dos recursos provenientes do Fundo de Manutenção e Desenvolvimento do Ensino Fundamental e de Valorização do Magistério (FUNDEF), revertidos em insumos escolares no ensino fundamental (laboratórios de ciências e informática, quadras de esportes e a proporção de Professores com o terceiro grau), causou uma melhoria do rendimento escolar, principalmente quando se comparam os indicadores de escolas municipais cujos municípios perderam recursos do fundo. Reforçam ainda mais esses resultados, o relatório da Education at a Glance (OECD, 2007) da Organisation for Economic Co-operation and Development (OCDE) que avaliou a relação existente entre desempenho e investimento por aluno nos países pertencentes a OCDE, e constatou que o investimento em educação é considerado um pré-requisito essencial para a qualidade de um sistema educacional.

Por sua vez, os resultados do estudo de Conte e Donin (2013) indicam que as notas dos alunos nas avaliações da Prova Brasil e do IDEB não estão diretamente relacionadas com o investimento por aluno, contrariando assim a expectativa de que maiores recursos estivessem interligados a desempenhos superiores. Corrobora com esse resultado, o estudo de Puccinelli e Slomski (2010), que analisou o investimento feito no ensino fundamental no Brasil e o desempenho dos alunos nas avaliações do SAEB e da Prova Brasil em cada Estado Brasileiro no período de 1998 a 2007. Os autores concluíram que as notas nas avaliações não estão diretamente relacionadas com o investimento por aluno.

Nesta mesma linha, Amaral e Menezes-Filho (2008), após analisar se os investimentos em educação aumentam o aprendizado dos alunos de $4^{\mathrm{a}}$ e $8^{\mathrm{a}}$ séries do ensino fundamental, 
concluíram que há poucos indícios na relação direta entre investimentos educacionais e desempenho escolar. "Fica claro, em conclusão, que para se obter melhorias no desempenho escolar não basta um aumento nos recursos destinados à educação" (AMARAL; MENEZESFILHO, 2008, p.18).

Para Felício e Fernandes (2005), a dificuldade de se encontrar uma forte relação positiva entre investimento em educação, convertido em insumos escolares, e desempenho dos estudantes podem ter diferentes explicações. Segundo os autores, a primeira delas seria que insumos escolares têm, de fato, pouca influência sobre o desempenho escolar, não adiantando, desse modo, investir recursos nas escolas dos alunos com dificuldade de aprendizagem se eles continuarem a viver em suas famílias. Essa interpretação traz uma visão pessimista em relação ao progresso social das camadas mais carentes da população, de modo que, os indivíduos são pobres porque possuem pouca escolaridade e, por sua vez, possuem pouca escolaridade porque seus pais eram pobres e tinham pouca escolaridade.

Para Felício e Fernandes (2005), uma segunda hipótese, frequentemente levantada na literatura, assim como usualmente admitido na teoria da produção, aponta que a função de produção escolar é côncava em relação aos seus insumos. Neste caso, os estudantes de escolas com poucos recursos poderiam se beneficiar significativamente com o incremento de mais e melhores insumos escolares, entretanto, a partir de certo nível de recursos esses incrementos passariam a ser pouco significativo no desempenho dos alunos.

Outro fator relevante que é destacado por alguns autores, principalmente aqueles relacionados à corrente de que maiores investimentos não estão relacionados com melhores desempenhos, é a gestão dos recursos, pois para se obter um melhor desempenho educacional não há a necessidade de se investir mais em educação e sim gerir de modo mais eficiente os recursos financeiros disponíveis.

Conte e Donin (2013) corroboram com tal constatação ao explanar sobre as inúmeras discussões realizadas atualmente sobre como maximizar as expectativas de desempenho dos alunos, tendo como base a alocação dos recursos públicos, de modo que possibilitem melhorias no desempenho escolar, e no sentido de analisar se os recursos públicos aplicados no ensino estão proporcionando para os alunos uma educação de qualidade. 
Dentre esses pesquisadores está Menezes-Filho (2007), que ao tentar explicar a desigualdade no desempenho médio de escolas públicas em diferentes municípios do Brasil aponta que as diferenças na gestão dos recursos, ou seja, na forma de alocá-los, são mais importantes para explicar o desempenho escolar do que a simples quantidade de recursos disponíveis. Para o autor é necessário gerir de maneira mais eficiente os recursos disponíveis em cada escola, pois a incompetência na gestão dos recursos contribui para a grande heterogeneidade existentente no desempenho dos alunos, com escolas muito boas e muito ruins dentro da mesma rede.

Savian, Bezerra e Melo (2012) corroboram com tal constatação ao avaliar a eficiência dos gastos públicos com educação nas séries iniciais do ensino fundamental nos municípios do Estado do Paraná nos anos de 2005 e 2009, por meio da aplicação da técnica DEA, que possibilitou a classificação dos municípios quanto à eficiência dos recursos aplicados no ensino fundamental, permitindo assim, realizar comparações entre os municípios do Estado.

Os resultados encontrados apontaram que na maioria dos municípios paranaenses os gastos públicos com educação se mostraram ineficientes, pois foram constatados que os municípios que possuem melhor desempenho econômico não são necessariamente os mais eficientes. Os autores concluem que se mostra necessário uma revisão das práticas de gestão na grande maioria dos municípios paranaenses, por meio de melhoria nos métodos adotados e uma ação mais efetiva por parte do poder executivo, para que se torne possível um melhor aproveitamento dos gastos públicos no Estado do Paraná através de alocações eficientes dos recursos e seja possível ofertar à população uma educação básica que atenda às necessidades essenciais, promovendo igualdade de oportunidades para todos os indivíduos.

Ainda que não haja consenso entre os pesquisadores sobre o impacto dos investimentos em educação sobre o desempenho dos alunos, a importância do investimento em educação, principalmente no desenvolvimento socioeconômico do país, é inquestionável (GREMAUD, FERNANDES, ULYSSEA, 2006). Savian, Bezerra e Melo (2012) corroboram com tal constatação afirmando que o investimento em educação deve ser prioridade do estado, pois ele é capaz de promover cidadania, justiça social, aumento da produtividade, melhora o nível de bem-estar da população, além de criar uma série de outros benefícios para a sociedade. 


\subsubsection{O Investimento em educação no Brasil}

A crescente preocupação do país com a melhoria do ensino público pode ser evidenciada pelos sucessivos aumentos do investimento em educação, em especial a partir de 2005. Segundo o INEP (2013), o Brasil possui uma evolução no aumento do investimento público direto em educação, com recursos provenientes das três esferas do governo (Federal, Estadual e Municipal) que passou de 4,5\% do Produto Interno Bruto nacional (PIB) em 2005 para 6,1\% em 2011, além de estar em debate no senado o novo Plano Nacional de Educação (PNE), que prevê um aumento do investimento para 10\% do PIB em um prazo de dez anos (BRASIL, 2014).

Tabela 3 - Investimento Público Total em Educação em relação ao PIB, por Nível de Ensino

\begin{tabular}{|c|c|c|c|c|c|c|c|}
\hline \multirow[b]{4}{*}{ Ano } & \multicolumn{7}{|c|}{ Percentual do Investimento Público Total em relação ao PIB (\%) } \\
\hline & \multirow{3}{*}{$\begin{array}{c}\text { Todos os } \\
\text { Níveis de } \\
\text { Ensino }\end{array}$} & \multicolumn{6}{|c|}{ Níveis de Ensino } \\
\hline & & \multirow[b]{2}{*}{$\begin{array}{c}\text { Educação } \\
\text { Básica }\end{array}$} & \multirow[b]{2}{*}{$\begin{array}{c}\text { Educação } \\
\text { Infantil }\end{array}$} & \multicolumn{2}{|c|}{ Ensino Fundamental } & \multirow[b]{2}{*}{$\begin{array}{l}\text { Ensino } \\
\text { Médio }\end{array}$} & \multirow[b]{2}{*}{$\begin{array}{c}\text { Educação } \\
\text { Superior }\end{array}$} \\
\hline & & & & $\begin{array}{c}\text { De } 1^{\mathrm{a}} \text { a } 4^{\mathrm{a}} \\
\text { séries ou } \\
\text { anos } \\
\text { iniciais }\end{array}$ & $\begin{array}{c}\text { De } 5^{\mathrm{a}} \text { a } 8^{\mathrm{a}} \\
\text { séries ou } \\
\text { anos finais }\end{array}$ & & \\
\hline 2000 & 4,7 & 3,7 & 0,4 & 1,5 & 1,2 & 0,6 & 0,9 \\
\hline 2001 & 4,8 & 3,8 & 0,4 & 1,4 & 1,3 & 0,7 & 0,9 \\
\hline 2002 & 4,8 & 3,8 & 0,4 & 1,7 & 1,3 & 0,5 & 1,0 \\
\hline 2003 & 4,6 & 3,7 & 0,4 & 1,5 & 1,2 & 0,6 & 0,9 \\
\hline 2004 & 4,5 & 3,6 & 0,4 & 1,5 & 1,3 & 0,5 & 0,8 \\
\hline 2005 & 4,5 & 3,7 & 0,4 & 1,5 & 1,3 & 0,5 & 0,9 \\
\hline 2006 & 5,0 & 4,1 & 0,4 & 1,6 & 1,5 & 0,6 & 0,8 \\
\hline 2007 & 5,1 & 4,3 & 0,4 & 1,6 & 1,5 & 0,7 & 0,8 \\
\hline 2008 & 5,5 & 4,6 & 0,4 & 1,7 & 1,7 & 0,8 & 0,9 \\
\hline 2009 & 5,7 & 4,8 & 0,4 & 1,9 & 1,8 & 0,8 & 0,9 \\
\hline 2010 & 5,8 & 4,9 & 0,4 & 1,8 & 1,7 & 0,9 & 0,9 \\
\hline 2011 & 6,1 & 5,0 & 0,5 & 1,8 & 1,7 & 1,1 & 1,0 \\
\hline
\end{tabular}

Fonte: INEP (2013)

A utilização do percentual do PIB investido em educação é um indicador usual nos estudos de políticas públicas educacionais. Entretanto, segundo Amaral (2013), é preciso ter cautela ao utilizar esse indicar, pois ele não revela precisamente o volume de recursos financeiros e a importância que um país atribui à educação. Segundo o autor, a utilização deste indicador deve ser acompanhada de duas outras informações, sendo, o valor do PIB do país e a quantidade de pessoas do país que estão em idades educacionais corretas, culminando assim, no investimento per capta em educação. 
Deste modo, o volume de recursos financeiros investido em educação no Brasil gera opiniões divergentes entre alguns autores que defendem que o Brasil possui investimentos suficientes em educação, quando considerado o percentual do PIB, sendo inclusive, equivalente a países desenvolvidos (IOSCHPE, 2004; SOARES, 2006) e aqueles que defendem que o investimento per capta em educação no Brasil ainda é baixo, principalmente também quando comparado a países desenvolvidos como Noruega, Finlândia, Suíça, EUA, França, Canadá e Alemanha, sendo necessário um aumento do investimento neste setor (BARBOSA, 2014; AMARAL, 2013).

A fim de aumentar o investimento em educação, juntamente com o aumento previsto pelo PNE, em julho de 2013 foi aprovado pelo Senado Federal um projeto proposto pela Câmara dos Deputados que direciona recursos oriundos dos royalties provenientes da exploração de petróleo para a Educação. Segundo o projeto, $75 \%$ dos royalties devem ser direcionados para a área da educação e o restante para a área da saúde. De acordo com o projeto, no caso da educação, as receitas dos estados poderão ser aplicadas no custeio de despesas com manutenção e desenvolvimento do ensino, especialmente na educação básica de tempo integral (BRASIL, 2013). Desta forma, a expectativa com estas ações é que o aumento de recursos possa melhorar a qualidade da educação oferecida nos municípios brasileiros.

Dentre as várias possibilidades de aplicação dos recursos educacionais o investimento na formação dos Professores é visto por muitos especialistas como um fator imprescindível para o aumento da qualidade no ensino. Setúbal (2010) corrobora com tal constatação ao afirmar que um melhor desempenho escolar de nossos alunos está associado a Professores bons, competentes, comprometidos e apoiados pedagogicamente pela direção da escola e pelos órgãos centrais. O autor conclui destacando que é preciso colocar o Professor no centro das políticas educacionais, por meio da valorização da profissão, da capacitação continuada e proporcionar suporte didático para a sala de aula.

Veloso (2009) destaca que as pesquisas internacionais também têm apontado a qualidade do Professor como fator determinante no nível de aprendizado dos alunos e consequentemente na melhoria da educação. Dentre estas pesquisas destacam-se os trabalhos de Hanushek (2002; 2005) ao apontar que o investimento na qualificação do Professor se justifica pelo fato de que os bons Professores são capazes de fazer com que seus alunos adquiram em um ano letivo normal o equivalente a um ano e meio de aprendizado escolar, enquanto os Professores ruins 
conseguem fazer com que seus alunos aprendam somente o equivalente há um semestre. Para o autor, o Professor altamente qualificado também é capaz de reverter os atrasos típicos que são observados em crianças com ambiente familiar desvantajoso.

Segundo Vegas (2008), o impacto de um Professor sobre os resultados de aprendizagem dos alunos é cumulativo e duradouro, de modo que um Professor ineficaz reduz potencialmente o desempenho do aluno durante anos. Para minimizar os impactos negativos dos Professores no desempenho dos alunos o autor sugeriu em seu trabalho duas categorias de políticas eficientes na gestão dos Professores, são elas: os incentivos que buscam atrair, motivar e reter Professores de alta qualidade e as políticas que buscam melhorar as habilidades e os conhecimentos dos Professores, através de treinamento e capacitação.

Ao reconhecer a importância do Professor sobre a qualidade da educação, o Brasil vem atuando no sentido de assegurar a melhor formação dos Professores, que atuarão ou que já estão em exercício nas escolas públicas brasileiras, por meio de uma parceria entre as universidades públicas e as escolas técnicas federais com o ensino fundamental, que culminou na criação do Plano Nacional de Formação de Professores da Educação Básica, sob responsabilidade da Coordenação de Aperfeiçoamento de Pessoal de Nível Superior (CAPES) (BRASIL, 2007). Além desta iniciativa também foi criada a Universidade Aberta do Brasil, que amplia a oferta de cursos e programas de ensino superior a Professores da rede pública, por meio da educação à distância (BRASIL, 2006). Deste modo, o aumento do investimento em educação direcionado ao aperfeiçoamento e capacitação dos Professores pode representar um fator impactante no desempenho dos alunos e na qualidade da educação oferecida pelas escolas públicas brasileiras.

Apesar do esforço político para o aumento de recursos destinados à educação, como forma de melhorar a qualidade no ensino, não existe consenso entre os pesquisadores sobre a eficiência desta ação, bem como a garantia da melhoria nos indicadores educacionais brasileiro.

Givisiez e Oliveira (2011) ao analisar o efeito das rendas petrolíferas sobre os indicadores educacionais, em nove municípios do estado do Rio de Janeiro, durante um período de doze anos, não identificaram efeito positivo consistente destes recursos sobre os indicadores da educação. Segundo os autores, esperava-se que os municípios que se beneficiavam dos royalties do petróleo deveriam possuir estrutura e indicadores educacionais superiores aos das 
demais escolas do país localizadas em municípios de mesmo porte, entretanto, os resultados indicaram que as vantagens orçamentárias desses municípios não refletiram em melhorias dos indicadores educacionais, contrariando assim a expectativa de que maiores investimentos representam um aumento na qualidade da educação.

Nesta mesma linha, Nogueira e Ramos (2010) analisaram, por meio da técnica de Análise Envoltória de Dados $\left(\mathrm{DEA}^{6}\right)$, a eficiência dos municípios do estado do Rio de Janeiro, na utilização dos recursos provenientes dos royalties do petróleo com um melhor desempenho nos indicadores de qualidade de vida, medido pelo índice de desenvolvimento humano (IDH). Os resultados encontrados pelos autores apontam para uma ineficiência na gestão pública dos recursos dos royalties, indicando um fracasso, em especial, na melhoria da qualidade de vida de sua população. Os autores concluem a afirmativa de que essas ineficiências só tendem a aumentar, dado o aumento da exploração do petróleo, fator esse justificado pela má gestão dos recursos públicos.

Soares (2006) corrobora com tal constatação ao afirmar que o sistema educacional brasileiro precisa de um choque de gestão, de modo que já existem recursos no sistema escolar que poderiam ser transformados em melhores resultados cognitivos dos alunos. Nesta mesma linha, com resultados similares ao de Savian, Bezerra e Melo (2012), o estudo de Zoghbi et al. (2009) avaliou a eficiência dos investimentos estaduais em educação fundamental e média e apontou que os estados com melhor desempenho não são necessariamente os mais eficientes e que na realidade há grandes possibilidades para melhorar a eficiência, por meio de esforços destinados as melhores práticas de gestão de recursos, já que foi constatado que em alguns casos o mesmo índice de eficiência de insumos poderia ser obtido com a redução de cerca de $50 \%$ desses recursos.

Dentro deste contexto fica evidente que a elevação dos investimentos em educação feitos recentemente pelo Brasil deve ser acompanhada de mais critério e qualidade na sua gestão, pois eles devem proporcionar eficiência e igualdade nos sistemas de ensino, a fim de que o desempenho e o desenvolvimento dos alunos possam se concretizar (BRUNET; BERTÊ; BORGES, 2008).

\footnotetext{
${ }^{6}$ A Análise Envoltória de Dados é conhecida pela sigla DEA, originada das iniciais do nome em inglês Data Envelopment Analysis (DEA)
} 


\subsubsection{Nível Socioeconômico}

Nível socioeconômico é um construto teórico que resume as características dos indivíduos em relação a sua renda, ocupação e escolaridade. O interesse pela discussão sobre o NSE nas pesquisas educacionais se dá principalmente pela forte correlação existente entre os resultados escolares e o NSE e cultural das familias (ALVES; SOARES, 2012). Para Soares e Alves (2003), o NSE representa o fator que mais impacta no desempenho escolar dos alunos. Segundo os autores, o indicador deve ser analisado com critério para o caso brasileiro. Para Soares e Alves (2003),

[...] o tamanho da influência da média do nível socioeconômico no Brasil deve ser destacado. O país possui hoje um sistema de educação básica muito segmentado, com a maioria dos estudantes de nível socioeconômico mais alto freqüentando escolas privadas. [...] A interação entre rede e nível socioeconômico médio da escola é significativa e mostra o especial privilégio dos poucos brasileiros que freqüentam escolas privadas, onde o nível médio socioeconômico é alto (SOARES; ALVES, 2003, p. 156).

Os primeiros estudos empíricos que destacaram a influência do NSE no desempenho dos alunos surgiram nas décadas de 1950 e 1960, entre eles está o conhecido Relatório Coleman. Segundo Brooke e Soares (2008), o Relatório Coleman foi uma pesquisa realizada nos Estados Unidos cujo objetivo era conhecer as razões da falta de disponibilidade educacional igual para indivíduos por razão de raça, cor, religião ou naturalidade, em todos os níveis das instituições públicas educacionais. Segundo os autores, a pesquisa investigou mais de quinhentos mil alunos norte-americanos matriculados em escolas primárias e secundárias. A amplitude da amostra, que também inclui Professores, gestores escolares e pais de alunos, permitiu que fossem descritos aspectos relacionados ao desempenho dos alunos, medido através de testes padronizados, especialmente os que envolvem leitura e matemática (BROOKE; SOARES, 2008).

Para Brooke e Soares (2008), os resultados do Relatório Coleman foram surpreendentes, principalmente por evidenciar que o NSE dos alunos foi o fator que melhor contribuiu para o seu desempenho escolar, em detrimento da estrutura das escolas, de seus processos internos e da qualificação de seus Professores. Para Soares (2004), uma das principais conclusões do Relatório Coleman é expressa na polêmica frase “As escolas não fazem diferença”, essa afirmação destaca a irrelevante influência da escola no desempenho dos alunos americanos. Soares e Andrade (2006) complementam afirmando que o Relatório Coleman atribui o 
desempenho escolar dos alunos apenas à sua origem social e às práticas culturais de sua família, ou seja, a escola apenas reproduziria as diferenças socioeconômicas já existentes na sociedade.

Segundo Brooke e Soares (2008), a divulgação dos resultados de Coleman causou grande inquietação na comunidade científica, que não aceitavam suas conclusões como um ponto final para a discussão sobre a contribuição da escola. De acordo com os autores, a principal justificativa era a de que embora os efeitos do NSE dos alunos não sejam desprezíveis, não se pode admitir que a escola fizesse pouca ou nenhuma diferença no desempenho escolar de seus alunos.

Em decorrência de tais resultados, iniciou-se um profundo debate entre acadêmicos, políticos e a sociedade em geral, sobre a efetiva contribuição dos recursos escolares para o aprendizado dos alunos (FIPE, 2007; ALVES; SOARES, 2008). Desde então surgiram diversos estudos, alguns buscando justificar a influência da escola no desempenho cognitivo dos alunos (RUTTER et al.,1979; LEE, 2000; TEDDIE; REYNOLDS, 2000) e outros que corroboraram com as afirmações do Relatório Coleman (PLOWDEN et al., 1967; GAMORAN; LONG, 2006).

Dentre os que corroboraram com o resultado do Relatório Coleman está o estudo de Gamoran e Long (2006) que ao fazer uma revisão do relatório reforçaram a conclusão de Coleman (1966) de que os fatores determinantes para o desempenho escolar dos estudantes em ordem de importância eram primeiramente a família, seguido pelos colegas, enquanto que a escola apresentou apenas uma singela relevância. De acordo com os autores, o impacto dos recursos escolares no desempenho dos alunos foi modesto em comparação com o impacto do contexto familiar dos alunos.

Gremaud, Felicio e Brondi (2007) destacam que as diversas pesquisas que surgiram após o Relatório Coleman tentaram aprimorar a explicação da relação entre a qualidade da escola e o aprendizado dos alunos, passando a considerar também as características dos alunos, bem como suas famílias, os Professores e Diretores e os insumos escolares. Dentro deste contexto, no Brasil se destacam os trabalhos realizados por Soares e Andrade (2006), Soares e Alves (2003) e Soares (2004). 
Soares e Andrade (2006) alertam que não se deve desconsiderar o NSE dos alunos nos estudos sobre a realidade educacional brasileira. Entretando, os autores destacam que atualmente se reconhece que os fatores que determinam o desempenho dos alunos pertencem a três categorias: a estrutura escolar, a família e as características do próprio aluno. De acordo com os autores, as melhores análises incorporam todos esses fatores ao invés de se apoiar em apenas uma área, ou seja, nem os fatores extraescolares conseguem explicar sozinhos os desempenhos dos alunos, nem a escola faz toda a diferença.

Soares e Andrade (2006) em seu estudo sobre o NSE, qualidade e equidade das escolas de Belo Horizonte concluíram que algumas escolas, públicas e privadas, conseguem, por meio de suas políticas e práticas pedagógicas, fazer a diferença no desempenho de seus alunos mesmo quando esses são socioeconômicamente desfavorecidos. Segundo os autores, essas escolas podem ser estudadas no sentido de identificar as melhores práticas, ou seja, aquelas que realmente fazem a diferença.

Embora o NSE seja um determinante fundamental no desempenho dos alunos, conforme visto na literatura, Soares e Alves (2003) afirmam que ainda não há consenso sobre como medir o NSE para estudos de desempenho escolar. Segundo os autores se, por um lado, considera-se que o índice deva incluir indicadores de renda, educação e prestigio ocupacional dos pais, não é claro como cada um desses indicadores deva ser construído.

Para suprir essa lacuna e criar um índice de medida que expresse as variações socioeconômicas entre as famílias, Alves e Soares (2009) apresentam uma metodologia para medir o NSE, realizada por meio da Teoria de Resposta ao Item e utilizando como referência empírica os dados da Pesquisa Longitudinal da Geração Escolar de 2005 (GERES) do pólo de Belo Horizonte, que segundo os autores, consiste em um estudo que acompanha cerca de vinte mil alunos a partir do primeiro ano do ensino fundamental em mais de trezentas escolas (públicas e privadas) de cinco cidades brasileiras. O resultado obtido foi uma escala hierárquica que mede o NSE a partir de uma combinação ponderada das diferentes combinações dos fatores escolaridade, ocupação e renda.

A criação de escalas e índices que categorizam o NSE das famílias é fundamental para o desenvolvimento de pesquisas que buscam identificar os fatores que contribuem para que 
grupos de alunos ou escolas com características socioeconomicas semelhantes possuam desempenho diferente em avaliações de larga escala. Isso pode ser evidenciado mediante a afirmação de Alves e Soares (2009) de que uma escola é eficaz ao proporcionar um conhecimento suficiente ao aluno para que o seu desempenho ao final de cada etapa escolar seja acima do esperado para um aluno de seu NSE, ou seja, mediante a categorização do NSE em classes é possível comparar o desempenho dos alunos que se encontram em situações socioeconômicas similares, matriculados em escolas diferentes.

Segundo Soares e Alves (2003), diminuir as diferenças entre a condição socioeconômica e cultural dos alunos de um sistema de ensino, através de políticas sociais, terá impacto direto nos resultados cognitivo dos alunos. Alves e Soares (2007) corroboram com essa afirmação ao concluir que em qualquer contexto os alunos de melhor NSE têm maior probabilidade de se beneficiar de suas vantagens extraescolares e de apresentar melhores resultados.

\subsubsection{Background Familiar}

Segundo Suliano e Oliveira (2011), um ambiente familiar favorável ao aprendizado é extremamente relevante para a ampliação do conhecimento. Menezes-Filho (2007) destaca que as variáveis que mais explicam o desempenho escolar dos alunos estão relacionadas ao background familiar e características do aluno, tais como a educação da mãe, cor, atraso escolar e reprovação prévia, número de livros e presença de computador em casa e trabalho fora de casa. Dentre essas váriaveis, a que mais impacta o desempenho escolar do aluno, segundo o autor, é a escolaridade da mãe, de modo que, uma mãe mais instruída aumenta a pressão sobre a escola para melhorar a qualidade do ensino, além de acompanhar e cobrar melhores resultados escolares de seus filhos, criando assim um ambiente favorável para o desenvolvimento do conhecimento e gerando motivação ao Professor, que encontra maior facilidade para ensinar em uma sala com um alto nível de background familiar.

Suliano e Oliveira (2011) apontam que, em relação ao rendimento escolar no Brasil, a estrutura familiar é responsável por até $70 \%$ da variação no desempenho dos alunos, sendo isso um indicativo de que boa parte do que se conhece hoje sobre diferença de desempenho escolar é algo que já vem com os próprios alunos, não sendo determinado em sala de aula. Conforme Marturano (2006), o interesse dos pesquisadores no estudo da influência familiar 
sobre o aprendizado escolar aumentou a partir dos anos 1950, sendo que, a partir da década de 1960, passou-se a investigar também, além das variáveis socioeconômicas, a influência de processos da vida familiar sobre o desempenho escolar. Os resultados dessas pesquisas indicaram que a família pode influenciar positivamente o aprendizado escolar, a motivação para os estudos e competências interpessoais para um bom relacionamento com Professores e colegas.

Segundo Riani e Rios-Neto (2008), no Brasil muitos estudos sobre determinantes educacionais têm dado destaque ao papel da família na educação dos filhos, entre eles se destacam os trabalhos de Silva e Hasenbalg (2002) e Barros e Lam (1996), mostrando que os fatores de background familiar, com destaque para o nível de educação dos pais, possuem impactante influência no resultado educacional.

Suliano e Oliveira (2011) concluíram em seu trabalho o quanto o background familiar é importante para o nível de aprendizado do aluno ao obter o resultado que apontava que o fato da mãe possuir ensino médio completo juntamente com acesso a internet em casa aumentava significativamente o desempenho do aluno, enquanto uma mãe que trabalha fora contribui negativamente no desempenho escolar do filho.

Ferreira e Barrera (2010) afirmam que quanto mais o ambiente familiar apresenta recursos culturais e a presença de um adulto capaz de mediar esses recursos, melhor será o desempenho escolar dessa criança, e isso desde a educação infantil. $\mathrm{O}$ autor conclui dizendo que quanto mais escolarizada for a mãe, mais direcionados são os recursos do ambiente familiar para influenciar positivamente nas questões educacionais, isso porque a figura da mãe é sempre mais presente no dia-dia da criança.

Para inúmeros estudiosos o background familiar é imprescíndivel para um bom desempenho escolar dos alunos, no entanto, Ferreira e Barrera (2010) concluem que não basta culpar a família quando esta, muitas vezes, tenta e cumpre, de acordo com suas possibilidades, com o seu papel de apoiar a criança em relação a questões escolares. É preciso, segundo os autores, incentivar o trabalho conjunto entre família e escola, buscando uma maior aproximação desses contextos educacionais, com vistas à obtenção de metas e objetivos em comum que possuem um único propósito que é a criação de um ambiente cultural rico que proporcione a criança um melhor desempenho escolar. 


\subsubsection{Tamanho da escola e desempenho escolar}

O impacto do tamanho da escola sobre o desempenho dos alunos é um tema que causa opiniões contraditórias em inúmeros pesquisadores que destacam vantagens e desvantagens tanto nas escolas de grande porte quanto nas de pequeno porte. O tamanho da escola é dado pela sua capacidade física de atendimento, indicado pelo número de salas de aula permanentes de que dispõe e pelo número total de alunos matriculados na unidade de ensino (WAISELFISZ, 2000).

Segundo o INEP (2005), as escolas de pequeno porte são caracterizadas por possuírem menos de 200 alunos, enquanto as escolas de médio porte possuem de 200 a 999 alunos, já as escolas de grande porte são caracterizadas por possuírem mais de 1.000 alunos.

De acordo com Soares (2004), os estudos de Lee e Smith (1997) e de Raywid (1999), apontam que o desempenho dos alunos tende a ser maior em escolas menores. Segundo as observações feitas pelo autor, embora uma escola de grande porte possa conseguir com maior facilidade recursos adicionais e oferecer a seus alunos uma maior diversidade de experiências, as energias necessárias para fazê-la funcionar bem podem ser usadas de modo mais eficaz em uma escola de pequeno porte. Por outro lado, as observações feitas por Waiselfisz (2000) sobre as oportunidades educacionais indicam que:

Um dos argumentos de peso, frequentemente apresentado por educadores e administradores educacionais, é que as escolas de grande porte oferecem um leque bem mais amplo de oportunidades educacionais e de alternativas curriculares para seus alunos. Essa maior amplitude originaria, como consequência, melhor qualidade do ensino ministrado. Considerando-se que as escolas menores localizam-se, prioritariamente, nas periferias urbanas e nas zonas rurais, e atendem às populações menos favorecidas, um segundo argumento, derivado do anterior, é que se estaria oferecendo menores oportunidades aos setores da população que mais necessitam de estímulos educacionais para compensar os baixos níveis educacionais do meio de onde seus alunos se originam (WAISELFISZ, 2000, p.36).

Waiselfisz (2000) afirma que durante um longo tempo julgou-se que quanto maior o tamanho da escola, maior seria a sua eficiência pedagógica e financeira, por se reunirem condições de oferecer mais e melhores serviços educacionais com custos, por aluno, relativamente menores. Segundo o autor, essa visão passa a sofrer mudanças em vários países após a década de 1980, onde, diversas pesquisas tendem a mostrar que escolas menores obtêm melhores 
resultados curriculares, maior frequência dos alunos, menores taxas de evasão e de repetência, entre outras vantagens para as escolas de pequeno porte.

Dentre essas pesquisas ocupa uma posição de destaque os estudos feitos por Cotton (1996) que identifica os aspectos que colaboram com as escolas de pequeno porte no que se refere ao desenvolvimento de atitudes e comportamentos sociais, na participação em atividades extracurriculares, no senso de pertencer a uma comunidade escolar, na autoestima do aluno, nas relações interpessoais (entre alunos e destes com os Professores), fatores esses que favorece para um melhor desempenho do aluno.

Já Burke (1987), destaca que não é possível afirmar que o tamanho da escola influencia o desempenho do aluno. Para o autor, existem claras evidências de que a relação entre resultado escolar e tamanho da escola não é clara, o que não permite afirmar que a escola de grande porte é melhor que a de pequeno porte ou vice e versa. Holanda, Petterini e Barbosa (2006) corroboram com a constatação do autor ao confirmar que de acordo com as evidências da literatura, acerca do desempenho dos alunos, o tamanho das escolas parece não ser um ponto tão relevante.

Diante dos inúmeros estudos que buscaram identificar o impacto do tamanho da escola sobre o desempenho dos alunos terem contribuído para a explicação dessa relação, Gomes (2005) afirma que parte importante do efeito direto do tamanho da escola sobre o desempenho do aluno ainda permanece inexplicada.

\subsection{Infraestrutura escolar}

A infraestrutura escolar adequada é condição necessária para a oferta de uma educação de qualidade (CEPAL, 2000), pois "a infraestrutura das escolas brasileiras tem uma influência decisiva no rendimento dos seus alunos" (GAME, 2002, p. 15). De modo semelhante Teixeira (2009) aponta que diferentemente do que se observam nos países desenvolvidos, no Brasil as condições de infraestrutura das escolas constituem fatores relevantes para o resultado escolar dos alunos. 
Deste modo, é fundamental que as pesquisas realizadas em qualquer universo no Brasil levem em consideração os elementos relacionados à infraestrutura escolar. A infraestrutura envolve elementos como: número de alunos nas turmas, estado de conservação do prédio, adequação das instalações, recursos didáticos e a existência e qualidade da biblioteca. Esses itens são elementos essenciais dentro de uma escola, e a sua inexistência ou a sua existência de forma precária podem interferir diretamente no desempenho escolar dos alunos (GAME, 2002).

Nesse mesmo sentido, Dourado, Santos e Oliveira (2007) alertam para as condições mínimas de infraestrutura escolar necessárias para se ofertar um ensino de qualidade. Segundo os autores, dentre as condições destacam-se:

[...] ambiente escolar adequado à realização de atividades de ensino, lazer e recreação, práticas desportivas e culturais, reuniões com a comunidade etc.; equipamentos em quantidade, qualidade e condições de uso adequadas às atividades escolares; biblioteca com espaço físico apropriado para leitura, consulta ao acervo, estudo individual e/ou em grupo, pesquisa online, dentre outros, incluindo, acervo com quantidade e qualidade para atender ao trabalho pedagógico e ao númerode alunos existentes na escola; laboratórios de ensino, informática; $[. .$.$] garantia de condições de acessibilidade e atendimento para$ portadores de necessidades especiais; e ambiente escolar dotado de condições de segurança para os alunos, Professores, funcionários, pais e comunidade em geral (DOURADO, SANTOS, OLIVEIRA, 2007, p. 20).

Para Soares (2004), dentre os itens de infraestrutura a biblioteca merece um destaque especial, pois ela é considerada um local privilegiado para a aprendizagem, e o seu uso constante pelos alunos influencia fortemente o resultado escolar. Segundo o autor, é difícil de imaginar uma escola que mereça esse nome sem abrigar uma biblioteca. Segundo Quinhões (1999), a biblioteca deve funcionar como um centro estimulador, pois juntamente com outras atividades, ela pode tornar o currículo mais eficaz e orientar para um melhor desempenho individual e coletivo na formação do cidadão. Entretanto, Soares (2004) afirma que para produzir um efeito positivo no desempenho dos alunos, é fundamental que os Professores estimulem a frequência dos alunos à biblioteca e que estes realmente utilizem os recursos nela disponível (SOARES, 2004). Motta (1999) também destaca que a biblioteca escolar deve possuir organização e regras claras quanto ao seu funcionamento a fim de facilitar o ensino e a aprendizagem dos alunos. Bezerra (2008) complementa afirmando que a biblioteca deve ser um lugar bem gerenciado, organizado e prazeroso.

Em relação ao acervo da biblioteca, Bezerra (2008) afirma que ele deve conter materiais bibliográficos diversificados, em uma quantidade que atenda e dê suporte ao seu corpo 
discente e docente. A autora ainda destaca a importância deste acervo estar organizado e em perfeito estado de uso, pois um bom acervo enriquece o processo de ensino-aprendizagem e, deste modo, fomenta a aprendizagem no aluno (QUINHÕES, 1999).

Outro elemento da infraestrutura que merece destaque é o transporte público escolar, pois o Brasil possui como característica um grande número de alunos residindo na área rural, deste modo, a dificuldade de acesso, dado pela distância entre a casa dos alunos e as escolas, podem motivar a evasão escolar.

Segundo Moura e Cruz (2013), o transporte escolar é uma política educacional essencial para o acesso de considerável número de alunos de escolas públicas ao ambiente escolar. Deste modo, ele se torna condição indispensável para a garantia do direito a educação. Dado a sua importância, Moura e Cruz (2013) afirmam que é fundamental destacar que:

[...] o transporte escolar é um direito assegurado pela Constituição Federal de 1988, em seu artigo 28, pela Lei de Diretrizes e Bases da Educação Nacional (LDB), no artigo 4, e pelo Estatuto da Criança e do Adolescente (ECA), em seu artigo 54, com o objetivo de promover o acesso do alunado às escolas, condições básicas para a garantia do direito à educação (MOURA, CRUZ, 2013, p. 2).

Nesse sentido, é necessário "fortalecer, na sociedade de um modo geral e nos gestores, em particular, a percepção da garantia ao transporte público escolar como um direito, estreitamente relacionado à educação de qualidade" (BRASIL, 2006, p.4). Moura e Cruz (2013) destacam a necessidade de se ampliar os recursos destinados à oferta do transporte público escolar, para que se garanta em quantidade e qualidade adequadas à demanda deste serviço por parte dos estudantes das escolas públicas rurais e urbanas no Brasil.

A infraestrutura também envolve a disponibilidade de laboratório de informática nas escolas. De acordo com o Censo Escolar da Educação Básica de 2012, esse foi o recurso que as escolas mais disponibilizaram, sendo oferecido por 49\% delas (INEP, 2013). Entretanto, Menezes-Filho (2007) afirma que existe muita discussão a respeito da inclusão digital, ou seja, o uso de computadores nas escolas públicas.

Para Gladcheff, Zuffi e Silva (2001), o uso do computador pode ser considerado um grande aliado do desenvolvimento cognitivo dos alunos. Entretanto, os autores destacam que:

[...] o bom uso que se possa fazer dessa ferramenta na sala de aula depende tanto da metodologia utilizada, quanto da escolha de softwares, em função 
dos objetivos que se pretende atingir e da concepção de conhecimento e de aprendizagem que orienta o processo (GLADCHEFF, ZUFFI, SILVA, 2001, p. 2).

Por se tratar de um instrumento lógico e simbólico, Gladcheff, Zuffi e Silva (2001) afirmam que o computador pode a vir contribuir muito para que a criança, já no ensino fundamental, aprenda a lidar com sistemas representativos simbólicos, linguísticos ou numéricos. Os estudos de Suliano e Oliveira (2011) corroboram com tal afirmação ao destacar que o uso de computadores provoca um efeito positivo no desempenho dos alunos.

Enquanto Menezes-Filho (2007) aponta em seu estudo, sobre os determinantes do desempenho escolar no Brasil, que o número de computadores na escola tem efeitos muito reduzidos sobre o desempenho dos alunos. Já Kulik (2003) ao analisar o impacto da utilização de computadores no ensino fundamental demonstrou que não se podem associar melhorias no desempenho de leitura dos alunos ao uso dos computadores. Bionde e Felício (2007) concluem que a existência de laboratório de informática na escola está relacionada negativamente com o desempenho dos alunos, entretanto, existem evidências de que o uso de computadores para fins pedagógicos tem efeitos positivos sobre a proficiência.

Segundo Dourado, Santos e Oliveira (2007), as pesquisas e estudos na área educacional indicam a importância do financiamento para o estabelecimento de infraestrutura escolar que ofereça condições mínimas para a oferta de uma educação de qualidade.

A preocupação com a melhoria da infraestrutura escolar brasileira é evidenciada por uma pesquisa realizada pelo INEP (2011) com 3.410 dirigentes municipais de educação do Brasil no ano de 2010. Segundo o INEP, a maior preocupação dos dirigentes é com a insuficiência de infraestrutura das escolas e a dificuldade na conservação dos prédios.

Considerando o total de dirigentes participantes da pesquisa, o tema apontado por mais dirigentes como prioritário foi melhorar a infraestrutura das escolas (46,2\%). Tal preocupação deve alertar as políticas públicas para a evidente necessidade de investimento de recursos nessa área, pois a criação de um ambiente escolar adequado ao desenvolvimento da aprendizagem é fundamental para a melhoria no desempenho dos estudantes. 


\subsection{Sistema de Avaliação da Educação}

A avaliação do sistema educacional representa uma ferramenta indispensável na busca por uma educação de qualidade, pois ela permite identificar as redes de ensino que apresentam um baixo desempenho escolar, e que em função disso, necessitam de maior apoio financeiro e principalmente uma melhor gestão dos recursos disponíveis (MEC, 2008).

Segundo Marchelli (2010), os sistemas educacionais são avaliados sob as dimensões da aprendizagem e da escola, o que envolve tanto o conhecimento adquirido pelo aluno quanto os mecanismos utilizados pelo Estado com a finalidade de fornecer a educação. Segundo o autor (2010),

[...] a avaliação externa dos sistemas de ensino foi assim adotada pelos governos como um instrumento de controle político do desenvolvimento social. Os resultados dos exames aplicados aos estudantes passaram a ocupar um lugar central na agenda do planejamento educacional, considerados a forma de melhor eficácia para aferir a qualidade. Entendeu-se que os resultados da aprendizagem dizem respeito ao sistema escolar como um todo, que engloba a infraestrutura, meios de financiamento, organização do trabalho dos Professores, administração de recursos pedagógicos, envolvimento dos pais e da comunidade, entre outros aspectos que podem ser destacados (MARCHELLI, 2010, pp. 562-563).

Vidal e Farias (2005) revelam que a preocupação com a avaliação da aprendizagem no Brasil não é recente, pois desde a década de 1980 começaram a ser desenvolvidas iniciativas para se conhecer melhor o sistema educacional brasileiro. Segundo Horta Neto (2007), um dos primeiros estudos que objetivou estabelecer um sistema de avaliação ocorreu no Programa de Educação Básica para o Nordeste Brasileiro. Desde então, o desempenho escolar dos alunos passou a ser utilizado constantemente para medir o impacto dos programas e políticas públicas educacionais.

Segundo Sousa e Oliveira (2010), a partir da década de 1990 a avaliação de sistemas escolares passou a ser visto como um fator indispensável nas políticas públicas, sendo recomendado pelo Ministério da Educação e por Secretárias de Educação de diversos estados brasileiros, como elemento fundamental para a melhoria da qualidade do ensino básico. 


\subsubsection{Sistema Nacional de Avaliação da Educação Básica (SAEB)}

A avaliação é um importante instrumento para averiguar a qualidade, eficiência e equidade de qualquer sistema educacional, tornando-se de grande importância para paises focados na qualidade do ensino (CASTRO, 1998).

Segundo Waltenberg e Vandenberghe (2007), o SAEB é composto por testes aplicados em todo o país, tendo como objetivo avaliar as habilidades cognitivas dos alunos em português e matemática. As informações e resultados do teste é aclopado com dados sobre aspectos relevantes dos alunos e seus familiares, bem como Professores, Diretores e características da escola. O SAEB representa a primeira iniciativa de se avaliar a educação em nosso país, institucionalizado mais adiante como um processo nacional de avaliação da educação pela Portaria 1.795 de 27 de dezembro de 1994. A partir de então se intensifica a atenção aos resultados do desempenho escolar da educação brasileira (FREITAS, 2012).

A primeira avaliação do SAEB ocorreu em 1990 e em 1992 sua aplicação ficou sobre a responsabilidade do Instituto Nacional de Estudos e Pesquisas Educacionais Anísio Teixeira (INEP), que desde então, definiu que sua aplicação seria a cada dois anos (HORTA NETO, 2007). Até o ano de 2005, o SAEB era tido como um mecanismo para acompanhar o desempenho médio dos alunos de escolas públicas e particulares e estabelecer correlações estatísticas envolvendo os desempenhos obtidos e as variáveis apuradas no questionário. $\mathrm{O}$ SAEB era composto de um exame (questionário) realizado a cada dois anos que era aplicado a uma amostra de alunos de cada estado (HADDAD, 2008). No entanto, para o autor, o SAEB era muito restrito e apresentava algumas limitações, entre elas citam-se: a amostra analisada não era representativa de cada rede municipal ou de cada escola, o que não permitia analisar se o desempenho educacional dos municípios estava adequado e muito menos em que pontos cada escola deveriam concentrar seus esforços para melhorar as condições de aprendizagem que apresentavam.

Em 2005 houve a reformulação do SAEB, por meio da implementação e realização da primeira avaliação universal da educação básica pública, a Prova Brasil, que foi aplicada a mais de três milhões de alunos da quarta e da oitava séries das escolas públicas urbanas, com a finalidade de criar um sistema nacional de avaliação que melhor acompanhasse as condições educacionais e a aprendizagem em busca de uma formação básica comum. A partir de sua 
reformulação, o SAEB passou a disponibilizar seus dados por redes de ensino e por escolas, possibilitando deste modo uma melhor avaliação da qualidade do ensino básico, com a identificação de boas práticas de escolas e redes de ensino que tiveram desempenhos satisfatórios e que poderiam ser disseminadas e deficiências que deveriam ser sanadas de forma efetiva.

Após sua reformulação, o Sistema Nacional de Avaliação da Educação Básica passou a ser composto por duas avaliações complementares, são elas: a Avaliação Nacional da Educação Básica (ANEB), que permite produzir resultados médios de desempenho conforme os dados amostrais, promovendo por meio da aplicação de questionários estudos que investiguem a equidade e a eficiência dos sistemas e redes de ensino; e a Avaliação Nacional do Rendimento Escolar (ANRESC) conhecida também como Prova Brasil, que é aplicada somente a estudantes de $4^{\mathrm{a}}$ série $/ 5^{\circ}$ ano e $8^{\mathrm{a}}$ série $/ 9^{\circ}$ ano de escolas da rede pública de ensino, tendo como prioridade evidenciar os resultados de cada unidade escolar dessa rede (MEC, 2008).

De acordo com Freitas (2012), as avaliações que compõe o SAEB tem o objetivo comum de avaliar a qualidade do ensino oferecido pelo sistema educacional brasileiro, por meio de testes padronizados e aplicados em larga escala, gerando informações claras e confiáveis que contribua para uma melhor gestão da educação no Brasil. Neste sentido, de acordo com Soares (2006), os testes do SAEB,

[...] visam avaliar processos cognitivos ao invés de mero conteúdo, e para medir as habilidades esperadas dos alunos ao final do $4^{\circ}, 8^{\circ}$ e $11^{\circ}$ ano do ensino básico. As especificações dos testes são baseadas nos Parâmetros Curriculares Nacionais (PCN) e as Diretrizes da Educação Nacional e da Lei-Quadro (LDB), e os resultados de uma consulta nacional completa com Professores, pesquisadores e especialistas (SOARES, 2006, p.181).

\subsubsection{Prova Brasil}

A Prova Brasil é uma avaliação nacional de rendimento escolar, que compõe o Sistema Nacional de Avaliação da Educação Básica e é aplicada a cada dois anos a alunos de escolas públicas do ensino fundamental. Segundo Oliveira (2011), ela foi idealizada pelo Governo Federal para oferecer aos gestores estaduais, municipais, distritais e a toda sociedade, informações sobre a qualidade do Ensino Fundamental ministrado em cada unidade escolar. 
Segundo Hanushek (2005), a avaliação da qualidade do ensino fundamental, medida pelo desempenho dos alunos em testes padronizados tem sido foco de muitos estudos na literatura educacional nos últimos anos, por representar um grande avanço na quantificação da qualidade do ensino, ou seja, seus resultados funcionam como o termômetro da educação básica do país mostrando o nível da qualidade do ensino oferecido, além de fornecer subsidios importantes para a formulação de políticas públicas eficientes que promova uma melhora da qualidade educacional.

A Prova Brasil teve sua primeira aplicação em novembro de 2005 e foi realizada em 5.387 municípios de todas as unidades da federação, avaliando 3.392 .880 alunos de $4^{\mathrm{a}}$ e $8^{\mathrm{a}}$ séries do ensino fundamental, distribuidos em 125.852 turmas de 40.962 escolas públicas urbanas com mais de 30 alunos matriculados na série avaliada. A prova envolveu a resolução de questões de Língua Portuguesa (com foco em leitura) e Matemática (foco na resolução de problemas), além de um questionário que coletou informações sobre aspecto social, econômico e cultural dos alunos (FIPE, 2007). Segundo Santos (2008), os resultados obtidos pelos estudantes na Prova Brasil são classificados em três níves de proficiência, sendo: elementar, intermediário e adequado, em que, cada série avaliada estes níveis descrevem as competências que os estudantes já desenvolveram.

De acordo com a Portaria Ministerial no 931, de 21 de Março de 2005 (BRASIL, 2005), os objetivos gerais da Prova Brasil são:

a) Avaliar a qualidade do ensino ministrado nas escolas, de forma que cada unidade escolar receba o resultado global;

b) Contribuir para o desenvolvimento, em todos os níveis educativos, de uma cultura avaliativa que estimule a melhoria dos padrões de qualidade e equidade da educação brasileira e adequados controles sociais de seus resultados;

c) Concorrer para a melhoria da qualidade de ensino, redução das desigualdades e a democratização da gestão do ensino público nos estabelecimentos oficiais, em consonância com as metas e políticas estabelecidas pelas diretrizes da educação nacional; e

d) Oportunizar informações sistemáticas sobre as unidades escolares. Tais informações serão úteis para a escolha dos gestores da rede as quais pertençam.

A nota da prova Brasil é calculada considerando as respostas dadas pelos alunos nos testes aplicados (Lingua Portuguesa e Matemática), a partir daí, cria-se uma distribuição dos alunos por nível da escala de proficiência que varia entre 0 e 500 pontos, conforme mostram a Tabela 4 e a Tabela 5 . A escala de proficiência de Língua Portuguesa é apresentada a seguir em uma escala de 9 níveis. 
Tabela 4 - Escala de proficiência Língua Portuguesa

\begin{tabular}{cc}
\hline Nível & Pontuação \\
\hline Nível 0 & 125 ou menos \\
Nível 1 & 125 a 150 \\
Nível 2 & 150 a 175 \\
Nível 3 & 175 a 200 \\
Nível 4 & 200 a 225 \\
Nível 5 & 225 a 250 \\
Nível 6 & 250 a 275 \\
Nível 7 & 275 a 300 \\
Nível 8 & 300 a 325 \\
Nível 9 & Maior que 325 \\
\hline
\end{tabular}

Fonte: INEP (2011)

De maneira similar, a distribuição dos alunos por nível da escala de proficiência de Matemática é apresentada na Tabela 5. De acordo com a tabela, a pontuação dos alunos está distribuída em uma escala de 12 níveis. Os dados da escala de proficiência em Matemática, de acordo com o nível e a pontuação respectiva de cada nível é apresentada a seguir.

Tabela 5 - Escala de proficiência de Matemática

\begin{tabular}{cc}
\hline Nível & Pontuação \\
\hline Nível 0 & 125 ou menos \\
Nível 1 & 125 a 150 \\
Nível 2 & 150 a 175 \\
Nível 3 & 175 a 200 \\
Nível 4 & 200 a 225 \\
Nível 5 & 225 a 250 \\
Nível 6 & 250 a 275 \\
Nível 7 & 275 a 300 \\
Nível 8 & 300 a 325 \\
Nível 9 & 325 a 350 \\
Nível 10 & 350 a 375 \\
Nível 11 & 375 a 400 \\
Nível 12 & Maior que 400 \\
\hline
\end{tabular}

Fonte: INEP (2011)

Segundo Haddad (2008), os resultados da Prova Brasil possibilita a identificação de grandes desigualdades regionais no país, além de demonstrar a realidade de cada escola em cada município brasileiro, avaliando as competências construídas e as habilidades desenvolvidas, com o objetivo de identificar as dificuldades de aprendizagem dos alunos.

Segundo Kusiak (2012), o resultado desta avaliação, como um instrumento cognitivo, é utilizado para ampliar a gama de informações que subsidiarão a implementação das medidas e 
propostas que venham a auxiliar e superar as deficiências detectadas em cada escola avaliada. Segundo o Ministério da Educação (2008), os resultados da Prova Brasil contribui para dimensionar os problemas da educação básica brasileira e orientar a formulação, implementação e a avaliação de políticas públicas educacionais que conduzam a formação de uma escola de melhor qualidade.

\subsubsection{Indicadores de Rendimento}

Os indicadores de rendimento são representados pelas taxas de rendimento escolar, calculada com base nas informações sobre aprovação, reprovação e abandono dos alunos. As taxas de rendimento buscam avaliar se o aluno esta preenchendo ou não os requisitos de aproveitamento e frequência ao final de um ano letivo (PORTILHO, 2013). O INEP (2013) destaca essas três taxas e seus focos de avaliação como sendo;

1- Taxa de aprovação (APR), indica a porcentagem de alunos que, ao final do ano letivo, alcançaram os critérios mínimos para a conclusão satisfatória da etapa de ensino na qual se encontrava;

2- Taxa de Reprovação (REP), indica a porcentagem de alunos que, ao final do ano letivo, não alcançaram os critérios mínimos para a conclusão da etapa de ensino na qual se encontrava; e

3- Taxa de abandono (ABA), indica a porcentagem de alunos que deixaram de frequentar a escola após a data de referência do censo.

Segundo o INEP (2011), as taxas de rendimento escolar constituem elementos imprescindíveis para a avaliação da qualidade da educação oferecida em nosso país, de modo que, os resultados obtidos com os níveis de aprovação, reprovação e abandono dos alunos do ensino fundamental e médio são os insumos utilizados para calcular o IDEB que é referência para as metas do Plano de Desenvolvimento da Educação (PDE), do Ministério da Educação. De acordo com o INEP (2012), para o cálculo das taxas de rendimento escolar (aprovação, reprovação e abandono) são delimitadas unidades de agregação, ou seja, escola, municipio e rede, considerando o conjunto de matrículas que as compõem, disponível na base de dados do Educacenso. 
Segundo o Censo Escolar da Educação Básica de 2012, o Educacenso é um sistema informatizado de levantamento de dados do Censo Escolar, que utiliza ferramentas web na coleta, organização, transmissão e disseminação dos dados censitários. Segundo o autor, o Censo Escolar consiste no maior e mais completo levantamento de dados e informações sobre a educação básica do nosso país, objetivando subsidiar a elaboração de análises, diagnósticos e planejamento do sistema educacional brasileiro (INEP, 2013).

Segundo o INEP (2012), ao final do ano letivo a matrícula feita pelo aluno deverá apresentar apenas uma das seguintes situações:

1- Falecido (FAL);

2- Aprovado (APR);

3- Reprovado (REP);

4- Abandono (ABA);

5- Sem informação de rendimento, falecimento ou abandono (SIR).

Com base nas informações anteriores, realiza-se o cálculo de matrículas consideradas na apuração das taxas de rendimento escolar da seguinte forma:

\section{(I) n - FAL - SIR}

onde,

$\mathbf{n}=$ é o total de matrículas iniciais;

FAL = é a quantidade de matrículas de alunos falecidos; e

$\mathbf{S I R}=$ são as matrículas que não tiveram a situação de rendimento escolar ou abandono informado.

De acordo com o INEP (2012), para cada uma dessas matrículas, foi possível identificar a condição de rendimento escolar: aprovado (APR), reprovado (REP) ou de abandono (ABA).

Logo, se verifica a seguinte igualdade:

(II) $\quad$ n - FAL - SIR $=$ APR + REP + ABA 
Desta forma, segundo INEP (2012), as taxas de rendimento escolar são calculadas da seguinte forma:

Taxa de Aprovação $=[\mathbf{A P R} /(\mathbf{A P R}+\mathbf{R E P}+\mathbf{A B A}] \mathbf{x} \mathbf{1 0 0}$

Taxa de Reprovação = $[\mathbf{R E P} /(\mathbf{A P R}+\mathbf{R E P}+\mathbf{A B A})] \mathbf{x}$ 100;

Taxa de Abandono $=[\mathbf{A B A} /(\mathbf{A P R}+\mathbf{R E P}+\mathbf{A B A})] \mathbf{x} \mathbf{1 0 0}$

Onde,

Taxa de Aprovação + Taxa de Reprovação + Taxa de Abandono = 100 .

E para verificar se há representatividade das taxas de rendimento escolar, foi calculado um indicador associado, denominado Taxa de Não Resposta (TNR), que aponta a porcentagem de alunos que tiveram as informações de rendimento/movimento computadas na situação do aluno por falta de informação ou por inconsistências, é dado por:

(III) $\quad$ TNR $=[$ SIR $/($ n-FAL $] \times 100$.

\subsection{4 Índice de Desenvolvimento da Educação Básica (IDEB)}

O Índice de Desenvolvimento da Educação Básica é um indicador de qualidade educacional que relaciona de forma positiva informações de rendimento escolar (aprovação) e desempenho (Proficiências) em exames padronizados, como a Prova Brasil e o Saeb (FERNANDES, 2007). Segundo o autor, o IDEB foi criado em 2007 pelo INEP, dado a necessidade de se estabelecer padrões de qualidade e critérios para o monitoramento permanente do sistema de ensino brasileiro.

Segundo INEP (2011), o IDEB é mais que um indicador estatístico, pois ele nasceu como condutor de política pública pela melhoria da qualidade da educação, tanto no âmbito nacional, como nos estados, municipios e escolas. Sua composição possibilita não apenas o diagnóstico atualizado da situação educacional em todas as esferas, mas também a projeção de metas individuais intermediárias rumo ao incremento da qualidade do ensino. 
De acordo com o INEP (2011), a questão do acesso à escola não é mais um problema para o Brasil, já que quase a totalidade das crianças ingressa no Sistema educacional. No entanto, surgem outros desafios para o sistema de ensino brasileiro, como as altas taxas de repetência dos alunos, o alto nível de abandono antes mesmo de concluir a educação básica, e a baixa proficiência dos alunos em testes padronizados. Desta forma, o IDEB representa a iniciativa de agrupar em um único indicador esses conceitos considerados tão relevantes para a qualidade educacional do país.

Para o cálculo do IDEB são considerados dois indicadores: o fluxo escolar (passagem dos alunos pelas séries sem repetir, avaliado pelo Programa Educacenso) e o desempenho dos alunos (avaliado pela Prova Brasil/Saeb nas áreas de Língua Portuguesa e Matemática). Para Fernandes (2007), a combinação entre fluxo e aprendizagem do IDEB vai expressar em valores de 0 a 10 o andamento dos sistemas de ensino, em âmbito nacional, nas unidades da Federação e municípios, e é calculada por meio da seguinte fórmula:

$$
\operatorname{IDEB}_{j i}=N_{j i} P_{j i} ; \quad 0 \leq N_{j} \leq 10 ; 0 \leq \mathrm{P}_{j} \leq 1 \quad \text { e } \quad 0 \leq \operatorname{IDEB}_{j} \leq 10
$$

em que,

$\mathbf{i}=$ ano do exame (Saeb e Prova Brasil) e do Censo Escolar;

$\mathbf{N}_{j i}=$ média da proficiência em Língua Portuguesa e Matemática, padronizada para um indicador entre 0 e 10 , dos alunos da unidade $\mathrm{j}$, obtida em determinada edição do exame realizado ao final da etapa de ensino;

$\mathbf{P}_{j i}=$ indicador de rendimento baseado na taxa de aprovação da etapa de ensino dos alunos da unidade $\mathrm{j}$.

Segundo o INEP (2011), o IDEB é o resultado do produto entre o desempenho e o rendimento escolar (ou o inverso do tempo médio de conclusão de uma série) então ele pode ser interpretado da seguinte maneira: para uma escola $A$ cuja média padronizada da prova Brasil, $4^{\mathrm{a}}$ série, é 5,0 e o tempo médio de conclusão de cada série é de 2 anos, a rede/escola terá o IDEB igual a 5,0 multiplicado por 1/2, ou seja, IDEB = a 2,5. Já uma escola $B$ com média padronizada da Prova Brasil, $4^{\mathrm{a}}$ série, igual a 5,0 e tempo médio para conclusão igual a 1 ano, terá IDEB =5,0. 
De acordo com Veloso (2011), o motivo pelo qual se combinou os resultados da Prova Brasil/SAEB e os dados do Educacenso é evitar o surgimento de distorções no IDEB como, por exemplo: o incentivo das escolas à evasão de alunos com baixos desempenhos para obter uma maior nota na Prova Brasil. Ademais, a escola que tentar aumentar seu índice de aprovação, através da diminuição de sua taxa de reprovação, estará sujeita a uma queda nas notas da Prova Brasil e consequentemente apresentará uma redução no IDEB.

Fernandes (2007) também defende a idéia de que um sistema educacional que reprova constantemente seus estudantes, contribuindo para que grande parte deles abandone a escola antes mesmo de completar a educação básica, não é desejável, mesmo que aqueles que concluem essa etapa de ensino atinjam elevadas pontuações nos exames padronizados. Por outro lado, um sistema em que todos os alunos concluem o ensino médio no período correto não é de interesse caso os alunos aprendam muito pouco na escola. Em suma, o autor considera que um sistema de ensino ideal seria aquele em que todas as crianças e adolescentes tivessem acesso à escola, não desperdiçassem tempo com repetências, não abandonassem a escola precocemente e, ao final de tudo, aprendessem.

De acordo com o INEP (2011), indicadores educacionais como o IDEB são desejaveis por permitirem o monitoramento de sistema de ensino do país. Sua importância, em termos de diagnóstico e norteamento de ações políticas focalizadas na melhoria do sistema educacional, está em detectar escolas e redes de ensino cujos alunos apresentam baixa performance em termos de rendimento e proficiência, além de monitorar a evolução temporal do desempenho dos alunos dessas escolas e redes de ensino.

Com a criação do IDEB em 2007, o Brasil se comprometeu a alcançar a média nacional de 6,0 pontos até 2022, ano do bicentenário da independencia, sendo que este índice já é alcançado pelos países da (OCDE) Organização para a Cooperação e o Desenvolvimento Econômico (BRASIL, 2012).

Atingir esse resultado seria um grande feito para a educação brasileira, entretanto, Marchelli (2010) destaca que a média fixada em seis pontos pelo MEC como meta educacional baseada na média dos países da OCDE é ambígua no que se refere à formulação do IDEB, pois a OCDE realiza seus cálculos a partir dos resultados do PISA que possui uma metodologia divergente em relação à apresentada pelo IDEB. 
A metodologia do PISA não permite a realização de uma classificação dos resultados por municípios, o máximo que se consegue medir com esse índice são os resultados obtidos nas cinco regiões brasileiras, diferentemente do IDEB que realiza uma análise mais minuciosa sendo calculado com base nas médias obtidas pelos municípios no SAEB, permitindo que o governo possa formular suas políticas públicas concebidas por meio de suas unidades administrativas municipais. Dessa forma, a associação comparativa com a média da OCDE torna a meta anunciada pelo MEC pouco precisa. Neste caso o autor sugere que esta meta deveria ter sido fixada como meta do Brasil no PISA.

Segundo Padilha et al. (2012), o IDEB é considerado o indicador brasileiro mais abrangente sobre o monitoramento da qualidade da educação básica, entretanto, mesmo assim ele possui algumas limitações para representar a qualidade da educação. São elas: 1. O IDEB é construído sobre a média da nota dos alunos, sendo muito influenciado por valores extremos, o cálculo da média pode gerar um incentivo para as escolas investirem nos alunos melhores, eliminando os mais fracos ou induzindo-os a faltar no dia da prova. 2. Quando utilizado para avaliar os estados e municípios o IDEB não permite qualquer conclusão sobre a cobertura educacional das redes, ou seja, um municipio pode obter um alto IDEB investindo em educação para apenas uma parcela de sua população, excluindo os mais vulneráveis.

Já para Fernandes (2007), o IDEB é o mecanismo mais eficiente disponível no país para avaliar e monitorar a qualidade do sistema educacional. Segundo o autor, ele possibilita, por meio de sua metodologia, a obtenção de esforços individuais necessários e as trajetórias a serem percorridas pelas redes de ensino e até mesmo pelas unidades escolares para que o país atinja em 2022 o nível de qualidade desejável à educação brasileira.

\subsubsection{Programa Internacional de Avaliação de Estudantes (PISA)}

Além das avaliações nacionais, o Brasil também participa de sistemas internacionais de avaliação da educação, como o Programa Internacional de Avaliação de Estudantes (PISA) desenvolvido e coordenado pela Organização para a Cooperação e Desenvolvimento Econômico (OCDE) e aplicado no Brasil, sob a coordenação do INEP. Realizado trienalmente com a participação de estudantes de diversos países, o Brasil participou do PISA em cinco 
avaliações, nos anos de 2000, 2003, 2006, 2009 e 2012. A Tabela 6 apresenta a participação do Brasil no programa.

Tabela 6 - Resultados do Brasil no PISA

\begin{tabular}{lccccc}
\hline & Pisa 2000 & Pisa 2003 & Pisa 2006 & Pisa 2009 & Pisa 2012 \\
\hline Número de alunos participantes & 4.893 & 4.452 & 9.295 & 20.127 & 18.589 \\
Leitura & 396 & 403 & 393 & 412 & 410 \\
Matemática & 334 & 356 & 370 & 386 & 391 \\
Ciências & 375 & 390 & 390 & 405 & 405 \\
\hline
\end{tabular}

Fonte: INEP (2014)

O objetivo do PISA é comparar a efetividade dos sistemas de ensino entre os países associados a OCDE, por meio de provas que a cada ano foca uma entre as três áreas de conheciento (leitura, matemática e ciências) e, para isso, avalia o desempenho de alunos na faixa de 15 anos de idade, faixa etária em que se pressupõe o término do ensino fundamental (MARCHELLI, 2010; NUNES; VIEIRA, 2011).

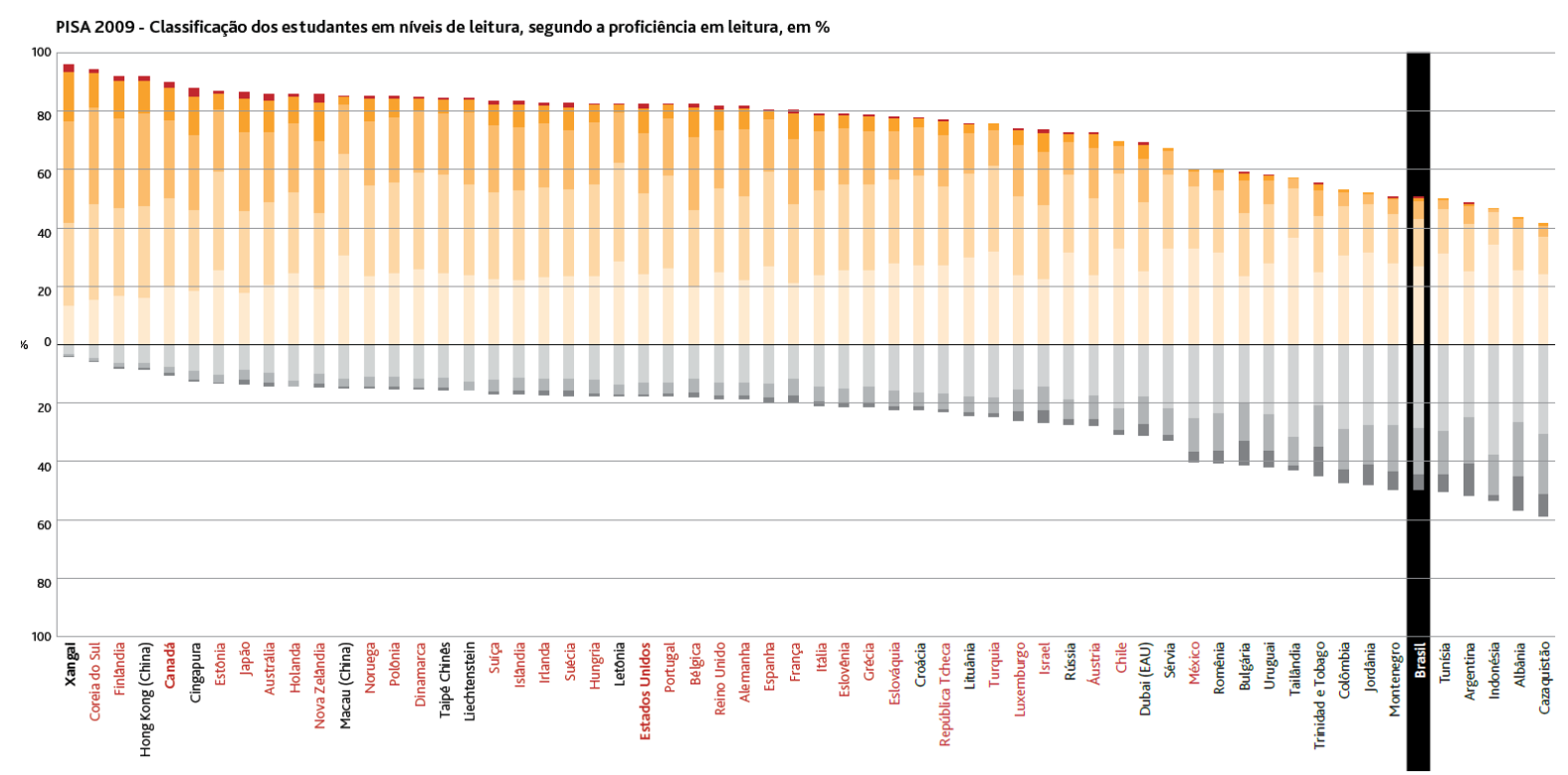

Gráfico 5 - Classificação dos estudantes em níveis de leitura na avaliação PISA 2009 Fonte: OCDE, elaborado por Cruz e Monteiro (2014)

Segundo Menezes-Filho (2007), o desempenho brasileiro no PISA é pífio, estando abaixo de países com renda per capta similar a sua, tais como a Tunísia, México, Uruguai e Turquia. O que é surpreendente segundo o autor, é que como a amostra é representativa do ensino público e privado no Brasil, mostra que mesmo as melhores escolas brasileiras não estão conseguindo passar um nível de aprendizado de padrão internacional a seus alunos. 
Para Blömeke et al. (2011), uma das maneiras de melhorar a qualidade de ensino se dá pela formação dos Professores. Os autores, ao discutir este aspecto na formação de educadores em matemática, consideram que duas medidas são possíveis para aumentar a eficácia na formação dos Professores e, consequentemente, melhorar o desempenho dos alunos. Segundo Blömeke et al. (2011),

Para conseguir um aumento de eficácia da formação de Professores, de acordo com nossos estudos, são possíveis duas medidas, cada uma com efeitos diferentes. Fornecer oportunidade de aprendizado em matemática e pedagogia matemática, bem como aumentar a seletividade de entrada pode ter consequências positivas para os resultados de formação de Professores primários e, portanto, em longo prazo para o desempenho do aluno em matemática (BLÖMEKE et al., 2011)

Segundo Freitas (2012), com base nos dados das avaliações acredita-se ser possível fazer um diagnóstico da situação educacional do país, o que permite a criação de medidas eficazes que objetivam atacar os problemas e promover o desenvolvimento da educação no Brasil. 


\subsection{Análise de Eficiência}

O conceito de eficiência é utilizado em diversas áreas do conhecimento, com importantes aplicações nas áreas de gestão e econômica. De acordo com Salgado Junior (2013), para evitar erros de interpretação com relação à eficiência, é necessário entender o significado de eficácia (atingir os objetivos com os recursos disponíveis) e produtividade (relação entre insumos e produtos).

Os estudos de análise de eficiência frequentemente relacionam insumos (inputs) e produtos (outputs) para avaliar ganhos ou perda de produtividade (razão entre o que foi produzido com o que foi gasto para produzir). Frank Knight, em uma publicação de 1933, apresentou o primeiro cálculo de produtividade para uma unidade tomadora de decisão (DMU). A partir da publicação de Knight, vários pesquisadores desenvolveram conceitos relacionados à produtividade e outros conceitos relacionados, como eficiência de um sistema produtivo. De maneira genérica, produtividade pode ser descrita da seguinte forma matemática:

Produtividade $=\frac{\text { Soutputs }}{\text { Sinputs }}$

A eficiência de um sistema, por sua vez, refere-se à relação entre os inputs e outputs produzidos e utilizados por esse sistema. A eficiência relaciona um indicador (valor observado) com seu correspondente máximo (valor ótimo), resultando em valores que variam entre zero (quando o indicador é zero) e 100\% (quando o indicador corresponde ao valor máximo comparado). Assim, a eficiência é uma relação entre um indicador de desempenho e o máximo que esse indicador poderia alcançar. Segundo Almeida (2007), a eficiência pode ser classificada como relativa (quando a produtividade máxima é representada como a produtividade da DMU mais eficiente) ou absoluta (quando a produtividade máxima é um valor teórico idealizado). Matematicamente o cálculo da eficiência pode ser representado pela equação:

Eficiência $=\frac{\text { Produtividade }}{\text { Produtividade }_{\text {Máx }}}$

Segundo Chiavenato (2003), eficiência pode ser definida como uma medida comparativa entre os valores observados e os valores ótimos. 


\subsubsection{Técnicas para a Análise de Eficiência}

Para estimar a eficiência relativa entre DMUS são encontradas na literatura a abordagem paramétrica (que especifica uma função para a função produção) e a abordagem não paramétrica (que utilizam técnicas de programação matemática), sendo que escolha da abordagem depende do tipo do problema, das variáveis selecionadas, da correlação e colinearidade, da presença de outliers, do surgimento de ruídos, da quantidade de DMUs que serão comparadas e da verificação do modelo (SARAFADIS, 2002; NIEDERAUER, 2002).

A Figura 1 apresenta as técnicas de análise de mensuração de eficiência, baseadas nas abordagens paramétricas e não paramétricas.

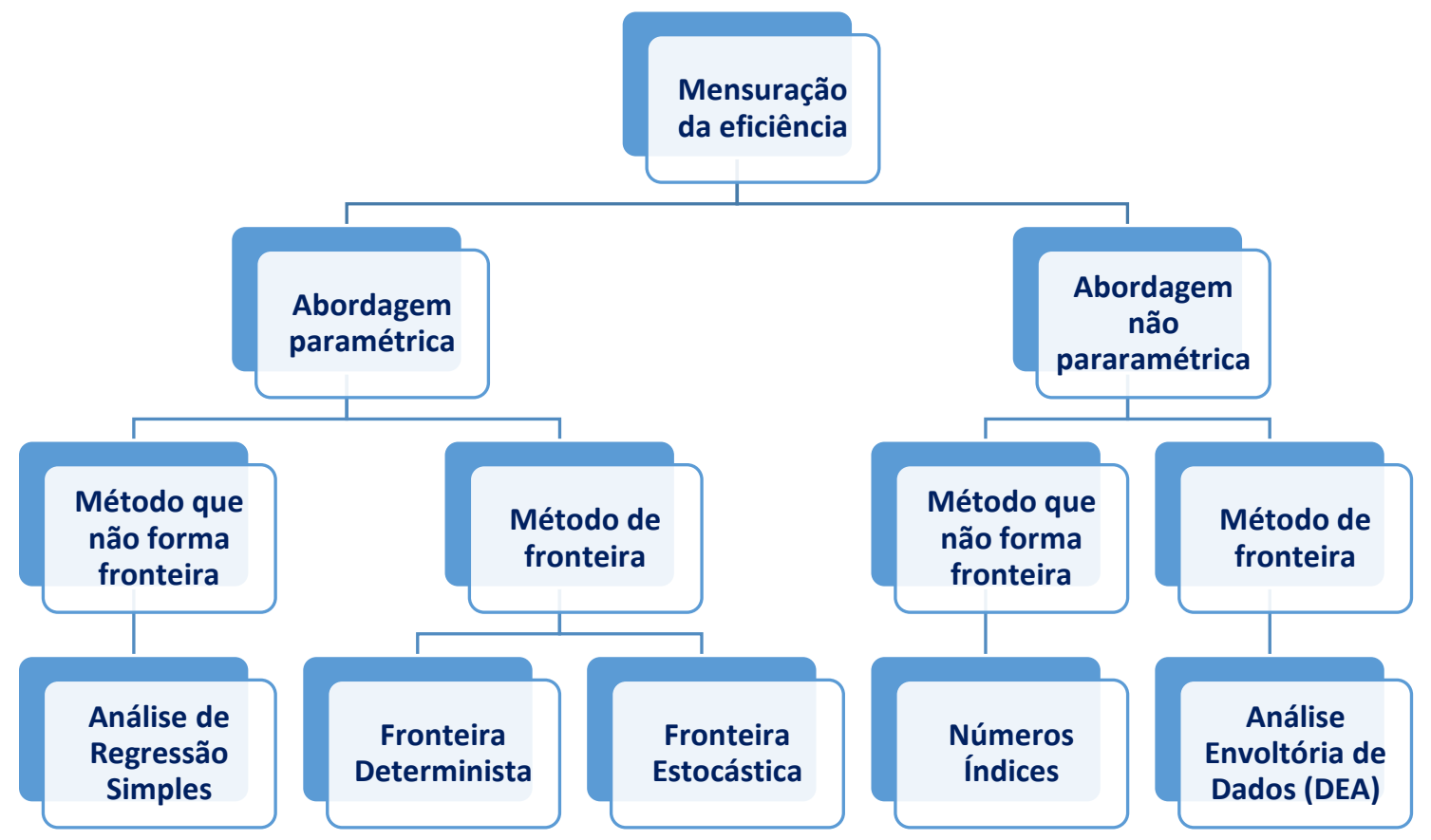

Figura 1 - Organograma das técnicas de avaliação de eficiência

Fonte: Sarafidis (2002) e Mariano (2008)

Dentre as técnicas de análise de eficiência, a técnica DEA foi escolhida para ser utilizada neste trabalho por apresentar algumas vantagens em comparação às outras técnicas. De acordo com Pimentel (2014),

[...] as principais vantagens da DEA são que a técnica permite análise individual da eficiência de cada DMU, diferenciando organizações eficientes de ineficientes. Comparado aos outros modelos, a DEA consegue captar ineficiências que outras técnicas não podem, além de utilizar em seus cálculos, simultaneamente, vários inputs e outputs. Por ser um método não paramétrico, não necessita da especificação de uma função de produção prévia para construção da fronteira (PIMENTEL, 2014, p. 117). 
Segundo Charnes et al (1997), a abordagem paramétrica (como é o caso da Análise de Regressão) requer a construção de uma função-produção que relaciona variáveis independentes com a variável dependente, além de exigir pressupostos específicos sobre a distribuição dos termos de erro e outras restrições. Em comparação com a Análise de Regressão, a DEA não necessita de uma função produção para estimação de eficiência. Niederauer (2002) aponta que a função, produção estimada para a análise de regressão, pode estar incorreta e comprometer a análise de eficiência. Além destas considerações, Niederauer (1998) aponta que a reta de regressão não representa as DMUs eficientes, fazendo do DEA uma ferramenta comparativamente mais precisa para este tipo de análise, conforme apresentado na Figura 2.

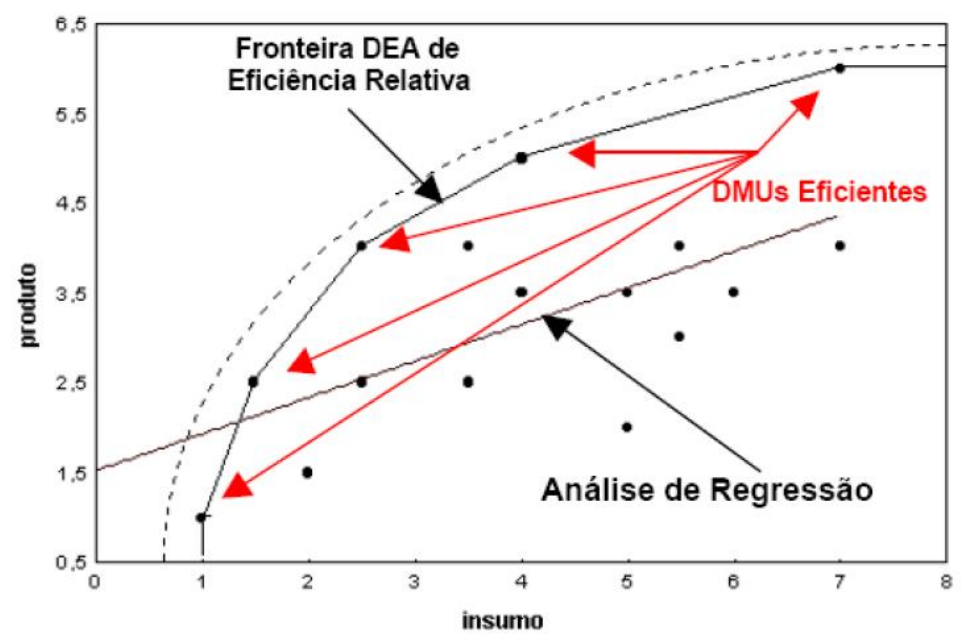

Figura 2 - Comparação entre DEA e Análise de Regressão

Fonte: Niederauer (1998)

Os outros métodos de abordagem paramétrica (fronteira estocástica e determinística) requerem a construção de uma função produção, como é o caso de análise de regressão apresentado na Figura 2 e, da mesma forma, não representam as DMUs mais eficientes (SARAFIDIS, 2002). Como desvantagem em relação à abordagem paramétrica, a DEA pode ter a análise de eficiência comprometida pela presença de outliers, fazendo com que o modelo deixe de encontrar ineficiência como um todo (NIEDERAUER, 2002).

Em comparação com os Números Índices (abordagem não-paramétrica), a DEA apresenta a vantagem de que as utilidades de todos os inputs e outputs das DMUs são calculadas e fornecidas para o modelo enquanto que no caso dos Números Índices elas precisam ser calculadas (gerando margem para erros). Além disto, a análise por Números Índices é limitada à comparação de duas DMUs de cada vez. 


\subsubsection{Análise Envoltória de Dados (DEA)}

A técnica DEA busca calcular a eficiência a partir da construção de uma fronteira de eficiência com o uso de técnicas de programação linear, com o objetivo de encontrar o conjunto de pesos para cada unidade tomadora de decisão (DMU) que maximize o seu escore de eficiência (variando de 0 a 1). Assim, por meio desta técnica cada DMU é comparada com sua projeção na fronteira eficiente gerando um escore de eficiência, podendo ser comparado com outras DMUs (eficiência relativa) (SARAFADIS, 2002; MARIANO, 2008).

A definição de DMU permite que vários tipos de organizações e atividades econômicas, desde que utilizem processos tecnológicos semelhantes para transformar os mesmos insumos e recursos em produtos e resultados semelhantes (SALGADO JUNIOR; BONACIM; PACAGNELLA JUNIOR, 2009). Cooper, Seiford e Tone (2007) destacam que é importante que as DMUs sejam comparáveis e atuem nas mesmas condições. Com relação aos inputs e outputs, para a análise devem ser utilizados os mesmos insumos e produtos, com diferenças apenas na intensidade de magnitude para cada DMU.

Uma DMU, com múltiplos inputs e múltiplos outputs, pode ser representada pela Figura 3.

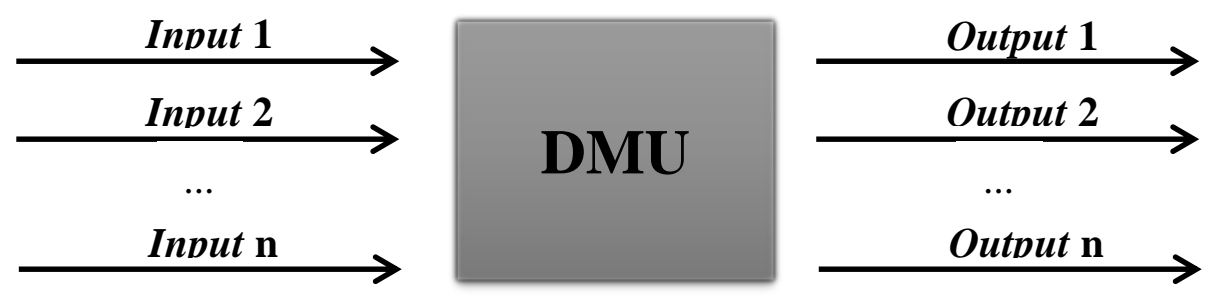

Figura 3 - Elementos de uma unidade tomadora de decisão (DMU)

Fonte: Jubran (2006)

As origens da análise envoltória de dados encontram-se a partir da segunda metade do século XIX em pesquisas relacionadas à teoria da produção, produtividade, programação linear e medidas de eficiência, com destaque aos pesquisadores Von Thünen, Cournot, Walras, Pareto, Moore e Marshall. Com a formalização do conceito da função produção por Cobb e Douglas em 1928, a publicação de pesquisas com cálculos de múltiplos inputs e outputs por Knight em 1933 e o desenvolvimento da programação linear por Dantizig em 1947, vários autores passam a contribuir para o desenvolvimento da análise de eficiência, com destaque para a publicação de Farrel em 1957. O artigo de Farrel, "The Measurement of Productive Efficiency", é considerado por diversos autores um marco para o desenvolvimento da técnica 
DEA por ter contribuído para a evolução dos conceitos de medidas de eficiência produtiva e modelagem de processos de produção (FARREL, 1957; MARIANO, 2008, FERREIRA; GOMES, 2012).

Com base na publicação de Farrel (1957) e o desenvolvimento da formulação eficiência relativa, Charnes, Cooper e Rhodes (1978) desenvolveram a formulação mais aceita da Análise Envoltória de Dados, conhecida como modelo CCR. O modelo proposto por Charnes, Cooper e Rhodes generalizava as medidas de Farrel (1957) e permitia medir a eficiência produtiva com múltiplos inputs e múltiplos outputs, considerando retornos constantes de escala. Posteriormente Banker, Charnes e Cooper (1984), ao considerar tecnologias com rendimentos variáveis, desenvolveram o modelo BCC (Retornos Variáveis de Escala).

Além dos modelos CCR e BCC, os outros modelos de DEA são utilizados para análise de desempenho. A publicação de Charnes, Cooper, Seiford e Stutz (1982) deu origem aos modelos Multiplicativos, que se baseiam em combinações multiplicativas entre inputs e outputs, dando origem aos inputs e outputs virtuais. Por não concordarem com a existência de DMUs virtuais proposta pelo modelo Multiplicativo; De Prins, Simar e Tulkens (1984) desenvolvem o modelo Free Disposal Hull (FDH), que relaxa a suposição de convexidade da DEA. Por fim, Charnes, Cooper, Golany, Seiford e Stutz (1985) desenvolvem os modelos Aditivos que, baseado nas folgas de inputs e outputs, consideram a redução de insumos e aumento da produção simultaneamente. A comparação entre os modelos DEA é apresentada no Quadro 2.

\begin{tabular}{|c|c|c|c|c|c|c|c|c|}
\hline Modelo & $\begin{array}{l}\text { Retorno à } \\
\text { Escala }\end{array}$ & $\begin{array}{l}\text { Forma da } \\
\text { Fronteira }\end{array}$ & $\begin{array}{c}\text { Tipo de } \\
\text { Eficiência }\end{array}$ & $\begin{array}{c}\text { Formulação } \\
\text { Original }\end{array}$ & Orientação & $\begin{array}{c}\text { Unidade } \\
\text { de } \\
\text { Medição }\end{array}$ & $\begin{array}{l}\text { Vantagens } \\
\text { Adicionais }\end{array}$ & Folga \\
\hline $\begin{array}{l}\text { Aditivo } \\
\text { Variante } \\
\end{array}$ & Variável & $\begin{array}{c}\text { Linear } \\
\text { por partes }\end{array}$ & \multirow{4}{*}{$\begin{array}{l}\text { Não } \\
\text { calcula }\end{array}$} & \multirow{4}{*}{$\begin{array}{l}\text { Programação } \\
\text { Linear }\end{array}$} & \multirow{4}{*}{ Mista } & $\begin{array}{c}\text { Influencia } \\
\text { o }\end{array}$ & $\begin{array}{c}\text { Calcula a } \\
\text { eficiência de }\end{array}$ & \multirow{4}{*}{$\begin{array}{l}\text { Servem de } \\
\text { parâmetro } \\
\text { no cálculo } \\
\text { das metas }\end{array}$} \\
\hline $\begin{array}{l}\text { Aditivo } \\
\text { Invariante }\end{array}$ & Constante & $\begin{array}{c}\text { Reta de } \\
45^{\circ}\end{array}$ & & & & Resultado & menor esforço & \\
\hline $\begin{array}{l}\text { Multiplicativo } \\
\text { Variante }\end{array}$ & Variável & $\begin{array}{c}\text { Cobb- } \\
\text { Douglas } \\
\text { por partes }\end{array}$ & & & & \multirow{5}{*}{$\begin{array}{c}\text { Não } \\
\text { influencia } \\
\text { o } \\
\text { resultado }\end{array}$} & \multirow{2}{*}{$\begin{array}{c}\text { Calcula as } \\
\text { elasticidades e } \\
\text { lida com } \\
\text { superfícies } \\
\text { côncavas e } \\
\text { convexas }\end{array}$} & \\
\hline $\begin{array}{l}\text { Multiplicativo } \\
\text { Invariante }\end{array}$ & Constante & $\begin{array}{l}\text { Log- } \\
\text { Linear }\end{array}$ & & & & & & \\
\hline FDH & Variável & Degraus & \multirow[b]{2}{*}{ Técnica } & $\begin{array}{l}\text { Programação } \\
\text { inteira mista }\end{array}$ & \multirow{3}{*}{$\begin{array}{c}\text { Ao input } \\
\text { ou ao } \\
\text { output }\end{array}$} & & \multirow{3}{*}{$\begin{array}{c}\text { Analisa em } \\
\text { separado } \\
\text { inputs } \mathrm{e} \\
\text { outputs }\end{array}$} & \multirow{3}{*}{$\begin{array}{c}\text { Servem } \\
\text { para corrigir } \\
\text { distorções } \\
\text { na fronteira } \\
\text { de } \\
\text { eficiência }\end{array}$} \\
\hline $\mathrm{BCC}$ & Variável & $\begin{array}{c}\text { Linear } \\
\text { por partes }\end{array}$ & & \multirow{2}{*}{$\begin{array}{l}\text { Programação } \\
\text { Fracionária }\end{array}$} & & & & \\
\hline $\mathrm{CCR}$ & Constante & $\begin{array}{c}\text { Reta de } \\
45^{\circ}\end{array}$ & Total & & & & & \\
\hline
\end{tabular}

Quadro 2 - Quadro resumo dos modelos DEA

Fonte: Mariano (2008) 
Dos modelos apresentados, três modelos (CCR, BCC e FDH) calculam eficiência por meio de eficiência técnica ou total. Segundo Coelli (1998), a eficiência técnica refere-se à habilidade da unidade de produção obter o máximo nível de produção (output), dado um conjunto de insumos (inputs) ou, a partir de um determinado nível de produto, conseguir produzir com a menor combinação de insumos. A eficiência total (eficiência econômica total) considera, além da eficiência técnica, também a eficiência alocativa, ou seja, a combinação ótima para um determinado nível de preços de input ou output (FARREL, 1957). A eficiência alocativa na seleção de inputs envolve a seleção de insumos que produzem uma dada quantidade de produto (output), a mínimo custo (COELLI, 1998, p. 5).

O modelo CCR (Retornos Constantes à Escala), tem como hipótese que os inputs e outputs são proporcionais entre si, formando uma reta de $45^{\circ}$ como formato da fronteira de eficiência. $\mathrm{O}$ modelo BCC (Retornos Variáveis à Escala), compara DMUs que operam em escala semelhante, fazendo com que a fronteira de eficiência seja formada por um conjunto de retas de ângulos variados. Assim, devido às diferenças (retorno constante ou variável de escala), modelos CCR e BCC calcularão tipos diferentes de eficiência, sendo que o modelo CCR calcula a eficiência total ou produtiva enquanto o modelo BCC calcula a eficiência técnica (MARIANO, 2008). A Figura 4 representa as fronteiras BBC e BCR para o caso bidimensional.

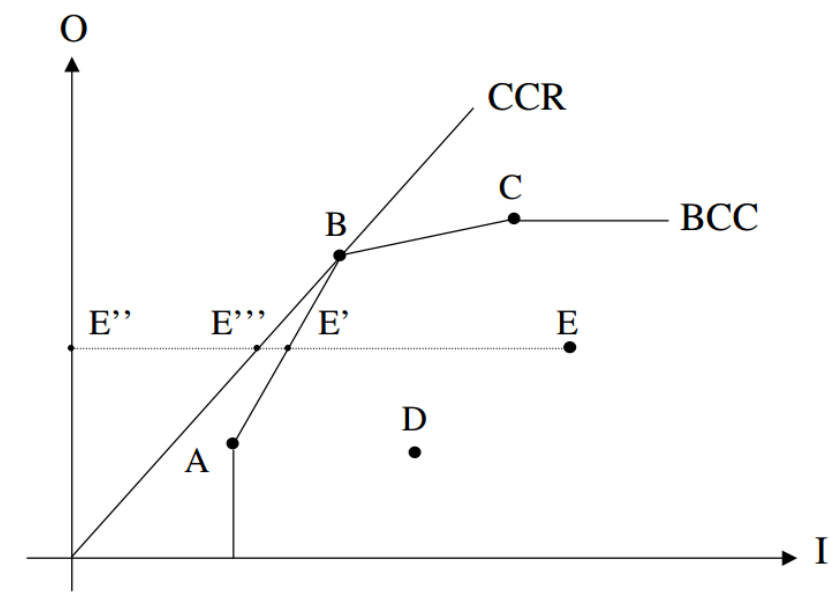

Figura 4 - Comparação entre os modelos BBC e CCR

Fonte: Mello et al (2004, p. 92) 
Os modelos CCR e BCC podem ser orientados a inputs ou a outputs (CHARNES ET AL, 1997). Nos modelos orientados a inputs, busca-se reduzir a quantidade de insumos, sem alterar a produção. Da mesma forma, os modelos orientados a outputs, busca-se alcançar o maior nível de produção, mantendo constantes os insumos (VILELA, 2004).

A classificação dos modelos em relação à escala e orientação é apresentada na Figura 5.

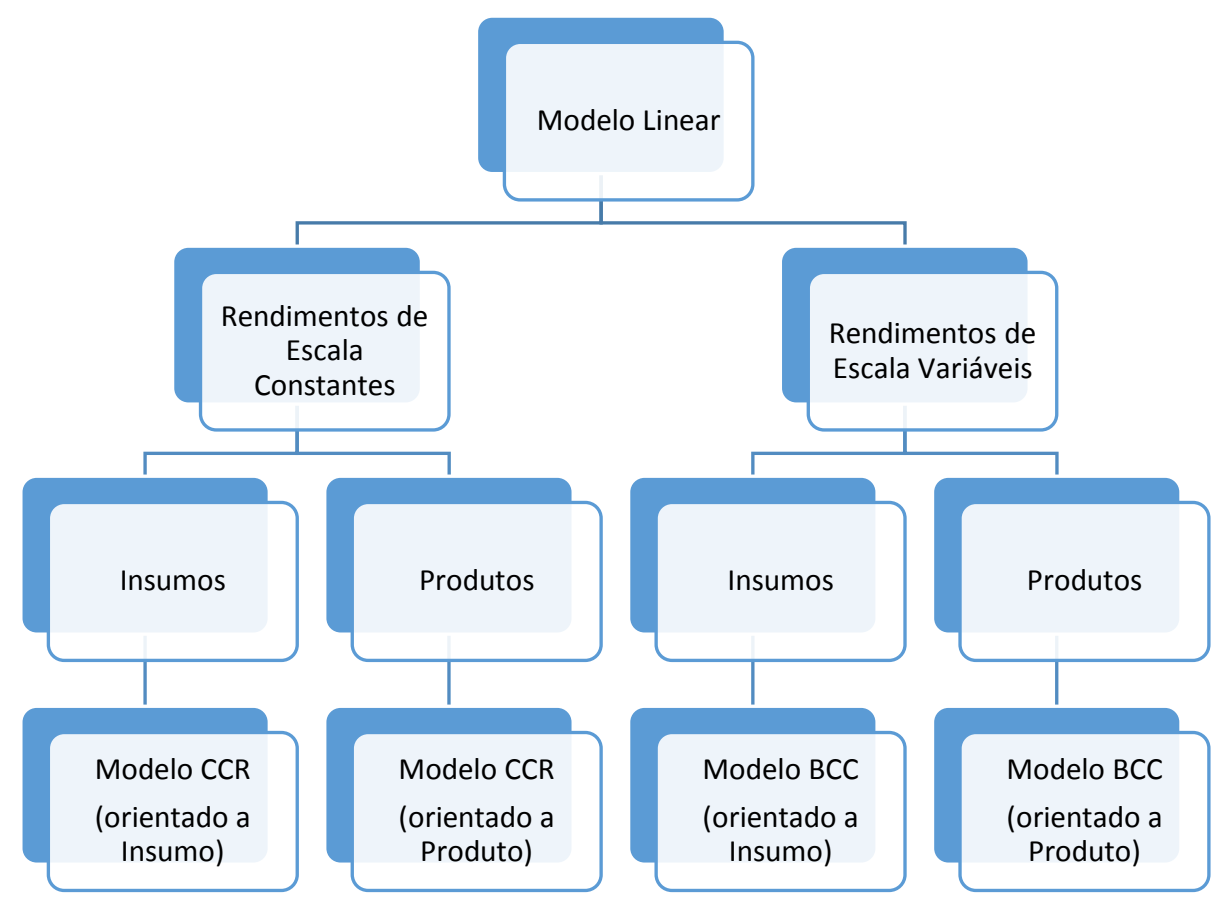

Figura 5 - Classificação entre ganhos de escala e orientação

Fonte: Charnes et al (1997, p. 67)

Quando comparado ao modelo BCC, o modelo FDH apresenta a fronteira de eficiência em formato de degraus, eliminando as combinações lineares entre DMUs. Neste modelo, a DMU ineficiente seja comparada apenas com DMUs reais (MARIANO, 2008). A comparação gráfica das fronteiras de eficiência entre os dois modelos é apresentada na Figura 6. 


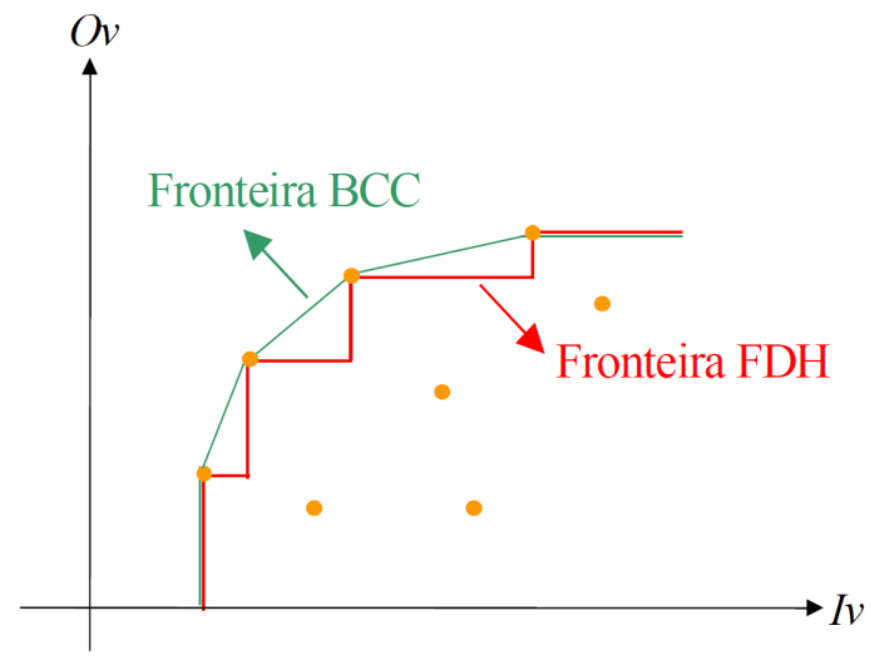

Figura 6 - Comparação do modelo FDH com o modelo BCC

Fonte: Mariano (2008, p. 132)

Ao buscar a eficiência técnica avaliando quais DMUs que têm melhor desempenho no IDEB (maximizar o output) partindo de inputs selecionados, o modelo adotado para esta dissertação foi o modelo BCC. Ao analisar as DMUs eficientes na fronteira de eficiência, este modelo apresenta vantagens em relação às técnicas paramétricas (que dependem de uma forma funcional) e em relação a outros modelos não paramétricos (CCR e FDH) que, conforme apresentados anteriormente, possuem limitações.

\subsubsection{Modelo BCC}

A função produção de uma DMU pode sofrer influência da escala de produção, sendo esta função apresentada nas formas de retornos constantes de escala (RCE), em que as variações nos inputs resultam em variações proporcionais nos outputs ou retornos variáveis à escala (RVE). Quando o conjunto de DMUs tem tamanho e características diversas elas tendem a ter diferentes rendimentos em escala (FERREIRA; GOMES, 2012).

De acordo com Thanassoulis (2003), retornos crescentes de escala ocorrem quando um aumento nos níveis dos inputs provoca um aumento proporcionalmente maior nos níveis de output. Já no caso de retornos decrescentes de escala um aumento nos níveis de input de uma DMU eficiente provoca um aumento proporcionalmente menor nos níveis de output. 
Neste sentido, o modelo BCC considera os rendimentos variáveis de escala (crescente, constante ou decrescente) para o cálculo da eficiência relativa, conforme apresentado na Figura 7. A figura ainda aponta no modelo o chamado rendimento não crescente de escala (RNC) e o rendimento não decrescente de escala (RND).

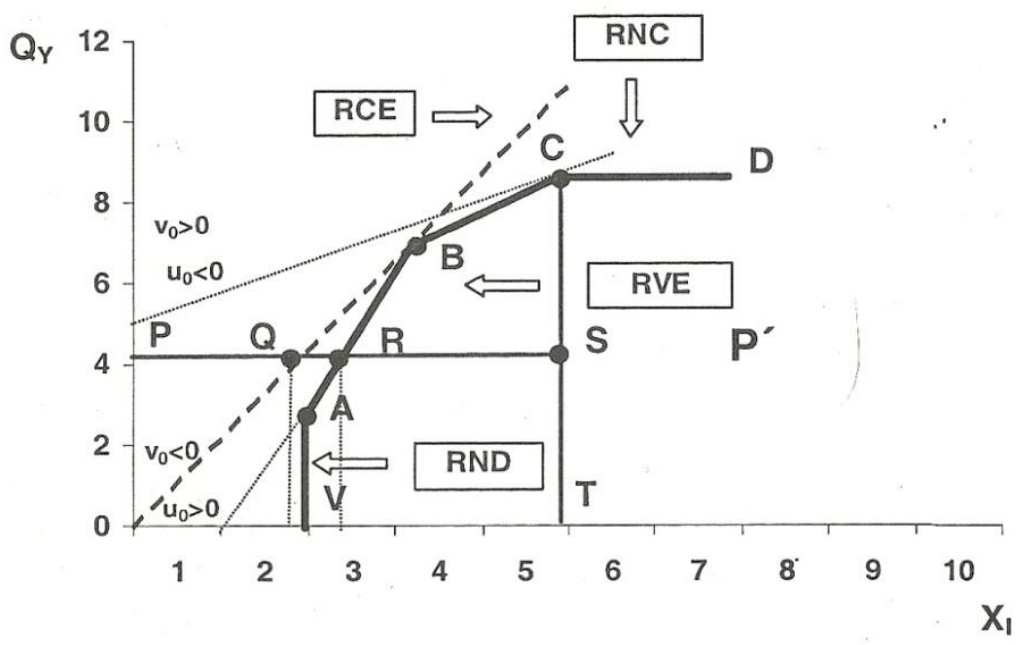

Figura 7 - Regiões gráficas da influência da escala de produção

Fonte: Ferreira e Gomes (2012, p. 116)

O modelo de eficiência BCC compara cada DMU com seu equivalente na fronteira. Desta forma, o cálculo de eficiência é dado pela equação:

$$
\text { Eficiência }=\frac{q s}{q C}
$$

Em que

qs é a distância do eixo y até a fronteira (projeção do ponto C na fronteira de eficiência); qC é a distância do eixo y até a DMU C

De acordo com esta equação, caso a DMU não esteja na fronteira à eficiência será sempre menor do que 1 pois nestes casos o denominador (qC) vai ser sempre maior do que sua projeção na fronteira (qs). Nos casos em que a DMU está na fronteira (como é o caso da DMU B no exemplo a seguir), a eficiência é 1, ou seja, máxima eficiência relativa. A Figura 8 ilustra o cálculo de eficiência. 


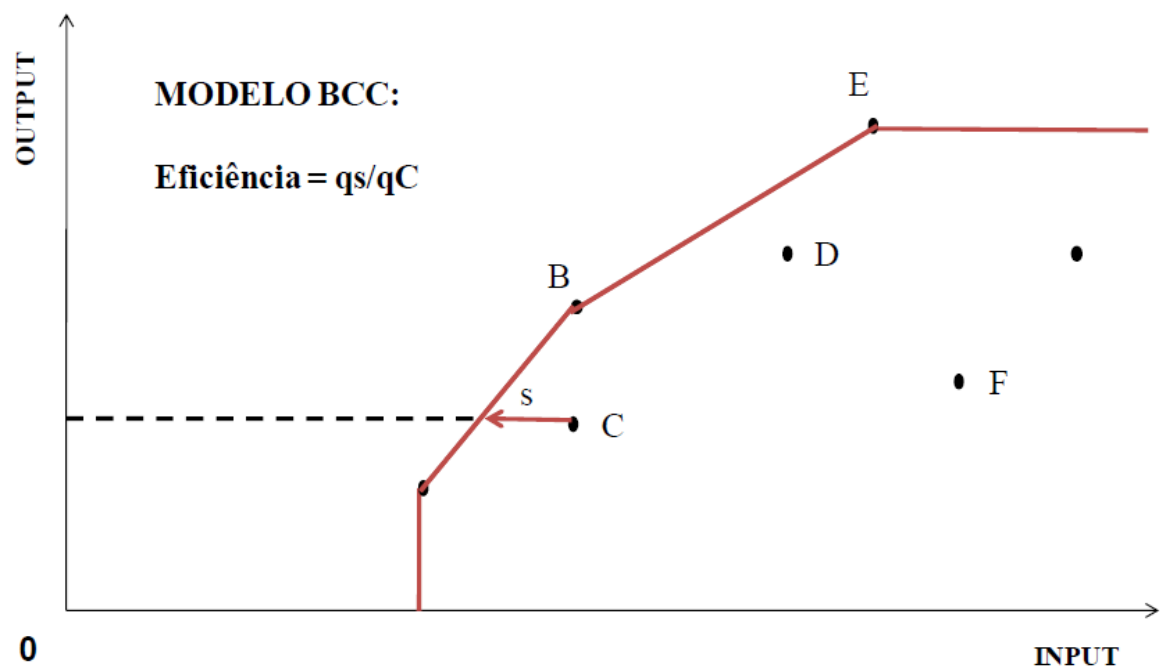

Figura 8 - Fronteira eficiente em um modelo DEA do tipo de retorno de escala constante (BCC) Fonte: Cooper, Seiford e Tone (2007)

Segundo Salgado Junior (2013), a formulação matemática do modelo BCC (rendimentos variáveis de escala), orientado a output é apresentada a seguir.

$\operatorname{Max} \sum_{r=1}^{m} v_{i} y_{k i}+v_{0}$

sujeito a

$\sum_{r=1}^{m} u_{y} x_{r k}=1$

Onde :

$\sum_{r=1}^{m} u_{r} y_{j r} \leq \sum_{i=1}^{n} v_{i} x_{j r}+v_{k}$

$\mathrm{y}=$ outputs; $\mathrm{x}=$ inputs; $\mathrm{u}, \mathrm{v}=$ pesos;

$r=1, \ldots, m ; i=1, \ldots, n ; e j=1, \ldots, N$

$u_{j}, v_{i} \geq 0$

\subsubsection{Etapas da Análise de Eficiência}

A análise de eficiência envolve várias etapas, iniciando pela seleção de DMUs e da quantidade de DMUs para a análise. Para que seja possível fazer a análise, as DMUs devem ter os mesmos insumos (inputs) e produtos (outputs), que não precisam necessariamente ser proporcionais entre si. Os inputs e outputs podem variar em intensidade em cada DMU, estando presente em todas. A quantidade de DMUs utilizada para a análise deve ser 
considerada para evitar erros e distorções como sugerem Cooper et al. (2001) e Jubran (2006). Cooper et al. (2001), sugerem que a quantidade mínima de DMUs seja dada pela função:

$\mathrm{z}=\operatorname{MAX}\{\mathrm{n} \cdot \mathrm{m} ; 3 \cdot(\mathrm{n}+\mathrm{m})\}$

em que,

n é o número de inputs;

m é o número de outputs; e

z é o número de DMUs em avaliação.

Para Jubran (2006), o número mínimo de DMUs recomendado deve ser:

$\mathrm{z}=2 . \mathrm{n} . \mathrm{m}$

em que

n é o número de inputs;

m é o número de outputs; e

z é o número de DMUs em avaliação.

A etapa seguinte envolve a seleção de inputs e outputs. Golany e Roll (1989), Mello et al. (2004), Senra, Naci e Angulo Meza (2005) e Senra et al (2007) sugerem metodologias para a seleção dos insumos e produtos da análise. O Quadro 3 apresenta os principais métodos (ou etapas) para a seleção de insumos e produtos.

\begin{tabular}{|l|l|}
\hline \multicolumn{1}{|c|}{ Autor } & Método / Etapas \\
\hline Golany e Roll (1989) & $\begin{array}{l}\text { Etapa - Judgmental screening (distinção entre variáveis } \\
\text { determinantes de eficiência e variáveis explicativas de ineficiência) } \\
\text { Etapa 2 - Non-DEA quantitative analysis (regressão para definir } \\
\text { inputs e outputs) } \\
\text { Etapa 3 - DEA based analysis (identificar as variáveis que deverão } \\
\text { ser excluídas) }\end{array}$ \\
\hline Mello et al (2004) & Modelo Multicritério de Apoio à Decisão \\
\hline Senra, Nanci e Angulo Meza (2005) & $\begin{array}{l}\text { Método Multicritério } \\
\text { Método Multicritério Combinatório Inicial } \\
\text { Sétodo Multicritério Combinatório por Cenários } \\
\text { Sétodo Multicritério Total } \\
\text { Método Multicritério Total Simplificado }\end{array}$ \\
\hline Senra et al (2007) & Método I-O Stepwise (input-output Stepwise). \\
\hline
\end{tabular}

Quadro 3 - Métodos para seleção de inputs e outpus

Fonte: Autor, baseado em Golany e Roll (1989), Mello et al. (2004), Senra, Naci e Angulo Meza (2005) e Senra et al (2007)

Na literatura o fluxograma do modelo proposto por Golany e Roll (1989) é citado com frequência. A Figura 9 apresenta o fluxograma, partindo da definição do conjunto de DMUs, 
passando pelas etapas apresentadas no Quadro 3 (judgment, quantitative analysis e based analysis) até a formalização do modelo final.

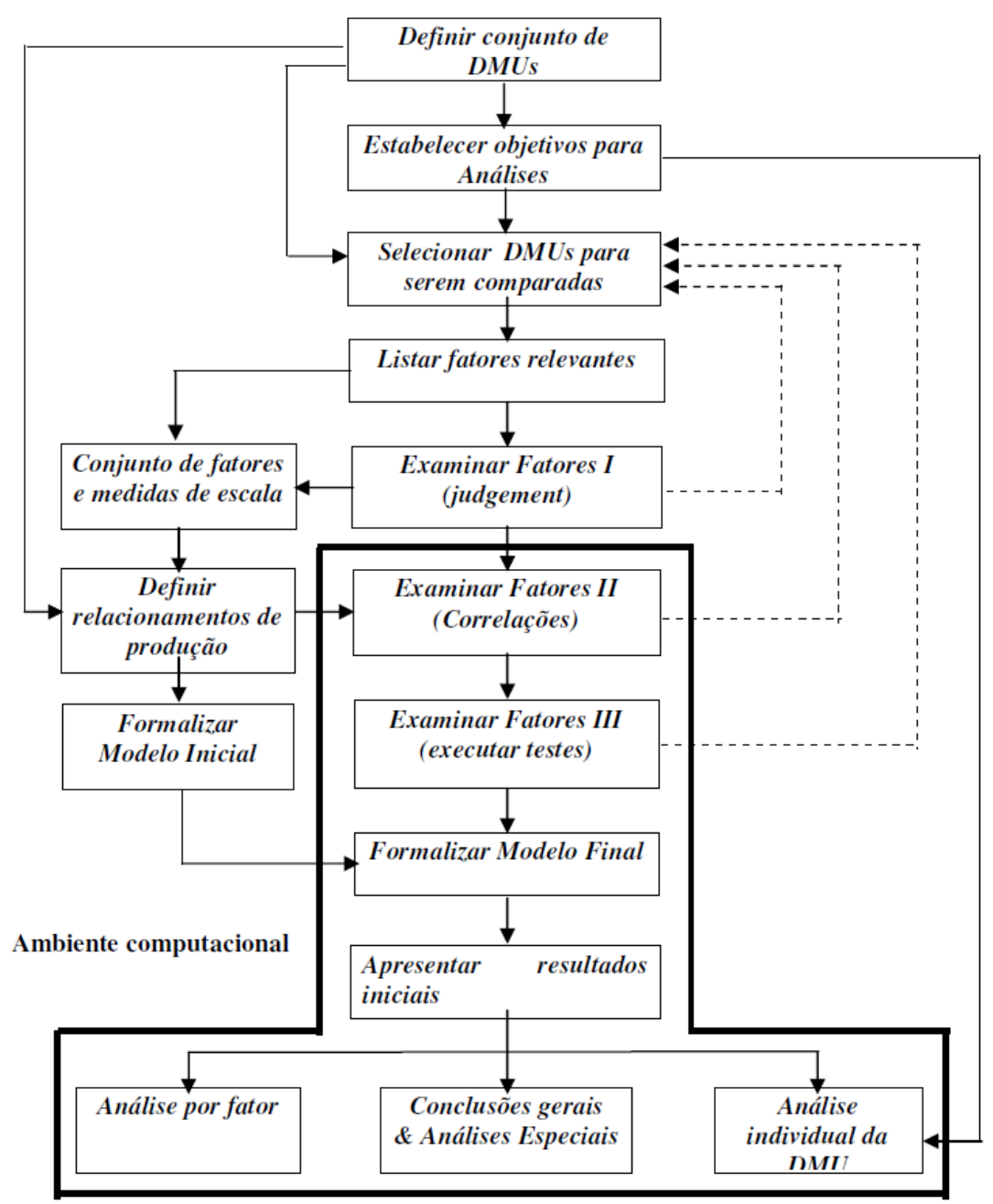

Figura 9 - Fluxograma para desenvolvimento de uma aplicação DEA Fonte: Golany e Roll (1989)

Uma vez definidas as DMUs, os inputs e outputs, é necessária a escolha da técnica de análise de eficiência (utilizando a abordagens paramétrica ou não-paramétrica). As técnicas, modelos, orientação e perspectivas devem ser escolhidas de acordo com o problema que se quer resolver e nas limitações de cada técnica, conforme apresentado no Quadro 2. Segundo Mariano (2008), a escolha do software para a análise de eficiência depende da complexidade do problema e da técnica escolhida, podendo ser utilizados programa mais simples como o Solver Excel ou programas mais robustos e completos como o Maple, Statistica, Matlab, Lindo, Otimiza e Frontier Analyst (dentre outros). Com a ferramenta escolhida e adequada ao problema é feita a implementação da técnica (aplicação do modelo) e a análise dos resultados obtidos. 


\section{Procedimentos Metodológicos}

Este tópico tratará dos aspectos metodológicos desta pesquisa, que envolve a classificação do tipo da pesquisa realizada, a descrição dos métodos utilizados para o alcance dos objetivos propostos, considerações a respeito da caracterização e do tratamento dos dados da pesquisa, a modelagem DEA e o protocolo de estudo de caso.

\subsection{Classificação e Método da pesquisa}

Este estudo trata-se de uma pesquisa aplicada e explicativa.

Segundo Appolinário (2004), a pesquisa aplicada tem como objetivo resolver problemas ou necessidades concretas e imediatas. De acordo com Barros e Lehfeld (2000), a pesquisa aplicada é motivada pela necessidade de produzir conhecimento para aplicação de seus resultados, com o objetivo de contribuir para fins práticos, visando à solução do problema encontrado na realidade. Para Gil (2006), as pesquisas explicativas têm como peocupação fundamental identificar os fatores que determinam ou que contribuem para a ocorrência de

fenômenos. É o tipo de pesquisa "que mais aprofunda o conhecimento da realidade, por explicar a razão, o porquê das coisas" (GIL, 2009). Andrade (2002) classifica a pesquisa explicativa como sendo um tipo de pesquisa mais complexa, pois além de registrar, analisar, classificar e interpretar os fenômenos estudados procura identificar os seus determinantes, aprofundando o conhecimento e buscando a razão para determinado fenômeno.

Em relação ao procedimento técnico utilizado, segundo Gil (2009), este estudo pode ser classificado como uma pesquisa ex-post facto, cujo propósito básico é verificar a existência de relações entre variáveis, baseado em um fenômeno passado, com a aplicação de um estudo de multiplos casos para avaliar com maior profundidade a possível relação entre as variáveis estudadas na pesquisa. De acordo com Richardson (2007), método de pesquisa é a escolha de procedimentos sistemáticos para a descrição e explicação de fenômenos. O método de pesquisa utilizado nesta dissertação está dividido em duas etapas, uma quantitativa e outra qualitativa.

A primeira fase deste estudo corresponde ao método quantitativo, onde foi utilizada a técnica de Análise Envoltória de Dados (DEA) para a escolha e seleção das escolas públicas municipais do ensino fundamental do estado de São Paulo eficientes em transformar investimento financeiro, nível socieconômico e infraestrutura em desempenho no IDEB. 
Na segunda fase, cujo método é o qualitativo, foi realizado um estudo de múltiplos casos, por meio de entrevistas semiestruturadas, análise documental e observação assistemática, nas quais os resultados foram descritos por meio da análise de conteúdo, nas escolas eficientes (identificadas pela técnica DEA) e em cinco escolas ineficientes (grupo de controle), escolhidas em função de possuírem características semelhantes e serem localizadas nas mesmas cidades das eficientes. Após as visitas às escolas, identificaram-se as práticas com maior frequência nas escolas eficientes e menor frequência nas escolas ineficientes. Deste modo, tais práticas foram consideradas como possíveis fatores que melhor contribuem para o desempenho dos alunos no IDEB.

O estudo de caso é um estudo de natureza empírica que investiga um determinado fenômeno, geralmente contemporâneo, dentro de um contexto real de vida. [...] A principal tendência em todos os tipos de estudo de caso, é que estes tentam esclarecer o motivo pelo qual uma decisão ou um conjunto de decisões foram tomadas, como foram implementadas e com quais resultados alcançados (MIGUEL, 2007, p. 219).

A Figura 10 apresenta o resumo das etapas que envolvem esta pesquisa.

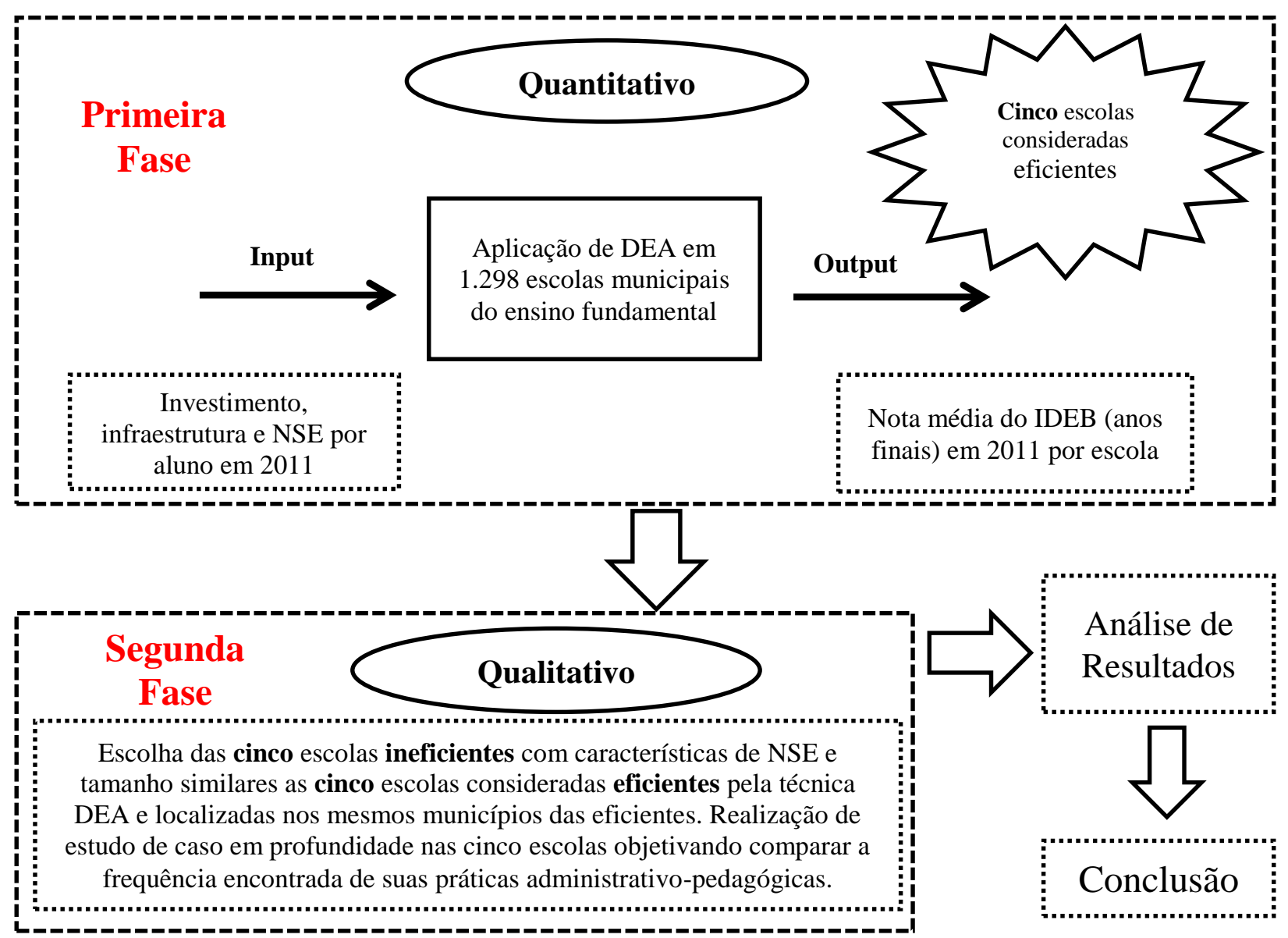

Figura 10 - Método de pesquisa adaptado da metodologia proposta por Salgado Junior (2013)

Fonte: Salgado Junior (2013) 


\subsection{Método de pesquisa quantitativo}

Para a realização da primeira fase deste estudo, caracterizado como quantitativo, foram consideradas como unidades tomadoras de decisão (DMUs) as 1.298 escolas públicas municipais do ensino fundamental do estado de São Paulo. O objetivo desta primeira fase é identificar, por meio da aplicação da técnica DEA, as escolas públicas municipais do estado de São Paulo eficientes em transformar investimento financeiro, NSE e infraestrutura, considerados como inputs nesta pesquisa, em desempenho no IDEB, considerado como output. De acordo com Richardson (2007), o método quantitativo é caracterizado pela utilização da quantificação tanto nas modalidades de coleta de informações, quanto no tratamento delas.

\subsubsection{Escolha e orientação do modelo teórico}

A modelagem aplicada na técnica DEA exige a definição das DMUs, assim como as variáveis de avaliação no modo de inputs e outputs para a ferramenta e a escolha do modelo DEA a ser utilizado. Deste modo, o modelo teório envolve a utilização das variaveis investimento financeiro anual municipal por aluno e infraestrutura, ponderado pelo NSE e desempenho dos alunos no IDEB. Assim, a Figura 11 apresenta os inputs e outputs utitlizados no modelo.

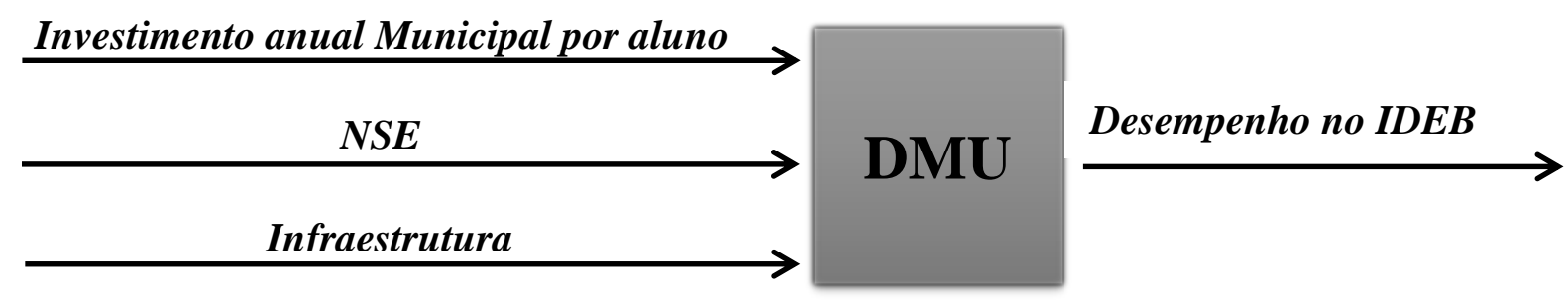

Figura 11 - Inputs e Outputs utilizados no modelo

Fonte: Elaborado pelo autor.

As DMUs analisadas são escolas públicas municipais do ensino fundamental do estado de São Paulo. A escolha por escolas públicas municipais se deu pela representatividade que elas possuem sobre o total de matrículas do ensino fundamental, que correponde a 68,2\% dos 29,7 milhões de alunos matriculados no ano de 2012 (INEP, 2013). Outro fator que determinou a escolha deste grupo como DMU deve-se a restrição do FINBRA em disponibilizar apenas o 
investimento feito para este grupo de escolas (municipais), o que não ocorre nas escolas estaduais, federais e particulares.

Este trabalho busca avaliar a eficiência técnica, considerando quais escolas (DMUs) conseguem gerar maior desempenho no IDEB (output) a partir dos inputs selecionados. Desta forma, a respeito do modelo e orientação da técnica DEA adotado neste trabalho, foi considerado mais apropriado à utilização do modelo BCC, com orientação a output, por três fatores principais: pela impossibilidade de estabelecer uma relação de proporcionalidade entre inputs e outputs (hipótese básica do modelo CCR) quando é considerada a relação entre investimento financeiro em educação, NSE, infraestrutura e desempenho no IDEB; pelo uso da eficiência técnica para avaliar o desempenho das escolas e devido à orientação aos outputs, que consiste em calcular a escola com maior capacidade de gerar desempenho no IDEB, considerando que todas as escolas tenham investimento por aluno, NSE e infraestrutura semelhantes (MARIANO, 2008; SALGADO JUNIOR, 2013).

A Figura 12 demonstra a representação do modelo (BCC) e sua orientação. Todas as DMUs que estiverem na fronteira foram consideradas eficientes, enquanto as DMUs que estiverem abaixo da fronteira, consideraram-se ineficientes.

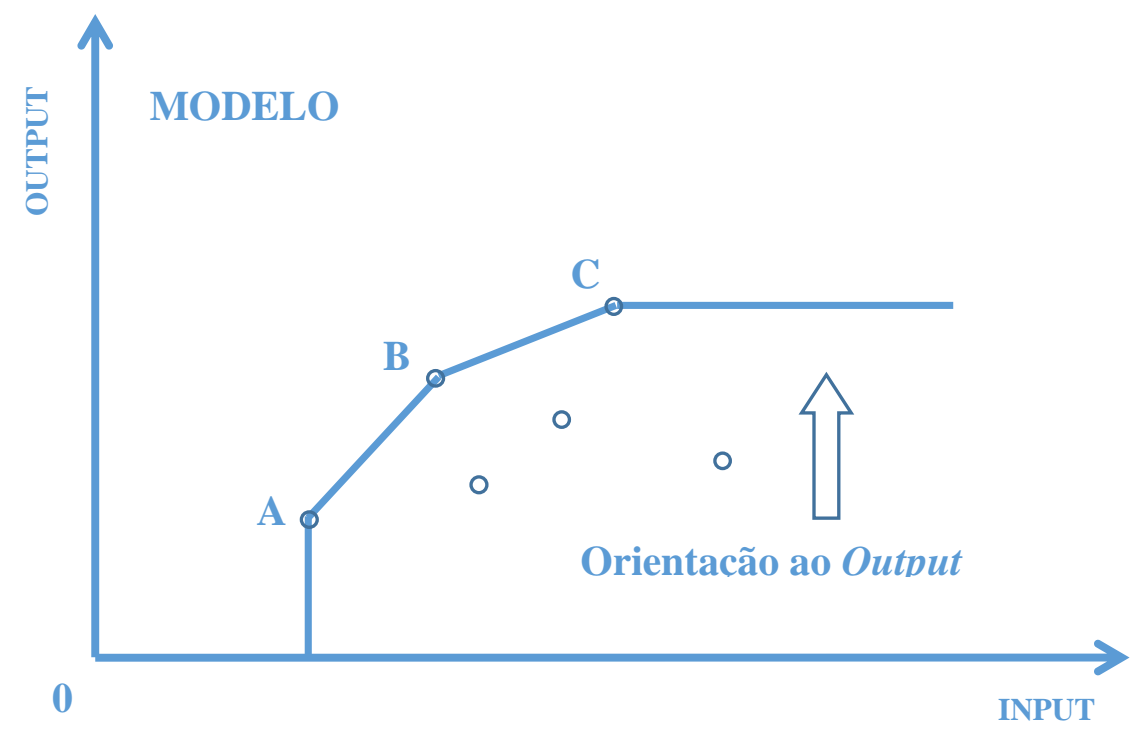

Figura 12 -- Representação gráfica da escolha e orientação do modelo DEA

Fonte: Adaptado pelo autor

As variáveis utilizadas no modelo, bem como suas definições e fontes são apresentadas na subseção a seguir. 


\subsubsection{Variáveis utilizadas no modelo}

Para a obtenção da variável investimento financeiro foi calculado o quociente do investimento financeiro anual do município em educação no ano de 2011, disponibilizado pelo FINBRA, pelo número de alunos matriculados no município no mesmo período, fornecido pelo Censo Escolar e disponibilizado pelo INEP, obtendo-se assim o valor do investimento financeiro anual por aluno de cada município no ensino fundamental ( $1^{\text {a à }} 9^{\mathrm{a}}$ série $)$. Já o NSE médio das escolas foi disponibilizado por Alves, Soares e Xavier (2014). Referente à variável infraestrutura foi considerado o número de computadores por aluno e o número de salas de aula por aluno, disponibilizado pelo INEP. Para finalizar, os dados sobre o desempenho médio por escola pública municipal no IDEB dos alunos do estado de São Paulo no ano de 2011 foi obtido na base de dados do INEP.

O Quadro 4 apresenta as variáveis utilizadas no modelo teórico, suas classificações como inputs e outputs do modelo DEA e suas respectivas definições.

\begin{tabular}{c|l|l|l}
\hline Variáveis & \multicolumn{1}{|c|}{ Variável } & \multicolumn{1}{c}{ Definição } & \multicolumn{1}{c}{ Fonte } \\
\hline Input & $\begin{array}{l}\text { Investimento Anual } \\
\text { Municipal (R\$) por } \\
\text { aluno do Ensino } \\
\begin{array}{l}\text { Fundamental }\left(1^{a} \text { à } 9^{\text {a }}\right. \\
\text { série) em 2011 }\end{array}\end{array}$ & $\begin{array}{l}\text { Razão entre o Investimento Anual } \\
\text { Municipal destinado às escolas } \\
\text { públicas do ensino fundamental pelo } \\
\text { número de alunos por município neste } \\
\text { nível de ensino em 2011. }\end{array}$ & FINBRA/INEP \\
\hline Input & $\begin{array}{l}\text { Nível Socioeconômico } \\
\text { (NSE) médio dos } \\
\text { alunos por escola em } \\
\text { 2011 }\end{array}$ & $\begin{array}{l}\text { Situação economica e social dos } \\
\text { alunos }\end{array}$ & $\begin{array}{l}\text { Alves, Soares e } \\
\text { Xavier (2014) }\end{array}$ \\
\hline Output & $\begin{array}{l}\text { Infraestrutura } \\
\text { nota média por escola } \\
\text { estado de São Paulo no } \\
\text { ano de 2011 }\end{array}$ & $\begin{array}{l}\text { Número de computadores por aluno } \\
\text { Número de salas por aluno } \\
\text { educacional que relaciona de forma } \\
\text { positiva informações de rendimento } \\
\text { escolar (aprovação) e desempenho } \\
\text { (proficiências) em testes padronizados. }\end{array}$ & INEP \\
\hline
\end{tabular}

Quadro 4 - Classificação das variáveis utilizadas no modelo teórico

Fonte: Elaborado pelo autor.

A escolha das variáveis que compõem o modelo teórico é justificada pela literatura utilizada no referencial teórico deste trabalho. Deste modo, o NSE é um dos fatores que mais contruibuem para o desempenho dos alunos. Tal constatação foi verificada inicialmente pelo relatório Coleman (1966) e ratificada posteriormente por inúmeros autores. Quanto ao 
investimento financeiro, os resultados são controversos de modo que alguns autores afirmam que quanto maior for o investimento educacional, maior será o desempenho dos alunos, enquanto outros destacam que o investimento educacional não impacta no desempenho ou impacta até determinado nível de investimento. A infraestrutura, por sua vez, é condição necessária para uma educação de qualidade (CEPAL, 2000; GAME, 2002). Por fim, o IDEB é considerado o mecanismo mais eficiente disponível no país para avaliar e monitorar a qualidade do sistema educacional (FERNANDES, 2007).

O Quadro 5 apresenta a relação de autores que relacionam as variáves com aumento de desempenho em educação.

\begin{tabular}{l|l}
\hline Variáveis & Autores \\
\hline \multirow{4}{*}{ Investimento } & Barros e Mendonça (1998) \\
& OCDE (2007) \\
& Franco (2008) \\
& INEP (2011) \\
& Batalha, Miranda e Lírio (2012) \\
\hline & Coleman (1966) \\
& Plowden et al. (1967) \\
& Soares e Alves (2003) \\
& Gamoran e Long (2006) \\
& Soares e Andrade (2006) \\
\hline \multirow{5}{*}{ Infraestrutura } & Quinhões (1999) \\
& CEPAL (2000) \\
& GAME (2002) \\
& Dourado, Santos e Oliveira (2007) \\
& Teixeira (2009) \\
\hline
\end{tabular}

Quadro 5 - Autores que relacionam positivamente cada variável com desempenho educacional Fonte: Elaborado pelo autor.

\subsubsection{Fonte de Dados}

As principais fontes utilizadas neste trabalho são o INEP, o FINBRA e o banco de dados fornecido por Alves, Soares e Xavier (2014) ${ }^{7}$, que disponibilizam o índice de NSE médio das escolas por meio de uma escala de 0 a 10, além de categorizarem sete grupos de níveis socioeconômicos, onde as escolas podem ser classificadas de acordo com o seu perfil socioeconômico, sendo: (1) Mais Baixo; (2) Baixo; (3) Médio Baixo; (4) Médio; (5) Médio Alto; (6) Alto; e (7) Mais Alto.

\footnotetext{
${ }^{7}$ A base de dados fornecida de Alves, Soares e Xavier (2014) está em sua em sua terceira versão, sendo a última atualização em 2014.
} 


\subsubsection{INEP}

Dentre as bases de dados utilizados nesta pesquisa está o Instituto Nacional de Pesquisas Educacionais Anísio Teixeira (INEP), que representa a principal fonte de dados educacionais do país. Ele é uma autarquia federal vinculada ao Ministério da Educação (MEC), cuja missão é promover estudos, pesquisas e avaliações sobre o Sistema Educacional Brasileiro com o objetivo de subsidiar a formulação e implementação de políticas públicas para a área educacional a partir de parâmentros de qualidade e equidade, bem como produzir informações claras e confiáveis aos gestores, pesquisadores, educadores e público em geral (INEP, 2011).

Para gerar seus dados e estudos educacionais o INEP realiza levantamentos estatísticos e avaliativos em todos os níveis e modalidades de ensino, como o Censo Escolar, Censo Superior, Avaliação dos Cursos de Graduação, Avaliação Institucional, Sistema Nacional de Avaliação da Educação Superior, Exame Nacional do Ensino Médio (Enem), Exame Nacional para Certificação de Competências (Encceja) e o Sistema Nacional de Avaliação da Educação Básica (Saeb) (INEP, 2011). Além dos levantamentos estatísticos e avaliações, o INEP promove encontros para discutir os temas educacionais e disponibiliza também outras fontes de consulta sobre educação (INEP, 2011).

\subsubsection{FINBRA}

Neste estudo também foi utilizado à base de dados Finanças do Brasil (FINBRA) da Secretaria do Tesouro Nacional (STN), que disponibiliza o acesso às informações sobre despesas e receitas de cada município brasileiro. De acordo com Orair et al. (2011), o FINBRA é a fonte tradicionalmente mais utilizada nos estudos sobre finanças públicas municipais brasileiras.

Segundo a Fundação Instituto de Pesquisas Econômicas (FIPE, 2007), o FINBRA é a base de dados mais completa disponível sobre finanças públicas municipais e estaduais. Deste modo, ela representa a principal fonte de pesquisa por disponibilizar informações sobre execução orçamentária (receita e despesa) e de balanço patrimonial (ativo e passivo). O acesso a estas 
informações possibilita a construção de inúmeros indicadores para avaliação da educação municipal e estadual.

Segundo Ferraz, Polena e Quirino (2013), o FINBRA utiliza o Sistema de Coleta de Dados Contábeis (SISTN) da Caixa Econômica Federal, onde a organização desse sistema acontece da seguinte forma: os municípios preenchem um formulário com dados do seu balanço e devem encaminhar as informações em papel, disquete ou via internet para a caixa, que por sua vez, organiza os dados em um arquivo e encaminha ao STN, que trata os dados com o objetivo de cumprir suas atribuições legais e atender à demanda de informações.

Por se tratar de uma base de dados autodeclarável, o FINBRA apresenta algumas limitações que envolvem a inconsistencia de dados. De acordo com Ferraz, Polena e Quirino (2013) no ano de 2005, 813 municípios apresentavam problemas em seus dados disponíveis no FINBRA, entre esses problemas destacavam-se: dados zerados, dados negativos e municípios que não haviam repassado suas informações financeiras para esta base de dados. Segundo Ferraz, Polena e Quirino (2013), mesmo com suas limitações o FINBRA ainda se destaca como a principal fonte de pesquisa no que se refere a informações municipais, por permitir a consulta dos dados de forma agregada (municipal e estadual) em uma única planilha.

\subsubsection{Softwares utilizados e tratamento de dados}

Em relação à leitura dos dados do censo escolar foi utilizado o software Stata ${ }^{\circledR}$, do fornecedor StataCorp LP. Para a manipulação e configuração dos dados foi utilizado o software SAS®, do fornecedor SAS Institute Inc., disponível nas instalações da FEA-RP/USP, sendo que a utilização do software da Microsoft Excel® limita o número de linhas por planilha, restringindo assim sua utilização.

Para a utilização do Stata ${ }$, foi preciso realizar um conjunto de procedimentos: utilizou-se o Bloco de Notas ${ }^{\circledR}$ do Windows para a leitura dos dados obtidos no site do INEP, logo depois, estes dados foram transferidos para o Microsoft Excel® afim de que fossem formatados. Em seguida, os dados já formatados foram novamente transferidos para o Bloco de Notas, onde foi criado um dicionário, no qual é inserido um conjunto de ordens de programação necessário 
para que o Stata® pudesse trabalhar com os dados do INEP. Na sequência, os dados foram importados para o Stata ${ }^{\circledR}$, através do dicionário criado e foram trabalhados para a criação de uma tabela com especificações necessárias para a realização deste estudo.

Por meio do desenvolvimento dessa base de dados, onde estão disponíveis as informações sobre o investimento finanaceiro por escola pública municipal, o número de alunos por escola, bem como os itens de infraestrutura, o NSE médio das escolas e o desempenho médio por escola pública municipal no IDEB, tornou-se possível à identificação das escolas eficientes através da aplicação da técnica DEA.

Para a aplicação da técnica DEA foi utilizado o software Frontier Analyst 4.1, do fabricante Banxia Software ${ }^{\circledR}$. As Unidades Tomadoras de Decisão (DMUs), estudadas pela técnica DEA, foram todas as 1.298 escolas públicas municipais do ensino fundamental do estado de São Paulo existentes em 2011, a fim de se comparar a eficiencia relativa destas instituições de ensino em transformar input em output.

A utilização do Censo escolar de 2011 e do FINBRA 2011 se deram em função de serem os dados mais recentes sobre as escolas públicas municipais do ensino fundamental do estado de São Paulo desde o início da tabulação dos dados e realização desta pesquisa. Já a utilização do índice de NSE médio das escolas proposto por Alves, Soares e Xavier (2014) se deu por ser um dos mais citados na literatura.

O FINBRA disponibiliza, como unidade monetária em reais, os valores investidos anualmente por cada municipio nas escolas públicas do ensino fundamental, enquanto o INEP fornece o desempenho médio por escola dos alunos no IDEB em uma escala de 0 a 10 , os itens de infraestrutura presentes em cada escola e o número de alunos matriculados.

Com a definição e classificação das variáveis, será possível, por meio da técnica DEA e da aplicação do software Frontier Analyst 4.1 identificar as escolas públicas municipais do estado de São Paulo eficientes em transformar inputs (investimento financeiro, NSE e infraestrutura) em output (desempenho no IDEB). 


\subsection{Método de pesquisa qualitativo}

$\mathrm{O}$ instrumento de coleta de dados utilizado na fase qualitativa deste estudo consiste em um roteiro de entrevista semiestruturado. Segundo Triviños (1987), a entrevista semiestruturada tem como característica principal os questionamentos básicos que são apoiados em teorias e hipóteses que se relacionam ao tema da pesquisa.

De acordo com Richardson (2007) na entrevista semiestruturada, o pesquisador possui um pré-conhecimento dos aspectos relevantes da pesquisa que deseja realizar, e com base neles, elabora as questões a serem tratadas, proporcionando ao entrevistado a liberdade de se expressar como preferir, sendo apenas guiado pelo entrevistador, de acordo com os interesses da pesquisa. Hair et al. (2005) destacam a entrevista semiestruturada pela liberdade do pesquisador em conduzir perguntas relacionadas ao contexto da pesquisa, podendo contribuir com novas questões relevantes que possam surgir ao longo da entrevista. Deste modo, a entrevista semiestrurada se apresenta como uma ferramenta que possui orientações gerais, mas que é ao mesmo tempo flexível a inclusão de questões adicionais de acordo com a conveniência do estudo.

A elaboração do instrumento de pesquisa e consequentemente do roteiro de entrevistas semiestruturada, que foram utilizados na condução de entrevistas com os Secretários municipais de educação, Diretores de escolas, Professores de língua portuguesa e matemática, pais e alunos, foi feito com base no trabalho de Salgado Junior (2013) e na literatura sobre os fatores que influenciam o desempenho escolar. Baseadas nestas informações foram realizadas correlações buscando identificar os fatores ou variáveis que impactam o desempenho dos alunos. As variáveis utilizadas na correlação são apresentadas no Quadro 6.

\begin{tabular}{l|l}
\hline Variável & Descrição da variável \\
\hline IDEB & Desempenho no IDEB \\
\hline Alunos/Docentes & Razão entre número de alunos e docentes \\
\hline Alunos/Salas & Razão entre número de alunos e salas \\
\hline Alunos/Computador & Razão entre número de alunos e computadores \\
\hline Alunos/Funcionários & Razão entre número de alunos e funcionários \\
\hline Média Idade & Média de idade dos alunos \\
\hline$\%$ masc & Percentual de alunos do sexo masculino \\
\hline Branco & Percentual de alunos brancos \\
\hline Preta & Percentual de alunos negros \\
\hline Parda & Percentual de alunos pardos \\
\hline Amarela & Percentual de alunos asiáticos \\
\hline Indígena & Percentual de alunos de origem indígena \\
\hline
\end{tabular}




\begin{tabular}{l|l}
\hline Masculino & Percentual de Professores do sexo masculino \\
\hline Media Idade Professor & Idade média dos Professores \\
\hline Ensino Fundam. Incompleto & Percentual de Professores com ensino fundamento incompleto \\
\hline Ensino Fundam. Completo & Percentual de Professores com ensino fundamento completo \\
\hline Ensino Médio Completo & Percentual de Professores com ensino médio completo \\
\hline Ensino Superior Completo & Percentual de Professores com ensino superior completo \\
\hline Especialização & Percentual de Professores com especialização \\
\hline Mestrado & Percentual de Professores com mestrado \\
\hline Doutorado & Percentual de Professores com doutorado \\
\hline Educação Física & Existência de aulas de educação física \\
\hline Ensino Religioso & Existência de aulas de ensino religioso \\
\hline Informática & Existência de aulas de informática \\
\hline Sala Diretoria & Existência de sala de Diretoria \\
\hline Sala Professor & Existência de sala dos Professores \\
\hline Laboratório de Informática & Existência de aulas de laboratório de informática \\
\hline Laboratório de Ciências & Existência de aulas laboratório de ciências \\
\hline Sala Atendimento Especial & Existência de sala de atendimento especial \\
\hline Biblioteca & Existência de bibliotecas \\
\hline Sala de Leitura & Existência de sala de leitura \\
\hline Internet & Disponibilidade de internet de banda larga \\
\hline NSE & Nível socioeconômico da escola \\
\hline População & População do município \\
\hline Total de alunos da escola & Quantidade de alunos matriculados na escola \\
\hline Português & Desempenho em Língua Portuguesa \\
\hline Matemática & Desempenho em Matemática \\
\hline Investimento & Investimento anual em educação por aluno \\
\hline
\end{tabular}

Quadro 6 - Descrição das variáveis utilizadas nas correlações de Spearman e Pearson

Fonte: Elaborado pelo autor.

Depois de realizadas as correlações de Spearman (Apêndice G) e Pearson (Apêndice H) foram constatadas que não houve correlações estatisticamente significativas entre as variáveis. Com o objetivo de identificar as práticas que possam contribuir para o desempenho dos alunos foi realizada uma estatística descritiva envolvendo as variáveis relacionadas à escola, aos alunos, aos Professores e funcionários e ao modelo teórico.

$\mathrm{Na}$ análise descritiva foi realizada uma comparação entre as escolas eficientes, determinadas pela técnica DEA, as $10 \%$ do total de escolas com maior escore DEA, as $10 \%$ do total de escolas com menor escore DEA e a média das escolas do estado de São Paulo. Com isso foi possível identificar algumas hipóteses desta análise.

A análise descritiva é apresentada na Tabela 7 (variáveis relacionadas à escola), Tabela 8 (variáveis relacionadas aos alunos), Tabela 9 (variáveis relacionadas aos Professores e funcionários) e Tabela 10 (variáveis relacionadas ao modelo teórico). 
Tabela 7 - Estatística descritiva das variáveis relacionadas às escolas

\begin{tabular}{|c|c|c|c|c|c|c|c|c|c|c|c|c|c|}
\hline & $\begin{array}{c}\text { Escolas } \\
\text { na área } \\
\text { urbana }\end{array}$ & $\begin{array}{l}\text { Sala de } \\
\text { Diretoria }\end{array}$ & $\begin{array}{l}\text { Sala do } \\
\text { Professor }\end{array}$ & $\begin{array}{l}\text { Laborat. de } \\
\text { Informática }\end{array}$ & $\begin{array}{l}\text { Laborat. de } \\
\text { Ciências }\end{array}$ & $\begin{array}{c}\text { Quadra de } \\
\text { esportes } \\
\text { coberta }\end{array}$ & $\begin{array}{l}\text { Quadra de } \\
\text { esportes } \\
\text { descoberta }\end{array}$ & Cozinha & Biblioteca & $\begin{array}{l}\text { Sala de } \\
\text { Leitura }\end{array}$ & $\begin{array}{l}\text { Alunos por } \\
\text { computador }\end{array}$ & Internet & $\begin{array}{l}\text { Banda } \\
\text { Larga }\end{array}$ \\
\hline Eficientes & 0,667 & 1,000 & 0,833 & 0,667 & 0,167 & 0,500 & 0,000 & 1,000 & 0,333 & 0,500 & 34,384 & 1,000 & 1,000 \\
\hline $10 \%$ com maior escore DEA & 0,915 & 0,992 & 0,962 & 0,900 & 0,292 & 0,646 & 0,369 & 1,000 & 0,331 & 0,669 & 19,487 & 0,992 & 0,977 \\
\hline $10 \%$ com menor escore DEA & 0,977 & 0,985 & 0,992 & 0,946 & 0,208 & 0,592 & 0,631 & 0,992 & 0,231 & 0,762 & 31,218 & 0,969 & 0,900 \\
\hline Média SP & 0,852 & 0,853 & 0,840 & 0,658 & 0,082 & 0,412 & 0,301 & 0,980 & 0,245 & 0,417 & 13,080 & 0,854 & 0,834 \\
\hline
\end{tabular}

Fonte: Elaborado pelo autor.

Com base na Tabela 7 foi possível identificar uma maior proporção de escolas eficientes na área rural, quando comparada as demais. Nestas escolas (eficientes) há uma menor proporção de laboratórios de informática em relação às 10\% do total de escolas com maior escore DEA e, apesar de possuírem bibliotecas em maior proporção, entretanto possuem menos salas de leitura quando comparadas a este grupo. Também foi identificado que as escolas eficientes possuem menos computadores por aluno.

Tabela 8 - Estatística descritiva das variáveis relacionadas aos alunos

\begin{tabular}{|c|c|c|c|c|c|c|c|c|}
\hline & $\begin{array}{l}\text { Disciplina de } \\
\text { Artes }\end{array}$ & $\begin{array}{l}\text { Educação } \\
\text { Física }\end{array}$ & $\begin{array}{c}\text { Ensino } \\
\text { Religioso }\end{array}$ & Informática & Média de idade & $\begin{array}{c}\% \text { sexo } \\
\text { masculino }\end{array}$ & $\%$ Urbana & $\begin{array}{c}\text { Usa transporte } \\
\text { público }\end{array}$ \\
\hline Eficientes & $100,00 \%$ & $100,00 \%$ & $10,00 \%$ & $16,67 \%$ & 11,56835 & $48,90 \%$ & $59,27 \%$ & $41,74 \%$ \\
\hline $10 \%$ com maior escore DEA & $99,01 \%$ & $92,75 \%$ & $8,68 \%$ & $24,34 \%$ & 11,36472 & $51,17 \%$ & $86,48 \%$ & $20,59 \%$ \\
\hline $10 \%$ com menor escore DEA & $95,58 \%$ & $57,79 \%$ & $5,35 \%$ & $63,86 \%$ & 11,38429 & $51,89 \%$ & $95,10 \%$ & $10,44 \%$ \\
\hline Média SP & $94,20 \%$ & $90,21 \%$ & $11,10 \%$ & $28,43 \%$ & 9,159668 & $51,74 \%$ & $81,94 \%$ & $19,70 \%$ \\
\hline
\end{tabular}

Fonte: Elaborado pelo autor

É possível observar na Tabela 8 que as escolas eficientes possuem um número menor de aulas de informática quando comparadas às $10 \%$ do total de escolas com maior escore DEA. Foi identificado que um maior número de alunos reside na zona rural, também comparado às $10 \%$ do total de escolas com maior escore DEA, e estes alunos utilizam proporcionalmente mais o transporte público para ir à escola. 
Com relação aos Professores e funcionários, apresentados na Tabela 9, há uma maior porcentagem de Professores do sexo feminino nas escolas eficientes, quando comparado às demais. Em relação à média das escolas do estado de São Paulo, as escolas eficientes têm menos Professores com magistério e mais Professores com licenciatura, nível superior completo e especialização. Também foi identificado que há menos funcionários por alunos nas escolas eficientes quando comparado à média de São Paulo.

Tabela 9 - Estatística descritiva das variáveis relacionadas aos Professores e funcionários

\begin{tabular}{|c|c|c|c|c|c|c|c|c|c|c|c|c|}
\hline & $\begin{array}{c}\% \text { sexo } \\
\text { Masculino }\end{array}$ & $\begin{array}{c}\text { Média } \\
\text { de idade }\end{array}$ & $\begin{array}{c}\% \text { Ensino } \\
\text { Fundamental } \\
\text { completo }\end{array}$ & $\begin{array}{l}\text { \% Ensino } \\
\text { Médio } \\
\text { completo }\end{array}$ & $\begin{array}{c}\text { \% Ensino } \\
\text { Médio } \\
\text { Magistério }\end{array}$ & $\begin{array}{l}\% \text { Ensino } \\
\text { Superior } \\
\text { completo }\end{array}$ & $\begin{array}{c}\% \\
\text { Licenciatura }\end{array}$ & $\begin{array}{l}\text { \% Compl. } \\
\text { Pedagógica }\end{array}$ & $\begin{array}{c}\% \\
\text { Especialização } \\
\end{array}$ & $\begin{array}{c}\% \\
\text { Mestrado }\end{array}$ & $\begin{array}{c}\% \\
\text { Doutorado }\end{array}$ & $\begin{array}{l}\text { Alunos por } \\
\text { funcionário }\end{array}$ \\
\hline Eficientes & $18,49 \%$ & 39,056 & $0,00 \%$ & $0,11 \%$ & $1,97 \%$ & $97,92 \%$ & $72,95 \%$ & $20,21 \%$ & $37,04 \%$ & $0,00 \%$ & $0,00 \%$ & 10,843 \\
\hline $10 \%$ com maior escore DEA & $23,69 \%$ & 40,707 & $0,01 \%$ & $0,34 \%$ & $1,52 \%$ & $98,08 \%$ & $72,85 \%$ & $23,01 \%$ & $34,70 \%$ & $1,47 \%$ & $0,09 \%$ & 9,934 \\
\hline $10 \%$ com menor escore DEA & $26,72 \%$ & 41,894 & $0,00 \%$ & $0,31 \%$ & $1,96 \%$ & $97,61 \%$ & $78,95 \%$ & $16,88 \%$ & $22,20 \%$ & $2,04 \%$ & $0,16 \%$ & 10,942 \\
\hline Média SP & $20,42 \%$ & 39,098 & $0,03 \%$ & $1,85 \%$ & $7,15 \%$ & $90,70 \%$ & $57,82 \%$ & $28,24 \%$ & $32,09 \%$ & $0,72 \%$ & $0,07 \%$ & 5,497 \\
\hline
\end{tabular}

Fonte: Elaborado pelo autor

Com relação ao modelo teórico, as escolas eficientes possuem um investimento por aluno e NSE menores que a média do estado de São Paulo, conforme apresentado na Tabela 10.

Tabela 10 - Estatística descritiva das variáveis relacionadas ao modelo teórico

\begin{tabular}{lllr}
\hline & $\begin{array}{l}\text { Investimento } \\
\text { por aluno }\end{array}$ & $\begin{array}{l}\text { NSE } \\
\text { Médio }\end{array}$ & $\begin{array}{l}\text { IDEB } \\
\text { Médio }\end{array}$ \\
\hline Eficientes & $\mathrm{R} \$ 4.660,58$ & 4,167 & 5,402 \\
$10 \%$ com maior escore DEA & $\mathrm{R} \$ 5.865,37$ & 4,946 & 5,592 \\
$10 \%$ com menor escore DEA & $\mathrm{R} \$ 5.746,05$ & 4,423 & 3,540 \\
Média SP & $\mathrm{R} \$ 5.767,41$ & 4,643 & 4,519 \\
\hline
\end{tabular}

Fonte: Elaborado pelo autor 
Ademais foram realizados dois focus group com Ana Maria Fiori Rufato, ex-secretária municipal de educação do município de Brodowski (SP), e Rosimary Aparecida Amorim Merli, ex-Diretora de escola e ex-secretária municipal de educação com o objetivo de adaptar os roteiros de entrevistas semiestruturadas, proposto por Salgado Júnior (2013) e acrescentar fatores que possam influenciar o desempenho dos alunos no IDEB.

Segundo Oliveira e Freitas (1998), o focus group é um tipo de pesquisa em profundidade realizada em grupo, cujas reuniões apresentam características definidas quanto à proposta, tamanho, composição e procedimentos de condução. As características gerais do focus group são o envolvimento de pessoas, as reuniões em série, a homogeneidade dos participantes quanto aos aspectos de interesse da pesquisa, a geração de dados, a natureza qualitativa e a discussão focada em um tópico que é determinado pelo propósito da pesquisa (KRUEGER, 1994).

De acordo com Oliveira e Freitas (1998), o objetivo do focus group é obter o entendimento dos participantes sobre o tópico de interesse da pesquisa, não importando se é utilizado sozinho ou em conjunto com outros métodos, nem mesmo se busca questões ou respostas. Segundo Galego e Gomes (2005), o focus group pode ser um instrumento fundamental na criação de roteiros de entrevista, na medida em que através dos investigadores se podem ouvir o que as pessoas têm a dizer acerca da área a investigar.

De acordo com Oliveira e Freitas (1998), é recomendável que o grupo tenha tamanho médio, isto é, sejam constituídos de seis a doze pessoas, de modo que ele seja pequeno o suficiente para que todos tenham a oportunidade de partilhar suas percepções e grande o bastante para fornecer diversidade de percepções.

O processo de construção do instrumento de pesquisa e, posteriormente, os roteiros de entrevistas que foram aplicados para os agentes envolvidos com a educação nas escolas eficientes e ineficientes (Secretário municipal de educação, Diretor, Professor, alunos e pais de alunos), envolvendo a adaptação da proposta de Salgado Júnior (2013), da literatura, das correlações entre as variáveis, da análise descritiva e do focus group é ilustrado pela Figura 13. 


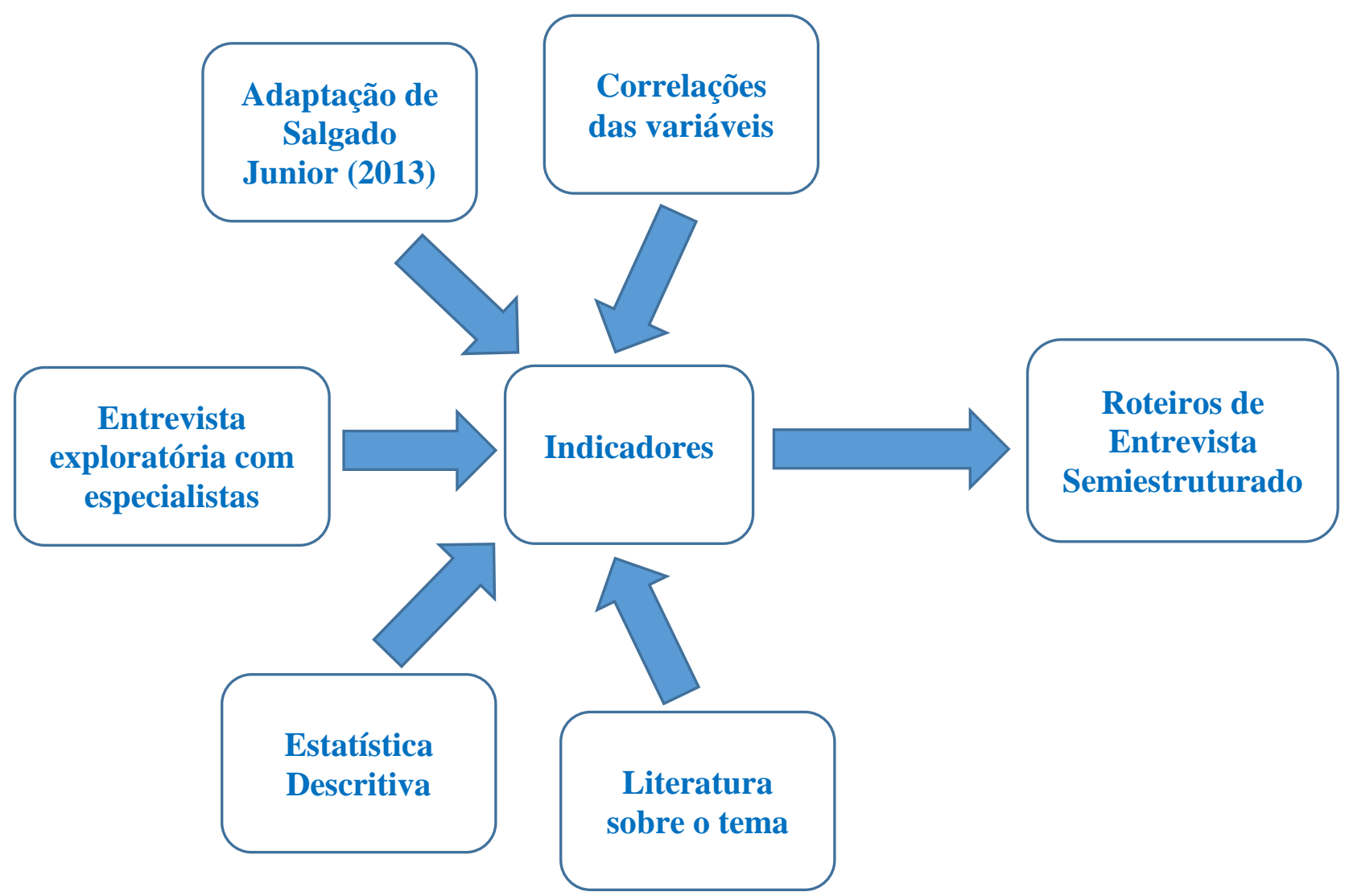

Figura 13 - Processo de construção do instrumento e roteiro semiestruturado

Fonte: Elaborado pelo autor

Como resultado, foram elabordos três instrumentos de pesquisa, com indicadores a fim de medir as práticas administrativo-pedagógicas das escolas eficientes e ineficientes, aplicados para o Secretário municipal de educação, o Diretor da escola, Professores, pais e alunos, além de um roteiro para avaliar vários itens de infraestrutura da escola. Tais práticas foram medidas por meio de uma escala de frequência de 1 a 10, conforme apresentado nos Apêndices I, J e $\mathrm{K}$.

O Quadro 7 apresenta o instrumento de pesquisa direcionado a medir as práticas administrativas envolvendo a Secretaria Municipal de Educação. 


\begin{tabular}{|c|c|c|}
\hline Indicador & Descrição Atividade & Questões (Apêndice) \\
\hline \multirow{6}{*}{ 1. Constituição da SME } & $\begin{array}{l}\text { 1.1. Todo corpo administrativo por indicação } \\
\text { política }\end{array}$ & $8-\mathrm{A}$ \\
\hline & $\begin{array}{l}\text { 1.2. Parte concursada e parte por indicação } \\
\text { política }\end{array}$ & $8-\mathrm{A}$ \\
\hline & 1.3. Escolha do Diretor & \\
\hline & 1.3.1. Indicação política & $8-\mathrm{A} ; 10-\mathrm{B}$ \\
\hline & 1.3.2. Eleição pela comunidade escolar & $8-\mathrm{A} ; 10-\mathrm{B}$ \\
\hline & 1.3.3. Concurso público & $8-\mathrm{A} ; 10-\mathrm{B}$ \\
\hline \multirow{3}{*}{$\begin{array}{l}\text { 2. Organização } \\
\text { Secretaria }\end{array}$} & 2.1. Organograma & $11-\mathrm{A}$ \\
\hline & 2.2. Governança & $12-\mathrm{A}$ \\
\hline & 2.3. Organização de projetos (área de captação) & $11-\mathrm{A}$ \\
\hline \multirow{9}{*}{ 3. Secretário } & 3.1. Formação (curso superior etc.) & $2-\mathrm{A}$ \\
\hline & 3.2. Cursos complementares em Gestão & $2-\mathrm{A}$ \\
\hline & 3.3. Pré-requisito para se tornar Secretário & $4-\mathrm{A} ; 5-\mathrm{A}$ \\
\hline & 3.3.1. Formação em Pedagogia & $4-\mathrm{A}$ \\
\hline & 3.3.2. Curso superior & $4-\mathrm{A}$ \\
\hline & 3.3.3. Não há pré-requisitos & $4-\mathrm{A}$ \\
\hline & $\begin{array}{l}\text { 3.4. Autonomia para criação/alteração de } \\
\text { políticas educacionais }\end{array}$ & $6-\mathrm{A}$ \\
\hline & 3.5. Análise crítica da situação do município & $\begin{array}{l}9-\mathrm{A} ; 10-\mathrm{A} ; 20-\mathrm{A} ; 21- \\
\mathrm{A}\end{array}$ \\
\hline & 3.6. Autonomia para decisões financeiras & $7-\mathrm{A}$ \\
\hline \multirow{4}{*}{$\begin{array}{l}\text { 4. Capacidade da SME } \\
\text { na captação de recursos } \\
\text { financeiros }\end{array}$} & 4.1. Projetos federais e estaduais & $13-\mathrm{A} ; 16-\mathrm{A}$ \\
\hline & 4.2. Parceria com empresas & $17-\mathrm{A}$ \\
\hline & $\begin{array}{l}\text { 4.3. Grau de conhecimento dos indicadores } \\
\text { financeiros municipais }\end{array}$ & $21-\mathrm{A}$ \\
\hline & 4.4. Recursos providos da APM & $14-\mathrm{A}$ \\
\hline \multirow{3}{*}{$\begin{array}{l}\text { 5. Destinação do recurso } \\
\text { financeiro } \\
\text { descentralizado e } \\
\text { centralizado }\end{array}$} & 5.1. Reparos emergenciais & $15-\mathrm{A} ; 19-\mathrm{A}$ \\
\hline & 5.2. Transporte & $15-\mathrm{A} ; 19-\mathrm{A} ; 33-\mathrm{B}$ \\
\hline & $\begin{array}{l}\text { 5.3. Cursos, palestras, orientações didático- } \\
\text { pedagógicas }\end{array}$ & 15 - A; 19 - A; 30-A; 37-B \\
\hline $\begin{array}{l}\text { 6. Transição de novo } \\
\text { Secretário e nova equipe }\end{array}$ & $\begin{array}{l}\text { 6.1. Grau de alteração do quadro de } \\
\text { funcionários ao fim de cada gestão da prefeitura } \\
(4 \text { anos })\end{array}$ & $29-\mathrm{A}$ \\
\hline \multirow{2}{*}{$\begin{array}{l}\text { 7. Critério para } \\
\text { matrícula de alunos }\end{array}$} & 7.1. Por zoneamento & 24 - A; 17-B \\
\hline & 7.2. Por escolha da família & 24 - A; 17-B \\
\hline $\begin{array}{l}\text { 8. Ensino Fundamental } \\
\text { ofertado exclusivamente } \\
\text { pela rede pública }\end{array}$ & $\begin{array}{l}\text { 8.1. Exclusividade da oferta do Ensino } \\
\text { Fundamental pela rede pública }\end{array}$ & $23-\mathrm{A}$ \\
\hline \multirow{3}{*}{$\begin{array}{l}\text { 9. Informações } \\
\text { adicionais }\end{array}$} & 9.1. Percentual de escolas rurais no município & $28-\mathrm{A}$ \\
\hline & $\begin{array}{l}\text { 9.2. Existência de política de progressão } \\
\text { continuada }\end{array}$ & $25-\mathrm{A} ; 18-\mathrm{B}$ \\
\hline & $\begin{array}{l}\text { 9.3. Incentivos para participação em olímpiadas } \\
\text { custeadas pelo município }\end{array}$ & $27-\mathrm{A} ; 18-\mathrm{A}$ \\
\hline
\end{tabular}

Quadro 7 - Instrumento de Pesquisa - Secretário Municipal de Educação

Fonte: Elaborado pelo autor 
O Quadro 8 apresenta o instrumento direcionado a medir as práticas administrativas desenvolvidas pelo Diretor da escola.

\begin{tabular}{|c|c|c|}
\hline Indicador & Descrição Atividade & Questões (Apêndice) \\
\hline $\begin{array}{l}\text { 1. Especificidades } \\
\text { do município } \\
\text { pequeno }\end{array}$ & 1.1. Cobrança da comunidade perante o Diretor & $\begin{array}{l}13-\mathrm{B} ; 32-\mathrm{B} ; 4 \text { - E; } \\
5 \text { - E; 6 - E; } 8 \text { - E; } 9 \\
\mathrm{E} ; 22-\mathrm{E}\end{array}$ \\
\hline \multirow{4}{*}{$\begin{array}{l}\text { 2. Alimentação } \\
\text { dos alunos }\end{array}$} & 2.1. Duas ou mais refeições por período & $38-\mathrm{B} ; 29-\mathrm{D}$ \\
\hline & 2.2. Parcialmente cultivadas pelos alunos & $38-\mathrm{B} ; 31-\mathrm{D}$ \\
\hline & 2.3. Orientação nutricional & 38-B \\
\hline & 2.4. Refeição farta, variada e balanceada & $30-\mathrm{D}$ \\
\hline \multirow{3}{*}{$\begin{array}{l}\text { 3. Processo } \\
\text { Seletivo }\end{array}$} & 3.1. Prova para ingressar na escola & $19-\mathrm{B} ; 31-\mathrm{C}$ \\
\hline & 3.2. Não receber aluno por transferência & $20-\mathrm{B}$ \\
\hline & 3.3. Transferência compulsória em caso de reprovação & $21-\mathrm{B}$ \\
\hline \multirow{8}{*}{ 4. Diretor } & 4.1. Formação (curso superior etc.) & $6-\mathrm{B} ; 7-\mathrm{B} ; 8-\mathrm{B}$ \\
\hline & 4.2. Cursos complementares (Gestão, Pedagogia etc.) & $6-\mathrm{B} ; 9-\mathrm{B}$ \\
\hline & 4.3. Autonomia para decisões & $12-\mathrm{B} ; 11-\mathrm{B}$ \\
\hline & 4.4. Escolha do Diretor & \\
\hline & 4.4.1. Indicação política & $10-\mathrm{B}$ \\
\hline & 4.4.2. Eleição pela comunidade escolar & $10-\mathrm{B}$ \\
\hline & 4.4.3. Concurso público & $10-\mathrm{B}$ \\
\hline & 4.4. Salário Compatível com a função & $14-\mathrm{B} ; 15-\mathrm{B} ; 22-\mathrm{A}$ \\
\hline \multirow{4}{*}{$\begin{array}{l}\text { 5. Capacidade do } \\
\text { Diretor na } \\
\text { captação de } \\
\text { recursos } \\
\text { financeiros } \\
\end{array}$} & 5.1. Projetos federais e estaduais & $28-\mathrm{B}$ \\
\hline & 5.2. Parceria com empresas & $29-\mathrm{B}$ \\
\hline & 5.3. Rifas e festividades & $30-\mathrm{B}$ \\
\hline & 5.4. Recursos providos da APM & $31-\mathrm{B} ; 11-\mathrm{E}$ \\
\hline \multirow{6}{*}{$\begin{array}{l}\text { 6. Destinação do } \\
\text { recurso financeiro } \\
\text { descentralizado e } \\
\text { centralizado }\end{array}$} & 6.1. Programas de computador e softwares & $42-B$ \\
\hline & 6.2. Equipamentos para a sala de informática & $40-\mathrm{B} ; 42-\mathrm{B}$ \\
\hline & 6.3. Acervo para a biblioteca (livros, assinaturas, jornais) & $42-\mathrm{B} ; 39-\mathrm{B} ; 12-\mathrm{D}$ \\
\hline & 6.4. Reparos emergenciais & $42-B$ \\
\hline & 6.5. Materiais didáticos diversos & $42-\mathrm{B}$ \\
\hline & 6.6. Cursos, palestras, orientações didático-pedagógicas & $42-\mathrm{B} ; 36-\mathrm{C} ; 19-\mathrm{A}$ \\
\hline
\end{tabular}

Quadro 8 - Instrumento de Pesquisa - Diretor

Fonte: Elaborado pelo autor

O Quadro 9 apresenta o instrumento de pesquisa destinado a medir as práticas pedagógicas desenvolvidas pela escola. 


\begin{tabular}{|c|c|c|}
\hline Indicador & Descrição Atividade & Questões (Apêndice) \\
\hline \multirow{8}{*}{$\begin{array}{l}\text { 1. Desempenho } \\
\text { Prova Português }\end{array}$} & 1.1. Autonomia do docente no ensino dessa disciplina. & 6-C ; 7-C; 23-B \\
\hline & 1.2. Frequência de leitura dos alunos. & 8-C; 10-D;16- E \\
\hline & 1.3. Rotatividade dos Professores nessa disciplina. & 9-C; 22-B \\
\hline & $\begin{array}{l}\text { 1.4. Frequência que o docente acompanha o } \\
\text { desempenho do aluno. }\end{array}$ & 10-C; 6-D \\
\hline & 1.5. Recuperação paralela e reforço no contraturno. & 11-C; 7-D; 14-E; 25-B \\
\hline & 1.6. Projetos que colaborem para melhor desempenho. & $\begin{array}{l}\text { 12-C; 8-D; 15-E; 27-A; } \\
\text { 26-B }\end{array}$ \\
\hline & $\begin{array}{l}\text { 1.7. Distribuição da carga horária ou da grade } \\
\text { curricular com os requisitos avaliados na Prova Brasil }\end{array}$ & 13-C; 26-A; 27-B \\
\hline & 1.8. Preparação específica para a Prova Brasil. & 14-C; 9-D; 27-B \\
\hline \multirow{7}{*}{$\begin{array}{l}\text { 2. Desempenho } \\
\text { Prova de } \\
\text { Matemática }\end{array}$} & 2.1. Autonomia do docente no ensino dessa disciplina. & 6-C; 7-C; 23-B \\
\hline & $\begin{array}{l}\text { 2.2. Frequência que o docente acompanha o } \\
\text { desempenho do aluno. }\end{array}$ & $10-\mathrm{C} ; 19-\mathrm{D}$ \\
\hline & 2.3. Rotatividade dos Professores nessa disciplina. & 9-C; 22-B \\
\hline & 2.4. Recuperação paralela e reforço no contraturno. & 11-C; 20-D; 19-E; 25-B \\
\hline & $\begin{array}{l}\text { 2.5. Projetos que colaborem para um melhor } \\
\text { desempenho. }\end{array}$ & $\begin{array}{l}\text { 12-C; 21-D; 20-E; 26-B; } \\
27-\mathrm{A}\end{array}$ \\
\hline & $\begin{array}{l}\text { 2.6. Distribuição da carga horária ou da grade } \\
\text { curricular com os requisitos avaliados na Prova Brasil }\end{array}$ & 13-C; 26-A; 27-B \\
\hline & 2.7. Preparação específica para a Prova Brasil. & 14-C; 22-D; 27-B \\
\hline \multirow{7}{*}{$\begin{array}{l}\text { 3. Participação } \\
\text { da família }\end{array}$} & 3.1. Participação dos pais nas reuniões. & 15-C; 37-D; E-6; 32-B \\
\hline & $\begin{array}{l}\text { 3.2. Participação dos pais em eventos festivos da } \\
\text { escola. }\end{array}$ & 16-C; 36-D; 5-E; 32-B \\
\hline & $\begin{array}{l}\text { 3.3. Contribuição na manutenção da estrutura física } \\
\text { escolar. }\end{array}$ & 17-C; 7-F; 11-E \\
\hline & 3.4. Participação dos pais na APM. & 18-C; 35-D; 4-E \\
\hline & $\begin{array}{l}\text { 3.5. Acompanhamento dos pais nos deveres escolares } \\
\text { dos filhos. }\end{array}$ & 38-D; 3-E \\
\hline & 3.6. Apoio dos pais na validação das ações da escola. & 19-C; 34-D; 12-E \\
\hline & $\begin{array}{l}\text { 3.7. Frequência com que os pais utilizam o transporte } \\
\text { público para ir à escola. }\end{array}$ & 39-D; 7-E; 33-B \\
\hline \multirow{5}{*}{$\begin{array}{l}\text { 4. Reprovação } \\
\text { discente e } \\
\text { sistema } \\
\text { disciplinar }\end{array}$} & $\begin{array}{l}\text { 4.1. Autonomia do docente no processo de reprovação } \\
\text { do aluno. }\end{array}$ & $6-\mathrm{C}$ \\
\hline & 4.2. Existência de sistema de reprovação. & 20-C; 41-D; 18-B \\
\hline & 4.3. Regras claras e definidas do sistema disciplinar. & 21-C; 32-D; 13-E \\
\hline & $\begin{array}{l}\text { 4.4. Grau de disciplinaridade no comportamento } \\
\text { discente. }\end{array}$ & 22-C; 40-D \\
\hline & $\begin{array}{l}\text { 4.5. Respeito dos discentes em relação à figura do } \\
\text { Professor, Diretor e funcionários. }\end{array}$ & 23-C; 33-D \\
\hline \multirow{3}{*}{$\begin{array}{l}\text { 5. Laboratório } \\
\text { de Informática }\end{array}$} & 5.1. Existência de laboratório de informática na escola. & $\begin{array}{l}\text { 24-C; 5-F; 24-D; 21-E; } \\
40-\mathrm{B}\end{array}$ \\
\hline & 5.2. Frequência das aulas de informática. & $25-\mathrm{C} ; 25-\mathrm{D}$ \\
\hline & 5.3. Número de computadores para cada 100 alunos & $25-\mathrm{C} ; 5-\mathrm{F}$ \\
\hline \multirow{2}{*}{ 6. Biblioteca } & 6.1. Tamanho do acervo da biblioteca. & 26-C; 4a-F; 12-D \\
\hline & 6.2. Variedade do acervo da biblioteca. & 27-C; 4g-F; 13-D \\
\hline
\end{tabular}




\begin{tabular}{|c|c|c|}
\hline \multirow{2}{*}{ 7. Sala de leitura } & 7.1. Existência de sala de leitura na escola. & $\begin{array}{l}\text { 29-C; 6-F; 14-D; 18-E; } \\
\text { 39-B }\end{array}$ \\
\hline & 7.2. Utilização da sala de leitura & 30-C; 6-F; 15-D \\
\hline \multirow{2}{*}{ 8. Transporte } & $\begin{array}{l}\text { 8.1. Frequência com que os alunos utilizam o } \\
\text { transporte público para ir à escola. }\end{array}$ & 33-C; 3-D; 10-E \\
\hline & 8.2. Número de matrículas & $\begin{array}{ll}\text { Enviado para } \\
\text { Secretaria }\end{array}$ \\
\hline \multirow{10}{*}{ 9. Docentes } & $\begin{array}{l}\text { 9.1. Porcentagem de docentes pertencentes ao gênero } \\
\text { feminino. }\end{array}$ & $\begin{array}{ll}\text { Enviado para } \\
\text { Secretaria }\end{array}$ \\
\hline & $\begin{array}{l}\text { 9.2. Porcentagem dos docentes tem o magistério } \\
\text { concluído. }\end{array}$ & $\begin{array}{ll}\text { Enviado para } \\
\text { Secretaria }\end{array}$ \\
\hline & $\begin{array}{l}\text { 9.3. Porcentagem dos docentes que tem o curso de } \\
\text { licenciatura concluído. }\end{array}$ & \begin{tabular}{|ll} 
Enviado para \\
Secretaria
\end{tabular} \\
\hline & $\begin{array}{l}\text { 9.4. Porcentagem dos docentes que tem ensino superior } \\
\text { concluído. }\end{array}$ & $\begin{array}{ll}\text { Enviado para } \\
\text { Secretaria }\end{array}$ \\
\hline & $\begin{array}{l}\text { 9.5. Porcentagem dos docentes que tem especialização } \\
\text { concluída. }\end{array}$ & \begin{tabular}{|l} 
Enviado para \\
Secretaria
\end{tabular} \\
\hline & 9.6. Número de docentes para cada 100 alunos. & \begin{tabular}{|ll} 
Enviado para \\
Secretaria
\end{tabular} \\
\hline & 9.7. Incentivo financeiro & C-34; A-32; A-31; B-37 \\
\hline & 9.7.1. Plano de carreira financeiramente atrativo & 31-A; 32-A; 34-C \\
\hline & 9.7.2. Salário acima da média regional & A-33; 43-B; 34-C \\
\hline & 9.7.3. Progressão salarial & $35-\mathrm{C}$ \\
\hline 10. Funcionários & 10.1. Número de funcionários para cada 100 alunos & $\begin{array}{l}\text { Enviado } \\
\text { Secretaria }\end{array}$ \\
\hline
\end{tabular}

Quadro 9 - Instrumento de Pesquisa - Pedagógico

Fonte: Elaborado pelo autor

Por meio dos instrumentos de pesquisa foram elaborados cinco roteiros de entrevistas semiestruturados, que foram aplicados aos Secretários municipais de educação, Diretores de escolas, Professores, pais e alunos. Os respectivos roteiros estão disponíveis nos apêndices (do Apêndice A ao Apêndice E). Além dos três instrumentos que originaram os cinco roteiros de entrevista, também foi desenvolvido um roteiro para avaliar itens de infraestrutura das escolas (Apêndice F).

Para a realização da pesquisa de campo é necessário seguir um protocolo de pesquisa a fim de sistematizar as atividades desenvolvidas e garantir confiabilidade na pesquisa. $\mathrm{O}$ protocolo de estudo de caso é uma maneira de aumentar a confiabilidade da pesquisa e se destina o orientar o pesquisador na realização da coleta de dados, tanto em um estudo de um único caso (mesmo se o caso fizer parte de um estudo maior, de múltiplos casos) ou de um único respondente. Miguel (2007) aponta uma proposta de conteúdo e seqüência para a condução de um estudo de caso, apresentada a seguir. 


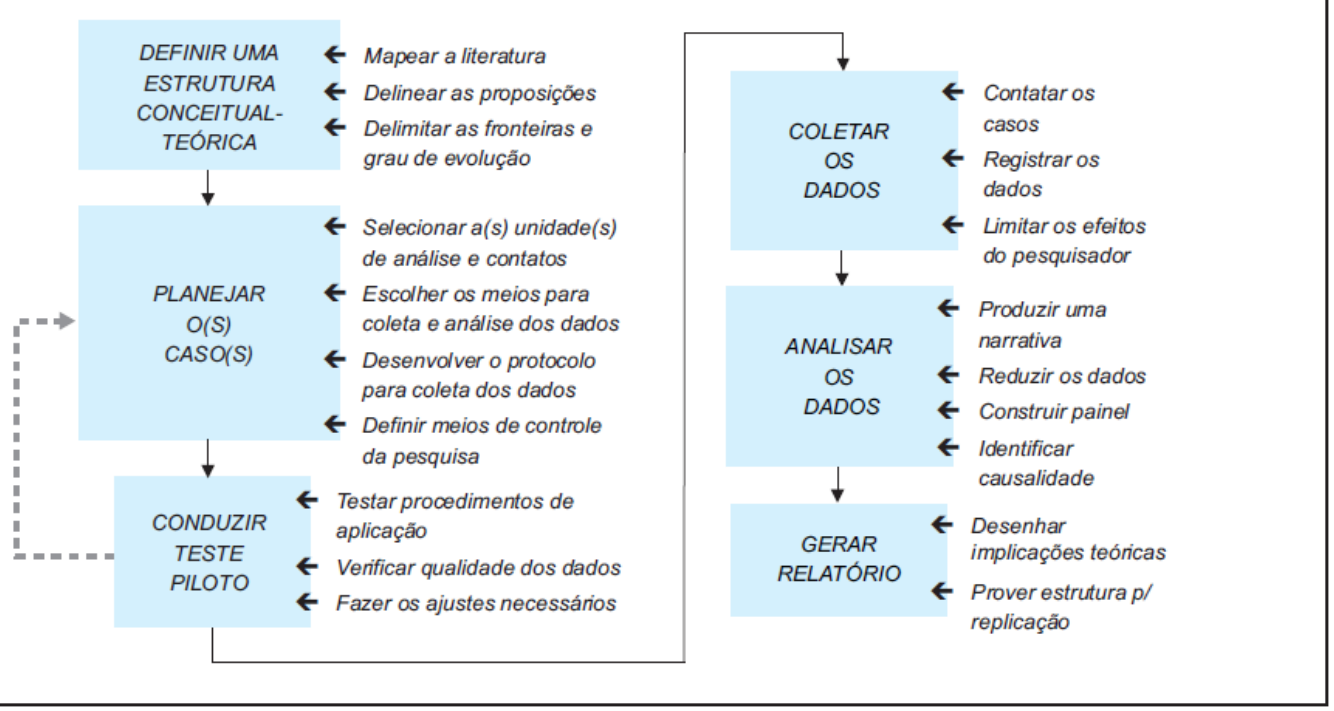

Figura 14 - Condução do estudo de caso

Fonte: Miguel (2007, p. 221)

$\mathrm{Na}$ fase do planejamento do estudo, Miguel (2007) destaca como uma das etapas o desenvolvimento do protocolo do estudo de caso. De acordo com Yin (2010),

[...] o protocolo é mais do que um questionário ou um instrumento. Em primeiro lugar, o protocolo contém o instrumento, mas também contém os procedimentos e as regras gerais a serem seguidas no uso do protocolo. Em segundo lugar, o protocolo é dirigido a um grupo inteiramente diferente do grupo do questionário de levantamento. [...] Em terceiro lugar, ter um protocolo de estudo de caso é desejável sob todas as circunstâncias, mas é essencial se você estiver realizando um estudo de casos múltiplos. (YIN, 2010, p. 106).

Para Yin (2010), o protocolo de estudo de casos deve conter uma visão geral do projeto; os procedimentos de campo; as questões do estudo de caso e um guia para o relatório do estudo de caso. Com relação à visão do projeto, devem ser destacados os objetivos do projeto, os temas do estudo e leituras relevantes sobre o tópico investigado. Os procedimentos de campo devem considerar o acesso aos locais a serem visitados, aspectos relativos à disponibilidade e proteção dos participantes, fontes de dados e advertências de procedimentos. As questões específicas do estudo (núcleo do protocolo) devem ser utilizadas pelo pesquisador na coleta de dados, estrutura das tabelas e potenciais fontes de informação, refletindo a linha de investigação. Por fim, o guia para o relatório do estudo de caso geralmente falta na maioria dos projetos, contudo o planejamento neste estágio significa que uma tentativa de esboço deve aparecer no protocolo de estudo de caso. A maioria dos relatórios segue um esboço similar: apresentação das questões de pesquisa e das hipóteses; descrição do projeto de pesquisa; os 
procedimentos de coleta de dados; apresentação e análise dos dados; e a discussão de constatações e conclusões (YIN, 2010).

Assim, o protocolo deste estudo contém os procedimentos, instrumentos e regras gerais que devem ser seguidas no uso de instrumentos de coleta de campo. Neste sentido, seguindo a metodologia adotada por Salgado Junior (2013), são descritos a seguir o plano amostral, as pessoas-chave para as entrevistas, os procedimentos de coleta de dados, as questões de orientação de estudo de caso e a estrutura do relatório final.

De acordo com Campomar (1991), o estudo de caso envolve a análise intensiva de um número relativamente pequeno de situações, em que é dada ênfase à completa descrição e compreensão do relacionamento dos fatores e variáveis envolvidas na pesquisa. Neste sentido, o plano amostral deve reconhecer o universo a que se refere o estudo, a população que será estudada e a unidade amostral, cabendo ao pesquisador decidir se a amostra deve ser aleatória ou por conveniência (intencional). No caso das escolas eficientes, selecionadas pela técnica DEA, será realizado um estudo de caso em cada uma das instituições. Da mesma forma, o grupo de controle (escolas ineficientes) foi selecionado por conveniência, por apresentarem características semelhantes e estarem localizadas no mesmo município das escolas eficientes.

As pessoas-chave para a entrevista, com maior potencial de contribuição para este estudo são o Secretário municipal da educação do município onde a escola está localizada; o Diretor da escola; os Professores de língua portuguesa e matemática das escolas selecionadas; os alunos, escolhidos aleatoriamente e os pais de alunos, escolhidos pelas escolas.

Com relação aos procedimentos para a coleta de dados, o instrumento de pesquisa deste trabalho consiste em um roteiro de entrevista semiestruturado utilizado em conjunto com análise documental. As entrevistas foram agendadas nas escolas e nas SMEs de acordo com a disponibilidade das pessoas-chave envolvidas na pesquisa e das instituições.

Com base na literatura sobre o tema, estatística descritiva, Focus Group, adaptação de Salgado Junior (2013) e correlações de variáveis foram elaboradas questões utilizadas nos roteiros de entrevistas, servindo como um guia para o pesquisador. Com o objetivo de obter melhor aproveitamento de cada pessoa-chave, os roteiros de entrevistas foram divididos em 5 grupos (Secretário municipal de educação, Diretor, Professor, aluno e pais de alunos), além de 
um roteiro para avaliar a infraestrutura de cada escola. Os roteiros de entrevista são apresentados nos Apêndices (do Apêndice A ao Apêndice F).

Por fim, a estrutura do relatório do final é composta pelos estudos de casos individuais de cada SME e escola, sendo que os dados foram apresentados separadamente para, posteriormente, serem relacionados gerando informações e considerações.

A primeira etapa será estruturada (1) pela apresentação de cada organização; (2) a apresentação do relato sobre a coleta de dados, considerando a evolução do processo de visita e entrevistas; (3) identificação de limitações em relação ao acesso às informações e (4) análise dos resultados obtidos. Com base nos resultados obtidos, foram feitas análises de informações cruzadas observando a complementaridade dos resultados, os conflitos de resultados e a análise do atendimento aos objetivos da pesquisa.

A técnica para a análise qualitativa adotada neste trabalho é a análise de conteúdo. A escolha pela técnica foi feita pela aderência entre o objetivo da pesquisa e a adoção de entrevistas semiestruturadas (instrumento de pesquisa). De acordo com Minayo (2000), a análise de conteúdo visa ultrapassar o nível do senso comum e do subjetivismo na interpretação, buscando uma visão crítica em relação à comunicação de documentos, textos literários, biografias, entrevistas ou observação. De acordo com Cappele, Melo e Gonçalves (2003),

[...] a transformação de dados coletados, ainda no seu estado bruto, em resultados de pesquisa envolve a utilização de determinados procedimentos para sistematizar, categorizar e tornar possível sua análise por parte do pesquisador. No caso específico da análise de comunicações, são exigidos mecanismos apropriados para encontrar em dados obtidos por meio de entrevistas, mensagens e documentos em geral, informações que ilustrem, expliquem ou ajudem a revelar os fenômenos investigados. Entre esses mecanismos, inserem-se a análise de conteúdo e a análise de discurso como propostas teórico-metodológicas, com a pretensão de ultrapassarem o status de simples técnicas de análise para comporem um campo do conhecimento (CAPPELE; MELO; GONÇALVES, 2003, p. 1)

Bardin (2011) destaca que a aplicação da análise de conteúdo é dividida em pré-análise; exploração do material e tratamento dos resultados, a inferência e a interpretação. De acordo com o autor, a análise de conteúdo pode ser utilizada em diversas situações, quando considerado o número de pessoas implicadas na comunicação e o código e suporte da comunicação. 


\begin{tabular}{|c|c|c|c|c|}
\hline Código e suporte & \multicolumn{4}{|c|}{ Número de pessoas implicadas na comunicação } \\
\hline & $\begin{array}{l}\text { Uma pessoa } \\
\text { (monólogo) }\end{array}$ & $\begin{array}{l}\text { Comunicação } \\
\text { dual (diálogo) }\end{array}$ & Grupo restrito & $\begin{array}{c}\text { Comunicação de } \\
\text { massa }\end{array}$ \\
\hline Linguístico escrito & $\begin{array}{l}\text { Agendas, maus } \\
\text { pensamentos, } \\
\text { congeminações, } \\
\text { diários íntimos. }\end{array}$ & $\begin{array}{l}\text { Cartas, } \\
\text { respostas a } \\
\text { questionários e } \\
\text { a testes } \\
\text { projetivos, } \\
\text { trabalhos } \\
\text { escolares. }\end{array}$ & $\begin{array}{l}\text { Ordens de serviço } \\
\text { numa empresa, } \\
\text { todas as } \\
\text { comunicações } \\
\text { escritas, trocadas } \\
\text { dentro de um } \\
\text { grupo. }\end{array}$ & $\begin{array}{l}\text { Jornais, livros, } \\
\text { anúncios } \\
\text { publicitários, } \\
\text { cartazes, } \\
\text { literatura, textos } \\
\text { jurídicos, } \\
\text { panfletos. }\end{array}$ \\
\hline Linguístico oral & $\begin{array}{l}\text { Delírio do doente } \\
\text { mental, sonhos. }\end{array}$ & $\begin{array}{l}\text { Entrevistas e } \\
\text { conversações de } \\
\text { qualquer } \\
\text { espécie. }\end{array}$ & $\begin{array}{l}\text { Discussões, } \\
\text { entrevistas, } \\
\text { conversações de } \\
\text { grupo de qualquer } \\
\text { natureza. }\end{array}$ & $\begin{array}{l}\text { Exposições, } \\
\text { discursos, rádio, } \\
\text { televisão, } \\
\text { cinema, } \\
\text { publicidade, } \\
\text { discos. }\end{array}$ \\
\hline $\begin{array}{l}\text { Icônico (sinais, } \\
\text { grafismos, imagens, } \\
\text { fotografias, filmes, } \\
\text { etc.) }\end{array}$ & $\begin{array}{l}\text { Garatujas mais ou } \\
\text { menos } \\
\text { automáticas, } \\
\text { grafitos, sonhos. }\end{array}$ & $\begin{array}{l}\text { Resposta aos } \\
\text { testes } \\
\text { projetivos, } \\
\text { comunicação } \\
\text { entre duas } \\
\text { pessoas } \\
\text { mediante } \\
\text { imagem. }\end{array}$ & $\begin{array}{l}\text { Toda a } \\
\text { comunicação } \\
\text { icônica num } \\
\text { pequeno grupo } \\
\text { (p.ex.: símbolos } \\
\text { icônicos numa } \\
\text { sociedade secreta, } \\
\text { numa casta...). } \\
\end{array}$ & $\begin{array}{l}\text { Sinais de } \\
\text { trânsito, cinema, } \\
\text { publicidade, } \\
\text { pintura, cartazes, } \\
\text { televisão. }\end{array}$ \\
\hline $\begin{array}{l}\text { Outros códigos } \\
\text { semióticos (i.e., tudo } \\
\text { que não sendo } \\
\text { linguístico pode ser } \\
\text { portador de } \\
\text { significações; ex.: } \\
\text { música, objetos, } \\
\text { comportamento, } \\
\text { espaço, tempo, sinais } \\
\text { patológicos, etc.) }\end{array}$ & $\begin{array}{l}\text { Manifestações } \\
\text { histéricas da } \\
\text { doença mental, } \\
\text { posturas, gestos, } \\
\text { tiques, dança, } \\
\text { coleções de } \\
\text { objetos. }\end{array}$ & \multicolumn{2}{|c|}{$\begin{array}{l}\text { Comunicação não verbal com destino } \\
\text { a outrem (posturas, gestos, distância } \\
\text { espacial, sinais olfativos, } \\
\text { manifestações emocionais, objetos } \\
\text { quotidianos, vestuário, } \\
\text { alojamento...), comportamentos } \\
\text { diversos, tais como os ritos e as } \\
\text { regras de cortesia. }\end{array}$} & $\begin{array}{l}\text { Meio físico e } \\
\text { simbólico: } \\
\text { sinalização } \\
\text { urbana, } \\
\text { monumentos, } \\
\text { arte; mitos, } \\
\text { estereótipos, } \\
\text { instituições, } \\
\text { elementos de } \\
\text { cultura. }\end{array}$ \\
\hline
\end{tabular}

Quadro 10 - Domínios possíveis da aplicação da análise de conteúdo

Fonte: Elaborado pelo autor

Segundo Vergara (2012), a análise de conteúdo é considerada uma técnica para o tratamento de dados que visa identificar o que está sendo dito a respeito de determinado tema, sendo utilizadas para fins exploratórios confirmando ou não hipóteses preestabelecidas.

Para a realização da análise de conteúdo é necessário definir o tema e o problema de pesquisa, elaborar uma revisão da literatura pertinente ao problema, definição das suposições para o problema e os meios de coleta de dados (relatórios, documentos da organização, entrevistas e aplicação de questionários). De acordo com Flick (2009), existem diversas formas de documentação do material coletado, na maioria das vezes constituindo-se de material textual: 
notas de campo, diário de pesquisa, fichas de documentação, transcrição, além de ser documentado por meio de fotos, filmes, áudio dentre outros meios, possibilitando uma adequada análise.

No caso da realização de entrevistas, quando gravadas ou disponíveis, pode-se fazer sua transcrição. Posteriormente define-se o tipo de grade para análise (fechada, aberta ou mista) e procede-se à leitura do material selecionado na coleta de dados. Por fim, realiza-se à análise de conteúdo apoiando-se em procedimentos estatísticos, interpretativos ou ambos (VERGARA 2012).

O tipo de grade utilizada neste trabalho foi a fechada, em que são definidas preliminarmente as categorias pertinentes ao objetivo da pesquisa. Posteriormente os elementos a serem integrados na categoria estabelecida são identificados no material selecionado. Desta forma, foi criado o protocolo de entrevista com categorias preestabelecidas, em que foi analisado o conteúdo da comunicação de acordo com estas categorias e sistematizado em tabelas e, por fim, foram dadas notas para efeito de comparação.

\subsubsection{Rastreabilidade do estudo de caso}

De acordo com Miguel (2007), a importância metodológica de um trabalho pode ser justificada pela necessidade de embasamento científico adequado para que sejam desenvolvidos trabalhos melhor estruturados que possam ser replicados e aperfeiçoados por outros pesquisadores. Desta forma, a utilização criteriosa e adequada de procedimentos metodológicos permite o desenvolvimento de teorias, por meio de sua extensão ou refinamento, proposição de novas teorias e geração de conhecimento.

Após a seleção e escolha das cinco escolas eficientes e das cinco escolas ineficientes foi possível realizar um estudo de múltiplos casos em ambos os grupos de escolas. Para efeito de rastreabilidade da pesquisa, para que este estudo possa ser replicado, foram descritos os passos que envolveram a realização dos estudos de caso. 
Passo 1: Solicitação de autorização para realização do estudo nas escolas e prestação de esclarecimentos sobre a pesquisa aos Secretários Municipais de Educação. Este passo segue os preceitos éticos para elaboração da pesquisa que devem ter a anuência da escola e o compromisso de manter sigilo e proteção das informações coletadas pelo pesquisador.

Passo 2: Realização do agendamento das visitas às escolas e na SME. Essa etapa envolveu a definição dos horários que a SME e as escolas seriam visitadas e os atores escolares que seriam entrevistados (Secretário Municipal de Educação, Diretor, Professor, alunos e pais de alunos).

Passo 3: Visita às escolas e as SME. Essa etapa é caracterizada pela realização das entrevistas semiestruturadas com os Secretários Municipais de Educação, Diretores, Professores de Português e Matemática, alunos e pais de alunos, e também pela análise documental e observação assistemática nas escolas e SME. Durante a realização desta etapa foi adotado um padrão na ordem das visitas nos municípios, em que a SME foi a primeira a ser visitada no período da manhã, seguida pela escola eficiente ainda no mesmo período e pela escola ineficiente no período da tarde.

Em visita à SME, foi realizada uma entrevista semiestruturada com o Secretário Municipal de Educação, onde foi aplicado o roteiro de entrevista do Secretário, disponível no apêndice A, a fim de identificar suas práticas administrativas medidas pelo instrumento administrativo do Secretário.

$\mathrm{Na}$ visita realizada às escolas eficientes, as entrevistas com os atores escolares ocorreram na seguinte ordem: $\left(1^{\circ}\right)$ Diretor, em que foi aplicado o roteiro do Diretor, disponível no apêndice $\mathrm{B}$, a fim de identificar as práticas administrativas medidas pelo instrumento administrativo do Diretor; $\left(2^{\circ}\right)$ Professores de Português e Matemática, em que foi aplicado o roteiro de entrevista do Professor, disponível no apêndice $C ;\left(3^{\circ}\right)$ alunos, cuja entrevista foi conduzida pelo roteiro de entrevista dos alunos, disponível no apêndice $\mathrm{D}$; e $\left(4^{\circ}\right)$ pais de alunos, em que foi aplicado o roteiro de entrevista dos pais, localizado no apêndice E, com o objetivo de identificar as práticas pedagógicas das escolas medidas pelo Instrumento Pedagógico. 
A visita realizada às escolas ineficientes seguiu à mesma ordem de entrevistas adotada nas escolas eficientes.

Passo 4: Preenchimentos das escalas de avaliação e elaboração do relatório. Ao final de cada dia de visita, foi realizado, de acordo com a percepção do pesquisador, o preenchimento das Escalas de Frequência de Avaliação dos Indicadores Administrativos da SME (Apêndice I), dos indicadores administrativos do Diretor (Apêndice $\mathrm{J}$ ) e dos indicadores pedagógicos da escola (Apêndice K), além da elaboração de um relatório descrevendo os principais aspectos identificados nas entrevistas com o Secretário na SME e com os Diretores, Professores, alunos, pais de alunos, infraestrutura e demais documentos analisados nas escolas (eficientes e ineficientes). A composição desses relatórios culminou na descrição dos estudos de casos realizados neste estudo, apresentado na seção 5.2.1.

$\mathrm{Na}$ seção seguinte são apresentados e discutidos os resultados da etapa quantitativa e qualitativa. 


\section{Apresentação e Análise de Resultados}

Nesta seção são apresentados os resultados da aplicação da metodologia, segmentada nas etapas quantitativa e qualitativa. A etapa quantitativa foi responsável pela identificação das escolas eficientes e ineficientes (grupo de controle). Para a seleção das DMUs foi aplicada a técnica DEA, sendo utilizado o modelo BCC orientado a output.

A etapa qualitativa envolve o estudo de múltiplos casos nas escolas eficientes e ineficientes identificadas pela técnica DEA, utilizando um roteiro de entrevistas semiestruturado. A finalidade desta etapa é conhecer os processos internos destas escolas a fim de comparar, por meio de um quadro, as práticas administrativo-pedagógicas encontradas com frequência em cada um dos grupos (eficientes e ineficientes). As práticas encontradas com alta frequência nas escolas eficientes e não identificadas (ou identificadas com baixa frequência) nas escolas ineficientes foram consideradas como práticas que podem colaborar para um melhor desempenho no IDEB.

Os resultados da etapa quantitativa são apresentados a seguir.

\subsection{Resultados da etapa quantitativa}

Para a realização desta etapa da pesquisa foram utilizados o investimento financeiro municipal anual por aluno, o nível socieconômico, a infraestrutura escolar e o desempenho dos alunos no IDEB. Para obtenção da variável investimento financeiro foi calculado o quociente do investimento financeiro anual do município em educação no ano de 2011, disponibilizado pelo FINBRA, pelo número de alunos matriculados no município no mesmo período, fornecido pelo Censo Escolar e disponibilizado pelo INEP, obtendo-se assim o valor do investimento financeiro anual por aluno de cada município no ensino fundamental $\left(1^{\mathrm{a}}\right.$ a $9^{\mathrm{a}}$ série). Já o NSE médio das escolas foi disponibilizado por Alves, Soares e Xavier (2014), que classificam as escolas em sete grupos de acordo com seu perfil socioeconômico, sendo: (1) Mais Baixo; (2) Baixo; (3) Médio Baixo; (4) Médio; (5) Médio Alto; (6) Alto; e (7) Mais Alto. Referente à variável infraestrutura foram considerados itens como número de computadores por aluno e número de salas por aluno, disponibilizados pelo INEP. Para 
finalizar, os dados sobre o desempenho médio por escola pública municipal no IDEB dos alunos do estado de São Paulo, no ano de 2011, foram obtidos na base de dados do INEP.

Por meio do desenvolvimento desta base de dados onde estão disponíveis as informações sobre investimento financeiro anual por aluno em cada município, itens de infraestrutura, bem como o NSE médio das escolas e o desempenho médio por escola pública municipal no IDEB, tornou-se possível a aplicação da técnica DEA. Com o objetivo de identificar quais escolas (DMUs) conseguem gerar maior desempenho no IDEB, foi utilizado o modelo BCC, orientado a output. Com o uso deste modelo é construída a fronteira de eficiência e são identificadas as escolas eficientes e ineficientes.

No caso da aplicação da técnica DEA, as variáveis utilizadas com suas respectivas justificativas estão identificadas no Quadro 11.

\begin{tabular}{|c|c|c|c|}
\hline & Variável & Justificativa & Fonte \\
\hline \multirow{3}{*}{ Inputs } & $\begin{array}{l}\text { Investimento } \\
\text { anual por aluno } \\
\text { no ensino } \\
\text { fundamental }\end{array}$ & $\begin{array}{l}\text { O investimento em educação é relacionado na } \\
\text { literatura como um fator que pode contribuir } \\
\text { com um melhor desempenho dos alunos. }\end{array}$ & $\begin{array}{l}\text { Barros e Mendonça (1998) } \\
\text { OCDE (2007) } \\
\text { Franco (2008) } \\
\text { INEP (2011) } \\
\text { Batalha, Miranda e Lírio (2012) }\end{array}$ \\
\hline & NSE & $\begin{array}{l}\text { O NSE representa o fator de maior impacto } \\
\text { no desempenho escolar dos alunos }\end{array}$ & $\begin{array}{l}\text { Coleman et al. (1966) } \\
\text { Soares e Alves (2003) } \\
\text { Gamoran e Long (2006) }\end{array}$ \\
\hline & Infraestrutura & $\begin{array}{l}\text { A infraestrutura gera impacto positivo no } \\
\text { desempenho dos alunos e é condição } \\
\text { necessária para a oferta de uma educação de } \\
\text { qualidade }\end{array}$ & $\begin{array}{l}\text { CEPAL (2000) } \\
\text { GAME (2002) } \\
\text { Teixeira (2009) }\end{array}$ \\
\hline Output & $\begin{array}{l}\text { Desempenho no } \\
\text { IDEB }\end{array}$ & $\begin{array}{l}\text { O IDEB é considerado o mecanismo mais } \\
\text { eficiente disponível no país para avaliar e } \\
\text { monitorar a qualidade do sistema educacional }\end{array}$ & $\begin{array}{l}\text { Fernandes (2007) } \\
\text { INEP (2011) }\end{array}$ \\
\hline DMUs & $\begin{array}{l}1298 \text { escolas } \\
\text { públicas } \\
\text { municipais do } \\
\text { ensino } \\
\text { fundamental do } \\
\text { estado de São } \\
\text { Paulo }\end{array}$ & $\begin{array}{l}\text { O ensino fundamental foi escolhido devido } \\
\text { sua grande representatividade na educação } \\
\text { básica }(58,8 \%) \text {, sendo que a rede municipal } \\
\text { de ensino corresponde a } 68,2 \% \text { das } \\
\text { matrículas. O estado de São Paulo foi } \\
\text { escolhido por ser o mais representativo nas } \\
\text { matrículas do ensino fundamental do país } \\
(19,4 \%) \text {. }\end{array}$ & INEP (2013) \\
\hline
\end{tabular}

\section{Quadro 11 - Justificativa das variáveis utilizadas no modelo DEA}

Fonte: Elaborado pelo autor 
Por não haver autorização formal de publicação dos dados e para evitar exposição das escolas discutidas neste trabalho, elas foram tratadas por letras, em que as escolas eficientes estão representadas pelas letras A, B, C, D e E; e as ineficientes, pelas letras F, G, H, I e J. Outra consideração importante a se destacar refere-se ao tamanho da escola, que segundo o INEP (2005) podem ser caracterizadas como pequeno porte (com menos de 199 alunos), médio porte (de 200 a 999 alunos) e grande porte (acima de 1.000 alunos).

Os resultados da fase quantitativa correspondem à identificação e seleção, por meio da modelagem DEA, das escolas públicas municipais do estado de São Paulo eficientes em transformar inputs (investimento financeiro, NSE e infraestrutura) em outputs (desempenho no IDEB). Os resultados obtidos pela técnica DEA das escolas localizadas na fronteira de eficiência podem ser observados na Tabela 11.

Tabela 11 - Caracterização das cinco escolas eficientes selecionadas pela técnica DEA

\begin{tabular}{lcccccccc}
\hline Município & UF & $\begin{array}{c}\mathbf{n}^{\circ} \text { de } \\
\text { habitantes }\end{array}$ & Escola & $\begin{array}{c}\mathbf{n}^{\circ} \text { de } \\
\text { alunos }\end{array}$ & $\begin{array}{c}\text { Investimento anual } \\
\text { por aluno em 2011 }\end{array}$ & $\begin{array}{c}\text { IDEB } \\
\mathbf{2 0 1 1}\end{array}$ & $\begin{array}{c}\text { Escore } \\
\text { DEA }\end{array}$ & $\begin{array}{c}\text { NSE (ALVES; SOARES; } \\
\text { XAVIER, 2014) }\end{array}$ \\
\hline Cerquilho & SP & 40.393 & A & 383 & $3.535,48$ & 6,06 & 100,0 & 4 (Médio) \\
Mairinque & SP & 43.473 & B & 351 & $3.685,24$ & 3,52 & 100,0 & 3 (Médio-Baixo) \\
São José dos Campos & SP & 636.876 & C & 975 & $8.363,81$ & 6,29 & 100,0 & 5 (Médio-Alto) \\
Tuiuti & SP & 6.005 & D & 211 & $3.522,26$ & 4,98 & 100,0 & 5 (Médio-Alto) \\
Dois Córregos & SP & 24.933 & E & 413 & $4.367,93$ & 6,47 & 100,0 & 6 (Alto) \\
\hline
\end{tabular}

Fonte: Elaborado pelo autor.

Com relação às escolas eficientes pode-se identificar que a maioria delas está localizada em municípios com menos de 45.000 habitantes, sendo uma única escola localizada em um município com mais de 600.000 habitantes. Com relação ao tamanho das escolas, todas as escolas são de médio porte, segundo classificação do INEP (2005). Com relação ao NSE, as escolas variam de 3 (Médio-Baixo) a 6 (Alto). Por fim, o investimento anual por aluno em 2011 varia de $\mathrm{R} \$ 3.522,26$ a $\mathrm{R} \$ 8.363,81$.

Assim, como descrito anteriormente, também foram selecionadas por julgamento e conveniência cinco escolas ineficientes (considerou-se aquelas com escore DEA abaixo de 0,80 - em uma escala de 0 a 1) localizadas nos mesmos municípios das eficientes e com características de investimento financeiro, infraestrutura e NSE similar às escolas eficientes. Estas escolas servirão como grupo de controle para serem comparadas com as escolas eficientes, a fim de se identificar as práticas administrativo-pedagógicas que mais colaboram 
para o melhor desempenho dos alunos no IDEB. A Tabela 12 resume as escolas ineficientes selecionadas e suas principais características.

Tabela 12 - Caracterização das cinco escolas ineficientes selecionadas pela técnica DEA

\begin{tabular}{lcccccccc}
\hline Município & UF & $\begin{array}{c}\mathbf{n}^{\circ} \text { de } \\
\text { habitantes }\end{array}$ & Escola & $\begin{array}{c}\mathbf{n}^{\circ} \text { de } \\
\text { alunos }\end{array}$ & $\begin{array}{c}\text { Investimento anual } \\
\text { por aluno em 2011 }\end{array}$ & $\begin{array}{c}\text { IDEB } \\
\mathbf{2 0 1 1}\end{array}$ & $\begin{array}{c}\text { Escore } \\
\text { DEA }\end{array}$ & $\begin{array}{c}\text { NSE (ALVES; SOARES; } \\
\text { XAVIER, 2014) }\end{array}$ \\
\hline Cerquilho & SP & 40.393 & F & 421 & $3.535,48$ & 5,18 & 78,54 & 5 (Médio-Alto) \\
Mairinque & SP & 43.473 & G & 893 & $3.685,24$ & 3,64 & 60,09 & 4 (Médio) \\
São José dos Campos & SP & 636.876 & H & 628 & $8.363,81$ & 4,72 & 75,01 & 5 (Médio-Alto) \\
Tuiuti & SP & 6.005 & $\mathrm{I}$ & 294 & $3.522,26$ & 4,50 & 79,40 & 5 (Médio-Alto) \\
Dois Córregos & SP & 24.933 & $\mathrm{~J}$ & 148 & $4.367,93$ & 5,14 & 77,92 & 5 (Médio-Alto) \\
\hline
\end{tabular}

Fonte: Elaborado pelo autor.

Por serem localizadas nos mesmos munípios que as escolas eficientes, as escolas ineficientes possuem características semelhantes em relação ao número de habitantes e investimento por aluno. As diferenças estão relacionadas ao tamanho das escolas, em que uma das escolas ineficientes é de pequeno porte enquanto as outras quatro são de médio porte. Outra característica das escolas ineficientes refere-se ao NSE, em que há pequenas diferenças em relação às escolas eficientes. O Quadro 12 apresenta o NSE das escolas eficientes e ineficientes selecionadas pela DEA.

\begin{tabular}{|c|c|c|c|c|c|c|c|c|c|c|c|c|c|}
\hline & & & & $\mathrm{CO}$ & $\mathrm{as} \mathrm{e}$ & cie & & & $5 \mathrm{e}$ & cola & $\mathrm{s}$ in & fic & ates \\
\hline Indicador & $\begin{array}{l}\text { NSE (ALVES; } \\
\text { SOARES, e }\end{array}$ & & & col & & & $\mathrm{n}^{\circ} \mathrm{de}$ & & & $\mathrm{col}$ & & & $\mathrm{n}^{\circ} \mathrm{de}$ \\
\hline & Mais baixo & & & & & & 0 & & & & & & 0 \\
\hline & Baixo & & & & & & 0 & & & & & & 0 \\
\hline Nível & Médio-baixo & & $\mathrm{B}$ & & & & 1 & & & & & & 0 \\
\hline $\begin{array}{l}\text { Socioeconómico } \\
\text { médio dos alunos }\end{array}$ & Médio & $\mathrm{A}$ & & & & & 1 & & $\mathrm{G}$ & & & & 1 \\
\hline da escola & Médio-alto & & & $\mathrm{C}$ & $\mathrm{D}$ & & 2 & $\mathrm{~F}$ & & $\mathrm{H}$ & $\mathrm{I}$ & $\mathrm{J}$ & 4 \\
\hline & Alto & & & & & $\mathrm{E}$ & 1 & & & & & & 0 \\
\hline & Mais alto & & & & & & 0 & & & & & & 0 \\
\hline
\end{tabular}

Quadro 12 - NSE das escolas eficientes e ineficientes

Fonte: Adaptado de Salgado Junior (2013), com base em Alves e Soares (2014)

Com a identificação das escolas públicas municipais do estado de São Paulo eficientes e ineficientes pela técnica DEA se torna possível à realização da segunda etapa desta pesquisa, que consiste em um estudo de multiplos casos objetivando comparar os dois grupos. 


\subsection{Resultados da fase qualitativa}

Os resultados da fase qualitativa foram apresentados após as visitas às escolas eficientes e ineficientes, incluindo a descrição do estudo de caso realizado nas 10 escolas e SMEs selecionadas para este estudo.

\subsubsection{Descrição dos estudos de casos realizados nas escolas eficientes e ineficientes e em suas respectivas SMEs.}

Nesta seção estão apresentados resumidamente os principais relatos identificados por meio das entrevistas semiestruturadas realizadas nas escolas eficientes e ineficientes e em suas respectivas SMEs, localizadas nos cinco municípios selecionados de acordo com a metodologia desta dissertação. Como as escolas eficientes e ineficientes estão localizadas no mesmo município e sobre a gestão da mesma SME, primeiro será apresentado os resultados obtidos na SME, seguido pela escola eficiente e ineficiente do mesmo município.

\subsubsection{Escola "A" eficiente e respectiva SME}

- Data da visita: 09/09/2014

- Indicadores do município de Cerquilho

$\mathbf{N}^{0}$ de Habitantes: 40.393

IDHM: 0,782

- Indicadores da escola A

Número de alunos: 383

Investimento anual por aluno: $\mathrm{R} \$ 3.535,48$

Nota no IDEB (Anos Finais): 6,06

Nível socioeconômico: 4 (Médio)

Durante a visita realizada à escola "A", conforme ilustrado pela Figura 15, localizada no município de Cerquilho no estado de São Paulo, foi possível identificar inúmeras práticas administrativas e pedagógicas que colaboraram para que, no ano de 2011, a escola obtivesse uma nota de 6,06 no IDEB. A seguir são apresentados alguns dos principais aspectos mais relevantes que foram observados durante a visita à escola. 


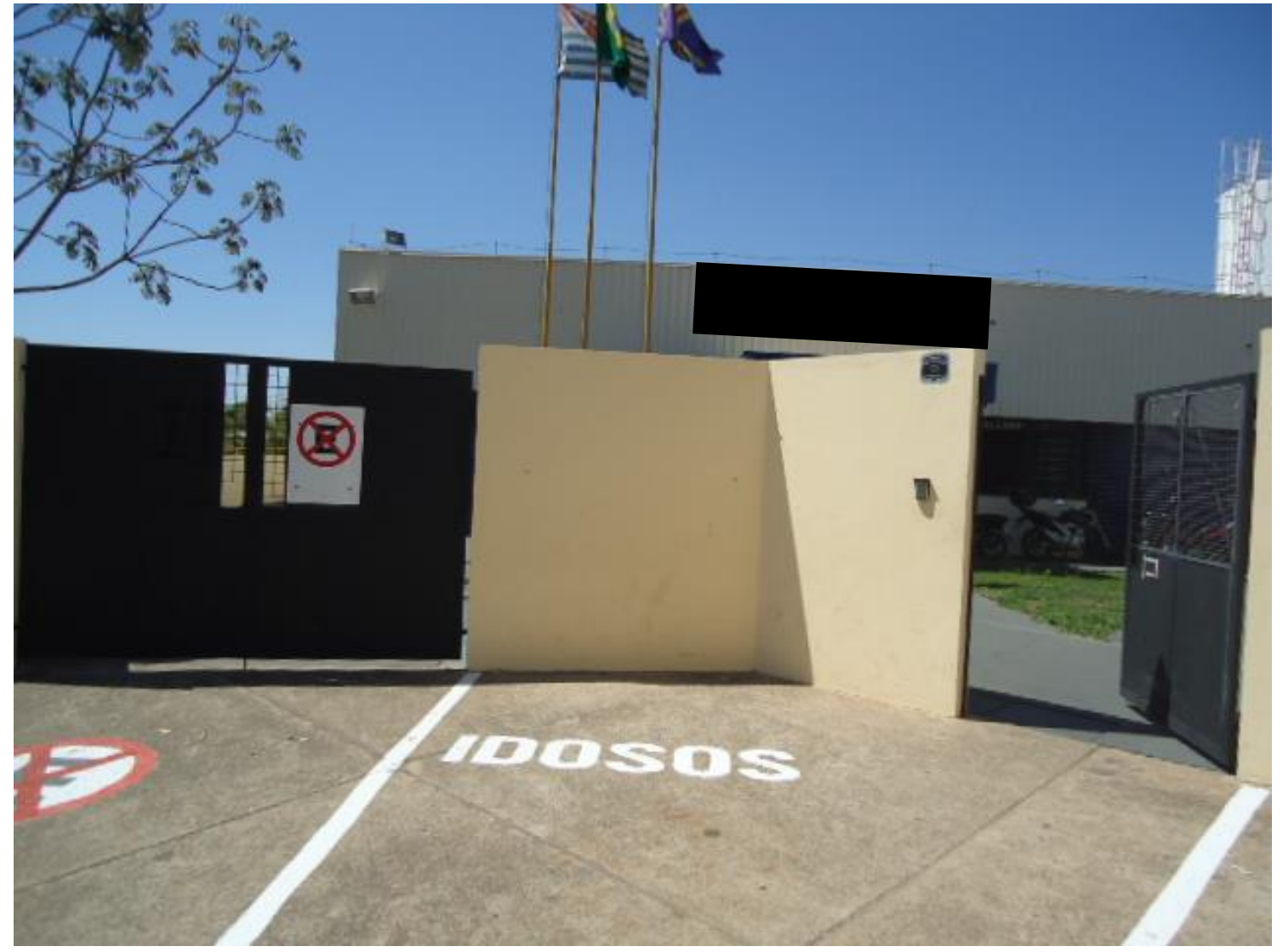

Figura 15 - Fachada da escola "A"

Fonte: Arquivo pessoal do autor

\subsection{Relatório de gestão e destinação dos recursos financeiros da SME}

\subsection{Constituição da SME}

Em conversa com a Secretária de Educação, observou-se que todos os colaboradores desta secretaria são nomeados por indicação política, salvo alguns cargos que são submetidos à aprovação de planos de gestão do Conselho Municipal. Além disso, a secretaria define como política do município que todos os Diretores sejam escolhidos por indicação política, contando ao final do processo com a aprovação do prefeito. Outro ponto a ser ressaltado é a formação dos funcionários da SME, pois os Supervisores de Ensino possuem formação em Pedagogia e/ou licenciaturas específicas da área e os Orientadores Pedagógicos, também são formados nas áreas específicas em que atuam. 


\subsection{Organização da SME}

Em visita à SME foi realizado uma entrevista com a secretária e as coordenadoras pedagógicas do município, a fim de identificar suas principais práticas de gestão. A Figura 16 mostra a fachada da SME do município de Cerquilho.

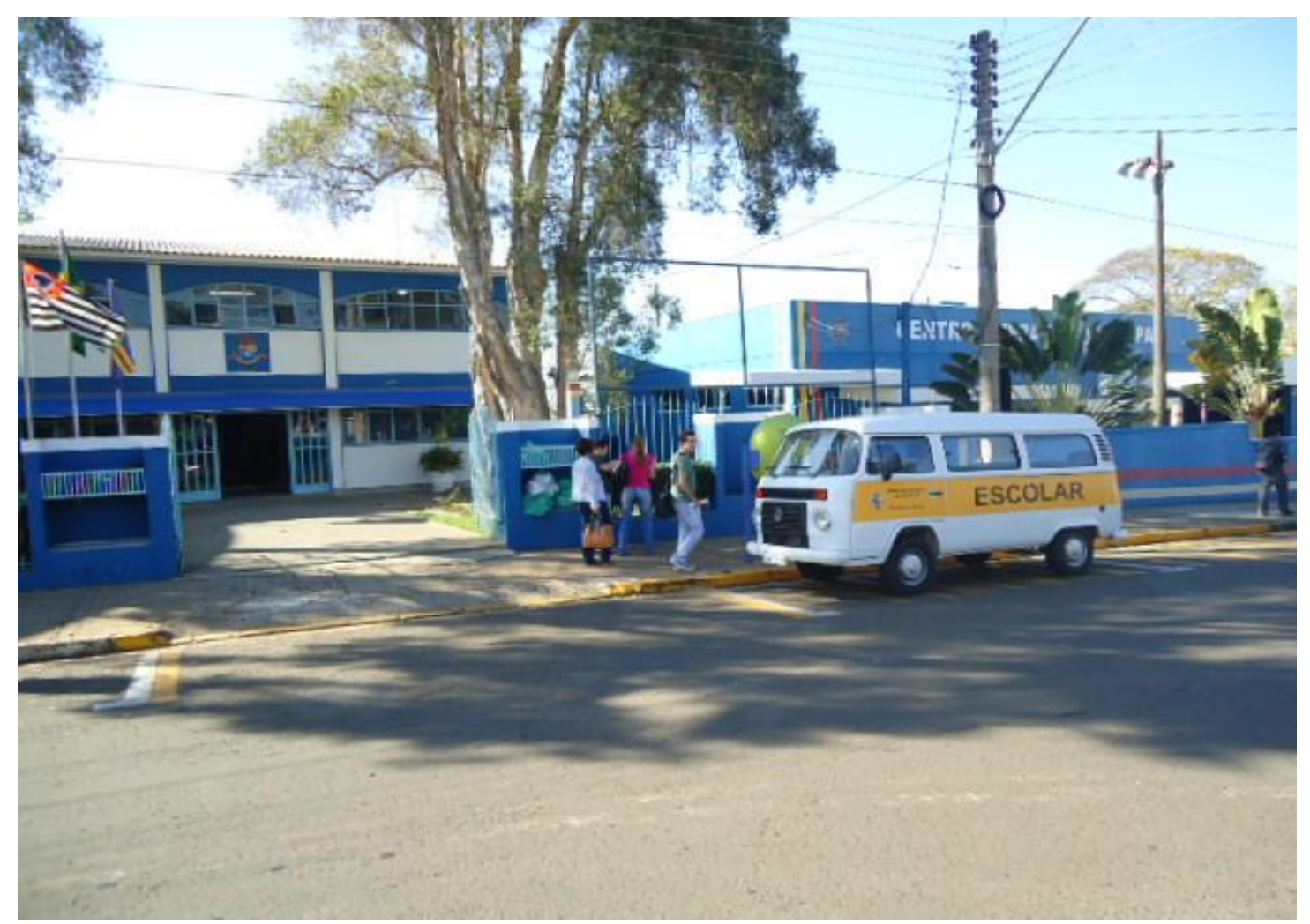

Figura 16 - Fachada da SME do município de Cerquilho

Fonte: Arquivo pessoal do autor

Em visita à SME, observou-se em relação à governança, que os supervisores se reportam diretamente a secretária, que por sua vez busca conciliar e mediar eventuais conflitos nas áreas que estão sob a tutela dos mesmos. Além disso, identificou-se a existência de seis supervisores, em que, de acordo com a secretária, cada um deles assume a responsabilidade de um setor, como o financeiro, projetos, etc. Não obstante, também se observou que a SME não possui uma área específica responsável pela captação de recursos.

\subsection{Secretário}

Em entrevista com a Secretária, observou-se que ela possui formação em Letras e em Pedagogia, com pós-graduação em Direito Educacional e Gestão Escolar. Em relação ao 
cargo de secretária, observou-se a existência de uma portaria que regula o seu acesso, em que para se candidatar ao cargo é necessária à formação de nível Superior Completo. Também foi observado que a secretária tem autonomia para criação de políticas educacionais, desde que não interfira no que o Estatuto da Educação do município regula. Observou-se ainda, que a secretária tem uma boa análise crítica da situação do município no que concerne aos principais desafios da educação. Não obstante, a autonomia financeira da secretária mostrouse elevada após a definição, por parte do governo federal, estadual e municipal, das macro áreas em que o dinheiro deveria ser investido. Além de que, a secretária afirma não possuir recursos descentralizados (recurso totalmente livre) onde ela pode investir naquilo que achar mais interessante para o desenvolvimento da educação no município.

\subsection{Capacidade da SME na captação de recursos financeiros}

Em visita à SME, observou-se que apenas em alguns casos isolados ela atua de modo a angariar recursos por meio de projetos federais e/ou estaduais, pois segundo a secretária, esta função é realizada por um funcionário próprio da prefeitura. Durante a visita à SME, também foi possível verificar que ela não estabelece nenhuma parceria com empresas privadas ou a APM, a fim de levantar recursos para a educação do município. Ademais, verificou-se que a secretária possui desconhecimento dos principais indicadores financeiros municipais, como o investimento anual por aluno.

\subsection{Destinação do recurso financeiro descentralizado e centralizado}

Em conversa com a secretaria, verificou-se que a destinação dos recursos financeiros se dá majoritariamente para o transporte dos alunos e o oferecimento de cursos, palestras e orientações didático-pedagógicas para Professores aprimorarem seu conhecimento e melhorarem o ensino da rede, enquanto os recursos destinados a reparos emergenciais representam um volume menor. Por outro lado, os recursos que chegam à secretaria e são destinados às escolas são repassados somente após um requerimento formal dos Diretores, que devem relacionar todos os itens que necessitam e o montante de cada um deles. A Figura 17 apresenta os itens adquiridos pela SME que será enviado as escolas. 


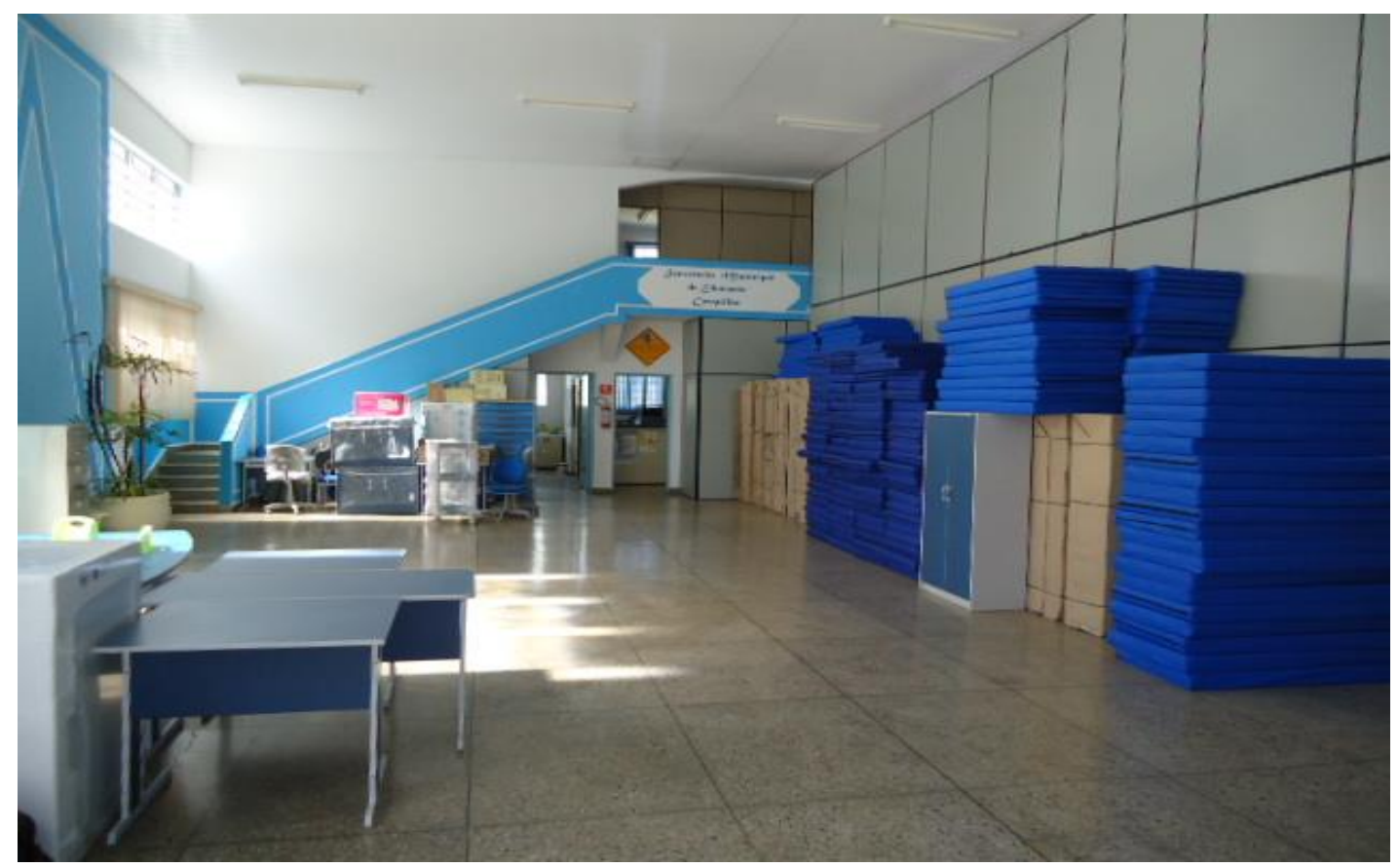

Figura 17 - Itens adquiridos pela SME que serão enviados às escolas Fonte: Arquivo pessoal do autor

\subsection{Transição de novo Secretário e nova equipe}

Em entrevista com a Secretária, observou-se que a maior parte dos colaboradores, juntamente com o próprio Secretário, são substituídos totalmente no caso de o novo prefeito ser do partido da oposição. Segundo a secretária, esta troca mostrou-se traumática na última vez que foi realizada, uma vez que nenhuma informação foi repassada aos novos colaboradores, dificultando assim o seu trabalho inicial nas atividades de secretaria.

\subsection{Critério para matrícula de alunos}

Em entrevista com a Secretária, observou-se que o critério adotado para a matrícula dos alunos é por zoneamento.

\subsection{Ensino fundamental ofertado exclusivamente pela rede pública}

Segundo a secretária municipal de educação, o ensino fundamental não é oferecido exclusivamente pela rede pública, pois o município também conta com escolas particulares que oferecem essa modalidade de ensino. 


\subsection{Informações adicionais}

Em visita à SME, constatou-se a existência de dez escolas urbanas e nenhuma escola rural no município. As escolas urbanas oferecem apenas o ensino fundamental, sendo que três são exclusivas de sexto ao nono ano; duas de primeiro ao nono ano e apenas cinco são de primeiro ao quinto ano. Ademais, observou-se que não existe uma política de progressão continuada no município, mas existem incentivos para a participação em Olimpíadas por meio do oferecimento de transportes e lanches para os alunos. Todavia, não há um conhecimento por parte da secretaria da porcentagem de recursos destinados à educação que são direcionados para folha de pagamento dos Professores.

\subsection{Relatório de gestão e destinação dos recursos financeiros do Diretor}

\subsection{Especificidades do município pequeno}

Em conversa com a Diretora da escola, observou-se que existe uma forte cobrança por parte da comunidade, em grande parte pela proximidade que o Diretor e os Professores vivem da escola, o que proporciona um encontro constante com os pais de alunos em locais de circulação rotineira (caso de padarias, supermercados etc.).

Segundo a Diretora, ela busca trazer os pais para a vida escolar dos filhos, bem como prestar contas de todas as ações desenvolvidas pela escola. A declaração da Diretora é corroborada pela existência de um blog em nome da escola, onde é possível baixar fotos e vídeos de eventos realizados pela escola, ler notícias, fazer comentários e dar sugestões para possíveis melhorias na escola, conforme ilustrado pela Figura 18. 


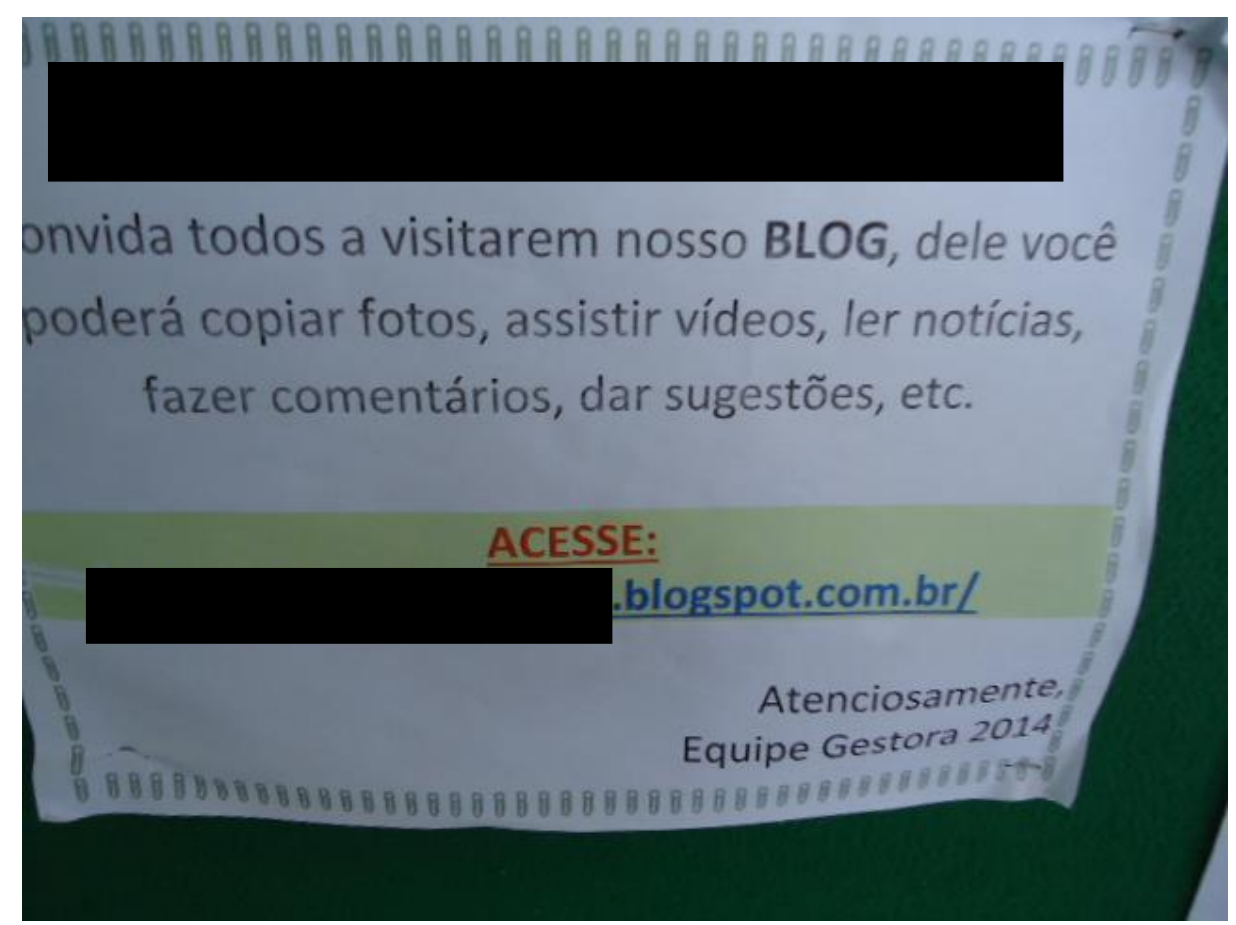

Figura 18 - Cartaz com o blog da escola "A"

Fonte: Arquivo pessoal do autor

\subsection{Alimentação dos alunos}

Em conversa com alunos e a Diretora da escola, identificou-se que são oferecidas um total de duas refeições por período aos alunos, sendo uma apenas para alunos que residem na zona rural (no caso, o café da manhã) e outra para todos os alunos. Além disso, observou-se também a existência de uma nutricionista responsável pela formação e acompanhamento do cardápio, entretanto, os alunos reclamaram da falta de variedade das refeições oferecidas pela escola. Durante visita à escola, também foi possível verificar a limpeza e organização da cozinha, que além de ser revestida com azulejo nas paredes e pisos no chão, sempre é mantida limpa pelas merendeiras, conforme nos mostra a Figura 19. 


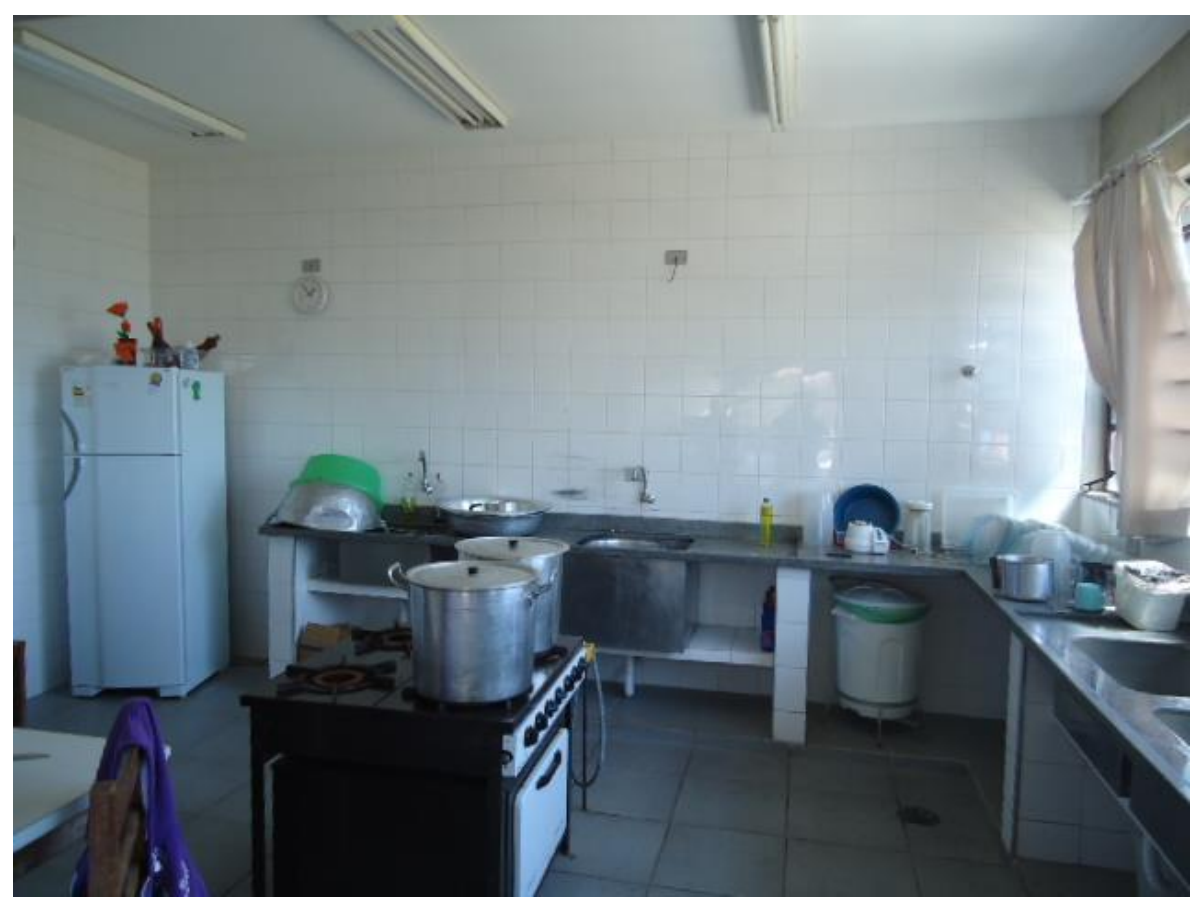

Figura 19 - Cozinha da escola " $A$ "

Fonte: Arquivo pessoal do autor

Ademais, observou-se que a escola possui um refeitório com espaço e condições adequadas para os alunos se alimentarem, conforme ilustrado pela Figura 20.

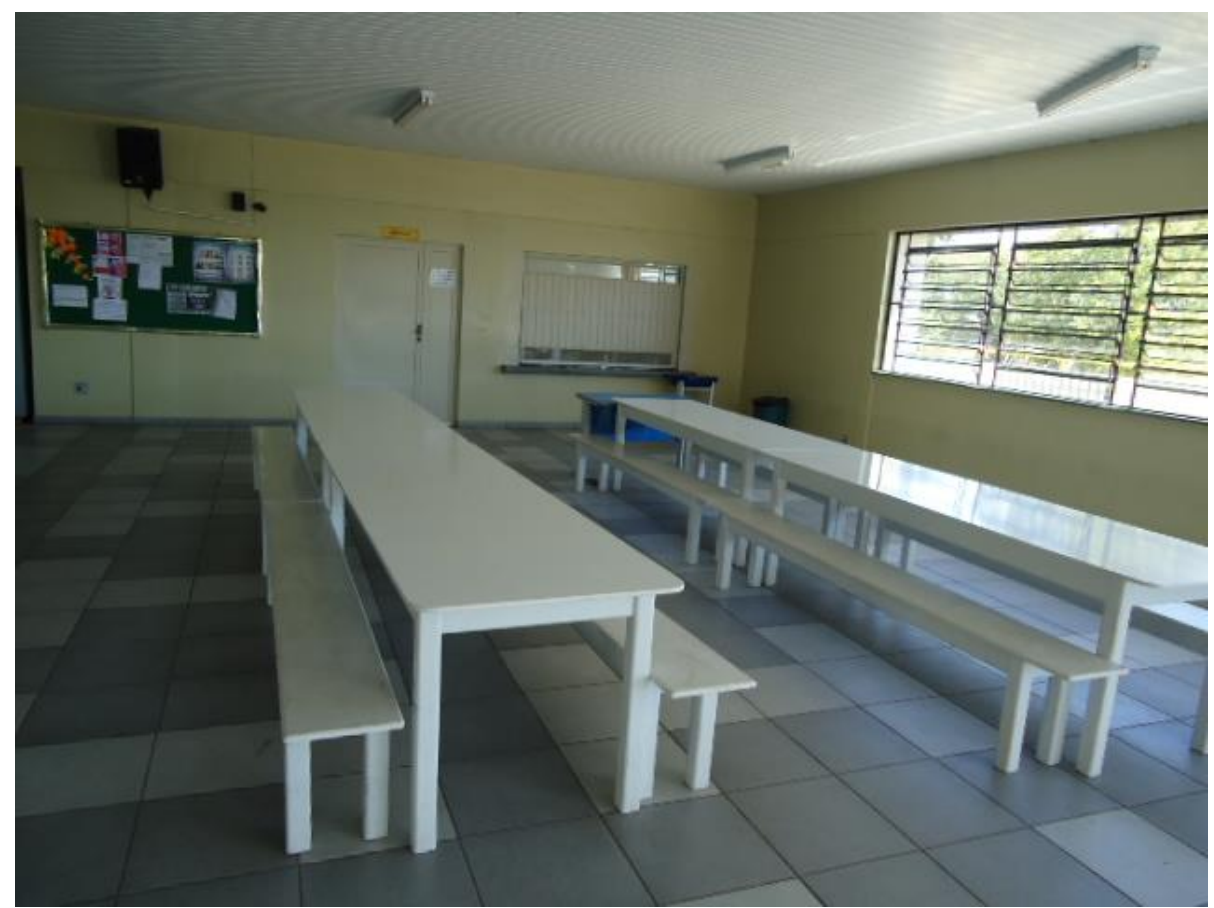

Figura 20 - Refeitório da escola "A"

Fonte: Arquivo pessoal do autor 


\subsection{Processo seletivo}

Em conversa com a Diretora, observou-se que não existe processo seletivo para entrar na escola e não existe também a transferência compulsória por causa de reprovações em disciplinas. Por outro lado, a escola recebe alunos por transferência, mas analisa caso a caso para entender por qual motivo o aluno não se matricula na sua zona delimitada de escola.

\subsection{Diretor}

Em conversa com a Diretora da escola, observou-se que ela possui formação em Pedagogia e pós-graduação em gestão educacional e assumiu o cargo por meio de indicação política. Além disso, verificou-se também a falta de autonomia financeira por parte da Diretora, que em nenhum momento recebe recursos descentralizados suficientes para poder auxiliar em alguma tomada de decisão. Não obstante, o antigo Secretário não permitia que as escolas tivessem outro tipo de renda que não fosse somente os recursos repassados pela federação, estado e município.

\subsection{Plano de carreira do Diretor}

Em visita à escola, observou-se que o salário do Diretor não é visto como compatível para a profissão que exerce, uma vez que não é considerado cargo efetivo, portanto, não apresenta progressão salarial. Dessa maneira, observou-se que não há incentivos, principalmente financeiros, para que Professores busquem estes cargos ou novas formações, uma vez que ganham mais dinheiro trabalhando como Professores em dois períodos. No caso desta escola, o Diretor também relatou que existem pessoas contrárias à sua atuação por ter sido escolhido por indicação política, precisando assim, gerenciar conflitos que, segundo ele, são de fácil resolução.

\subsection{Capacidade do Diretor na captação de recursos financeiros}

Durante entrevista realizada com a Diretora da escola, observou-se que ela atua de forma discreta na captação de recursos, obtendo apenas os recursos das fontes convencionais, que são repassadas pelos órgãos federais, estaduais e municipais, além de realizar algum evento 
com apoio da APM. Além disso, a secretaria é quem informa aos Diretores quando e quanto de recurso há disponível para que estes possam fazer requerimentos formais para compra de materiais escolares, cadeiras etc.

\subsection{Destinação do recurso financeiro descentralizado e centralizado}

Em visita à escola e entrevista com a Diretora, observou-se que os recursos financeiros centralizados e suas respectivas destinações não são monitorados quantitativamente para que seja possível mensurar o quanto é investido em cada item listado (equipamentos de consumo, permanente, materiais escolares etc.). Entretanto, verificou-se que a escola dispõe de uma excelente infraestrutura, com um pátio espaçoso, limpo e iluminado, além de possuir um palco para apresentações, conforme ilustrado pela Figura 21, e uma quadra de esporte coberta, com arquibancada e fechada com grade em seu entorno, conforme nos mostra a Figura 22.

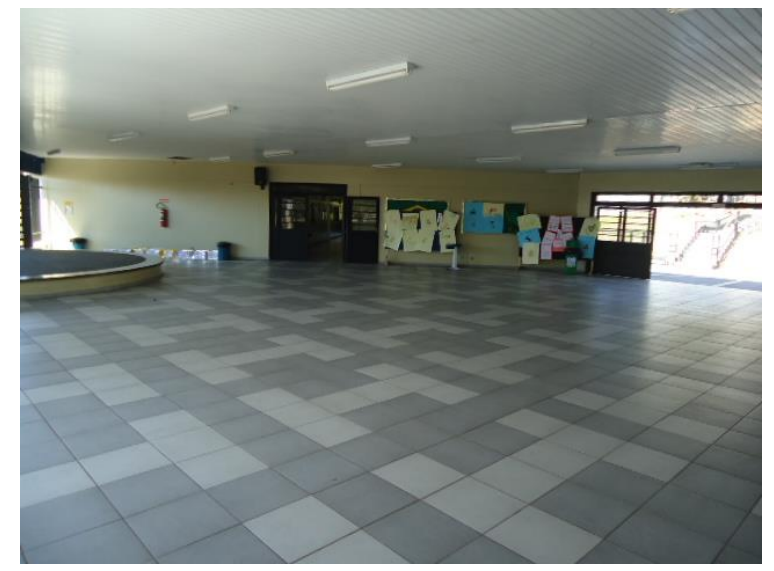

Figura 21 - Pátio da escola "A"

Fonte: Arquivo pessoal do autor

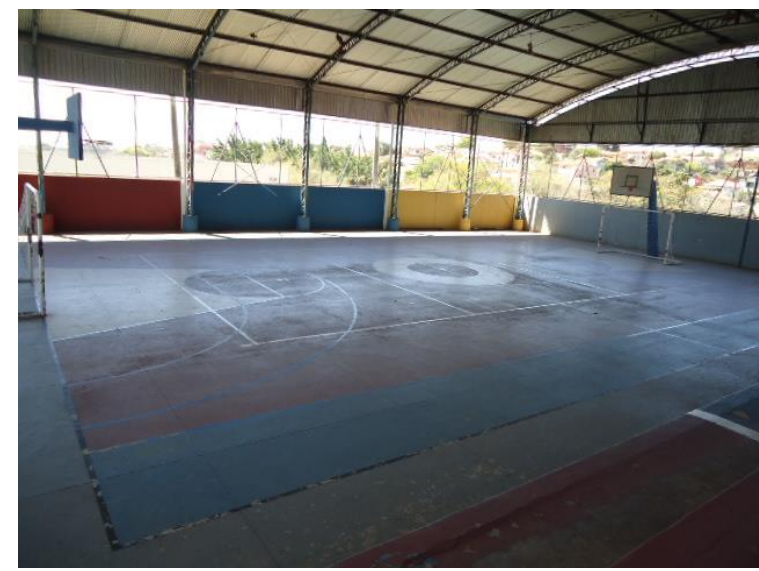

Figura 22 - Quadra de esportes da escola "A"

Fonte: Arquivo pessoal do autor
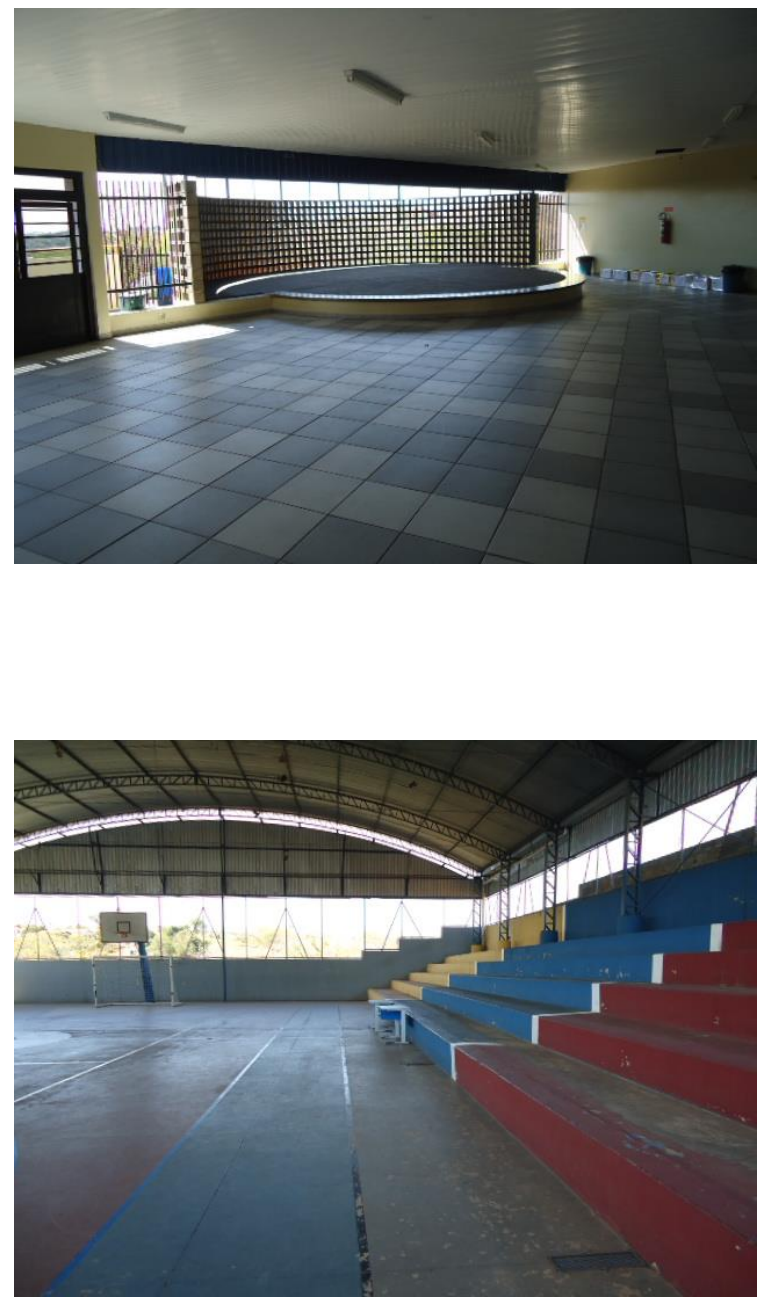


\subsection{Relatório pedagógico e socioeconômico}

\subsection{Desempenho na prova de português}

Em entrevista realizada com o docente, observou-se que ele possui autonomia moderada no ensino da disciplina. Segundo o docente, ele tem liberdade para escolher quando e de que forma aplicar trabalhos, provas e outras formas de avaliação que objetiva mensurar o desempenho dos discentes. O mesmo ocorre em relação às atividades realizadas em sala, ou ainda na questão de reprovação. Entretanto, isso não ocorre em relação à escolha do material didático, que é pré-determinado pela SME, cabendo ao docente apenas a possibilidade de utilizar conteúdos provenientes de outros materiais no intuito de complementar o entendimento sobre determinado assunto.

Segundo o docente, a frequência de leitura dos alunos era baixa até 2011, entretanto, esse indicador passou crescer nos últimos três anos, a partir da iniciativa da escola de trabalhar nas aulas de Leitura e Produção de Texto com livros contemporâneos, como por exemplo, as coleções de Walking Dead e Game of Thrones.

Quanto à rotatividade do docente, observou-se que a mesma pode ser considerada baixa, haja vista que o Professor, atualmente responsável pela disciplina, ingressou na instituição em 2007 e permanece na mesma desde então. Em entrevista com o Professor foi possível observar que o acompanhamento do desempenho dos alunos ocorre por meio da aplicação de diversas avaliações diagnósticas (de 5 a 6 por bimestre), que correspondem a trabalhos, seminários e outras atividades realizadas em sala. A partir dessas avaliações, o docente retoma o conteúdo caso necessário e atribui notas parciais aos alunos, avaliando assim o seu desempenho.

Em visita à escola, também foi possível observar que até junho de 2014 havia recuperação paralela e reforço no contraturno para todas as disciplinas. Entretanto, em virtude da baixa adesão dos alunos e também da dificuldade em se encontrar Professores, atualmente existe este tipo de aula apenas para as disciplinas de matemática e português, de forma que essa recuperação/reforço ocorre no mesmo horário das aulas. 
Segundo a docente, a escola também realiza atividades voltadas às avaliações externas (SARESP e Prova Brasil), como por exemplo, a discussão e elaboração de textos referentes a vídeos e imagens trazidas pelos próprios alunos. A discussão envolve questões como a análise de propagandas atualmente veiculadas na mídia. A distribuição da carga horária ou grade curricular não é influenciada pelos requisitos da Prova Brasil, pois elas seguem o padrão de 7 horas aula de português por semana. Entretanto, como destacado anteriormente, existe uma preparação específica para a Prova Brasil. Conforme a data de aplicação deste exame vai se aproximando, começam a serem feitos simulados da prova, e o Professor de português passa a trabalhar com os alunos conteúdos que têm maior probabilidade de serem cobrados nessa avaliação. Isso ocorre por meio do trabalho de textos e questões semelhantes ao que se encontra na própria Prova Brasil, aplicada em anos anteriores.

\subsection{Desempenho na prova de matemática}

Em entrevista realizada com o docente, observou-se que ele possui autonomia moderada no ensino da disciplina. Segundo o docente, em relação às formas de avaliação, ela afirma ter liberdade para escolher quando e de que forma irá aplicar os trabalhos e provas. O mesmo ocorre em relação às atividades realizadas em sala, ou ainda na questão da reprovação. Entretanto, isso não acontece com a escolha do material didático. Este por sua vez, é prédeterminado pela SME, cabendo à docente apenas a possibilidade de utilizar exercícios ou conteúdos provenientes de outros materiais, no intuito de complementar o entendimento sobre o assunto em pauta.

Quanto à rotatividade do docente responsável pela disciplina, a mesma pode ser considerada baixa, já que a atual Professora ingressou na instituição em 2007 e permanece na mesma desde então. Em entrevista com a docente, foi possível observar que o acompanhamento do desempenho dos alunos na disciplina ocorre por meio da aplicação de diversas avaliações diagnósticas (de 5 a 6 por bimestre), que correspondem a trabalhos e outras atividades realizadas em sala. A partir dessas avaliações, a docente retoma o conteúdo caso necessário e atribuem as notas parciais aos alunos.

Em visita à escola observou-se que é oferecido reforço para os alunos que apresentam dificuldade de aprendizagem na disciplina de matemática, entretanto, ele ocorre no mesmo horário das aulas. 
Em entrevista realizada com os Professores e alunos, observou-se também que são realizadas na escola atividades voltadas às avaliações externas (SARESP e Prova Brasil), de modo que, conforme a data de aplicação deste exame vai se aproximando, começam a serem realizados simulados da prova, e o Professor de matemática passa a trabalhar com os alunos os conteúdos que têm maior probabilidade de serem cobrados, como por exemplo, a resolução de questões que costumeiramente compõe essas avaliações. Entretanto, constatou-se que a distribuição da carga horária ou grade curricular não é influenciada pelos requisitos da Prova Brasil, pois elas seguem o padrão de 6 horas aula de matemática por semana.

Uma questão que chamou a atenção na escola é o oferecimento de aulas de Damas e Xadrez, que segundo a Diretora, além de objetivar o incentivo ao esporte, também desenvolve o aprimoramento do raciocínio lógico. A Figura 23 nos mostra o quadro com o nome do Professor, local, dia da semana e horário que são oferecidas as aulas.

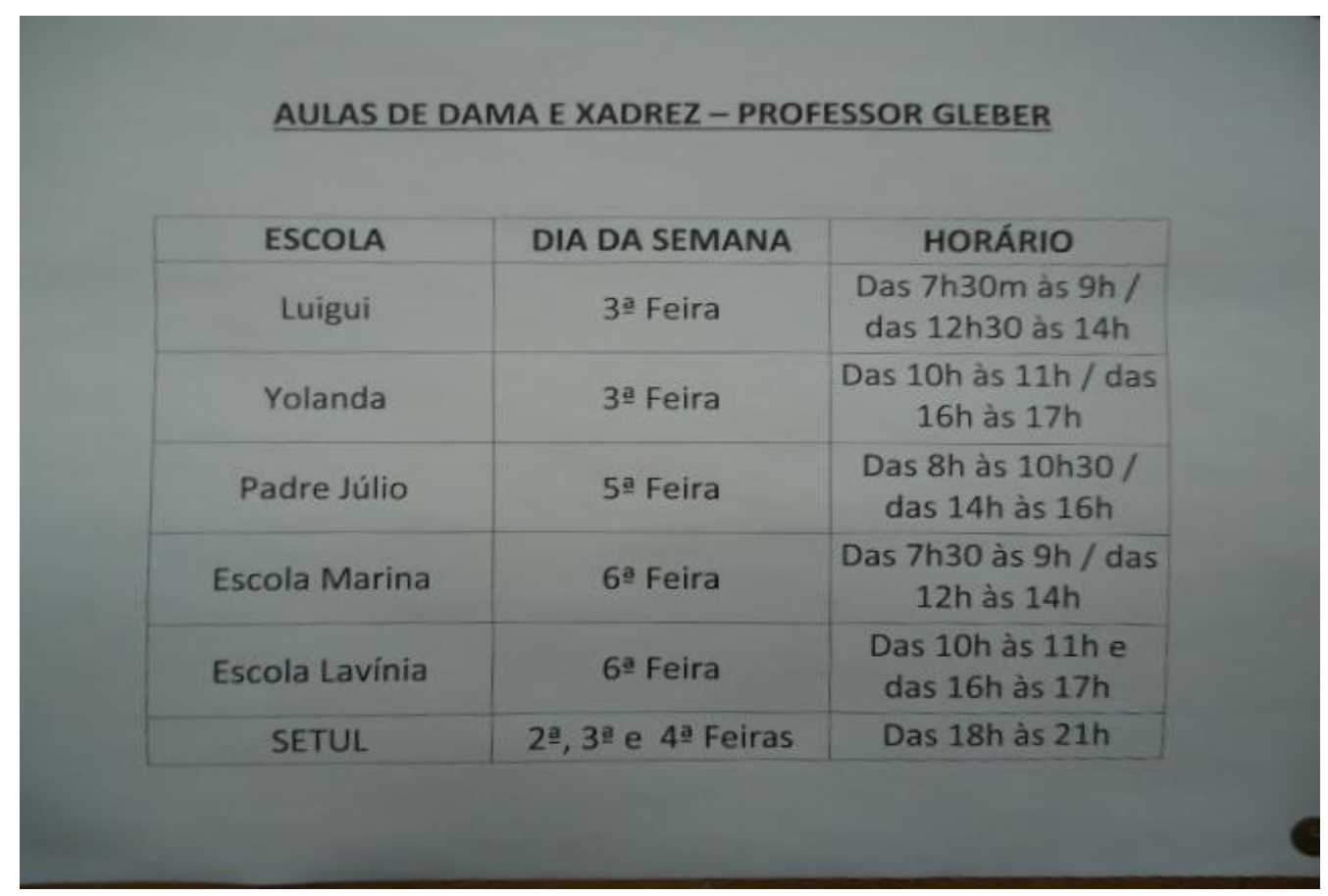

Figura 23 - Escala das aulas de xadrez oferecida aos alunos pela escola "A" Fonte: Arquivo pessoal do autor

\subsection{Participação da família}

Em visita à escola, foi possível identificar uma participação ativa dos pais na vida escolar dos filhos. Essa participação pode ser evidenciada pela frequência dos pais nas reuniões de pais e mestres, bem como em eventos festivos e demais reuniões realizadas pela escola para tratar do desempenho dos alunos. Os pais também contribuem com a escola no desenvolvimento de 
eventos que tem como objetivo levantar recursos que posteriormente serão direcionados, em reuniões de pais e mestres, para benfeitorias da escola, como aquisição bebedouros de água, conforme Figura 24. A Figura 25 nos mostra o cartaz promocional da primeira festa do pastel realizada pela escola com a colaboração dos pais.

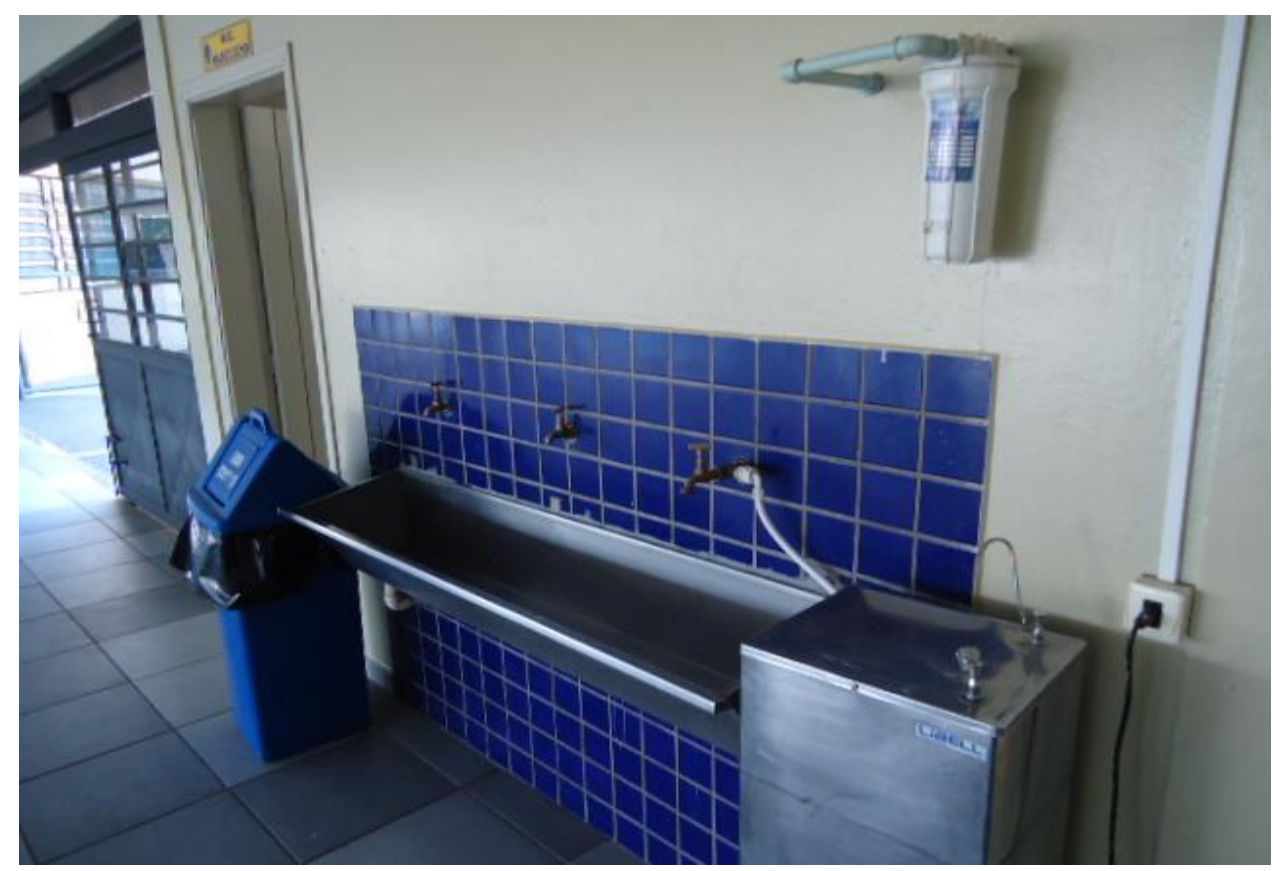

Figura 24 - Bebedouro de água adquirido com recursos da APM Fonte: Arquivo pessoal do autor

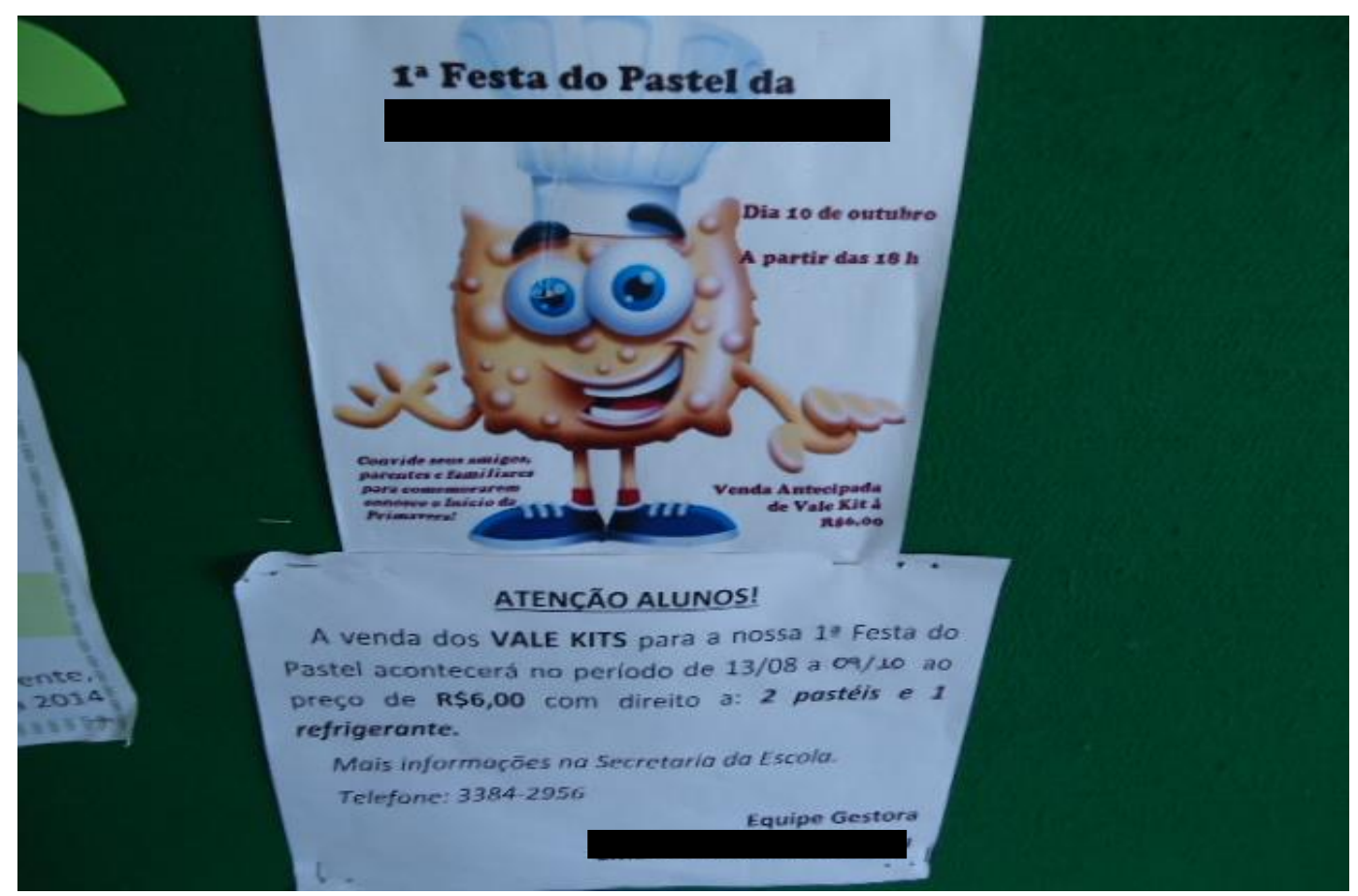

Figura 25 - Cartaz promocional da $\mathbf{1}^{\text {a }}$ festa do pastel realizada pela escola com apoio dos pais Fonte: Arquivo pessoal do autor 
Em entrevista com os pais, observou-se que existe uma parceria entre eles, que trocam informações sobre o comportamento de seus filhos na escola, principalmente quando algum pai não participou de alguma reunião. Outra prática que foi identificada na escola, refere-se ao apoio dos pais na validação das ações da escola, pois os pais afirmam ter confiança no trabalho desenvolvido pela equipe escolar (Diretor, Professor e demais funcionários) e se sentem seguros com os seus filhos na escola.

Também foi possível observar em entrevista com os pais, que a maioria deles não acompanha com frequência os deveres escolares de seus filhos, entretanto, quando percebem que eles estão com alguma dificuldade os incentiva a procurar o Professor no contraturno para sanar a dúvida. Por residirem em uma cidade caracterizada pelos pais como pequena, eles não utilizam o transporte público para ir à escola.

\subsection{Reprovação discente e sistema disciplinar}

Em visita à escola observou-se a existência de um sistema de reprovação, em que os docentes afirmam possuir autonomia para reprovar os alunos com baixo desempenho na disciplina. Também foi possível observar a existência de regras claras, conhecidas e respeitadas pela comunidade escolar. Dentre as regras destacam-se a obrigatoriedade do uso de uniformes, pontualidade na entrada da escola e a proibição do consumo de goma de mascar, balas e uso de celulares durante as aulas.

Segundo os pais, a escola envia as regras, por meio dos filhos, para que eles possam ler, assinar e devolvê-la à escola, demonstrando assim, conhecimento sobre as regras escolares. Como forma de divulgação aos alunos a escola fixa as regras na entrada de cada sala de aula, conforme mostra a Figura 26. 
- Horário de entrada é ideal que o aluno chegue 5 minutos antes do horário 7 horas (manhâ) e $12 \mathrm{~h} 30 \mathrm{~mm}$

hegam cedo demais e ficam na rua expostos a problemas e na saida todos para a casa:

- Uso de Uniforme é Obrigatório, pois o mesmo identifica o aluno. Nos dias de Educaçâo Fisica de tênis para maior segurança evitando acidentes;

Não será permitido o uso de boné dentro da Unidade Escolar;

Proibido trazer Corretivo para a escola - Solicitar com o professor caso precise usar,

- Caso seja necessário vir de bicicleta a mesma deverá ficar no bicicletário e utilizar cadeado pana e nesse caso a escola não se responsabilizará:

- Como a escola oferece lanche que $\hat{\varepsilon}$ acompanhado por nutricionista os alunos devem comé-lo ev casa. Caso seja necessário, o mesmo não poderá ser muito diferenciado. Chicletes, salgadinh proibidos na escola;

- Agenda Escolar deve ser acompanhada diariamente, pois é um meio de comunicação Fscola Fam marcarào atividades, pesquisas e provas;

- O aluno poderá entrar na Sala dos Professores e ou/ dependências administrativas somente quando for Acompanhar o aluno na verificação do material necessário para as aulas do dia, até que isso se tê possa fazer sozinho, Colocar nome no material;

- E proibido que o aluno traga para a escola objetos de valor, material cortante, equipamen principalmente celular, conforme a Lei Municipal 2.823/07, se forem surpreendidos com estes recolhidos e só entregues na presença dos pais/responsáveis mediante assinatura de recibo:

- As pemalidades de advertência verbal poderão ser aplicadas pelos Professores e demais Funcionairio

A repr censão por escrito poderá ser aplicada pela Direçâo, Vice-direçio, Coordenaçào da Professores, sendo exigida a presença do responsível no dia seguinte na Unidade Escolar.

Figura 26 - Regras escolares fixada na entrada das salas de aula Fonte: Arquivo pessoal do autor

Ademais, foi possível identificar, por meio de entrevista com o Diretor e Professores, que os alunos possuem respeito pelas regras escolares, pelo Diretor, Professores e demais funcionários da escola.

\subsection{Laboratório de informática}

Em visita à escola foi possível identificar a existência de laboratório de informática, o qual possui 15 computadores, entretanto, apenas 2 estão em funcionamento. A Figura 27 apresenta o laboratório de informática da escola "A". 


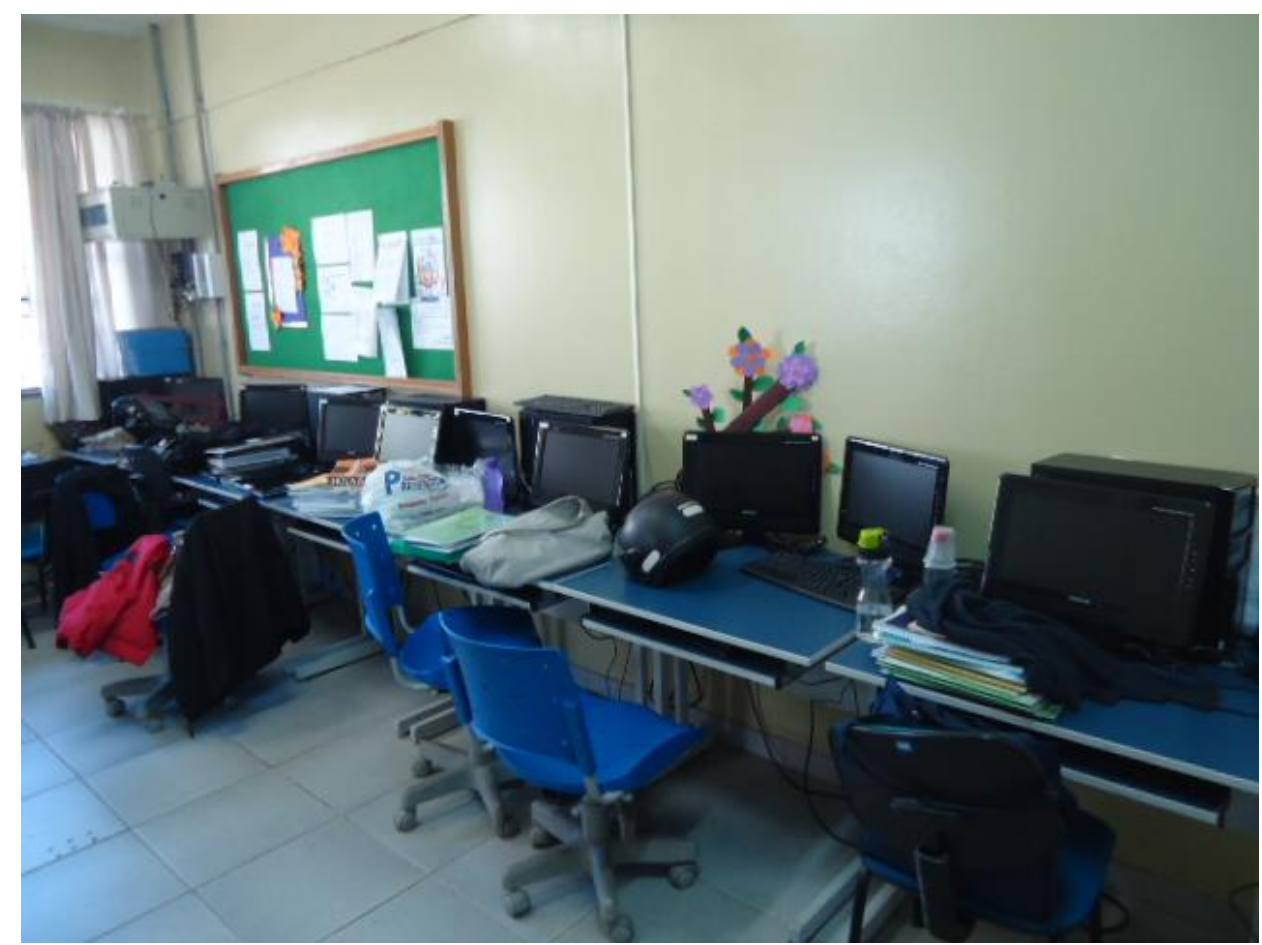

Figura 27 - Laboratório de informática da escola "A"

Fonte: Arquivo pessoal do autor

Durante a visita à escola constatou-se a inexistência de aulas de informática com Professor exclusivo, pois a utilização do laboratório ocorre apenas quando os docentes, por iniciativa própria, programam alguma atividade para ser realizada com os alunos que envolva o uso dos computadores. Além disso, em virtude de algumas reformas realizadas na escola, provisoriamente o laboratório de informática está sendo utilizado como sala de apoio aos docentes, o que impossibilita a sua utilização pelos alunos.

\subsection{Biblioteca}

Em visita à escola, verificou-se que a biblioteca tem um acervo de tamanho e variedade satisfatórios, entretanto, não foi possível identificar exatamente o número de livros, nem as diferentes obras componentes do acervo, pois não existe bibliotecário na instituição e o acervo é controlado por um livro manuscrito e sem um padrão de preenchimento. Durante a visita à escola, também se observou que não existe espaço para estudo coletivo. Os livros não podem ser retirados pelos alunos, apenas pelos Professores (portanto não há bom fluxo de alunos na biblioteca e a comunidade não pode utilizar o acervo). Entretanto, a biblioteca é bem iluminada e razoavelmente arejada, conforme mostra a Figura 28. 


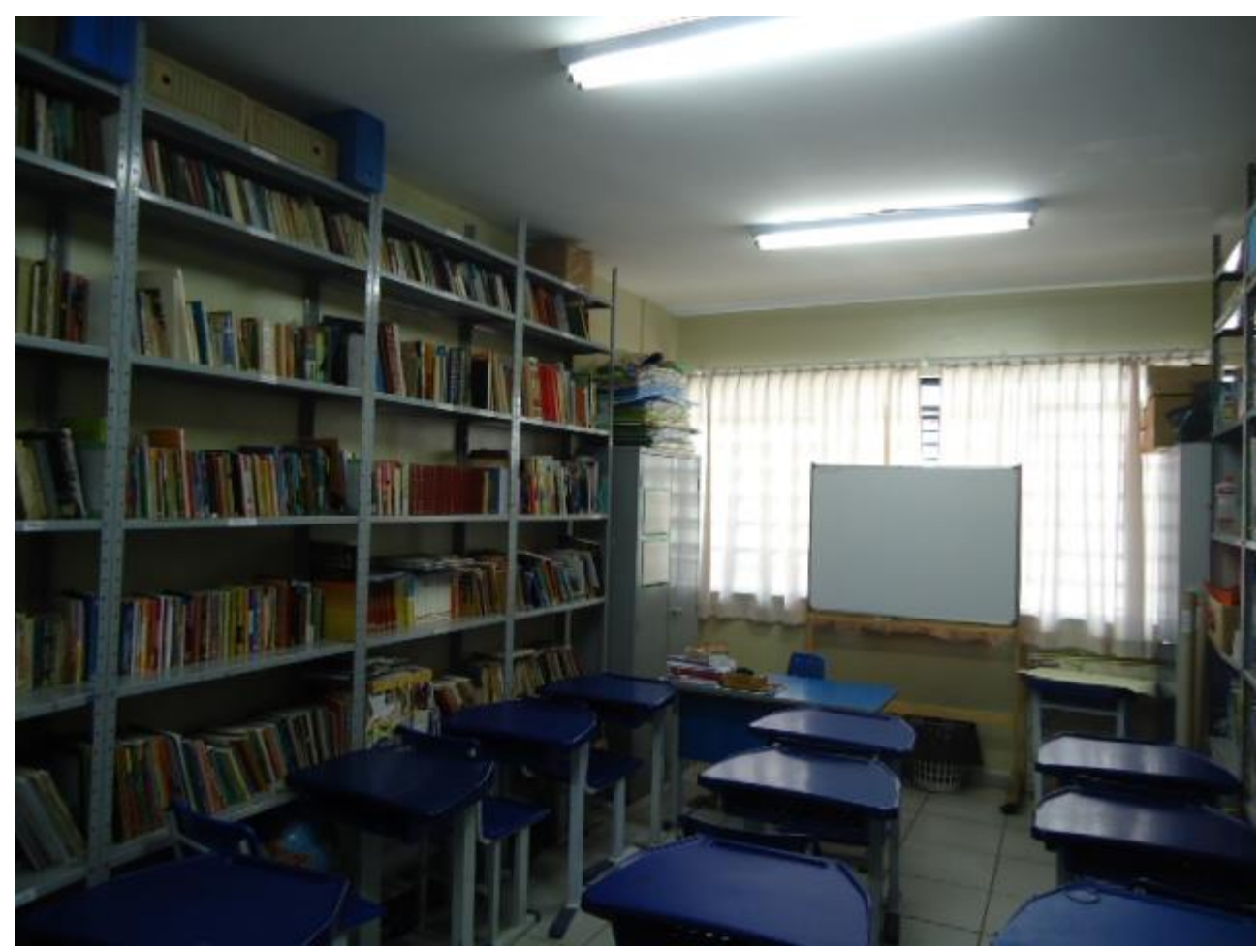

Figura 28 - Biblioteca da escola "A"

Fonte: Arquivo pessoal do autor

\subsection{Sala de leitura}

Durante visita à escola observou-se a inexistência de sala de leitura.

\subsection{Alunos}

Em visita à escola constatou-se que o sistema de matrículas dos alunos é por zoneamento, ou seja, os alunos são matriculados na escola mais próxima de sua casa. Observou-se também que alguns dos alunos que estudam nessa escola residem na área rural, nesse caso a secretaria municipal de educação oferece transporte público diariamente para esses alunos. O total de alunos matriculados nessa escola é 383.

\subsection{Docentes}

Com visita à escola foi possível identificar as seguintes características referentes ao seu corpo docente: 
Número de docentes para cada cem alunos: 8,40;

Porcentagem de docentes pertencente ao sexo feminino: 70,31;

Porcentagem dos docentes que possuem magistério concluído: 0,00;

Porcentagem dos docentes que possuem o curso de licenciatura concluído: 53,13;

Porcentagem dos docentes que possuem o ensino superior concluído: 100,00;

Porcentagem dos docentes que possuem especialização concluída: 22,66.

\subsection{Funcionários}

Número de Funcionários para cada cem alunos: 7,57

\subsubsection{Escola "F" abaixo da fronteira de eficiência}

- Indicadores da escola F

Número de alunos: 421

Investimento anual por aluno: $\mathrm{R} \$ 3.535,48$

Nota no IDEB (Anos Finais): 5,18

Nível socioeconômico: 5 (Médio-Alto)

Durante a visita realizada à escola "F", conforme nos mostra a Figura 29, localizada no município de Cerquilho no estado de São Paulo, foi possível identificar inúmeras práticas administrativas e pedagógicas que colaboraram para que, no ano de 2011, a escola obtivesse uma nota 5,18 no IDEB. A seguir são apresentados alguns dos principais aspectos mais relevantes que foram observados durante a visita à escola. 


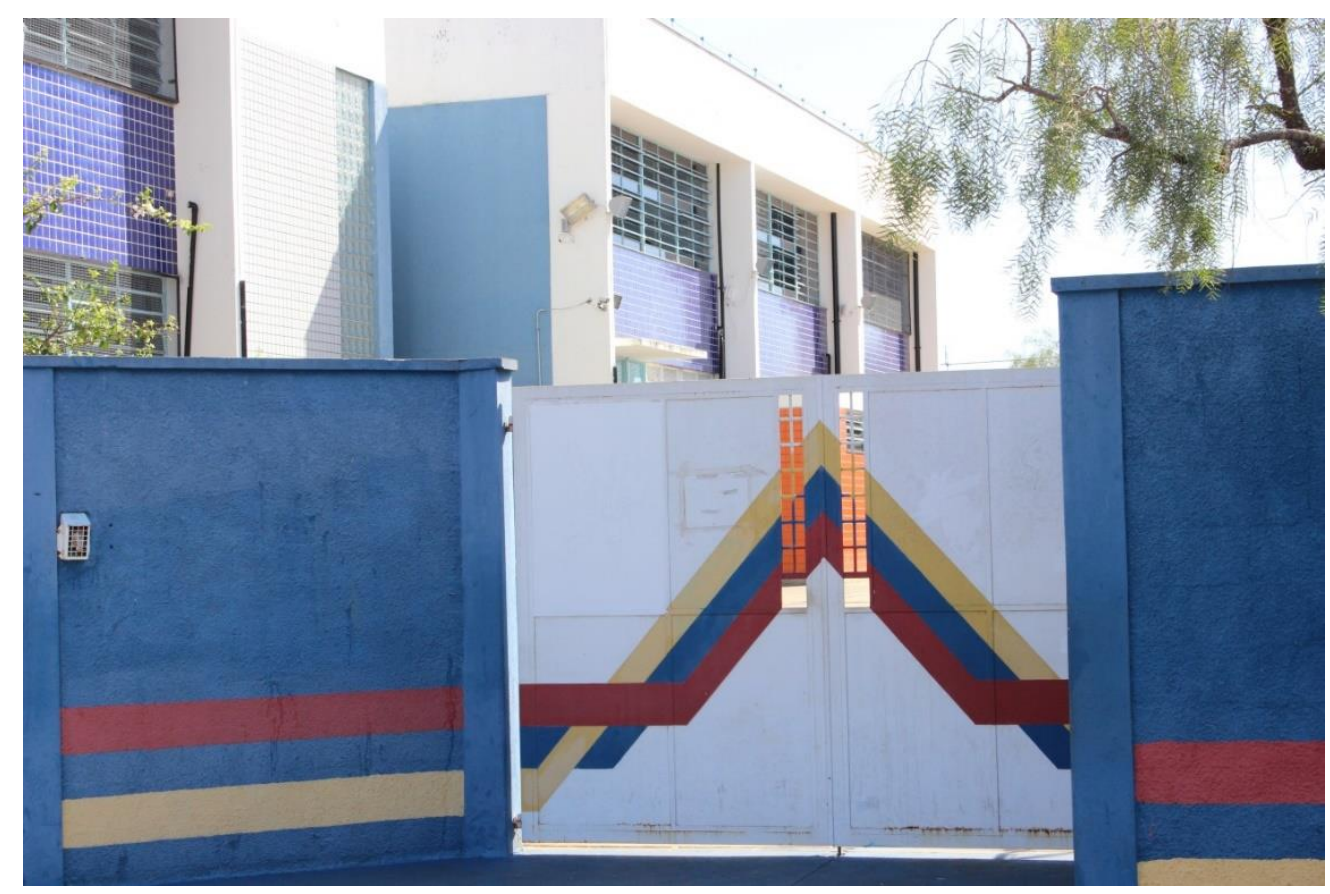

Figura 29 - Fachada da escola "F"

Fonte: Arquivo pessoal do autor

\subsection{Relatório de gestão e destinação dos recursos financeiros do Diretor}

\subsection{Especificidades do município pequeno}

Em conversa com o Diretor da escola, observou-se que a comunidade não exerce uma forte cobrança sobre a figura do Diretor. Segundo ele, isso ocorre em grande parte devido à baixa participação dos pais na vida escolar dos filhos, o que reflete na má reputação da escola perante as outras escolas do município.

\subsection{Alimentação dos alunos}

Em conversa com alunos e o Diretor, observou-se que são oferecidas duas refeições por período aos alunos, sendo que uma é exclusiva para os alunos que residem na zona rural (no caso o café da manhã). Além disso, observou-se também a existência de uma nutricionista que é responsável pela elaboração e acompanhamento do cardápio, entretanto, os alunos criticaram a falta de variação do cardápio oferecido pela escola, pois segundo eles, é oferecida sempre a mesma comida nos mesmos dias da semana. No dia da visita à escola, a refeição oferecida aos alunos foi macarrão, banana de sobremesa, conforme nos mostra a Figura 30. 


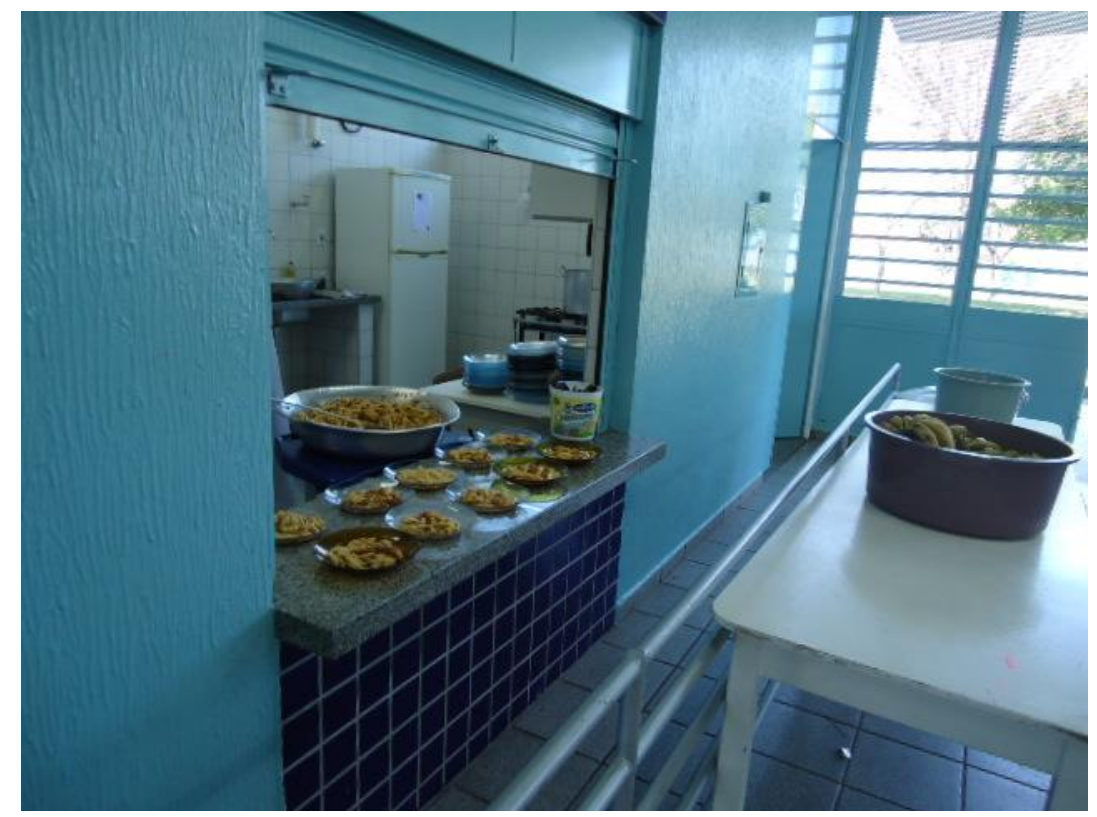

Figura 30 - Refeição oferecida aos alunos no dia da visita à escola Fonte: Arquivo pessoal do autor

Durante a visita, também foi possível observar que a escola possui um refeitório adequado, com espaço e comodidade para os alunos realizarem suas refeições, conforme nos mostra a Figura 31.
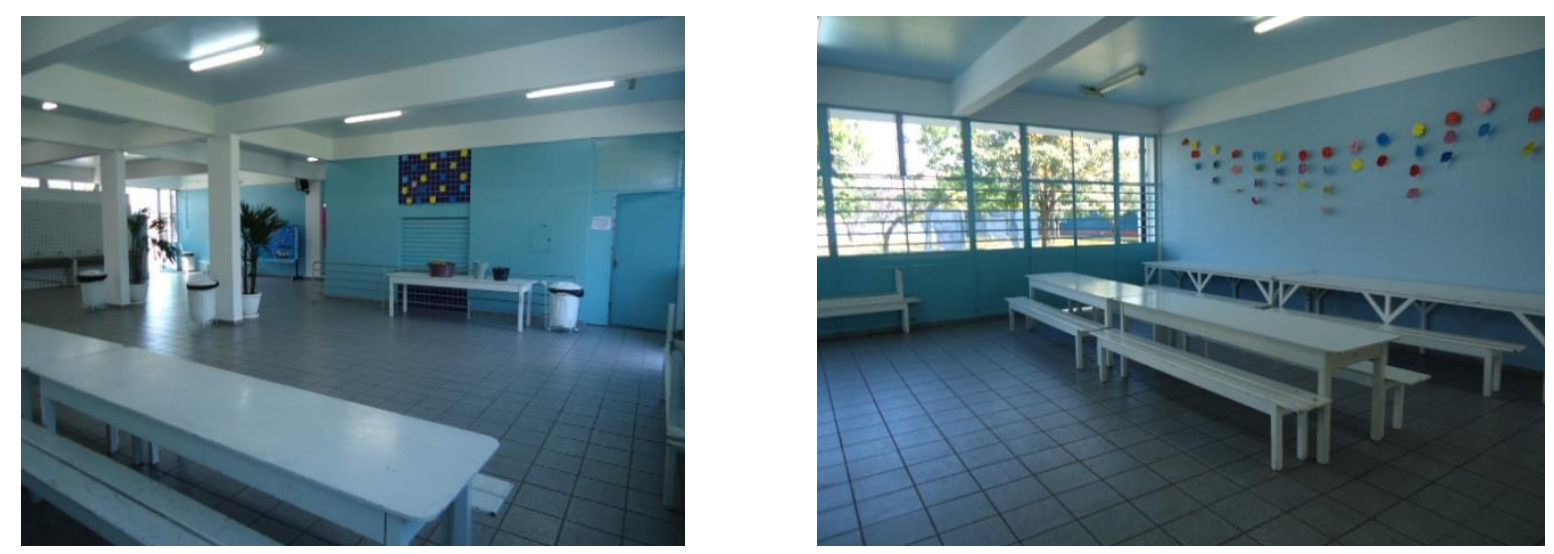

Figura 31 - Refeitório da escola "F" Fonte: Arquivo pessoal do autor

\subsection{Processo seletivo}

Em conversa com o Diretor, constatou-se que não existe processo seletivo para os alunos entrarem na escola e não existe também a transferência compulsória por causa de reprovações em disciplinas. Por outro lado, a escola recebe alunos por transferência, mas analisa caso a caso (boletins) para ver se este aluno seria um ponto positivo para adicionar no dia-a-dia da escola. 


\subsection{Diretor}

Em conversa com o Diretor, constatou-se que este tem formação em Engenharia, Ciências Biológicas e Pedagogia, juntamente com três pós-graduações, tendo assumido o cargo por indicação política. Nesta escola verificou-se também uma falta de autonomia do Diretor para decisões financeiras, uma vez que todos os recursos que chegam até ele já têm um destino previamente selecionado.

\subsection{Plano de carreira do Diretor}

Em visita à escola, constatou-se que o salário do Diretor não é visto como compatível para a profissão que exerce, uma vez que não é considerado cargo efetivo, portanto, não apresenta progressão salarial. Dessa maneira, constatou-se que não há incentivos, principalmente financeiros para que Professores busquem estes cargos ou novas formações, uma vez que eles ganham mais dinheiro lecionando em dois períodos. No caso desta escola, o último Diretor acabou sendo exonerado do cargo a pedido dos Professores por causa de conflitos internos, demonstrando a fraqueza que este posto tem atualmente na escola ao ser assumido por indicação política.

\subsection{Capacidade do Diretor na captação de recursos financeiros}

Durante entrevista realizada com o Diretor da escola, constatou-se que ele não atua em nenhum momento para realizar captação de recursos para a escola a não ser pelas fontes convencionais que são repassadas pelos órgãos federais, estaduais e municipais. Além disso, a secretaria é quem informa ao Diretor quando e quanto de recurso há disponível para que este possa fazer requisitos formais para compra de materiais escolares, cadeiras etc.

\subsection{Destinação do recurso financeiro descentralizado e centralizado}

Em visita à escola e entrevista com a Diretora, observou-se que os recursos financeiros centralizados e suas respectivas destinações não são monitorados quantitativamente para que seja possível mensurar o quanto é investido em cada item listado (equipamentos de consumo, 
permanente, materiais escolares etc.). Entretanto, observou-se que a escola possui uma excelente estrutura, com quadra de esportes coberta, conforme ilustrado pela Figura 32, sala de aula com carteiras e cadeiras dos alunos em boas condições de uso, conforme nos mostra a Figura 33, e sala de vídeo, de acordo com a Figura 34.

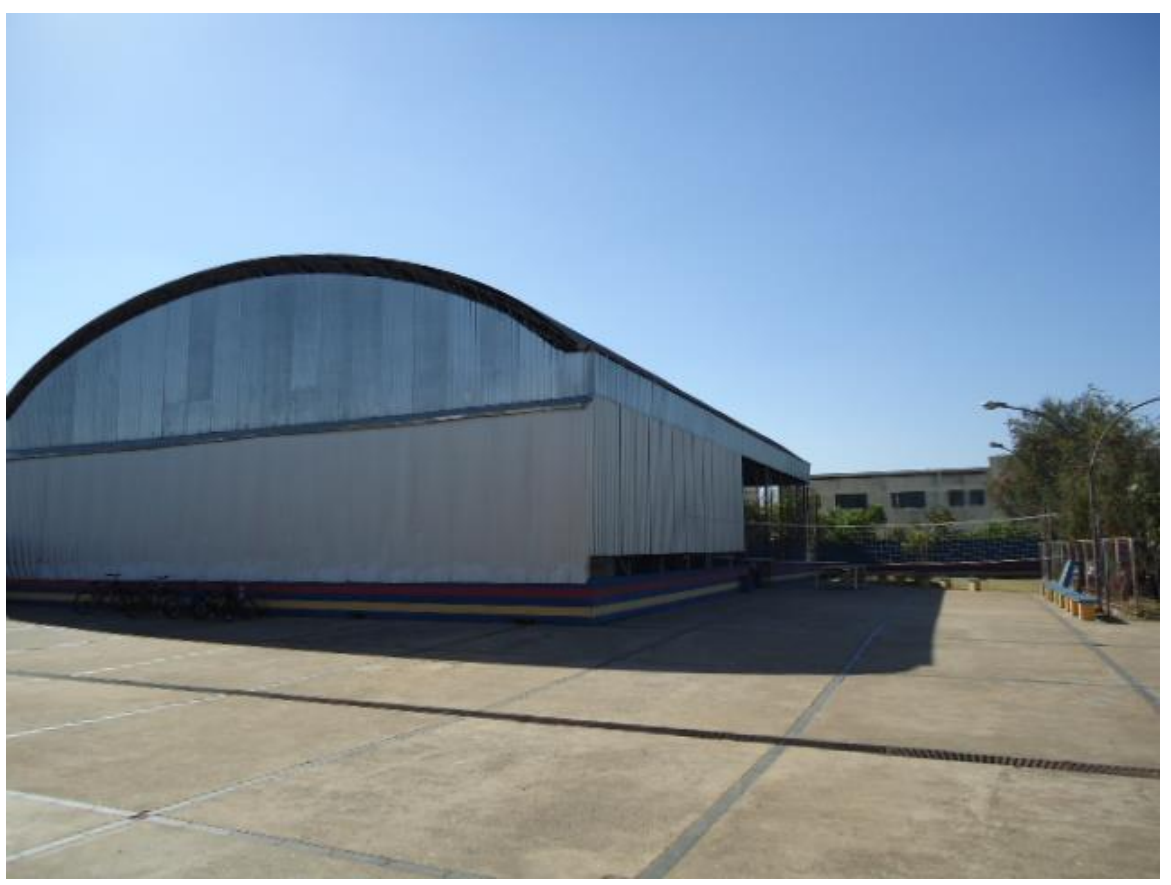

Figura 32 - Quadra de esportes da escola "F" Fonte: Arquivo pessoal do autor

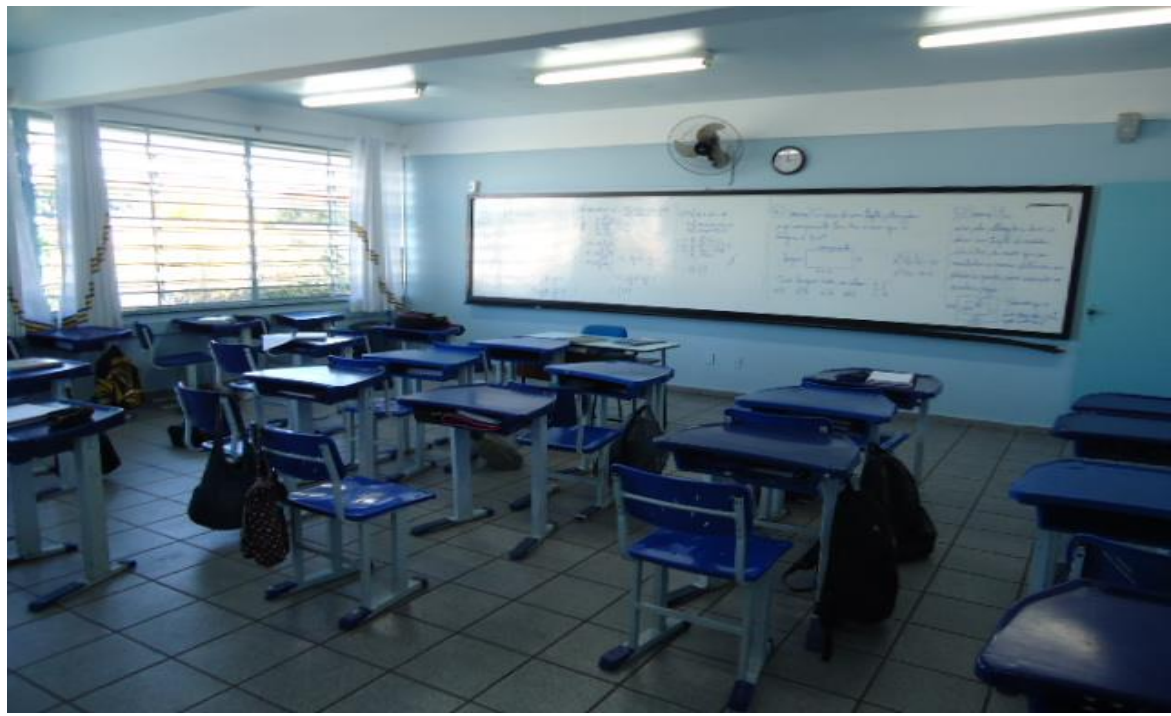

Figura 33 - Sala de aula da escola "F" Fonte: Arquivo pessoal do autor 


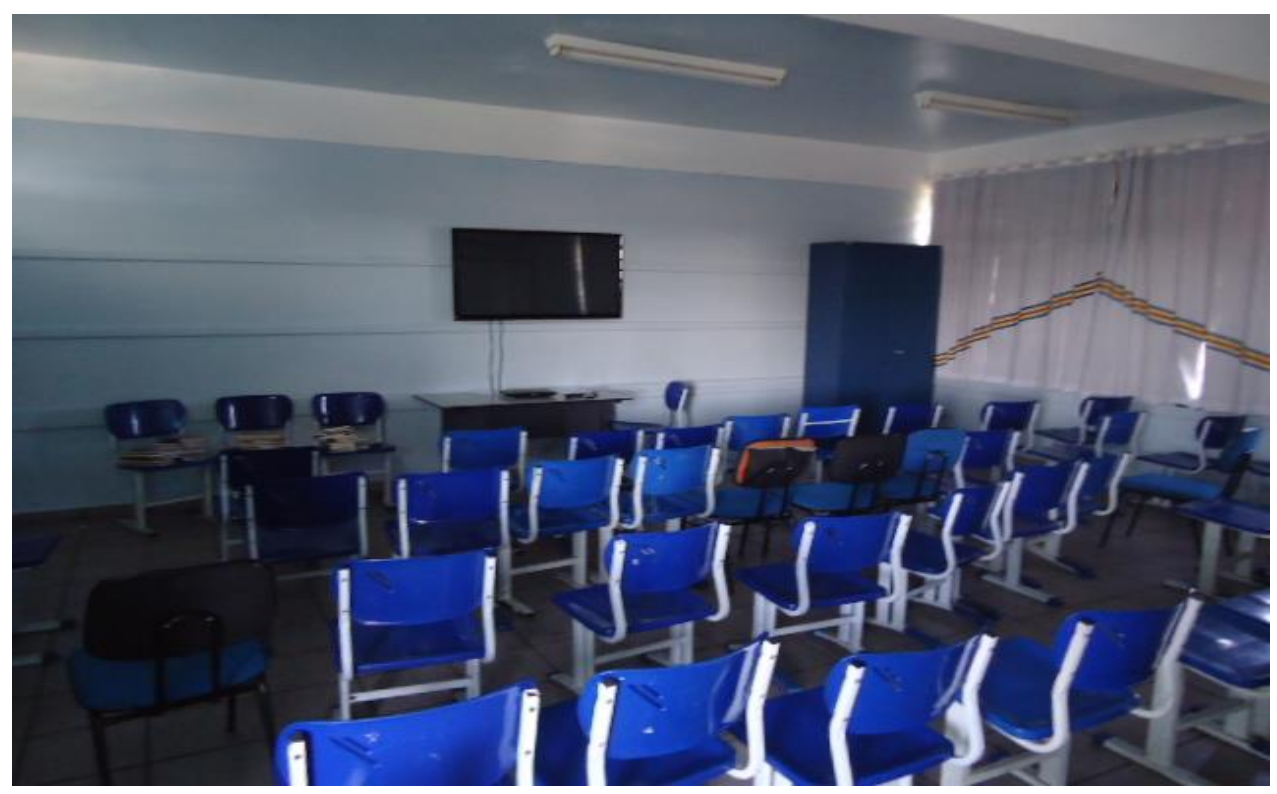

Figura 34 - Sala de vídeo da escola "F"

Fonte: Arquivo pessoal do autor

\subsection{Relatório pedagógico e socioeconômico}

\subsection{Desempenho na prova de português}

Em entrevista realizada com o docente, observou-se que ele possui autonomia moderada no ensino da disciplina. Segundo o docente, ele tem liberdade para escolher quando e de que forma aplicar trabalhos, provas e outras formas de avaliação que objetiva mensurar o desempenho dos discentes. O mesmo ocorre em relação às atividades realizadas em sala, ou ainda na questão de reprovação. Entretanto, isso não ocorre em relação à escolha do material didático, pois este é pré-determinado pela SME, cabendo ao docente apenas a possibilidade de utilizar conteúdos provenientes de outros materiais no intuito de complementar o entendimento sobre determinado assunto.

A frequência de leitura dos alunos sempre foi baixa nessa escola, e um dos fatores que pode contribuir para isso está relacionado à limitação de espaço na biblioteca, que inviabiliza a disponibilização de uma biblioteca com infraestrutura adequada para acomodação de mais obras literárias. Outro fator destacado pelo Professor entrevistado é o desinteresse de grande parte dos alunos pela leitura. 
Quanto à rotatividade do docente, a mesma pode ser considerada baixa, já que o Professor, atualmente responsável pela disciplina, ingressou na instituição em 2007 e permanece nela desde então. Entretanto, de acordo com o Professor entrevistado, no ano de 2011 diversos Professores entraram com pedidos de licença, em virtude de um conflito ocorrido com a direção da escola, que buscou implementar uma proposta didático-pedagógica elaborada juntamente com a SME sem o consentimento do corpo docente. As excessivas licenças acarretaram em vários dias sem aula, o que veio a prejudicar o desempenho dos alunos, não somente em português, mas em todas as disciplinas.

Em relação ao acompanhamento do desempenho dos alunos, observou-se em entrevista com o docente, que ele ocorre por meio da aplicação de diversas avaliações diagnósticas em sala, como trabalhos, seminários, elaboração de pesquisas ou outras atividades nas quais os alunos devem demonstrar se compreenderam ou não o conteúdo ministrado. Para os alunos que possuem dificuldade de aprendizado na disciplina, observou-se que é oferecido reforço, entretanto, ele ocorre apenas no mesmo horário das aulas.

Quanto aos projetos desenvolvidos pelo docente, o mesmo tentou utilizar-se de uma dinâmica denominada Justiça Restaurativa, na qual um conflito ocorrido em sala é discutido com os alunos, posicionados em círculo, de forma que eles opinem quanto à melhor solução possível para determinado problema. A partir dessa análise, eles trabalhariam a questão da argumentação e oralidade. Porém, essa proposta não foi aprovada pela direção e, portanto, não foi posta em prática.

A distribuição da carga horária ou grade curricular não é influenciada pelos requisitos da Prova Brasil, elas seguem o padrão de 7 horas aula por semana para português. Segundo o Professor entrevistado, até 2011 não ocorria uma preparação específica dos alunos em relação à Prova Brasil.

\subsection{Desempenho na prova de matemática}

Vale destacar que o docente responsável pela disciplina de matemática não foi entrevistado. Isso ocorreu pelo fato dele ter apenas um ano de trabalho na instituição, o que impossibilita a sua contribuição em relação ao que aconteceu na escola antes de 2011. Portanto, as 
informações mencionadas a seguir são provenientes da entrevista feita com o Professor de português.

De acordo com o docente entrevistado, o docente responsável pela disciplina de matemática na época, tinha moderada autonomia em relação às formas de avaliação, o que envolvia a liberdade de escolher quando e de que forma aplicar trabalhos, provas ou outras avaliações cujo objetivo era mensurar o desempenho dos discentes. $\mathrm{O}$ mesmo ocorria em relação às atividades realizadas em sala, ou ainda na questão de reprovação. Entretanto, isso não ocorria em relação à escolha do material didático, pois este era pré-determinado pela SME, cabendo ao docente apenas a possibilidade de utilizar exercícios ou conteúdos provenientes de outros materiais no intuito de complementar o entendimento sobre determinado assunto. Quanto à rotatividade do docente, a mesma é considerada como moderada, haja vista que alguns Professores ingressaram e saíram da instituição entre 2011 e 2014.

Em relação ao acompanhamento do desempenho dos alunos, o docente entrevistado não soube informar como ele ocorria, entretanto, afirmou que para os alunos que possuem dificuldade de aprendizado na disciplina é oferecido o reforço no mesmo horário das aulas. Quanto aos projetos desenvolvidos pelo docente, não se tem essa informação, pois o Professor responsável pela disciplina na época não foi encontrado.

De acordo com o Professor entrevistado a distribuição da carga horária ou grade curricular não é influenciada pelos requisitos da Prova Brasil, pois elas seguem o padrão de 6 horas aula por semana para matemática. O Professor ainda destaca que até o ano de 2011 não ocorria uma preparação específica dos alunos em relação à Prova Brasil.

\subsection{Participação da família}

Em visita à escola, foi possível identificar uma baixa participação dos pais na vida escolar dos alunos. Essa observação pode ser evidenciada pela ausência dos pais nas reuniões de pais e mestres e em eventos festivos e demais reuniões realizadas pela escola para tratar do desempenho dos filhos. Segundo os pais entrevistados, mesmo marcando o horário das reuniões fora do expediente de trabalho (a partir das 18:00hs) apenas uma pequena porcentagem dos pais participa das reuniões realizadas pela escola. Os pais afirmam não 
possuir confiança na figura do Diretor, afirmando que por ele ter vindo de uma creche ele tratava os alunos como crianças, o que demonstrava sua incapacidade de lidar com os alunos. Também foi observado que por residirem na cidade, os pais não utilizam o transporte público para ir à escola.

\subsection{Reprovação discente e sistema disciplinar}

Em visita à escola observou-se a existência de um sistema de reprovação de alunos. Dentro desse processo, foi possível observar que os Professores possuem autonomia para reprovar os alunos com baixo desempenho na disciplina, tal observação pode ser evidenciada pelo índice de reprovação dos alunos nessa escola. As regras da escola são claras e conhecidas pela comunidade escolar, entretanto, observou-se que elas não são seguidas pelos alunos, tal fato é corroborado com a afirmação dos pais de que a escola não possui boas referências, principalmente pela indisciplina dos alunos. A escola inclusive organiza os lugares aonde os alunos irão se sentar na sala de aula, a fim de obter maior controle, conforme nos mostra a Figura 35. Entretanto, mesmo assim os atos de indisciplina são frequentes. Em entrevista com os alunos, foi possível constatar essa indisciplina, pois segundo eles uma aluna teria discutido com um Professor em sala de aula.

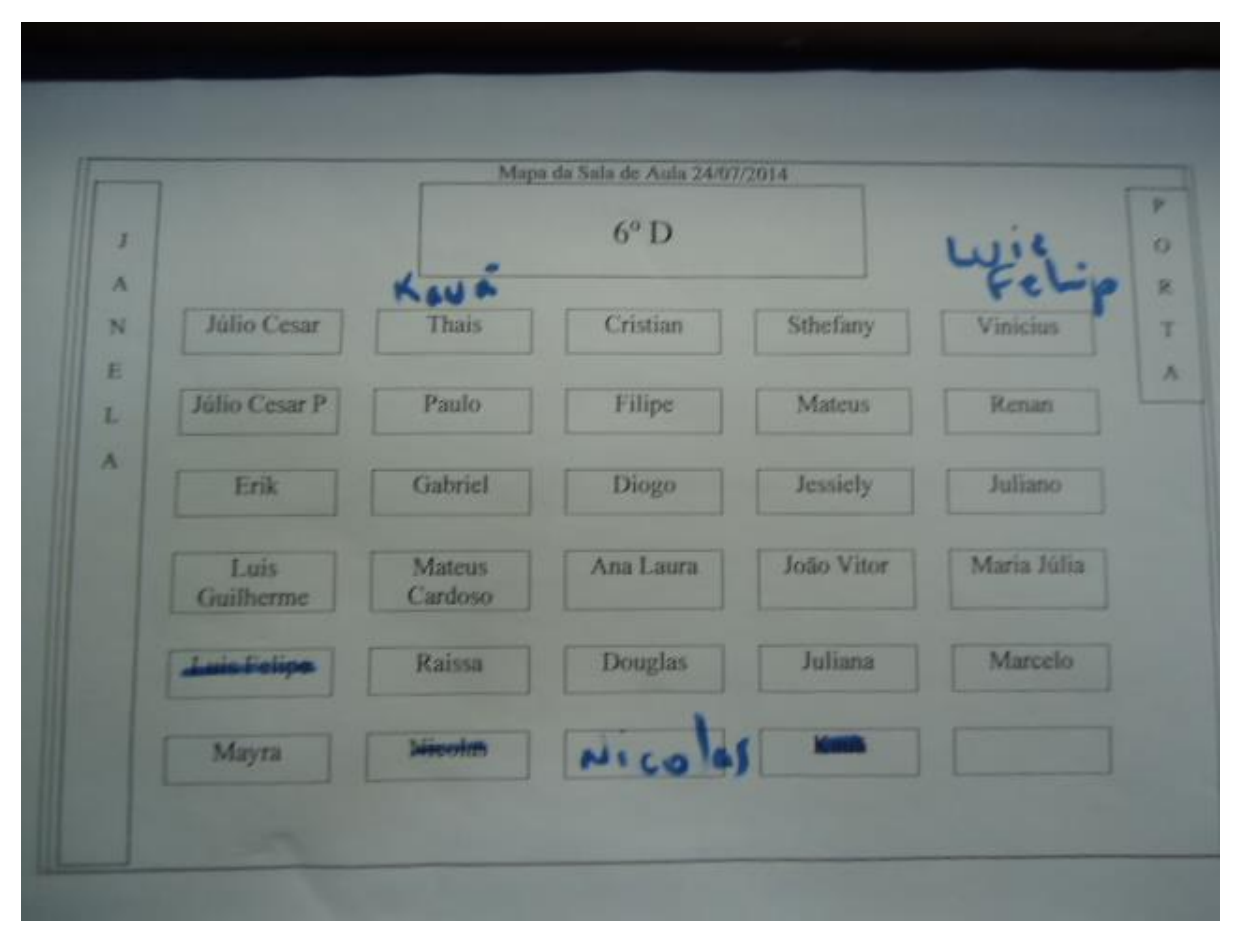

Figura 35 - Mapa dos lugares onde os alunos devem se sentar na sala de aula Fonte: Arquivo pessoal do autor 


\subsection{Laboratório de informática}

Em visita à escola foi possível identificar a existência de laboratório de informática, conforme ilustrado pela Figura 36, no qual possui 21 computadores, em que apenas 19 deles estão funcionando sem apresentar problemas. Também foi possível identificar que a escola não oferece aulas de informática com Professores capacitados nessa área aos alunos. A utilização do laboratório ocorre apenas quando os docentes, por iniciativa própria, programam alguma atividade para ser realizada com os alunos utilizando essa estrutura. De acordo com o Professor entrevistado, o laboratório de informática é utilizado com baixa frequência pelos alunos e Professores.

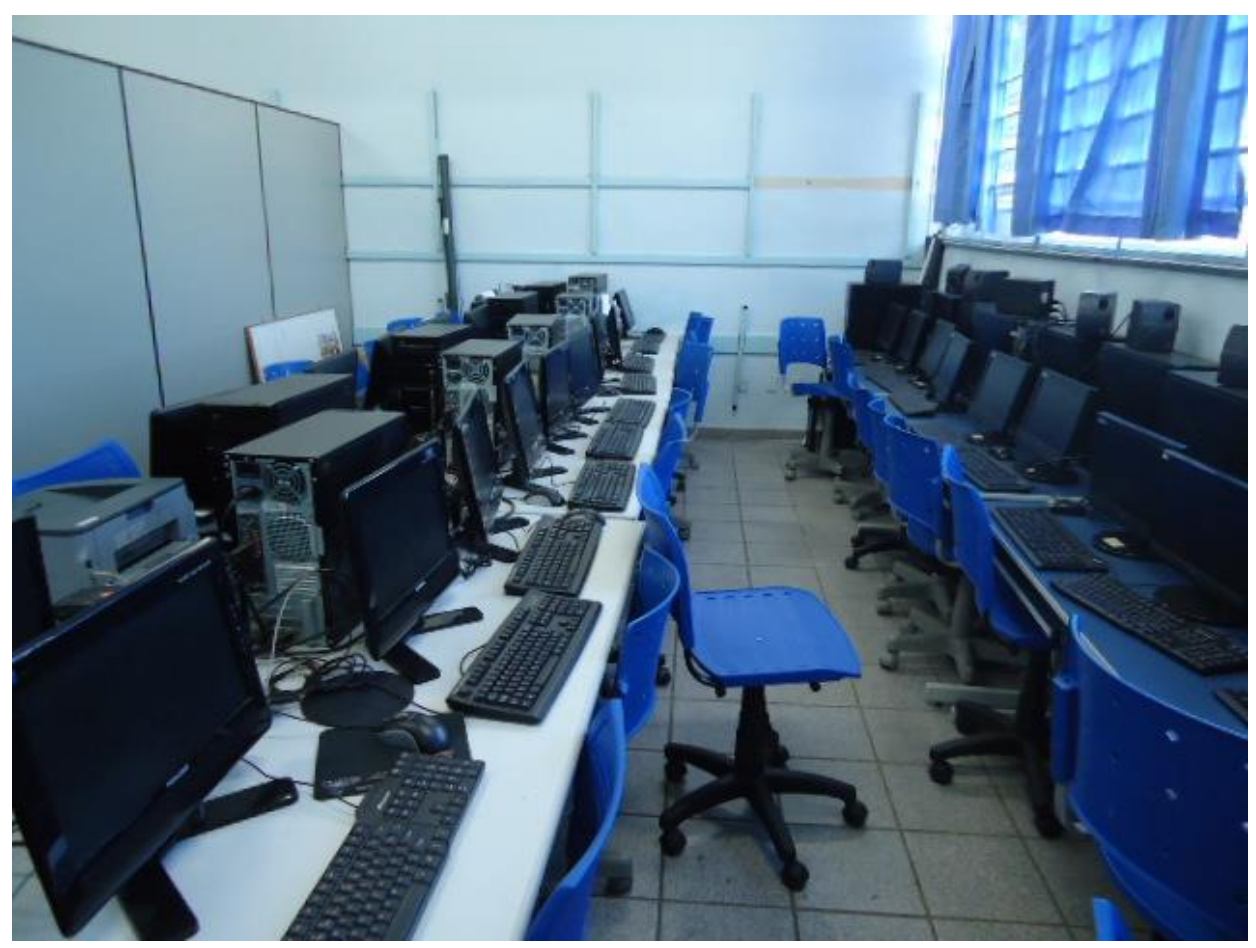

Figura 36 - Laboratório de informática da escola " $F$ " Fonte: Arquivo pessoal do autor

\subsection{Biblioteca}

Em visita à escola foi possível identificar que a biblioteca tem um acervo de tamanho insatisfatório, porém com boa variedade de obras literárias. Não foi possível identificar exatamente o número de livros, nem as diferentes obras componentes do acervo, pois o bibliotecário responsável não se encontrava presente. Devido à limitação de espaço, a 
biblioteca não possui área para estudo coletivo, o que contribui para o baixo nível de leitura dos alunos. Entretanto, a biblioteca é razoavelmente iluminada e arejada. Pela Figura 37 é possível verificar o tamanho do acervo e as condições da biblioteca.
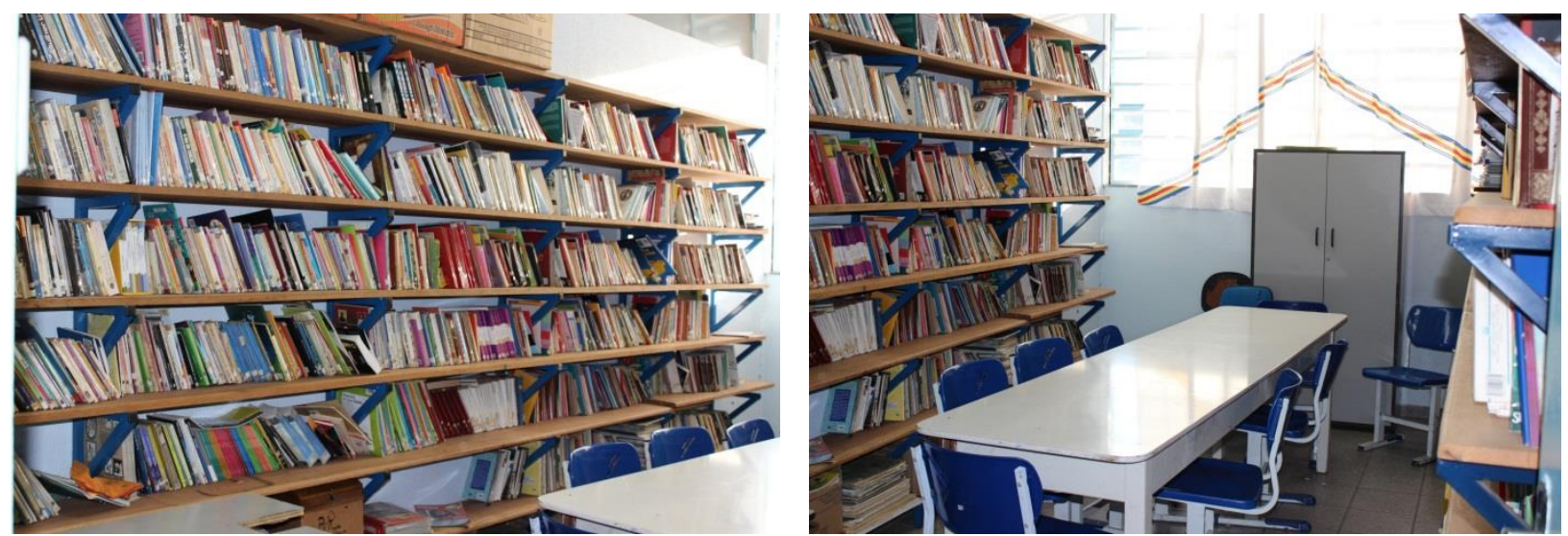

Figura 37 - Biblioteca da escola "F"

Fonte: Arquivo pessoal do autor

Também se observou que os livros podem ser retirados pelos alunos somente mediante o registro feito pela bibliotecária. De acordo com a Diretora, a biblioteca é restrita apenas aos alunos, ou seja, a comunidade não pode fazer uso do acervo.

\subsection{Sala de leitura}

Durante visita à escola observou-se a inexistência de sala de leitura.

\subsection{Alunos}

Em visita à escola, observou-se que o sistema de matrículas dos alunos é por zoneamento, ou seja, os alunos são matriculados na escola mais próxima de sua casa. No entanto, alguns alunos que estudam nessa escola residem na área rural, nesse caso específico, a secretaria municipal de educação oferece transporte público diariamente para esses alunos. O número total de alunos matriculados nessa escola é 421. 


\subsection{Docentes}

Em visita à escola foi possível identificar as seguintes características referentes ao seu corpo docente:

Número de docentes para cada cem alunos: 7,80;

Porcentagem de docentes pertencente ao sexo feminino: 60,87;

Porcentagem dos docentes que possuem magistério concluído: 0,62;

Porcentagem dos docentes que possuem o curso de licenciatura concluído: 72,67;

Porcentagem dos docentes que possuem o ensino superior concluído: 99,38;

Porcentagem dos docentes que possuem especialização concluída: 31,06.

\subsection{Funcionários}

Número de Funcionários para cada cem alunos: 9,74.

\subsubsection{Escola "B" eficiente e respectiva SME}

- Data da visita: $10 / 09 / 2014$

- Indicadores do município de Mairinque

$\mathbf{N}^{\mathbf{0}}$ de Habitantes: 43.473

IDHM: 0,743

- Indicadores da escola B

Número de alunos: 351

Investimento anual por aluno: $\mathrm{R} \$ 3.685,24$

Nota no IDEB (Anos Finais): 3,52

Nível socioeconômico: 3 (Médio-Baixo)

Durante a visita realizada à escola "B", conforme ilustrado pela Figura 38, localizada no município de Mairinque no estado de São Paulo, foi possível identificar inúmeras práticas administrativas e pedagógicas que colaboraram para que, no ano de 2011, a escola obtivesse uma nota 3,52 no IDEB. A seguir são apresentados alguns dos principais aspectos mais relevantes que foram observados durante a visita à escola. 


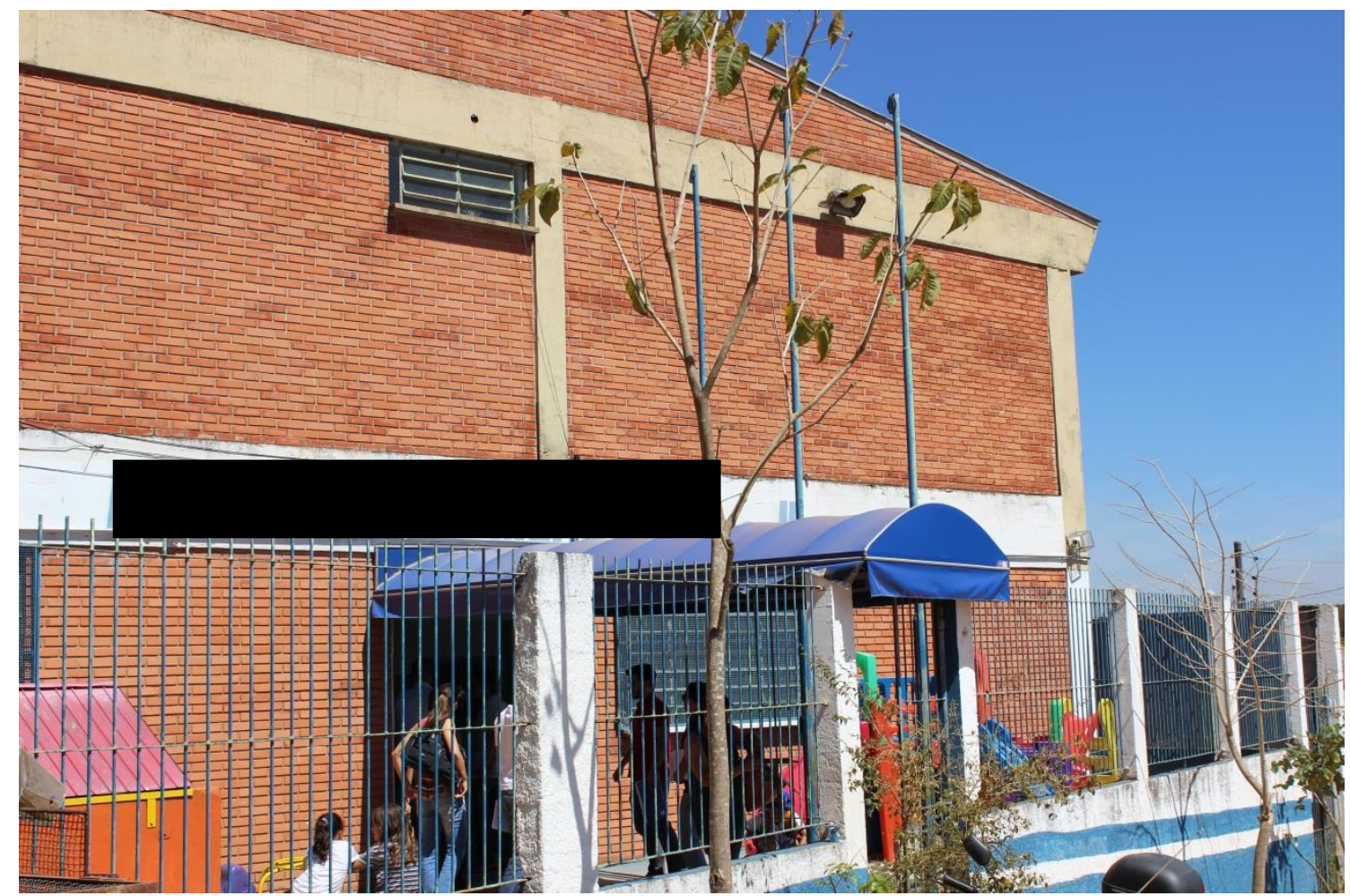

Figura 38 - Fachada da escola "B"

Fonte: Arquivo pessoal do autor

\subsection{Relatório de gestão e destinação dos recursos financeiros da SME}

\subsection{Constituição da SME}

Em conversa com a secretária de educação, observou-se que todos os colaboradores desta secretaria são nomeados por indicação política, salvo três cargos que são funcionários de carreira. Além disso, a secretaria define como política do município que os Diretores sejam escolhidos por indicação política, contando ao final do processo com a aprovação do prefeito. Em relação à formação dos colaboradores, a secretária informou que todos possuem graduação, em que a maioria é em pedagogia e os demais em áreas específicas de atuação.

\subsection{Organização da SME}

Em visita à SME foi possível observar em relação a sua governança, que existem cinco supervisores que se reportam diretamente a secretária, que por sua vez, busca conciliar e mediar eventuais conflitos nas áreas que estão sob a responsabilidade dos mesmos. Segundo a 
secretária, a SME conta com mais de 50 funcionários, que se divide em sete departamentos, sendo: (1) departamento de administração, (2) departamento de merenda, (3) departamento de Formação Pedagógica, (4) departamento de transporte, (5) departamento pedagógico, (6) departamento do núcleo administrativo municipal e (7) departamento de gestão. Ademais, observou-se que a SME não possui uma área específica responsável pela captação de recursos.

\subsection{Secretário}

Em entrevista com a Secretária, observou-se que ela possui formação em magistério e matemática, complementação em pedagogia e pós-graduação em educação especial e gestão de docência. Entretanto, segundo ela, existe no município uma portaria que regula o acesso ao cargo e exige como pré-requisito que o candidato tenha apenas formação em pedagogia.

Durante a visita, observou-se que o Secretário tem relevante autonomia para criação de políticas educacionais, desde que não interfira no que o estatuto de educação do município regula. Já em relação a autonomia financeira do Secretário, observou-se que ela é irrelevante, tendo em vista que a maior parte dos recursos é proveniente do governo federal e estadual e chegam na SME com a destinação pré-determinada.

Ademais, observou-se que a secretária tem uma análise crítica da situação do município irrelevante, principalmente no que se refere aos principais desafios da educação para o município.

\subsection{Capacidade da SME na captação de recursos financeiros}

Em visita à SME, observou-se não existem recursos provenientes de projetos federais e/ou estaduais que foram articulados e angariados pelo Secretário e sua equipe para possíveis investimentos no município. Ademais, a secretária não demonstrou pró-atividade na realização de atividades que tenha como objetivo levantar recursos para a educação, como parcerias com empresas privadas ou a APM. No mais, verificou-se que a secretária possui 
desconhecimento dos principais indicadores financeiros municipais, como o investimento anual por aluno.

\subsection{Destinação do recurso financeiro descentralizado e centralizado}

Em conversa com a secretária, verificou-se que a destinação dos recursos se dá majoritariamente para oferecimento de transporte aos alunos, uma vez que este é terceirizado e representa um alto investimento para o município. Por outro lado, os recursos destinados a reparos emergenciais e a cursos, palestras e orientações didático-pedagógicas podem ser considerados irrelevantes.

\subsection{Transição de novo Secretário e nova equipe}

Em entrevista com a secretária, observou-se que a maior parte dos colaboradores assume seus cargos por meio de indicação política. Nesse sentido, segundo a secretária, na última troca de gestão nenhuma informação foi repassada aos novos colaboradores, o que dificultou o seu trabalho inicial. A secretária finaliza afirmando que levou vários meses para reestruturar a secretaria e somente depois começar a desenvolver o seu trabalho.

\subsection{Critério para matrícula de alunos}

Em entrevista com a secretária, observou-se que o critério adotado para a matrícula dos alunos é por zoneamento.

\subsection{Ensino fundamental ofertado exclusivamente pela rede pública}

Segundo a secretária, o ensino fundamental é ofertado exclusivamente pela rede pública municipal.

\subsection{Informações adicionais}

Em visita à SME, constatou-se a existência de dezessete escolas urbanas e quatro escolas rurais no município que ofertam o ensino fundamental. Ademais, observou-se que o 
município adota a política de progressão continuada e não oferece incentivos relevantes para os alunos participarem de eventos, como as olimpíadas de matemática. Não obstante, a secretária não possui conhecimento da porcentagem de recursos destinados à educação que são direcionados para folha de pagamento dos Professores.

\subsection{Relatório de gestão e destinação dos recursos financeiros do Diretor}

\subsection{Especificidades do município pequeno}

Em conversa com o Diretor da escola, observou-se que existe uma cobrança por parte da comunidade, em grande parte pela proximidade que ele tem com os pais dos alunos. Entretanto, segundo o Diretor, nem sempre foi assim, pois antes dele assumir a direção da escola não havia nenhuma cobrança por parte dos pais e a comunidade olhava com descaso para a escola.

De acordo com o Diretor, ele conseguiu trazer a família para rotina escolar, demonstrando para os pais, que se importava com a educação de seus filhos. Uma das ações desenvolvidas pelo Diretor foi visitar a casa do aluno quando este faltava, para saber o motivo que o levou a se ausentar da aula. O Diretor ainda destaca que toda essa transformação só foi possível devido ao auxílio e suporte do grupo de Professores, que motivados constantemente por ele se uniram em torno do mesmo objetivo, que era melhorar a qualidade da educação oferecida pela escola. Segundo o Diretor, com o passar do tempo, os pais começaram a se envolver com a educação de seus filhos, acompanhando seu desenvolvimento escolar e dando total apoio as ações realizadas pela escola.

\subsection{Alimentação dos alunos}

Em conversa com o Diretor da escola, constatou-se que é oferecido três refeições por período aos alunos, com a possibilidade deles repetirem, sendo uma apenas para alunos que moram na zona rural (no caso o café da manhã). O Diretor destaca que o aumento de mais uma refeição por período, bem como a possibilidade dos alunos repetirem a refeição, foi uma exigência que ele fez a SME ao assumir o cargo de Diretor, tendo em vista que a maioria dos alunos que frequentam a escola é de família humilde, e em muitos casos passam necessidade em casa, tendo o que comer apenas na escola. Deste modo, o Diretor afirma que esta ação foi fundamental para a melhora de rendimento dos alunos. Além disso, observou-se também a 
existência de uma nutricionista responsável pela formação do cardápio, que é por sua vez, muito elogiado pelos alunos devido sua variedade e qualidade. Durante visita à escola, também foi possível verificar a limpeza e organização da cozinha, que além de ser revestida com azulejo nas paredes e pisos no chão, sempre é mantida limpa pelas merendeiras, conforme nos mostra a Figura 39.

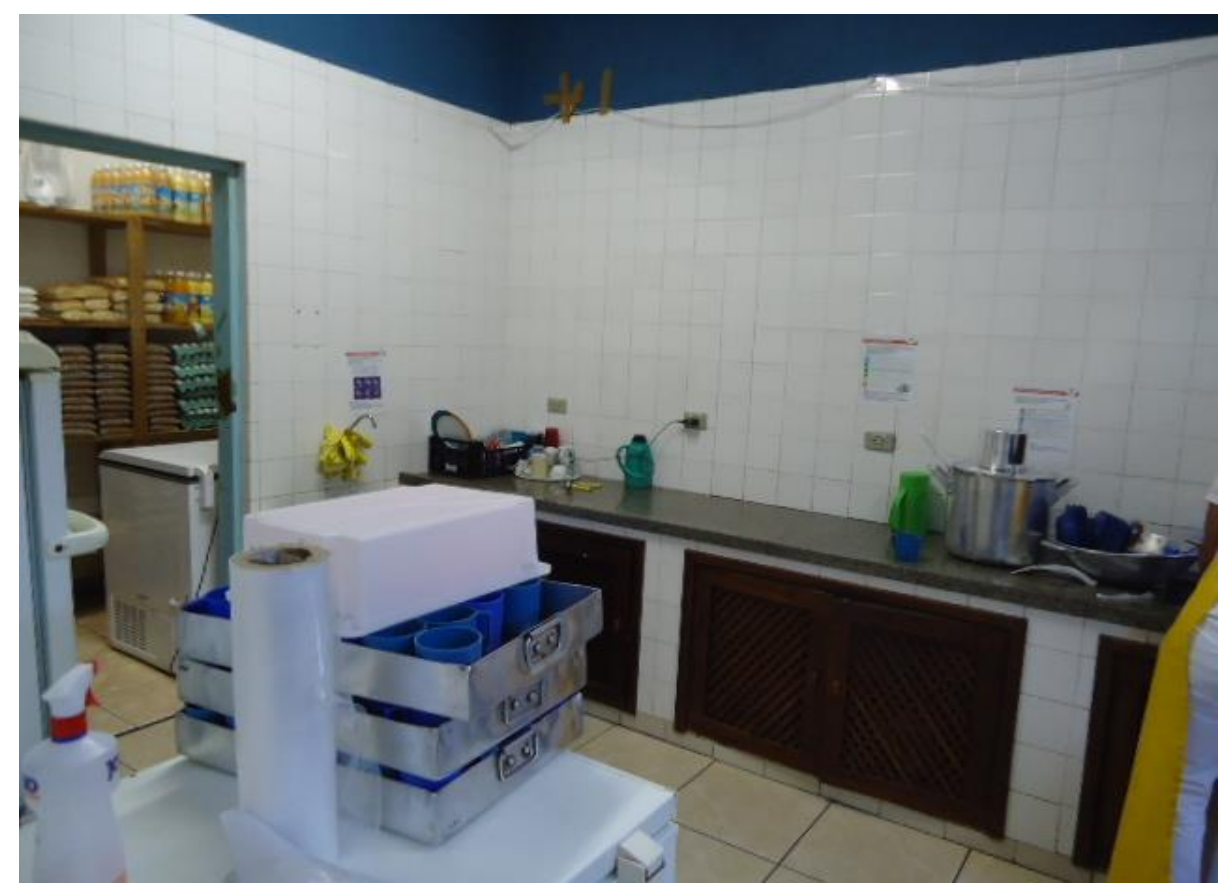

Figura 39 - Cozinha da escola "B"

Fonte: Arquivo pessoal do autor

Ademais, observou-se que a escola possui um refeitório adequado, com espaço e comodidade para os alunos realizarem suas refeições, conforme nos mostra a Figura 40. 


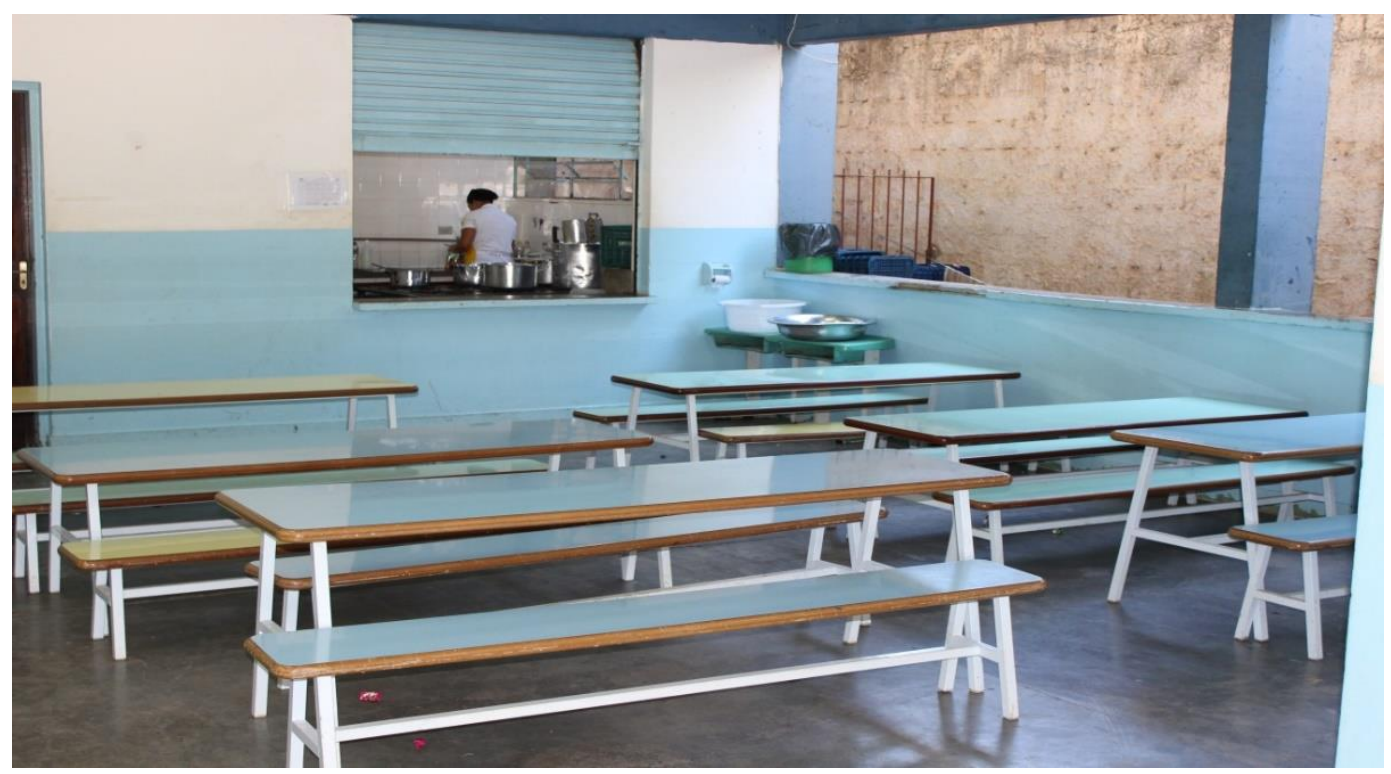

Figura 40 - Refeitório da escola "B"

Fonte: Arquivo pessoal do autor

\subsection{Processo seletivo}

Em conversa com o Diretor, constatou-se que não existe processo seletivo para os alunos ingressarem na escola, no entanto, existe a transferência compulsória por causa de reprovações em disciplinas e outros comportamentos tidos como inadequados (desacato a Professores, funcionários e Diretor; uso de drogas, etc.). Segundo o Diretor, ele insiste em recuperar o aluno, entretanto, quando percebe que este é caso perdido, ele realiza a transferência compulsória do aluno para que ele não influencie o comportamento dos demais. Por outro lado, observou-se que a escola recebe alunos por transferência somente mediante análise do caso, entretanto, como ela está localizada em uma região de difícil acesso, não tem recebido nenhum pedido de transferência.

\subsection{Diretor}

Segundo o Diretor, ele possui graduação em educação física e pedagogia e pós-graduação em avaliação e gestão do ensino público, tendo assumido o cargo por meio de indicação política. Outro fator relevante em relação ao Diretor refere-se ao conhecimento que ele possui em diversas áreas (além das de sua formação), tais como legislação, marketing, engenharia, 
psicologia e economia, que se mostram imprescindíveis para o bom desempenho de sua função.

Além disso, verificou-se também a falta de autonomia financeira do Diretor na utilização dos recursos centralizados e a ausência de recursos descentralizados. Nesse sentido, o Diretor destaca a necessidade de repasse de recursos descentralizados por parte da SME, a fim de auxiliar com rapidez a solução de problemas pontuais identificados pelo Diretor em conjunto com a comunidade. Sendo assim, observou-se que as atuais condições para exercer o cargo de Diretor não são estruturadas o suficiente no que tange a suporte e volume financeiro descentralizado para que seja possível uma tomada de decisão mais assertiva, cuja finalidade é buscar uma melhoria na qualidade da educação oferecida pela escola.

\subsection{Plano de carreira do Diretor}

Em visita à escola, verificou-se que o salário do Diretor não é visto como compatível para a profissão que exerce, uma vez que não é considerado cargo efetivo, portanto, não apresenta progressão salarial. Dessa maneira, observou-se que não há incentivos, principalmente financeiros, para que Professores busquem estes cargos ou novas formações, uma vez que ganham mais dinheiro trabalhando em dois períodos. No caso desta escola, o Diretor relatou que atua neste cargo apenas pelo incentivo da realização pessoal no que faz, uma vez que busca auxiliar na formação de jovens, dando-lhes opções para melhorarem suas vidas. Por outro lado, o Diretor relatou que seria preferível, em um primeiro momento, uma maior gama de recursos descentralizados e maior suporte para realização de suas atividades a um aumento de salário, mas que após a realização destas melhorias, a valorização do trabalho no âmbito financeiro traria grandes profissionais para atuar na gestão de escolas públicas municipais do ensino fundamental e, consequentemente melhorar a qualidade da educação.

\subsection{Capacidade do Diretor na captação de recursos financeiros}

Durante entrevista realizada com o Diretor, observou-se que ele atua de forma proativa na captação de recursos descentralizados, efetuando parcerias com empresas e profissionais autônomos. Segundo o Diretor, uma das ações realizadas por ele consiste em deixar um grupo de eletricistas utilizarem a quadra de esporte da escola no final de semana, na condição de que 
quando houvesse algum problema elétrico na escola eles prestariam os seus serviços gratuitamente. Segundo o Diretor, essas ações se mostraram fundamentais para a sua gestão financeira, tendo em vista que os recursos disponíveis para a escola eram bastante limitados, sendo insuficientes em várias áreas como no caso de reparos emergenciais.

\subsection{Destinação do recurso financeiro descentralizado e centralizado}

Em visita à escola e entrevista com o Diretor, observou-se que os recursos financeiros centralizados e suas respectivas destinações não são monitorados quantitativamente para que seja possível mensurar o quanto é investido em cada item listado (equipamentos de consumo, permanente, materiais escolares etc.). Entretanto, foi possível observar que a escola possui uma infraestrutura limitada, com salas de aula necessitando de pintura, conforme nos mostra a Figura 41.

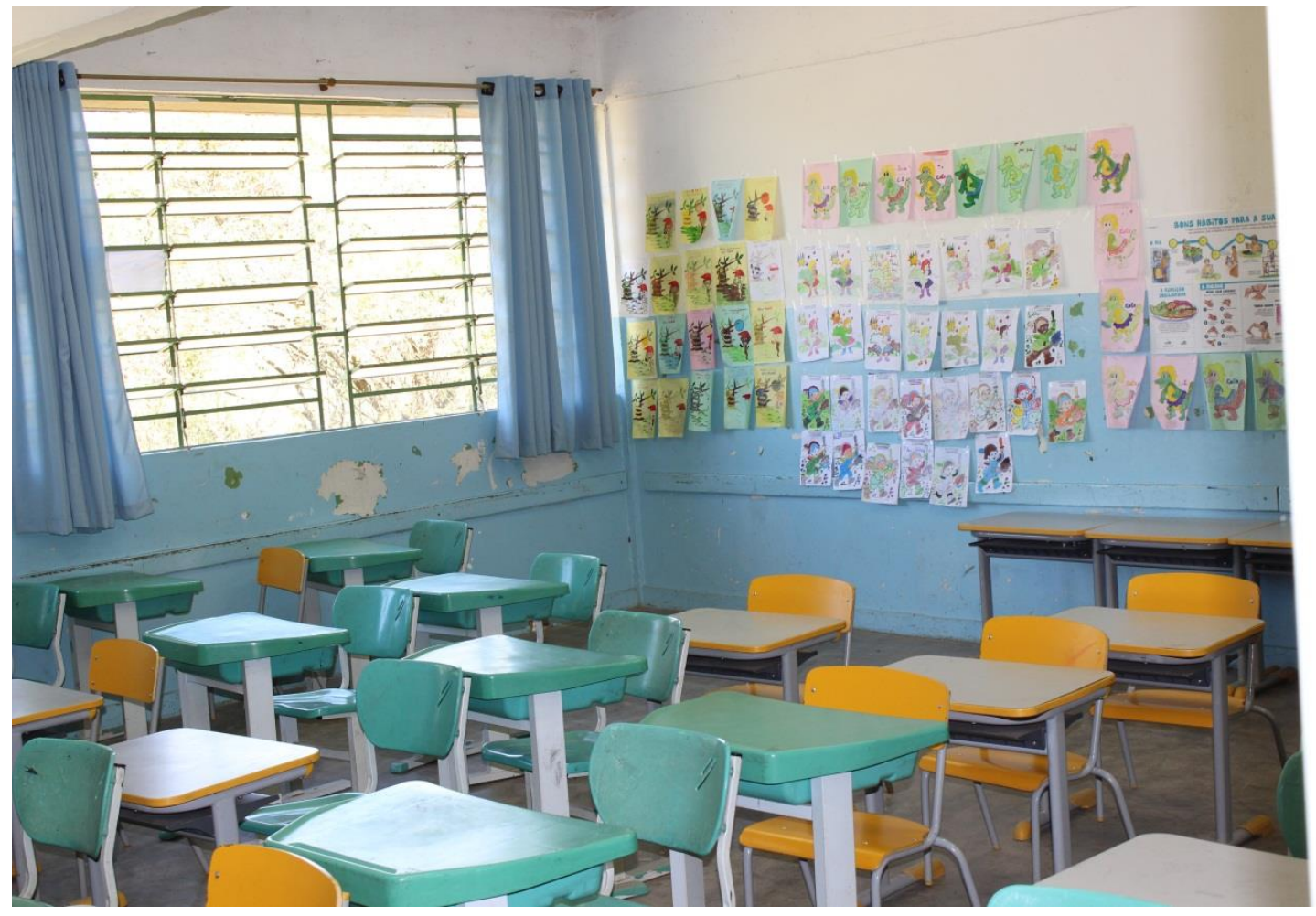

Figura 41 - Sala de aula da escola "B"

Fonte: Arquivo pessoal do autor

Problemas de infraestrutura também foram localizados em outras partes da escola, como na quadra de esportes que está apenas no contra piso, conforme Figura 42 e nos bebedouros d'agua danificados, de acordo com a Figura 43. 

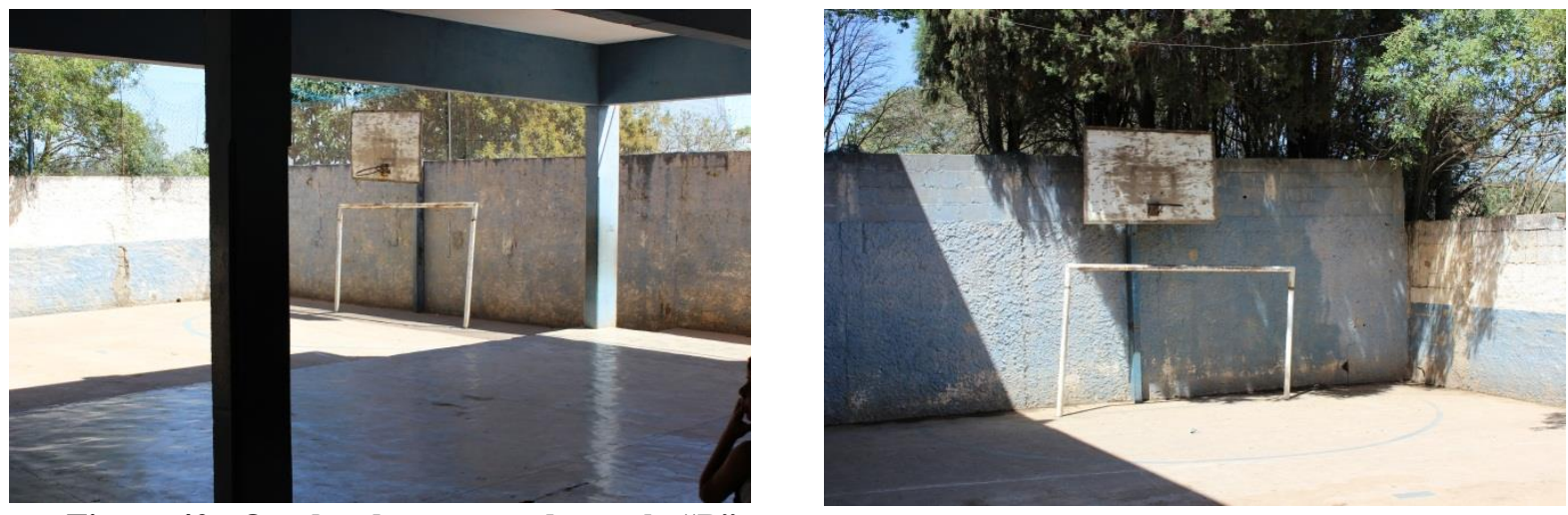

Figura 42 - Quadra de esportes da escola "B"

Fonte: Arquivo pessoal do autor

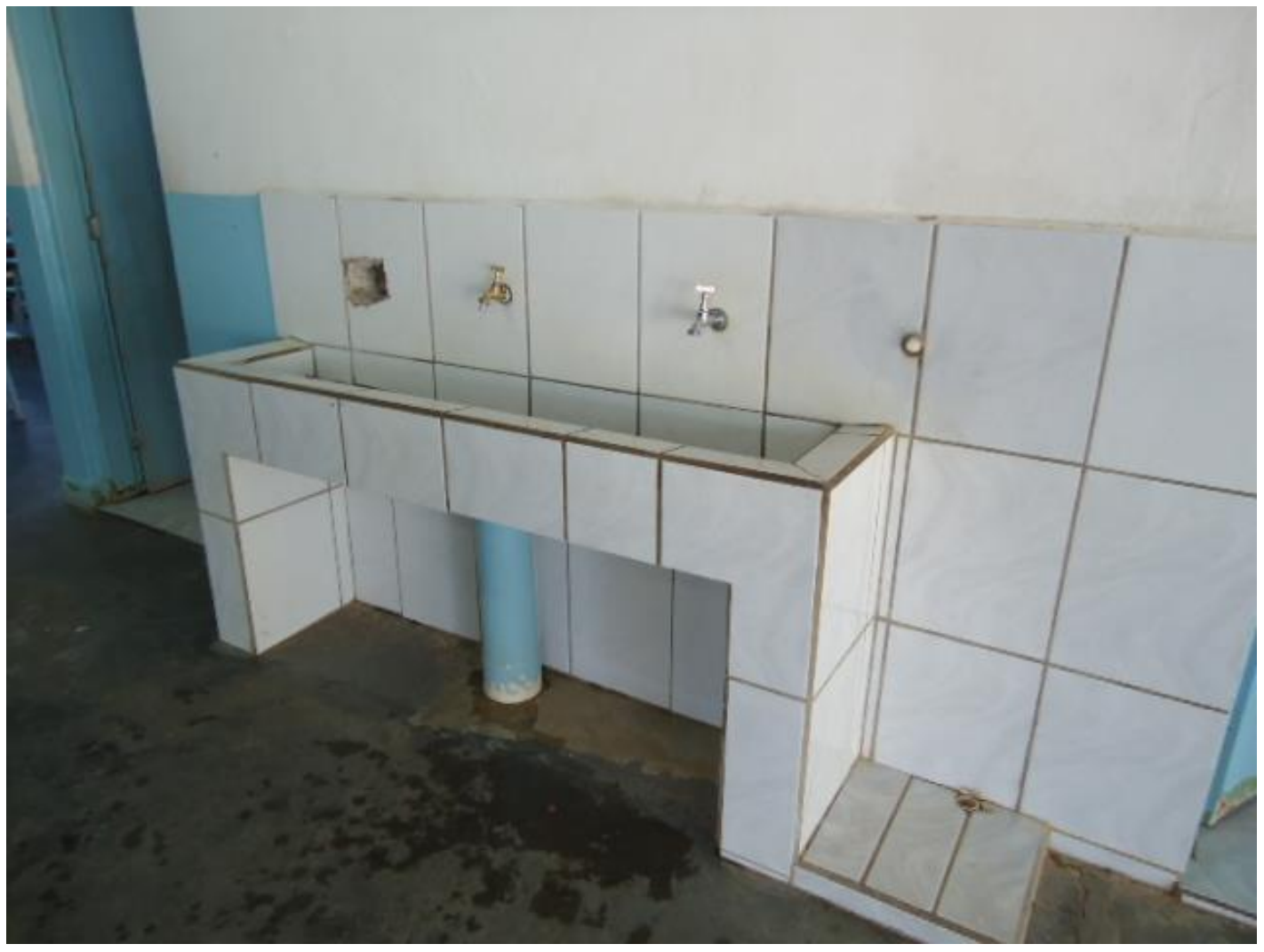

Figura 43 - Bebedouro d'agua da escola " $B$ "

Fonte: Arquivo pessoal do autor 


\subsection{Relatório pedagógico e socioeconômico}

\subsection{Desempenho na prova de português}

Em entrevista realizada com a docente, observou-se que ela possui autonomia no ensino da disciplina. Essa observação é corroborada pelo relato da docente ao afirmar que ela tem liberdade para realizar inúmeras atividades em sala, como projetos utilizando literatura de cordel e notícias. Em relação ao acompanhamento do desempenho dos alunos, a docente afirma que ele é diário, e ocorre por meio da avaliação de comportamento, correção de redações e também por duas provas aplicadas no bimestre. Os alunos que estão com dificuldade na matéria recebem apenas uma atenção especial no transcorrer das aulas convencionais, pois a recuperação e o reforço no contraturno não é uma prática utilizada por esta escola. Segundo a docente, ela tem autonomia para reprovar o aluno quando este tem um desempenho insatisfatório, porém ao final do ano ele pode ser aprovado pelo conselho de classe.

Em relação ao material didático, a docente afirma utilizar o material proveniente do estado, porém complementa o ensino de gramática com um material desenvolvido por ela mesma. Quanto à rotatividade do docente, a mesma pode ser considerada baixa, já que o Professor atualmente responsável pela disciplina leciona na escola a mais de dez anos. Um fator que merece destaque é a ampla experiência da docente entrevistada, que leciona há 46 anos e possui graduação em letras, com uma especialização em linguística e outra em gestão escolar.

Em entrevista com a docente, observou-se que a distribuição da carga horária ou grade curricular é influenciada pelos requisitos da Prova Brasil. Ademais, a docente entrevistada afirma que com a proximidade da Prova Brasil, são aplicados vários simulados para que os alunos pratiquem, com questões no padrão das que são exigidas na avaliação.

\subsection{Desempenho na prova de matemática}

Em entrevista realizada com a docente, observou-se que ela possui autonomia no ensino da disciplina. O relato da docente corrobora com tal observação ao afirmar que ela utiliza vários métodos de ensino em sala de aula, em que um deles consiste em ensinar aos alunos, de 
maneira didática, o conceito de eixo cartesiano. A ideia consiste em sobrepor o eixo ao mapa da cidade, ou ainda a uma foto do aluno e solicitar que ele identifique em quais pontos estão localizadas partes do seu rosto ou locais específicos da cidade como a sua casa, ou ainda a escola. No caso da foto do aluno, é ensinado para ele o conceito de razão e proporção, de forma que ele deve utilizar o eixo cartesiano para proporcionalmente aumentar ou diminuir a sua foto.

Em relação ao acompanhamento do desempenho dos alunos, a docente afirma que ele é diário, e ocorre por meio da aplicação de listas de exercícios, trabalhos em dupla ao final de cada conteúdo e provas. A docente ainda destaca que a escola não oferece recuperação e/ou reforço no contraturno, entretanto, para suprir a necessidade dos alunos que possuem dificuldade de aprendizagem na matéria, ela escolhe um aluno com bom desempenho em sua disciplina para ser o monitor da turma, e este aluno, juntamente com os outros que têm mais facilidade, irão auxiliar, sob sua supervisão, os alunos que precisam do reforço no transcorrer das aulas convencionais. Entretanto, ao termino do semestre, caso o aluno não atinja um desempenho satisfatório a Professora tem autonomia para reprová-lo, porém, posteriormente ele pode ser aprovado pelo conselho de classe.

Em relação ao material didático, a docente afirma utilizar o material proveniente do estado, porém, ela complementa grande parte do conteúdo com um material desenvolvido por ela mesmo. Quanto à rotatividade do docente, a mesma pode ser considerada baixa, já que o docente atualmente responsável pela disciplina ingressou na instituição em 2004.

Em entrevista com a docente, observou-se também que a distribuição da carga horária ou grade curricular é influenciada pelos requisitos da Prova Brasil. Ademais, a docente entrevistada afirma que com a proximidade da Prova Brasil são aplicados vários simulados para que os alunos pratiquem com questões no padrão das que são exigidas na avaliação.

\subsection{Participação da família}

Em visita à escola, observou-se que a maioria dos pais participa da vida escolar dos filhos. Em entrevista com os pais, eles corroboram com essa observação ao afirmar que a maioria dos pais frequentam as reuniões e os eventos festivos realizados pela escola. Os pais além de ajudar os filhos nos deveres escolares, incentivam a leitura, alguns deles inclusive levam os 
filhos na biblioteca municipal. Em entrevista com os pais, foi possível identificar que eles possuem um excelente relacionamento com o Diretor e Professores, o que fortalece a confiança e o apoio nas ações desenvolvidas pela escola, mesmo quando isso envolve alguma advertência formal aos seus filhos. Os pais também são unânimes em defender que a educação é fundamental para a vida de seus filhos.

\subsection{Reprovação discente e sistema disciplinar}

Em visita à escola observou-se a existência de um sistema disciplinar respeitado pela comunidade escolar, onde as regras são bem claras e conhecidas. Tal observação é corroborada pelos pais, que afirmam que no início de cada ano letivo a escola envia, através dos alunos, um regulamento com as regras (horário de entrada na escola, uso de uniformes, uso de celular, roupas curtas etc.) estipuladas pela escola. A escola também anexou um cartaz na porta da secretaria contendo o Decreto de LEI $\mathrm{n}^{\circ} 2.848 / 40$ sobre as consequências de desacato ao funcionário público, a fim de evitar esse tipo de problema, conforme nos mostra a Figura 44.

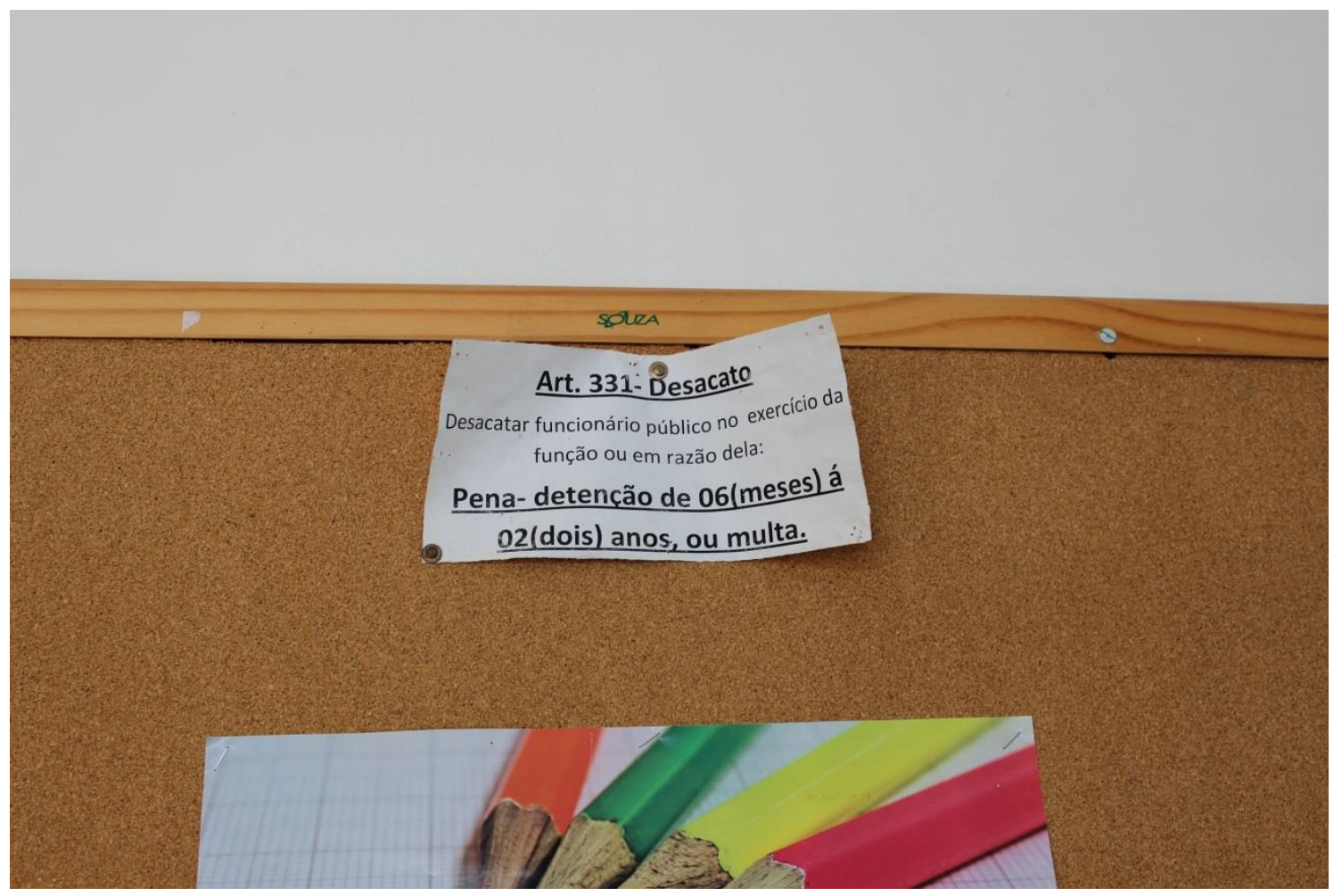

Figura 44 - Cartaz contendo a Lei $n^{\circ} \mathbf{2 . 8 4 8 / 4 0}$ sobre desacato a funcionário público Fonte: Arquivo pessoal do autor 
Em entrevista com os alunos, observou-se que eles são disciplinados durante as aulas e possuem admiração e respeito pela figura do Diretor e dos Professores. Em visita à escola, também foi possível identificar a existência de um sistema de reprovação com autonomia dada aos Professores para reprovar os alunos com baixo desempenho.

\subsection{Laboratório de informática}

Em visita realizada à escola constatou-se a inexistência de laboratório de informática no ano de 2011.

\subsection{Biblioteca}

Em visita à escola, verificou-se a existência de uma biblioteca muito bem organizada, iluminada, arejada, contendo inclusive ventiladores, conforme nos mostra a Figura 45. Segundo os Professores, a biblioteca possui um bom acervo, porém, com uma baixa variedade de obras.
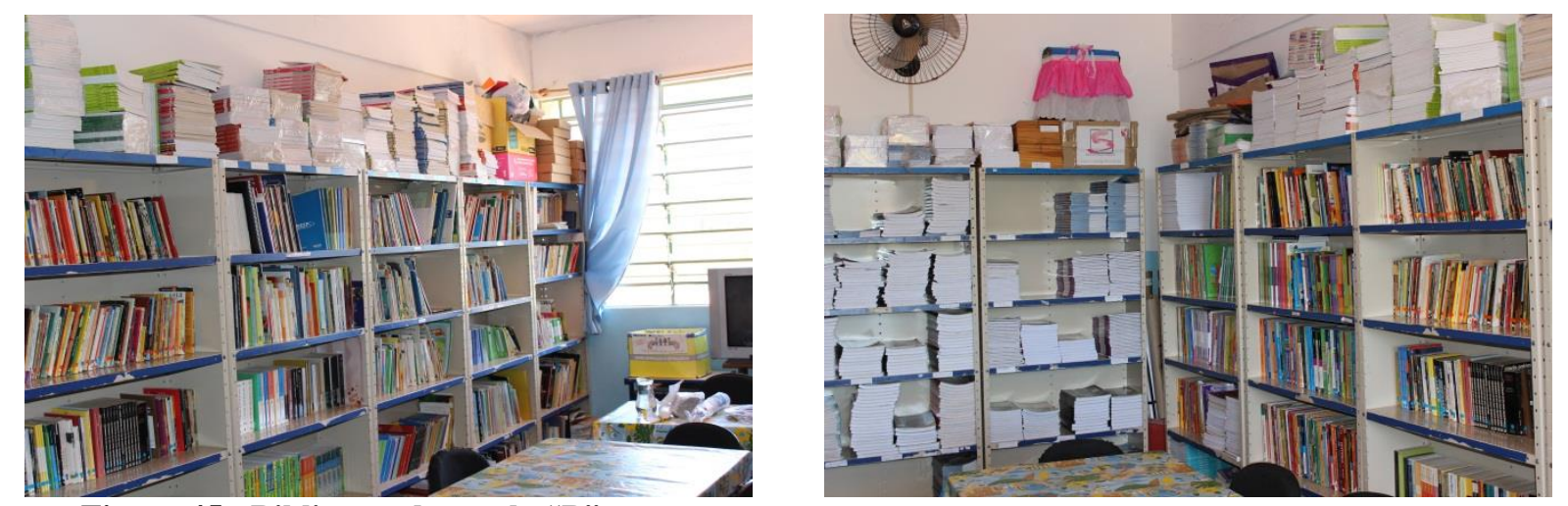

Figura 45 - Biblioteca da escola "B"

Fonte: Arquivo pessoal do autor

Mesmo nesse contexto, observou-se que os alunos possuem um bom nível de leitura, conforme nos mostra o controle de retirada de livros dos alunos, ilustrado pela Figura 46. 


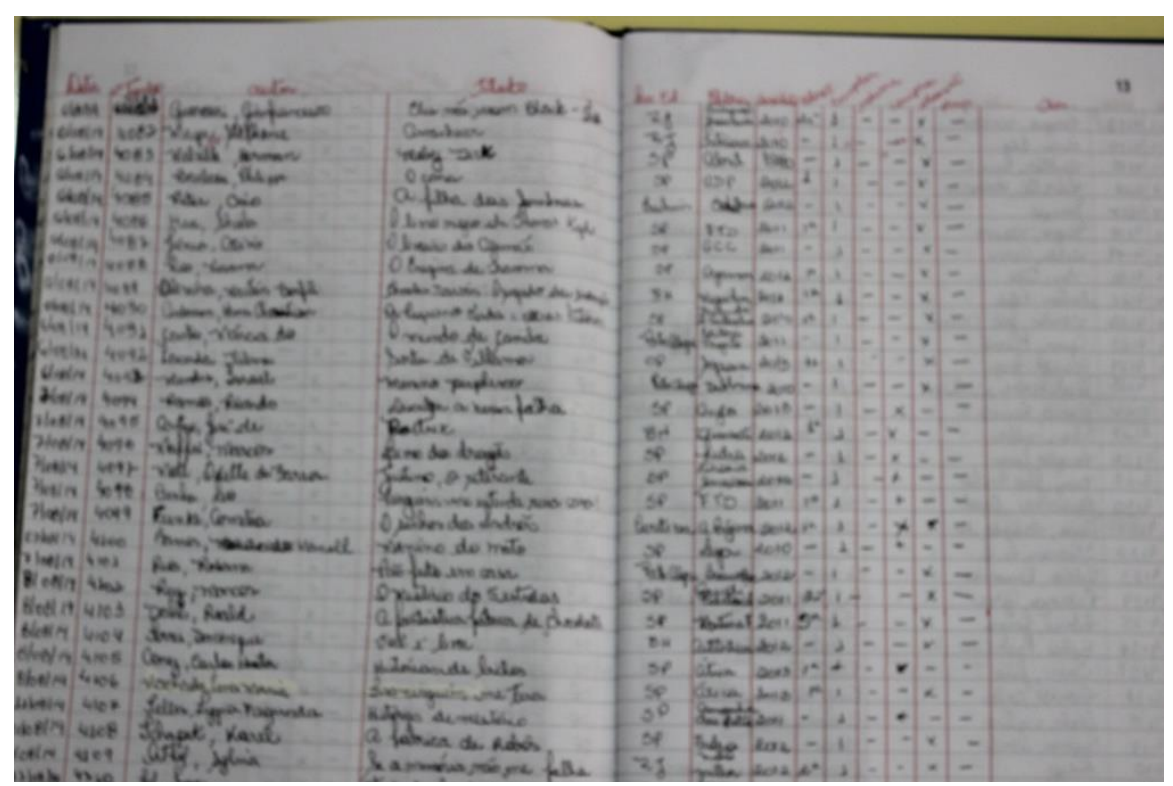

Figura 46 - Controle de retirada de livros dos alunos

Fonte: Arquivo pessoal do autor

A biblioteca também possui uma bibliotecária exclusiva, que é responsável pelo controle de retirada de livro dos alunos. Ademais, observou-se que o acervo da biblioteca é de uso exclusivo dos alunos, ou seja, não se estende a comunidade.

\subsection{Sala de leitura}

Em visita à escola, observou-se a inexistência de sala de leitura.

\subsection{Alunos}

Em visita à escola observou-se que o sistema de matrículas dos alunos é por zoneamento, ou seja, eles são matriculados na escola mais próxima de sua casa. A escola possui 351 alunos matriculados e por estar localizada na área rural os alunos utilizam diariamente o transporte público para ir à escola.

\subsection{Docentes}

Com a visita à escola foi possível identificar as seguintes características referentes ao seu corpo docente: 
Número de docentes para cada cem alunos: 6,03;

Porcentagem de docentes pertencente ao sexo feminino: 81,58;

Porcentagem dos docentes que possuem magistério concluído: 5,26;

Porcentagem dos docentes que possuem o curso de licenciatura concluído: 67,11;

Porcentagem dos docentes que possuem o ensino superior concluído: 94,74;

Porcentagem dos docentes que possuem especialização concluída: 31,58.

\subsection{Funcionários}

Número de Funcionários para cada cem alunos: 9,12.

\subsubsection{Escola "G" abaixo da fronteira de eficiência}

- Data da visita: $10 / 09 / 2014$

- Indicadores da escola G

Número de alunos: 893

Investimento anual por aluno: $\mathrm{R} \$ 3.685,24$

Nota no IDEB (Anos Finais): 3,64

Nível socioeconômico: 4 (Médio)

Durante a visita realizada à escola "G", conforme ilustrado pela Figura 47, localizada no município de Mairinque no estado de São Paulo, foi possível identificar inúmeras práticas administrativas e pedagógicas que colaboraram para que, no ano de 2011, a escola obtivesse uma nota 3,64 no IDEB. A seguir são apresentados alguns dos principais aspectos mais relevantes que foram observados durante a visita à escola. 


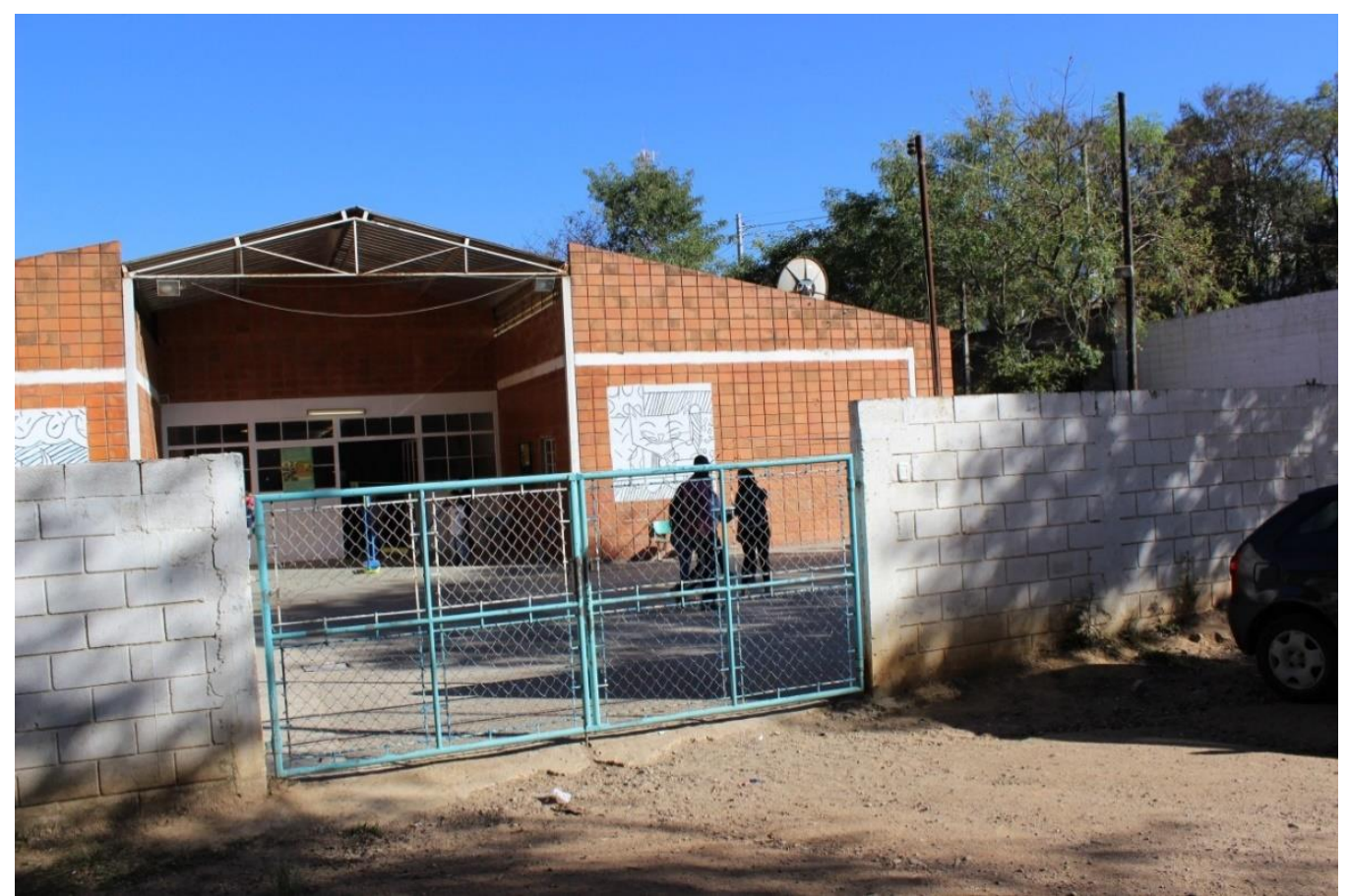

Figura 47 - Fachada da escola "G"

Fonte: Arquivo pessoal do autor

\subsection{Relatório de gestão e destinação dos recursos financeiros do Diretor}

\subsection{Especificidades do município pequeno}

Em conversa com o Diretor da escola, observou-se que a comunidade não participa ativamente da vida escolar dos filhos e muito menos exerce algum tipo de cobrança sobre ele ou Professores. De acordo com o Diretor, isso se deve a alta rotatividade das famílias na região, uma vez que a maioria delas vem do Nordeste para trabalhar em indústrias e serem caseiros em fazendas, e quando são demitidas de seus postos de trabalho, levam seus filhos para outras cidades, retornando somente após um mês ou um período ainda maior, não se interessando deste modo com a educação de seus filhos.

\subsection{Alimentação dos alunos}

Em conversa com os alunos e o Diretor, observou-se que é oferecida apenas uma refeição por período aos alunos, orientada, inclusive, por uma nutricionista, mas com reclamações por parte dos alunos, devido a sua falta de variedade. Ademais, observou-se que a escola possui um refeitório adequado, com espaço e comodidade para os alunos realizarem suas refeições, conforme nos mostra a Figura 48. 


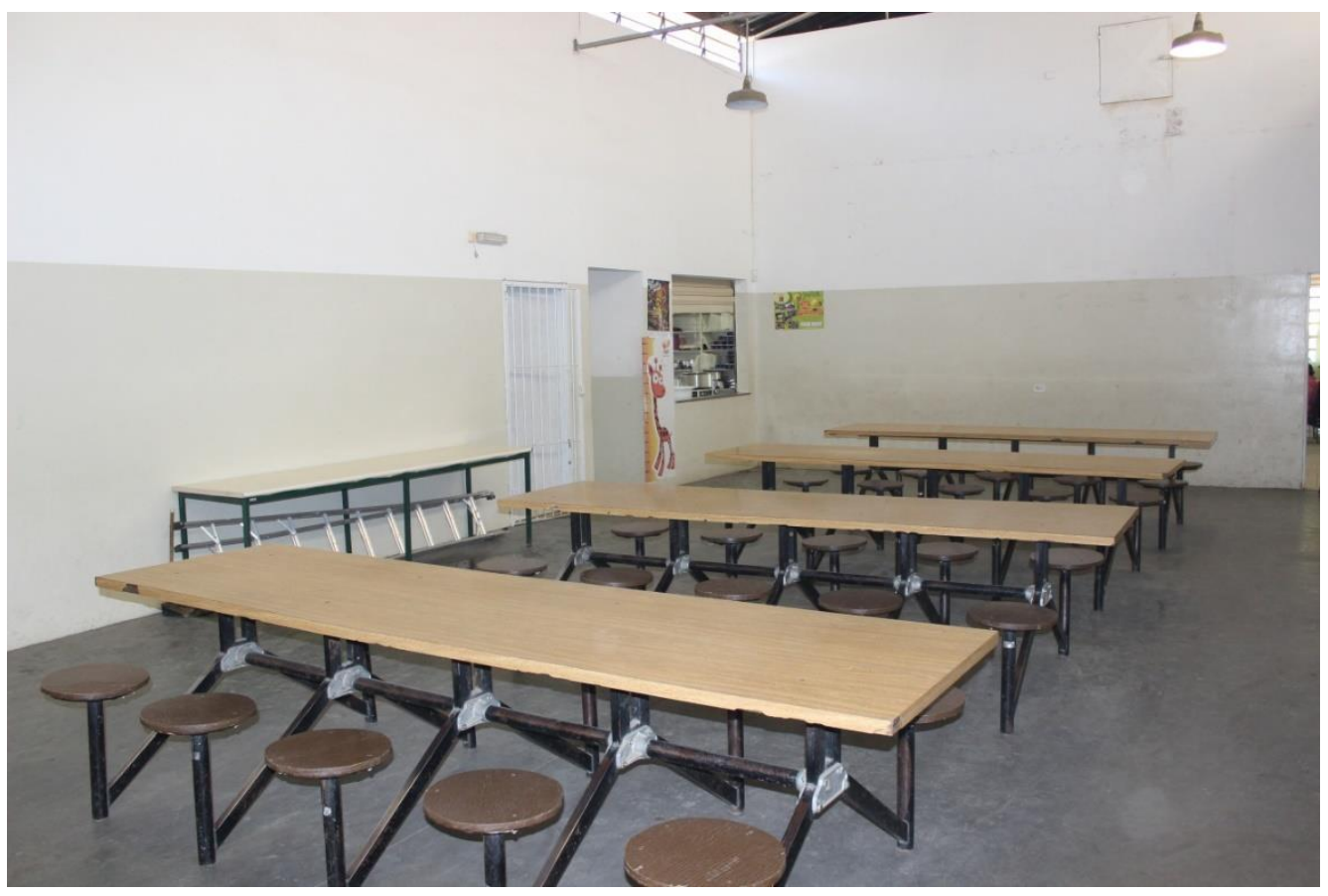

Figura 48 - Refeitório da escola "G"

Fonte: Arquivo pessoal do autor

\subsection{Processo seletivo}

Em conversa com o Diretor, constatou-se que não existe processo seletivo para entrar na escola e não existe também a transferência compulsória por causa de reprovações em disciplinas. Por outro lado, a escola recebe alunos por transferência, mas orienta que preferencialmente os alunos devem ser matriculados por zoneamento.

\subsection{Diretor}

Em conversa com o Diretor, constatou-se que este tem formação em Ciências Sociais e Educação Física, tendo assumido o cargo por indicação política. Nesta escola, verificou-se também uma razoável autonomia do Diretor para decisões financeiras, uma vez que todos os recursos que chegam até ele já têm um destino previamente selecionado, entretanto ele ainda possui uma pequena folga para selecionar os itens que são pertinentes para a escola no atual momento. 


\subsection{Plano de carreira do Diretor}

Em visita à escola, observou-se que o salário do Diretor não é visto como compatível para a profissão que exerce, uma vez que não é considerado cargo efetivo, portanto, não apresenta progressão salarial. Dessa maneira, constatou-se que não há incentivos, principalmente financeiros, para que Professores busquem estes cargos ou novas formações, uma vez que ganham mais dinheiro trabalhando em dois períodos. Além disso, segundo relato do Diretor da escola, o município de Sorocaba, que está próximo da cidade, costuma atrair os melhores profissionais pela remuneração que concede aos Professores, o que dificulta a contratação para as escolas do município, que constantemente perdem profissionais que passaram em concursos de outras cidades e, consequentemente, de pessoas que possuem capacitação técnica na área de gestão para assumirem cargos como o de Diretor.

\subsection{Capacidade do Diretor na captação de recursos financeiros}

Durante entrevista realizada com o Diretor, observou-se que ele não atua em nenhum momento para realizar captação de recursos para a escola, a não ser pelas fontes convencionais, que são aquelas repassadas pelos órgãos federais, estaduais e municipais. De acordo com o Diretor, quando a escola está necessitando de algo, ele elabora um requerimento com a lista dos itens necessários para a SME. Este requerimento, por sua vez, passará por uma análise, podendo ser aprovado ou não. O Diretor finaliza, destacando a dificuldade de se conseguir recursos, afirmando que a SME abandonou a escola e nunca ofereceu apoio e orientação para o Diretor sobre as alternativas de captação de recursos.

\subsection{Destinação do recurso financeiro descentralizado e centralizado}

Em entrevista com o Diretor, observou-se que os recursos financeiros centralizados e suas respectivas destinações não são monitorados quantitativamente para que seja possível mensurar o quanto é investido em cada item listado (equipamentos de consumo, permanente, materiais escolares etc.). Entretanto, observou que a escola dispõe de uma infraestrutura limitada, pois não possui um pátio adequado para os alunos ficarem durante a recreação e muito menos quadra de esportes para os alunos realizarem atividades físicas, no entanto, as salas de aula estão em bom estado de uso, conforme nos mostra a Figura 49. 


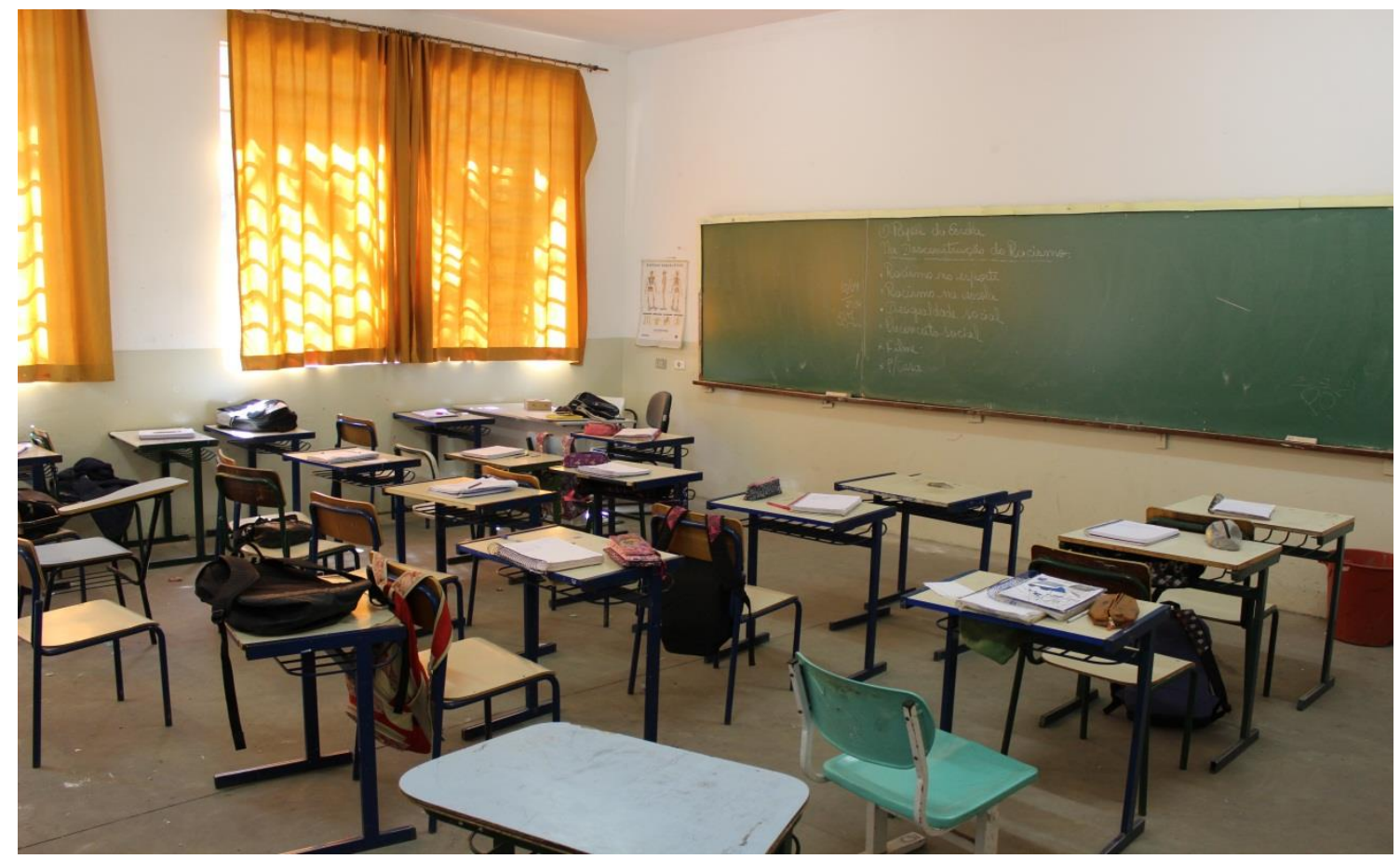

Figura 49 - Sala de aula da escola "G"

Fonte: Arquivo pessoal do autor

\subsection{Relatório pedagógico e socioeconômico}

\subsection{Desempenho na prova de português}

Em entrevista realizada com o docente, observou-se que ele possui autonomia no ensino da disciplina. Essa observação é corroborada pelo relato da docente ao afirmar que ele tem liberdade para realizar inúmeras atividades em sala. Em relação ao acompanhamento do desempenho dos alunos, observou-se que ele ocorre com baixa frequência, conforme relato dos alunos e dos pais entrevistados. Deste modo, os alunos que estão com dificuldade de aprendizagem na matéria não recebem recuperação e/ou reforço no contraturno, pois essa não é uma prática utilizada pela escola. Segundo o Diretor e o docente entrevistado, a ausência da recuperação e/ou reforço no contraturno ocorre devido a vários fatores, como a dificuldade de se encontrar docentes disponíveis, a limitação de espaço físico na escola e também pelo desinteresse dos alunos, pois como a maioria deles utilizam o transporte público para ir para a escola, eles teriam que esperar até o final da tarde para retornar para casa. 
Em relação ao material didático, o docente afirma utilizar o material proveniente da SME, porém, ele destaca possuir autonomia para complementar o ensino com material próprio. Vale ressaltar que, segundo o Professor entrevistado, o conteúdo do material utilizado não reflete o contexto social dos alunos, o que dificulta sua aprendizagem. Outro ponto relevante é que não existe uma continuidade no uso do material didático, pois o mesmo é trocado a cada eleição.

Quanto à rotatividade dos docentes, a mesma pode ser considerada alta, em virtude de alguns fatores, como a baixa remuneração oferecida pela instituição. Em entrevista com a docente, observou-se que a distribuição da carga horária ou grade curricular não é influenciada pelos requisitos da Prova Brasil. Ademais, observou-se que existe uma preparação específica para a Prova Brasil, porém limitada. De acordo com a docente entrevistada, com a proximidade da Prova Brasil é aplicado apenas alguns exercícios similares aos cobrados pela avaliação.

\subsection{Desempenho na prova de matemática}

Em entrevista realizada com o docente, observou-se que ele possui autonomia no ensino da disciplina, podendo aplicar inúmeras atividades em sala para os alunos. Em relação ao acompanhamento do desempenho dos alunos, foi possível identificar, através de entrevista realizada com o docente, que ele ocorre apenas de forma esporádica, por meio de provas convencionais ou ainda a chamada oral da tabuada. Deste modo, os alunos que estão com dificuldade de aprendizagem na matéria não recebem recuperação e/ou reforço no contraturno, pois essa não é uma prática utilizada pela escola. Segundo o Diretor, a ausência da recuperação e/ou reforço no contraturno ocorre devido a vários fatores, como a dificuldade de se encontrar docentes disponíveis, a limitação de espaço físico na escola e também pelo desinteresse dos alunos, pois como a maioria deles utilizam o transporte público para ir para a escola, eles teriam que esperar até o final da tarde para retornar para casa.

Em relação ao material didático, o docente afirma utilizar o material proveniente da SME, porém, ele destaca possuir autonomia para complementar o ensino com material próprio. Quanto à rotatividade dos docentes, a mesma pode ser considerada alta, em virtude de alguns fatores, como a baixa remuneração oferecida pela instituição. Ademais, não foi identificada a existência de projetos para o ensino da matemática, alteração na carga horária da disciplina em virtude da Prova Brasil, ou ainda uma preparação específica para essa avaliação. 


\subsection{Participação da família}

Em visita à escola foi possível observar uma baixa participação dos pais na vida escolar dos filhos, pois segundo relato dos pais entrevistados, além dos pais não acompanham frequentemente os deveres escolares dos filhos, são poucos (cerca de 20\%) os que participam ativamente das reuniões realizadas pela escola, o que promove desconhecimento pela maioria dos pais das ações realizadas pela escola. Entretanto, foi observou-se uma maior frequência dos pais em eventos festivos realizados pela escola. Outro fator identificado foi o desconhecimento dos pais sobre a existência de associação de pais e mestres.

\subsection{Reprovação discente e sistema disciplinar}

Em visita à escola observou-se a existência de um sistema de reprovação de alunos, entretanto, os Professores possuem baixa autonomia nesse processo, pois a reprovação é limitada a ciclos. Também foi possível identificar que o sistema disciplinar da escola não é conhecido e respeitado pela comunidade escolar. De modo geral os alunos não respeitam a figura do Diretor, Professor e funcionários. Tal observação é corroborada pela declaração dos alunos ao dizer que um de seus colegas agrediu um Professor em sala de aula. A indisciplina dos alunos também pode ser vista pelas marcas de chutes nas paredes e portas do banheiro da escola, conforme ilustrado pela Figura 50.
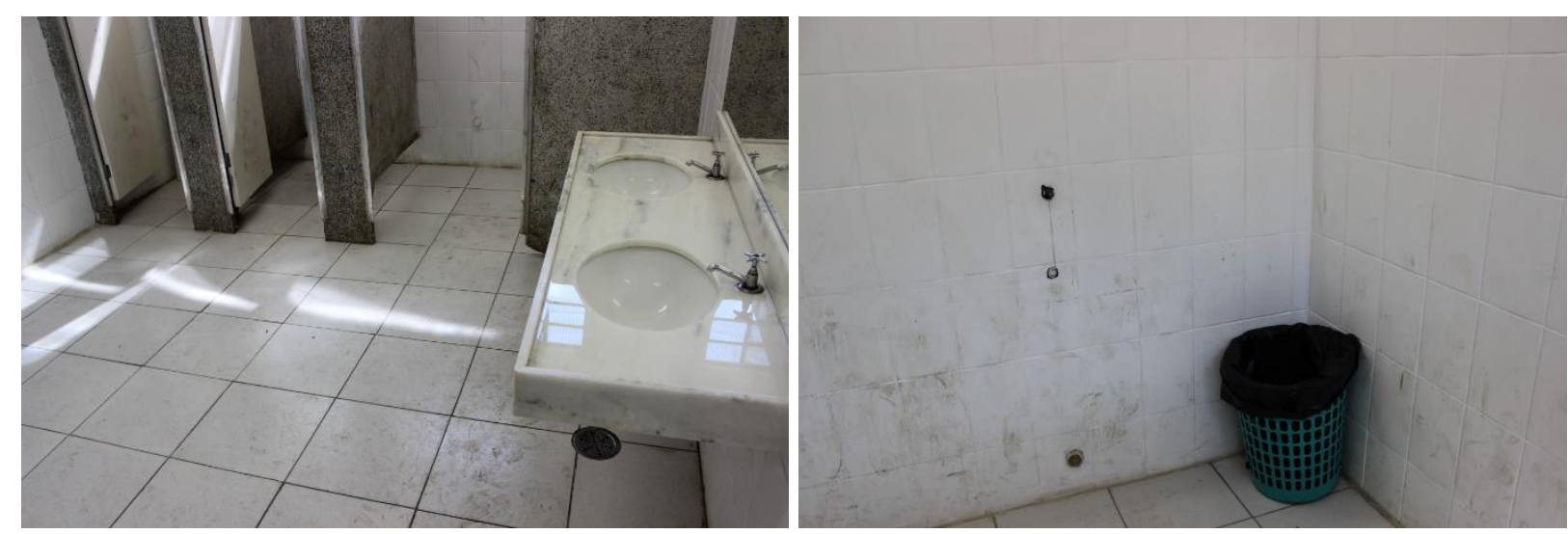

Figura 50 - Banheiro da escola "G"

Fonte: Arquivo pessoal do autor 


\subsection{Laboratório de informática}

Em visita realizada à escola, constatou-se a inexistência de laboratório de informática no ano de 2011. Vale destacar, que a escola possuía computadores, entretanto, eles estavam encaixotados.

\subsection{Biblioteca}

Em visita à escola, verificou-se a existência de uma biblioteca, porém pouco iluminada e arejada, e com um acervo de tamanho e variedade insatisfatória, conforme nos mostra a Figura 51. Dentro desse contexto, observou-se uma baixa frequência de leitura dos alunos, que afirmaram em entrevista que não tem o habito de ler.

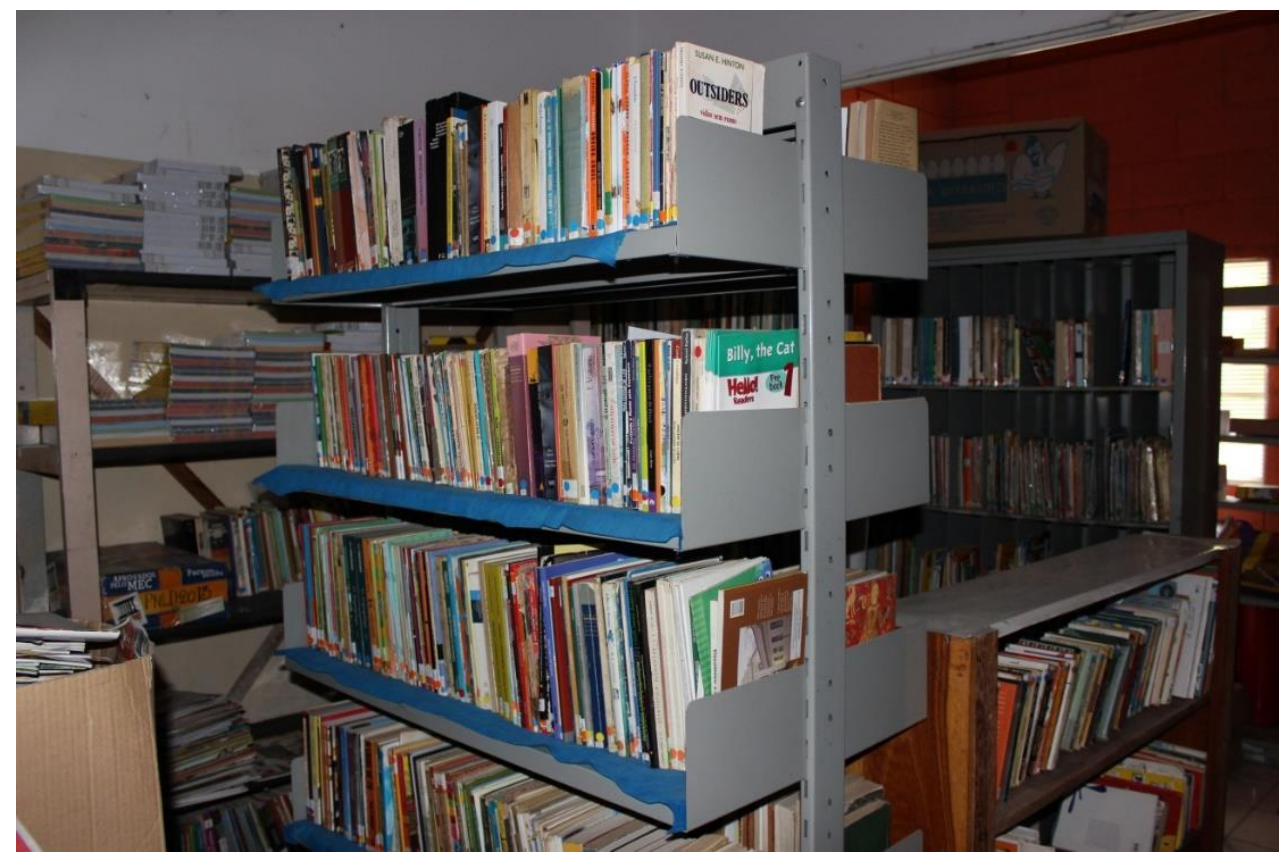

Figura 51 - Biblioteca da escola "G"

Fonte: Arquivo pessoal do autor

\subsection{Sala de leitura}

Em visita à escola observou-se a inexistência de sala de leitura.

\subsection{Alunos}

Em visita à escola constatou-se que o sistema de matrículas dos alunos é por zoneamento, ou seja, eles são matriculados na escola mais próxima de sua casa. Por residirem na área rural à 
maioria dos 893 matriculados na escola utilizam diariamente o transporte público para ir à escola.

\subsection{Docentes}

Com a visita à escola foi possível identificar as seguintes características referentes ao seu corpo docente:

Número de docentes para cada cem alunos: 5,00

Porcentagem de docentes pertencente ao sexo feminino: 78,77;

Porcentagem dos docentes que possuem magistério concluído: 4,79;

Porcentagem dos docentes que possuem o curso de licenciatura concluído: 65,07;

Porcentagem dos docentes que possuem o ensino superior concluído: 94,52;

Porcentagem dos docentes que possuem especialização concluída: 24,66.

\subsection{Funcionários}

Número de Funcionários para cada cem alunos: 6,83.

\subsubsection{Escola “C" eficiente e respectiva SME}

- Data da visita: $12 / 09 / 2014$

- Indicadores do município de São José dos Campos

$\mathbf{N}^{0}$ de Habitantes: 636.876

IDHM: 0,807

- Indicadores da escola C

Número de alunos: 975

Investimento anual por aluno: $\mathrm{R} \$ 8.363,81$

Nota no IDEB (Anos Finais): 6,29

Nível socioeconômico: 5 (Médio-Alto) 
Durante a visita realizada à escola "C", localizada no município de São José dos Campos no estado de São Paulo, foi possível identificar inúmeras práticas administrativas e pedagógicas que colaboraram para que, no ano de 2011, a escola obtivesse uma nota 6,29 no IDEB. A seguir são apresentados alguns dos principais aspectos mais relevantes que foram observados durante a visita à escola.

\subsection{Relatório de gestão e destinação dos recursos financeiros da SME}

\subsection{Constituição da SME}

Em visita à SME foi realizado uma entrevista com o Secretário de educação do município, a fim de identificar suas principais práticas de gestão. A Figura 52 nos mostra a fachada da SME do município de São José dos Campos-SP.

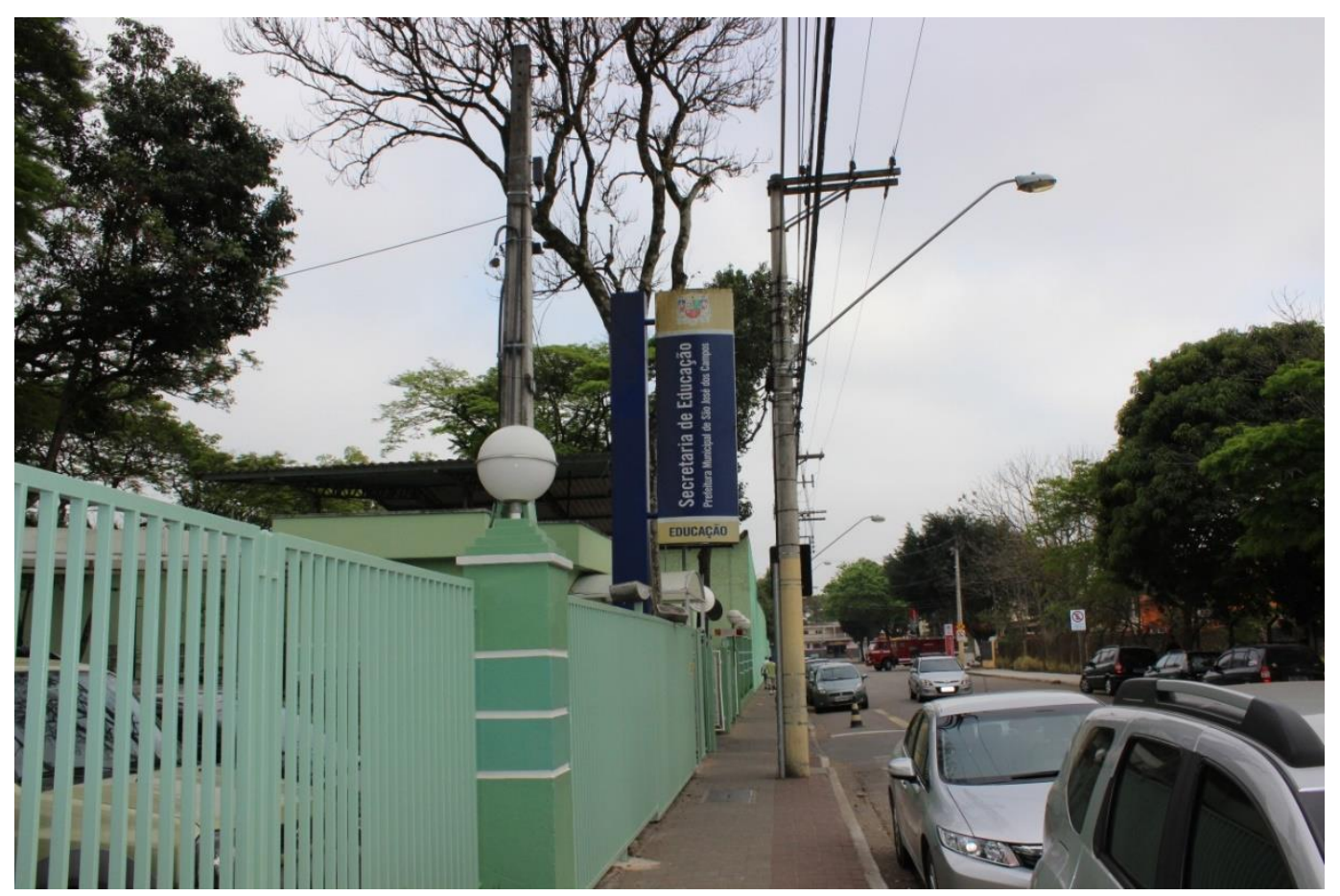

Figura 52 - Fachada da SME de São José dos Campos

Fonte: Arquivo pessoal do autor

Ao chegar à SME do município, foi possível identificar que ela possui conhecimento sobre o seu papel na oferta de uma educação de melhor qualidade, haja vista que logo na entrada existe uma placa destacando a missão da SME do município, conforme ilustrado pela Figura 53. 


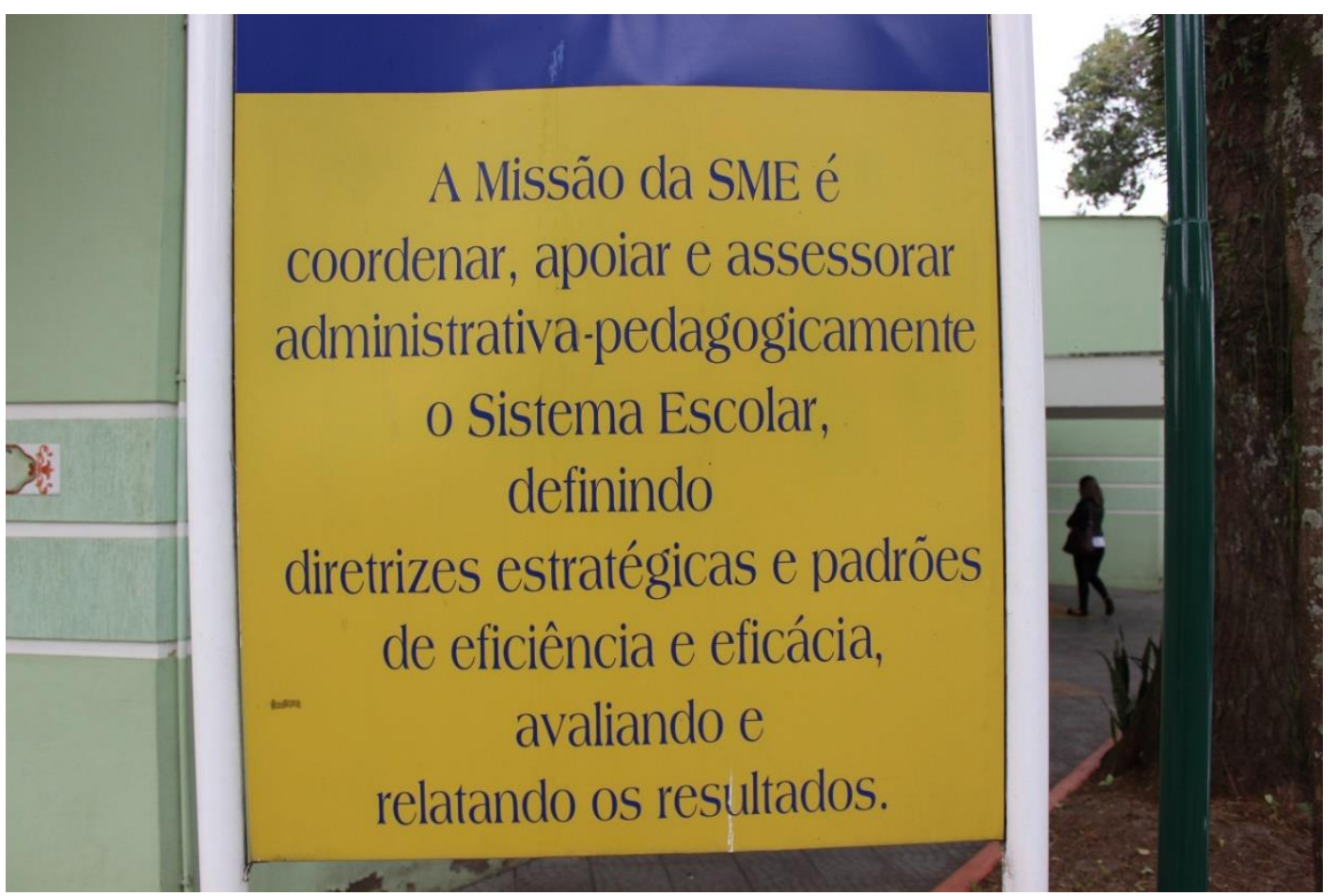

Figura 53 - Placa destacando a missão da SME

Fonte: Arquivo pessoal do autor

Em conversa com o Secretário de educação, observou-se que os colaboradores desta secretaria, salvo os chefes de divisão dos departamentos, que são nomeados por indicação política, são funcionários de carreira, tendo passado por um concurso para assumirem seus cargos. Além disso, a SME define como política do município que os Diretores sejam escolhidos por indicação política, contando ao final do processo com a aprovação do prefeito. Outro ponto a ser ressaltado é a formação dos funcionários da SME, pois a maioria deles possuem graduação em Matemática, Português e Pedagogia.

\subsection{Organização da SME}

Em visita à SME, observou-se em relação a sua governança, que os supervisores e chefes de divisões se reportam diretamente ao Secretário, que por sua vez, busca conciliar e mediar eventuais conflitos nas áreas. Não obstante, não foi encontrada uma área específica responsável pela Captação de Recursos, entretanto, constatou-se a existência de um departamento Administrativo-Financeiro, conforme ilustrado pela Figura 54, em que, segundo relato do Secretário, existe um funcionário encarregado de acompanhar as oportunidades de projetos estaduais ou federais que venham a surgir. 


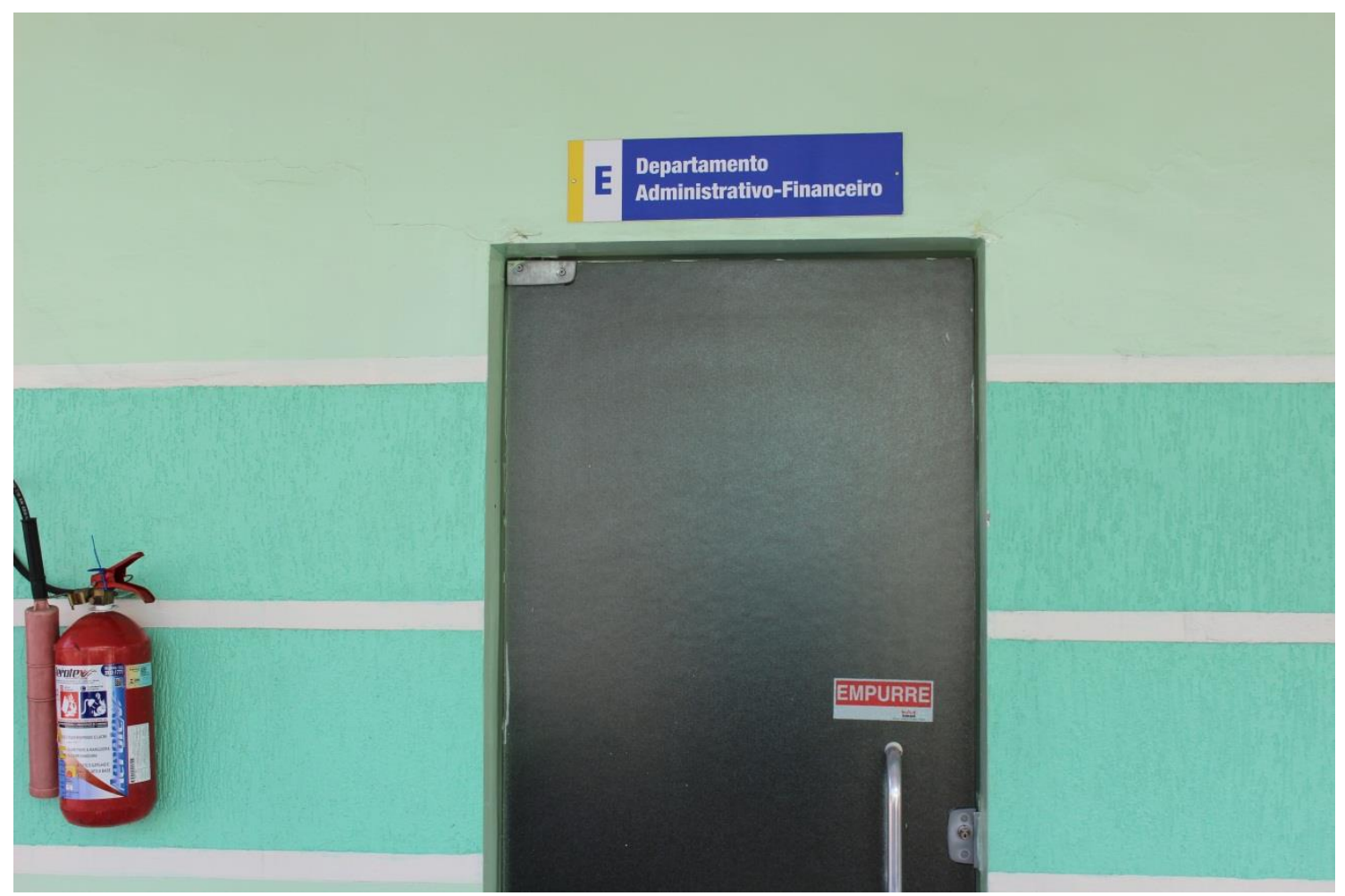

Figura 54 - Departamento Financeiro da SME de São José dos Campos Fonte: Arquivo pessoal do autor

Todavia, o Secretário acredita ser menos trabalhoso e melhor para a população que a demanda educacional seja atendida apenas com a utilização de recursos municipais, visto que, segundo ele, os programas ofertados pelo governo não se adequam ao nível de cobrança que existe em São José dos Campos, por causa da qualidade da estrutura fornecida pela SME para as escolas nos últimos anos (computadores e projetores de última geração).

Durante a visita à SME também foi possível observar sua organização, pois conforme ilustrado pela Figura 55, ela é dividida em departamentos específicos que atendem a várias necessidades administrativo-pedagógicas da educação. 

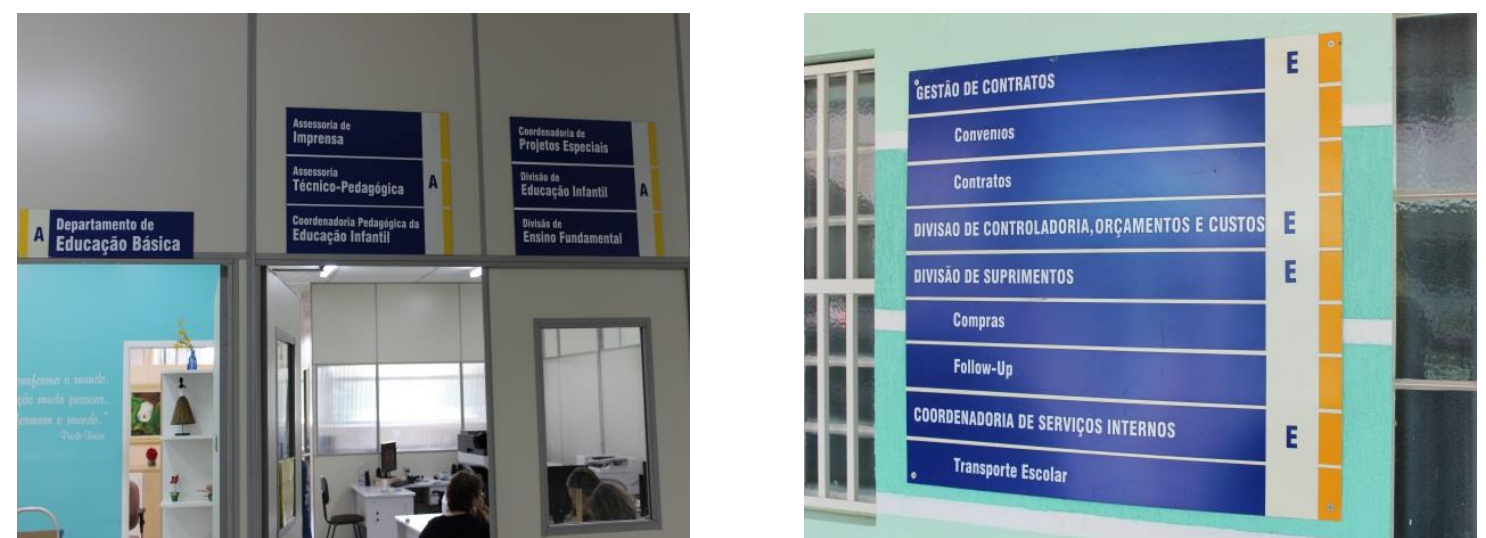

Figura 55 - Organização da SME de São José dos Campos

Fonte: Arquivo pessoal do autor

\subsection{Secretário}

Em entrevista com o Secretário, observou-se que ele possui formação em História e não possui nenhum curso complementar em gestão. Entretanto, de acordo com ele existe uma portaria no município que regula o cargo e não exige nenhum pré-requisito para se tornar Secretário municipal de educação. O Secretário, por sua vez, tem autonomia para criação de políticas educacionais, desde que não interfira no que o Estatuto da Educação do município regula. Ademais, observou-se que o Secretário tem uma boa análise crítica da situação do município no que concerne aos principais desafios da educação. Não obstante, a autonomia financeira do Secretário mostrou-se relevante, visto que este está implantando um novo programa na área tecnológica com a aquisição de tablets para os alunos da rede, além de ter também uma folga para utilizar os recursos centralizados da maneira que julgar conveniente desde que atenda uma macro área estipulada previamente pelo governo.

\subsection{Capacidade da SME na captação de recursos financeiros}

Em visita à SME, observou-se que não existem recursos provenientes de projetos federais e/ou estaduais que foram articulados e angariados pelo Secretário e sua equipe para possíveis investimentos no município, pois segundo o Secretário, os recursos e programas repassados pelo governo não se mostram interessantes para a realidade financeira do município, que tem muitos recursos provenientes da industrialização da região. Ademais, em algumas ocasiões o Secretário demonstrou pró-atividade na realização de parcerias com empresas privadas localizadas no município, entretanto, a SME não recebeu nenhum recurso da APM. Além 
disso, observou-se que o Secretário possui um bom grau de conhecimento sobre os principais indicadores financeiros municipais, como o investimento anual por aluno.

\subsection{Destinação do recurso financeiro descentralizado e centralizado}

Em conversa com o Secretário, verificou-se que a destinação dos recursos se dá majoritariamente para folha de pagamento, uma vez que existe o oferecimento de planos de aposentadoria integral, progressão salarial conforme a realização de cursos e outros benefícios para os Professores aprimorarem seu conhecimento e melhorarem o ensino da rede. Por outro lado, os recursos destinados à escola para reparos emergências, bem como aqueles destinados ao transporte dos alunos, não são considerados relevantes.

\subsection{Transição de novo Secretário e nova equipe}

Em entrevista com o Secretário, observou-se que a maior parte dos colaboradores, por serem concursados, não é substituída conforme novas gestões são eleitas, apenas os chefes de divisões são passivos de substituição na secretaria por indicação política.

\subsection{Critério para matrícula de alunos}

Em entrevista com o secretário, observou-se que o critério adotado para a matrícula dos alunos é por zoneamento.

\subsection{Ensino fundamental ofertado exclusivamente pela rede pública}

Segundo o Secretário municipal de educação, o ensino fundamental não é exclusivo da rede pública, haja vista que existem inúmeras escolas particulares na cidade.

\subsection{Informações adicionais}

Em visita à secretaria, constatou-se a existência de quarenta e três escolas urbanas e nenhuma escola rural no município. Ademais, não existe uma política de progressão continuada, no entanto, o município adota o sistema de reprovação por ciclos (o aluno pode reprovar apenas 
no terceiro, quinto, sétimo e nono ano). Já no caso de incentivos, observou-se que a SME apoia a participação dos alunos em Olimpíadas, oferecendo transporte e lanches durante a realização desses eventos. Todavia, não há um conhecimento por parte da secretaria sobre a porcentagem de recursos destinados à Educação que são direcionados para folha de pagamento dos Professores, mas segundo o Secretário, após um estudo, observou-se que não seria possível manter mais o sistema de benefícios adotados para os Professores, que inclui entre outros, a aposentadoria com salário integral. Deste modo, segundo o Secretário, desde o fim da última gestão foi criado um novo plano de carreira para a rede municipal, que por sua vez não agradou os Professores das escolas visitadas, que afirmam que esse novo plano não torna a carreira atrativa da maneira como era vista até então, além de estar dificultando a contratação de novos profissionais.

\subsection{Relatório de gestão e destinação dos recursos financeiros do Diretor}

\subsection{Especificidades do município pequeno}

Em visita realizada à escola $\mathrm{C}$, conforme ilustrado pela Figura 56, observou-se em conversa com a Diretora que a cobrança da comunidade é, em sua visão, maior em cidades pequenas, mas que ainda assim, em uma cidade do porte de São José dos Campos, a cobrança também existe, pois quando o Diretor ou o Professor reside no mesmo bairro da escola ocorre uma maior aproximação e convívio com a família dos alunos, uma vez que os alunos são matriculados prioritariamente por zonas de abrangência (zoneamento). De acordo com a Diretora esse contato ocorre em inúmeros lugares como: supermercados, padarias, bares etc. Ainda segundo a Diretora, a comunidade desta escola tem frequência assídua nas reuniões com os Professores, nas festividades e outros eventos realizados pela escola, o que torna o convívio um facilitador para os alunos que se sentem também na obrigação de cumprir seus deveres. 


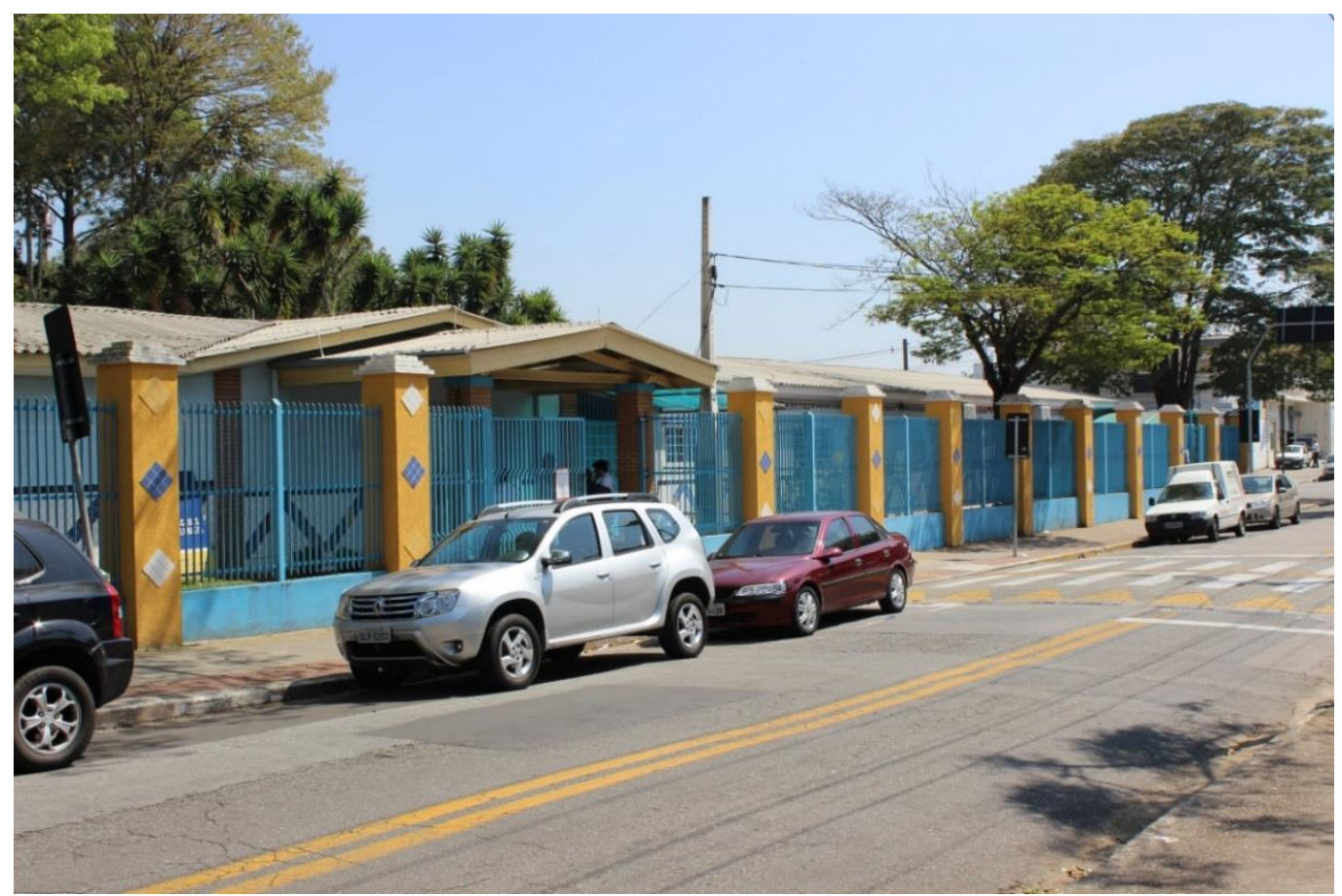

Figura 56 - Fachada da escola "C"

Fonte: Arquivo pessoal do autor

\subsection{Alimentação dos alunos}

Em conversa com os alunos e a Diretora da escola, observou-se que é oferecida uma refeição por período aos alunos. O cardápio da escola é elaborado por uma nutricionista e é apreciado pelos alunos, que afirmam que a qualidade da comida é excelente e o cardápio possui alta variedade de alimentos. Observou-se também que a escola possui um refeitório adequado para os alunos se alimentaram, conforme nos mostra a Figura 57.
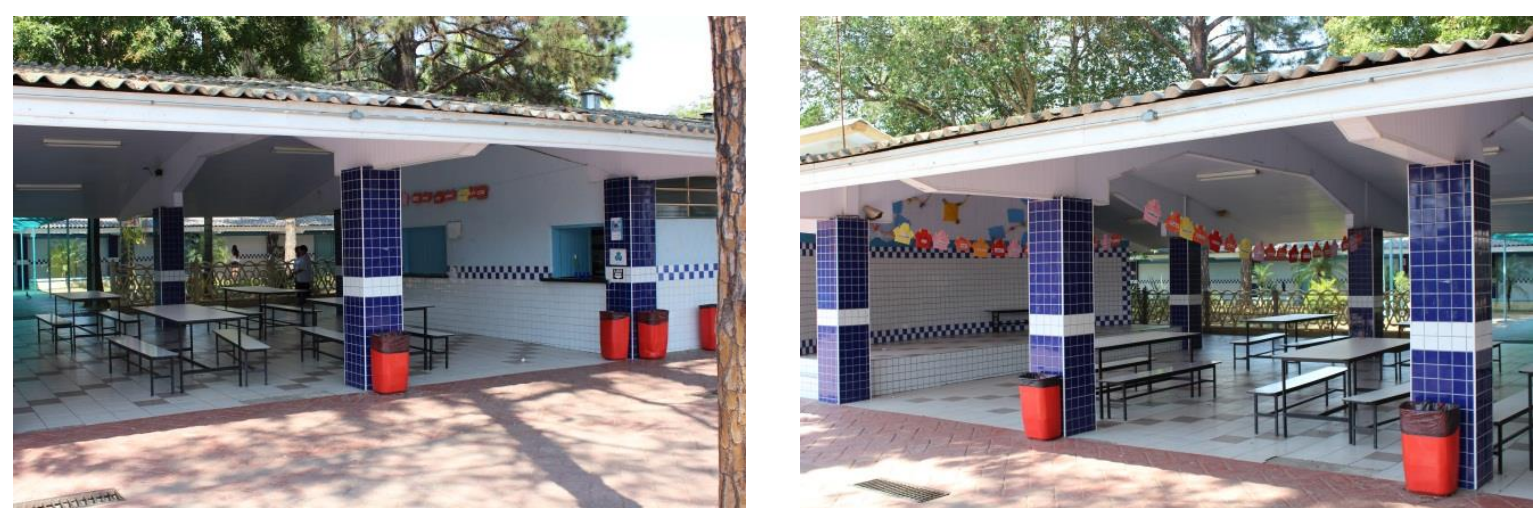

Figura 57 - Refeitório da escola "C"

Fonte: Arquivo pessoal do autor 
Além disso, foi observado, de acordo com a Figura 58, o cultivo de uma horta por parte dos alunos, que segundo a Diretora, tem a finalidade de ensinar os alunos a conhecer e cultivar os alimentos, que posteriormente irá servir para o consumo dos próprios alunos.

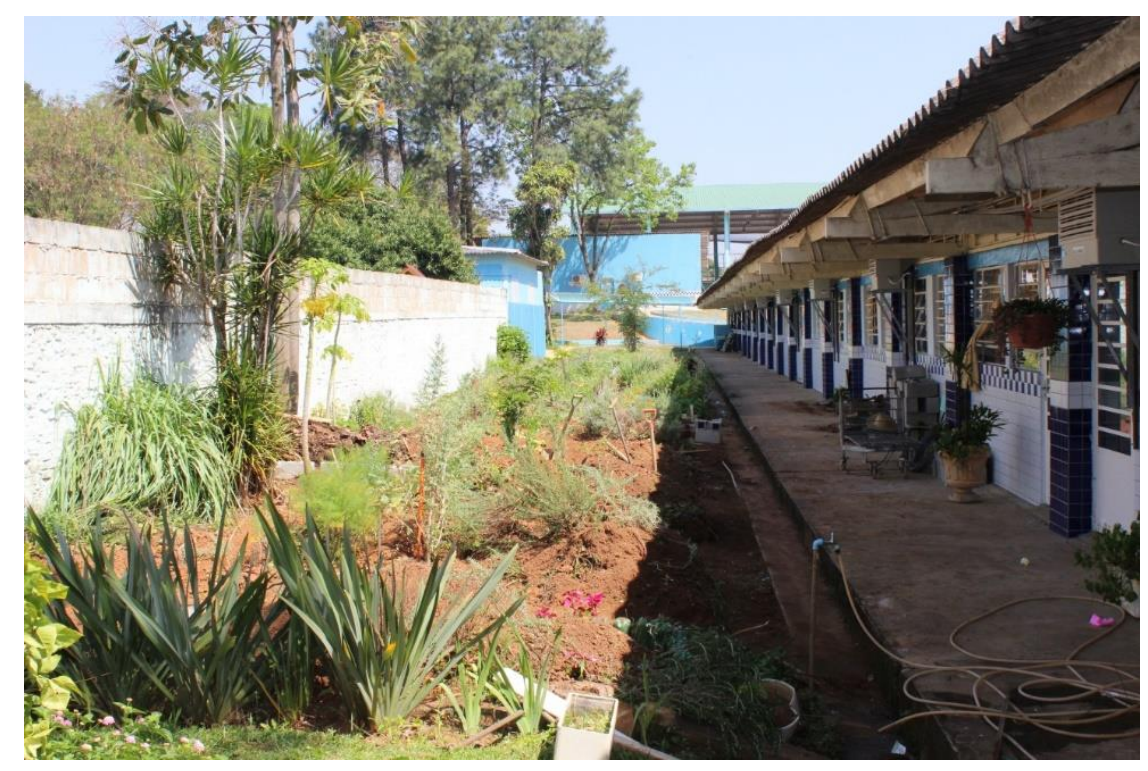

Figura 58 - Horta cultivada pelos alunos da escola "C"

Fonte: Arquivo pessoal do autor

\subsection{Processo seletivo}

Em conversa com a Diretora, observou-se que não existe processo seletivo para entrar na escola e não existe também a transferência compulsória por causa de reprovações em disciplinas. Por outro lado, a escola parou de receber alunos por transferência em decorrência da grande demanda de novos alunos que desejam transferir da rede estadual e de outras escolas municipais, ocasionando em salas de aula totalmente completas. Este fenômeno, segundo relato de diversos entrevistados (Professores, alunos, Diretor e pais de alunos), ocorre devido ao grande reconhecimento que a escola tem de sua infraestrutura, qualidade do corpo docente e seus bons resultados em avaliações externas.

\subsection{Diretor}

Em conversa com a Diretora que atuava no ano de 2011, constatou-se que esta tem formação em Ciências Sociais e Educação Física, juntamente com uma pós-graduação, tendo assumido o cargo por indicação política. Nesta escola, verificou-se também uma baixa autonomia do 
Diretor para decisões financeiras, uma vez que todos os recursos que chegam até ela já têm um destino previamente selecionado, mas com folga para selecionar os itens que são pertinentes no momento para a escola.

Durante a visita à escola foi possível observar que a Diretora possui uma postura proativa, sempre buscando motivar os Professores a ensinar, a Figura 59 nos mostra um quadro com uma frase de incentivo que ela colocou na sala dos Professores.

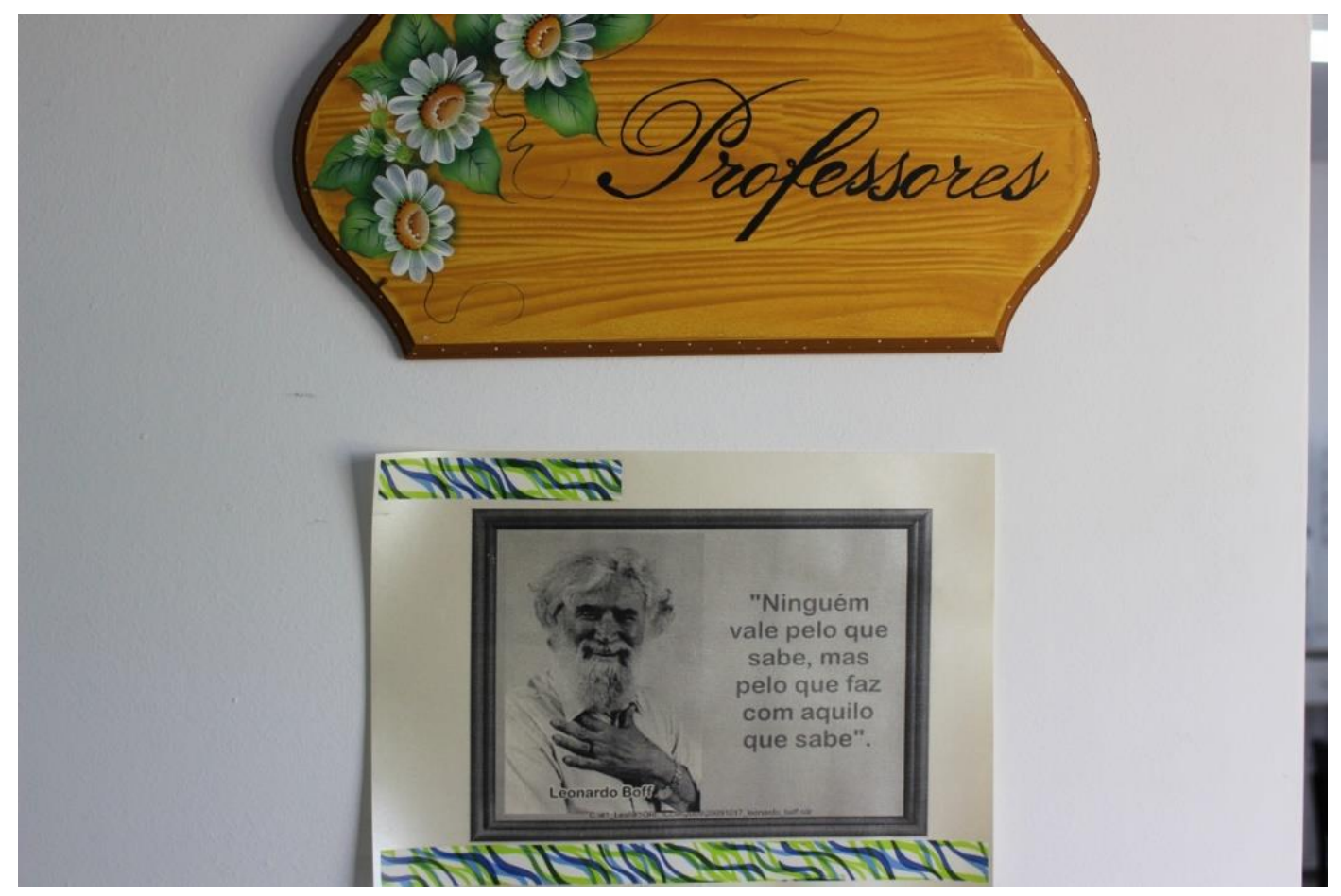

Figura 59 - Frase de incentivo aos Professores

Fonte: Arquivo pessoal do autor

A Diretora também busca criar bons hábitos nos alunos, como a reciclagem. Um exemplo desses hábitos foi a colocação de um cesto na escola para que os alunos possam reciclar as latas de alumínio, conforme ilustrado pela Figura 60. 


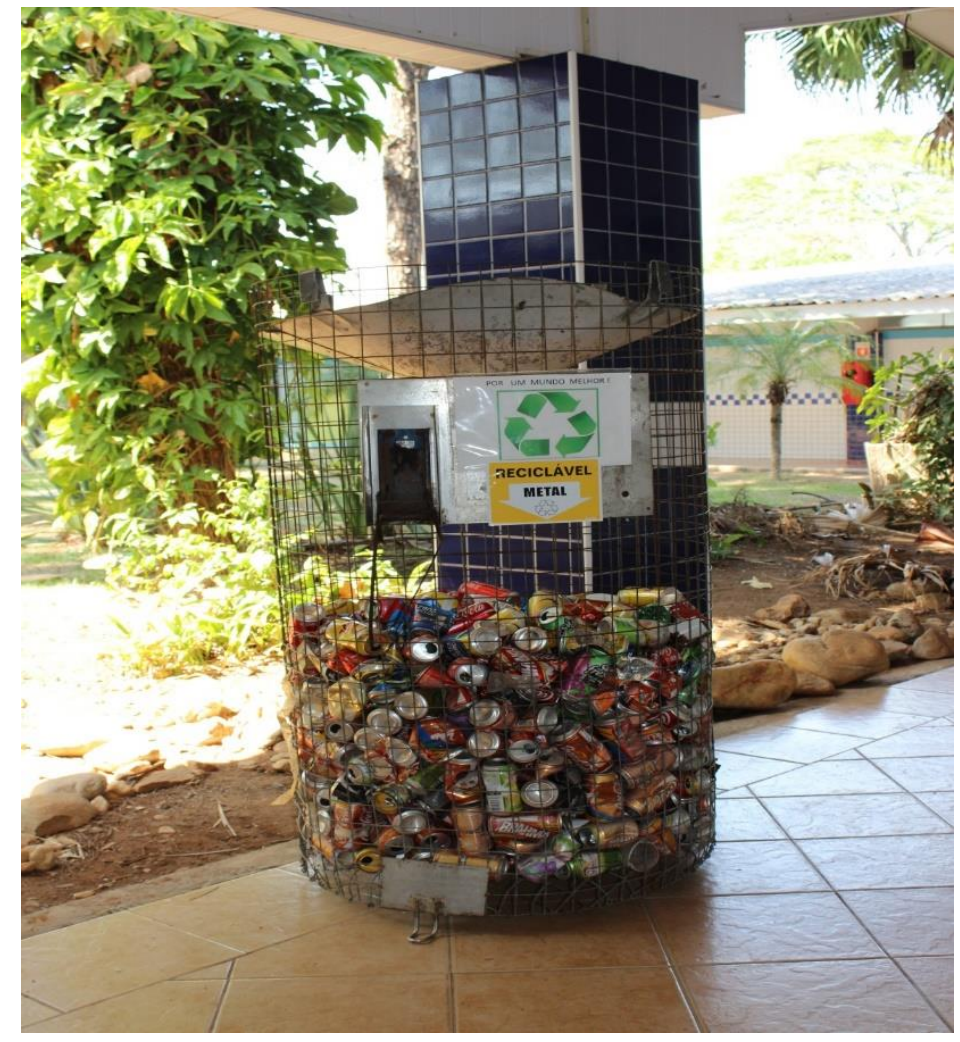

Figura 60 - Cesto para reciclagem de alumínio

Fonte: Arquivo pessoal do autor

Outra forma de criar bons hábitos entre os alunos foi por meio da fixação de cartazes em vários pontos da escola incentivando a reciclagem, conforme apresenta a Figura 61.

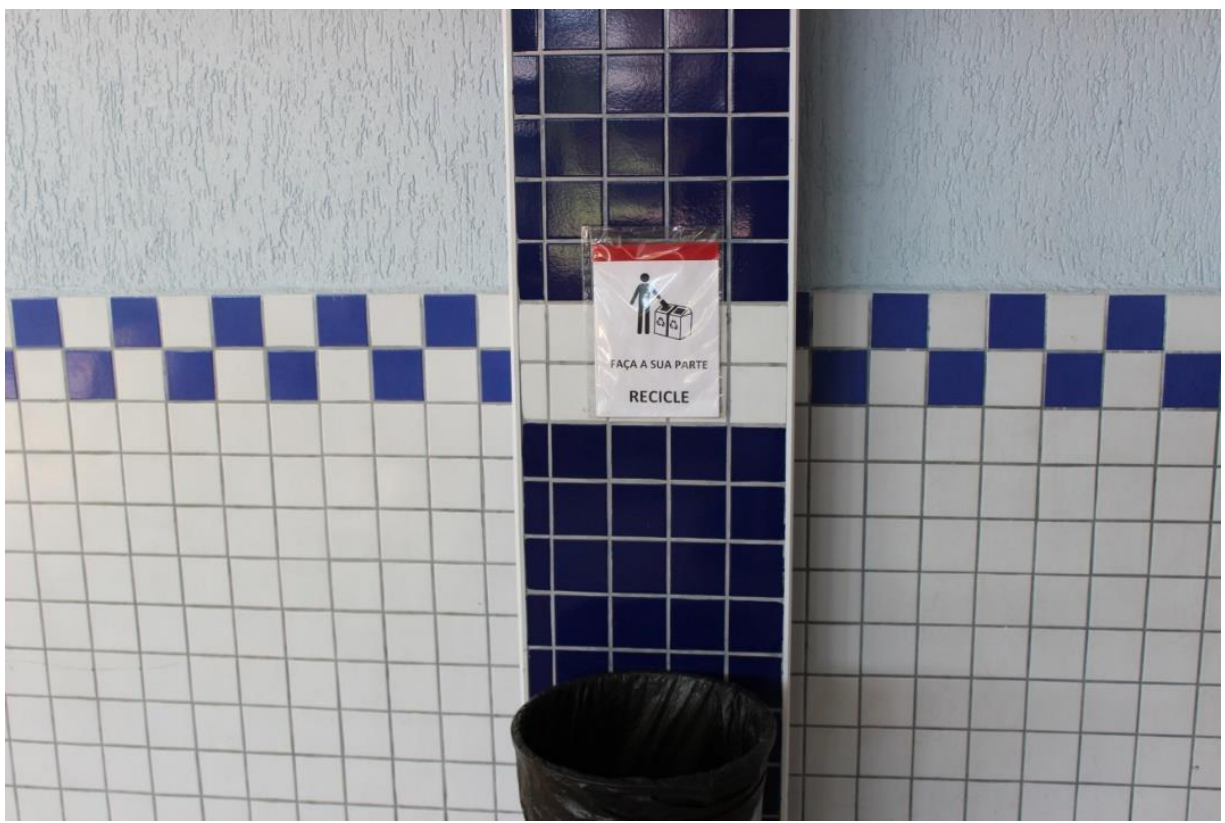

Figura 61 - Cartaz incentivando os alunos a reciclarem Fonte: Arquivo pessoal do autor 


\subsection{Plano de carreira do Diretor}

Em entrevista com a Diretora e com os Professores, observou-se que o salário do Diretor não é visto como compatível com o cargo que exerce caso não existisse o plano de carreira, que não é mais implantado no município para a rede municipal desde o fim da gestão anterior a secretaria atual, uma vez que a diferença salarial é irrelevante e o aumento de responsabilidades e carga horária não é proporcional. No caso desta escola, a Diretora relatou que atua neste cargo pelo incentivo de realização pessoal no que faz, uma vez que busca auxiliar na formação de jovens e dar-lhes opções de melhorarem suas vidas, e por estar na rede há mais de vinte anos, o que ocasionou um salário atrativo, ainda que exercendo o cargo de Diretor.

\subsection{Capacidade do Diretor na captação de recursos financeiros}

Durante entrevista realizada com a Diretora, observou-se que ela atua apenas em alguns momentos para realizar captação de recursos para a escola. Além das fontes convencionais que são repassadas pelos órgãos federais, estaduais e municipais, ela busca recursos na realização de eventos festivos como a festa junina e na cantina, o que lhe proporciona uma arrecadação média superior a $\mathrm{R} \$ 2.000,00$ por mês. Esse recurso reflete na boa infraestrutura da escola e nos acervos disponíveis na biblioteca.

\subsection{Destinação do recurso financeiro descentralizado e centralizado}

Em visita à escola e entrevista com o Diretor, observou-se que os recursos financeiros centralizados e suas respectivas destinações não são monitorados quantitativamente para que seja possível mensurar o quanto é investido em cada item listado (equipamentos de consumo, permanente, materiais escolares etc.). Dessa maneira, desconsiderando os recursos que a Diretora arrecada por meio de festividades e da cantina, os recursos são captados e utilizados apenas quando o Diretor se dispõe a elaborar requerimentos com os itens que a escola está necessitando. Posteriormente esses requerimentos são encaminhados para a Secretária Municipal de Educação que irá analisá-los, podendo eles ser deferidos ou não. Entretanto, durante a visita foi possível identificar o alto volume de investimento feito pela SME na escola, o que reflete na excelente infraestrutura que a escola possui atualmente, com salas de 
aula limpas, cadeiras e carteiras em ótimo estado de conservação, além de possuir climatizador de ar em todas as salas, conforme ilustrado pela Figura 62.

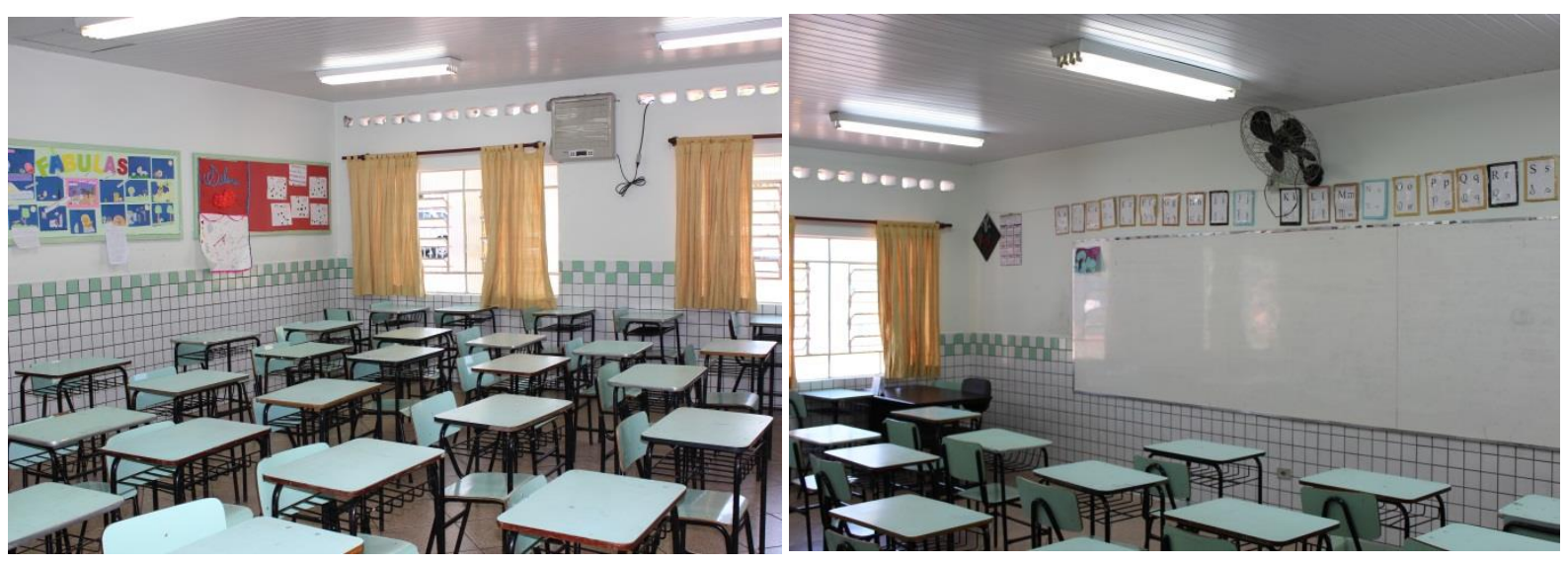

Figura 62 - Salas de aula da escola "C"

Fonte: Arquivo pessoal do autor

A escola também possui um consultório odontológico em funcionamento, com dentistas disponíveis a atender os alunos duas vezes na semana, conforme nos mostra a Figura 63.

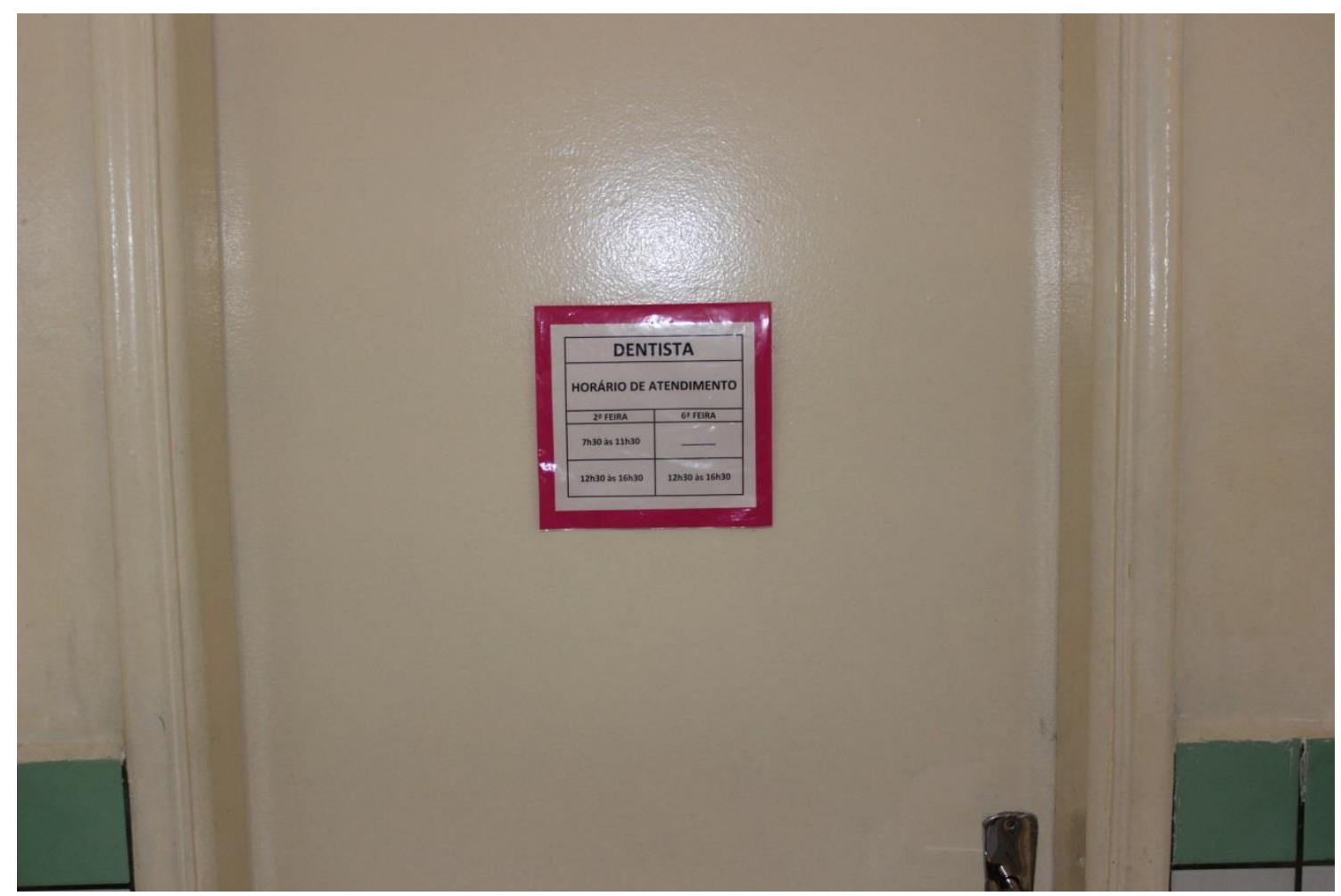

Figura 63 - Consultório odontológico da escola "C"

Fonte: Arquivo pessoal do autor

Também se constatou que ela possui uma quadra de esporte coberta, conforme a Figura 64, um parquinho de diversão, conforme Figura 65, e uma piscina disponível para uso dos alunos 
durante as aulas de educação física, conforme ilustrado pela Figura 66. A quadra de esporte é apresentada na figura a seguir.

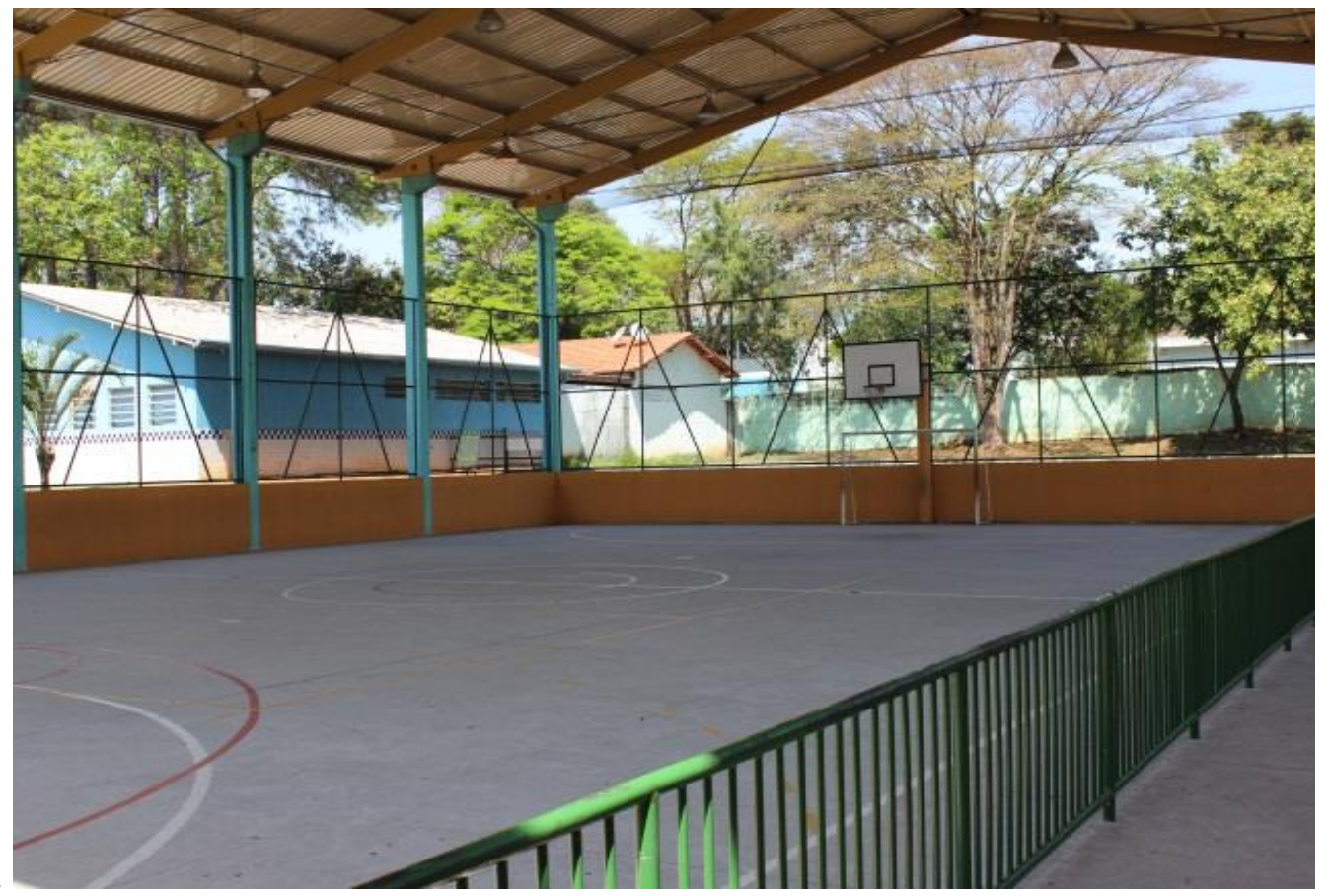

Figura 64 - Quadra de esportes da escola "C"

Fonte: Arquivo pessoal do autor

O parquinho de diversão é apresentado na Figura 65.

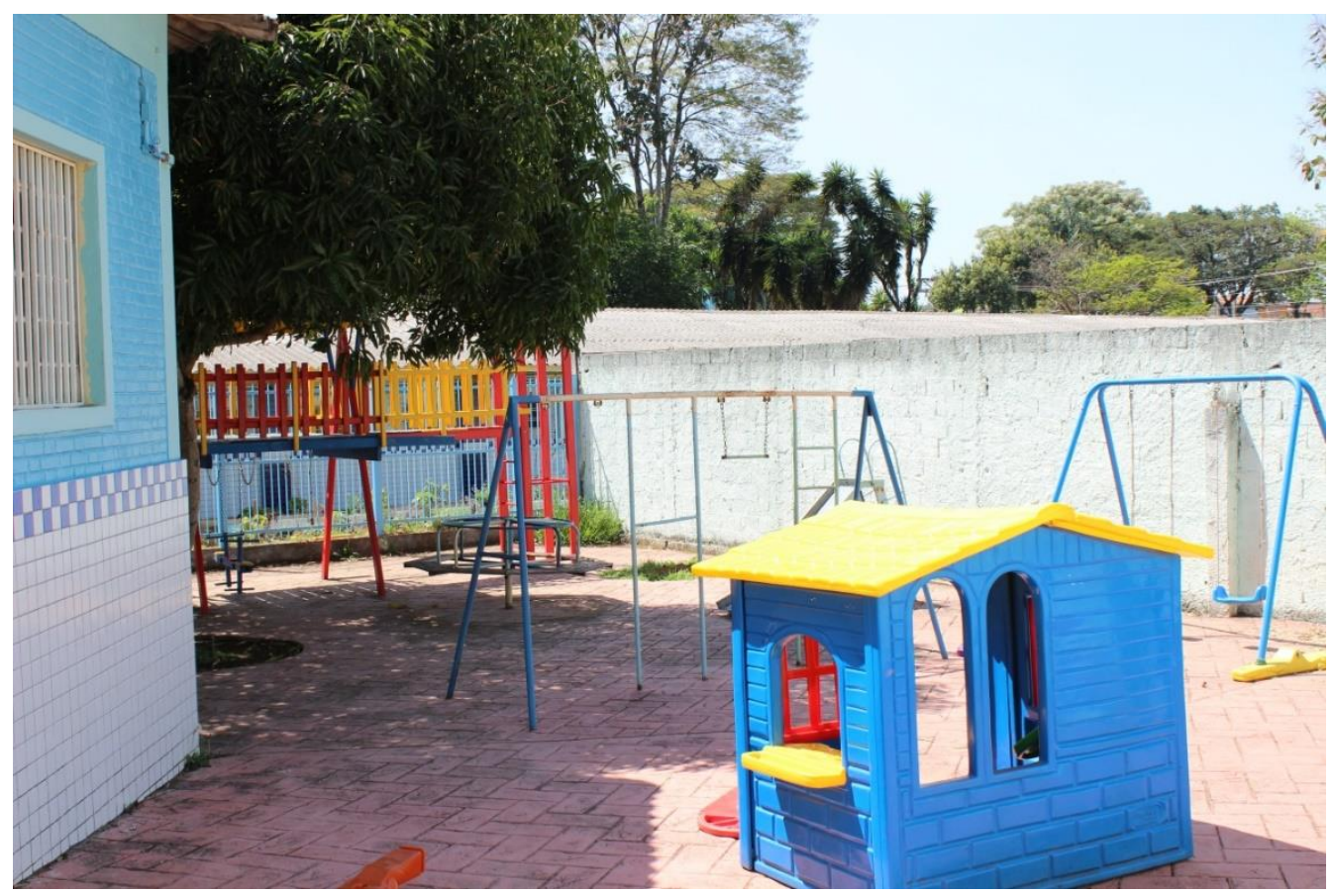

Figura 65 - Parquinho de diversão da escola "C"

Fonte: Arquivo pessoal do autor 
A piscina da escola "C" é apresentada na Figura 66.

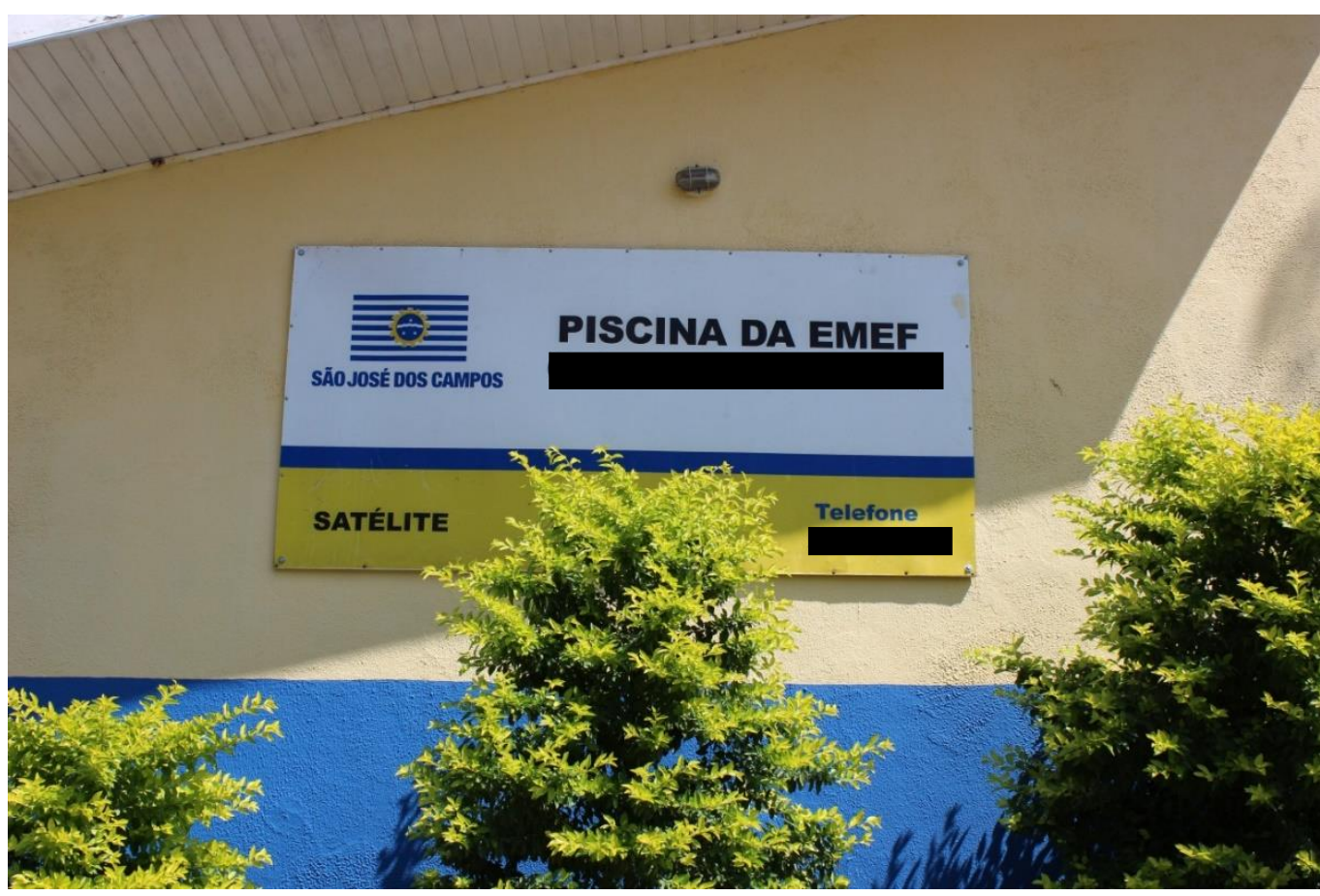

Figura 66 - Piscina da escola "C"

Fonte: Arquivo pessoal do autor

A escola também possui uma marcenaria, conforme nos mostra a Figura 67, em ótimo estado de uso e com inúmeras ferramentas. De acordo com a Diretora, os alunos possuem aulas semanais de marcenaria nessa oficina da escola com a finalidade de desenvolver suas habilidades criativas.
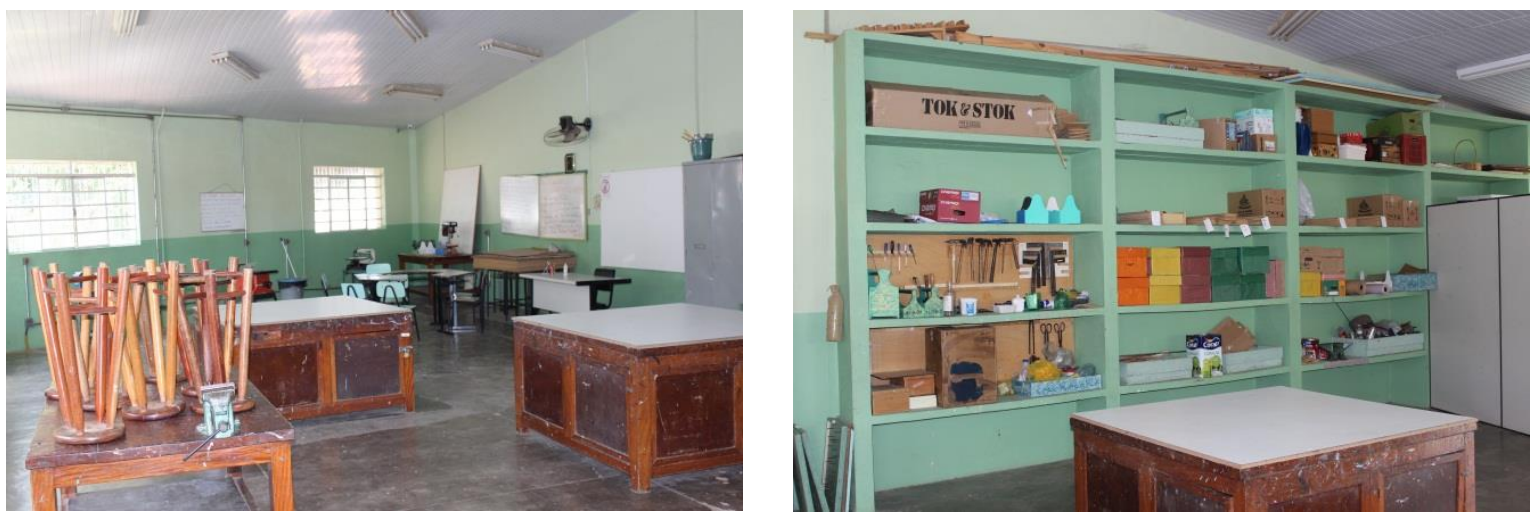

Figura 67 - Marcenaria da escola "C"

Fonte: Arquivo pessoal do autor 


\subsection{Relatório pedagógico e socioeconômico}

\subsection{Desempenho na prova de português}

Em entrevista realizada com a docente responsável pela disciplina de português, observou-se que ela está na instituição há 11 anos (o que indica uma baixa rotatividade de docentes nessa disciplina) e tem plena autonomia para a realização de atividades, assim como na forma de avaliação.

Uma vez por semana todas as salas passam 50 minutos na sala de leitura, onde os alunos costumam retirar algum livro para levar para ler em casa, tal ação contribui para o bom índice de leitura dos alunos, segundo a Professora algo em torno de $99 \%$ dos alunos retirava livros quase que semanalmente em 2011.

Em relação à escolha do material didático, a SME fornece uma lista com as opções e os docentes escolhem aquela que acreditam ser de melhor qualidade. Via de regra, sempre chega o material que foi solicitado por cada escola, dessa forma, não há um material padrão utilizado na rede e o mesmo é substituído a cada eleição. Além desse material, a docente tem autonomia para complementar as aulas com material próprio.

Outro ponto relevante diz respeito ao acompanhamento do desempenho dos alunos, o mesmo ocorre diariamente no qual a Professora passa de carteira em carteira verificando o desenvolvimento do aluno. De acordo com a Professora, também são feitos trabalhos em grupo com temas atuais e existe o laboratório para alunos com dificuldades no aprendizado, além da sala de recuperação intensiva onde ocorre o reforço e recuperação no contraturno. A Figura 68 nos mostra a sala de recuperação intensiva da escola C. 


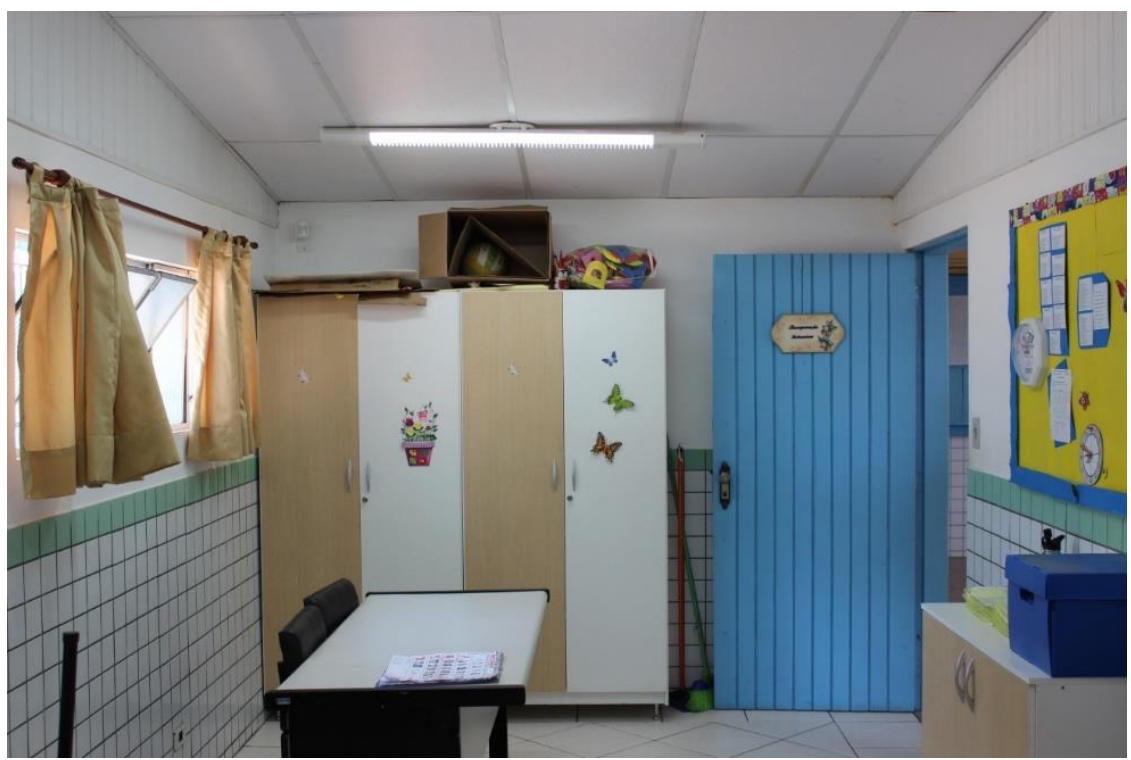

Figura 68 - Sala de recuperação intensiva da escola "C" Fonte: Arquivo pessoal do autor

Caso o discente falte dois dias consecutivos na escola, a direção entra em contato com os pais para saber o que está ocorrendo. Percebe-se um comportamento disciplinado por parte dos alunos e um comprometimento com sua própria aprendizagem, isso reflete no nível de participação dos alunos em projetos incentivados pela escola como Olimpíada Brasileira de Astronomia, Concurso de Redação e Desenho. A Figura 69 nos mostra os cartazes de incentivo a participação em olímpiadas e concursos realizados pela escola.

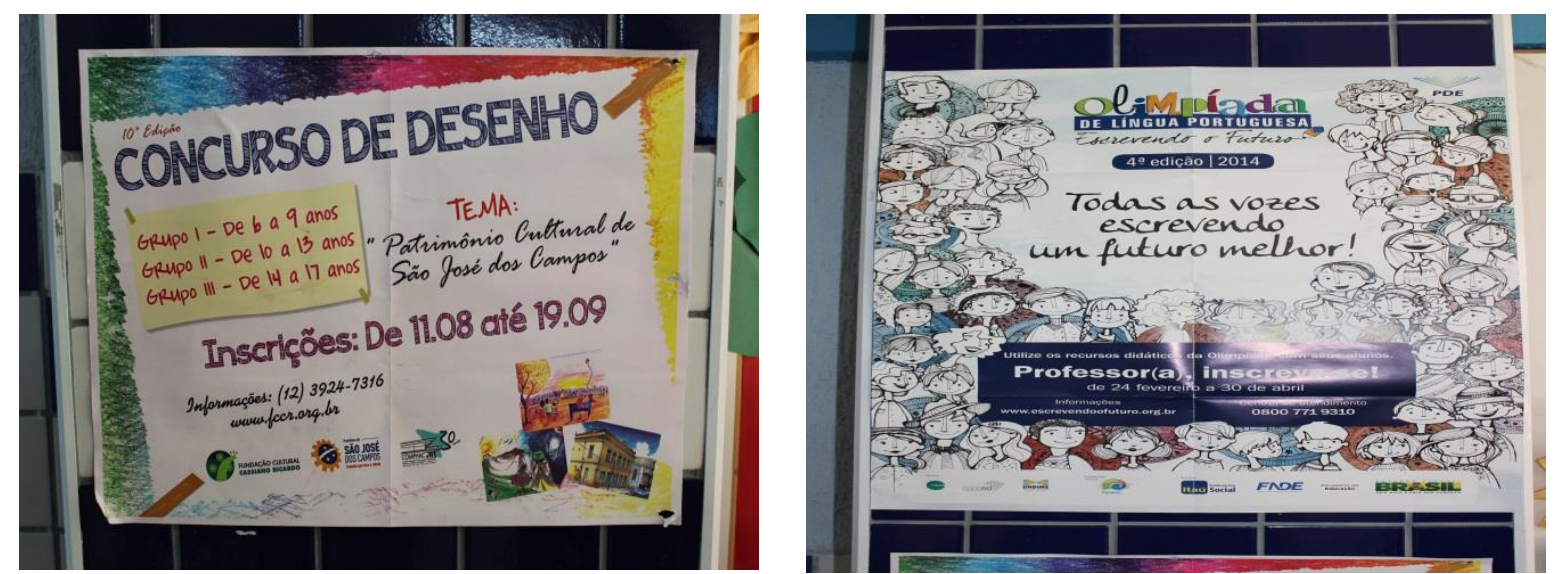

Figura 69 - Cartazes incentivando a participação dos alunos em olimpíadas e concursos Fonte: Arquivo pessoal do autor

Segundo a docente entrevistada, com a aproximação da Prova Brasil, são realizados inúmeros simulados para que os alunos pratiquem, com questões no padrão das que são exigidas na avaliação. 


\subsection{Desempenho na prova de matemática}

A docente está na instituição há 15 anos (o que indica uma baixa rotatividade de docentes nessa disciplina) e tem plena autonomia para a realização de atividades. Neste ano, o tema principal abordado foi a Copa do Mundo, de forma que os alunos tinham que aplicar conceitos de perímetro, área, ângulos numa figura que ilustrava um campo de futebol.

Em relação a escolha do material didático a SME fornece uma lista com as opções e os docentes escolhem aquela que acreditam ser de melhor qualidade. Via de regra, sempre chega o material que foi solicitado pelos docentes de cada escola, dessa forma, não há um material padrão utilizado na rede e o mesmo é substituído a cada eleição. Além desse material, a docente tem autonomia para complementar as aulas com material próprio.

Outro ponto relevante diz respeito ao acompanhamento do desempenho dos alunos, o mesmo ocorre diariamente no qual a Professora passa de carteira em carteira verificando o desenvolvimento do aluno. De acordo com a docente entrevistada, também são feitos trabalhos em grupo sempre abordando temas atuais que despertam o interesse dos alunos. A docente ainda destaca a existência de um laboratório para alunos com dificuldades no aprendizado, além da sala de recuperação intensiva onde ocorre o reforço e recuperação no contraturno.

Caso o discente falte dois dias consecutivos na escola, a direção entra em contato com os pais para saber o que está ocorrendo. Percebe-se um comportamento disciplinado por parte dos alunos e a sua participação em projetos incentivados pela escola como a Olimpíada de Matemática, clubes de matemática e o concurso de tabuada vanguarda, no qual a escola foi a campeã no ano de 2013. A Figura 70 nos mostra os inúmeros incentivos feitos pela escola aos alunos em eventos relacionados à matemática. 

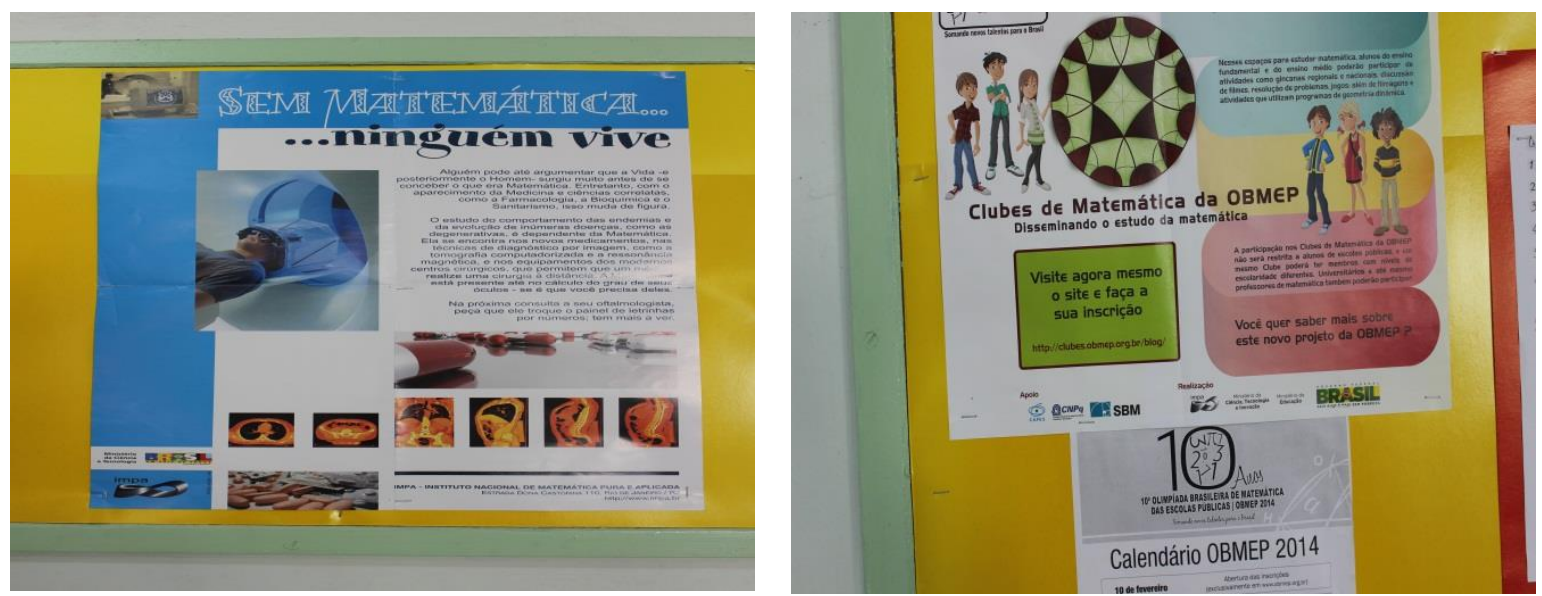

Figura 70 - Cartazes incentivando a participação dos alunos em eventos de matemática Fonte: Arquivo pessoal do autor

A Figura 71 apresenta o troféu de tabuada vanguarda, conquistado pela escola.

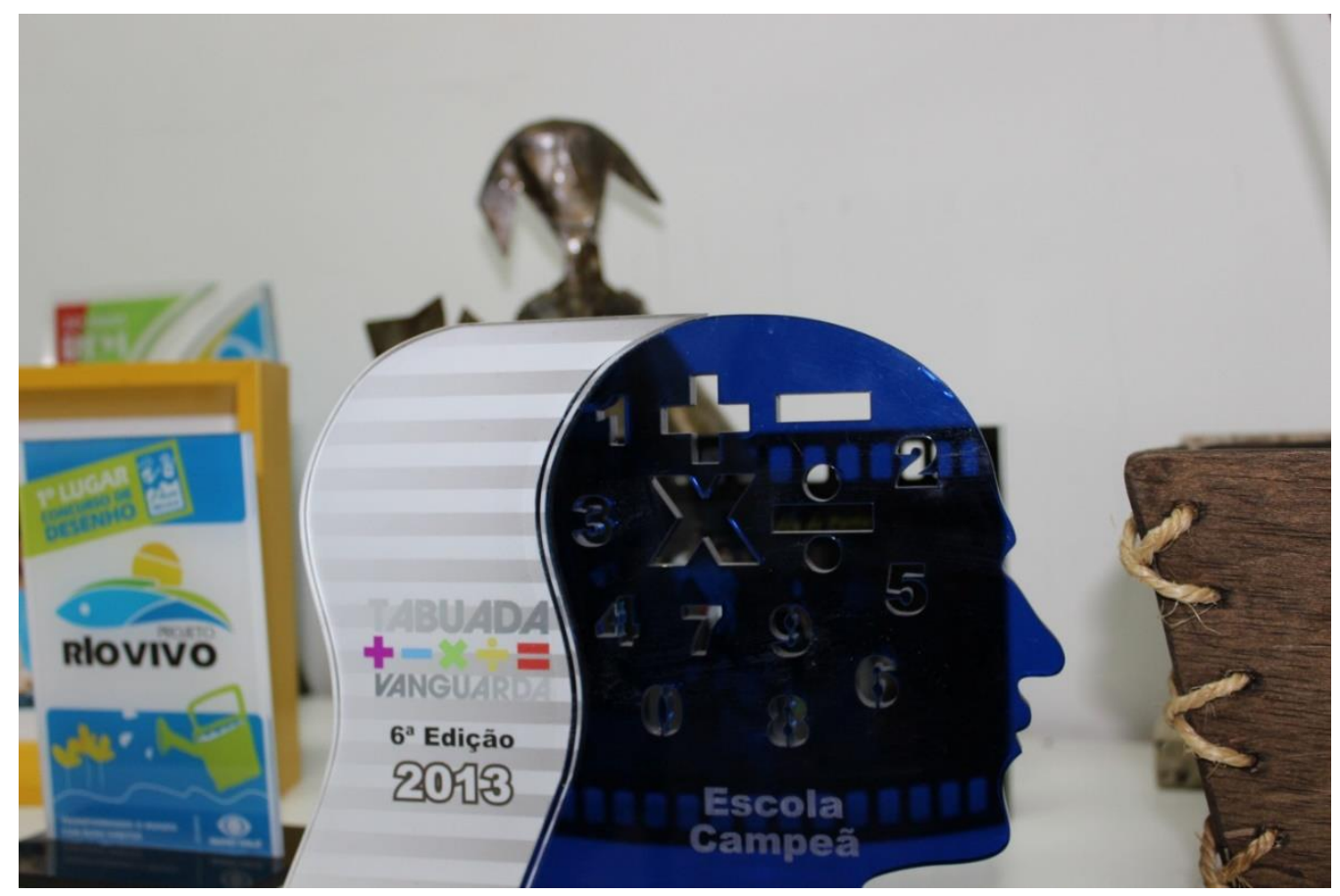

Figura 71 - Troféu de tabuada vanguarda conquistado pelos alunos da escola Fonte: Arquivo pessoal do autor

Segundo a docente entrevistada, com a aproximação da Prova Brasil são aplicados vários simulados para que os alunos pratiquem com questões no padrão das que são exigidas na avaliação. A docente ainda destaca como sendo um dos fatores fundamentais para o bom desempenho dos alunos a união dos Professores da rede municipal que realizam uma vez por mês um encontro dos profissionais da disciplina, no qual são discutidas práticas pedagógicas que foram testadas e deram resultado positivo. 


\subsection{Participação da família}

Em visita à escola notou-se que os pais participam intensamente na vida escolar dos filhos, essa participação é concretizada pelo acompanhamento diário nos deveres escolares e frequência assídua nas reuniões e eventos festivos realizados pela escola, bem como a participação, juntamente com a escola, em campanha de arrecadação de produtos alimentícios e de higiene pessoal, que tem como finalidade a doação para instituições de caridade, conforme ilustrado pela Figura 72.

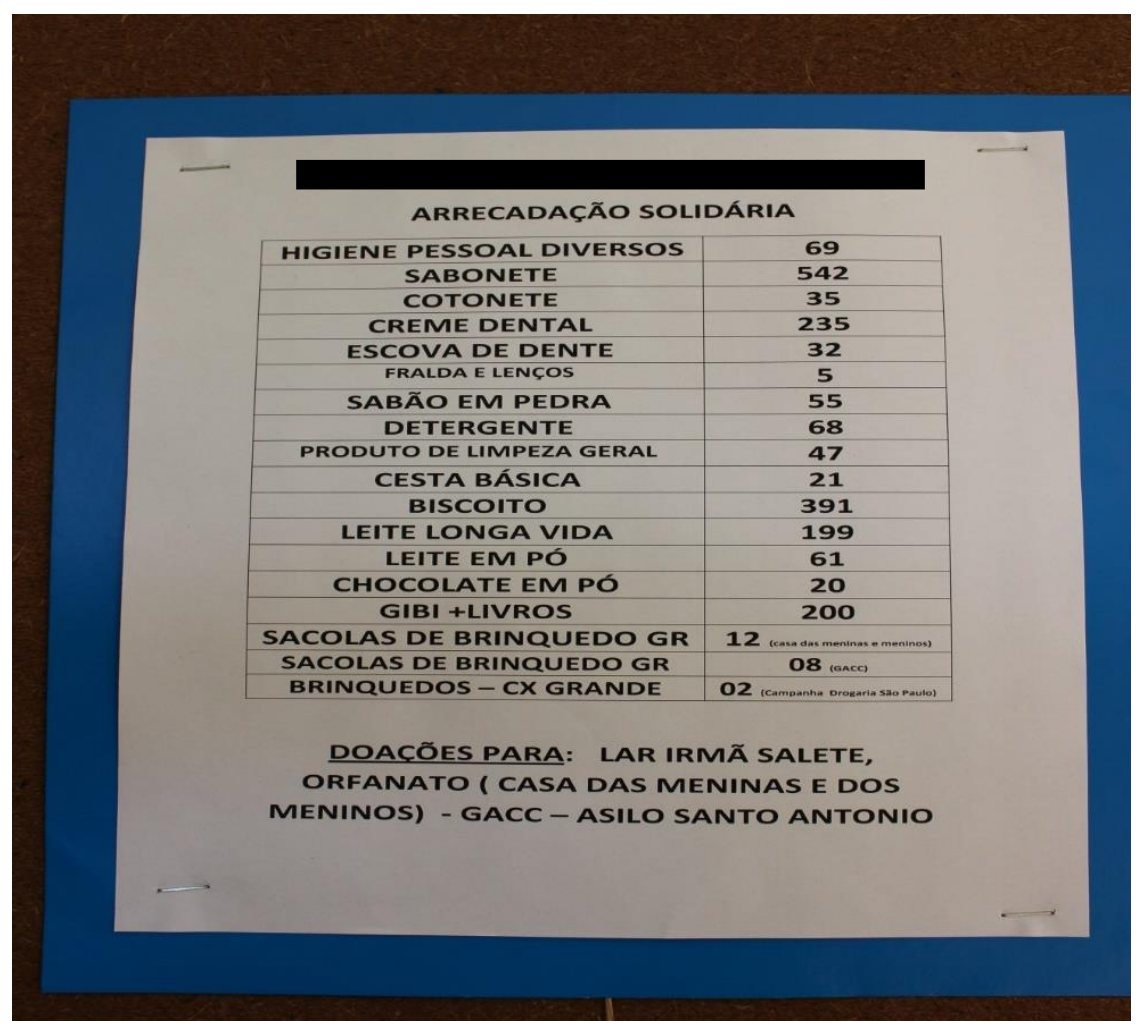

Figura 72 - Campanha de arrecadação solidária realizada pela escola com apoio dos pais Fonte: Arquivo pessoal do autor

Em reunião com os pais, observou-se que a escola contribui com o seu acompanhamento na vida escolar dos filhos, principalmente por realizar bimestralmente o conselho administrativo de classes, que consiste em uma reunião com os pais, Professores e direção da escola, onde é apresentada uma planilha com as notas e o índice de faltas e aproveitamento do aluno ao longo do bimestre, com a finalidade de discutir com os pais as possíveis melhorias no desempenho e comportamento de seus filhos. Observou-se também que os pais participam ativamente da associação de pais e mestres e decidem democraticamente o destino dos recursos financeiros recebido pela escola, como a aquisição de data show, cadeiras para a sala de vídeo e parquinho infantil. Em entrevista com pais e alunos, notou-se que a participação 
dos pais na vida escolar dos filhos faz com que eles se sintam mais motivados para estudar, principalmente pelos pais reconhecerem o seu esforço. Em entrevistas com os pais foi possível identificar que eles possuem uma relação de confiança com o Diretor, que sempre que necessário se mostra disponível para atendê-los. Essa relação faz com que os pais se sintam satisfeitos com as ações desenvolvidas pela escola. Por residirem próximos a escola a maioria dos pais não utilizam o transporte público para ir à escola.

\subsection{Reprovação discente e sistema disciplinar}

Em visita à escola identificou-se a existência de um sistema de reprovação dos alunos, entretanto, segundo relato da Diretora, a escola prioriza o reforço e outros métodos de ensino, utilizando a reprovação apenas como último recurso. Já em entrevista com os pais e alunos, foi possível identificar que as regras estabelecidas pela escola são claras, conhecidas e respeitadas pela comunidade escolar. A escola divulga essas regras no ato da matrícula, por meio de uma cartilha constando os direitos e deveres dos alunos, em que os pais devem assinar e devolver a direção da escola, demonstrando assim, conhecimento das regras escolares. A escola também atua de modo a inibir os atos de bullying, por meio de cartazes que são expostos em um quadro que fica localizado no pátio onde ocorre a recreação dos alunos, conforme ilustrado pela Figura 73.

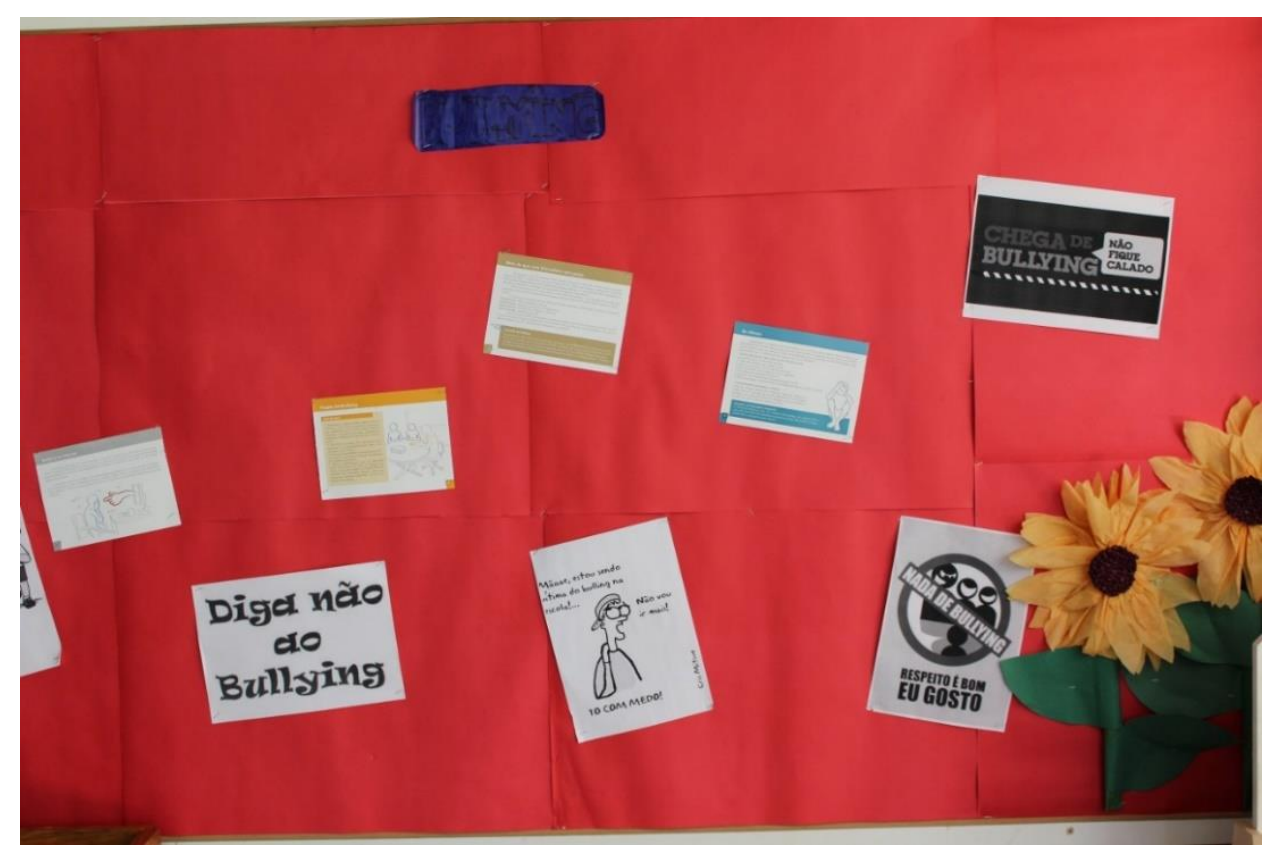

Figura 73 - Cartazes de conscientização e combate ao bullying na escola Fonte: Arquivo pessoal do autor 
Além disso, observou-se que os alunos são de modo geral disciplinados e que, além de respeitar, possuem admiração pelos Professores e amizade com os funcionários da escola, principalmente com os da limpeza. Segundo relato dos alunos, raramente ocorre atos de indisciplina, mas quando isso acontece a escola convoca imediatamente os pais do aluno e aplica uma advertência, se o aluno continuar com os atos de indisciplina o caso é encaminhado diretamente para o conselho tutelar. A Figura 74 nos mostra o momento em que um pai chega à escola para tratar de assuntos do filho.

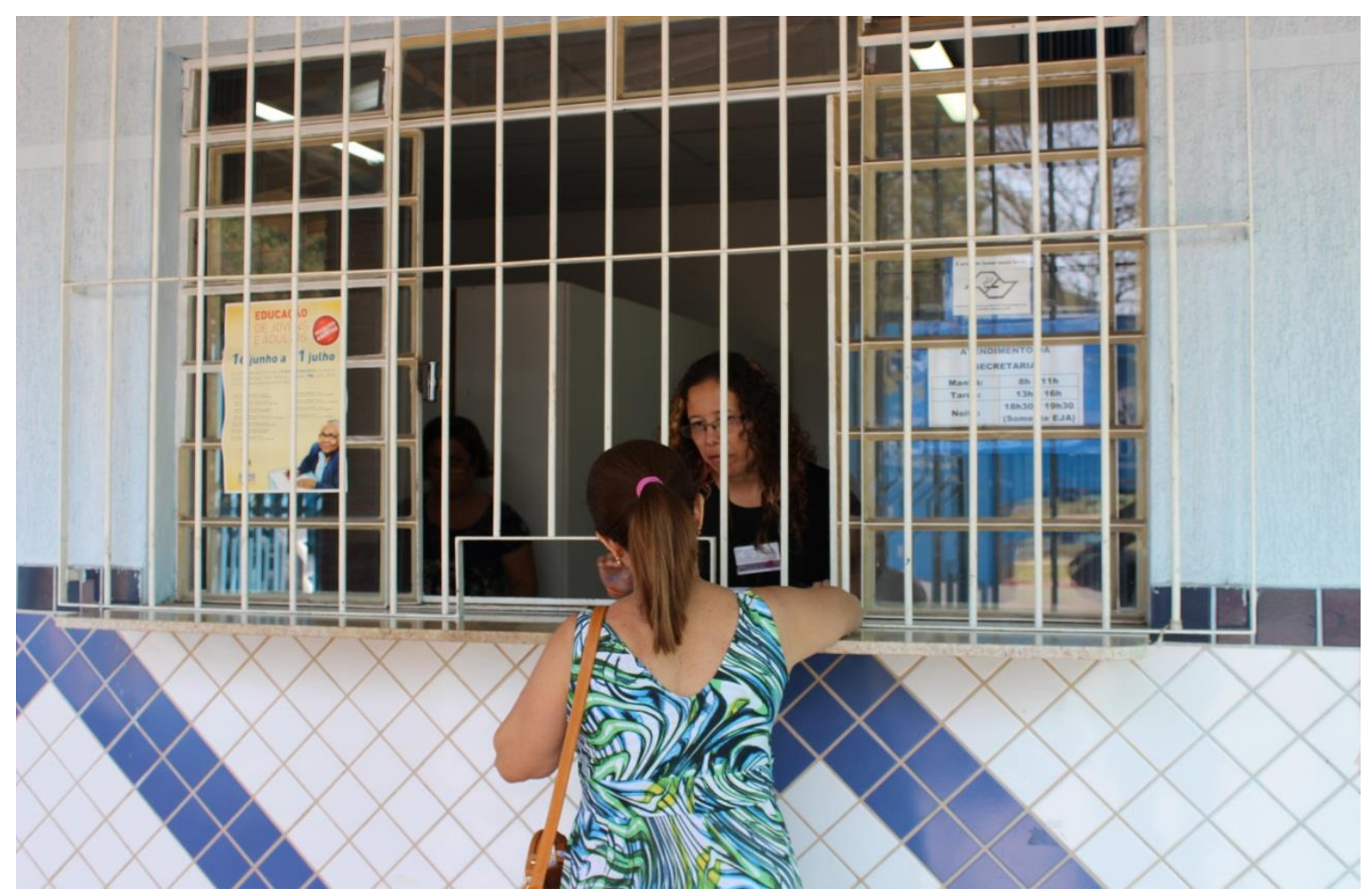

Figura 74 - Atendimento aos pais na escola

Fonte: Arquivo pessoal do autor

\subsection{Laboratório de informática}

Em visita à escola, constatou-se a existência de um excelente laboratório de informática, conforme ilustrado pela Figura 75, com ar-condicionado e inúmeros computadores em bom estado de uso. De acordo a Diretora, a escola já possuía laboratório de informática em 2011, porém não havia aulas de informática. $\mathrm{O}$ mesmo ficava à disposição para o uso dos docentes quando quisessem fazer alguma atividade específica. 

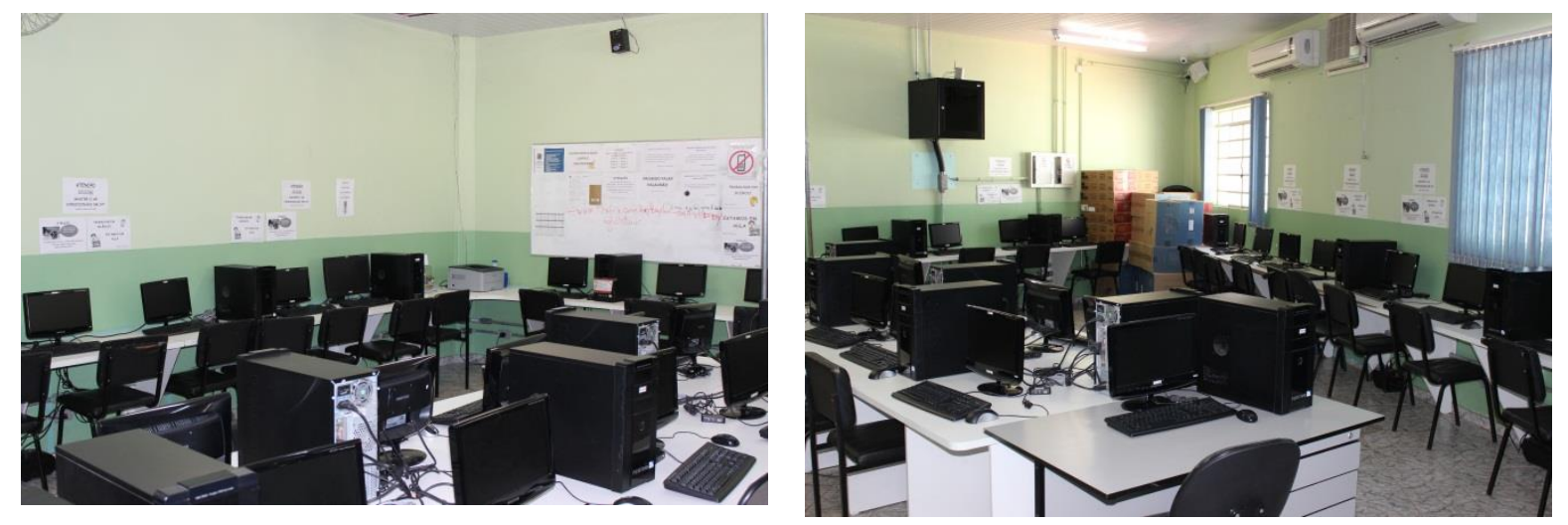

Figura 75 - Laboratório de informática da escola "C"

Fonte: Arquivo pessoal do autor

\subsection{Biblioteca}

Em visita à escola, verificou-se a existência de uma biblioteca muito bem organizada, iluminada, arejada, com ambiente climatizado, excelente acervo e com boa variedade de obras, incluindo coletâneas de seriados que são exibidos na televisão, conforme nos mostra a Figura 76.
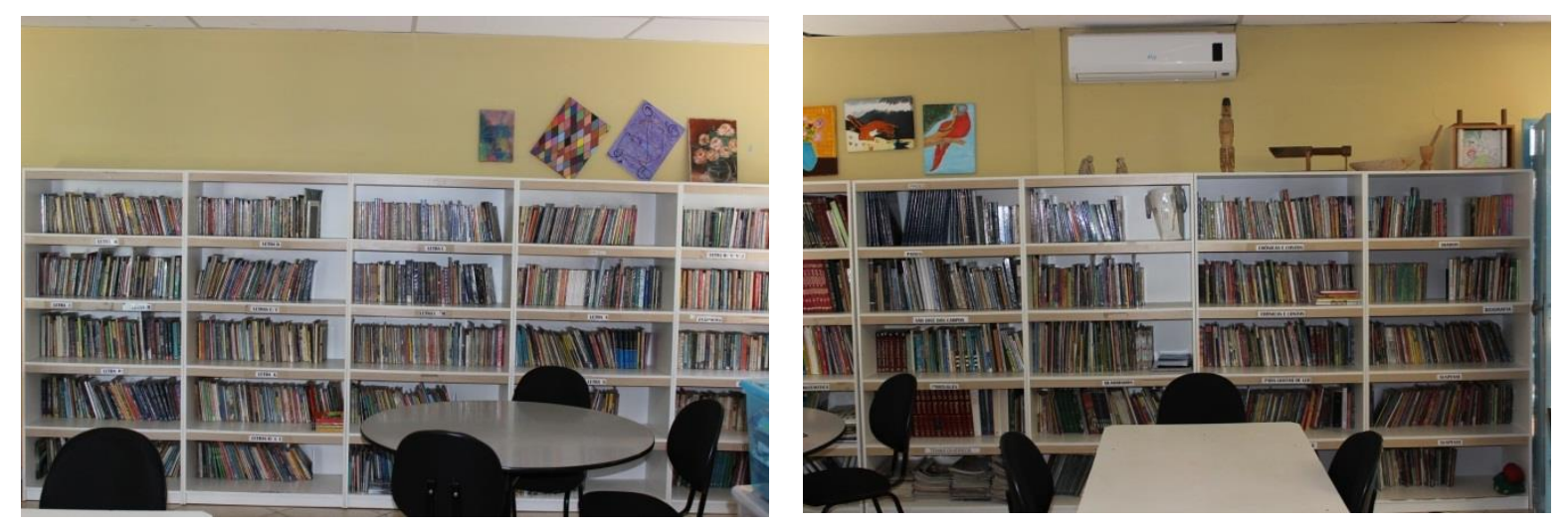

Figura 76 - Biblioteca da escola " $C$ "

Fonte: Arquivo pessoal do autor

Segundo os docentes entrevistados, a biblioteca existia antes mesmo de 2011 e a qualidade de seu acervo, juntamente com a boa variedade de obras, reflete na alta retirada de livros por parte dos alunos, conforme ilustrado pela Figura 77. 


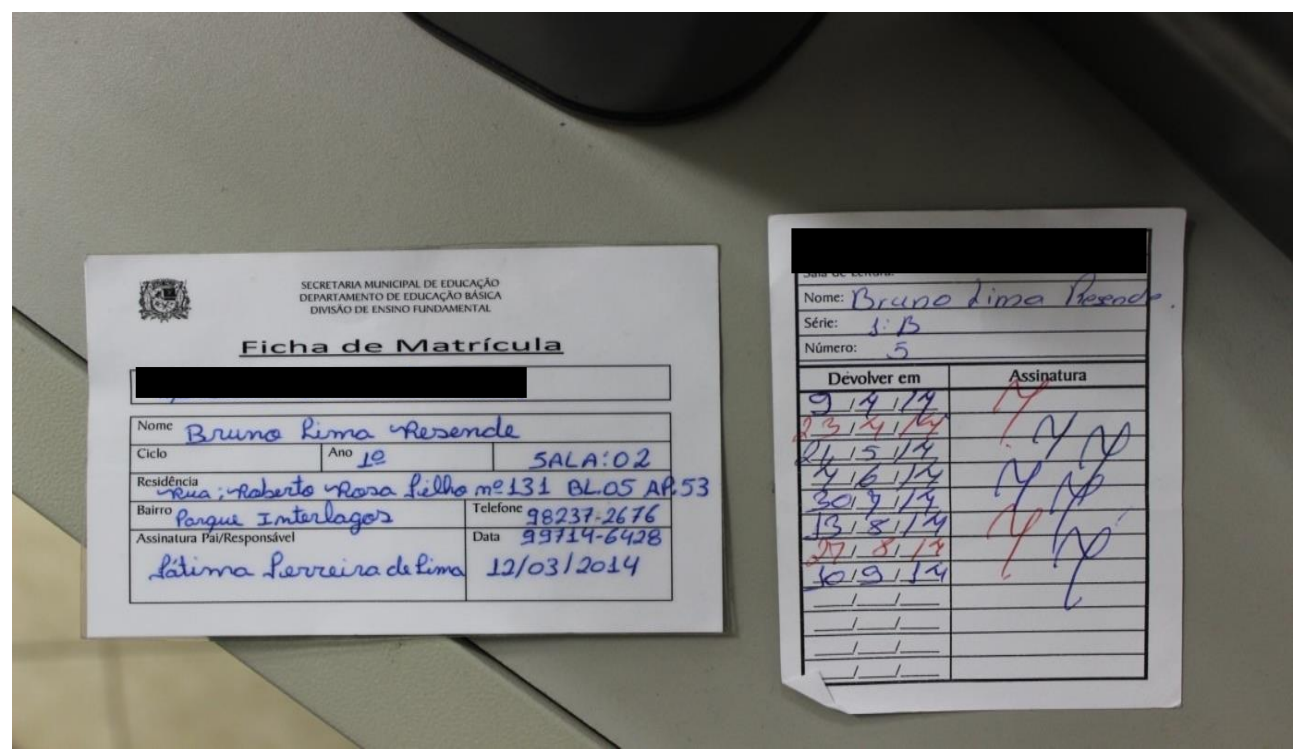

Figura 77 - Controle de retirada de livros dos alunos

Fonte: Arquivo pessoal do autor

Além disso, vale destacar a existência de uma Professora que trabalha exclusivamente na biblioteca organizando-a, oferecendo aulas de incentivo à leitura e acompanhando o índice de retirada de livros dos alunos, por meio de uma ficha de controle individual.

\subsection{Sala de leitura}

Em visita à escola observou-se a existência de uma sala de leitura apropriada e em excelente condição de uso, contendo inclusive ar condicionado. A sala de leitura fica localizada na biblioteca da escola, conforme ilustrado pela Figura 78.
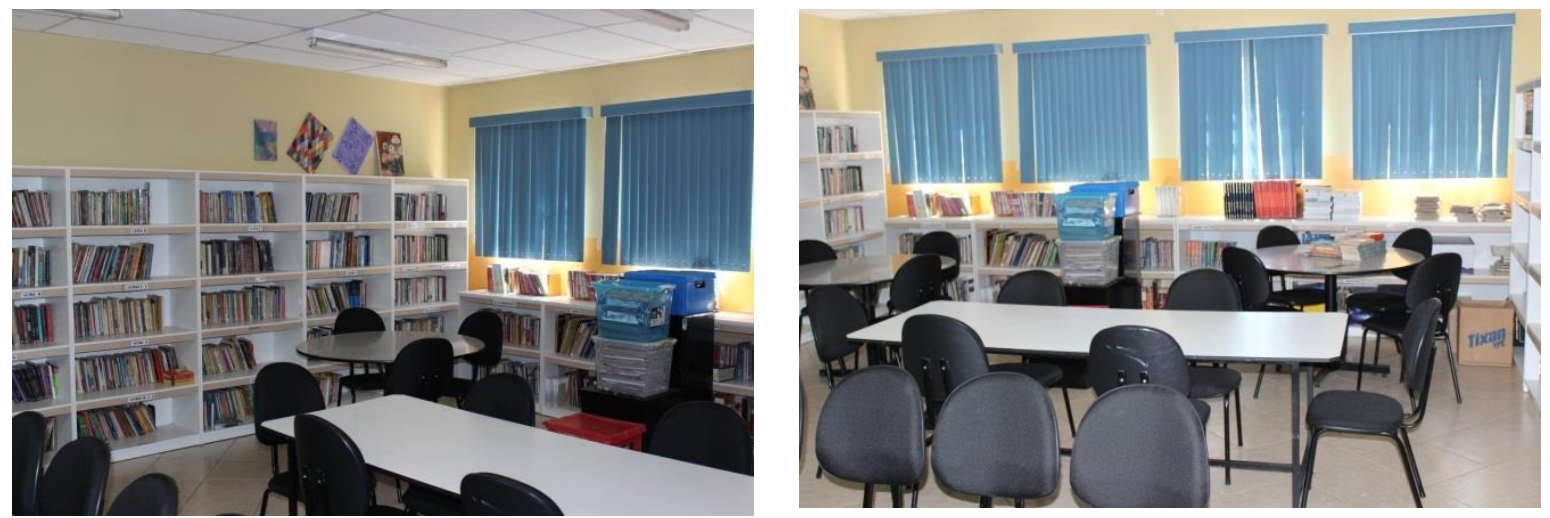

Figura 78 - Sala de leitura da escola "C"

Fonte: Arquivo pessoal do autor 


\subsection{Alunos}

Em visita à escola identificou-se que o sistema de matrículas dos alunos é por zoneamento e a maioria dos 975 alunos matriculados na escola residem na área urbana e não utilizam o transporte público para ir à escola.

\subsection{Docentes}

Com a visita à escola foi possível identificar as seguintes características referentes ao seu corpo docente:

Número de docentes para cada cem alunos: 5,10

Porcentagem de docentes pertencente ao sexo feminino: 94,19;

Porcentagem dos docentes que possuem magistério concluído: 0,00;

Porcentagem dos docentes que possuem o curso de licenciatura concluído: 79,35;

Porcentagem dos docentes que possuem o ensino superior concluído: 99,35;

Porcentagem dos docentes que possuem especialização concluída: 65,16.

\subsection{Funcionários}

Número de Funcionários para cada cem alunos: 8,72.

\subsubsection{Escola "H" abaixo da fronteira de eficiência}

- Data da visita: $12 / 09 / 2014$

- Indicadores da escola $\mathrm{H}$

Número de alunos: 628

Investimento anual por aluno: $\mathrm{R} \$ 8.363,81$

Nota no IDEB (Anos Finais): 4,72

Nível socioeconômico: 5 (Médio-Alto) 
Durante a visita realizada à escola "H", conforme ilustrado pela Figura 79, localizada no município de São José dos Campos no estado de São Paulo, foi possível identificar inúmeras práticas administrativas e pedagógicas que colaboraram para que, no ano de 2011, a escola obtivesse uma nota 4,72 no IDEB. A seguir são apresentados alguns dos principais aspectos mais relevantes que foram observados durante a visita à escola.

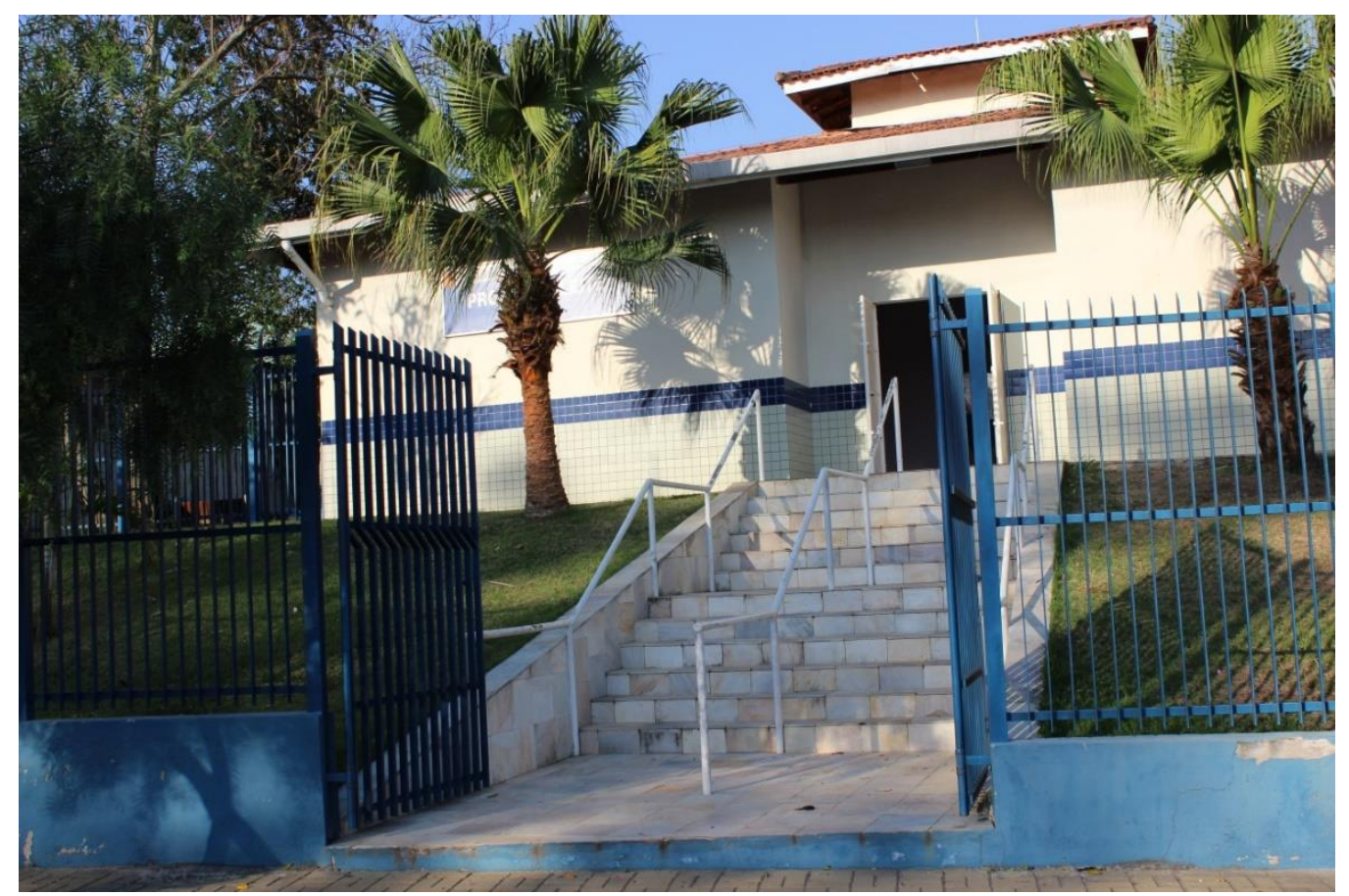

Figura 79 - Fachada da escola "H"

Fonte: Arquivo pessoal do autor

\subsection{Relatório de gestão e destinação dos recursos financeiros do Diretor}

\subsection{Especificidades do município pequeno}

Em conversa com o Diretor da escola, observou-se que a cobrança da comunidade é, em sua visão, maior em cidades pequenas, mas que ainda assim, em uma cidade do porte de São José dos Campos a cobrança também é grande, principalmente quando o Diretor mora no mesmo bairro da escola, pois pelos alunos serem matriculados prioritariamente por zonas de abrangência (zoneamento) o contato com suas famílias se torna mais próximo e constante. De acordo com o Diretor, sempre que os pais encontram o Professor ou o Diretor em um supermercado, padaria ou bar do bairro, quer saber como anda o comportamento de seu filho na escola. 


\subsection{Alimentação dos alunos}

Em conversa com o Diretor da escola, observou-se que é oferecido apenas uma refeição por período aos alunos. Além disso, foi observado também a existência de uma nutricionista, que é responsável pela formação do cardápio, que é muito elogiado pelos alunos. A escola também possui um refeitório adequado para os alunos realizarem sua alimentação, conforme ilustrado pela Figura 80.

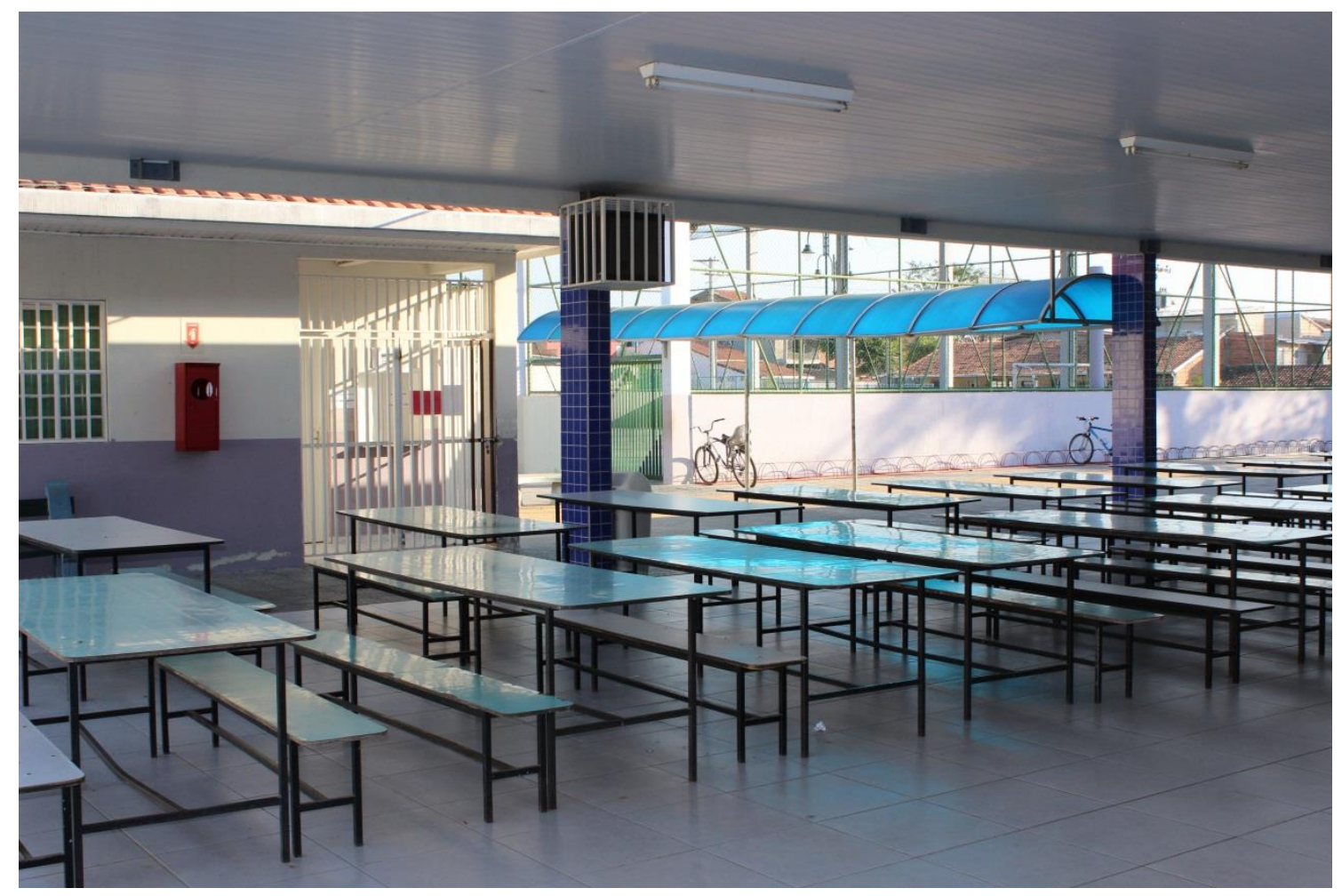

Figura 80 - Refeitório da escola "H"

Fonte: Arquivo pessoal do autor

\subsection{Processo seletivo}

Em conversa com o Diretor, observou-se que não existe processo seletivo para entrar na escola e também não existe transferência compulsória. Por outro lado, a escola recebia alunos por transferência, inclusive de municípios próximos como Caçapava-SP e Taubaté-SP. Segundo o Diretor, este fato deve-se a localização da escola na região periférica da cidade, próxima a rodovia é saída da cidade de São José dos Campos. 


\subsection{Diretor}

Em conversa com o Diretor da escola, observou-se que ele possui formação em Educação Física e Pedagogia, além de uma pós-graduação em Avaliação e Gestão do Ensino Público, tendo assumido o cargo por meio de indicação política. Além disso, verificou-se também a falta de autonomia financeira do Diretor sobre os recursos centralizados. A escola não recebe em nenhum momento recursos financeiros descentralizados de forma significativa para poder auxiliar em alguma tomada de decisão. Segundo o Diretor, existe uma necessidade de repasse de recursos descentralizados para auxiliar na rapidez e na solução de problemas que a escola apresenta. Deste modo, foi possível observar nessa escola que as atuais condições para exercer o cargo de Diretor não são estruturadas o suficiente no que diz respeito ao suporte de volume financeiro descentralizado para que seja possível uma tomada de decisão mais assertiva para a melhoria da educação oferecida pela escola.

\subsection{Plano de carreira do Diretor}

Em entrevista com o Diretor e os Professores da escola, observou-se que o salário do Diretor não é tido como compatível para o cargo que exerce caso não existisse o plano de carreira, que não é mais implantado no município para a rede municipal desde o fim da gestão anterior a secretária atual, uma vez que a diferença salarial é irrelevante quando comparado ao aumento de responsabilidades e a carga horária. No caso desta escola, o Diretor relatou que atua neste cargo pelo incentivo de realização pessoal no que faz, uma vez que busca auxiliar na formação de jovens e dar-lhes opções de melhorarem suas vidas, e por ter sido efetivado no cargo na época em que ainda havia uma compensação salarial atrativa com o passar dos anos na função.

\subsection{Capacidade do Diretor na captação de recursos financeiros}

Durante entrevista realizada com o Diretor da escola, verificou-se que não existe uma próatividade para a captação de recursos dos programas federais e estaduais que não sejam os comumente divulgados e incentivados pela rede municipal de ensino, mostrando desconhecimento de outros programas passíveis da escola se candidatar e arrecadar mais 
recursos, como livros, etc. Nesse sentido, observou-se que o Diretor fica à mercê de uma próatividade da Secretaria de Educação para que possa melhorar os recursos disponíveis para a escola, uma vez que ele não realiza parceria com empresas, ONGs e entidades da região.

\subsection{Destinação do recurso financeiro descentralizado e centralizado}

Em visita à escola e entrevista com o Diretor, observou-se que os recursos financeiros centralizados e suas respectivas destinações não são monitorados quantitativamente para que seja possível mensurar o quanto é investido em cada item listado (equipamentos de consumo, permanente, materiais escolares etc.). Entretanto, identificou-se que a escola possui uma boa infraestrutura, com salas de aulas limpas, arejadas e com carteiras e cadeiras em bom estado de uso, conforme ilustrado pela Figura 81.
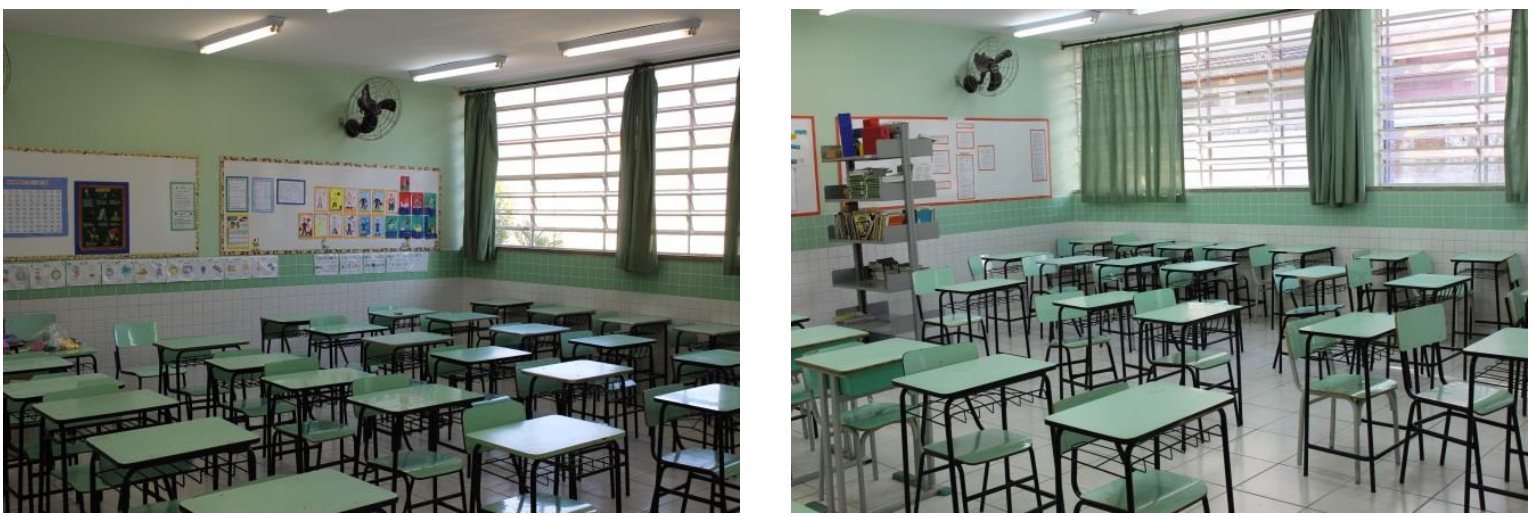

Figura 81 - Salas de aula da escola "H"

Fonte: Arquivo pessoal do autor

A escola também possui um pátio com um palco para os alunos realizarem apresentações culturais, bem como um amplo espaço para os alunos nos momentos de recreação, conforme nos mostra a Figura 82. 

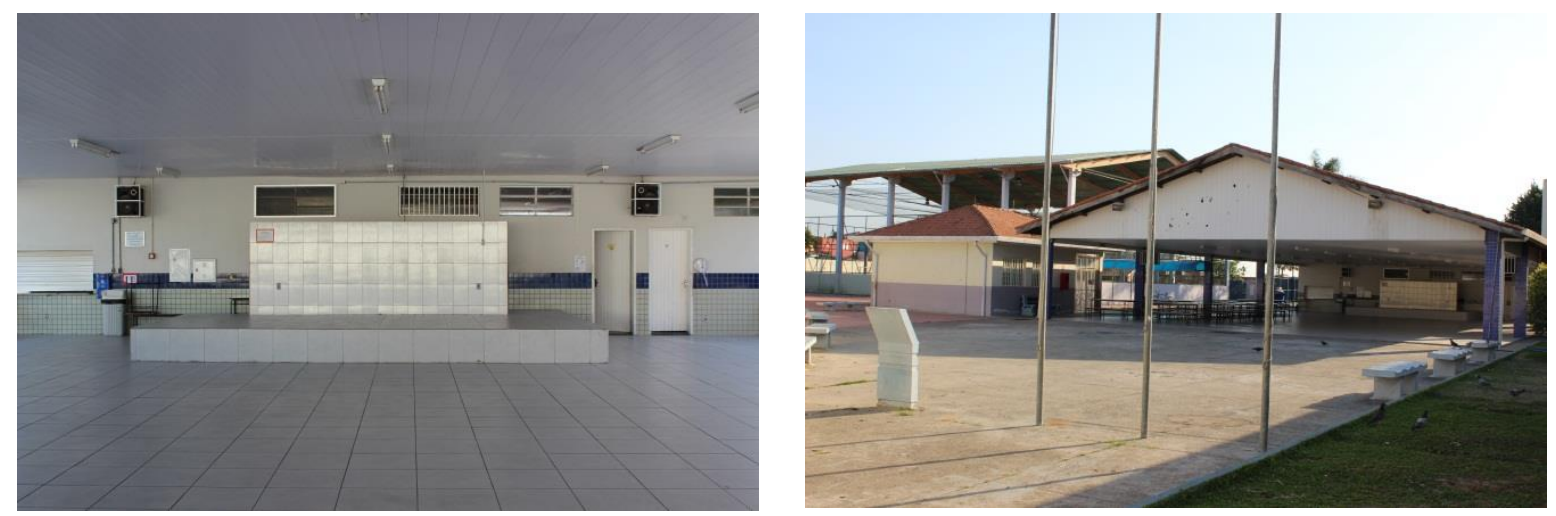

Figura 82 - Pátio da escola "H"

Fonte: Arquivo pessoal do autor

A escola ainda possui uma quadra de esportes coberta em excelente estado de conservação, com uma grade de proteção em seu entorno, gol de salão com rede e cesta de basquete com rede, o que possibilita a prática de inúmeros esportes, conforme ilustrado pela Figura 83.
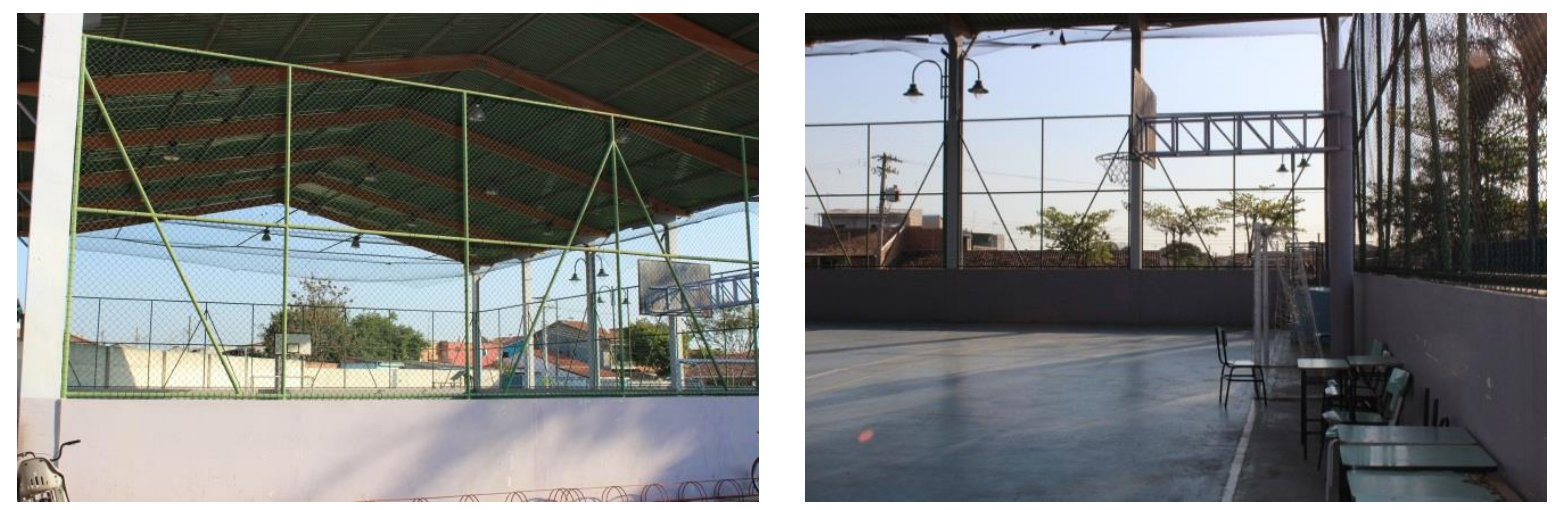

Figura 83 - Quadra de esportes da escola "H"

Fonte: Arquivo pessoal do autor

\subsection{Relatório pedagógico e socioeconômico}

\subsection{Desempenho na prova de português}

Em entrevista com um dos docentes responsáveis pela disciplina, observou-se que ele tem autonomia para a realização de atividades em sala. De acordo com a docente, ela utiliza o material didático proveniente da SME, que é escolhido pelos Professores de português da instituição com base em uma lista de opções fornecida pela SME, e complementa o ensino com um material desenvolvido por ela mesma. 
Em relação ao acompanhamento do desempenho do aluno na disciplina, ele ocorre por meio de duas avaliações e algumas atividades feitas no decorrer do bimestre. Segundo a Professora, ela tem autonomia para reprovar o aluno quando este tem um desempenho insatisfatório, porém ao final do ano ele pode ser aprovado pelo conselho de classe.

A recuperação e reforço no contraturno não era uma prática da escola, essas atividades eram realizadas no transcorrer das aulas convencionais, ocorrendo no primeiro ou no último horário de aula, de forma que nesse momento ficam em sala apenas os alunos que necessitam deste trabalho de reforço. De acordo com a docente entrevistada os alunos não tem o hábito de ler, entretanto, possuem grande interesse por arte, como o desenho de lendas folclóricas, que depois de elaboradas são expostas em quadros que ficam espalhados pelo corredor da escola e no fundo da sala de aula, conforme ilustrado pela Figura 84.
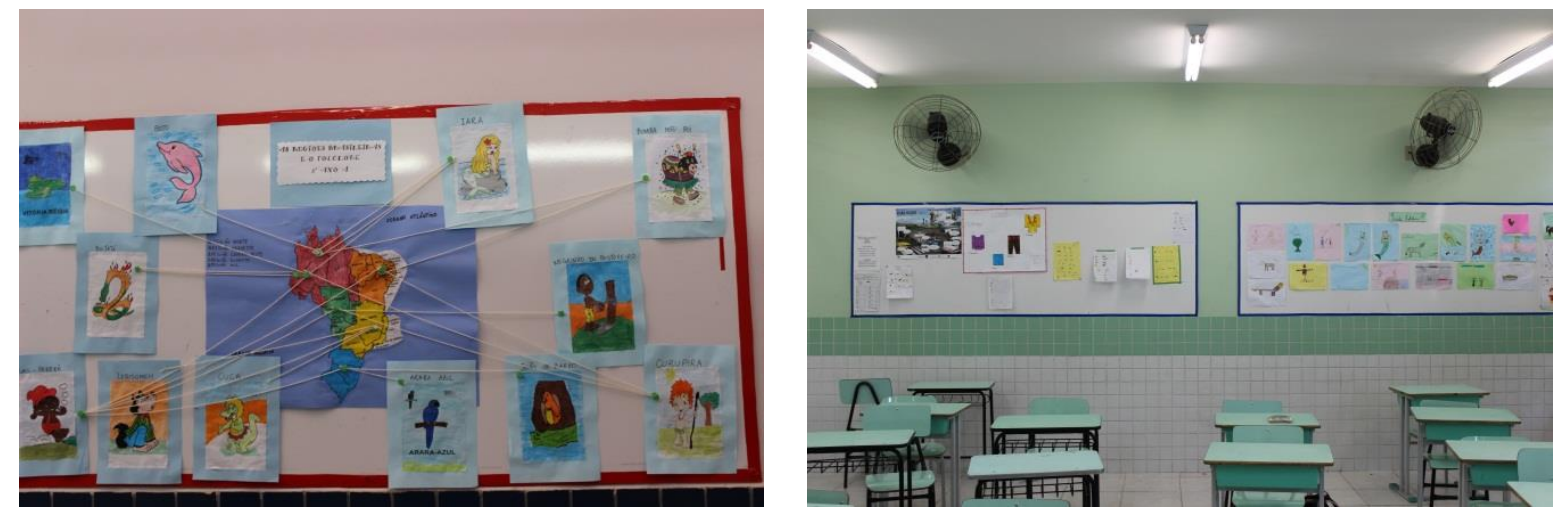

Figura 84 - Desenho de lendas folclóricas feito pelos alunos

Fonte: Arquivo pessoal do autor

A escola por sua vez, busca despertar a criatividade dos alunos e o interesse por temas atuais, através do incentivo a elaboração de charges, conforme a Figura 85.
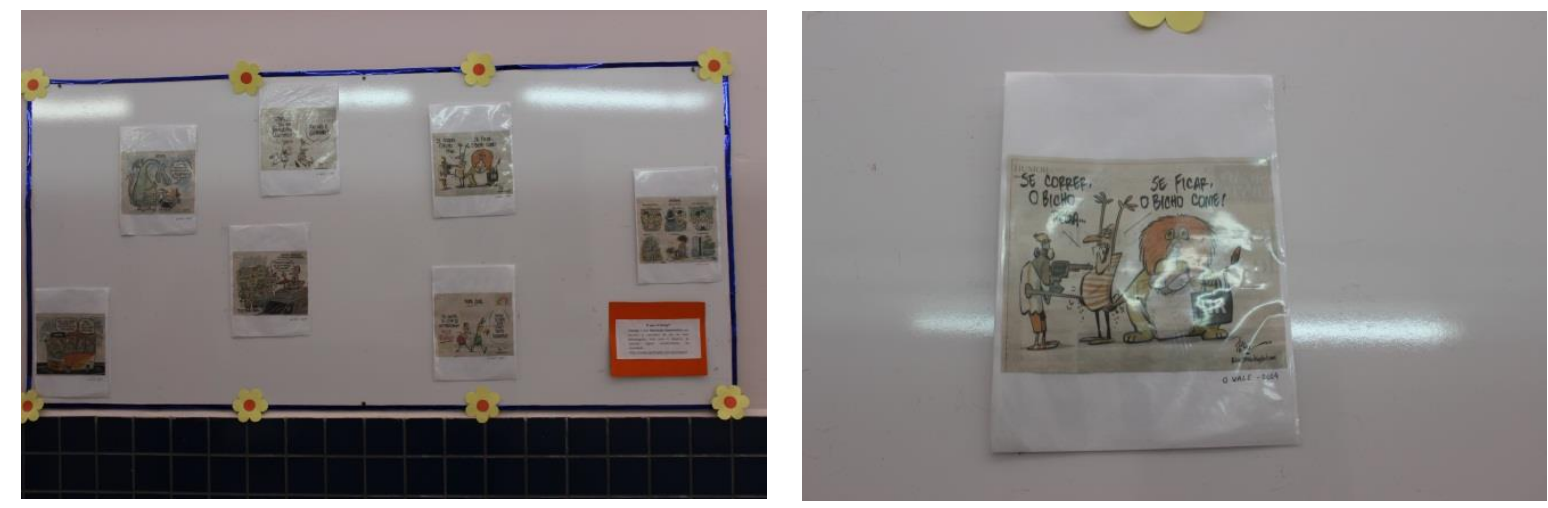

Figura 85 - Cartazes de incentivo a criação de charges Fonte: Arquivo pessoal do autor 


\subsection{Desempenho na prova de matemática}

Em entrevista com a docente, observou-se que ela possui autonomia no ensino da disciplina, principalmente nas atividades realizadas em sala. Segundo a docente, o material didático utilizado na disciplina é proveniente do estado e complementado por um material escolhido por todos os docentes da disciplina, baseado em uma lista de opções fornecida pela SME.

O acompanhamento do desempenho do aluno ocorre por meio de duas avaliações e algumas atividades feitas no decorrer do bimestre, como a realização de pesquisas, conforme ilustrado pela Figura 86. Segundo a Professora, ela tem autonomia para reprovar o aluno quando este tem um desempenho insatisfatório, porém ao final do ano ele pode ser aprovado pelo conselho de classe.

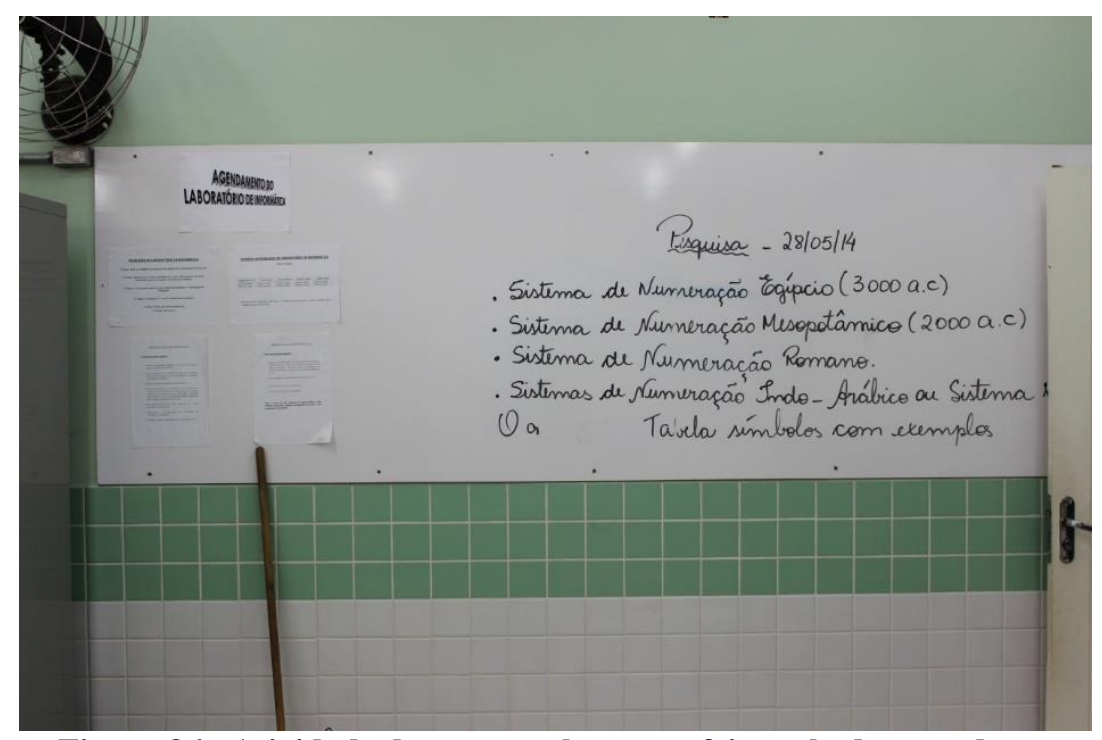

Figura 86 - Atividade de acompanhamento feita pelo docente de matemática Fonte: Arquivo pessoal do autor

A recuperação e reforço no contraturno não era uma prática da escola, pois essas atividades eram realizadas no transcorrer das aulas convencionais, ocorrendo no primeiro ou no último horário de aula, de forma que nesse momento ficam em sala apenas os alunos que necessitam deste trabalho de reforço. Outro fator de destaque que foi observado durante a visita à escola é o incentivo ao estudo da matemática, com frases pregadas na sala de aula destacando a importância da matemática e um modelo didático da tabuada desenhado na sala de aula, conforme ilustrado pelas Figura 87 e Figura 88. 


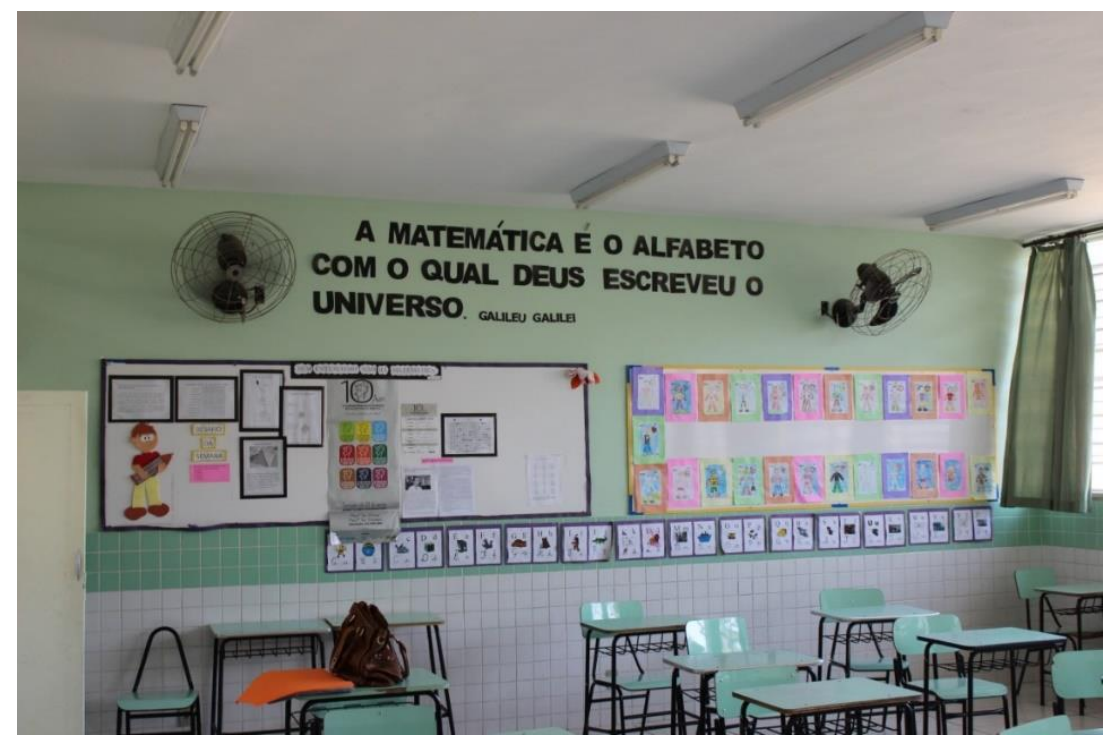

Figura 87 - Frase que destaca a importância da matemática

Fonte: Arquivo pessoal do autor

Na figura a seguir pode-se observar a tabuada fixada na parede como forma de incentivo.

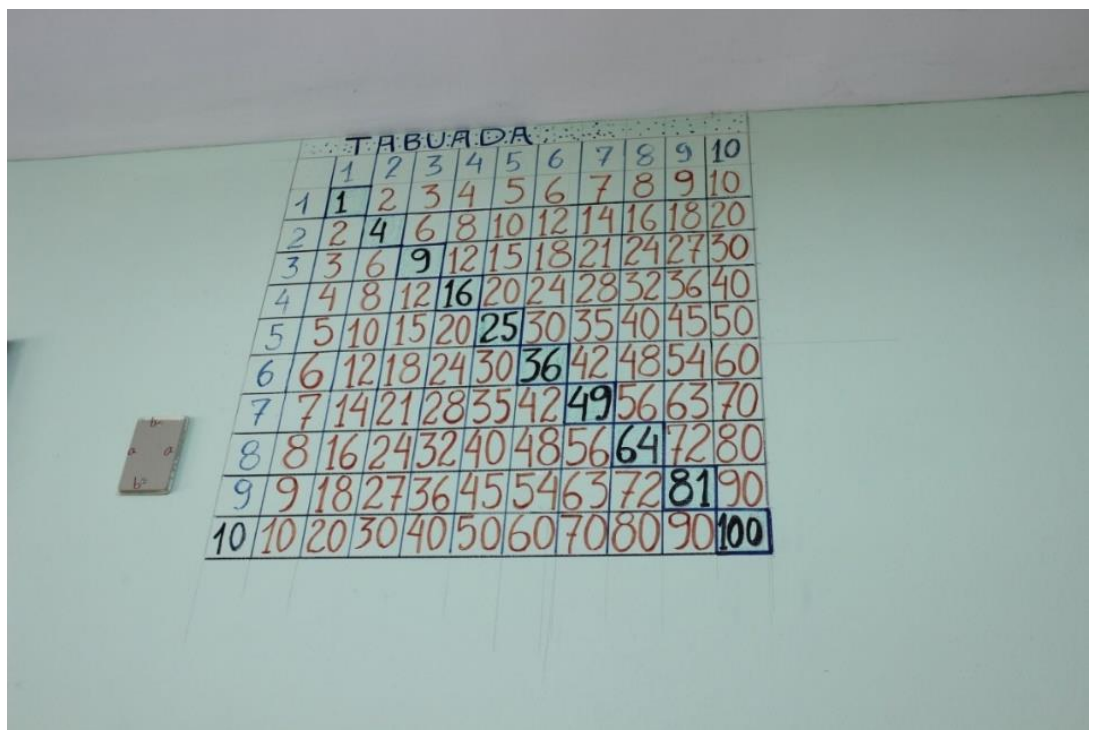

Figura 88 - Modelo didático da tabuada desenhado na sala de aula Fonte: Arquivo pessoal do autor

\subsection{Participação da família}

Em visita à escola observou-se que a maioria dos pais não participa da vida escolar dos filhos. Segundo relato dos pais e alunos, apenas uma pequena parte dos pais frequenta as reuniões realizadas pela escola e acompanham frequentemente os deveres escolares dos filhos. Segundo os alunos entrevistados, seus pais não frequentam as reuniões por elas serem cansativas e a direção dizer sempre a mesma coisa. Os pais também demonstraram desconhecimento sobre a existência e a finalidade da associação de pais e mestres. Entretanto, 
observou-se uma maior participação dos pais nos eventos festivos (festa junina, formatura, etc.) realizados pela escola. Por residirem próximos a escola, a maioria dos pais não utiliza o transporte público para frequentar as reuniões escolares.

\subsection{Reprovação discente e sistema disciplinar}

Durante visita à escola identificou-se a existência de um sistema de reprovação de alunos, entretanto, a escola prioriza o reforço aos alunos, utilizando a reprovação apenas em último caso. Em relação às regras do sistema disciplinar, observou-se que a escola faz sua divulgação por meio das reuniões de pais ao longo do ano, como a maioria dos pais não frequentam as reuniões as regras não são conhecidas e respeitadas por toda a comunidade escolar. Deste modo, a escola também anexou um cartaz na porta da secretaria contendo o Decreto de LEI $\mathrm{n}^{\circ}$ 2.848/40 sobre as consequências de desacato ao funcionário público, a fim de evitar esse tipo de problema, conforme nos mostra a Figura 89.

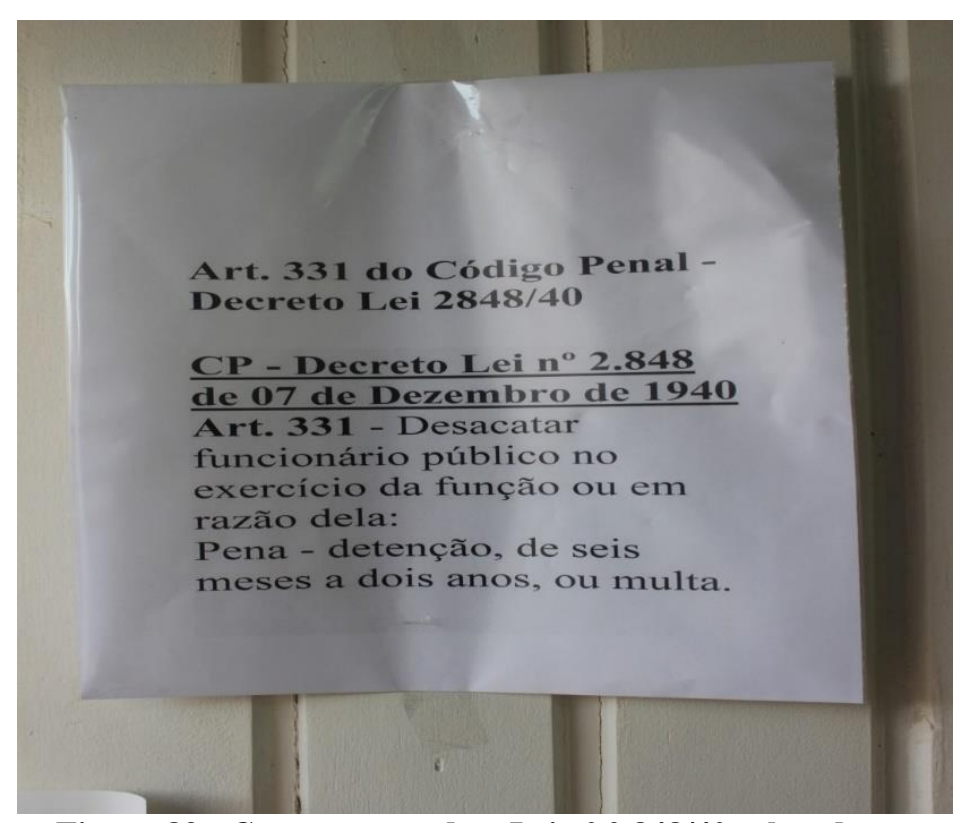

Figura 89 - Cartaz contendo a Lei ${ }^{\circ} \mathbf{2 . 8 4 8 / 4 0}$ sobre desacato a funcionário público Fonte: Arquivo pessoal do autor

Em entrevista realizada com pais e alunos, notou-se que os alunos são de modo geral indisciplinados. Segundo relato dos alunos, o comportamento discente é péssimo, o que atrapalha o aprendizado de quem está disposto a aprender. Também foi possível observar que os alunos não possuem respeito pela figura do Diretor e dos Professores. Segundo declaração dos alunos, os atos de desrespeito são frequentes na escola, recentemente um aluno ameaçou agredir o Professor com uma cadeira por ele ter chamado sua atenção na sala de aula e outro 
aluno ofendeu verbalmente a Diretora da escola por ela ter pedido para ele retirar o boné da cabeça.

\subsection{Laboratório de informática}

Durante a visita realizada à escola pôde ser observado à existência de um laboratório de informática em ótimo estado de conservação, com espaço adequado e limpo, ar condicionado e todos os computadores em bom estado de uso, conforme nos mostra a Figura 90. O laboratório fica à disposição para uso dos docentes, que contam com o auxílio e suporte de um estagiário com conhecimentos técnicos sobre informática.

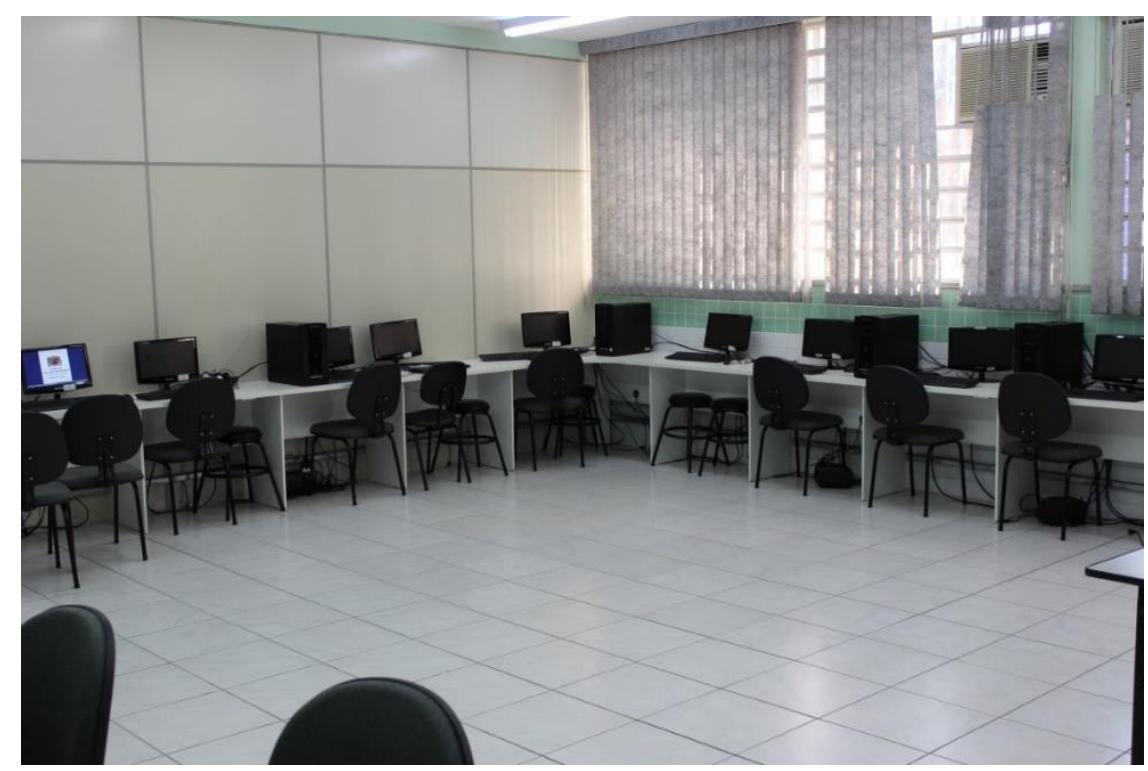

Figura 90 - Laboratório de informática da escola "H"

Fonte: Arquivo pessoal do autor

\subsection{Biblioteca}

Em visita à escola, constatou-se que a biblioteca contempla um espaço iluminado, arejado e organizado, no qual os alunos podem ler os livros ali mesmo, ou ainda podem levá-los para casa. Vale ressaltar que uma vez por semana os alunos são encaminhados à biblioteca para uma aula temática e a partir daí podem escolher um livro para ler. Entretanto, de acordo com os Professores entrevistados, a quantidade e variedade dos livros disponíveis na biblioteca, além de ser baixa e de péssima qualidade, o que contribui para o baixo índice de retirada dos livros por parte dos alunos. De acordo com a Diretora da escola, a biblioteca também é aberta ao uso da comunidade. A Figura 91 e a Figura 92 nos mostra a biblioteca da escola. 


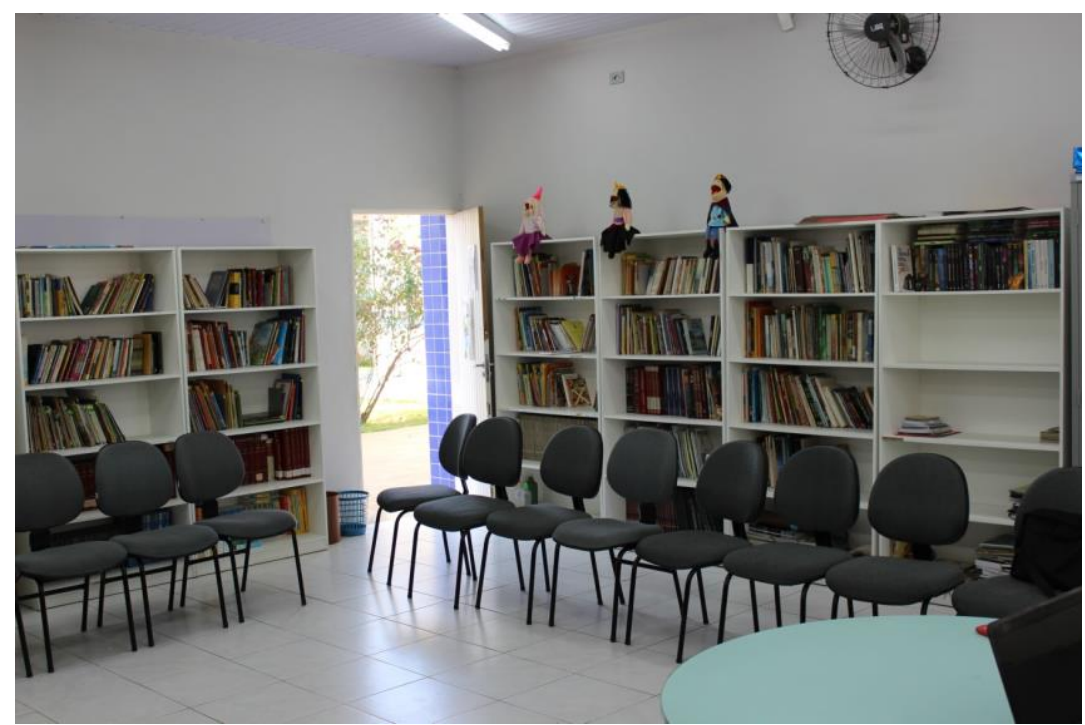

Figura 91 - Biblioteca da escola "H"

Fonte: Arquivo pessoal do autor

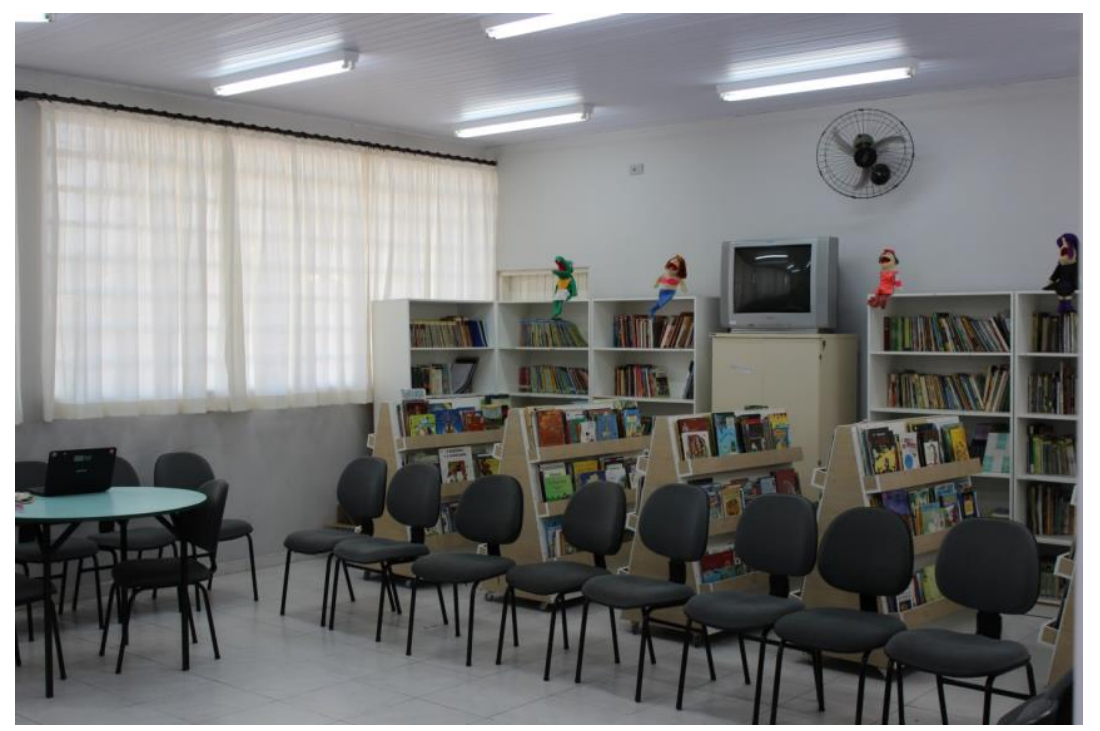

Figura 92 - Biblioteca da escola "H"

Fonte: Arquivo pessoal do autor

\subsection{Sala de leitura}

Em visita à escola observou-se a inexistência de uma sala de leitura específica, entretanto, foi identificado que existe um espaço adequado para leitura na própria biblioteca.

\subsection{Alunos}

Em visita à escola identificou-se que o sistema de matrículas dos alunos é por zoneamento e a maioria dos 628 alunos matriculados na escola residem na área urbana e não utilizam o 
transporte público para ir à escola, entretanto, segundo relato de alguns alunos que necessitam utilizar o transporte público para ir à escola o município contribui apenas com $50 \%$ do valor da passagem, ficando o restante a cargo do aluno.

\subsection{Docentes}

Com a visita à escola foi possível identificar as seguintes características referentes ao seu corpo docente:

Número de docentes para cada cem alunos: 5,40

Porcentagem de docentes pertencente ao sexo feminino: 80,77;

Porcentagem dos docentes que possuem magistério concluído: 0,00;

Porcentagem dos docentes que possuem o curso de licenciatura concluído: 70,19;

Porcentagem dos docentes que possuem o ensino superior concluído: 100,00;

Porcentagem dos docentes que possuem especialização concluída: 73,08.

\subsection{Funcionários}

Número de Funcionários para cada cem alunos: 9,39.

\subsubsection{Escola "D" eficiente e respectiva SME}

- Data da visita: $15 / 09 / 2014$

- Indicadores do município de Tuiuti

$\mathbf{N}^{\circ}$ de Habitantes: 6.005

IDHM: 0,728

- Indicadores da escola D

Número de alunos: 211

Investimento anual por aluno: $\mathrm{R} \$ 3.522,26$

Nota no IDEB (Anos Finais): 4,98

Nível socioeconômico: 5 (Médio-Alto) 
Em visita realizada à escola "D", conforme ilustrado pela Figura 93, localizada no município de Tuiuti no estado de São Paulo, foi possível identificar inúmeras práticas administrativas e pedagógicas que colaboraram para que, no ano de 2011, a escola obtivesse uma nota 4,98 no IDEB. A seguir são apresentados alguns dos principais aspectos mais relevantes que foram observados durante a visita à escola.

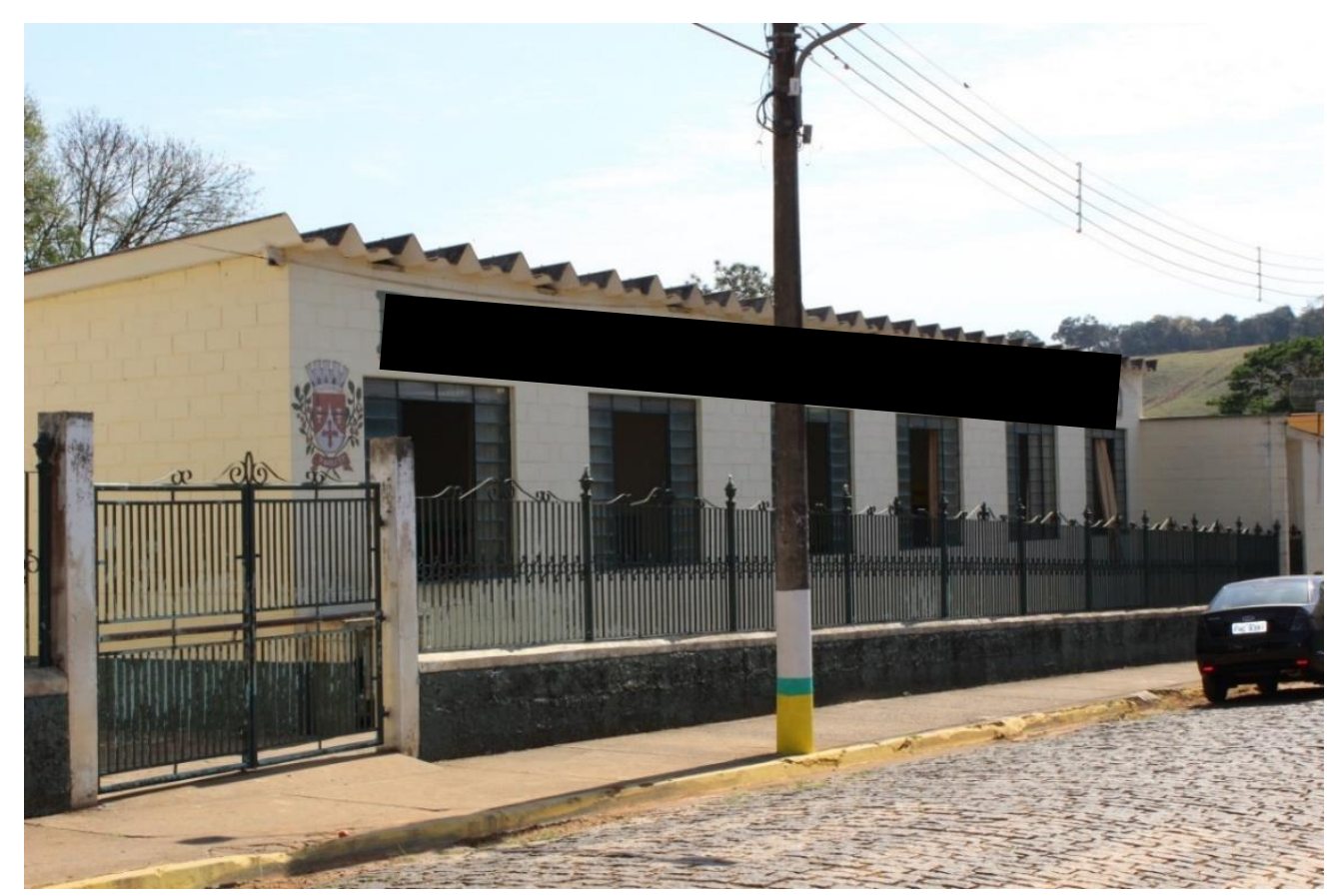

Figura 93 - Fachada da escola "D"

Fonte: Arquivo pessoal do autor

\subsection{Relatório de gestão e destinação dos recursos financeiros da SME}

\subsection{Constituição da SME}

Em conversa com a secretária de Educação, foi possível observar que os colaboradores desta secretaria são nomeados por indicação política. Ademais, observou-se que os Diretores, até o ano de 2010, também eram nomeados por meio de indicação política, todavia, neste ano em questão ocorreu um concurso para três das quatro vagas de Diretores municipais, que posteriormente assumiriam o cargo como funcionários de carreira. Outro fator a ser destacado é a formação dos funcionários da SME, pois todos eles, com exceção do motorista que possui apenas o ensino fundamental incompleto, possuem curso superior completo ou estão com o curso em andamento. 


\subsection{Organização da SME}

Em visita à SME, observou-se em relação a sua governança, que por ter sido criada recentemente ela ocorre com certa flexibilidade, uma vez que poucas pessoas precisam lidar com diversos assuntos cotidianos, e muitas vezes não precisam inclusive se reportar diretamente a secretária. Ademais, não foi encontrada uma área específica responsável pela captação de recursos.

\subsection{Secretário}

Em entrevista com a secretária, observou-se que ela possui uma formação técnica em Administração e Contabilidade, graduação em Letras e Pedagogia e especialização em Língua Portuguesa, e não possui nenhum curso complementar em gestão. Entretanto, para se candidatar ao cargo de Secretário Municipal de Educação não se exige nenhum pré-requisito. Também foi possível identificar que a secretária possui autonomia limitada para criação de políticas educacionais, uma vez que não apresenta estrutura nem recursos suficientes para esta função. Ademais, observou-se que a secretária não possui autonomia financeira sobre os recursos educacionais e tem uma análise crítica irrelevante dos principais indicadores do município, uma vez que assumiu o cargo há pouco tempo e não havia uma Secretaria estruturada antes de sua gestão.

\subsection{Capacidade da SME na captação de recursos financeiros}

Em visita à SME, observou-se que não existem recursos provenientes de projetos federais e/ou estaduais que foram articulados e angariados pelo Secretário e sua equipe para possíveis investimentos no município. Ademais, a secretária não demonstrou pró-atividade na realização de atividades que tenha como objetivo levantar recursos para a educação, como parcerias com empresas privadas ou a APM. Além disso, verificou-se que a secretária possui conhecimento de apenas alguns dos principais indicadores financeiros municipais, como a porcentagem do recurso da educação destinado a folha de pagamento do corpo docente.

\subsection{Destinação do recurso financeiro descentralizado e centralizado}

Em conversa com a secretária, verificou-se que a destinação dos recursos se dá majoritariamente para oferecimento de transporte aos alunos, uma vez que a maioria deles 
reside na zona rural e utilizam diariamente o transporte público para irem à escola. Por outro lado, os recursos destinados a reparos emergenciais e a cursos, palestras e orientações didático-pedagógicas podem ser considerados irrelevantes. Entretanto, segundo a secretária, o município destinava um grande volume de recursos no oferecimento de planos de aposentadoria integral, progressão salarial conforme a realização de cursos e outros benefícios para os Professores aprimorarem seu conhecimento e melhorarem o ensino da rede, no entanto, os Professores viram brechas no sistema de progressão salarial e um número relevante utilizou-se desta situação para fraudar o sistema e atingir o nível mais alto de remuneração, ocasionando uma inflação na folha salarial, o que fez o município tomar uma medida radical de cortes salariais.

\subsection{Transição de novo Secretário e nova equipe}

Em entrevista com a Secretária, observou-se que a maior parte dos colaboradores são substituídos conforme novas gestões são eleitas, uma vez que a maioria dos cargos da secretaria são nomeados por meio de indicação política.

\subsection{Critério para matrícula de alunos}

Em entrevista com a secretária, observou-se que o critério adotado para a matrícula dos alunos é por zoneamento.

\subsection{Ensino fundamental ofertado exclusivamente pela rede pública}

Segundo a secretária, o ensino fundamental é ofertado exclusivamente pela rede pública municipal.

\subsection{Informações adicionais}

Em visita à secretaria, constatou-se a existência de duas escolas rurais e duas escolas urbanas no município. Ademais, não existe uma política de progressão continuada no município. Em relação aos incentivos, observou-se que a SME apoia em algumas ocasiões a participação dos 
alunos em olímpiadas, por meio do oferecimento de transporte e lanches durante a competição. Todavia, não há um conhecimento preciso por parte da secretaria da porcentagem de recursos destinados à educação que são direcionados para folha de pagamento dos Professores.

\subsection{Relatório de gestão e destinação dos recursos financeiros do Diretor}

\subsection{Especificidades do município pequeno}

Em conversa com o Diretor da escola, observou-se que a cobrança da comunidade é, em sua visão, maior em cidade pequena, se intensificando ainda mais quando o Diretor reside no mesmo bairro da escola, uma vez que os alunos são matriculados prioritariamente por zonas de abrangência (zoneamento), o que resulta em um contato mais próximo e constante entre os pais, Professores e o Diretor no convívio da comunidade em bares, padarias, restaurantes, etc.

\subsection{Alimentação dos alunos}

Em conversa com o Diretor da escola, observou-se que é oferecido aos alunos duas refeições por período. Além disso, observou-se também a existência de uma nutricionista responsável pela elaboração e acompanhamento do cardápio, com grandes elogios por parte dos alunos sobre sua variedade e qualidade. A Figura 94 nos mostra o cardápio oferecido aos alunos no dia da visita à escola. 


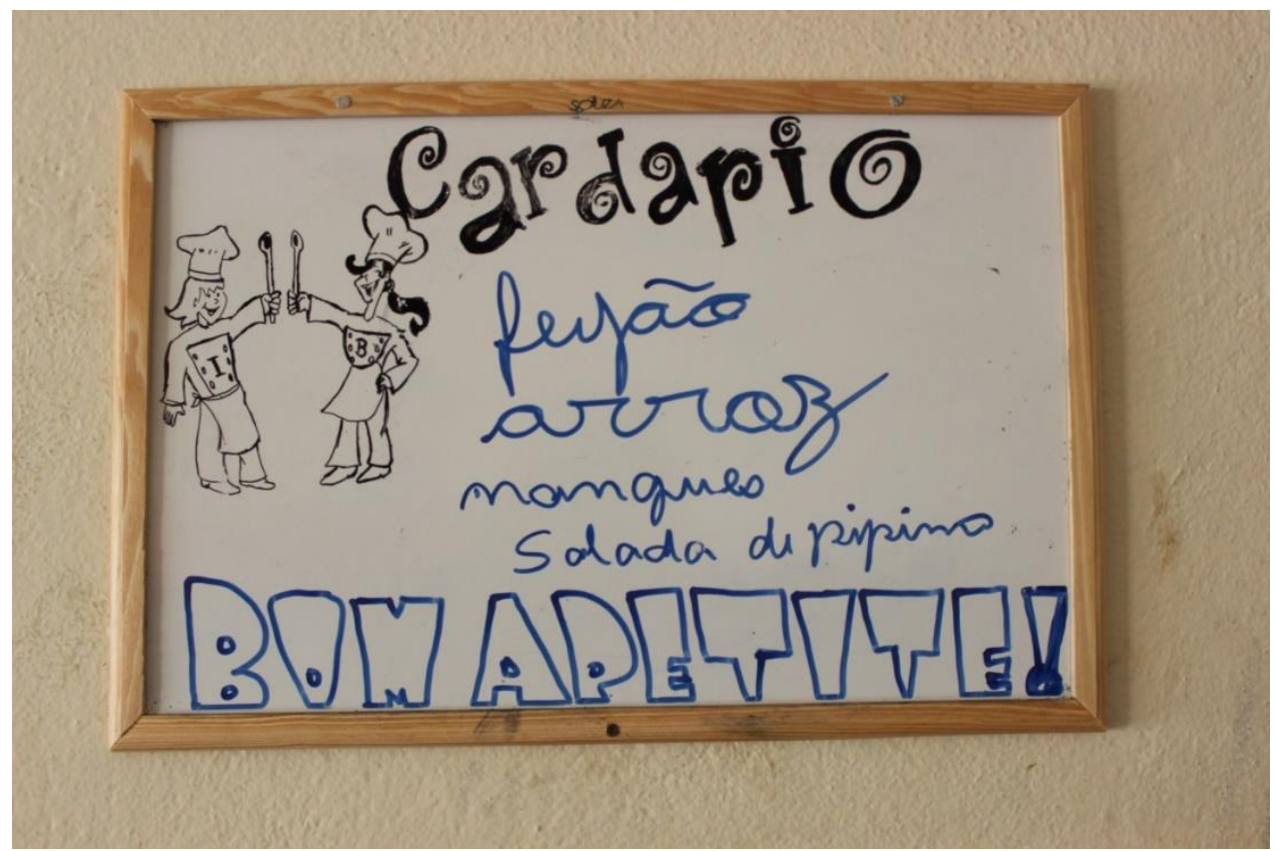

Figura 94 - Cardápio oferecido aos alunos

Fonte: Arquivo pessoal do autor

Durante a visita também foi possível constatar que a escola possui um refeitório adequado para os alunos realizarem sua alimentação, com espaço, limpeza, mesas cobertas com toalhas e ventilador, conforme ilustrado pela Figura 95.
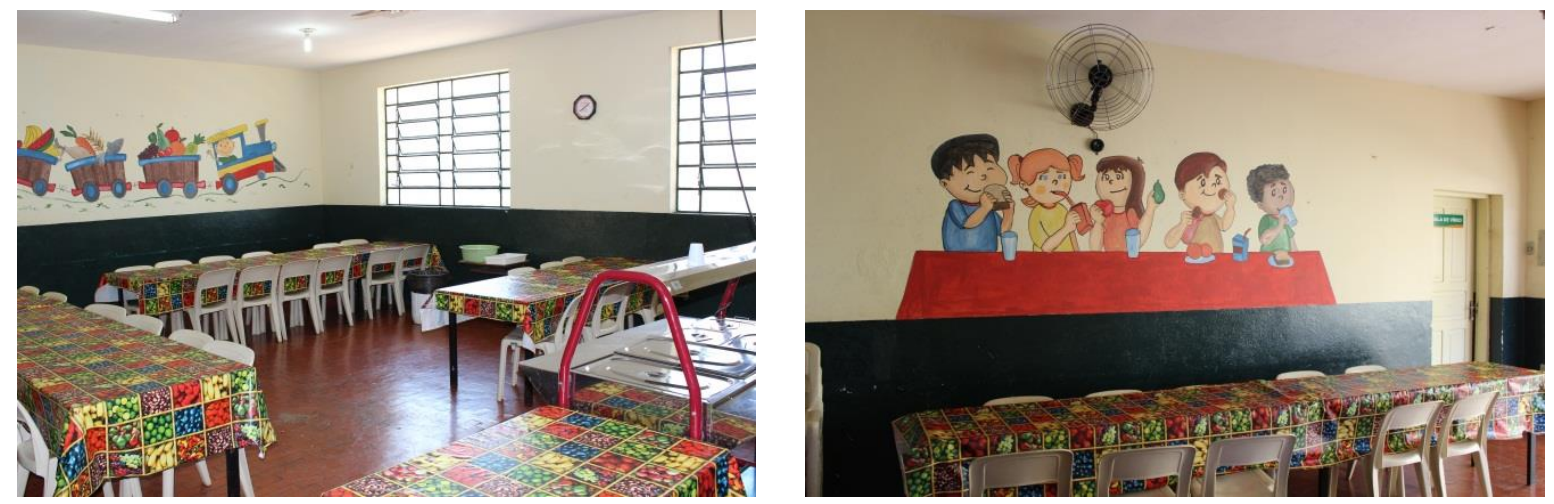

Figura 95 - Refeitório da escola "D"

Fonte: Arquivo pessoal do autor

\subsection{Processo seletivo}

Em conversa com o Diretor, observou-se que não existe processo seletivo para entrar na escola e também não existe transferência compulsória. Por outro lado, a escola recebia alunos por transferência, uma vez que sempre existiram vagas no município. 


\subsection{Diretor}

Em conversa com o Diretor da escola atuante no ano de 2010, observou-se que este tem formação em Pedagogia e pós-graduação em Psicopedagogia, tendo assumido o cargo por meio de concurso. Além disso, verificou-se também a falta de autonomia financeira para o Diretor nos recursos centralizados e o não recebimento de recursos descentralizados em nenhum momento de forma significante para poder auxiliar em alguma tomada de decisão.

Durante a visita, ficou evidente o acompanhamento da Diretora sobre os deveres do corpo docente da escola, tendo em vista os inúmeros comunicados fixados na sala dos Professores sobre prazos de entregas de documentos, abonos e horário de chegada e saída, de acordo com as figuras Figura 96, Figura 97 e Figura 98.

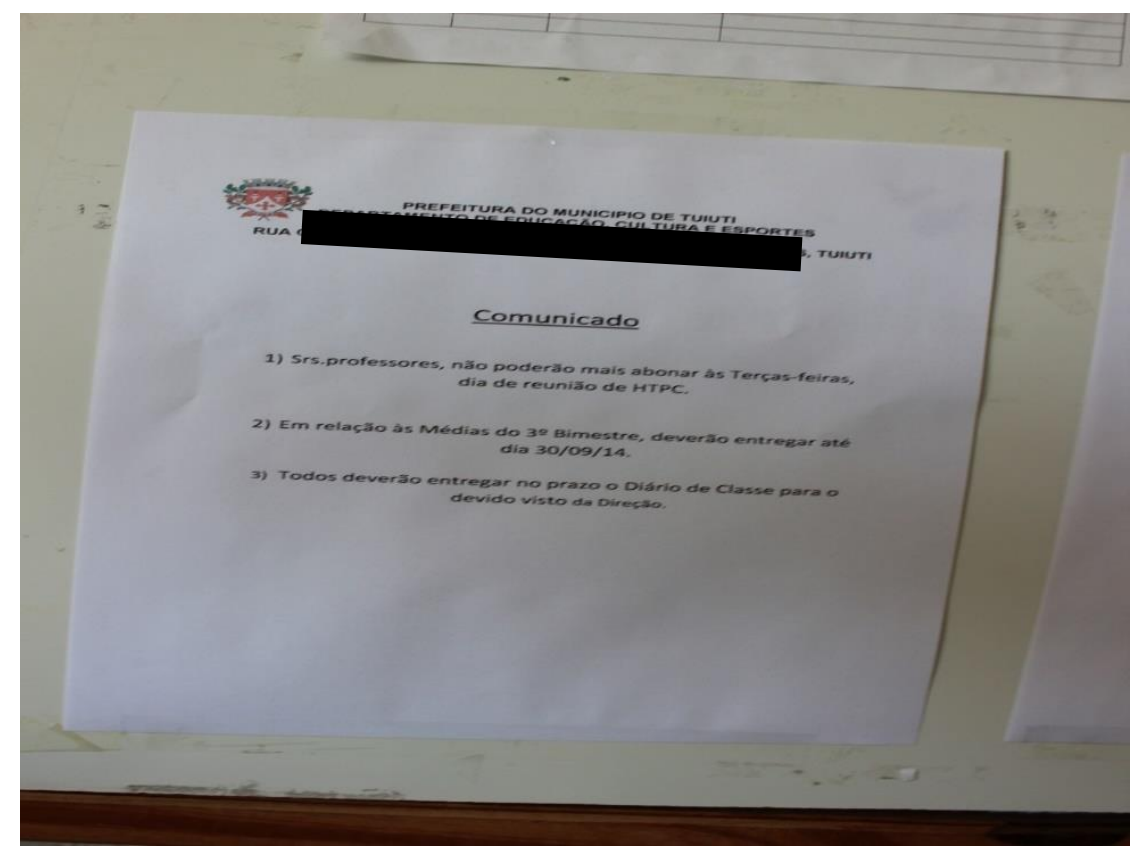

Figura 96 - Comunicado do Diretor aos docentes sobre abono e prazos de entrega de documentos Fonte: Arquivo pessoal do autor 


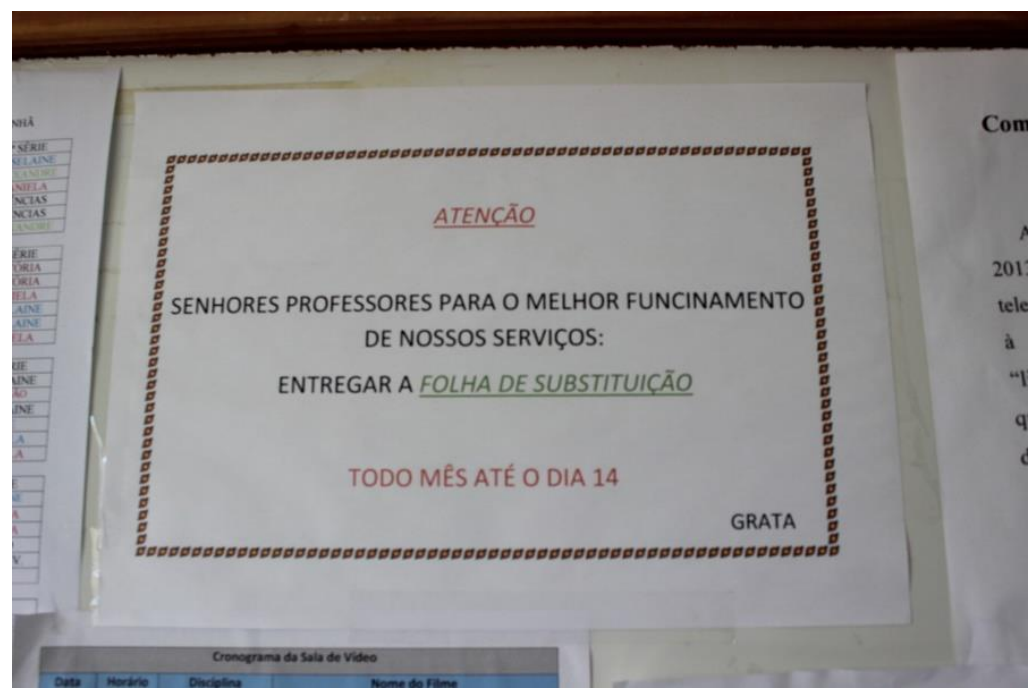

Figura 97 - Comunicado do Diretor aos docentes sobre o prazo de entrega da folha de substituição Fonte: Arquivo pessoal do autor

A Figura 98 destaca um comunicado do Diretor, direcionado ao corpo de docentes, sobre o horário de entrada e saída dos Professores. Esse é uma das formas de acompanhamento do Diretor sobre as obrigações dos funcionários, em especial do corpo docente.

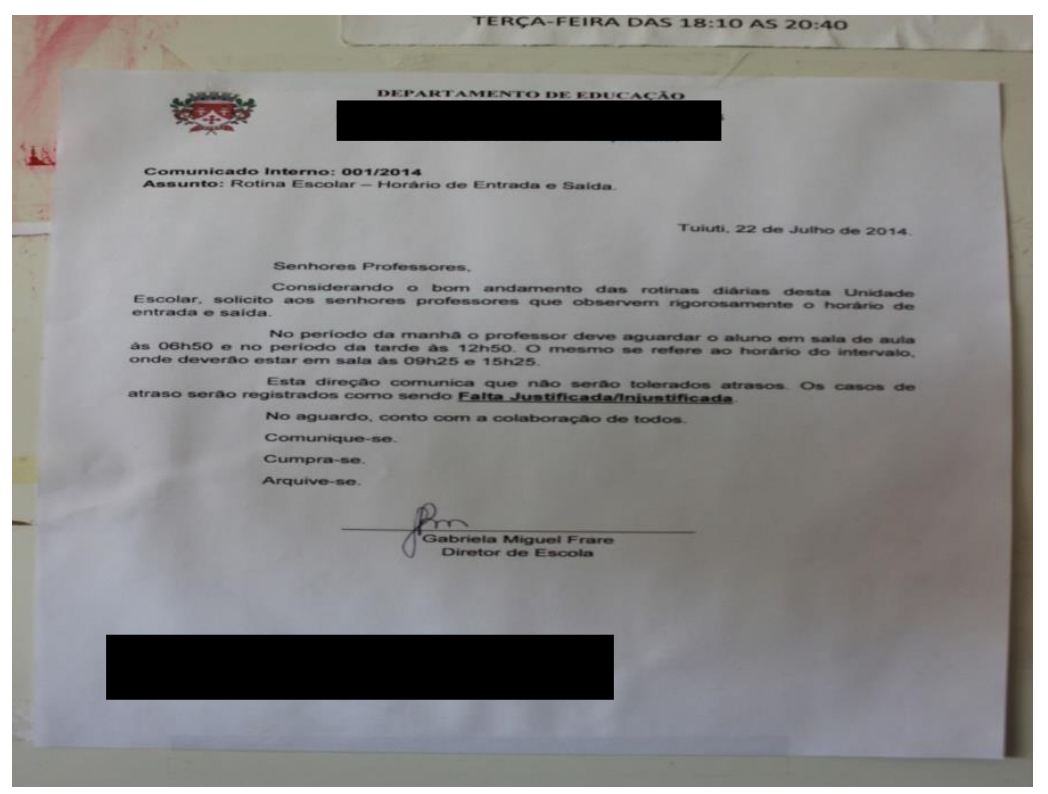

Figura 98 - Comunicado do Diretor aos docentes sobre os horários de entrada e saída da escola Fonte: Arquivo pessoal do autor 


\subsection{Plano de carreira do Diretor}

Em entrevista com o Diretor e Professores da escola, observou-se que o salário do Diretor não é tido como compatível para o cargo uma vez que na época de 2011 a Diretora recebia o mesmo que os Professores com um pequeno ajuste, mas com um aumento desproporcional de responsabilidades. No caso desta escola, o Diretor relatou que atua neste cargo pelo incentivo de realização pessoal no que faz em grande parte pelo desafio que o cargo oferecia para sua evolução profissional.

\subsection{Capacidade do Diretor na captação de recursos financeiros}

Durante entrevista realizada com o Diretor da escola, verificou-se que não existe uma próatividade para captar recursos de programas federais e estaduais que não seja os comumente divulgados e incentivados pela rede municipal de ensino, mostrando desconhecimento de outros programas passíveis da escola se candidatar e arrecadar mais recursos, como livros, etc. Nesse sentido, observou-se que o Diretor fica à mercê de uma pró-atividade da Secretaria da Educação para que possa melhorar os recursos disponíveis para a escola, uma vez que também não realiza parceria com empresas, ONGs e entidades da região.

\subsection{Destinação do recurso financeiro descentralizado e centralizado}

Em visita à escola e entrevista com o Diretor, observou-se que os recursos financeiros centralizados e suas respectivas destinações não são monitorados quantitativamente para que seja possível mensurar o quanto é investido em cada item listado (equipamentos de consumo, permanente, materiais escolares etc.), mas segundo relato do Diretor, uma parte relevante dos recursos era destinada para confraternizações da escola e dos Professores. Ademais, constatou-se que a escola dispõe de uma infraestrutura simples, com pátio para recreação dos alunos apenas no contra piso e com limitação de espaço, e cadeiras e carteiras em razoável condição de uso, conforme ilustrado pela Figura 99 e Figura 100. 


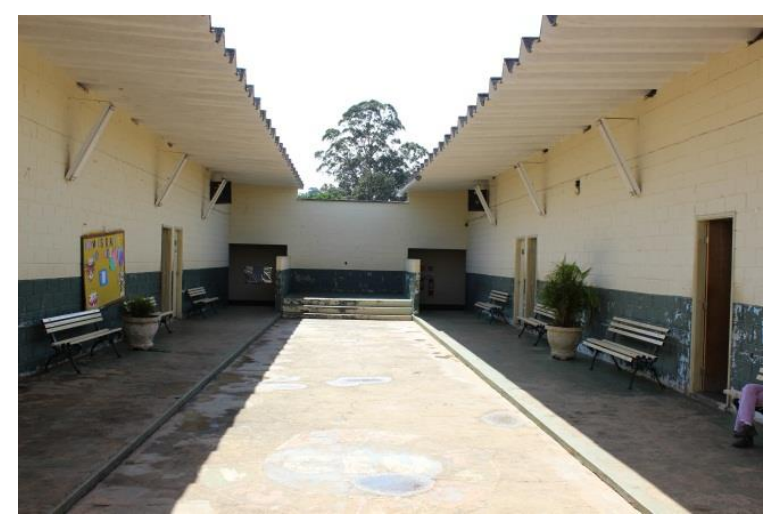

Figura 99 - Pátio da escola "D"

Fonte: Arquivo pessoal do autor

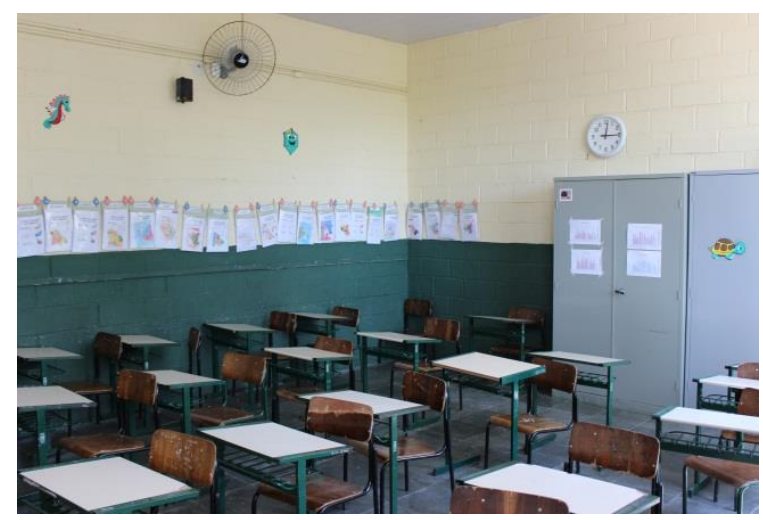

Figura 100 - Cadeiras e carteiras da escola "D" Fonte: Arquivo pessoal do autor
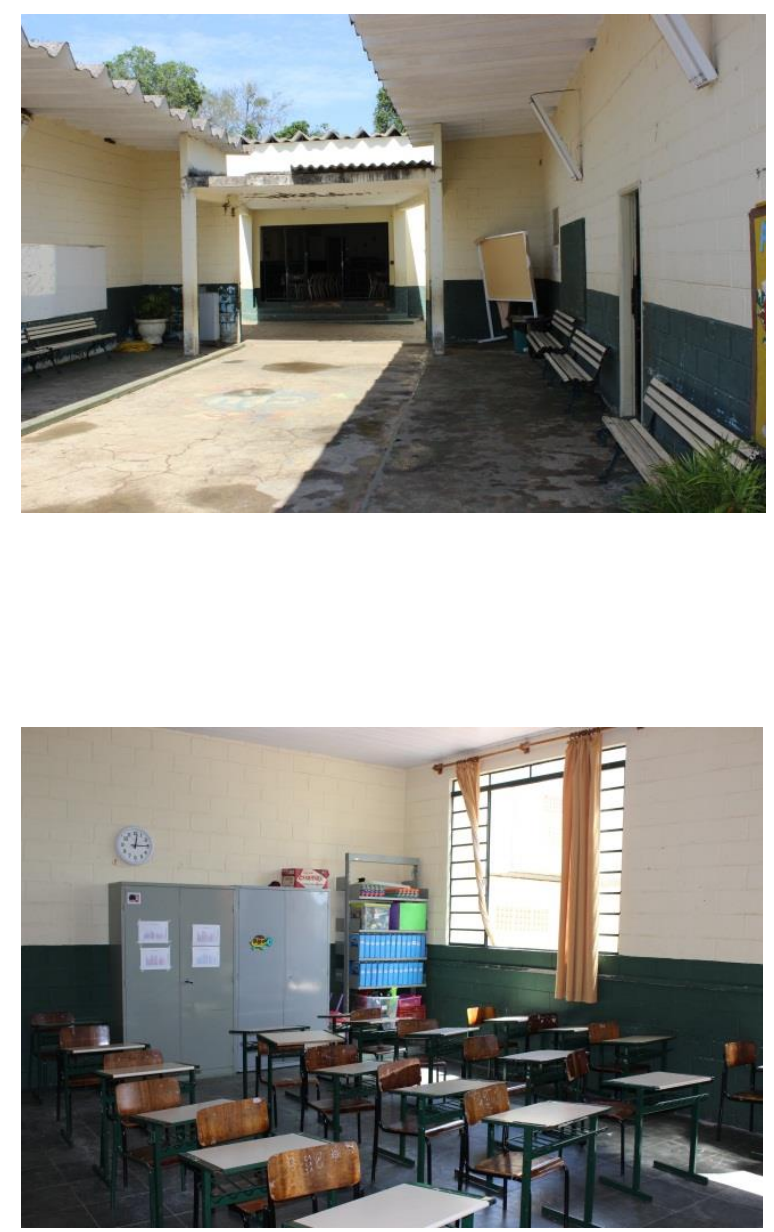


\subsection{Relatório pedagógico e socioeconômico}

\subsection{Desempenho na prova de português}

Em entrevista com a docente responsável pela disciplina observou-se que ela está na instituição desde 2005 (o que indica uma baixa rotatividade nessa disciplina) e tem plena autonomia para a realização de atividades, na forma de avaliação e também na reprovação dos alunos. Segundo a docente, uma vez por semana todas as salas passam 50 minutos na sala de leitura, onde os alunos são incentivados a retirar algum livro e levar para ler em casa, tal ação contribui para o bom índice de leitura dos alunos.

O material didático é definido pela SME e utilizado por toda rede municipal, de forma que, segundo a docente, ele é substituído cada vez que a oposição assume o poder no município. Além desse material, a docente tem autonomia para complementar as aulas com material próprio. Outro ponto relevante diz respeito ao acompanhamento do desempenho dos alunos, o mesmo ocorre diariamente por meio de trabalhos, produção textual e provas, totalizando algo em torno de 4 a 5 avaliações por bimestre. Quanto à recuperação e reforço para os alunos com dificuldades, a mesma não ocorria no contraturno, mas sim em horário normal de aula.

Com a aproximação da Prova Brasil a docente entrevistada afirma que são realizados simulados para que os alunos pratiquem com questões no padrão das que são exigidas na avaliação.

\subsection{Desempenho na prova de matemática}

Em entrevista com a docente responsável pela disciplina observou-se que ela está na instituição desde 2012 (o que indica uma baixa rotatividade nessa disciplina) e tem plena autonomia para a realização de atividades e também na forma de avaliação.

O material didático é definido pela SME e utilizado por toda rede municipal. Além desse material, a docente tem autonomia para complementar as aulas com material próprio. 
Outro ponto relevante diz respeito ao acompanhamento do desempenho dos alunos, o mesmo ocorre diariamente por meio de chamada oral da tabuada, listas de exercícios e provas, totalizando aproximadamente 4 avaliações por bimestre. Quanto à recuperação e reforço aos alunos com maior dificuldade de aprendizagem, a mesma não ocorria no contraturno, mas sim em horário normal de aula. A escola também incentiva seus alunos a participarem da Olimpíada Brasileira de Matemática das Escolas Públicas (OBMEP) em que inclusive, teve vários alunos classificados para a segunda fase, conforme nos mostra a Figura 102.

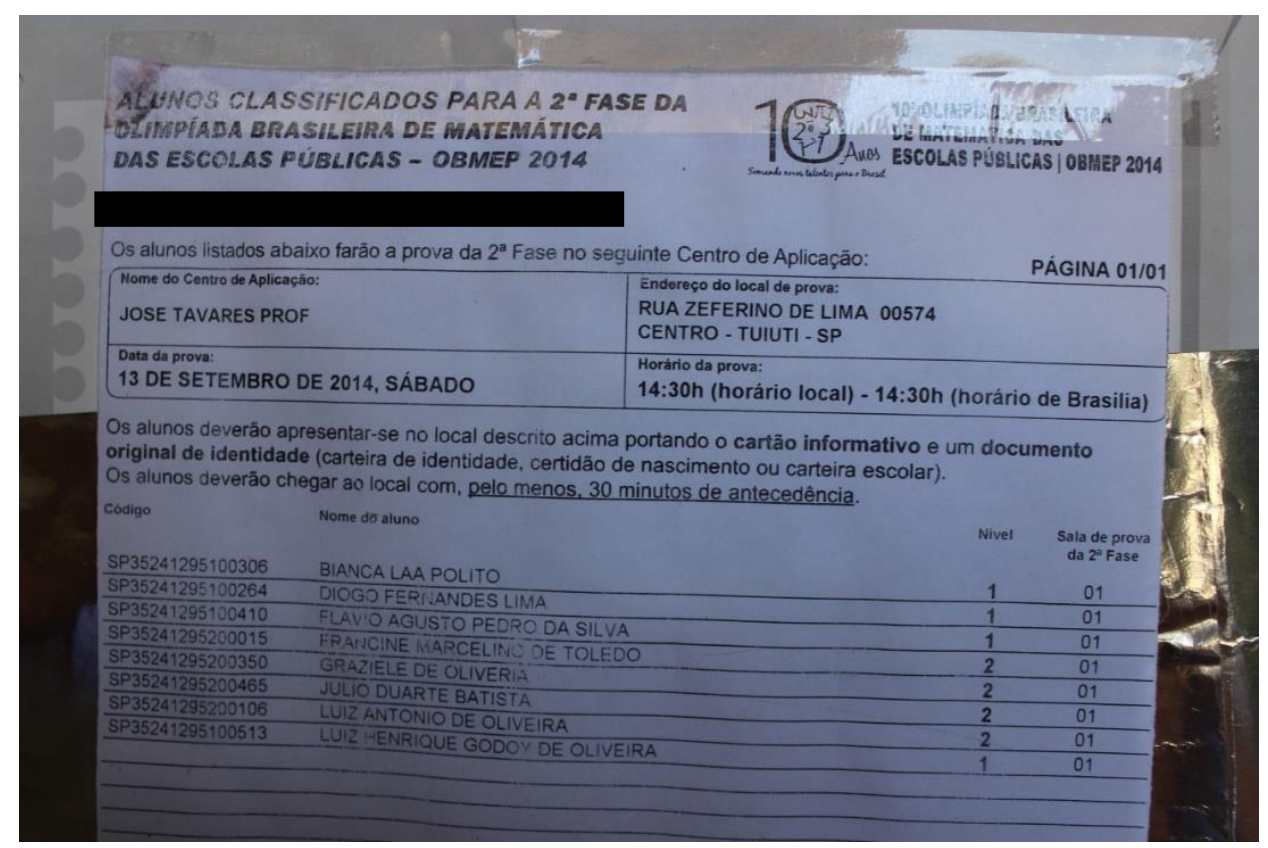

Figura 102 - Alunos da escola "D" classificados para a 2" fase da OBMEP Fonte: Arquivo pessoal do autor

De acordo com a docente entrevistada, com a aproximação da Prova Brasil são realizados simulados para que os alunos pratiquem com questões no padrão das que são exigidas na avaliação.

\subsection{Participação da família}

Em visita à escola observou-se que a maioria dos pais possui uma participação ativa na vida escolar dos filhos. Essa observação é corroborada pela declaração dos pais e da Diretora ao relatar que a maioria dos pais frequentam constantemente as reuniões realizadas pela escola e acompanham diariamente os deveres escolares dos filhos. Em reunião realizada com os pais, 
também foi possível observar seu comprometimento com a vida escolar dos filhos, pois eles sempre que possível conversam com seus filhos sobre o que aconteceu na escola e, além de ajuda-los com as pesquisas realizadas na internet, procuram incentiva-los a se reunir semanalmente com os outros colegas para resolver os deveres de casa. Entretanto, observouse que os pais desconhecem a existência e finalidade da associação de pais e mestres. Os pais também destacaram que a Diretora contribui para o seu acompanhamento na vida escolar dos filhos. Segundo os pais, ela é acessível e comprometida com o desempenho e comportamento dos alunos, pois sempre quando ocorre algum problema de indisciplina ou quando os alunos não estão com boas notas ela envia recado para os pais, além de estar sempre cobrando sua participação na rotina escolar, inclusive quando algum pai falta à reunião ela entra em contato para saber o que aconteceu. De acordo com os pais, ela é rígida em relação a disciplina e com isso ganhou o respeito dos alunos, os pais finalizam dizendo que confiam em seu trabalho, validando assim a maioria das ações desenvolvidas pela escola. Entretanto os pais disseram não concordar com a política da escola em cancelar as aulas da quinta e sexta-feira quando ocorre algum feriado na quarta-feira. Também se observou que a maioria dos pais reside na área rural e não utilizam o transporte público para ir à escola.

\subsection{Reprovação discente e sistema disciplinar}

Em visita à escola identificou-se a existência de um sistema de reprovação dos alunos, em que os Professores possuem autonomia para reprovar os alunos com baixo desempenho. Em relação ao sistema disciplinar observou-se que as regras são claras, conhecidas e respeitadas pela comunidade escolar. Como meio de divulgação a escola envia para os pais no início de cada ano um documento constando as regras escolares, em que eles devem assinar e devolver para a direção da escola, demonstrando assim conhecimento sobre as regras. Já para os alunos, a escola comunica as regras no início do ano, além de colar uma cópia em cada sala de aula, conforme ilustrado pela Figura 103. 


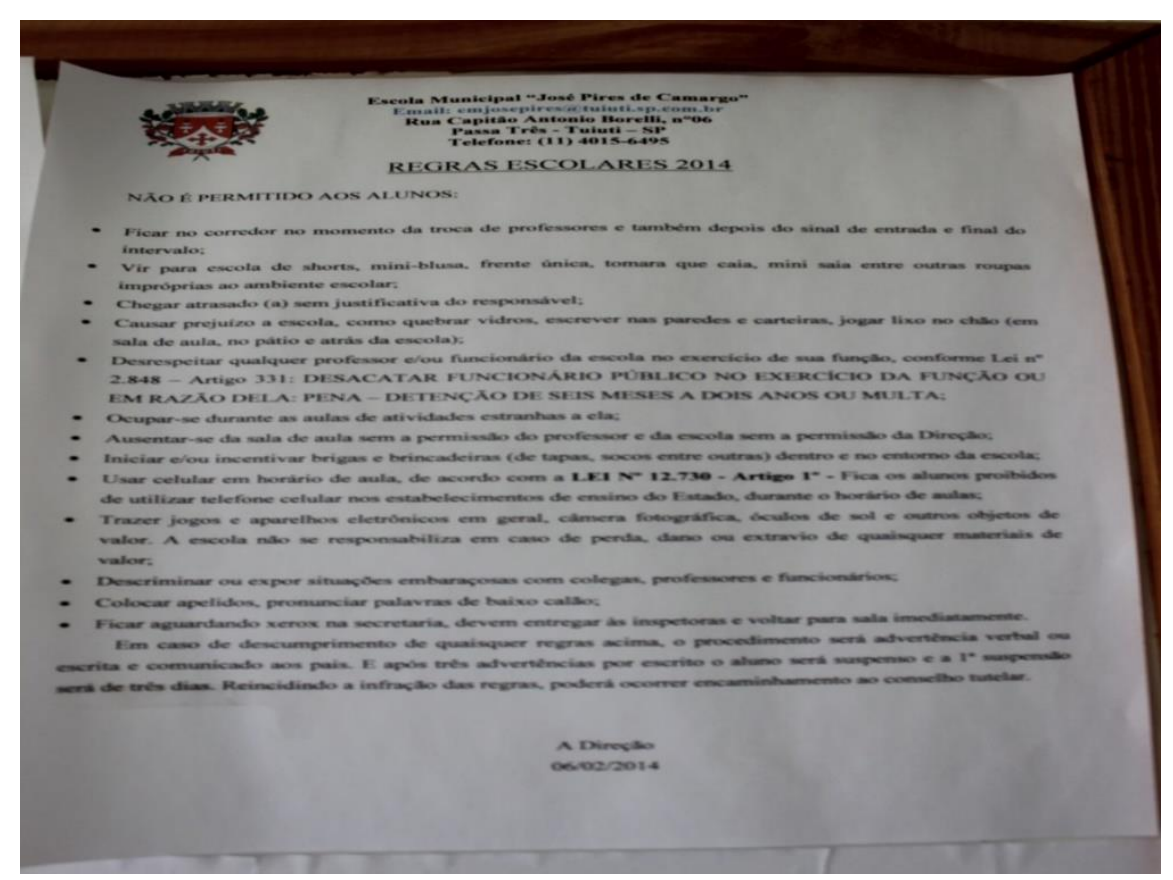

Figura 103 - Regras escolares aplicadas aos alunos

Fonte: Arquivo pessoal do autor

A escola é rígida em relação ao cumprimento de tais regras, inclusive quando o aluno descumpre alguma delas é advertido e o pai chamado prontamente a comparecer na escola. Segundo relato dos alunos, em uma ocasião o Professor tomou o celular do aluno que foi retirado somente na semana seguinte pelos seus pais. Os pais demonstram concordar e apoiar as regras estabelecidas pela escola, o que contribui para que os alunos respeitem a figura do Diretor, Professores e funcionários.

Em entrevista com os alunos eles afirmaram tratar seus Professores como familiares e os chamar carinhosamente de tio e tia. Já em entrevista com os pais e alunos, observou-se que os atos de indisciplina são raros na escola, eles afirmam não se lembrar de nenhum aluno que tenha agredido fisicamente ou verbalmente os Professores, Diretor ou funcionários da escola. Durante a visita, observou-se que a disciplina dos alunos é fruto de um trabalho que se inicia desde os seus primeiros anos na escola, pois já no segundo ano os alunos têm de escrever e anexar na sala de aula as regras de comportamento em sala que eles deverão cumprir ao longo do ano letivo, conforme ilustrado pela Figura 104. 


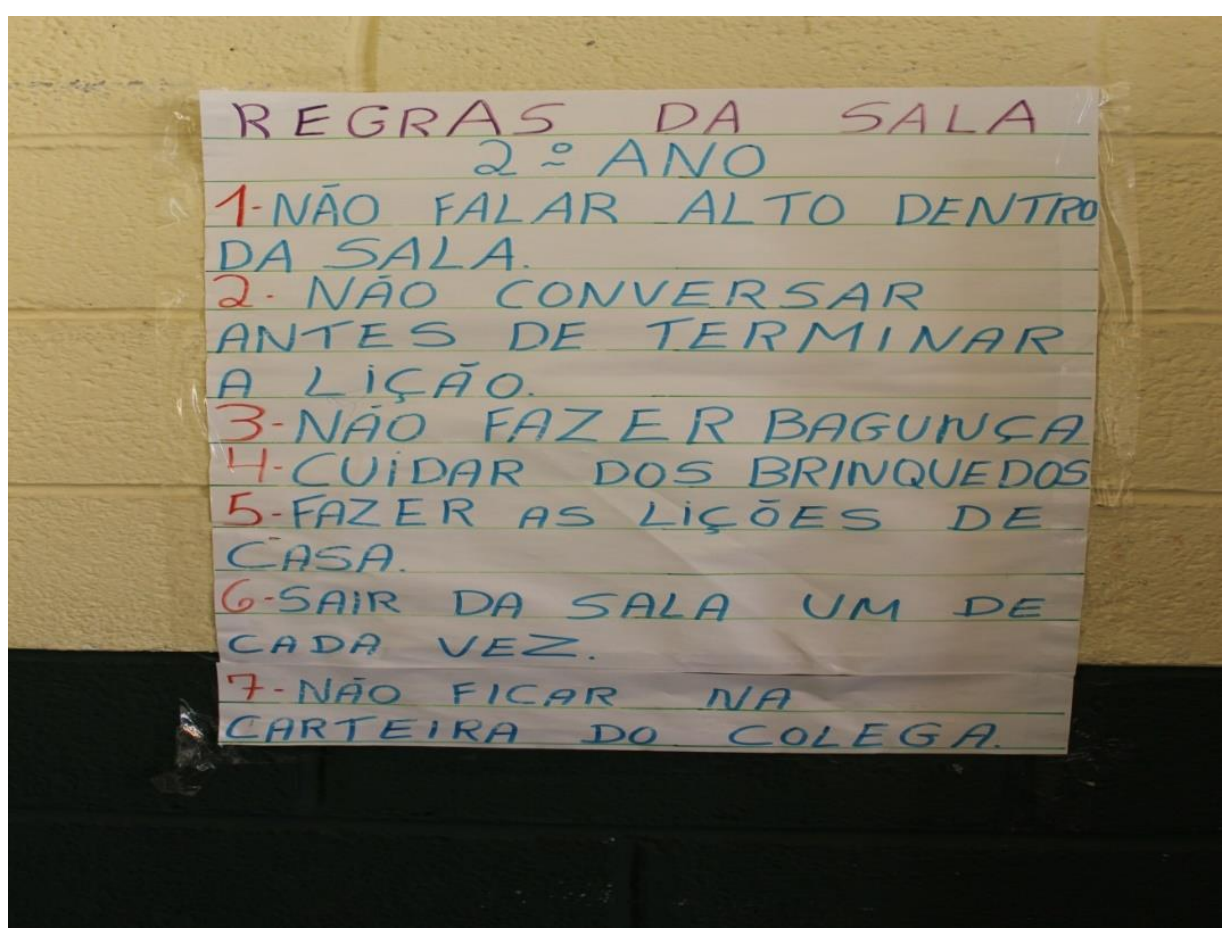

Figura 104 - Regras de comportamento em sala dos alunos do $2^{\circ}$ ano Fonte: Arquivo pessoal do autor

Os alunos finalizaram afirmando sentir orgulho de estudarem nessa escola, principalmente por ela ser considerada pela comunidade como a melhor escola da cidade.

\subsection{Laboratório de informática}

Em visita realizada à escola constatou-se a inexistência de laboratório de informática no ano de 2011.

\subsection{Biblioteca}

Em visita realizada à escola constatou-se que a biblioteca existia antes mesmo de 2011 e, segundo os docentes, ela possuía um acervo de quantidade e qualidade de nível mediano, porém com excelente retirada de livros por parte dos alunos, conforme nos mostra o controle de retirada de livros dos alunos no ano de 2011, ilustrado pela Figura 105, Figura 106 e Figura 107. 


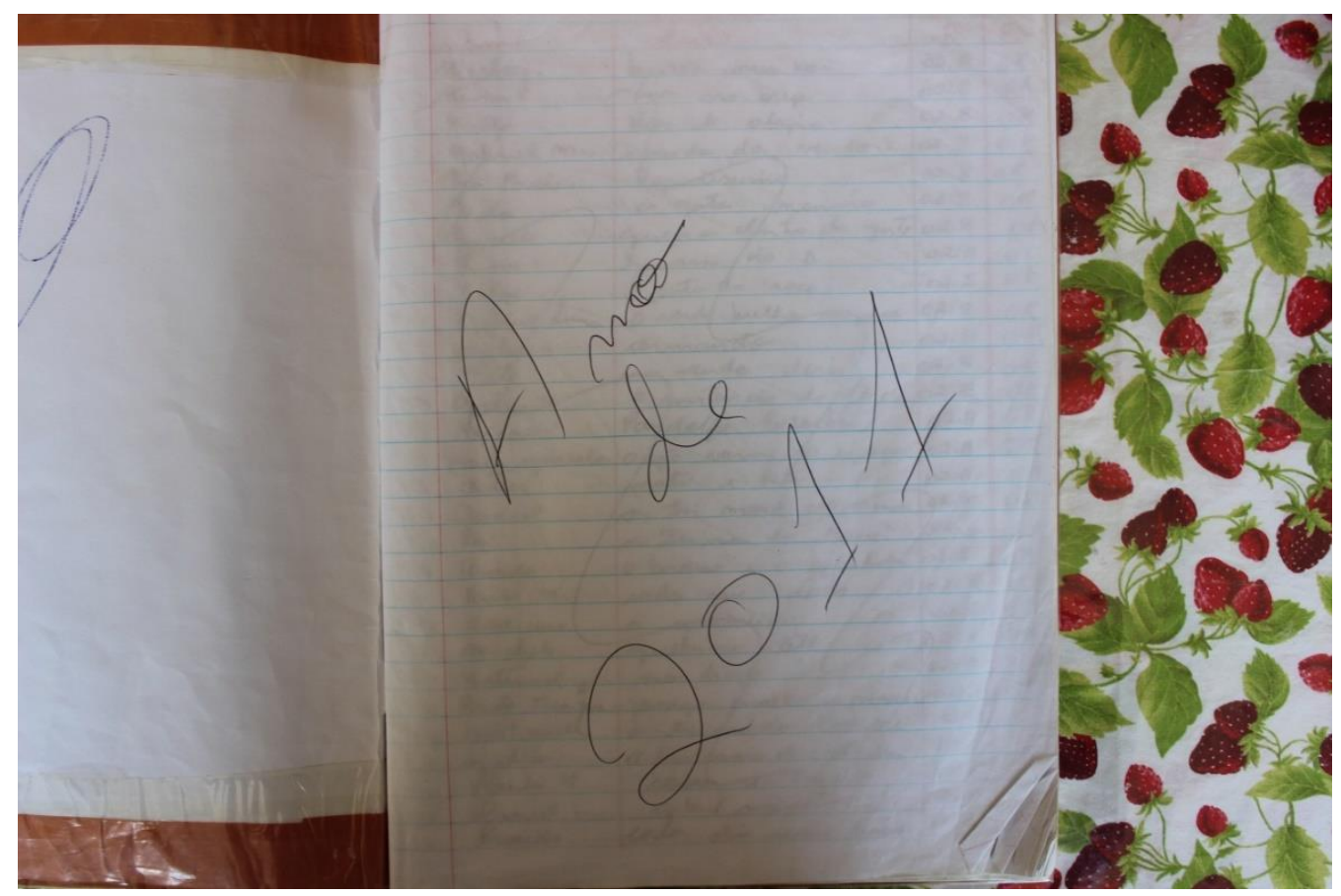

Figura 105 - Controle de retirada de livros dos alunos em 2011

Fonte: Arquivo pessoal do autor

Conforme apresentado a seguir, o controle de retirada de livro de alunos é bem organizado, com dados sobre o aluno, livro, série, data de retirada e devolução.

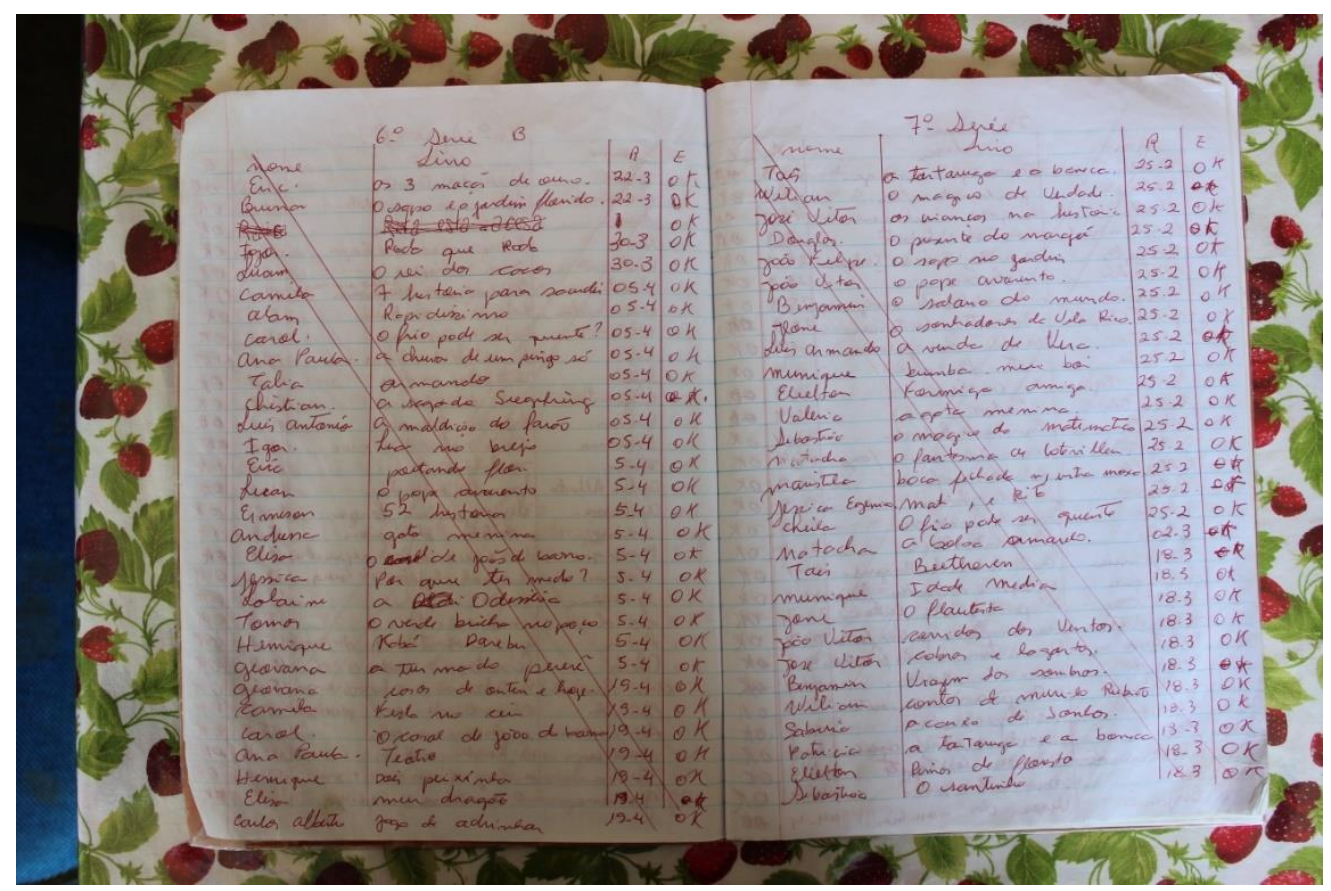

Figura 106 - Controle de retirada de livros dos alunos em 2011

Fonte: Arquivo pessoal do autor

Em outra imagem, pode-se observar na Figura 107 o controle da retirada de livros do ano de 2011. 


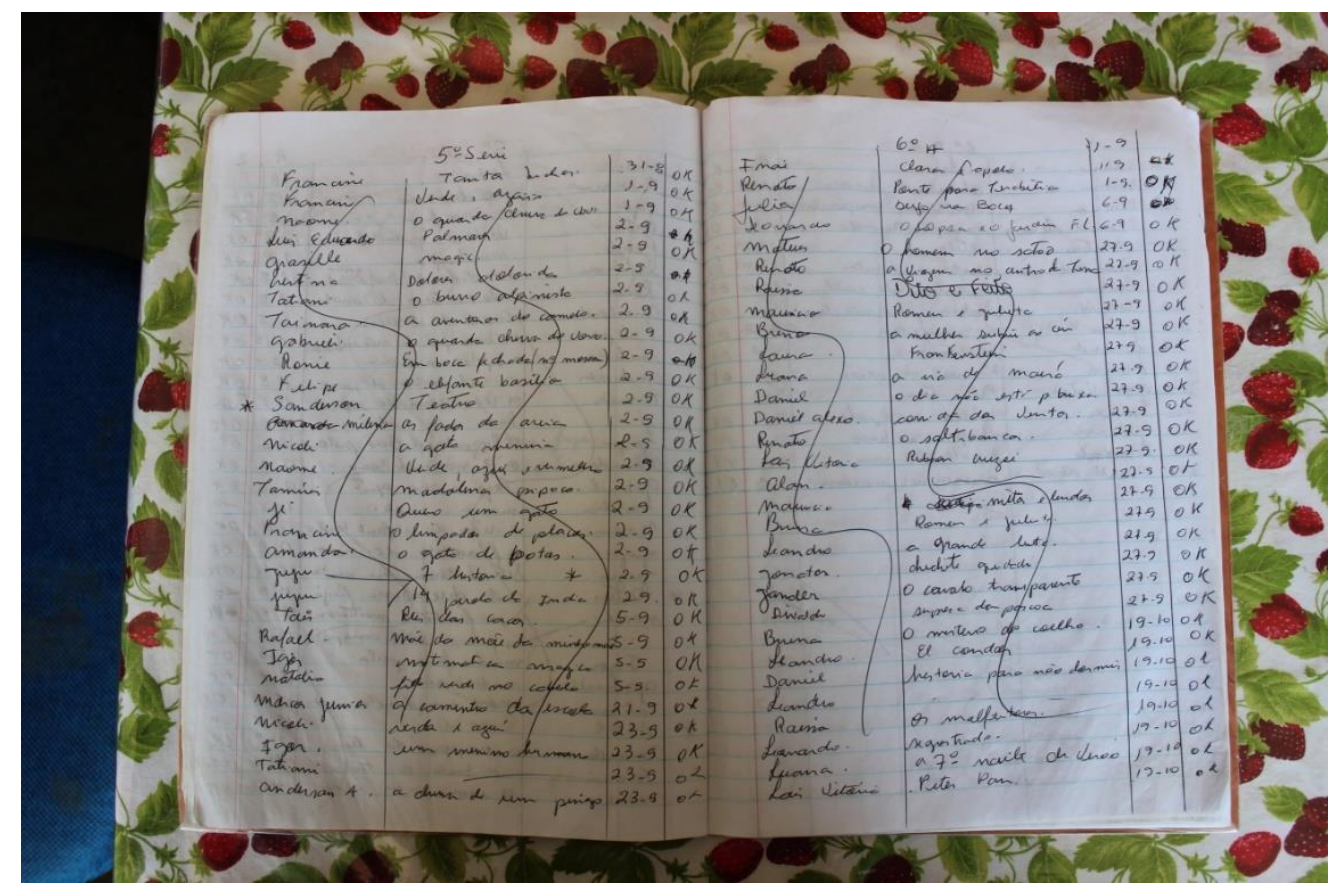

Figura 107 - Controle de retirada de livros dos alunos em 2011

Fonte: Arquivo pessoal do autor

A biblioteca possui espaço para estudos coletivos com até seis alunos, entretanto, o local não é bem iluminado, organizado e muito menos arejado, conforme nos mostra a Figura 108 e Figura 109.

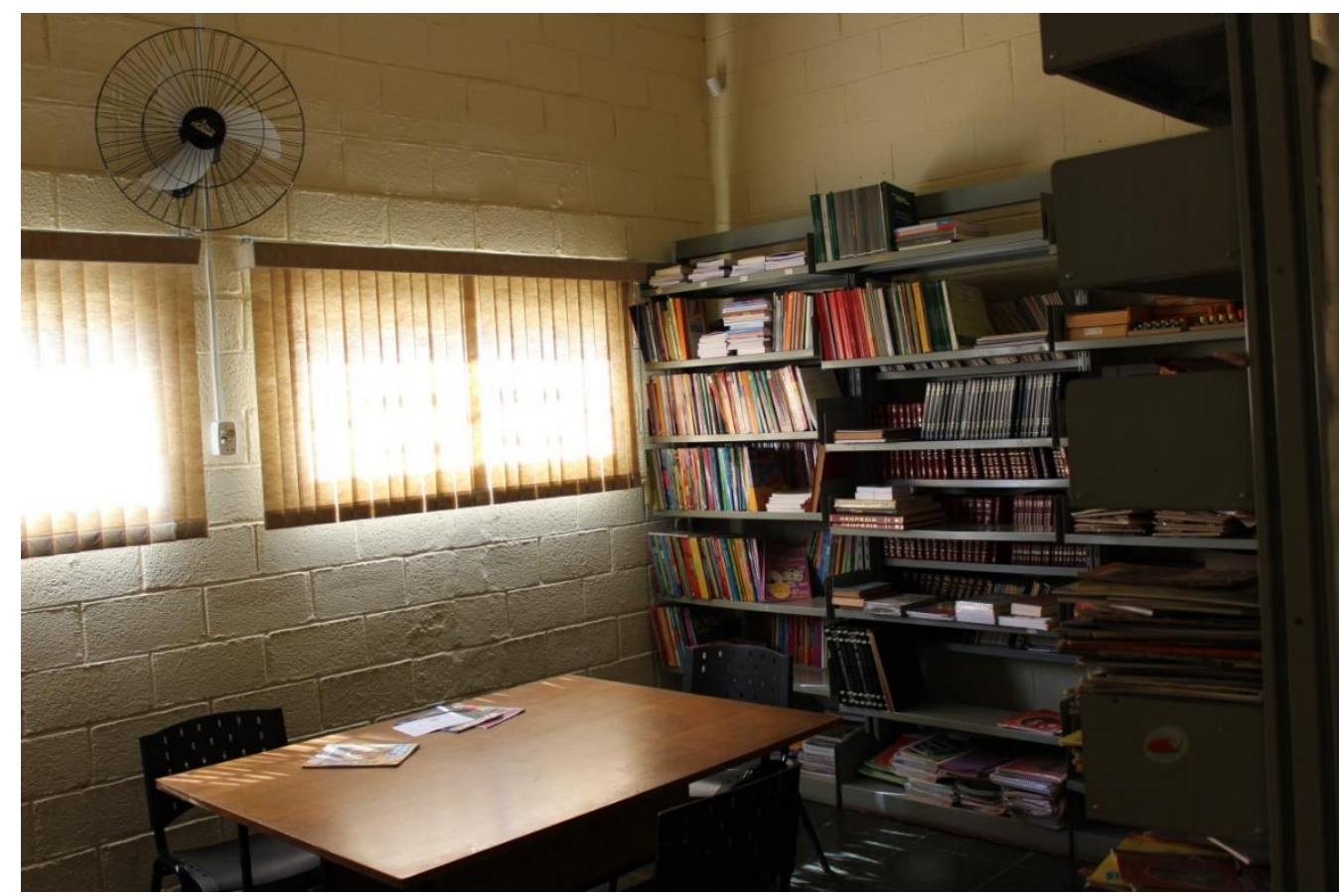

Figura 108 - Biblioteca da escola "D"

Fonte: Arquivo pessoal do autor 
Pode-se observar que a estrutura para organização da biblioteca é limitada, conforme apresenta a Figura 109.
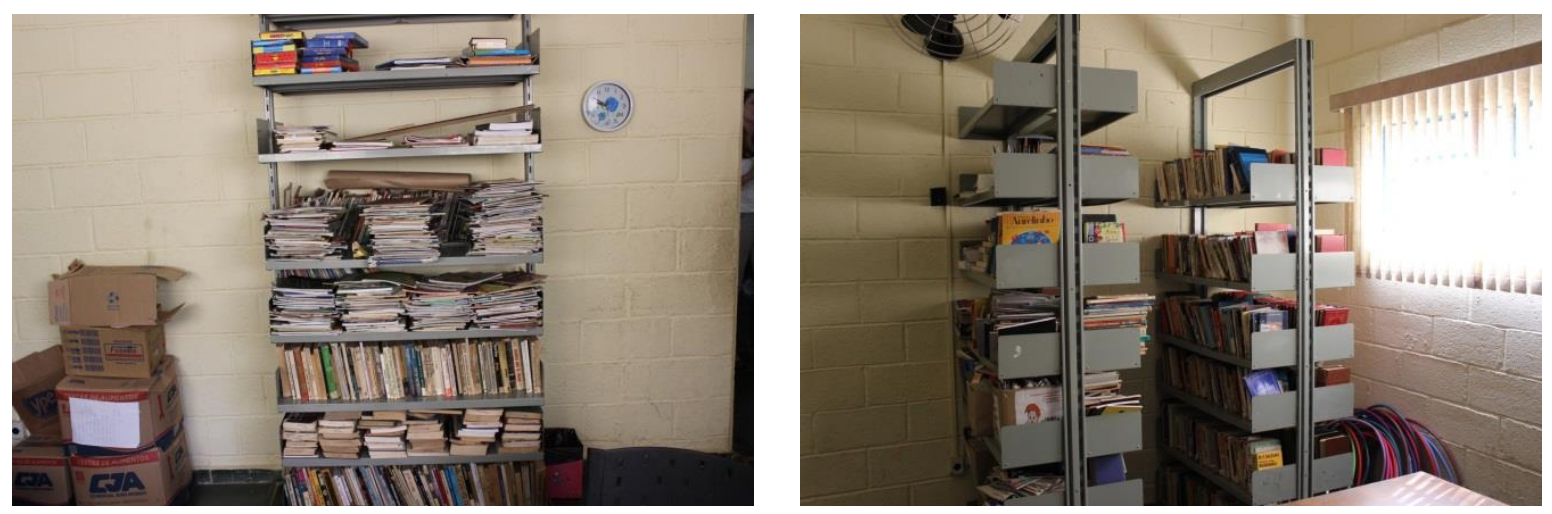

Figura 109 - Biblioteca da escola "D"

Fonte: Arquivo pessoal do autor

A orientação dos alunos na biblioteca e o controle de retirada de livros são feitos por uma docente que comparece diariamente no local. Segundo essa docente, os alunos criaram o hábito de retirar livros para ler em casa principalmente pela limitação de espaço da biblioteca. De acordo com a Diretora, o acervo da biblioteca da escola é restrito ao uso dos alunos, não se estendendo a comunidade.

\subsection{Sala de leitura}

Em visita à escola observou-se a inexistência de sala de leitura.

\subsection{Alunos}

Em visita à escola identificou-se que o sistema de matrículas dos alunos é por zoneamento e a maioria dos 211 alunos matriculados na escola residem na área rural e utilizam o transporte público diariamente para ir à escola. A Figura 110 nos mostra os ônibus escolares aguardando a saída dos alunos para leva-los para casa. 


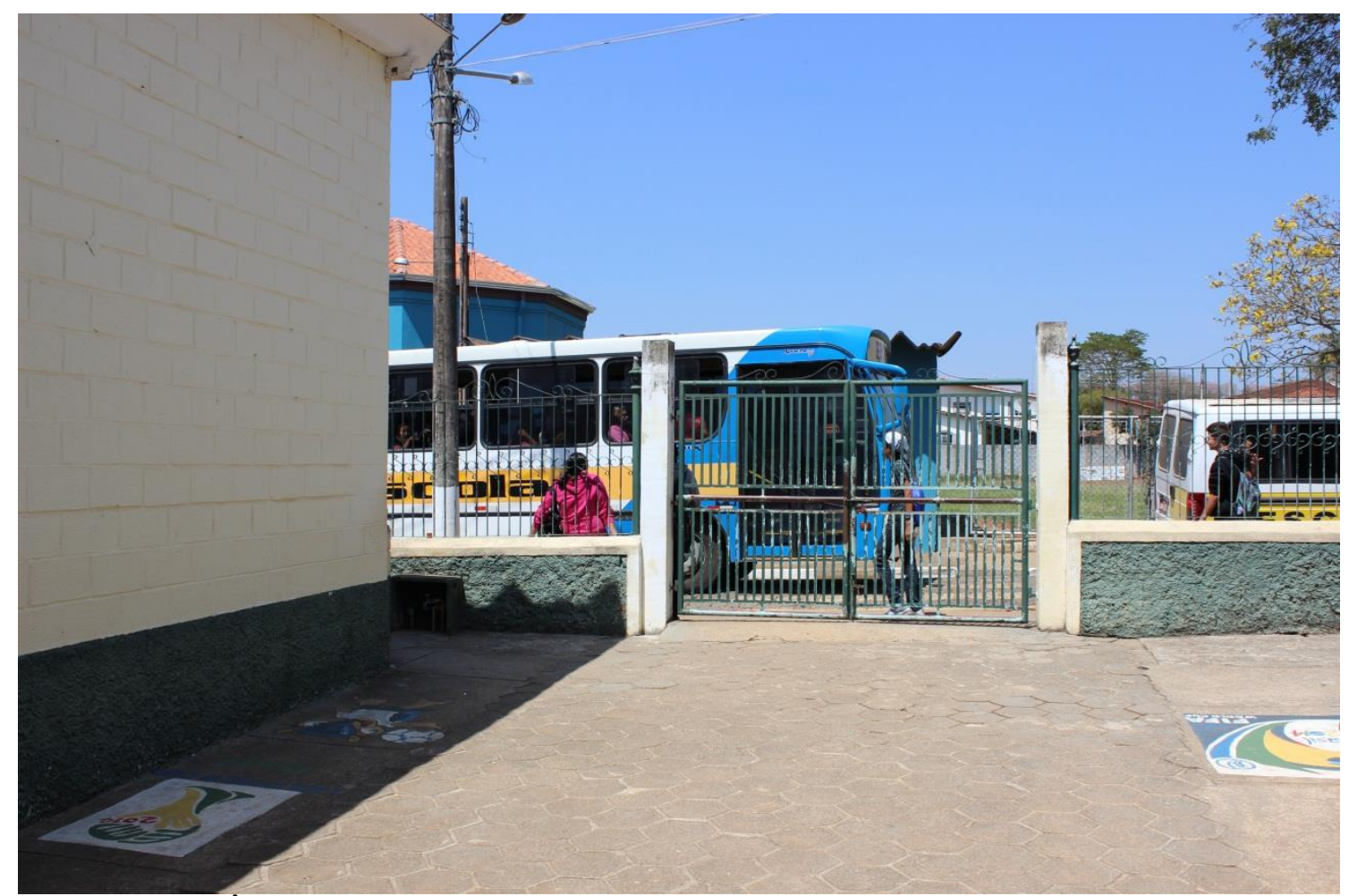

Figura 110 - Ônibus escolares aguardando a saída dos alunos

Fonte: Arquivo pessoal do autor

\subsection{Docentes}

Com a visita à escola foi possível identificar as seguintes características referentes ao seu corpo docente:

Número de docentes para cada cem alunos: 9,50

Porcentagem de docentes pertencente ao sexo feminino: 70,37;

Porcentagem dos docentes que possuem magistério concluído: 5,56;

Porcentagem dos docentes que possuem o curso de licenciatura concluído: 94,44;

Porcentagem dos docentes que possuem o ensino superior concluído: 94,44;

Porcentagem dos docentes que possuem especialização concluída: 35,19.

\subsection{Funcionários}

Número de Funcionários para cada cem alunos: 9,48. 


\subsubsection{Escola "I" abaixo da fronteira de eficiência}

- Data da visita: $15 / 09 / 2014$

- Indicadores da escola I

Número de alunos: 294

Investimento anual por aluno: $\mathrm{R} \$ 3.522,26$

Nota no IDEB (Anos Finais): 4,5

Nível socioeconômico: 5 (Médio-Alto)

Em visita realizada à escola "I", conforme ilustrado pela Figura 111, localizada no município de Tuiuti no estado de São Paulo, foi possível identificar inúmeras práticas administrativas e pedagógicas que colaboraram para que, no ano de 2011, a escola obtivesse uma nota 4,5 no IDEB. A seguir são apresentados alguns dos principais aspectos mais relevantes que foram observados durante a visita à escola.

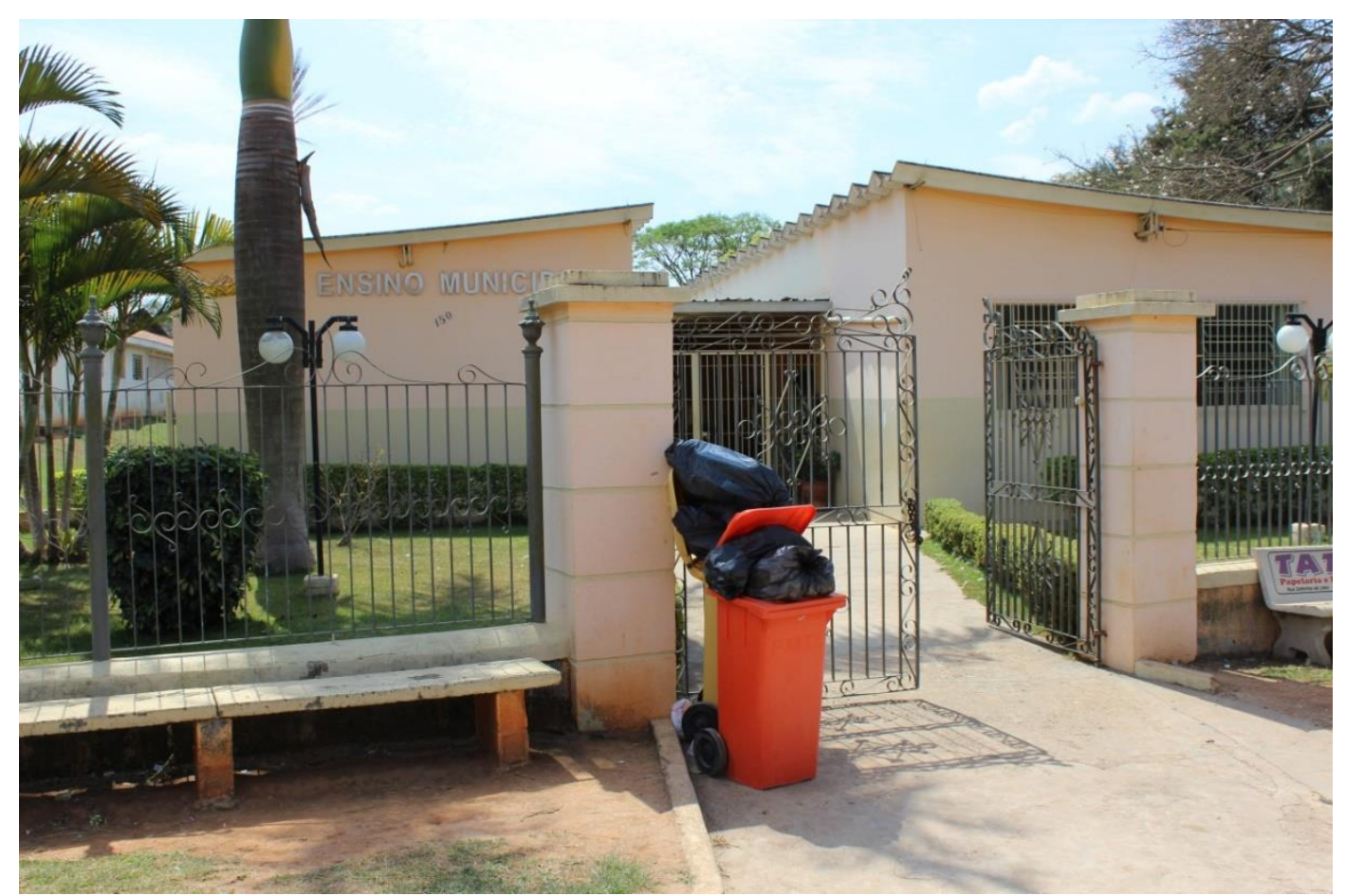

Figura 111 - Fachada da escola "I"

Fonte: Arquivo pessoal do autor 


\subsection{Relatório de gestão e destinação dos recursos financeiros do Diretor}

\subsection{Especificidades do município pequeno}

Em conversa com o Diretor, ele destaca que a cobrança da comunidade é maior em cidade pequena, principalmente em função do contato mais próximo e constante dos pais com o Diretor e Professores em locais como bares, padarias, supermercados, etc. Todavia, nesta escola em específico a comunidade não apresentou grande cobrança, segundo os outros atores entrevistados nesta pesquisa (Professores, pais de alunos etc.).

\subsection{Alimentação dos alunos}

Em conversa com o Diretor da escola, observou-se que é oferecido duas refeições por período aos alunos. Além disso, foi observado também a existência de uma nutricionista responsável pela elaboração e acompanhamento do cardápio, que é muito elogiado pelos alunos devido sua variedade e qualidade. A escola também possui um refeitório com espaço e condições adequadas para os alunos realizarem suas refeições, conforme ilustrado pela Figura 112.

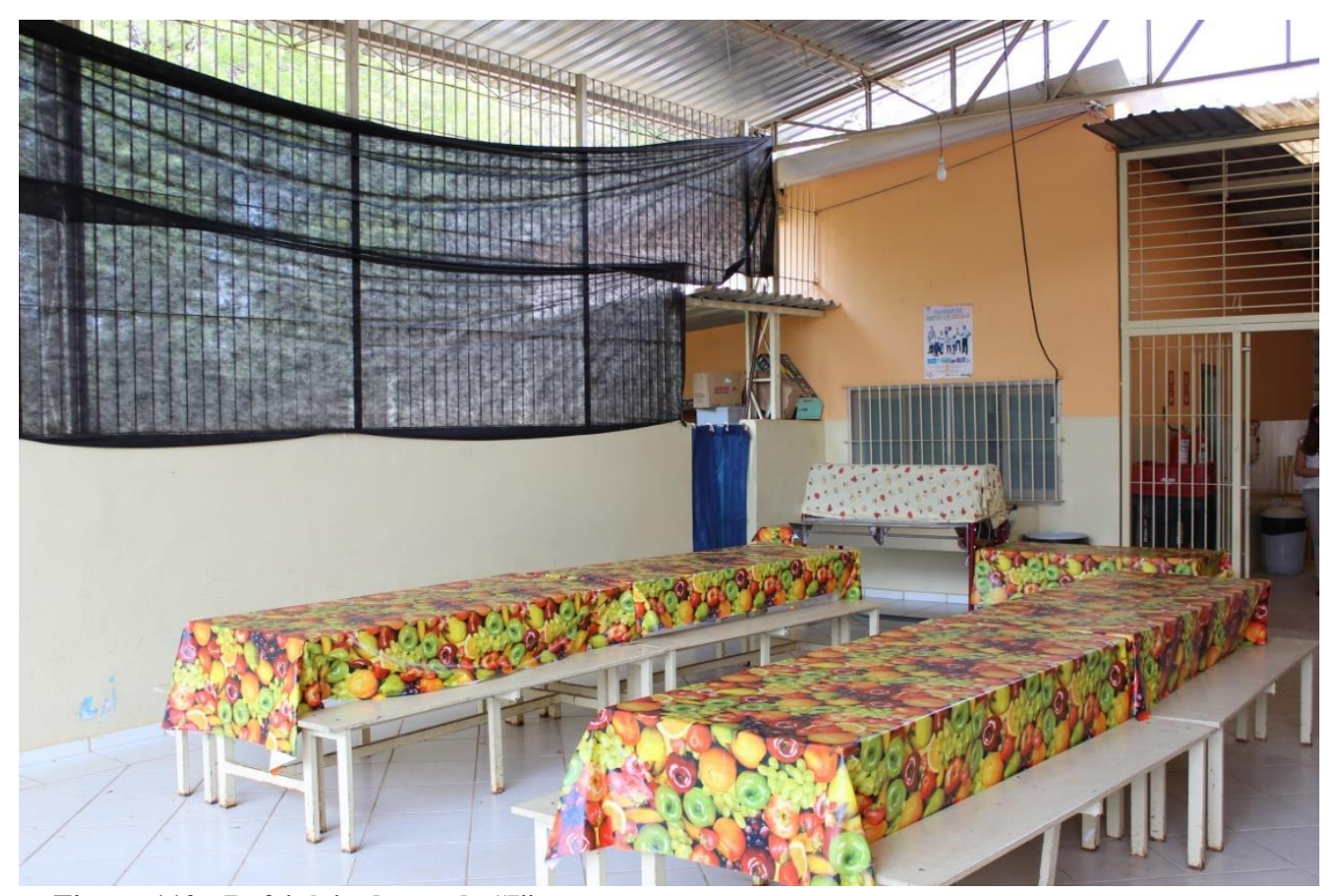

Figura 112 - Refeitório da escola "I" Fonte: Arquivo pessoal do autor 


\subsection{Processo seletivo}

Em conversa com o Diretor, observou-se que não existe processo seletivo para entrar na escola, mas já existiram casos de transferência compulsória. Por outro lado, a escola recebia alunos por transferência, uma vez que sempre existiram vagas no município.

\subsection{Diretor}

Em conversa com o Diretor que atuava no ano de 2010, constatou-se que este tem formação em Matemática e Pedagogia, juntamente com uma especialização em Matemática, tendo assumido o cargo por meio de concurso público. Nesta escola, verificou-se também uma baixa autonomia do Diretor para decisões financeiras, uma vez que todos os recursos que chegam até ele já têm um destino previamente selecionado, e estes recursos se apresentam escassos em sua opinião. O Diretor ainda destaca que promove juntamente com o corpo docente um acompanhamento da evolução da escola no IDEB, a fim de buscar um avanço no indicador e atingir a meta estabelecida para a escola ao longo dos anos, conforme ilustrado pela Figura 113.

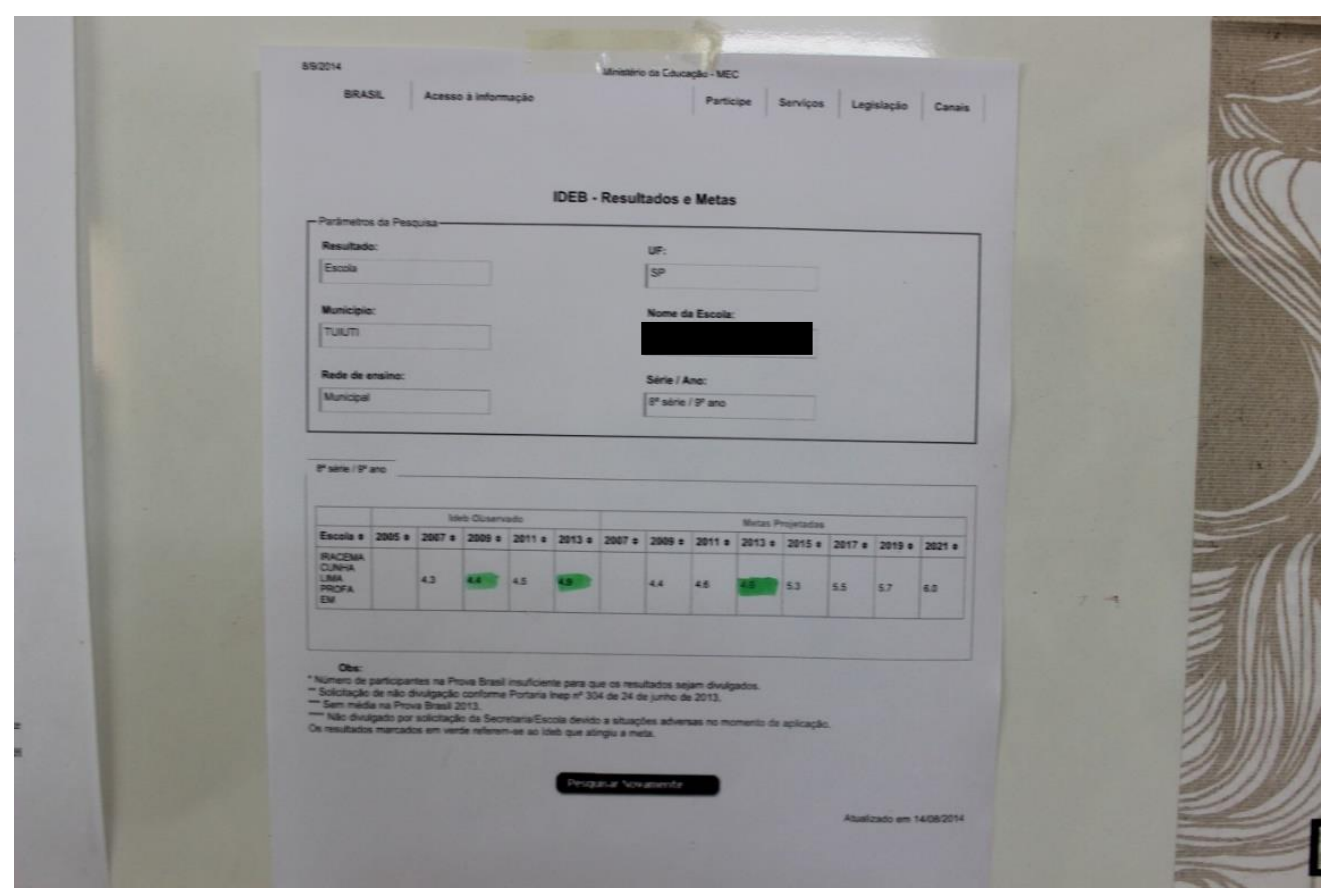

Figura 113 - Acompanhamento do Diretor nos resultados e metas do IDEB da escola Fonte: Arquivo pessoal do autor 


\subsection{Plano de carreira do Diretor}

Em entrevista com o Diretor e os Professores da escola, observou-se que o salário do Diretor não é tido como compatível para o cargo, uma vez que a Diretora recebe o mesmo que os Professores com um pequeno ajuste, mas com um aumento desproporcional de responsabilidades. No caso desta escola, o Diretor relatou que atua neste cargo por realização pessoal e também pelo desafio que o cargo oferece para sua evolução profissional.

\subsection{Capacidade do Diretor na captação de recursos financeiros}

Durante entrevista realizada com o Diretor da escola, observou-se que ele não atua em nenhum momento para realizar captação de recursos para a escola a não ser pelas fontes convencionais que são repassadas pelos órgãos federais, estaduais e municipais. Além disso, o recurso que provem da cantina da escola e de festividades - caso da festa junina - soma uma arrecadação média de $\mathrm{R} \$ 2.000,00$ por ano, o que reflete na falta de recursos descentralizados para atuação do Diretor.

\subsection{Destinação do recurso financeiro descentralizado e centralizado}

Em visita à escola e entrevista com o Diretor, observou-se que os recursos financeiros centralizados e descentralizados e suas respectivas destinações não são monitorados quantitativamente para que seja possível mensurar o quanto é investido em cada item listado (equipamentos de consumo, permanente, materiais escolares etc.). Entretanto, observou-se que a infraestrutura desta escola é razoável, com salas de aulas com ventiladores, cadeiras e carteiras em bom estado de uso, de acordo com a Figura 114. 


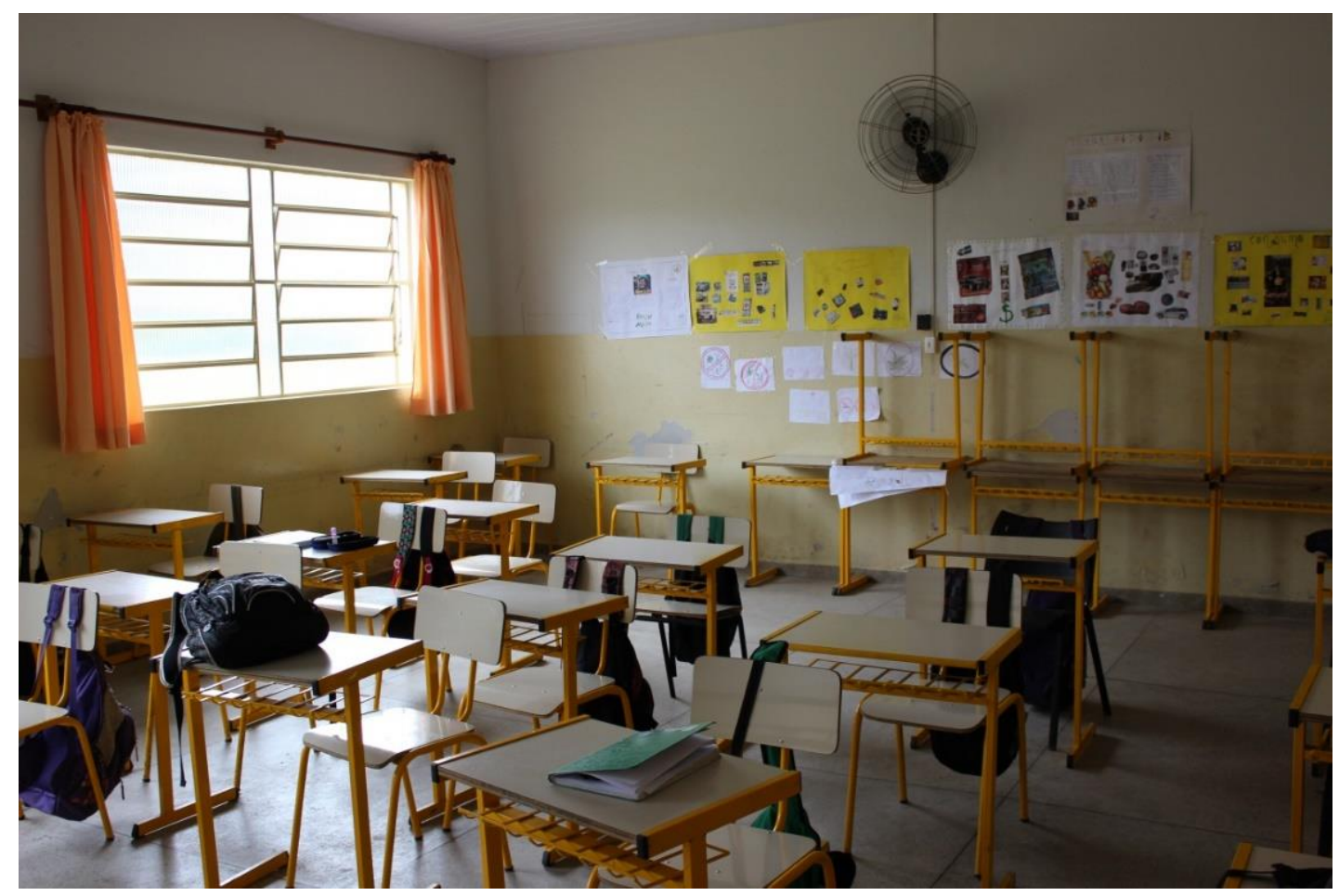

Figura 114 - Sala de aula da escola "I"

Fonte: Arquivo pessoal do autor

A boa infraestrutura também é observada na quadra de esporte coberta, porém sem proteção lateral, conforme apresenta a Figura 115.
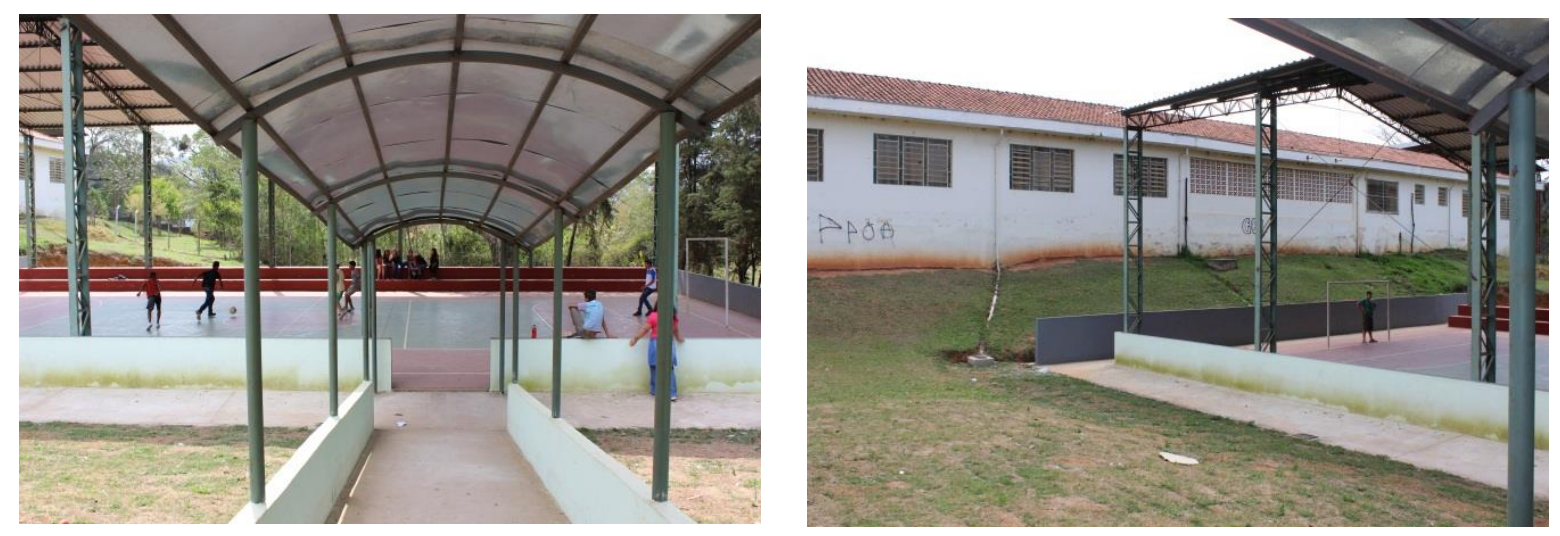

Figura 115 - Quadra de esportes da escola "I" Fonte: Arquivo pessoal do autor 


\subsection{Relatório pedagógico e socioeconômico}

\subsection{Desempenho na prova de português}

Em entrevista com a docente responsável pela disciplina, observou-se que ela está na instituição desde 2009 (o que indica uma baixa rotatividade nessa disciplina) e tem plena autonomia para a realização de atividades, na forma de avaliação e também na reprovação dos alunos.

A docente também destaca que uma vez a cada quinze dias ela leva todas as salas, que ela ministra aula, na biblioteca durante 50 minutos, onde os alunos são incentivados a retirar livros para ler em casa, entretanto, tal ação não vem surtindo efeito, haja vista o baixo índice de retirada de livros dos alunos, conforme nos mostra o controle de retirada de livros dos alunos, ilustrado pela Figura 116.
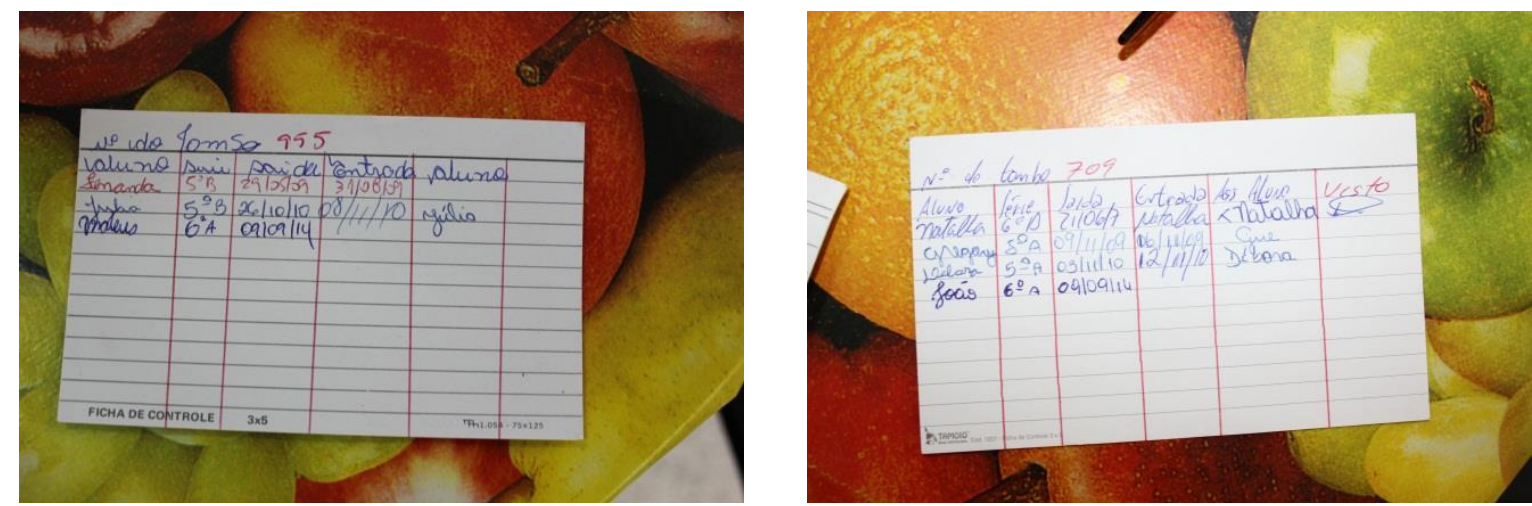

Figura 116 - Controle de retirada de livros dos alunos

Fonte: Arquivo pessoal do autor

De acordo com a docente entrevistada a escola também promove anualmente o concurso de poesias, com a finalidade de incentivar a criatividade e sensibilidade dos alunos, as poesias vencedoras ficam expostas no mural da escola, conforme nos mostra a Figura 117. 


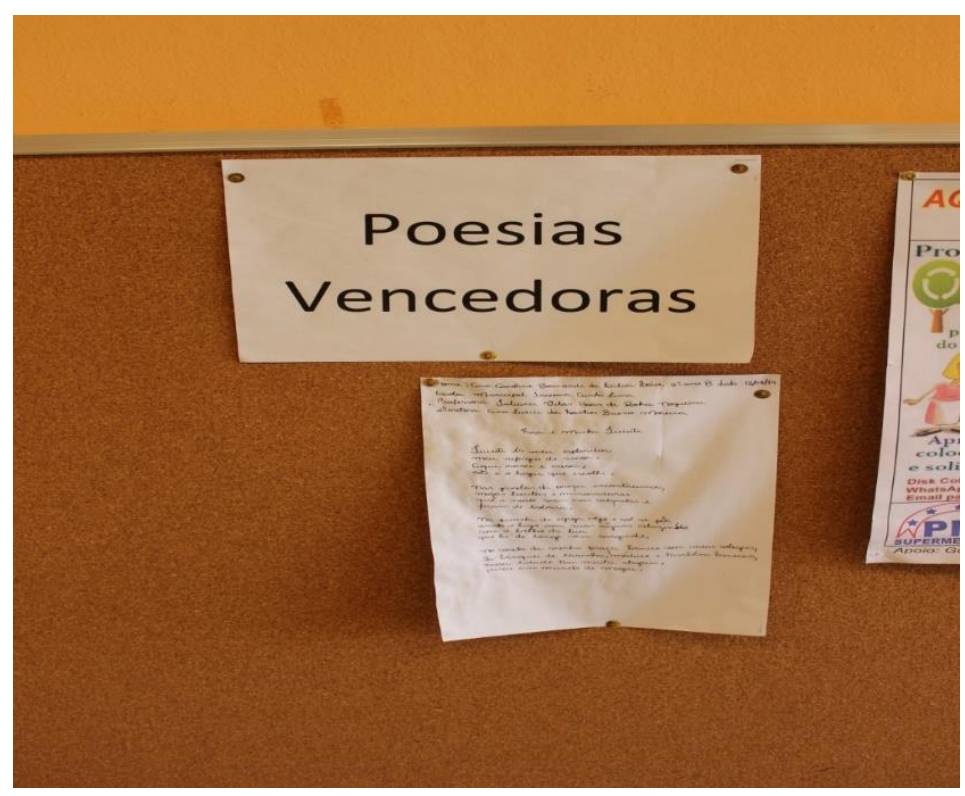

Figura 117 - Exposição das poesias vencedoras

Fonte: Arquivo pessoal do autor

O material didático é definido pela SME e utilizado por toda rede municipal. Além desse material, a docente tem autonomia para complementar as aulas com material próprio. Outro fator relevante diz respeito ao acompanhamento do desempenho dos alunos, o mesmo ocorre por meio de trabalhos, produção textual e provas, totalizando algo em torno de 5 a 6 avaliações por bimestre. Quanto à recuperação e reforço para os alunos com maior dificuldade de aprendizagem, a mesma não ocorre no contraturno, mas sim em horário normal de aula. A docente finaliza afirmando que não é realizado nenhum tipo de preparação específica conforme a proximidade da data de aplicação da Prova Brasil.

\subsection{Desempenho na prova de matemática}

A docente está na instituição desde 2008 (o que indica uma baixa rotatividade nessa disciplina) e tem plena autonomia para a realização de atividades em sala como avaliação, e reprovação dos alunos com baixo desempenho. Assim como na disciplina de português o material didático de matemática é definido pela SME e utilizado por toda rede municipal. Além desse material, a docente afirma ter autonomia para complementar as aulas com material próprio.

De acordo com a docente entrevistada o acompanhamento do desempenho dos alunos, ocorre por meio de trabalhos como exercícios sobre o tema que está sendo abordado em sala, 
totalizando cerca de cinco avaliações por bimestre. Quanto à recuperação e reforço, a mesma não ocorre no contraturno, mas sim em horário normal de aula.

A docente ainda destaca que busca juntamente com a escola, incentivar os alunos a participarem da OBMEP, o que vem dando resultados positivos, tendo em vista que alguns alunos se classificaram para a segunda fase da olímpiada, conforme ilustrado pela Figura 118.

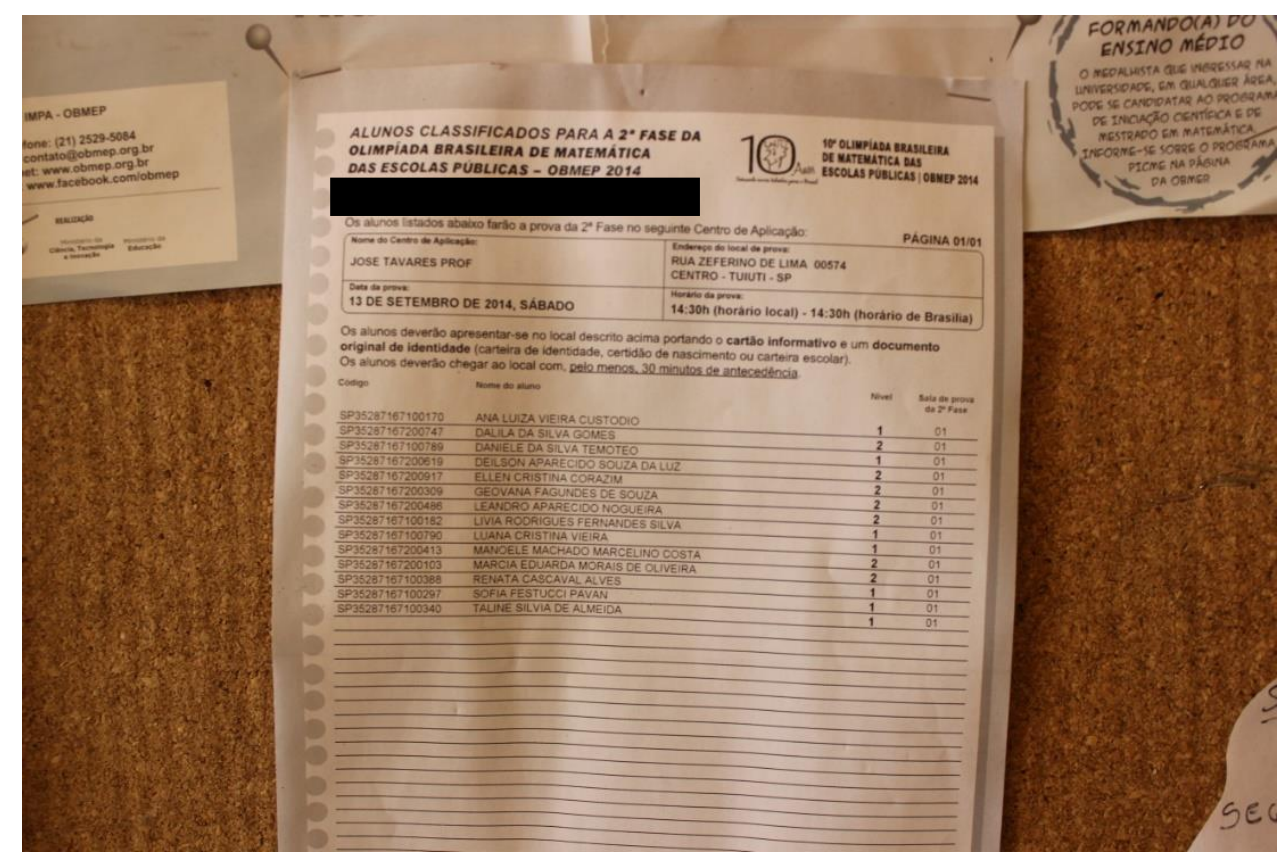

Figura 118 - Alunos da escola "I" classificados para a $2^{\text {a }}$ fase da OBMEP

Fonte: Arquivo pessoal do autor

Ademais, observou-se que não é realizado nenhum tipo de preparação específica conforme a proximidade da data de aplicação da Prova Brasil.

\subsection{Participação da família}

Em visita à escola notou-se que apenas a minoria dos pais participa ativamente da vida escolar dos filhos. Essa observação é corroborada pelo relato dos pais ao afirmarem que apenas uma pequena parte deles frequentam assiduamente as reuniões de pais e os eventos festivos realizados pela escola, eles também afirmaram não existir associação de pais e mestres na escola.

Em entrevista com os pais, identificou-se que apenas alguns deles acompanham os deveres escolares dos filhos, e a maioria dos pais que não acompanham, afirmam confiar em seus 
filhos, alegando que na sua idade não é mais necessário ficar conferindo diariamente seus deveres de casa. Os pais também destacaram que o Diretor sempre se mostrou disponível para atendê-los e que seu relacionamento com ele é muito bom.

Para os pais, conhecer a comunidade escolar (Diretor, Professores e funcionários) torna o contato e o acompanhamento do seu filho na escola mais fácil. Entretanto, devido à baixa participação dos pais nas reuniões, observou-se que a maioria deles desconhecem as ações realizadas pela escola, o que contribui para uma baixa cobrança por melhorias sobre a direção da escola. Em visita à escola também se notou que a maioria dos pais reside na área rural e o município não oferece o transporte público para eles irem à escola, o que pode ser um agravante para a sua ausência nas reuniões escolares.

\subsection{Reprovação discente e sistema disciplinar}

Em visita à escola identificou-se a existência de um sistema de reprovação dos alunos, em que os Professores possuem autonomia para reprovar os alunos com baixo desempenho. Também se observou a existência de regras claras e parcialmente conhecidas pela comunidade escolar. A escola divulga as regras para os pais na primeira reunião de pais do ano, enquanto os alunos tomam conhecimento delas, por meio dos Professores no primeiro dia de aula. A escola ainda fixa as regras em um quadro localizado na sala de aula para que os alunos nunca se esqueçam de como devem se comportar na escola, conforme nos mostra a Figura 119.

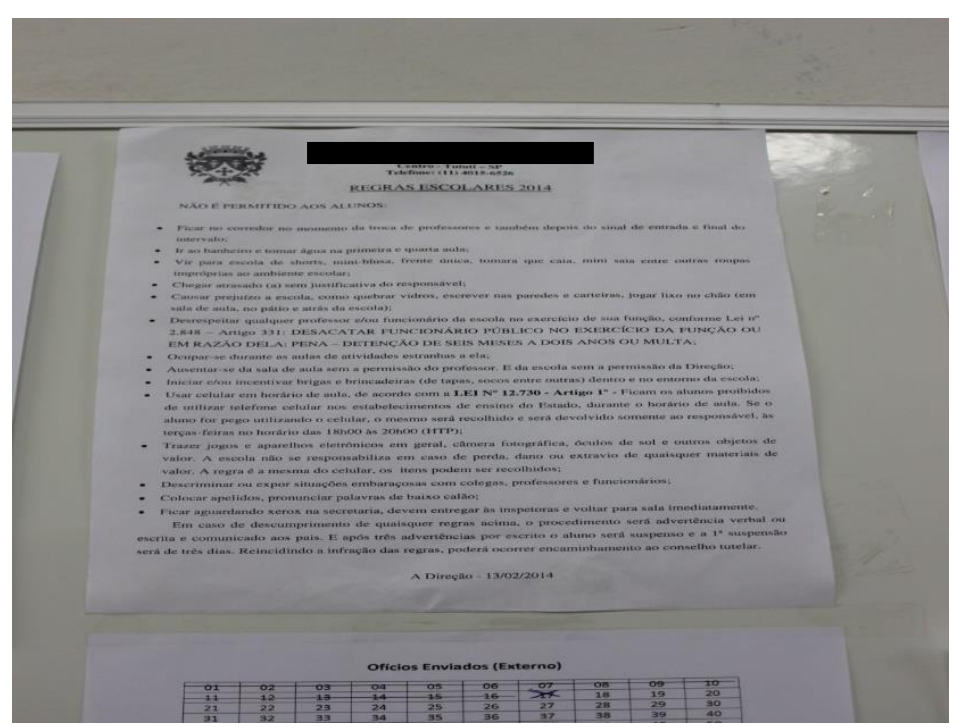

Figura 119 - Regras escolares fixadas na sala de aula Fonte: Arquivo pessoal do autor 
Segundo entrevista com os pais, aqueles que não frequentam a reunião de pais no início do ano são os que normalmente não respeitam as regras. Em entrevista com os Professores, pais e Diretor foi possível identificar que os alunos, de modo geral, respeitam a figura do Professor, Diretor e funcionários, entretanto, segundo entrevista com os alunos, a maioria de seus colegas conversa muito durante as aulas, o que atrapalha os alunos que querem aprender.

Ainda segundo os alunos, os atos de indisciplinas são raros na escola, entretanto, já aconteceu de algum aluno discutir com o Professor porque ele foi chamado à atenção. Os alunos finalizam dizendo que não sentem orgulho de estudar nessa escola e que se possível estudariam em outra escola, alegando que o Diretor e os Professores não cobram melhor comportamento dos alunos.

\subsection{Laboratório de informática}

Em visita à escola observou a inexistência de laboratório de informática.

\subsection{Biblioteca}

Em visita à escola identificou-se a existência de uma biblioteca que, segundo os Professores, possui limitação na quantidade e variedade de livros disponíveis, o que colabora segundo eles, para o baixo índice de retirada de livros dos alunos.

O local não possui espaço para estudos coletivos e é razoavelmente iluminado e organizado, conforme nos mostra a Figura 120. 


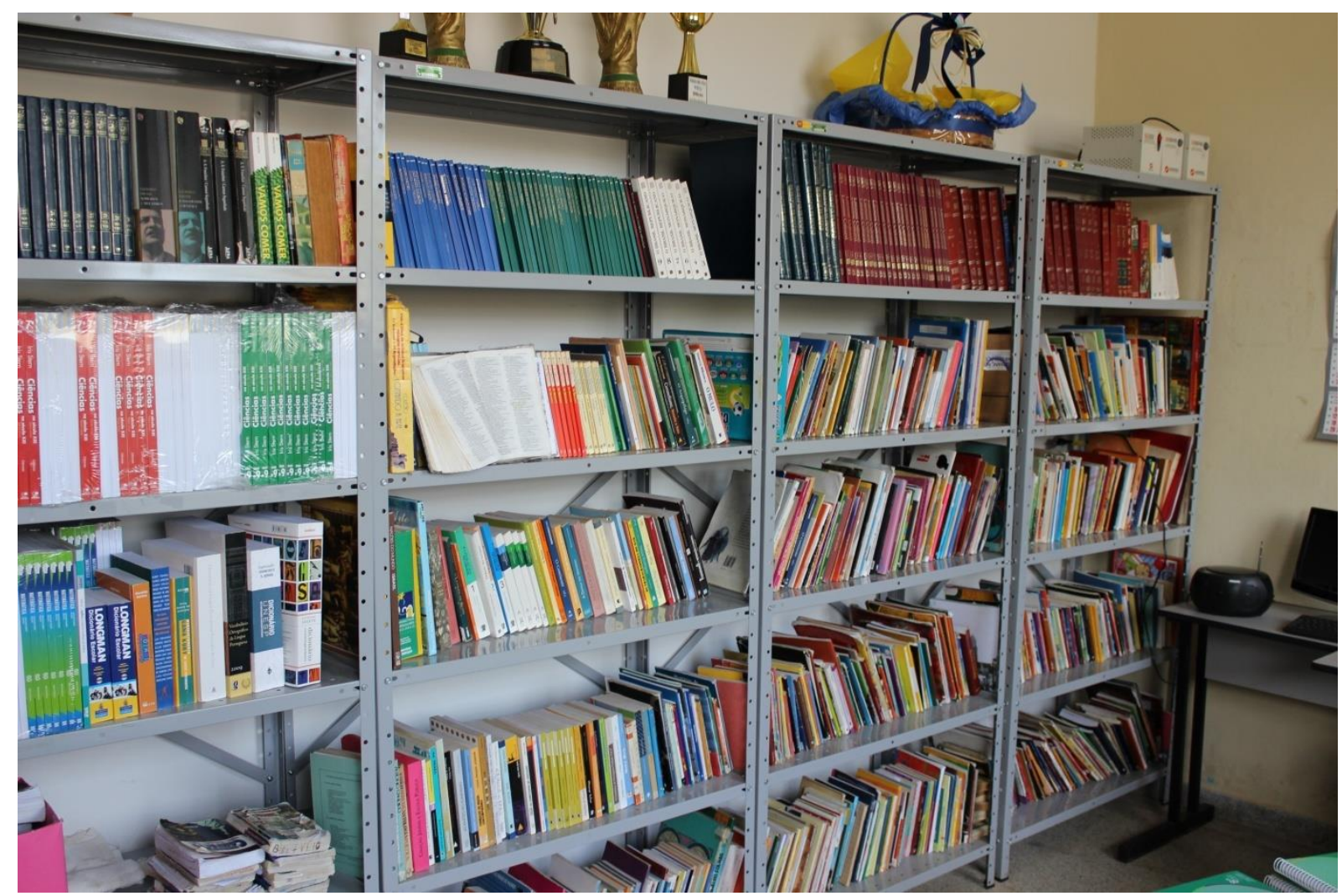

Figura 120 - Biblioteca da escola "I"

Fonte: Arquivo pessoal do autor

De acordo com a Diretora, a biblioteca não possui um funcionário exclusivo para realizar o atendimento aos alunos e o controle da retirada de livros, pois essas atividades são realizadas pelas supervisoras da escola.

\subsection{Sala de leitura}

Em visita à escola observou-se a inexistência de sala de leitura.

\subsection{Alunos}

Em visita à escola identificou-se que o sistema de matrículas dos alunos é por zoneamento e a maioria dos 294 alunos matriculados na escola residem na área rural e utilizam diariamente o transporte público para ir à escola. 


\subsection{Docentes}

Com a visita à escola foi possível identificar as seguintes características referentes ao seu corpo docente:

Número de docentes para cada cem alunos: 4,80

Porcentagem de docentes pertencente ao sexo feminino: 67,37;

Porcentagem dos docentes que possuem magistério concluído: 0,00;

Porcentagem dos docentes que possuem o curso de licenciatura concluído: 87,37;

Porcentagem dos docentes que possuem o ensino superior concluído: 100,00;

Porcentagem dos docentes que possuem especialização concluída: 10,53.

\subsection{Funcionários}

Número de Funcionários para cada cem alunos: 8,16.

\subsubsection{Escola "E" eficiente e respectiva SME}

- Data da visita: $16 / 09 / 2014$

- Indicadores do município de Dois Córregos

$\mathbf{N}^{\circ}$ de Habitantes: 24.933

IDHM: 0,725

- Indicadores da escola E

Número de alunos: 413

Investimento anual por aluno: $\mathrm{R} \$ 4.367,93$

Nota no IDEB (Anos Finais): 6,47

Nível socioeconômico: 6 (Alto) 
Durante a visita realizada à escola "E", conforme ilustrado pela Figura 121, localizada no município de Dois Córregos no estado de São Paulo, foi possível identificar inúmeras práticas administrativas e pedagógicas que colaboraram para que, no ano de 2011, a escola obtivesse uma nota 6,47 no IDEB. A seguir são apresentados alguns dos principais aspectos mais relevantes que foram observados durante a visita à escola.

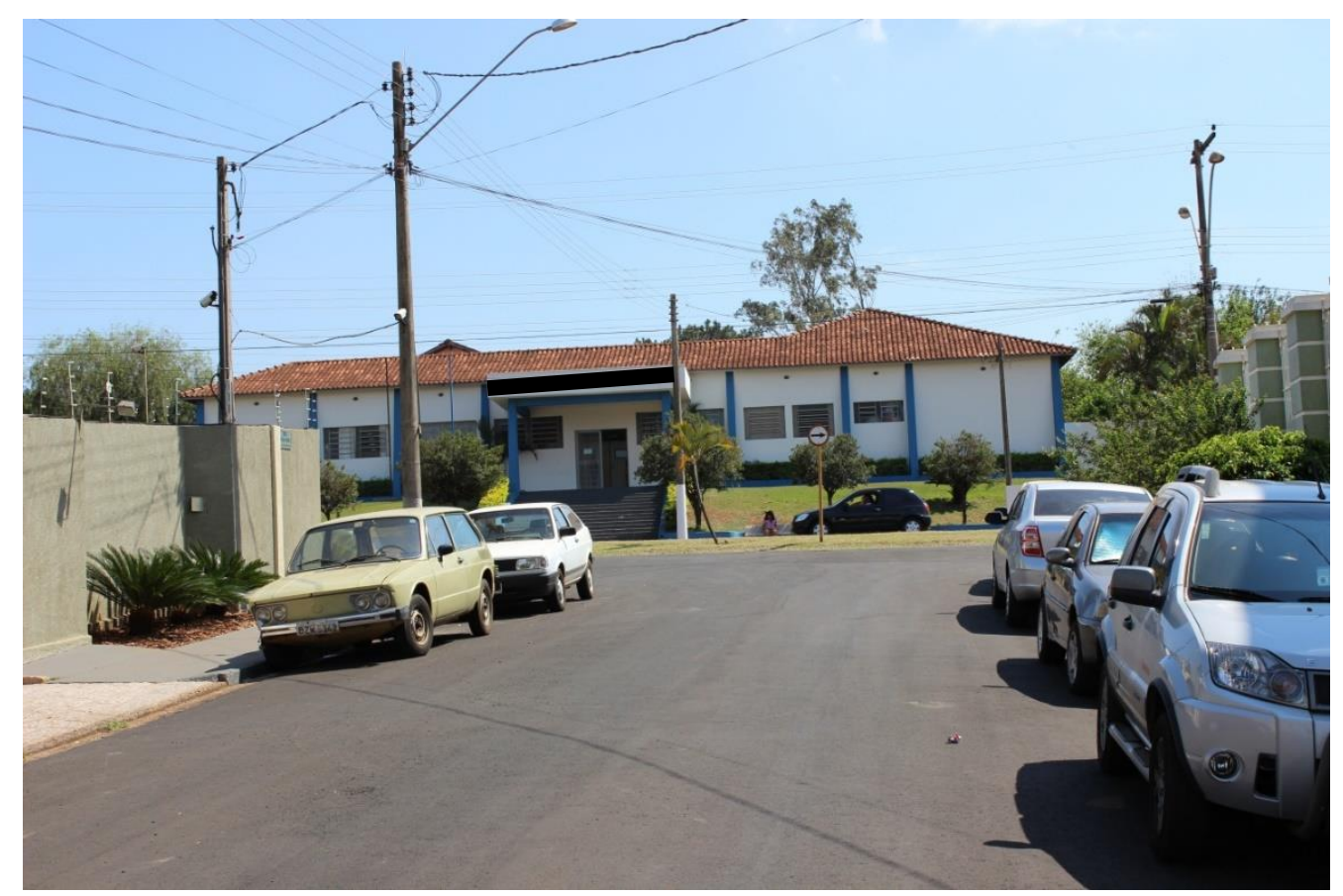

Figura 121 - Fachada da escola "E"

Fonte: Arquivo pessoal do autor

\subsection{Relatório de gestão e destinação dos recursos financeiros da SME}

\subsection{Constituição da SME}

Em entrevista com a Secretária de Educação, observou-se que os colaboradores desta secretaria são nomeados parte por indicação política e parte por concurso público. Segundo a secretária, os cargos nomeados por indicação política são em sua maioria os chefes de departamentos, enquanto os demais funcionários são nomeados por concurso público. Além disso, a secretaria define como política do município que para ocupar o cargo de Diretor é necessário possuir no mínimo cinco anos de atuação como Professor, atendendo esse requisito o candidato é escolhido por indicação política, com o aval do prefeito. Outro fator a ser destacado é a formação dos funcionários da SME, pois todos eles, com exceção de dois que tem apenas o ensino médio, possuem curso superior completo. 


\subsection{Organização da SME}

Em visita à SME, observou-se em relação a sua governança, a existência de inúmeros departamentos, como a supervisão de ensino, assessoria técnica, divisão de gestão educacional, divisão de transporte da educação e a divisão administrativa, todos eles se reportam diretamente à secretária. Esta por sua vez, se reporta apenas ao chefe do executivo. No mais, observou-se a inexistência de uma área específica responsável pela captação de recursos.

\subsection{Secretário}

Em entrevista com a Secretária, observou-se que ela possui formação em pedagogia e licenciatura em letras com francês e pós-graduação em linguística e teoria da literatura, e não possui nenhum curso complementar em gestão. Durante a entrevista, também foi possível observar que a secretária possui ampla experiência na área educacional, que foi adquirida segundo ela, dos cargos que ocupou como Professora e Diretora de escola estadual, supervisora de ensino na rede estadual e Diretora de escola municipal, sendo este último cargo exercido por um período de oito anos. Entretanto, observou-se que não existem pré-requisitos para se tornar Secretário de educação no município, sendo este cargo, escolhido por indicação política.

Durante a entrevista, também se observou que a secretária possui elevada autonomia para criação e alteração de políticas educacionais, pois segundo ela, o prefeito lhe deu aval para fazer o que considerasse melhor para a educação do município. Entretanto, ela possui autonomia mais limitada em relação às decisões financeiras, pois refere que os recursos destinados à educação já vêm carimbados, ou seja, com destinação previamente definida. Ademais, observou-se que ela tem uma boa análise crítica da situação do município no que refere aos principais desafios da educação, entretanto, ela demonstra desconhecimento dos indicadores financeiros do município, como o investimento anual por aluno.

\subsection{Capacidade da SME na captação de recursos financeiros}

Em visita à SME, observou-se que a secretária e sua equipe atuam, em alguns momentos, na busca de recursos por meio de projetos federais e/ou estaduais. Segundo a secretária, ela 
conseguiu alguns recursos do governo federal como um ônibus, do programa caminho da escola, quadra de esporte coberta e equipamentos de informática do programa mais educação e a construção de duas creches do programa Proinfância. Ademais, observou-se que a secretária não busca recursos oriundos de parcerias com empresas privadas ou outras fontes como a APM, que podem ser utilizados de forma descentralizada. Além disso, verificou-se também que a secretária possui desconhecimento dos principais indicadores financeiros municipais, como o investimento anual por aluno.

\subsection{Destinação do recurso financeiro descentralizado e centralizado}

Em visita à SME, verificou-se que a destinação dos recursos se dá majoritariamente para folha de pagamento do corpo docente. Segundo a secretária, a folha de pagamento está quase excedendo o total de recursos destinados à educação. Para ela, isto se deve a prioridade do município no reforço oferecido aos alunos no contraturno, o que demanda um novo docente e consequentemente mais recurso. A secretária ainda destaca que o município oferece cursos, palestras e orientações didático-pedagógicas para Professores aprimorarem seu conhecimento e melhorarem o ensino da rede. Ademais, o volume de recursos destinados a reparos emergenciais e ao transporte dos alunos é irrelevante.

\subsection{Transição de novo Secretário e nova equipe}

Em entrevista com a Secretária, observou-se que a maior parte dos colaboradores são substituídos conforme novas gestões são eleitas, com destaque para os chefes de departamentos e o Secretário, que são nomeados por indicação política.

\subsection{Critério para matrícula de alunos}

Em entrevista com a secretária, observou-se que o critério para matrícula dos alunos é por zoneamento. 


\subsection{Ensino fundamental ofertado exclusivamente pela rede pública}

Segundo a secretária municipal de educação, o ensino fundamental não é oferecido exclusivamente pela rede pública, pois o município também conta com duas escolas particulares que oferecem essa modalidade de ensino.

\subsection{Informações adicionais}

Em visita à SME, constatou-se a existência de cinco escolas urbanas e nenhuma escola rural no município que ofertam o ensino fundamental. Ademais, observou-se que não existe uma política de progressão continuada, mas existe o sistema de reprovação em ciclos, em que os alunos podem ser reprovados apenas no final de cada ciclo, sendo eles o $3^{\circ}$ ano, $5^{\circ}$ ano, $7^{\circ}$ ano e $9^{\circ}$ ano. Em conversa com a secretária, também se constatou que a SME busca incentivar a participação em Olimpíadas por meio do oferecimento de transportes e lanches para os alunos. Todavia, a secretária não soube informar onde é investido de forma percentual o total dos recursos destinados à educação.

\subsection{Relatório de gestão e destinação dos recursos financeiros do Diretor}

\subsection{Especificidades do município pequeno}

Em conversa com a Diretora da escola, observou-se que os pais participam da rotina escolar dos filhos e por isso exercem uma grande cobrança sobre a direção e os Professores. Segundo a Diretora, por Dois Córregos ser um município pequeno contribui para o acompanhamento dos pais na vida escolar dos filhos, pois o convívio dos pais com os Diretores, Professores e supervisores são frequentes em locais como supermercado, padaria, bares etc.

\subsection{Alimentação dos alunos}

Em conversa com alunos e a Diretora da escola, observou-se que é oferecido duas refeições por período aos alunos. Além disso, foi observada a existência de uma nutricionista que é responsável pela elaboração e acompanhamento do cardápio, que é por sua vez, elogiado 
pelos alunos, dado sua variedade e qualidade. Durante a visita observou-se também que a escola possui um refeitório com espaço e condições adequadas para os alunos se alimentaram, conforme apresenta a Figura 122.

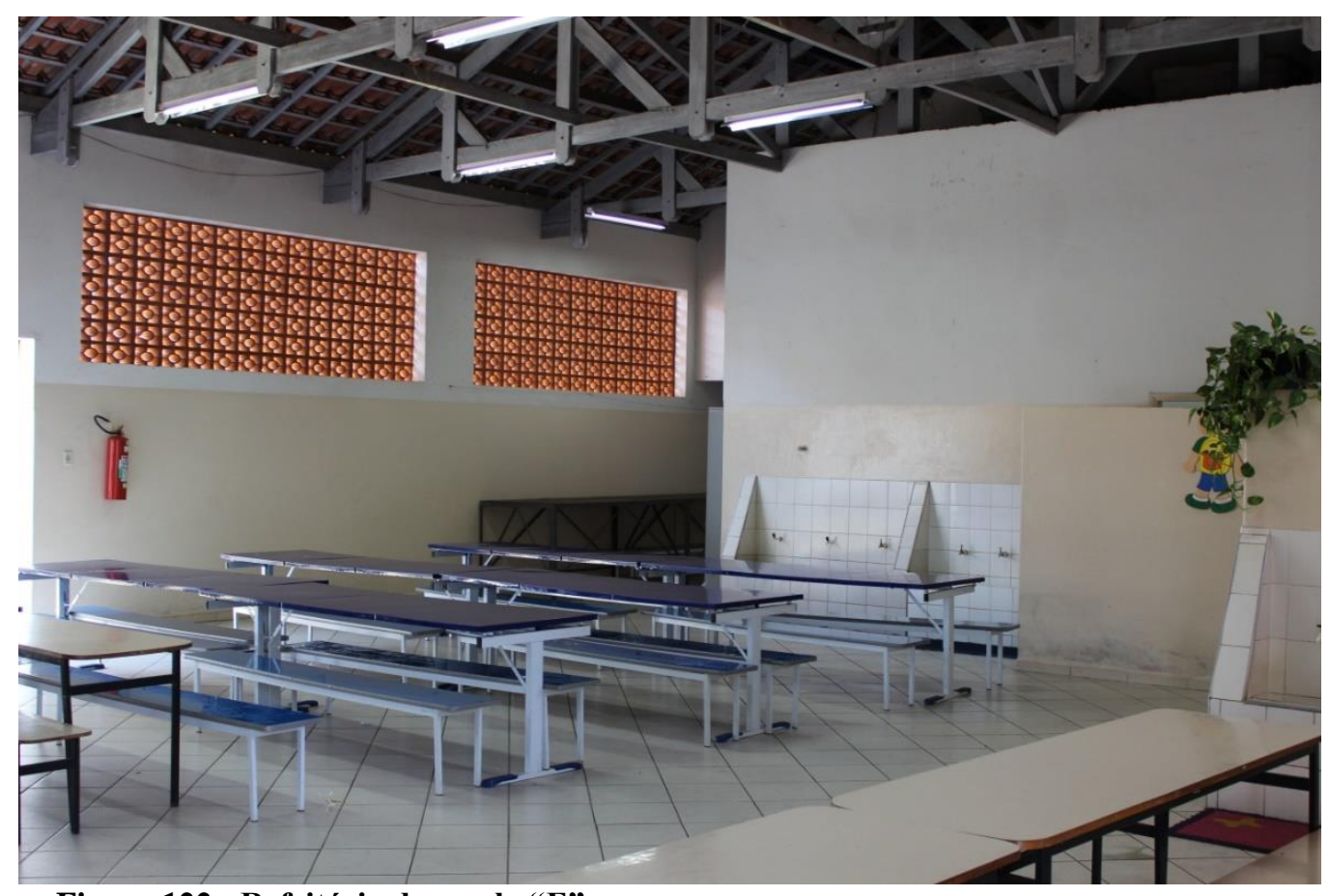

Figura 122 - Refeitório da escola "E"

Fonte: Arquivo pessoal do autor

\subsection{Processo seletivo}

Em conversa com a Diretora, constatou-se que não existe processo seletivo para entrar na escola e não existe também a transferência compulsória por causa de reprovações em disciplinas. Por outro lado, a escola recebe alunos por transferência, mas a prioridade é por zoneamento.

\subsection{Diretor}

Em conversa com a Diretora da escola, constatou-se que ela possui formação em Pedagogia e pós-graduação em Psicopedagogia e assumiu o cargo por meio de indicação política. Além disso, verificou-se também uma relevante autonomia financeira por parte da Diretora quanto aos recursos providos da Associação de Pais e Mestres e demais festividades realizadas pela escola. 


\subsection{Plano de carreira do Diretor}

Em conversa com o Diretor e Professores, observou-se que o salário do Diretor não é visto como compatível com a função que exerce, uma vez que ser Professor exige menos responsabilidades e permite atuar em dois períodos, o que proporciona uma renda superior ao de Diretor. Dessa maneira, observou-se que não há incentivos, principalmente financeiros, para que Professores busquem esse cargo.

\subsection{Capacidade do Diretor na captação de recursos financeiros}

Durante entrevista realizada com a Diretora, observou-se que ela atua de forma proativa em parceria com os pais de alunos para captar recursos para a escola, realizando inúmeros eventos como festa junina, rifas, etc. Tal ação permite que a escola levante recursos que possa ser utilizado de modo descentralizado, sem destinação definida, e também não dependa exclusivamente das fontes convencionais que são repassadas pelos órgãos federais, estaduais e municipais.

\subsection{Destinação do recurso financeiro descentralizado e centralizado}

Em visita à escola e entrevista com a Diretora, observou-se que os recursos financeiros centralizados e suas respectivas destinações não são monitorados quantitativamente para que seja possível mensurar o quanto é investido em cada item listado (equipamentos de consumo, permanente, materiais escolares etc.). Entretanto, o recurso descentralizado, proveniente da APM, é aplicado na aquisição de aparelhos como Datashow e televisor, conforme ilustrado pela Figura 123, bem como em qualquer outro fator que venham a contribuir para a melhoria do aprendizado dos alunos.
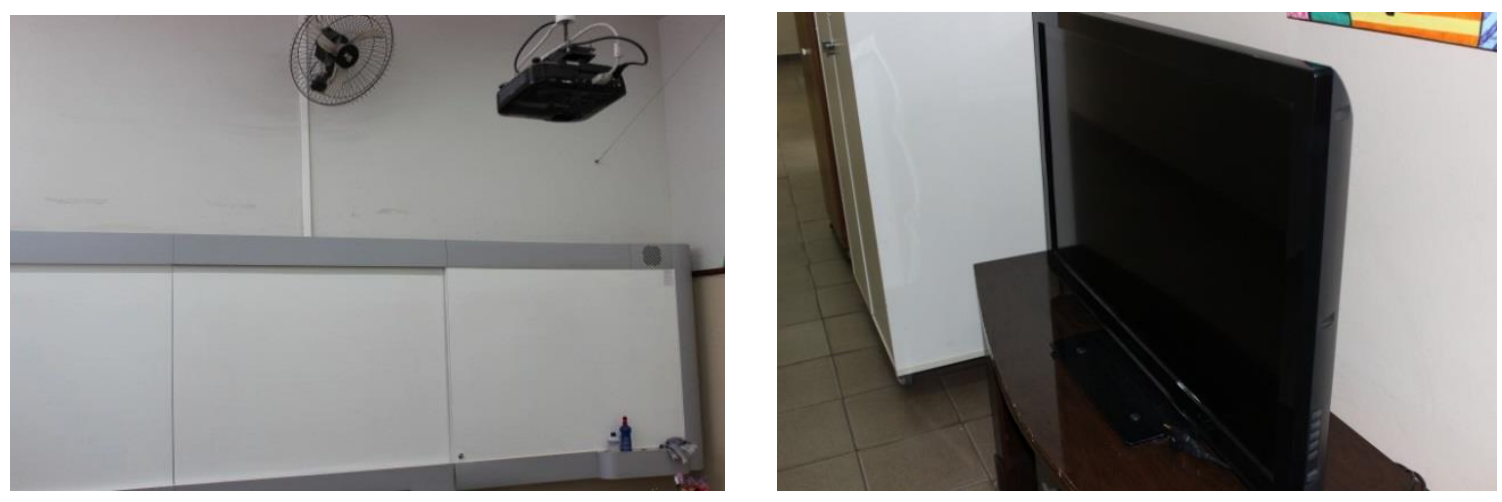

Figura 123 - Datashow e televisor adquirido com recurso descentralizado Fonte: Arquivo pessoal do autor 
Ademais pôde ser observado que a escola dispõe de uma excelente infraestrutura, com salas de aula em ótimo estado de conservação, conforme nos mostra a Figura 124, quadra de esporte, conforme Figura 125 e parque de diversão, conforme Figura 126.

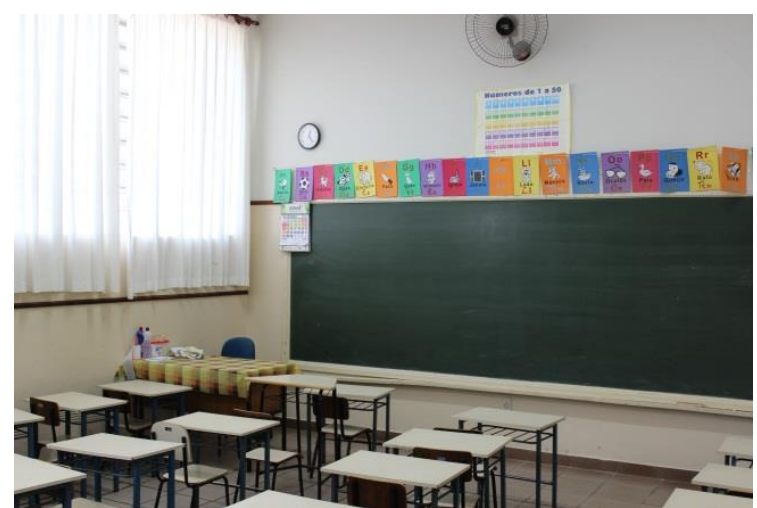

Figura 124 - Sala de aula da escola "E"

Fonte: Arquivo pessoal do autor

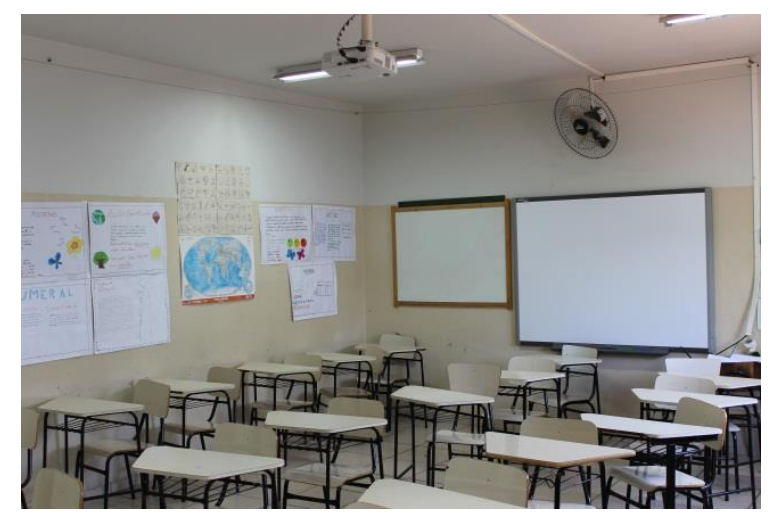


Na Figura 126 é apresentado o parque de diversões da escola "E.
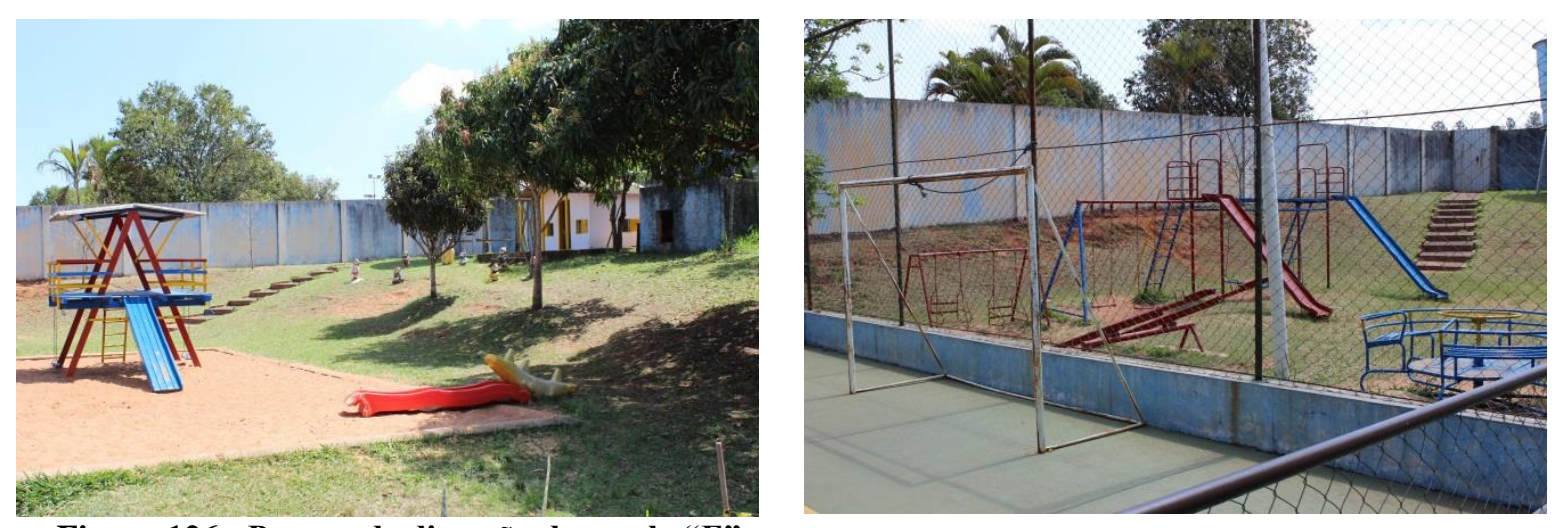

Figura 126 - Parque de diversão da escola "E"

Fonte: Arquivo pessoal do autor

Outro fator que chamou atenção em algumas salas de aula foi o modelo das cadeiras e carteiras, permitindo a formação de grupos com seis alunos sentados de modo interativo, conforme nos mostra a Figura 127.

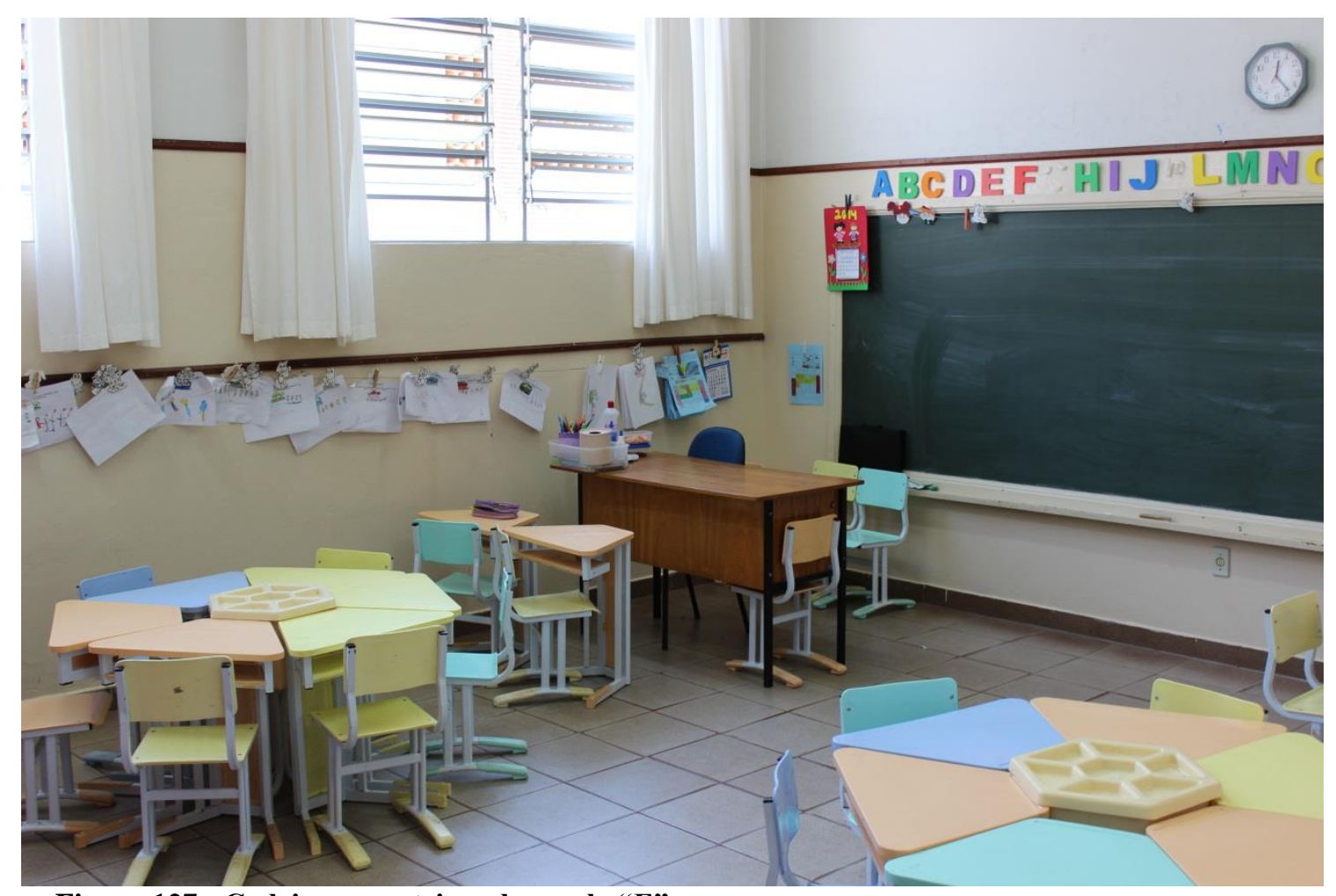

Figura 127 - Cadeiras e carteiras da escola "E"

Fonte: Arquivo pessoal do autor 


\subsection{Relatório pedagógico e socioeconômico}

\subsection{Desempenho na prova de português}

Em entrevista realizada com a docente responsável pela disciplina, observou-se que ela está na instituição desde 2005 (o que indica uma baixa rotatividade de docentes nessa disciplina) e tem autonomia para a realização de atividades em sala, bem como em avaliações. Segundo a docente, uma vez por semana todas as salas passam 50 minutos na biblioteca, onde os alunos são estimulados a retirarem algum livro e levar para ler em casa. A docente ainda destaca que uma vez por mês é feita a roda de leitura, no qual os alunos explicam a sua percepção sobre um livro indicado pela Professora para todos os seus colegas de sala, tal ação contribui de maneira positiva para o bom índice de leitura dos alunos, além de despertar nos alunos o interesse pela poesia. A Figura 128 nos mostra um quadro com uma poesia sobre a mão, escrita por uma aluna do nono ano, que fica exposto na parede da sala de aula.

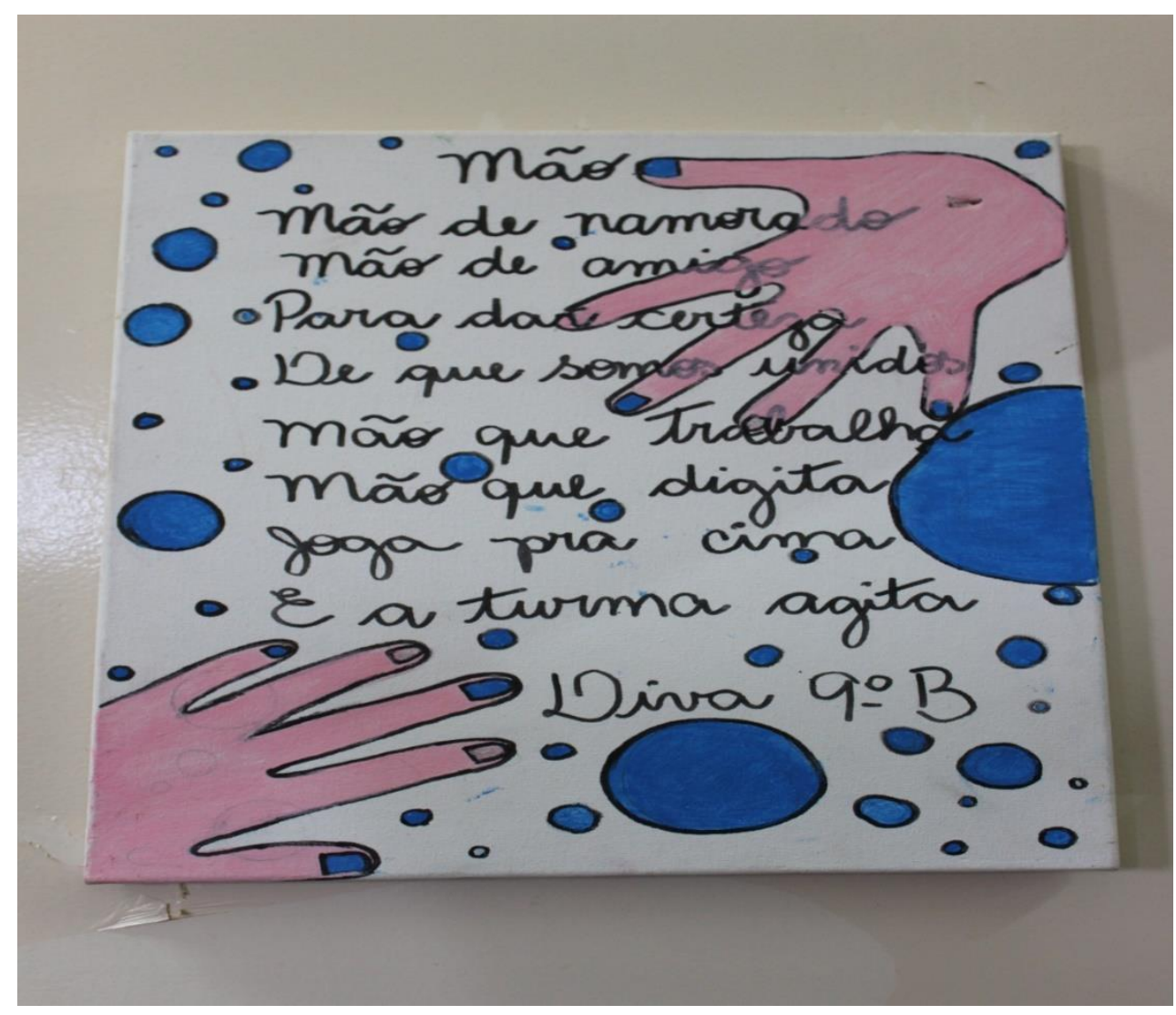

Figura 128 - Quadro com poesia escrita por uma aluna do nono ano Fonte: Arquivo pessoal do autor 
Segundo a docente, o acompanhamento do desempenho dos alunos é feito por meio da correção das tarefas de casa, aplicação de trabalhos em sala, produção textual e provas. Para os alunos com maior dificuldade existe a recuperação no contraturno. Quanto à reprovação, observou-se que a mesma ocorre apenas por ciclos.

O material didático é escolhido pela SME em parceria com todos os docentes que ministram aulas na disciplina, sendo este padrão para toda a rede municipal. Um fator relevante é que o mesmo material tem sido mantido nas últimas duas gestões do governo municipal. Além desse material, a docente tem autonomia para complementar as aulas com material próprio.

De acordo com a docente entrevistada, com a aproximação da Prova Brasil são realizados simulados para que os alunos pratiquem com questões no padrão das que são exigidas na avaliação. Outro fator que chamou a atenção durante a visita foi o envolvimento dos alunos em projetos como a Mostra Cultural, em que cada sala de aula possui um tema que será trabalhado e posteriormente apresentado a toda comunidade escolar.

\subsection{Desempenho na prova de matemática}

Em entrevista realizada com a docente responsável pela disciplina, observou-se que ela está na instituição desde 2011 (o que indica uma baixa rotatividade de docentes nessa disciplina) e tem autonomia para a realização de atividades em sala, bem como em qualquer tipo de avaliação. As aulas desta disciplina mostraram-se bastante dinâmicas, haja vista que os conteúdos da matéria são trabalhados com Jogos Interativos como os Jogos Mind, que consiste em jogos de raciocínio que tem por finalidade melhorar a competência e conhecimento dos alunos, conforme ilustrado pela Figura 129. Segundo a docente, essa iniciativa faz parte do projeto "Mente inovadora", que consiste em um sistema de aprendizagem cujo objetivo é ampliar as possibilidades de desenvolvimento cognitivo dos alunos utilizando jogos de raciocínio. Complementarmente a Professora também leva os alunos para fora da sala de aula e os desafia a medir alturas inacessíveis com base nas fórmulas matemáticas. 


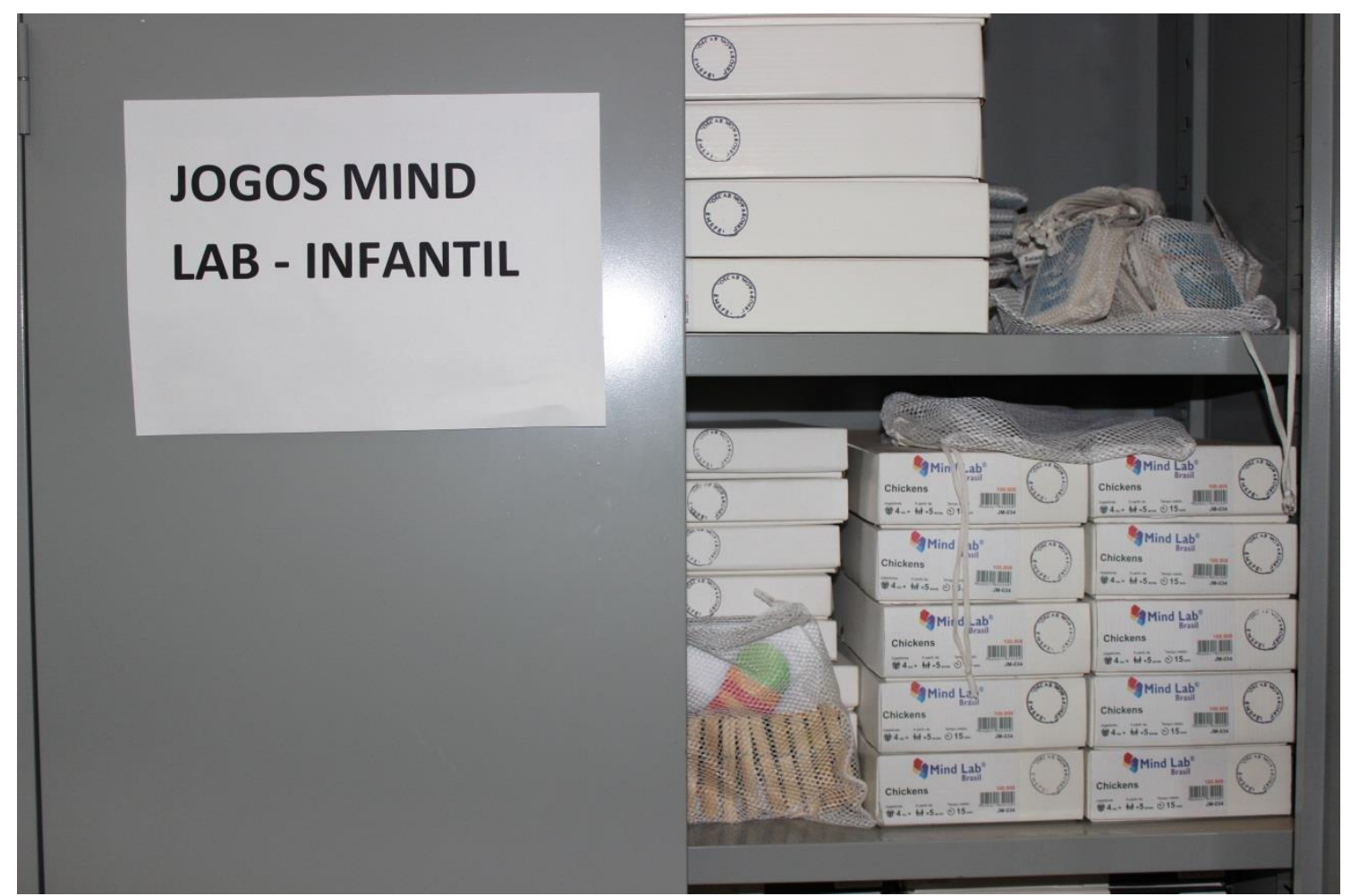

\section{Figura 129 - Jogos Mind}

Fonte: Arquivo pessoal do autor

Segundo a docente, o acompanhamento do desempenho dos alunos é feito diariamente por meio da correção da tarefa de casa, aplicação de trabalhos, pesquisa sobre história da matemática, tabuada e provas. Para os alunos com maior dificuldade é oferecido recuperação no contraturno. Quanto à reprovação de alunos, observou-se que ela ocorre apenas por ciclos.

Em relação ao material didático, ele é escolhido pela SME em parceria com todos os docentes que ministram aulas na disciplina, sendo este padrão para toda a rede municipal. Um fator relevante é que o mesmo material tem sido mantido nas últimas duas gestões do governo municipal. Além desse material, a docente tem autonomia para complementar as aulas com material próprio.

Segundo a docente entrevistada, com a aproximação da Prova Brasil são realizados simulados para que os alunos pratiquem com questões no padrão das que são exigidas na avaliação. 


\subsection{Participação da família}

Em visita à escola observou-se uma forte participação da família na vida escolar do filho. Essa observação é corroborada pela alta frequência dos pais nas reuniões de pais e mestres, nos eventos festivos realizados pela escola e nas demais reuniões de pais. Segundo relato dos pais entrevistados, cerca de $85 \%$ do total de pais participam ativamente de todas as reuniões e eventos festivos realizados pela escola. Dentre esses eventos, os pais destacaram a amostra cultural como uma tradição da escola, nela os alunos de cada sala possui um tema que será trabalhado e apresentado posteriormente a toda comunidade. Os pais também justificaram a forte presença da família nos eventos festivos ao afirmar que a festa junina realizada anualmente pela escola tem que ser feita em dois dias para poder acomodar todos os pais. Eles ainda afirmam conhecer e participar assiduamente das reuniões de pais e mestres, que é realizada quatro vezes por ano com a presença do Diretor, Professores, pais e alunos, nelas eles decidem democraticamente o destino dos recursos que a escola possui e acompanham a prestação de contas feita pelo Diretor.

Os pais também demonstraram conhecer as propostas pedagógicas que a escola pretende desenvolver durante o ano. Segundo eles, na primeira reunião de pais do ano a escola apresenta para os pais o material didático que será utilizado, assim como os projetos que a escola irá desenvolver ao longo do ano, como o projeto "aprender para ler e ler para escrever" e o projeto sobre empreendedorismo, em que os alunos são estimulados a se reunirem em sala e criar algum produto, que será posteriormente comercializado e o recurso revertido para seu próprio benefício.

Em entrevista com pais e alunos, observou-se que os pais se preocupam com a realização dos deveres de casa dos filhos. Tal observação é corroborada pelo relato dos pais ao destacarem que acompanham diariamente os deveres escolares dados pelos Professores, alguns deles afirmaram inclusive ajudar os filhos em caso de dúvidas. Para os pais os deveres escolares é um fator fundamental para o aprendizado de seus filhos. Segundo eles, os Professores colaboram com o seu acompanhamento nos deveres escolares de seus filhos, de modo que, quando algum aluno não faz o dever de casa o Professor envia um recado para os pais comunicando o ocorrido, o pai por sua vez deve assinar o recado no caderno do filho demonstrando conhecimento, caso o pai não assine o recado ele é convocado pelo Diretor a comparecer na escola. Os alunos concordam com a declaração dos pais ao afirmarem, durante 
a entrevista, que os pais e Professores cobram constantemente a realização dos deveres de casa. Os pais também afirmaram não utilizar o transporte público para ir à escola, porém o município oferece o transporte público para os pais em dias de reunião escolar.

\subsection{Reprovação discente e sistema disciplinar}

Em visita à escola observou-se a existência de um sistema de reprovação por ciclos, em que os Professores possuem autonomia para reprovar os alunos com baixo desempenho apenas no terceiro, quinto, sétimo e nono ano. Em visita à escola também foi possível identificar que as regras do sistema disciplinar da escola são claras, conhecidas e respeitadas rigorosamente por toda comunidade escolar. Segundo entrevistas com pais e alunos, a escola divulga as regras para os pais na primeira reunião de pais, que ocorre no primeiro dia de aula do ano, e posteriormente para os alunos em suas respectivas classes. Para os pais um dos fatores que contribui para o conhecimento e respeito das regras disciplinares estabelecidas pela escola se dá ao tempo que os alunos estudam nessa escola. Segundo os pais, a maioria dos alunos entra na escola na educação infantil (com quatro anos de idade) e fica até o nono ano do ensino fundamental (com quatorze anos de idade). Os alunos também destacaram que a escola é rígida em relação ao cumprimento dessas regras, inclusive quando algum aluno chega à escola sem estar trajado com o uniforme ele é barrado na portaria e os seus pais são comunicados sobre a necessidade de trazer o uniforme para seu filho adentrar na escola.

Em entrevista com os alunos foi possível observar que a maioria é disciplinada e respeitam a figura do Diretor, Professores e funcionários da escola. Essa observação é corroborada por um fato que ocorreu durante a escolha dos alunos que participaram da entrevista, pois ao solicitar a escolha aleatória desses alunos ao Diretor, fui acompanhado por ele em duas salas do nono ano do ensino fundamental, quando o Diretor adentrou em ambas as salas os alunos se levantaram imediatamente para recepcioná-lo e voltaram a se sentar somente após a autorização do Diretor. Durante a entrevista com os alunos perguntei se era regra da escola eles se levantarem quando o Diretor adentrasse na sala de aula, e eles me responderam prontamente dizendo que não, eles se levantavam apenas por respeitarem a figura do Diretor. Segundo os alunos, o respeito pelo Diretor, Professores e funcionários é fundamental para eles possuírem uma boa convivência. Eles concluíram dizendo sentir orgulho de estudar nessa 
escola, principalmente por ela ser considerada pela comunidade como a melhor escola da cidade.

\subsection{Laboratório de informática}

Em visita à escola, verificou-se a existência de um laboratório de informática, conforme ilustrado pela Figura 130, no qual os computadores estão em bom estado de uso. Também foi possível identificar que a escola não oferece aulas de informática com Professores capacitados nessa área aos alunos, pois o laboratório é utilizado apenas quando algum docente irá trabalhar um assunto que exige o uso dos computadores.

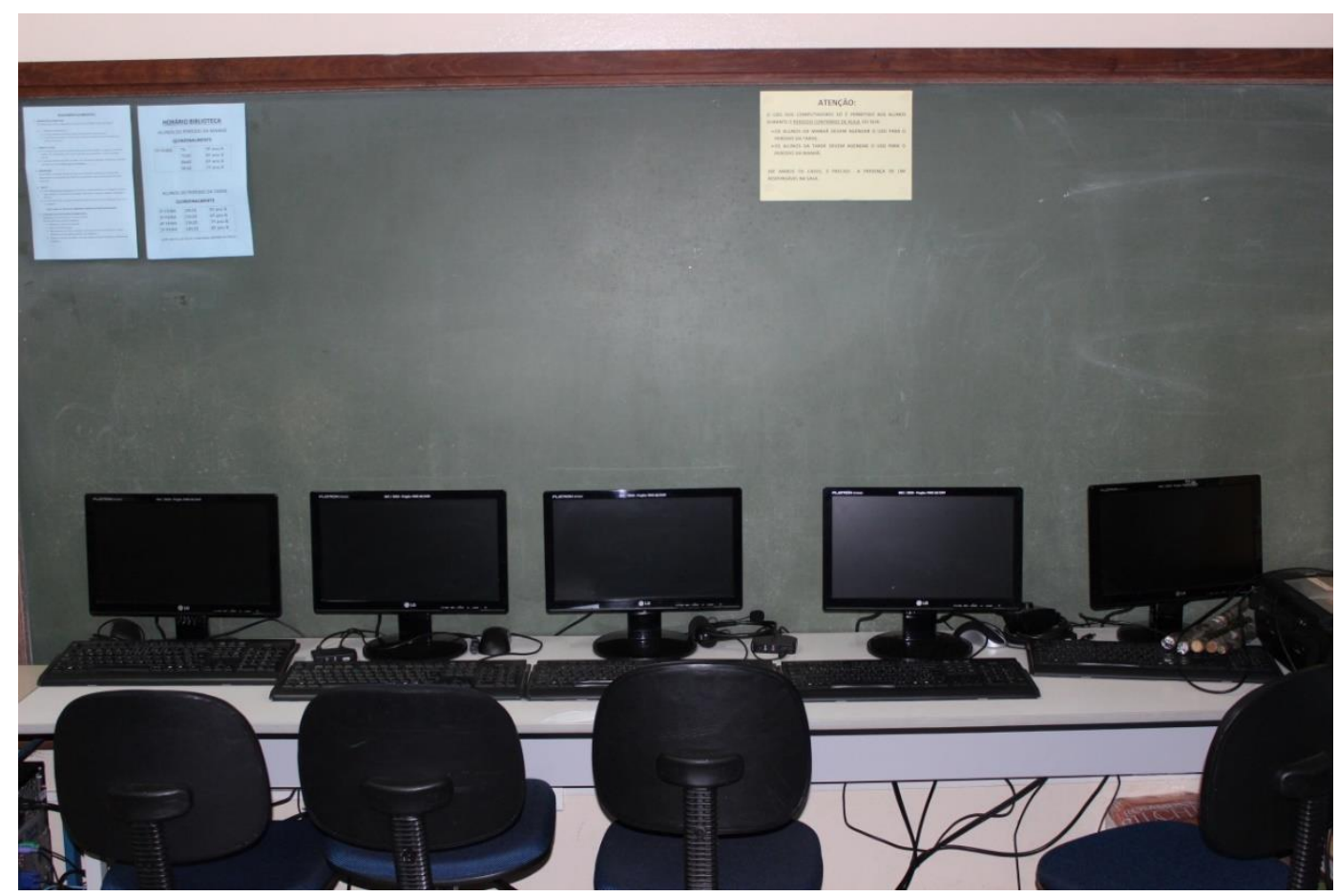

Figura 130 - Laboratório de informática da escola "E"

Fonte: Arquivo pessoal do autor

\subsection{Biblioteca}

Em visita à escola, verificou-se a existência de uma biblioteca que, segundo os Professores, possui um acervo de tamanho e variedade de nível mediano, porém com uma retirada de livros relativamente alta pelos alunos, conforme nos mostra o controle de retirada de livros dos alunos do nono ano, ilustrado pela Figura 131 e Figura 132. 


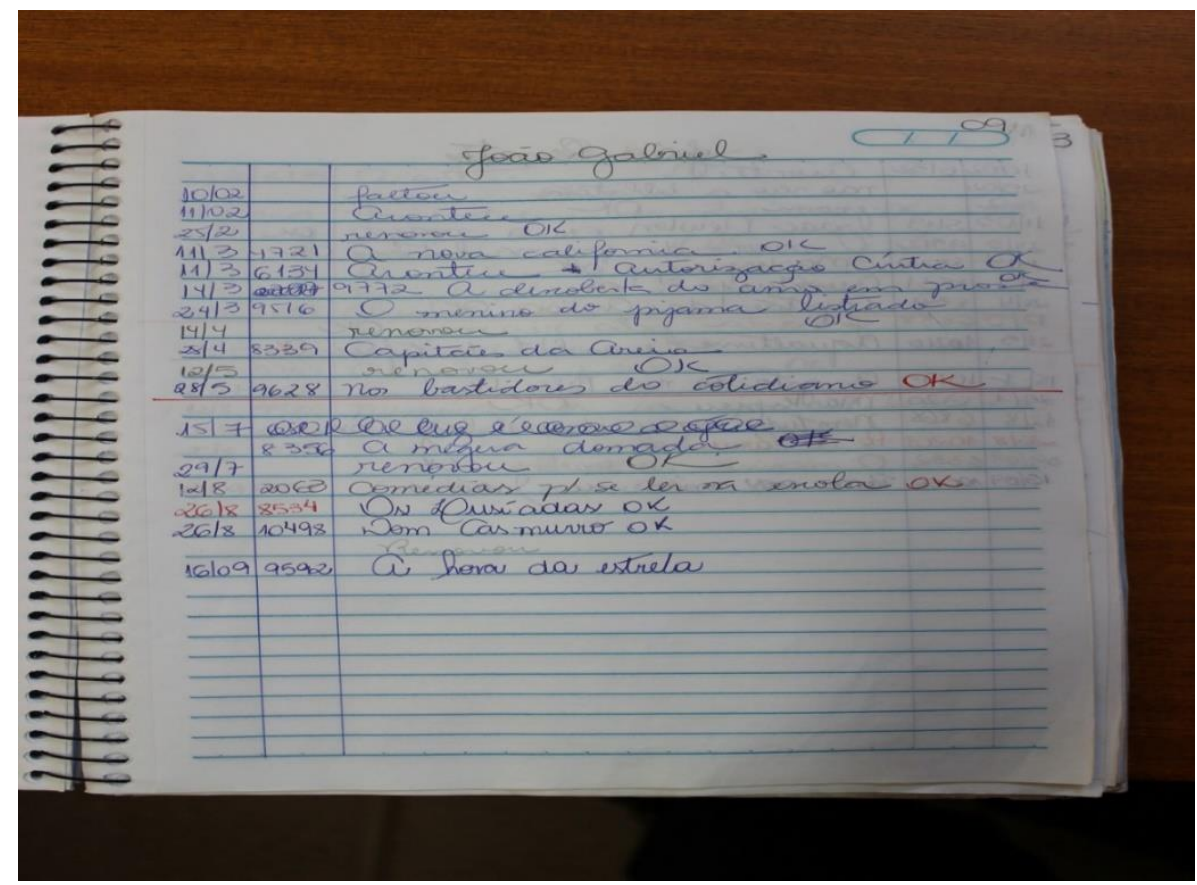

Figura 131 - Controle de retirada de livros dos alunos da escola "E"

Fonte: Arquivo pessoal do autor

Conforme apresentado em ambas as figuras, o livro de retirada dos alunos apresenta o histórico de retirada de livros por aluno.

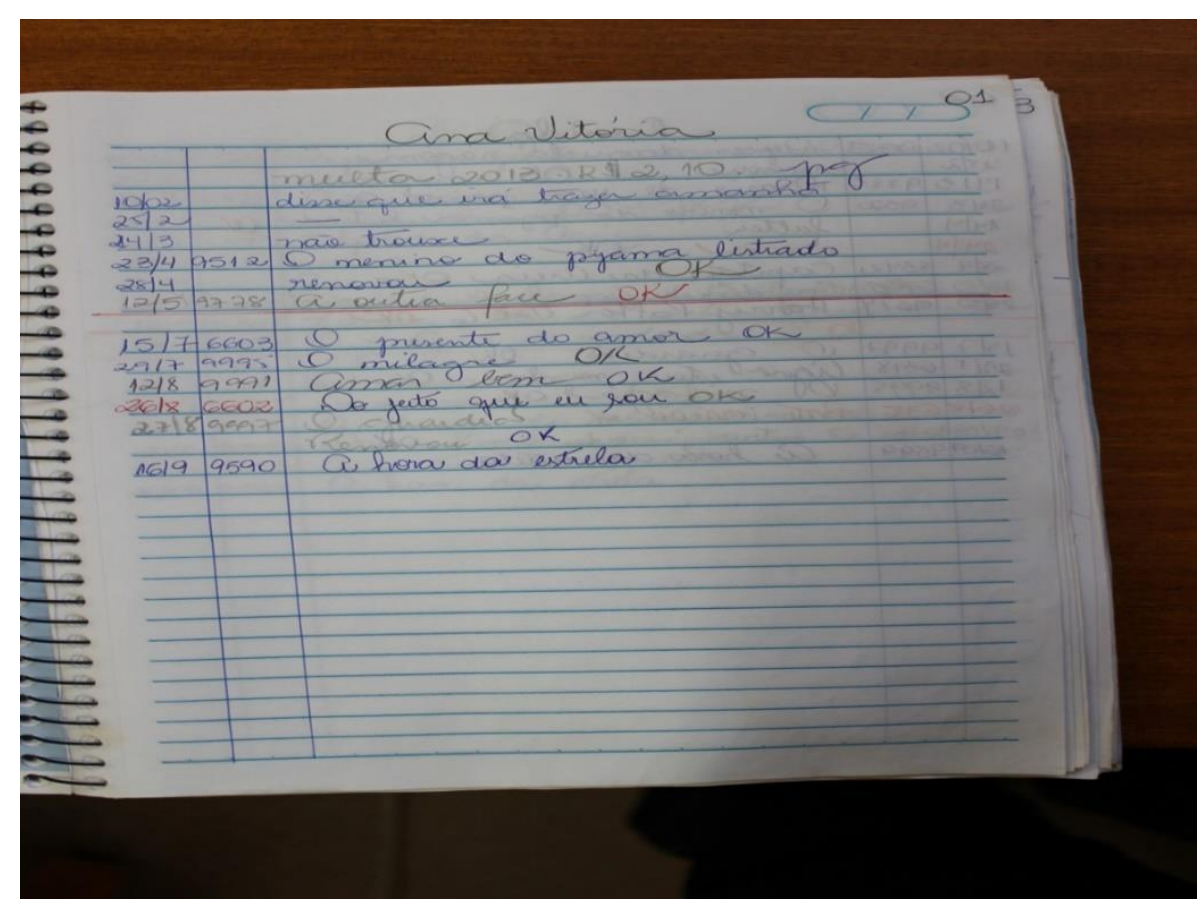

Figura 132 - Controle de retirada de livros dos alunos da escola "E"

Fonte: Arquivo pessoal do autor 
A biblioteca não possui um espaço adequado para estudos coletivos, entretanto, ela é bem organizada, iluminado e arejada, conforme nos mostra a Figura 133. Em entrevista com os Professores e alunos foi possível identificar que os alunos possuem o hábito de levar os livros para casa, porém isso é restrito aos mesmos, pois o atendimento não se estende à comunidade. Em relação à orientação aos alunos na biblioteca e o controle de retirada de livros, a escola destina uma Professora específica todos os dias que os alunos possuem programação de visita à biblioteca, para ficar responsável por essas atividades.
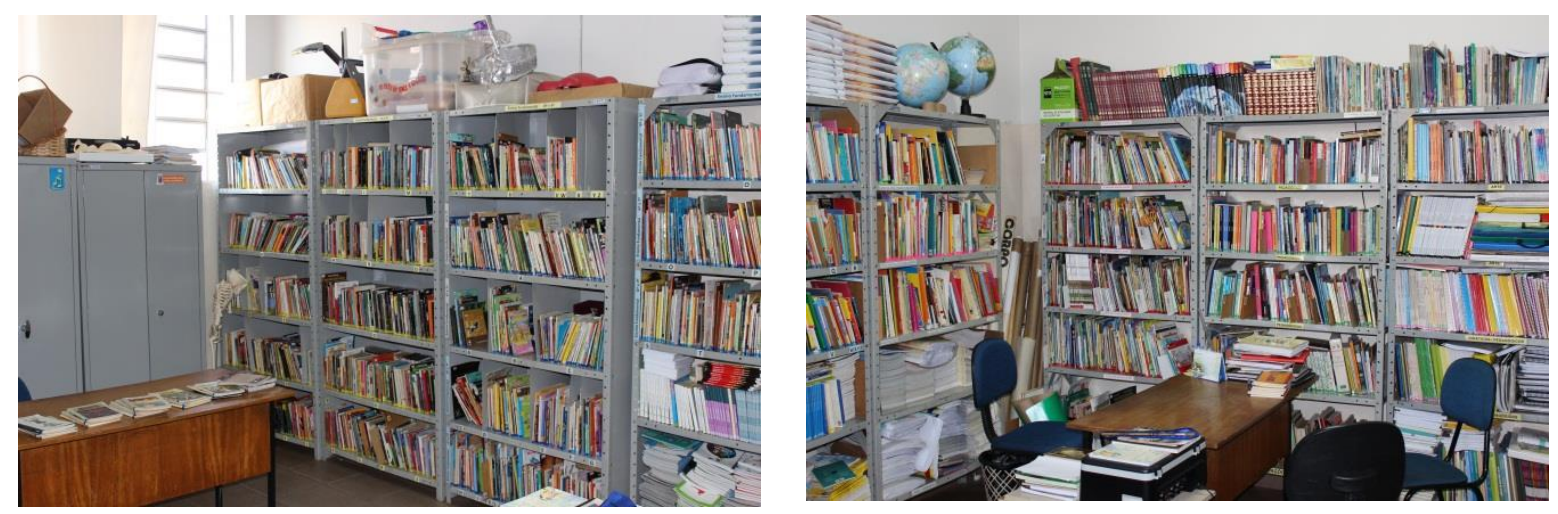

Figura 133 - Biblioteca da escola "E"

Fonte: Arquivo pessoal do autor

Um fator que chamou a atenção durante a visita à escola refere-se ao fato da escola possuir um acervo de livros em Braile para os alunos com deficiência visual, conforme ilustrado pela Figura 134.

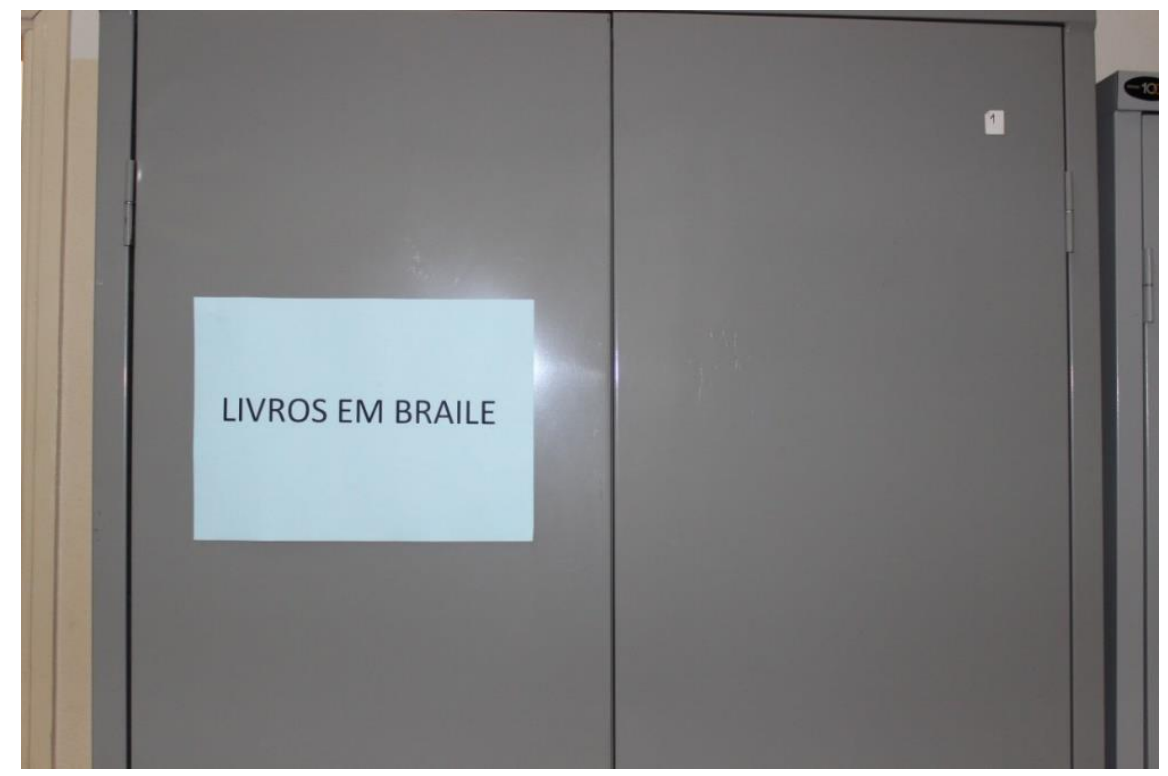

Figura 134 - Acervo de livros em Braile da escola "E" Fonte: Arquivo pessoal do autor 


\subsection{Sala de leitura}

Durante visita à escola observou-se a inexistência de sala de leitura.

\subsection{Alunos}

Em visita à escola identificou-se que o sistema de matrículas dos alunos é por zoneamento e a maioria dos 413 alunos matriculados na escola residem na área urbana e não utilizam o transporte público para ir à escola. Segundo entrevista com os pais, o município oferece o transporte público apenas para os alunos do ensino infantil.

\subsection{Docentes}

Com a visita à escola foi possível identificar as seguintes características referentes ao seu corpo docente:

Número de docentes para cada cem alunos: 8,50

Porcentagem de docentes pertencente ao sexo feminino: 80,00;

Porcentagem dos docentes que possuem magistério concluído: 1,00;

Porcentagem dos docentes que possuem o curso de licenciatura concluído: 77,00;

Porcentagem dos docentes que possuem o ensino superior concluído: 99,00;

Porcentagem dos docentes que possuem especialização concluída: 38,00.

\subsection{Funcionários}

Número de Funcionários para cada cem alunos: 14,29. 


\subsubsection{Escola "J" abaixo da fronteira de eficiência}

- Data da visita: $16 / 09 / 2014$

- Indicadores da escola J

Número de alunos: 148

Investimento anual por aluno: $\mathrm{R} \$ 4.367,93$

Nota no IDEB (Anos Finais): 5,14

Nível socioeconômico: 5 (Médio-Alto)

Durante a visita realizada à escola "J", conforme ilustrado pela Figura 135, localizada no município de Dois Córregos no estado de São Paulo, foi possível identificar inúmeras práticas administrativas e pedagógicas que colaboraram para que, no ano de 2011, a escola obtivesse uma nota 5,14 no IDEB. A seguir são apresentados alguns dos principais aspectos mais relevantes que foram observados durante a visita à escola.

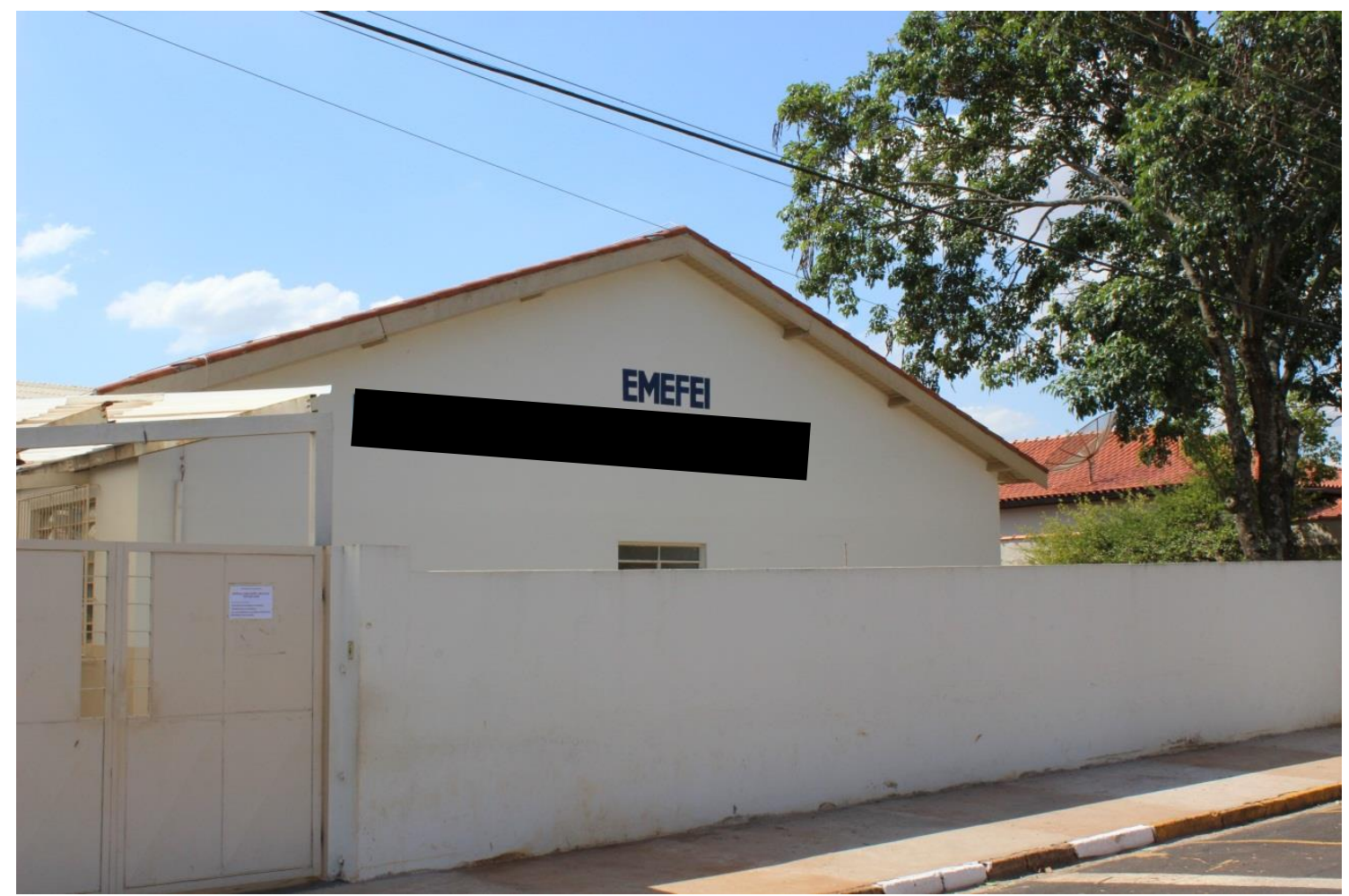

Figura 135 - Fachada da escola "J"

Fonte: Arquivo pessoal do autor 


\subsection{Relatório de gestão e destinação dos recursos financeiros do Diretor}

\subsection{Especificidades do município pequeno}

Em conversa com a Diretora, observou-se que a comunidade escolar não exerce nenhum tipo de cobrança sobre a escola. Isso ocorre, entre outros fatores, pela baixa participação dos pais na vida escolar dos filhos. Segundo a Diretora, muitos pais defendem os filhos mesmos quando os Professores mostram que estão certos nas suas posições. A Diretora ainda destaca o desinteresse dos pais com a vida escolar do filho ao afirmar que, para grande parte dos pais os filhos deveriam ter direito de não realizar os deveres escolares.

\subsection{Alimentação dos alunos}

Em conversa com alunos e a Diretora da escola, observou-se que é oferecido duas refeições por período aos alunos. Além disso, foi observada a existência de uma nutricionista que é responsável pela elaboração e acompanhamento do cardápio, que é por sua vez, elogiado pelos alunos, dado sua variedade e qualidade. Durante a visita observou-se também que a escola possui um refeitório com condições adequadas para os alunos se alimentarem, conforme nos mostra a Figura 136.
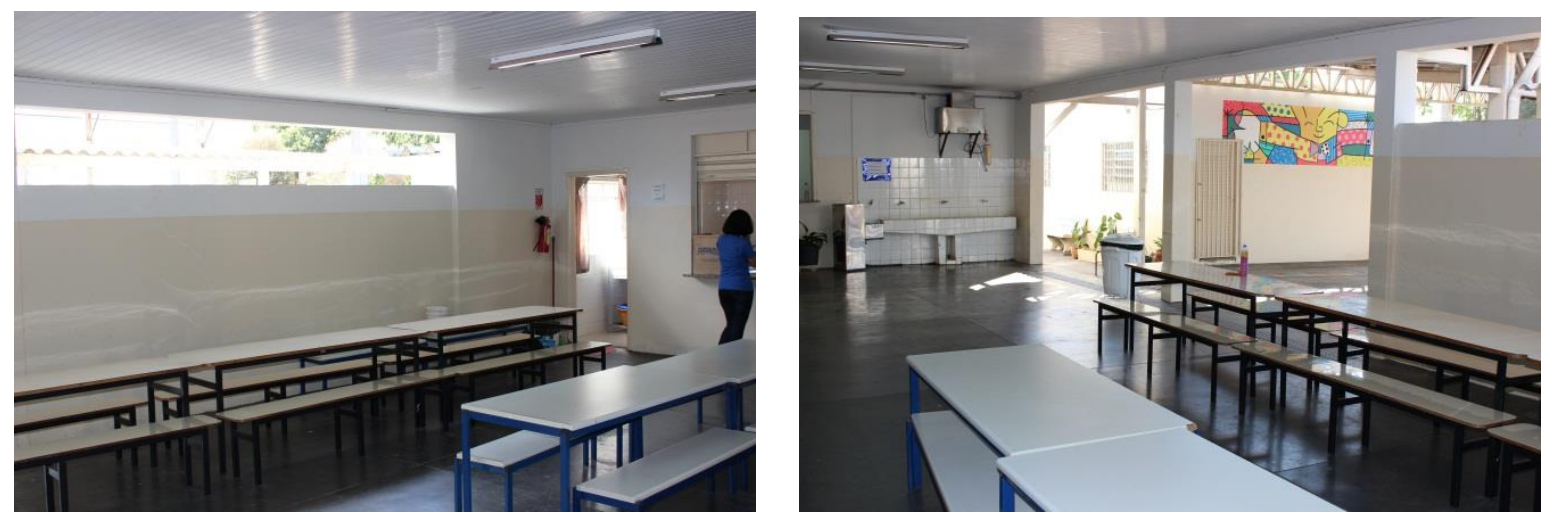

Figura 136 - Refeitório da escola "J"

Fonte: Arquivo pessoal do autor 


\subsection{Processo seletivo}

Em conversa com a Diretora, constatou-se que não existe processo seletivo para entrar na escola e não existe também a transferência compulsória por causa de reprovações em disciplinas. Por outro lado, a escola recebe alunos por transferência, mas a prioridade é por zoneamento.

\subsection{Diretor}

Em conversa com o Diretor, constatou-se que ele possui formação em Magistério e Pedagogia e pós-graduação em Gestão e Psicopedagogia, tendo assumido o cargo por indicação política. Nesta escola, verificou-se também uma falta de autonomia do Diretor para decisões financeiras, uma vez que todos os recursos que chegam até ele já têm um destino previamente selecionado, juntamente com a ausência de recursos descentralizados e a necessidade de aprovação da secretaria para todas as decisões.

\subsection{Plano de carreira do Diretor}

Em conversa com o Diretor e Professores, observou-se o salário do Diretor não é visto como compatível com a função que exerce, uma vez que, segundo o Diretor, os aumentos reais do salário ao longo dos anos foram negativos. Dessa maneira, observou-se que não há incentivos, principalmente financeiros, para que Professores busquem este cargo, uma vez que eles ganham mais dinheiro trabalhando em dois períodos como Professores.

\subsection{Capacidade do Diretor na captação de recursos financeiros}

Durante entrevista realizada com o Diretor da escola, foi possível observar que ele não atua em nenhum momento de forma proativa a fim de captar recursos para a escola. A única fonte de receita da escola são as convencionais, que são repassadas pelos órgãos federais, estaduais e municipais. Além disso, a Diretora fica aguardando a SME informar quando e quanto de recurso há disponível para que estes possam fazer requisitos formais para compra de materiais escolares, cadeiras etc. 


\subsection{Destinação do recurso financeiro descentralizado e centralizado}

Em conversa com o Diretor, observou-se que os recursos financeiros centralizados e suas respectivas destinações não são monitorados quantitativamente para que seja possível mensurar o quanto é investido em cada item listado (equipamentos de consumo, permanente, materiais escolares, etc.). Entretanto, pôde ser observado que a escola dispõe de uma boa infraestrutura, com excelentes salas de aula, contando com ventiladores, cadeiras e carteiras em bom estado de uso, conforme mostra a Figura 137.

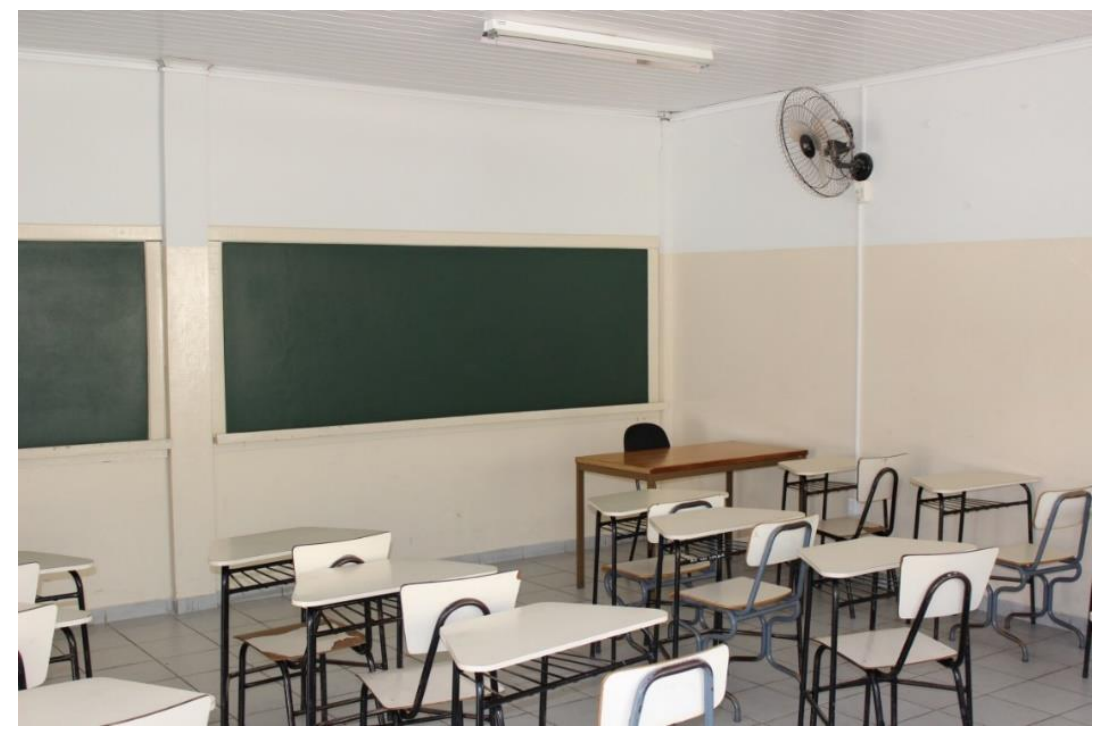

Figura 137 - Sala de aula da escola "J"

Fonte: Arquivo pessoal do autor

A quadra de esporte coberta e cercada com alambrado em seu entorno é apresentada na Figura 138.
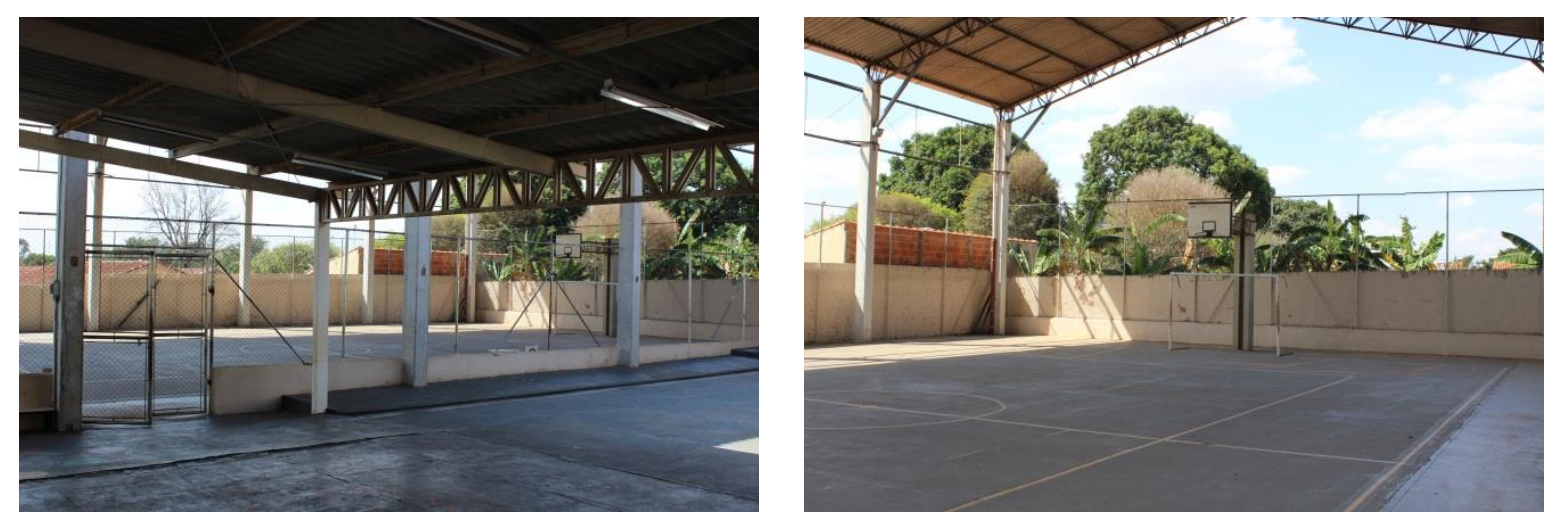

Figura 138 - Quadra de esportes da escola "J" Fonte: Arquivo pessoal do autor 
Por fim, o parque de diversão é apresentado na Figura 139. Vale destacar, entretanto, que o parque de diversão não fica dentro da escola, e sim em um prédio da prefeitura localizado ao lado da escola.

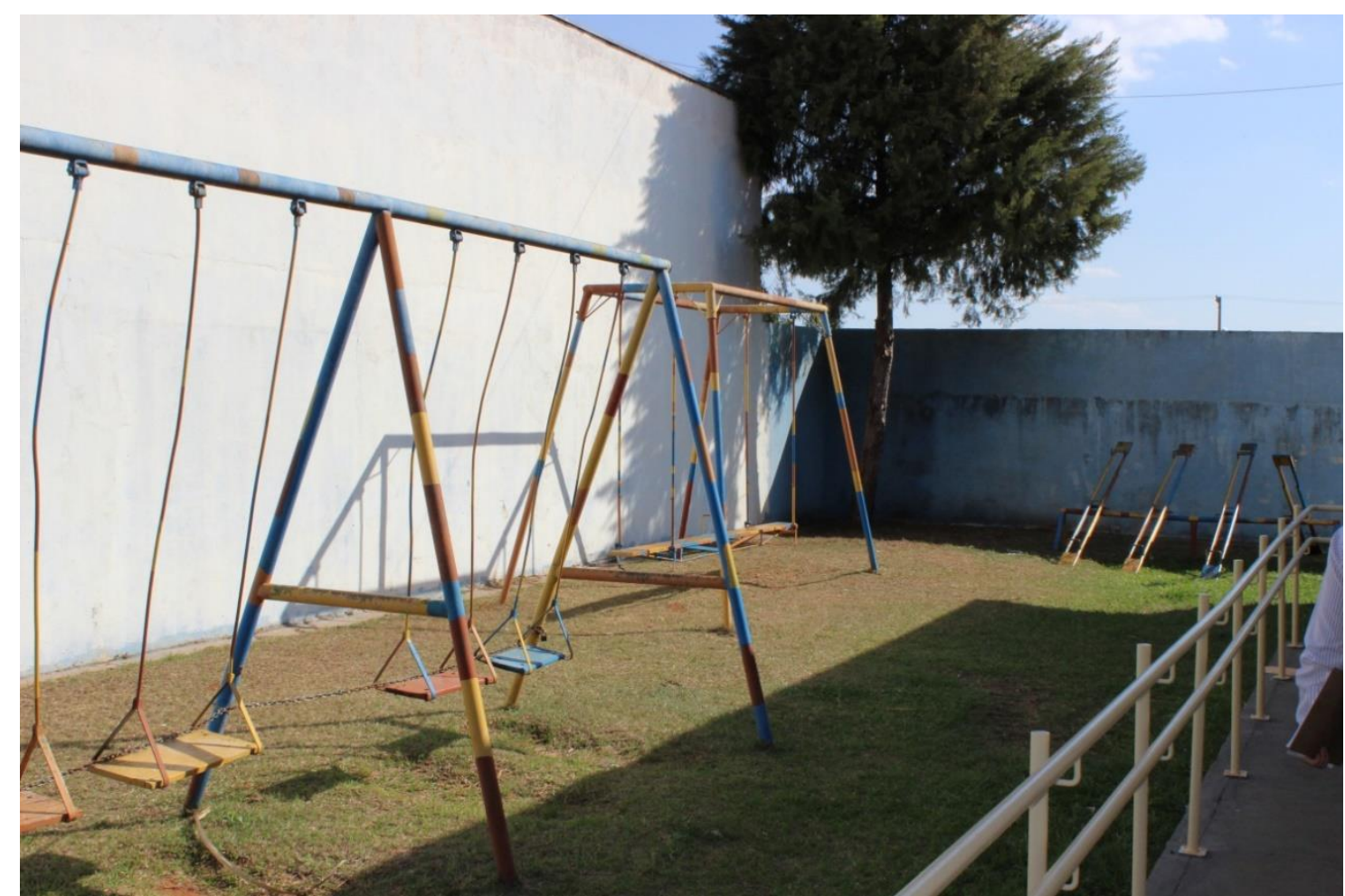

Figura 139 - Parque de diversão da escola "J"

Fonte: Arquivo pessoal do autor

\subsection{Relatório pedagógico e socioeconômico}

\subsection{Desempenho na prova de português}

Em entrevista realizada com a docente responsável pela disciplina, observou-se que ela está na instituição desde 2004 (o que indica uma baixa rotatividade de docentes nessa disciplina) e tem autonomia para a realização de atividades em sala, bem como em avaliações.

Em relação ao material didático, ele é escolhido pela SME em parceria com todos os docentes que ministram aulas na disciplina, sendo este padrão para toda a rede municipal. Um fator relevante é que o mesmo material tem sido mantido nas últimas duas gestões do governo 
municipal. Além desse material, a docente tem autonomia para complementar as aulas com material próprio.

Segundo a docente, o acompanhamento do desempenho dos alunos é feito por meio de trabalhos, produção textual e provas, totalizando algo em torno de cinco avaliações por bimestre. A docente ainda destaca que a produção de texto, envolvendo inúmeros temas, é fortemente incentivada por ela e pela escola. Os textos elaborados pelos alunos são fixados em um painel localizado no pátio da escola, conforme nos mostra a Figura 140.

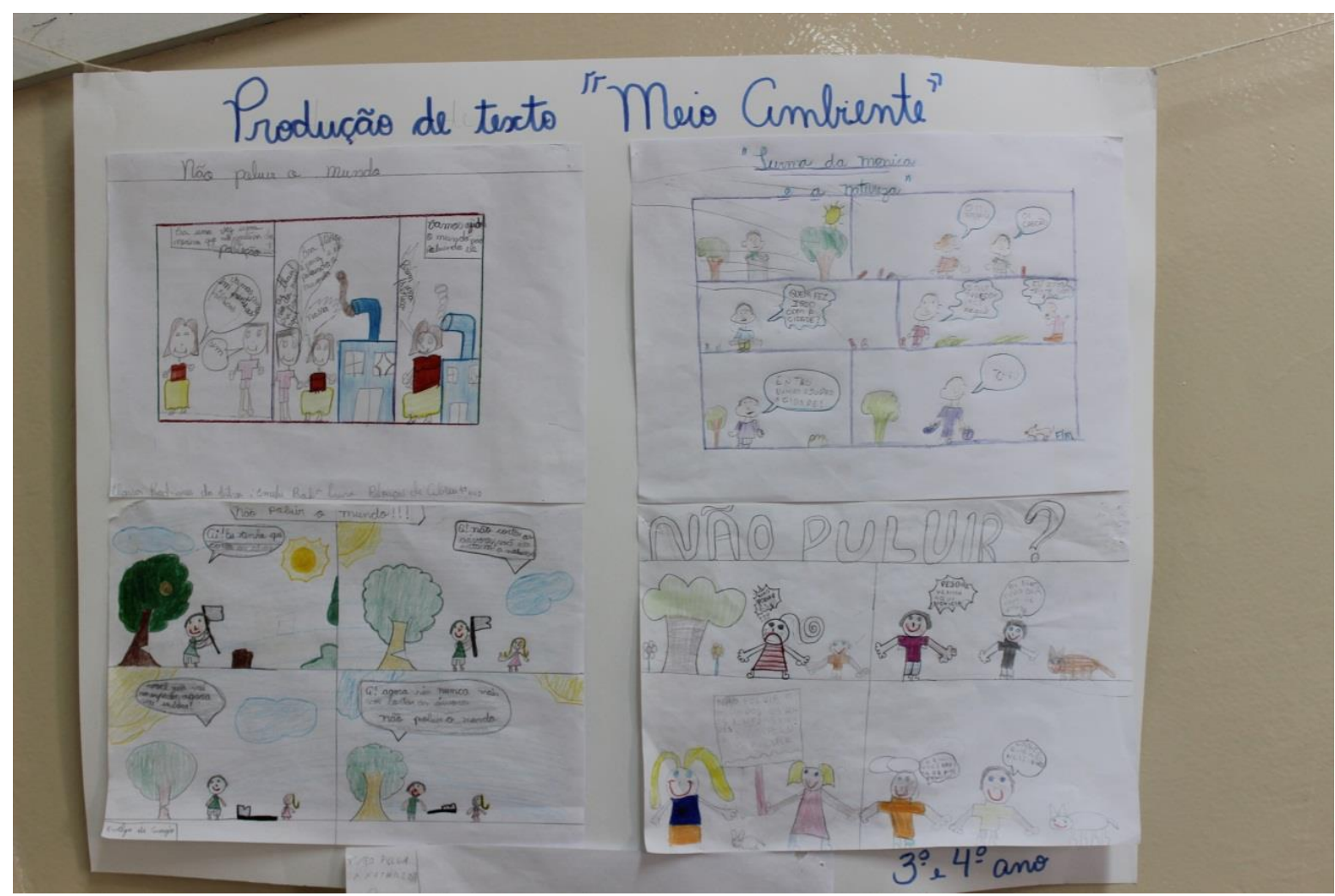

Figura 140 - Produção de texto sobre o meio ambiente elaborado pelos alunos

Fonte: Arquivo pessoal do autor

Outro fator interessante, que pôde ser observado durante a visita à escola, foi o primeiro concurso de frases promovido pela escola, cujo tema foi "Recursos naturais, vamos racionalizar", em que as frases vencedoras foram fixadas em um mural localizado no pátio da escola, conforme ilustrado pela Figura 141. 
1 CONCURSO DE FRASES 2014 - PROGRAMA VIVA MEIO AMBIENTE

TEMA: "RECURSOS NATURAIS, VAMOS RACIONALIZAR".

1ㅇ lugar: Merielen Silva Albuquerque - 9ㅇano-14 anos

Professora: Keila de Cassia Bueno Paiva

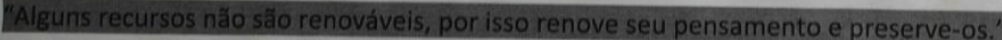

20 lugar: Inaira de Almeida Lima - 5 ano - 10 anos

Professora: Siomara Aparecida Polanzan Rabello

"Cuidar é renovar, plantar é recomeçar, para os recursos naturais não acabar jamais.'

39 lugar: Amanda Cristina Dinato - 92 ano - 13 anos

Professora: Keila de Cassia Bueno Paiva

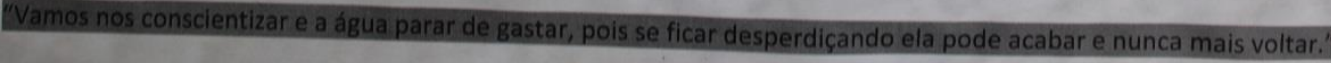

Figura 141 - Concurso de frases promovido pela escola " $\mathrm{J}$ "

Fonte: Arquivo pessoal do autor

Em relação ao reforço no contraturno, verificou-se que mesmo sendo uma prática incentivada pela SME, essa escola não oferece. Segundo a Diretora, a escola não adota essa prática pelo fato da maioria dos alunos residirem no meio rural, o que dificulta a acessibilidade à escola no contraturno.

Segundo a docente entrevistada, com a aproximação da Prova Brasil são realizados simulados para melhor preparar os alunos para a avaliação.

\subsection{Desempenho na prova de matemática}

Em entrevista realizada com a docente responsável pela disciplina, observou-se que ela está na instituição desde 2004 (o que indica uma baixa rotatividade de docentes nessa disciplina) e tem autonomia para a realização de atividades em sala, bem como em avaliações. Durante visita à escola, foi possível verificar uma avaliação, contendo três questões, realizada pela docente, conforme nos mostra a Figura 142. 


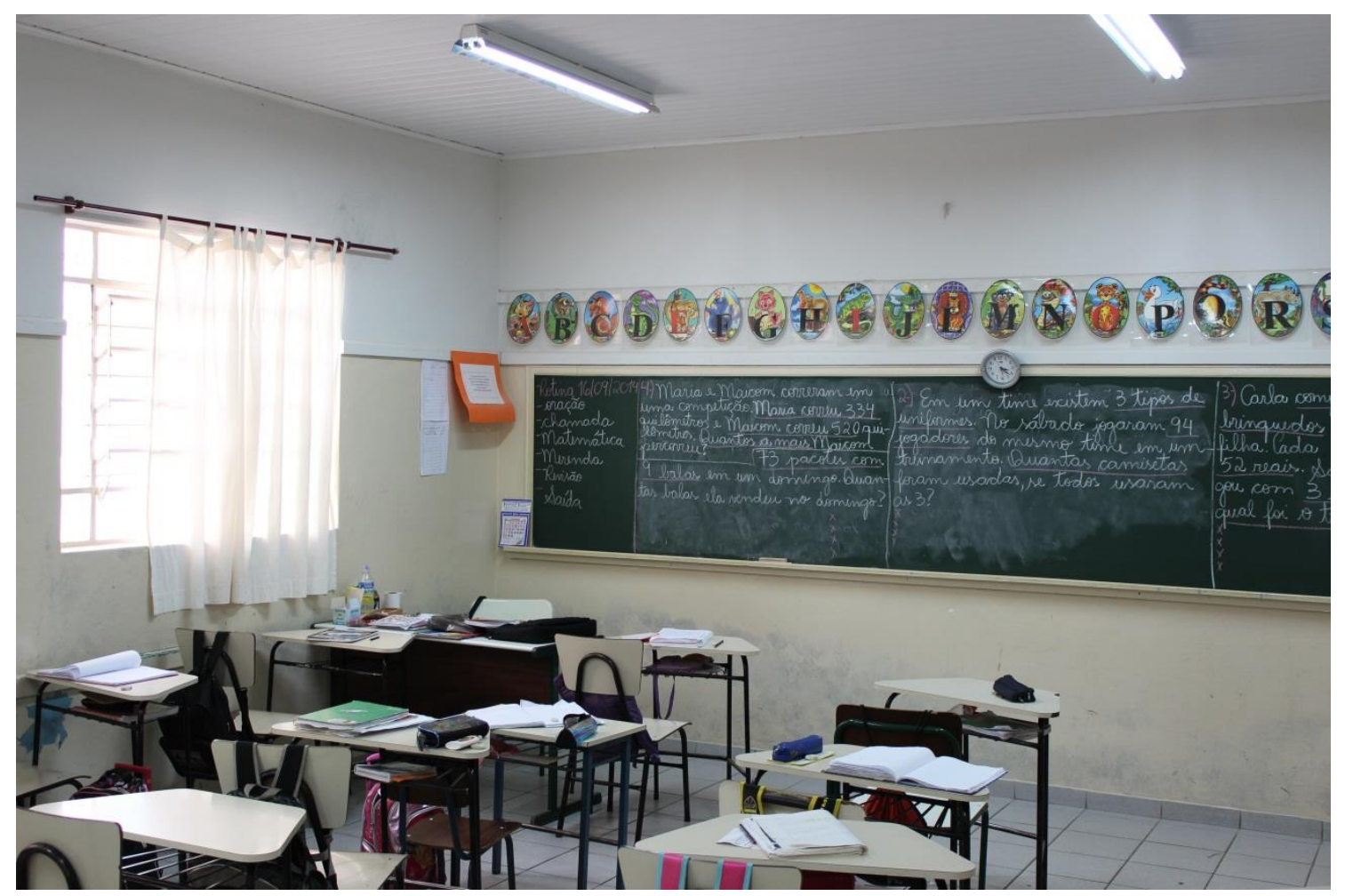

Figura 142 - Avaliação realizada pela docente de matemática Fonte: Arquivo pessoal do autor

Em relação ao material didático, ele é escolhido pela SME em parceria com todos os docentes que ministram aulas na disciplina, sendo este padrão para toda a rede municipal. Um fator relevante é que o mesmo material tem sido mantido nas últimas duas gestões do governo municipal. Além desse material, a docente tem autonomia para complementar as aulas com material próprio.

Segundo a docente entrevistada, o acompanhamento do desempenho dos alunos é feito por meio de trabalhos, provas e chamada oral de tabuada, totalizando cinco avaliações por bimestre. A docente ainda destaca, que conforme se aproxima a data de realização da Prova Brasil, são realizados simulados para melhor preparar os alunos para a avaliação.

\subsection{Participação da família}

Em visita à escola observou-se que apenas a minoria dos pais participa ativamente da vida escolar dos filhos. Os pais que participaram da entrevista corroboram com tal observação ao afirmar que um dos pontos fracos dessa escola é justamente a baixa participação dos pais nas reuniões realizadas pela escola. Para eles, a maioria dos pais não participa das reuniões de 
pais, da associação de pais e mestres, dos eventos festivos realizados pela escola e da vida escolar do filho de um modo geral, porque a maioria deles trabalha e não possui tempo disponível para isso. De acordo com os pais, a Diretora da escola busca encontrar meios de incentivar e promover uma maior participação dos pais, como a realização de reuniões no final da tarde, para que os pais que trabalham possam participar. Em entrevista com os pais eles também demonstraram desconhecer as propostas pedagógicas que a escola vai desenvolver ao longo do ano e afirmaram que apenas os pais que residem na área rural utilizam o transporte público para ir à escola.

\subsection{Reprovação discente e sistema disciplinar}

Em visita à escola, observou-se a existência de um sistema de reprovação por ciclos, em que os Professores possuem autonomia para reprovar os alunos com baixo desempenho apenas no terceiro, quinto, sétimo e nono ano.

Em entrevistas com os pais e alunos, observou-se que as regras do sistema disciplinar não são conhecidas e respeitadas por toda comunidade escolar. Segundo os pais entrevistados, a escola comunica as regras para os pais no início do ano, enquanto os alunos tomam conhecimento por meio dos Professores na sala de aula. Para os pais entrevistados, alguns pais, principalmente aqueles que não frequentam as reuniões escolares, além de não concordar com algumas regras, não colaboram com a escola no seu cumprimento, de modo que, quando o seu filho é advertido por cometer algum ato de indisciplina e ele é convocado a comparecer na escola, ele não comparece, o que estimula os alunos a continuarem cometendo atos de indisciplina.

Segundo os pais e alunos, os atos de indisciplinas e o desrespeito com a figura do Professor e Diretor são constantes na escola. De acordo com o relato dos pais e dos alunos, alguns alunos respondem para os Professores quando possui a atenção chamada. Um aluno, inclusive, já quebrou o vidro da janela da sala de aula, e em uma ocasião outro aluno agrediu um Professor com socos e chutes, tendo que ser contido pela Diretora da escola. Os pais finalizam com a afirmativa de que é necessário que a escola aplique punições mais severas para os alunos que cometem atos de indisciplinas. 


\subsection{Laboratório de informática}

Em visita realizada à escola constatou-se a inexistência de laboratório de informática.

\subsection{Biblioteca}

Em visita realizada à escola, constatou-se a existência de uma biblioteca com acervo de quantidade e qualidade de nível mediano. Um fator importante a ser destacado é que a biblioteca não fica localizada no interior da escola, e sim em um prédio da prefeitura localizado ao lado da escola. Na visita à biblioteca, verificou-se que ela não possui espaço para estudos coletivos, o espaço é desorganizado, pois alguns livros ficam em cima de cadeiras e arquivados ao lado de equipamentos musicais, e o ambiente é razoavelmente iluminado e arejado, conforme nos mostra a Figura 143 e a Figura 144.
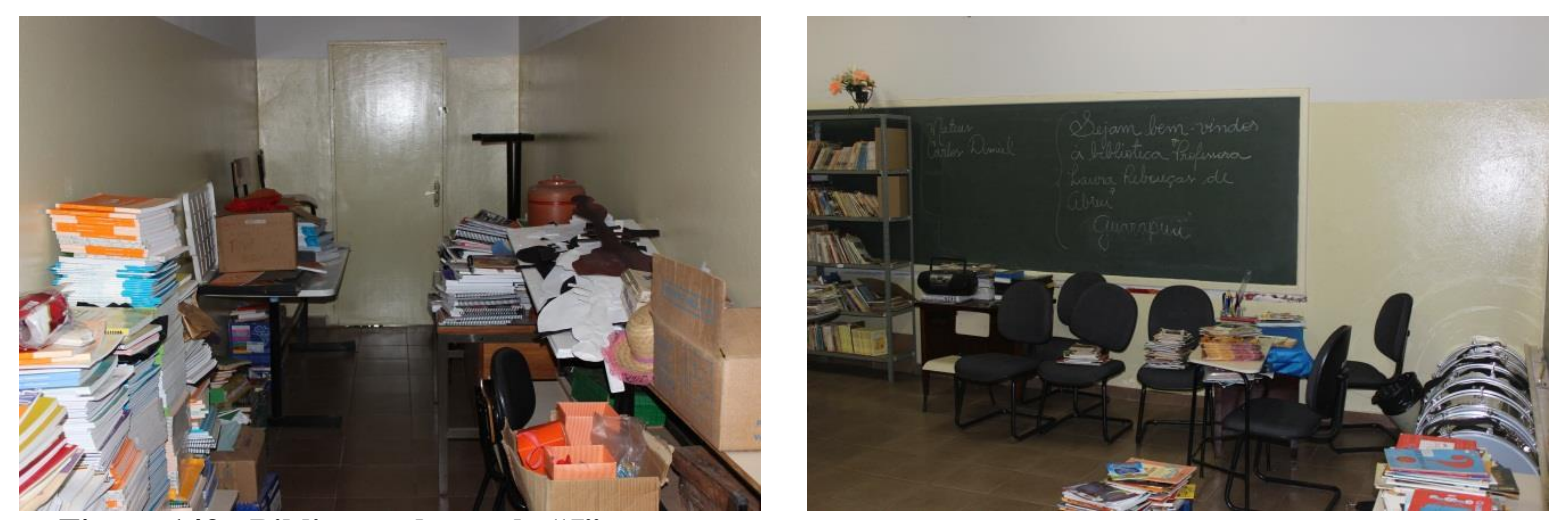

Figura 143 - Biblioteca da escola "J"

Fonte: Arquivo pessoal do autor

Uma importante observação é que as condições de acesso, estudo e uso da biblioteca pode ser um dos fatores que contribui para o baixo nível de leitura dos alunos. A Figura 144 apresenta a organização da biblioteca. 


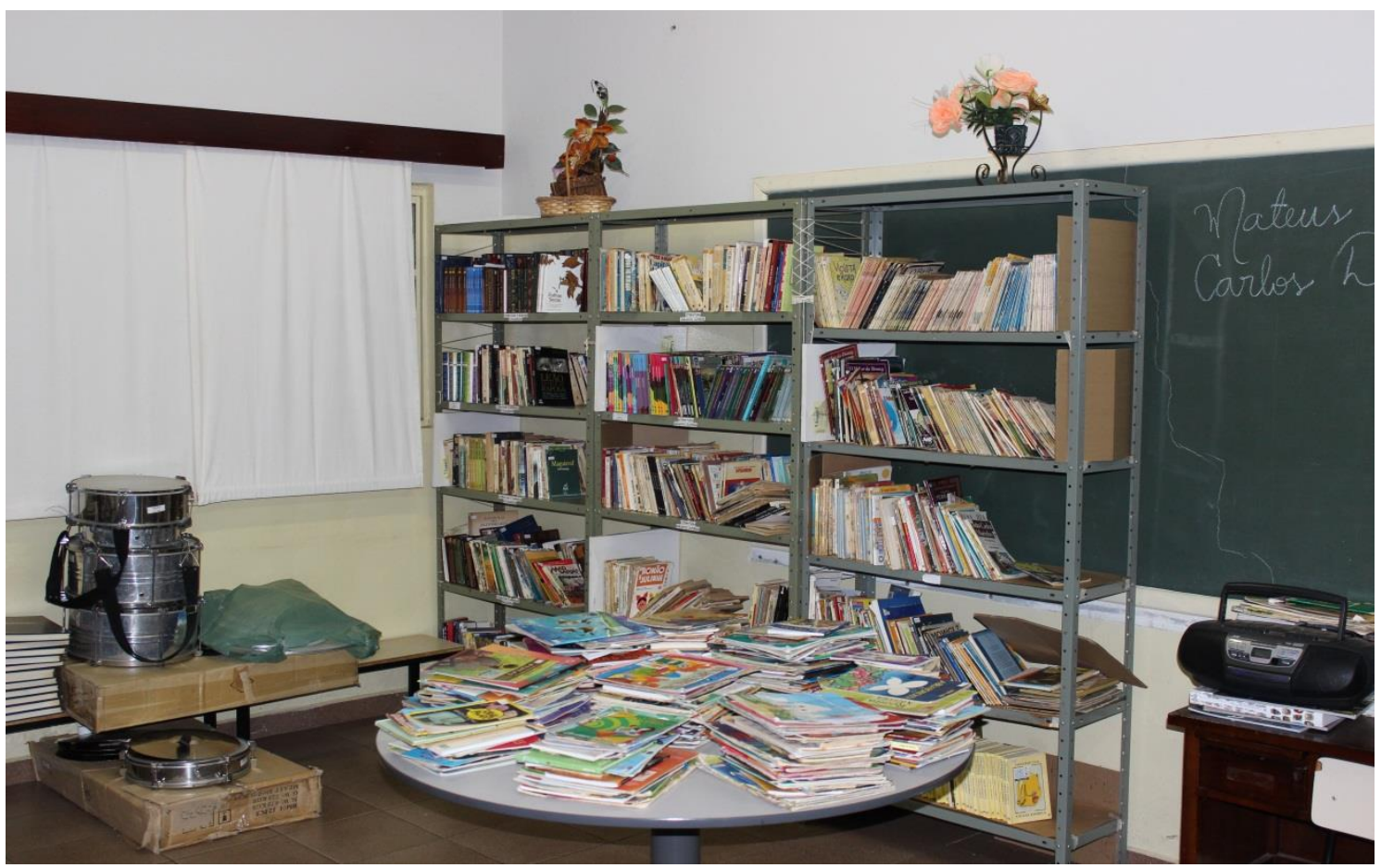

Figura 144 - Biblioteca da escola "J"

Fonte: Arquivo pessoal do autor

Em relação à orientação aos alunos na biblioteca e o controle de retirada de livros, ela é feita pelo Professor que acompanha a sala durante a visita à biblioteca. Segundo a Diretora, a biblioteca não é aberta para a comunidade, ou seja, o seu uso é restrito apenas aos alunos da escola.

\subsection{Sala de leitura}

Em visita à escola observou-se a inexistência de sala de leitura

\subsection{Alunos}

Em visita à escola identificou-se que o sistema de matrículas dos alunos é por zoneamento e a maioria dos 148 alunos matriculados na escola residem na área urbana e apenas os alunos que residem na área rural utilizam o transporte público para ir à escola. 


\subsection{Docentes}

Com a visita à escola foi possível identificar as seguintes características referentes ao seu corpo docente:

Número de docentes para cada cem alunos: 12,80

Porcentagem de docentes pertencente ao sexo feminino: 80,77;

Porcentagem dos docentes que possuem magistério concluído: 3,85;

Porcentagem dos docentes que possuem o curso de licenciatura concluído: 61,54;

Porcentagem dos docentes que possuem o ensino superior concluído: 96,15;

Porcentagem dos docentes que possuem especialização concluída: 42,31.

\subsection{Funcionários}

Número de Funcionários para cada cem alunos: 19,59. 


\subsubsection{Análise dos resultados dos estudos de caso}

Nesta seção foram apresentados e analisados os resultados encontrados nos estudos de caso realizados nas escolas eficientes e ineficientes, identificados por meio dos instrumentos de pesquisa propostos (Instrumento Administrativo aplicado ao SME, Instrumento Administrativo aplicado ao Diretor e Instrumento Pedagógico aplicado a escola). Deste modo, a apresentação das práticas avaliada pelos instrumentos, será apresentada por meio de gráficos e tabelas, onde poderá ser verificada a frequência que cada atividade foi encontrada em cada uma das escolas e SMEs.

Os resultados foram comparados por meio da frequência na qual essas atividades foram identificadas nas escolas eficientes e ineficientes, entretanto, caberá apenas discutir a seu respeito, tendo em vista que foram encontrados na literatura estudos que convergem ou divergem desses resultados, do mais os resultados não podem ser generalizados, tendo em vista que se trata de estudos de casos realizados em apenas dez escolas.

\subsubsection{Resultado do estudo de caso nas cinco escolas eficientes}

Neste item, a apresentação dos resultados encontrados nas cinco escolas eficientes foi dividida em dois subitens. O primeiro refere-se à apresentação dos resultados das práticas administrativas do Diretor das escolas eficientes e o segundo refere-se à apresentação dos resultados das práticas pedagógicas das escolas eficientes. Os quadros sintetizam os resultados encontrados em cada escola para cada atividade de cada indicador que compõe o instrumento administrativo aplicado ao Diretor e o instrumento pedagógico aplicado a escola.

\subsection{Resultado das Práticas Administrativas do Diretor nas Escolas Eficientes}

O Quadro 13 sintetiza a contribuição de cada escola na composição da frequência de cada atividade que constitui os indicadores do instrumento administrativo aplicado aos Diretores das cinco escolas eficientes. A contribuição de cada escola é dada em algumas práticas por um indicador de frequência (que varia de zero a dez) e outras por um indicador binário (possui ou não possui). Neste estudo optou-se por esta escala para resumir os resultados. Desta forma, coube ao pesquisador identificar a frequência ou presença de cada prática encontrada em cada escola. 


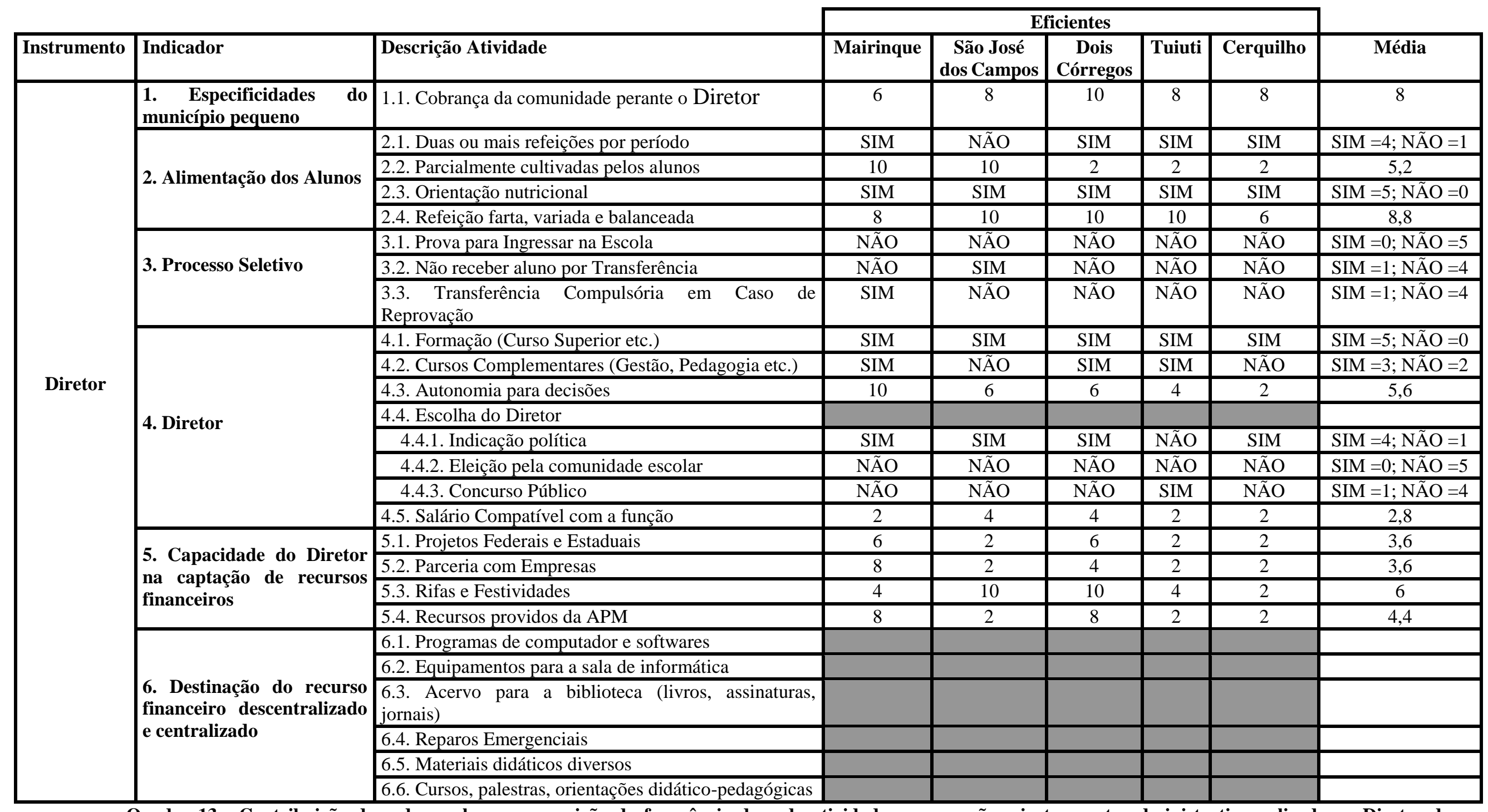

Quadro 13 - Contribuição de cada escola na composição da frequência de cada atividade que compõe o instrumento administrativo aplicado ao Diretor das escolas eficientes

Fonte: Elaborado pelo autor com base nos resultados dos estudos de caso 


\subsection{Resultado das Práticas Pedagógicas nas Escolas Eficientes}

O Quadro 14 sintetiza a contribuição de cada escola na composição da frequência de cada atividade que constitui os indicadores do instrumento pedagógico aplicado nas cinco escolas eficientes. A contribuição de cada escola é dada em algumas práticas por um indicador de frequência (que varia de zero a dez) e outras por um indicador binário (possui ou não possui). Neste estudo optou-se por esta escala para resumir os resultados.

Desta forma, coube ao pesquisador identificar a frequência ou presença de cada prática encontrada em cada escola.

\begin{tabular}{|c|c|c|c|c|c|c|c|c|}
\hline \multirow[b]{2}{*}{ Instrumento } & \multirow[b]{2}{*}{ Indicador } & \multirow[b]{2}{*}{ Descrição Atividade } & \multicolumn{5}{|c|}{ Eficientes } & \multirow[b]{2}{*}{ Média } \\
\hline & & & Mairinque & $\begin{array}{c}\begin{array}{c}\text { São José dos } \\
\text { Campos }\end{array} \\
\end{array}$ & $\begin{array}{c}\text { Dois } \\
\text { Córregos }\end{array}$ & Tuiuti & Cerquilho & \\
\hline \multirow{17}{*}{ Pedagógico } & \multirow{7}{*}{$\begin{array}{l}\text { 1. Desempenho } \\
\text { Prova Português }\end{array}$} & 1.1. Autonomia do docente no ensino dessa disciplina & 8 & 10 & 10 & 8 & 6 & 8,4 \\
\hline & & 1.3. Rotatividade dos Professores nessa disciplina & 2 & 2 & 2 & 4 & 2 & 2,4 \\
\hline & & $\begin{array}{l}\text { 1.4. Frequência que o docente acompanha o desempenho do } \\
\text { aluno }\end{array}$ & 10 & 10 & 10 & 8 & 8 & 9,2 \\
\hline & & 1.5. Recuperação paralela e reforço no contraturno & 2 & 10 & 8 & 2 & 6 & 5,6 \\
\hline & & 1.6. Projetos que colaborem para melhor desempenho & 2 & 2 & 8 & 2 & 8 & 4,4 \\
\hline & & $\begin{array}{l}\text { 1.7. Distribuição da carga horária ou da grade curricular com os } \\
\text { requisitos avaliados na Prova Brasil }\end{array}$ & 8 & 8 & 2 & 2 & 2 & 4,4 \\
\hline & & 1.8. Preparação específica para a Prova Brasil & 8 & 10 & 10 & 8 & 8 & 8,8 \\
\hline & \multirow{6}{*}{$\begin{array}{l}\text { 2. Desempenho } \\
\text { Prova de } \\
\text { Matemática }\end{array}$} & 2.1. Autonomia do docente no ensino dessa disciplina & 8 & 10 & 10 & 8 & 6 & 8,4 \\
\hline & & $\begin{array}{l}\text { 2.2. Frequência que o docente acompanha o desempenho do } \\
\text { aluno }\end{array}$ & 8 & 10 & 10 & 8 & 8 & 8,8 \\
\hline & & 2.3. Rotatividade dos Professores nessa disciplina & 2 & 2 & 2 & 4 & 2 & 2,4 \\
\hline & & 2.5. Projetos que colaborem para um melhor desempenho & 2 & 2 & 2 & 2 & 2 & 2 \\
\hline & & $\begin{array}{l}\text { 2.6. Distribuição da carga horária ou da grade curricular com os } \\
\text { requisitos avaliados na Prova Brasil }\end{array}$ & 8 & 8 & 2 & 2 & 2 & 4,4 \\
\hline & & 2.7. Preparação específica para a Prova Brasil & 8 & 10 & 10 & 8 & 8 & 8,8 \\
\hline & \multirow{4}{*}{ 3. Participação } & 3.1. Participação dos pais nas reuniões & 8 & 10 & 10 & 10 & 8 & 9,2 \\
\hline & & 3.2. Participação dos pais em eventos festivos da escola & 8 & 10 & 10 & 6 & 8 & 8,4 \\
\hline & & 3.3. Contribuição na manutenção da estrutura física escolar & 2 & 2 & 2 & 2 & 2 & 2 \\
\hline & & 3.4. Participação dos pais na APM & 2 & 10 & 10 & 2 & 8 & 6,4 \\
\hline
\end{tabular}




\begin{tabular}{|c|c|c|c|c|c|c|c|}
\hline \multirow[t]{2}{*}{ da Família } & 3.5. Acompanhamento dos pais nos deveres escolares dos filhos & 6 & 8 & 10 & 8 & 4 & 7,2 \\
\hline & $\begin{array}{l}3.7 \text { Frequência com que os pais utilizam o transporte público para } \\
\text { ir à escola }\end{array}$ & 4 & 2 & 2 & 2 & 2 & 2,4 \\
\hline \multirow{4}{*}{\begin{tabular}{|l} 
4. Reprovação \\
Discente \\
Sistema \\
Disciplinar
\end{tabular}} & 4.1. Autonomia do docente no processo de reprovação do aluno. & 10 & 4 & 8 & 10 & 6 & 7,6 \\
\hline & 4.3. Regras claras e definidas do sistema disciplinar & 10 & 8 & 10 & 10 & 10 & 9,6 \\
\hline & 4.4. Grau de disciplinaridade no comportamento discente & 10 & 10 & 10 & 10 & 10 & 10 \\
\hline & $\begin{array}{l}\text { 4.5. Respeito dos discentes em relação à figura do Professor, } \mathrm{d} \\
\text { Diretor e funcionários }\end{array}$ & 10 & 10 & 10 & 10 & 10 & 10 \\
\hline \multirow{2}{*}{$\begin{array}{l}\text { 5. Laboratório } \\
\text { de Informática }\end{array}$} & 5.2 Frequência das aulas de informática & 2 & 2 & 2 & 2 & 2 & 2 \\
\hline & 5.3 Número de computadores para cada 100 alunos & 5,13 & 1,85 & 4,12 & 1,90 & 3,92 & 3,4 \\
\hline \multirow{2}{*}{ 6. Biblioteca } & 6.1 Tamanho do acervo da biblioteca & 8 & 10 & 10 & 6 & 6 & 8 \\
\hline & 6.2 Variedade do acervo da biblioteca & 4 & 10 & 10 & 6 & 6 & 7,2 \\
\hline \multirow{2}{*}{$\begin{array}{|ll|}7 . \quad \text { Sala de } \\
\text { Leitura }\end{array}$} & 7.1 Existência de sala de leitura na escola & NÃO & SIM & $\mathrm{NÃO}$ & $\overline{\mathrm{NÃO}}$ & NÃO & $\mathrm{SIM}=1 ; \mathrm{NÃO}=4$ \\
\hline & 7.2 Utilização da sala de leitura & 2 & 10 & 2 & 2 & 2 & 3,6 \\
\hline 8. Transporte & $\begin{array}{l}\text { 8.1 Frequência com que os alunos utilizam o transporte público } \\
\text { para ir à escola }\end{array}$ & 10 & 4 & 2 & 10 & 4 & 6 \\
\hline \multirow{7}{*}{ 9. Docentes } & 9.4 Porcentagem dos docentes que tem ensino superior concluído & 94,74 & 99,35 & 99 & $\overline{94,44}$ & 100 & 97,5 \\
\hline & 9.5 Porcentagem dos docentes que tem especialização concluída & 31,58 & 65,16 & 38 & 35,19 & 22,66 & 38,5 \\
\hline & 9.6 Número de docentes para cada 100 alunos & 6,3 & 5,1 & 8,5 & 9,5 & 8,4 & 7,5 \\
\hline & 9.7 Incentivo financeiro & $\mathrm{NA \tilde {O }}$ & $\mathrm{NA \tilde {O }}$ & SIM & SIM & SIM & $\mathrm{SIM}=3 ; \mathrm{NÃO}=2$ \\
\hline & 9.7.1 Plano de carreira financeiramente atrativo & $\mathrm{NA \tilde {O }}$ & NÃO & SIM & SIM & SIM & $\mathrm{SIM}=3 ; \mathrm{NA} O=2$ \\
\hline & 9.7.2 Salários acima da média regional & $\mathrm{NA \tilde {O }}$ & NÃO & SIM & SIM & SIM & $\mathrm{SIM}=3 ; \mathrm{NA} O=2$ \\
\hline & 9.7.3 Progressão salarial & NÃO & SIM & SIM & $\overline{\mathrm{SIM}}$ & SIM & $\mathrm{SIM}=4 ; \mathrm{NÃO}=1$ \\
\hline 10. Funcionários & 10.1 Número de funcionários para cada 100 alunos & 9,12 & 8,72 & 14,29 & 9,48 & 7,57 & 9,8 \\
\hline
\end{tabular}

Quadro 14 - Contribuição de cada escola na composição da frequência de cada atividade que compõe o instrumento pedagógico das escolas eficientes Fonte: Elaborado pelo autor com base nos resultados dos estudos de caso 


\subsubsection{Resultado do estudo de caso nas cinco escolas ineficientes}

Neste item, a apresentação dos resultados encontrados nas cinco escolas ineficientes foi dividida em dois subitens. O primeiro refere-se à apresentação dos resultados das práticas administrativas do Diretor das escolas ineficientes e o segundo refere-se à apresentação dos resultados das práticas pedagógicas das escolas ineficientes.

Os quadros sintetizam os resultados encontrados em cada escola para cada atividade de cada indicador que compõe o instrumento administrativo aplicado ao Diretor e o instrumento pedagógico aplicado à escola.

\subsection{Resultado das práticas administrativas do Diretor nas escolas ineficientes}

O Quadro 15 sintetiza a contribuição de cada escola na composição da frequência de cada atividade que constitui os indicadores do instrumento administrativo aplicado aos Diretores das cinco escolas ineficientes. A contribuição de cada escola é dada em algumas práticas por um indicador de frequência (que varia de zero a dez) e outras por um indicador binário (possui ou não possui). Neste estudo optou-se por esta escala para resumir os resultados. Desta forma, coube ao pesquisador identificar a frequência ou presença de cada prática encontrada em cada escola. 


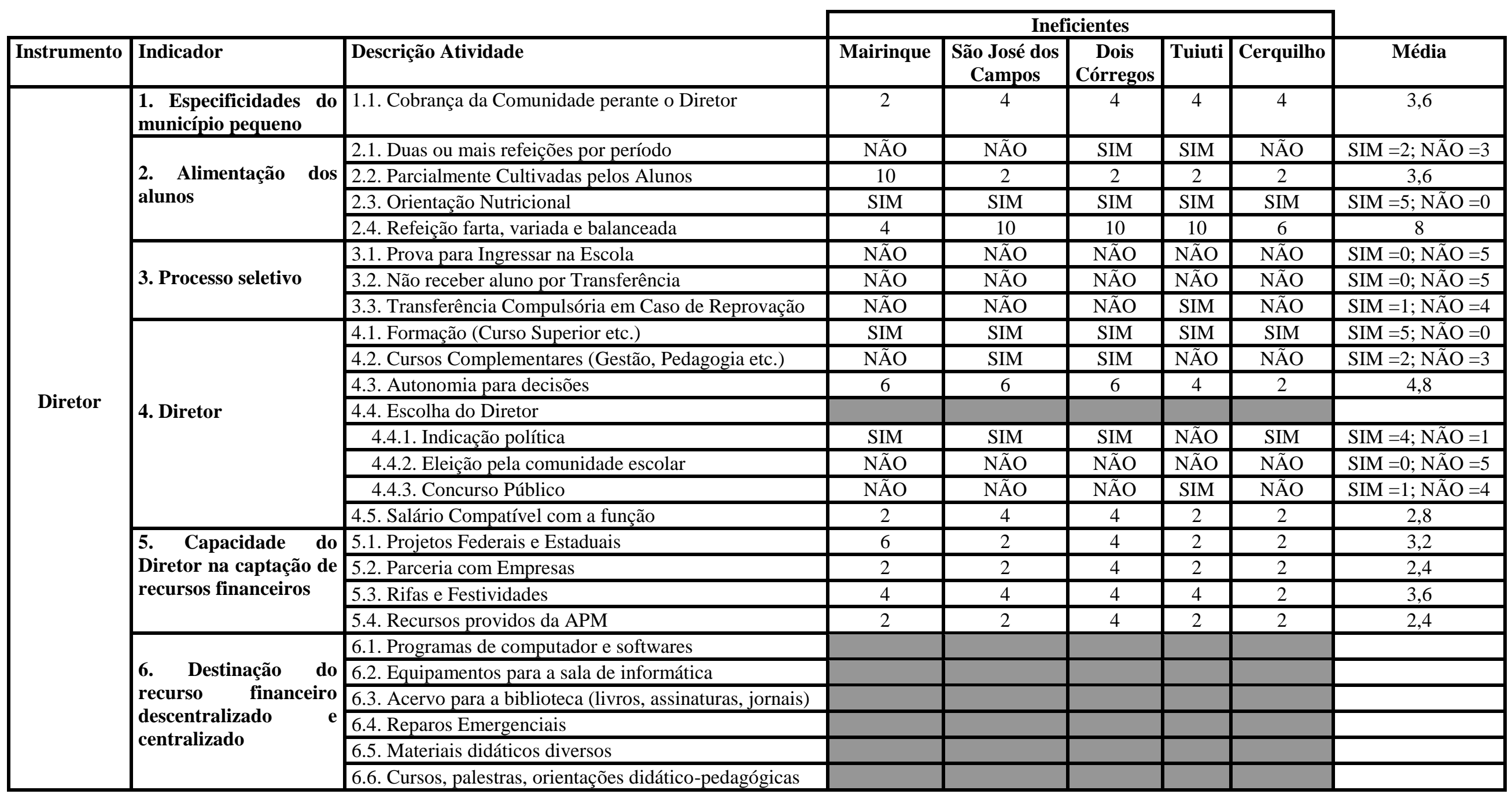

Quadro 15 - Contribuição de cada escola na composição da frequência de cada atividade que compõe o instrumento administrativo aplicado ao Diretor das escolas ineficientes

Fonte: Elaborado pelo autor com base nos resultados dos estudos de caso 


\subsubsection{Resultado das Práticas Pedagógicas nas Escolas Ineficientes}

O Quadro 16 sintetiza a contribuição de cada escola na composição da frequência de cada atividade que constitui os indicadores do instrumento pedagógico aplicado nas cinco escolas ineficientes. A contribuição de cada escola é dada em algumas práticas por um indicador de frequência (que varia de zero a dez) e outras por um indicador binário (possui ou não possui). Neste estudo optou-se por esta escala para resumir os resultados. Desta forma, coube ao pesquisador identificar a frequência ou presença de cada prática encontrada em cada escola.

\begin{tabular}{|c|c|c|c|c|c|c|c|c|}
\hline \multirow[b]{2}{*}{ Instrumento } & \multirow[b]{2}{*}{ Indicador } & \multirow[b]{2}{*}{ Descrição Atividade } & \multicolumn{5}{|c|}{ Ineficientes } & \multirow[b]{2}{*}{ Média } \\
\hline & & & Mairinque & \begin{tabular}{|c|}
$\begin{array}{c}\text { São José dos } \\
\text { Campos }\end{array}$ \\
\end{tabular} & $\begin{array}{c}\text { Dois } \\
\text { Córregos } \\
\end{array}$ & Tuiuti & Cerquilho & \\
\hline \multirow{16}{*}{ Pedagógico } & \multirow{6}{*}{$\begin{array}{l}\text { 1. Desempenho } \\
\text { prova Português }\end{array}$} & 1.1. Autonomia do docente no ensino dessa disciplina & 8 & 10 & 8 & 8 & 8 & 8,4 \\
\hline & & 1.3. Rotatividade dos Professores nessa disciplina & 10 & 10 & 2 & 10 & 6 & 7,6 \\
\hline & & 1.4. Frequência que o docente acompanha o desempenho do aluno & 4 & 6 & 6 & 4 & 6 & 5,2 \\
\hline & & 1.5. Recuperação paralela e reforço no contraturno & 2 & 6 & 2 & 2 & 4 & 3,2 \\
\hline & & $\begin{array}{l}\text { 1.7. Distribuição da carga horária ou da grade curricular com os } \\
\text { requisitos avaliados na Prova Brasil }\end{array}$ & 2 & 2 & 2 & 2 & 2 & 2 \\
\hline & & 1.8. Preparação específica para a Prova Brasil & 4 & 2 & 4 & 4 & 2 & 3,2 \\
\hline & \multirow{6}{*}{$\begin{array}{l}\text { 2. Desempenho } \\
\text { prova de } \\
\text { Matemática }\end{array}$} & 2.1. Autonomia do docente no ensino dessa disciplina & 8 & 10 & 8 & 8 & 8 & 8,4 \\
\hline & & 2.2. Frequência que o docente acompanha o desempenho do aluno & 2 & 6 & 6 & 4 & 6 & 4,8 \\
\hline & & 2.3. Rotatividade dos Professores nessa disciplina & 10 & 10 & 2 & 10 & 6 & 7,6 \\
\hline & & 2.4. Recuperação paralela e reforço no contraturno & 2 & 6 & 2 & 2 & 4 & 3,2 \\
\hline & & 2.5. Projetos que colaborem para um melhor desempenho & 2 & 2 & 4 & 2 & 2 & 2,4 \\
\hline & & 2.7. Preparação específica para a Prova Brasil & 2 & 2 & 4 & 4 & 2 & 2,8 \\
\hline & & 3.1. Participação dos pais nas reuniões & 2 & 2 & 4 & 6 & 4 & 3,6 \\
\hline & & 3.2. Participação dos pais em eventos festivos da escola & 6 & 4 & 4 & 6 & 2 & 4,4 \\
\hline & & 3.3. Contribuição na manutenção da estrutura física escolar & 2 & 2 & 2 & 2 & 2 & 2 \\
\hline & & 3.4. Participação dos pais na APM & 2 & 2 & 4 & 2 & 2 & 2,4 \\
\hline
\end{tabular}




\begin{tabular}{|c|c|c|c|c|c|c|c|}
\hline \multirow{3}{*}{$\begin{array}{l}\text { 3. Participação da } \\
\text { família }\end{array}$} & 3.5. Acompanhamento dos pais nos deveres escolares dos filhos & 2 & 2 & 2 & 4 & 2 & 2,4 \\
\hline & 3.6. Apoio dos pais na validação das ações da escola & 2 & 4 & 4 & 2 & 4 & 3,2 \\
\hline & $\begin{array}{l}\text { 3.7 Frequência com que os pais utilizam o transporte público para ir à } \\
\text { escola. }\end{array}$ & 2 & 2 & 4 & 2 & 2 & 2,4 \\
\hline \multirow{5}{*}{$\begin{array}{l}\text { 4. Reprovação } \\
\text { discente e sistema } \\
\text { disciplinar }\end{array}$} & 4.1. Autonomia do docente no processo de reprovação do aluno & 4 & 2 & 4 & 10 & 10 & 6 \\
\hline & 4.2. Existência de Sistema de Reprovação & SIM & SIM & SIM & SIM & SIM & $\overline{\mathrm{SIM}}=5 ; \mathrm{NA} O=0$ \\
\hline & 4.3. Regras claras e definidas do sistema disciplinar & 2 & 4 & 4 & 6 & 2 & 3,6 \\
\hline & 4.4. Grau de disciplinaridade no comportamento discente & 2 & 4 & 4 & 4 & 4 & 3,6 \\
\hline & $\begin{array}{l}\text { 4.5. Respeito dos discentes em relação à figura do Professor, Diretor e } \\
\text { funcionários }\end{array}$ & 2 & 4 & 4 & 6 & 4 & 4 \\
\hline \multirow{3}{*}{$\begin{array}{l}\text { 5. Laboratório de } \\
\text { informática }\end{array}$} & 5.1 Existência de laboratório de informática na escola & NÃO & SIM & $\mathrm{NÃO}$ & NÃO & SIM & $\mathrm{SIM}=2 ; \mathrm{NA} \tilde{\mathrm{O}}=3$ \\
\hline & 5.2 Frequência das aulas de informática & 2 & 2 & 2 & 2 & 2 & 2 \\
\hline & 5.3 Número de computadores para cada 100 alunos & 4,03 & 2,07 & 9,46 & 1,02 & 4,04 & 4,1 \\
\hline \multirow{2}{*}{ 6. Biblioteca } & 6.1 Tamanho do acervo da biblioteca & 4 & 10 & 10 & 2 & 4 & 6 \\
\hline & 6.2 Variedade do acervo da biblioteca & 4 & 10 & 10 & 2 & 6 & 6,4 \\
\hline \multirow{2}{*}{ 7. Sala de leitura } & 7.1 Existência de sala de leitura na escola & NÃO & SIM & NÃO & $\mathrm{NÃO}$ & SIM & $\mathrm{SIM}=2 ; \mathrm{NA} O=3$ \\
\hline & 7.2 Utilização da sala de leitura & 2 & 4 & 2 & 2 & 4 & 2,8 \\
\hline \multirow[t]{2}{*}{ 8. Transporte } & $\begin{array}{l}\text { 8.1 Frequência com que os alunos utilizam o transporte público para } \\
\text { ir à escola }\end{array}$ & 8 & 2 & 4 & 10 & 4 & 5,6 \\
\hline & 8.2 Número de matrículas & 893 & 628 & 148 & 294 & 421 & 476,8 \\
\hline \multirow{10}{*}{ 9. Docentes } & 9.1 Porcentagem de docentes pertencentes do gênero feminino & 78,77 & 80,77 & 80,77 & 67,37 & 60,87 & 73,7 \\
\hline & 9.2 Porcentagem dos docentes tem o magistério concluído & 4,79 & 0 & 3,85 & 0 & 0,62 & 1,9 \\
\hline & $\begin{array}{l}9.3 \text { Porcentagem dos docentes que tem o curso de licenciatura } \\
\text { concluído }\end{array}$ & 65,07 & 70,19 & 61,54 & 87,37 & 72,67 & 71,4 \\
\hline & 9.4 Porcentagem dos docentes que tem ensino superior concluído & 94,52 & 100 & 96,15 & 100 & 99,38 & 98,0 \\
\hline & 9.5 Porcentagem dos docentes que tem especialização concluída & 24,66 & 73,08 & 42,31 & 10,53 & 31,06 & 36,3 \\
\hline & 9.6 Número de docentes para cada 100 alunos & 5,0 & 5,4 & 12,8 & 4,8 & 7,8 & 7,2 \\
\hline & 9.7 Incentivo financeiro & NÃO & NÃO & SIM & SIM & SIM & $\overline{\mathrm{SIM}}=3 ; \mathrm{NA \tilde {O }}=2$ \\
\hline & 9.7.1 Plano de carreira financeiramente atrativo & NÃO & $\mathrm{NA \tilde {O }}$ & SIM & SIM & SIM & $\mathrm{SIM}=3 ; \mathrm{NA \tilde {O }}=2$ \\
\hline & 9.7.2 Salários acima da média regional & NÃO & $\mathrm{NÃO}$ & SIM & SIM & SIM & $\mathrm{SIM}=3 ; \mathrm{NA \tilde {O } = 2}$ \\
\hline & 9.7.3 Progressão salarial & NÃO & SIM & SIM & SIM & SIM & $\mathrm{SIM}=4 ; \mathrm{NA \tilde {O }}=1$ \\
\hline 10. Funcionários & 10.1 Número de funcionários para cada 100 alunos & 6,83 & 9,39 & 19,59 & 8,16 & 9,74 & 10,7 \\
\hline
\end{tabular}

Quadro 16 - Contribuição de cada escola na composição da frequência de cada atividade que compõe o instrumento pedagógico das escolas ineficientes

Fonte: Elaborado pelo autor com base nos resultados dos estudos de caso 


\subsubsection{Análise comparativa dos resultados encontrados nas escolas eficientes e ineficientes}

Nesta subseção é apresentada a comparação dos resultados encontrados nos grupos das escolas eficientes e ineficientes, relacionados aos indicadores que compõe os instrumentos propostos, na forma de quadros e gráficos. Desta forma, é possível identificar a frequência e a existência ou inexistência (quando a atividade for binária) das atividades que caracterizam cada indicador que compõe os instrumentos deste estudo, agrupados em três categorias: administrativo aplicado ao Diretor, administrativo aplicado ao Secretário e pedagógico aplicado aos atores que envolvem a escola (Professores, alunos e pais de alunos). Concluir e generalizar os resultados que são apresentados nos Quadros 17, 19 e 21 não constituem os objetivos desta subseção, que os apresenta de forma a proporcionar discussões e comparações relacionadas aos estudos encontrados na literatura.

Como não há consenso na literatura em relação aos temas discutidos nesta dissertação, realizaram-se algumas discussões sobre os pontos que convergem ou divergem dos fatores identificados nos dois grupos de escolas.

A influência do fator no desempenho do aluno, no IDEB, aumenta à medida que há um incremento na diferença da frequência encontrada pela mesma atividade nas escolas eficientes e ineficientes. Por outro lado, quando esta diferença é pequena, a tendência é que a influência desta atividade no desempenho do aluno seja reduzida, uma vez que ela tem menor poder para explicar como as escolas com condições similares (investimento financeiro, NSE, infraestrutura, etc.), podem obter resultados diferentes no IDEB.

Segundo critério de julgamento, com base na experiência adquirida no estudo de caso nas dez escolas e cinco SMEs visitadas pelo pesquisador, foi definido o limite que torna a diferença entre os dois grupos de escola relevante, todavia, este limite não é conceitual, podendo ser questionado e redefinido por outro pesquisador que deseja refazer este estudo no mesmo ou em outro universo de escolas.

Dessa forma, para este grupo formado por cinco escolas eficientes e cinco ineficientes, os critérios para definir uma diferença expressiva, da influência da atividade no desempenho do 
aluno no IDEB, seguirão a seguinte regra: (1) quando a diferença das médias entre escolas eficientes e ineficiente for entre 0 e 1,99 não há diferença expressiva; (2) quando a diferença entre as médias for entre 2,0 e 3,99 a diferença é pouco expressiva e (3) quando a diferença entre as médias for igual ou superior a 4,0 a diferença é considerada expressiva. É importante não confundir este conceito com o nível de significância definida por Stevenson (2001).

Para as atividades medidas pelo indicador binário o critério para definição de uma prática com diferença expressiva seguirá a seguinte regra: (1) quando o modulo da diferença entre o número de respostas "sim" das escolas eficientes e ineficientes for entre 0 e 2 não há diferença expressiva; (2) quando o modulo da diferença entre o número de respostas "sim" for 3 a diferença é considerada pouco expressiva; e (3) quando o modulo da diferença entre o número de respostas “sim” for maior ou igual a 4 a diferença é considerada expressiva.

Além destas considerações, é importante destacar que as atividades com diferença pouco expressiva são destacadas em cor alaranjada e as diferenças expressivas são destacadas em cor amarela. Neste contexto, visando analisar cada um dos fatores, eles foram apresentados de forma individual e contínua, comparando sua frequência nos dois grupos de escolas (eficientes e ineficientes).

\subsection{Análise comparativa das práticas administrativas do Diretor entre as escolas eficientes e ineficientes}

No Quadro 17 é possível verificar a frequência das atividades que caracteriza cada indicador do instrumento administrativo aplicado aos Diretores nas escolas eficientes e ineficientes. Nos gráficos apresentados nesta seção foi analisada a frequência de todas as atividades encontradas nas escolas eficientes e ineficientes, que colabora na formação de cada indicador.

Os resultados foram analisados de forma comparativa, objetivando destacar as atividades com diferença expressiva de frequência entre as escolas eficientes e ineficientes. Além disto, os resultados dos estudos de caso foram comparados à literatura, destacando-se para cada atividade as principais convergências e divergências entre os resultados encontrados e a percepção dos autores. 


\begin{tabular}{|c|c|c|c|c|c|}
\hline Instrumento & Indicador & Descrição Atividade & \begin{tabular}{|c|}
$\begin{array}{c}\text { Média das Escolas } \\
\text { Eficientes }\end{array}$ \\
\end{tabular} & $\begin{array}{c}\text { Média das Escolas } \\
\text { Ineficientes }\end{array}$ & Diferença \\
\hline \multirow{26}{*}{ Diretor } & 1. Especificidades do município pequeno & 1.1. Cobrança da comunidade perante o Diretor & 8 & 3,6 & 4,4 \\
\hline & \multirow{4}{*}{ 2. Alimentação dos alunos } & 2.1. Duas ou mais refeições por período & $\mathrm{SIM}=4 ; \mathrm{NÃO}=1$ & $\mathrm{SIM}=2 ; \mathrm{N} \tilde{\mathrm{AO}}=3$ & 2 \\
\hline & & 2.2. Parcialmente Cultivadas pelos Alunos & 5,2 & 3,6 & 1,6 \\
\hline & & 2.3. Orientação Nutricional & $\mathrm{SIM}=5 ; \mathrm{NÃO}=0$ & $\mathrm{SIM}=5 ; \mathrm{NÃO}=0$ & 0 \\
\hline & & 2.4. Refeição farta, variada e balanceada & 8,8 & 8 & 0,8 \\
\hline & \multirow{3}{*}{ 3. Processo seletivo } & 3.1. Prova para Ingressar na Escola & $\mathrm{SIM}=0 ; \mathrm{NÃO}=5$ & SIM $=0 ; \mathrm{NÃO}=5$ & 0 \\
\hline & & 3.2. Não receber aluno por Transferência & $\mathrm{SIM}=1 ; \mathrm{NÃO}=4$ & SIM $=0 ; \mathrm{NÃO}=5$ & 1 \\
\hline & & 3.3. Transferência Compulsória em Caso de Reprovação & $\mathrm{SIM}=1 ; \mathrm{NÃO}=4$ & $\mathrm{SIM}=1 ; \mathrm{NÃO}=4$ & 0 \\
\hline & \multirow{8}{*}{ 4. Diretor } & 4.1. Formação (Curso Superior etc.) & $\mathrm{SIM}=5 ; \mathrm{NÃO}=0$ & $\mathrm{SIM}=5 ; \mathrm{NÃO}=0$ & 0 \\
\hline & & 4.2. Cursos Complementares (Gestão, Pedagogia etc.) & $\mathrm{SIM}=3 ; \mathrm{NÃO}=2$ & $\mathrm{SIM}=2 ; \mathrm{NÃO}=3$ & 1 \\
\hline & & 4.3. Autonomia para decisões & 5,6 & 4,8 & 0,8 \\
\hline & & 4.4. Escolha do Diretor & & & \\
\hline & & 4.4.1. Indicação política & $\mathrm{SIM}=4 ; \mathrm{NÃO}=1$ & $\mathrm{SIM}=4 ; \mathrm{NÃO}=1$ & 0 \\
\hline & & 4.4.2. Eleição pela comunidade escolar & $\mathrm{SIM}=0 ; \mathrm{NÃO}=5$ & $\mathrm{SIM}=0 ; \mathrm{NÃO}=5$ & 0 \\
\hline & & 4.4.3. Concurso Público & $\mathrm{SIM}=1 ; \mathrm{NA \tilde {O } = 4}$ & $\mathrm{SIM}=1 ; \mathrm{NÃO}=4$ & 0 \\
\hline & & 4.5. Salário Compatível com a função & 2,8 & 2,8 & 0,0 \\
\hline & \multirow{4}{*}{$\begin{array}{l}\text { 5. Capacidade do Diretor na captação de } \\
\text { recursos financeiros }\end{array}$} & 5.1. Projetos Federais e Estaduais & 3,6 & 3,2 & 0,4 \\
\hline & & 5.2. Parceria com Empresas & 3,6 & 2,4 & 1,2 \\
\hline & & 5.3. Rifas e Festividades & 6 & 3,6 & 2,4 \\
\hline & & 5.4. Recursos providos da APM & 4,4 & 2,4 & 2,0 \\
\hline & \multirow{6}{*}{$\begin{array}{l}\text { 6. Destinação do recurso financeiro } \\
\text { descentralizado e centralizado }\end{array}$} & 6.1. Programas de computador e softwares & & & \\
\hline & & 6.2. Equipamentos para a sala de informática & & & \\
\hline & & 6.3. Acervo para a biblioteca (livros, assinaturas, jornais) & & & \\
\hline & & 6.4. Reparos Emergenciais & & & \\
\hline & & 6.5. Materiais didáticos diversos & & & \\
\hline & & 6.6. Cursos, palestras, orientações didático-pedagógicas & & & \\
\hline
\end{tabular}

Quadro 17 - Comparação entre as escolas eficientes e ineficientes pelo indicador administrativo do Diretor

Fonte: Elaborado pelo autor com base nos resultados dos estudos de caso 
Com base no Quadro 17, a atividade 1.1 apresenta diferença expressiva $(4,4)$ quando se compara sua frequência nas escolas eficientes e ineficientes. O Gráfico 6 apresenta os dados da cobrança da comunidade perante o Diretor, apontando a pontuação das escolas eficientes e ineficientes. Com base no gráfico pondera-se que nas escolas eficientes a cobrança da comunidade, perante o Diretor, é maior, sugerindo que o desempenho é maior em comunidades mais participativas e com maior cobrança. Estas considerações estão em convergência com a pesquisa de MEC e UNICEF (2006), Leme, Peredes e Souza (2009) e dados publicados pela revista Veja (VEJA, 2013).

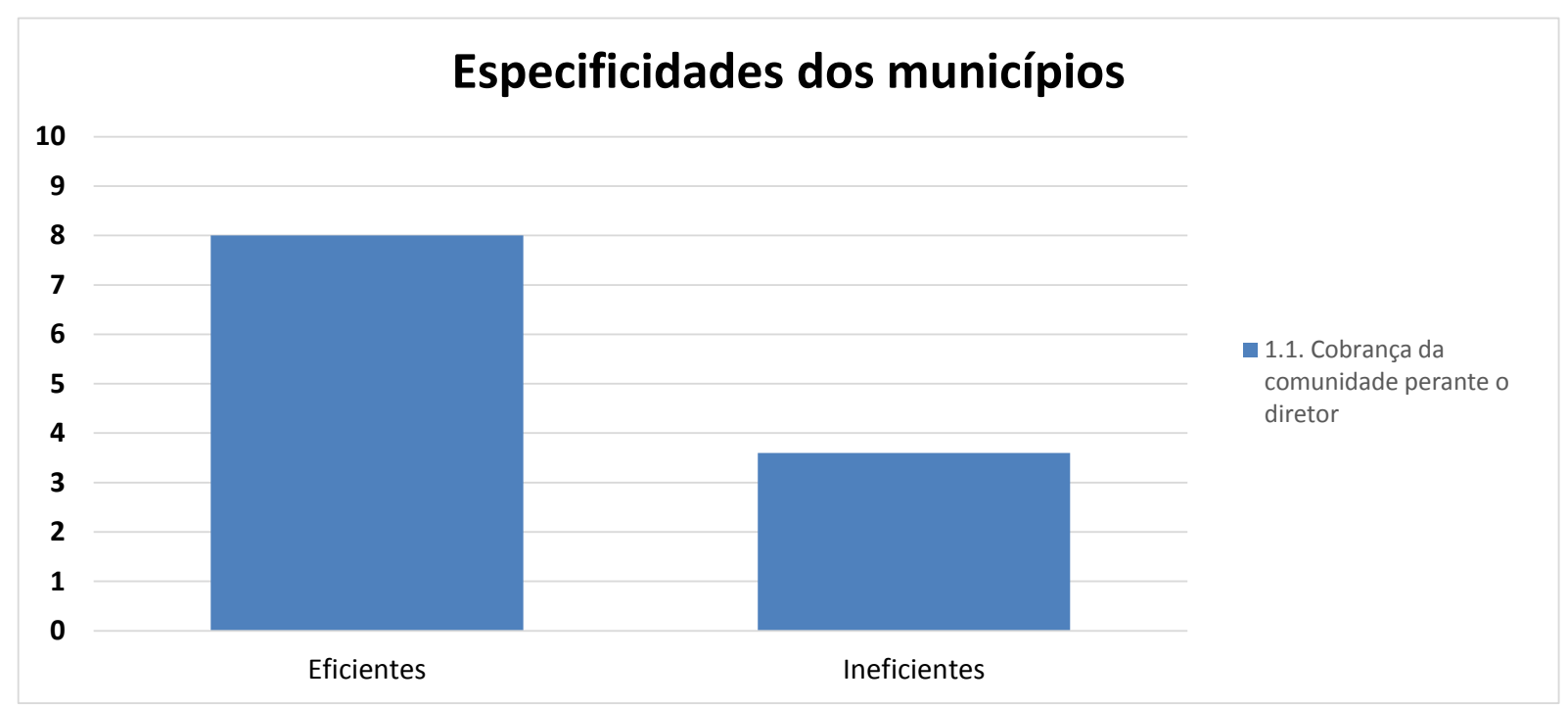

Gráfico 6 - Cobrança da comunidade perante o Diretor

Fonte: Elaborado pelo autor, com base nos resultados dos estudos de caso

O Gráfico 7 e o Gráfico 8 apresentam a frequência das escolas eficientes e ineficientes de cada atividade que compõe o indicador alimentação dos alunos. Ambas as atividades (2.1 e 2.3) as respostas são binárias ( da diferença de respostas positivas entre as escolas eficientes e as ineficientes.

No Gráfico 7, as atividades 2.1 e 2.3 não apresentam diferença expressiva quando são comparadas suas frequências nas escolas eficientes e ineficientes. Ademais, identificou-se na literatura estudos que corroboram e divergem dos resultados encontrados. Os resultados encontrados por Salgado Junior (2013) corroboram com o resultado encontrado na atividade 2.1, ou seja, não relaciona a quantidade de refeições com desempenho dos alunos, enquanto 
Freitas (2002), Zorzi (2003) e Danelon, Danelon e Silva (2006) e Salgado Junior (2013) divergem do resultado encontrado nesta dissertação quanto à orientação nutricional.

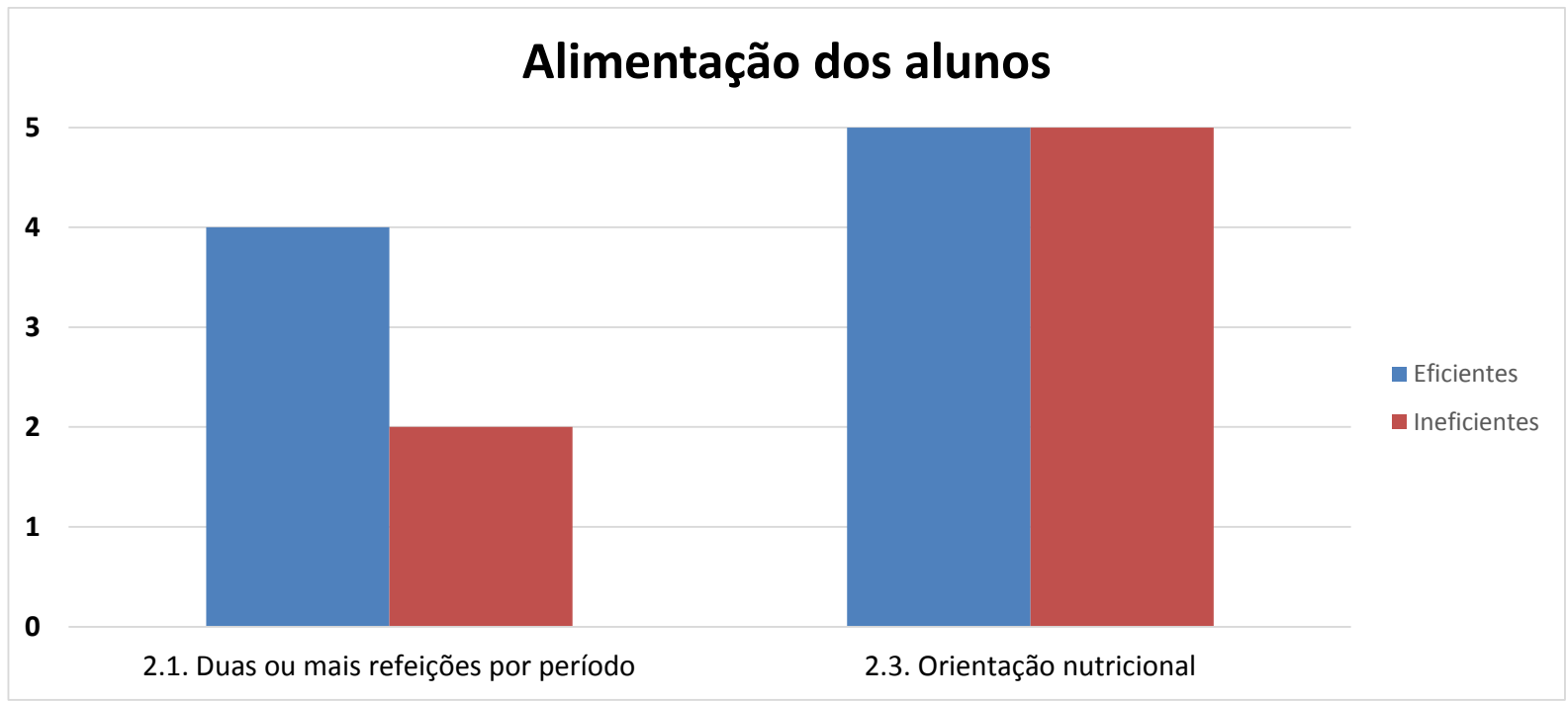

Gráfico 7 - Quantidade de refeições e orientação nutricional

Fonte: Elaborado pelo autor, com base nos resultados dos estudos de caso

Conforme se observa no Gráfico 8, as atividades 2.2 e 2.4 não apresentam diferença expressiva quando se compara sua frequência nas escolas eficientes e ineficientes. $\mathrm{Na}$ atividade 2.2, com uma diferença de 1,6 em relação às escolas ineficientes, a maior participação na prática de cultivo da alimentação por parte das escolas eficientes não implica em diferença no desempenho. Com relação à refeição, a diferença entre escolas eficientes e ineficientes é menor $(0,8)$, conforme indica a atividade 2.4 , sendo inconclusiva para identificar fatores que expliquem o desempenho das escolas. Freitas (2002), Zorzi (2003), Danelon, Danelon e Silva (2006) e Salgado Junior (2013) divergem do resultado encontrado sugerindo que a refeição farta, variada e balanceada influencia no desempenho dos alunos. 


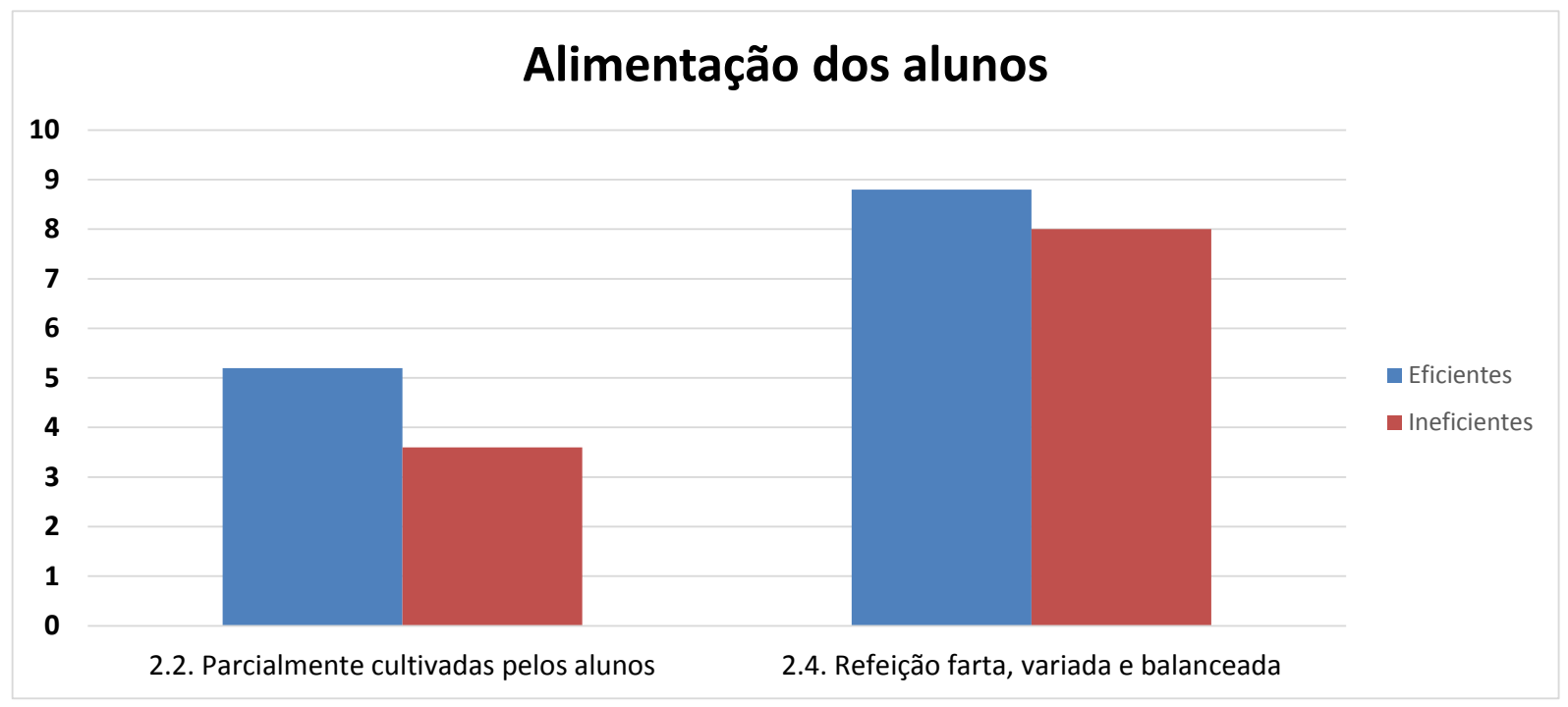

Gráfico 8 - Características da alimentação dos alunos

Fonte: Elaborado pelo autor, com base nos resultados dos estudos de caso

Com relação ao indicador de processo seletivo, a comparação entre as escolas eficientes e ineficientes é apresentada no Gráfico 9. Neste indicador todas as atividades são avaliadas por respostas binárias (sim e não). Em nenhuma das escolas analisadas há provas como forma de seleção de alunos. Assim, o resultado encontrado na atividade 3.1 sugere que a realização de prova para ingressar na escola não é relevante para influenciar o desempenho dos alunos. Esse resultado é corroborado por Menezes-Filho (2007), Perrone e Brandão (2009) e Salgado Junior (2013).

Conforme apresentado na atividade 3.2, em uma das escolas eficientes não é possível a transferência do aluno como forma de entrada. Também foi verificado que na atividade 3.2 não há diferença expressiva quando se compara sua frequência nas escolas eficientes e ineficientes sugerindo que esta atividade não tem capacidade explicativa no desempenho dos alunos, mesmo resultado encontrado em Salgado Junior (2013). Com relação à transferência compulsória em caso de reprovação não há diferença expressiva quando se compara sua frequência nas escolas eficientes e ineficientes conforme aponta a atividade 3.3. Esse resultado sugere que a transferência compulsória em caso de reprovação não influencia o desempenho dos alunos no IDEB, resultado corroborado por Salgado Junior (2013). 


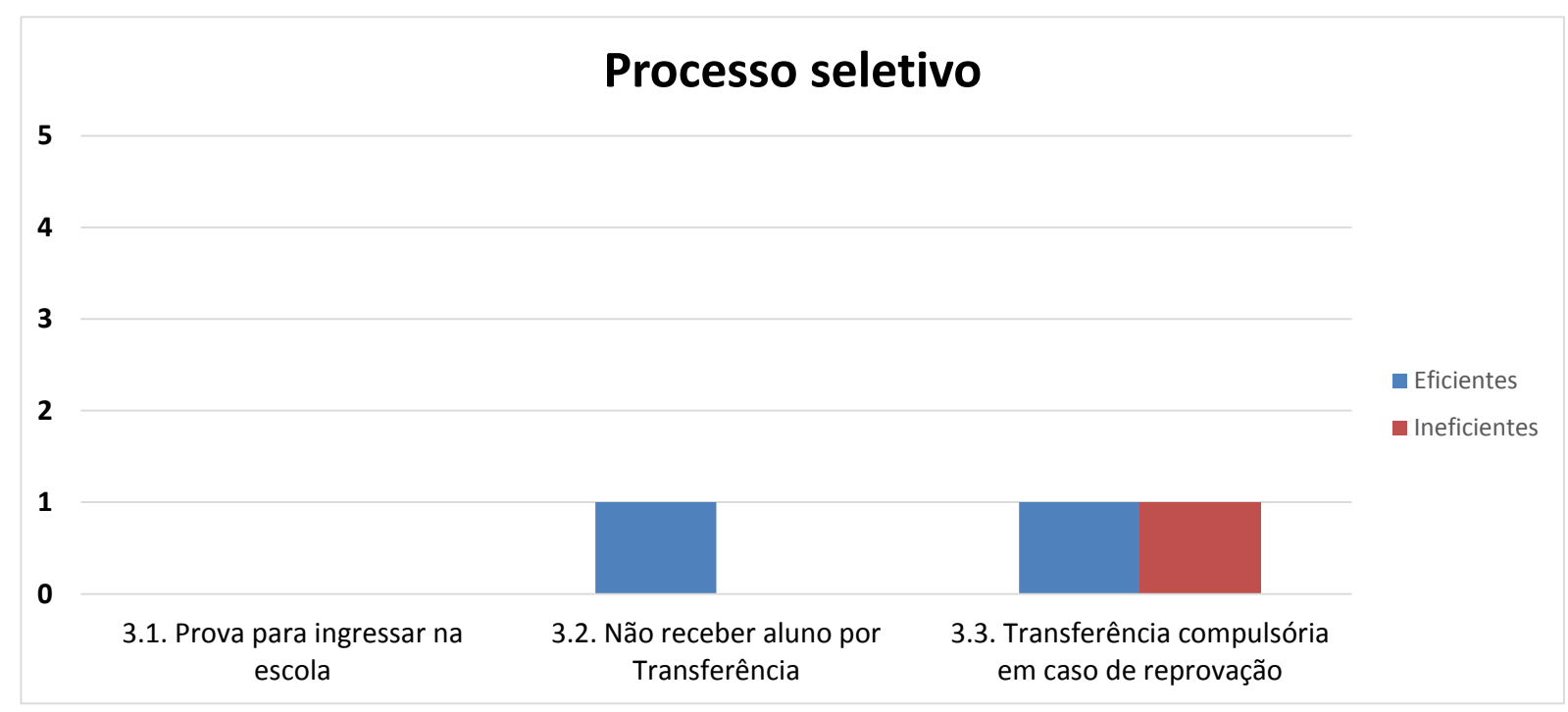

Gráfico 9 - Processo Seletivo

Fonte: Elaborado pelo autor, com base nos resultados dos estudos de caso

Os gráficos 10, 11, 12 e 13 apresentam a frequência das escolas eficientes e ineficientes de cada atividade que compõe o indicador Diretor.

No Gráfico 10 são apresentadas as atividades relacionadas à formação do Diretor (atividade 4.1) e cursos complementares (4.2). Em todas as escolas o Diretor possui curso de formação superior e, desta forma, não há diferença expressiva de frequência entre as escolas eficientes e ineficientes conforme apresenta a atividade 4.1. Assim, os resultados encontrados neste trabalho sugerem que a formação do Diretor não influencia no desempenho das escolas. Com relação à formação do Diretor, há na literatura trabalhos que divergem (LEVINE, 1996; MAYER, 1999) e que corroboram (SALGADO JUNIOR, 2013) com o resultado encontrado.

Ainda que o número de Diretores com cursos complementares nas escolas eficientes seja maior que nas ineficientes, não foi encontrada diferença expressiva (diferença de 1,0) na atividade 4.2 quando se compara sua frequência nas escolas eficientes e ineficientes. Isso sugere que, neste caso analisado, a formação complementar do Diretor não tem capacidade explicativa no desempenho das escolas. Esse resultado também foi encontrado por Salgado Junior (2013), porém identificou-se na literatura alguns estudos que divergem destes resultados (INEP, 2007; LÜCK, 2009; MEDEIROS et.al, 2011). 


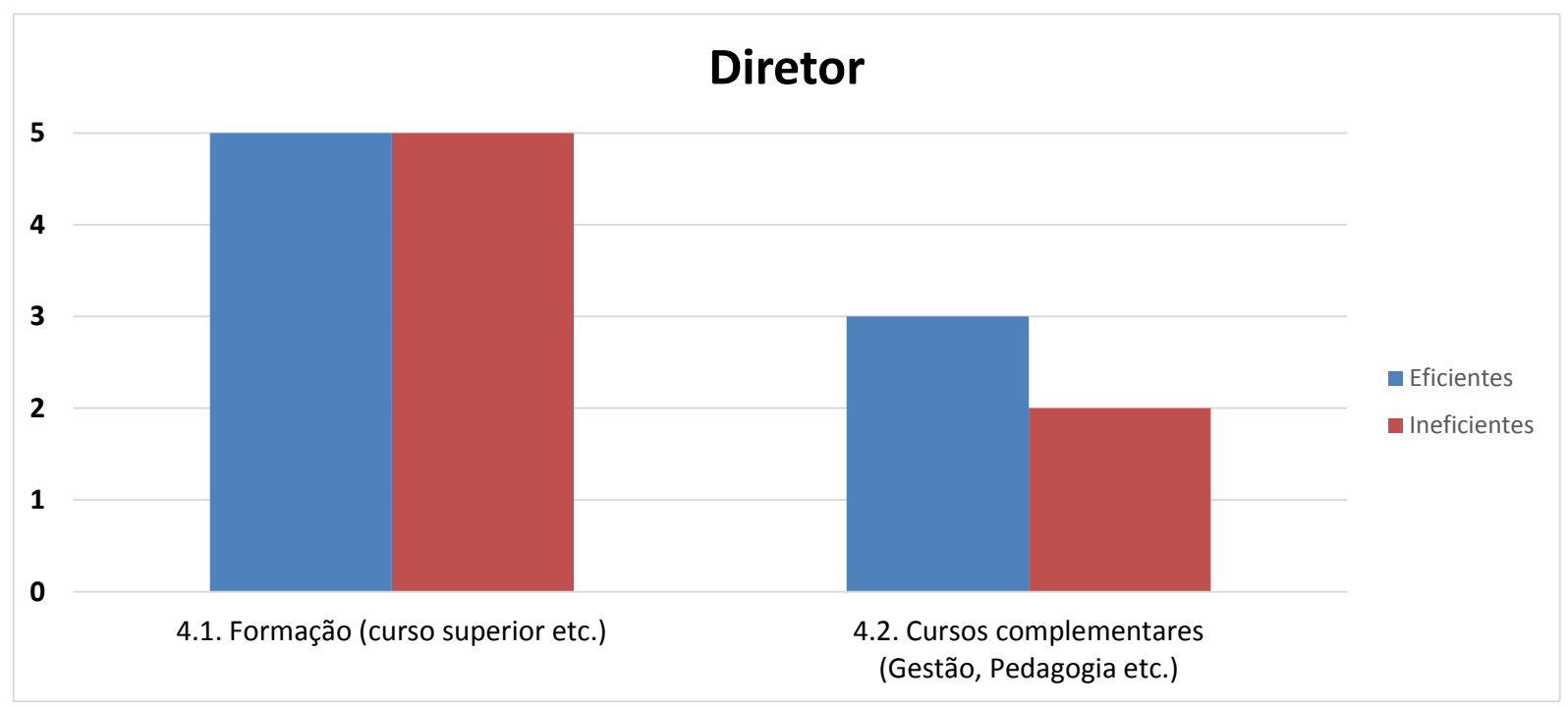

Gráfico 10 - Formação e cursos complementares do Diretor

Fonte: Elaborado pelo autor, com base nos resultados dos estudos de caso

O Gráfico 11 apresenta a questão da autonomia do Diretor para tomada de decisões dentro da escola, sem a necessidade de reportar-se com o SME. De acordo com o gráfico, na atividade 4.3 não foi encontrada diferença expressiva $(0,8)$ quando se compara sua frequência nas escolas eficientes e ineficientes. Esse resultado (sem diferença expressiva) era esperado uma vez que as escolas eficientes e ineficientes de cada município estão sob a gestão da mesma SME e por isso tem autonomia similar. Libâneo, Oliveira e Toschi (2003), Fundescola et al (2006) e Lück (2009) divergem dos resultados encontrados neste trabalho.

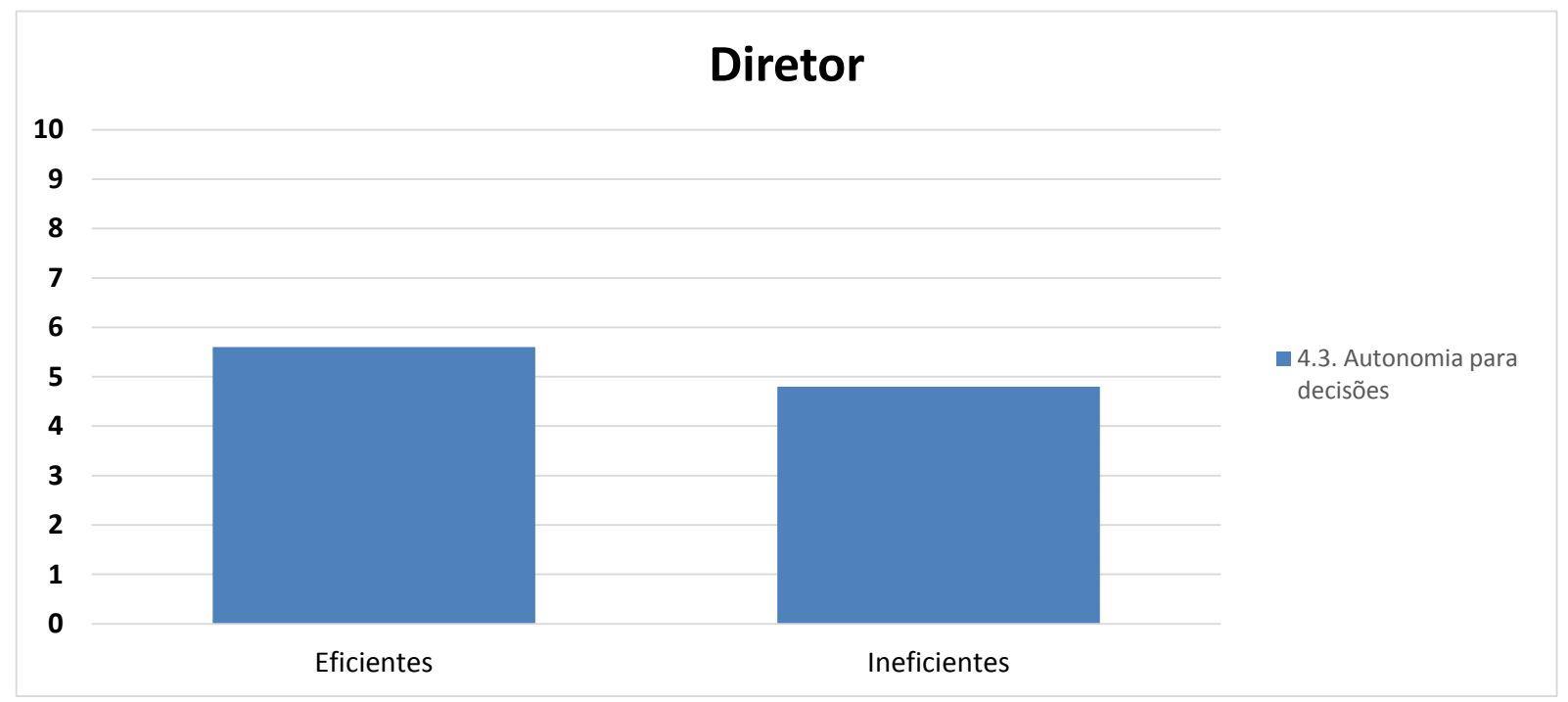

Gráfico 11 - Autonomia para decisões do Diretor

Fonte: Elaborado pelo autor, com base nos resultados dos estudos de caso 
A escolha do Diretor, apresentada no Gráfico 12, é descrita as atividades 4.4.1, 4.4.2 e 4.4.3. De acordo com os dados apontados na atividade 4.4.1, a maioria das escolas (4 escolas eficientes e 4 escolas ineficientes) escolhem o Diretor por indicação política. Não há escolha de Diretor por meio de eleição pela comunidade escolar (atividade 4.4.2) e apenas em Tuiuti, a escolha do Diretor é feita por meio de concurso público, conforme apontado na atividade 4.4.3. Assim, não há diferença expressiva na forma de escolha do Diretor quando se compara a frequência nas escolas eficientes e ineficientes sobre o desempenho dos alunos no IDEB.

Mendonça (2001), Menezes-Filho (2007), Lück (2009) e Salgado Junior (2013) corroboram com os resultados encontrados, sugerindo que a forma de escolha do Diretor não tem capacidade explicativa para justificar o desempenho dos alunos. Biondi e Felício (2007), no entanto, apontam que a forma de escolha dos Diretores tem efeito sobre o desempenho dos alunos. Considerando que neste trabalho são comparadas escolas (eficientes e ineficientes) geridas pelas mesmas SME, não é possível fazer a análise comparativa entre o desempenho de escolas por forma de escolha do Diretor, pois os resultados sempre foram os mesmos.

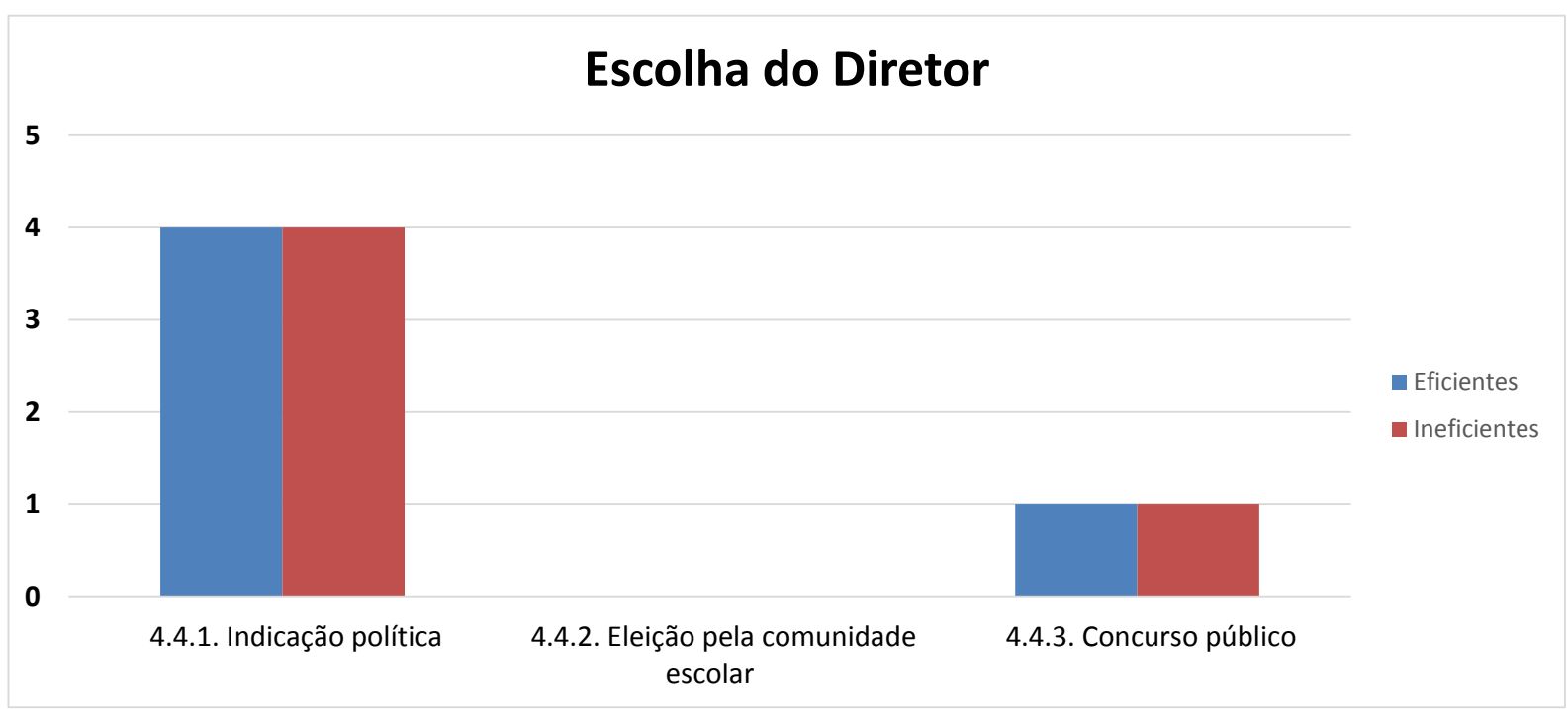

Gráfico 12 - Critérios para escolha do Diretor

Fonte: Elaborado pelo autor, com base nos resultados dos estudos de caso

Com relação à compatibilidade do salário do Diretor com sua função, apresentada no Gráfico 13 pela atividade 4.5 , tanto nas escolas eficientes quanto nas escolas ineficientes os Diretores acreditam que o salário não é totalmente compatível com a função. Desta forma, não há 
diferença expressiva quando comparada a frequência entre as escolas eficientes e ineficientes. Identificou-se na literatura estudos que corroboram com o resultado encontrado (CASTRO, 2009; SALGADO JUNIOR, 2013).

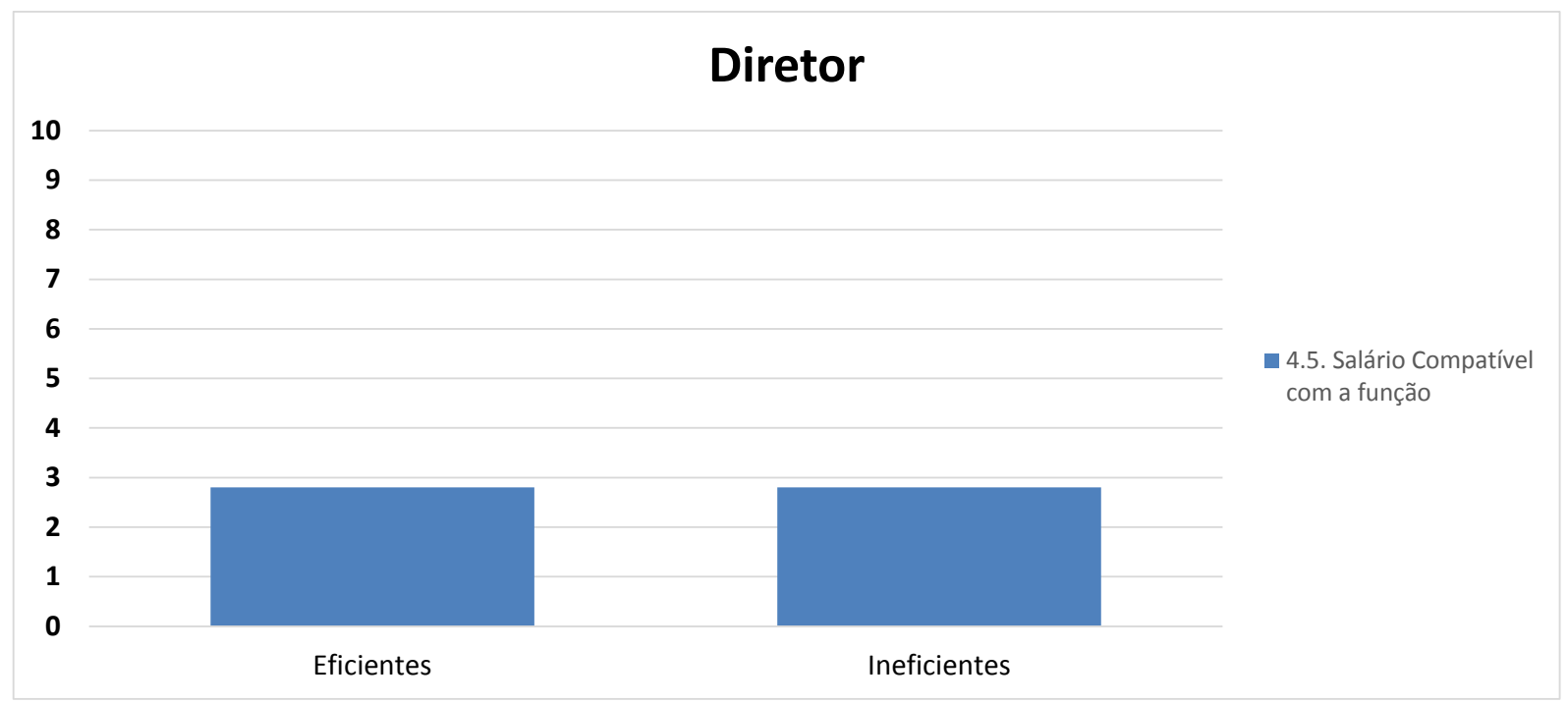

Gráfico 13 - Compatibilidade do salário com a função do Diretor

Fonte: Elaborado pelo autor, com base nos resultados dos estudos de caso

O Gráfico 14 apresenta a capacidade do Diretor na captação de recursos financeiros, baseado nas atividades 5.1, 5.2, 5.3 e 5.4. Com relação aos projetos federais e estaduais, apontados na atividade 5.1, não há diferença expressiva $(0,4)$ entre a frequência encontrada nas escolas eficientes e ineficientes. A baixa pontuação em ambas as escolas sugere que os Diretores das escolas municipais não têm muito poder de captação de recursos de projetos federais e estaduais (o que era esperado uma vez que são esferas diferentes de governo) e que a pequena diferença entre as escolas eficientes e ineficientes faz com que essa atividade não seja explicativa no desempenho. Na literatura foram encontrados estudos que divergem do resultado encontrado (MEC; UNICEF, 2006; FRANCO, 2008; INEP, 2011) e outro que corrobora com o resultado encontrado (SALGADO JUNIOR, 2013).

Também apontada no Gráfico 14, a atividade 5.2 refere-se à capacidade do Diretor na captação de recursos por meio de parceria com empresas. Apesar dos dados apontarem maior frequência de parceria com empresas nas escolas eficientes, não há diferença expressiva $(1,2)$ quando se compara sua frequência com as escolas ineficientes. Isso sugere que, nas escolas analisadas neste trabalho, a captação de recursos por meio de parcerias com empresas não 
influencia no desempenho dos alunos no IDEB. Esse resultado foi corroborado por Salgado Junior (2013) e contestado por MEC e UNICEF (2006; 2008).

A capacidade do Diretor na captação de recursos financeiros apresentou diferença pouco expressiva na atividade relacionada à festividade e rifas (atividade 5.3) e na atividade relacionada aos recursos da APM (atividade 5.4). De acordo com o Gráfico 14, a atividade 5.3 apresenta diferença pouco expressiva $(2,4)$ quando se compara sua frequência nas escolas eficientes e ineficientes assim como a atividade 5.4, que apresentou diferença similar $(2,0)$. Os resultados encontrados sugerem que a captação de recursos financeiros em atividades relacionadas à festividade e rifas tem capacidade explicativa no desempenho dos alunos. Esse resultado é corroborado por Zaikievicz e Schneckenberg (2011) e Salgado Junior (2013). Quanto à captação de recursos financeiros relacionados à APM, os resultados indicam que estes recursos também podem influenciar positivamente o desempenho dos alunos no IDEB. $\mathrm{Na}$ literatura, esse resultado é apoiado por MEC e UNICEF (2006), Zaikievicz e Schneckenberg (2011) e Salgado Junior (2013).

Rocha (2006), no entanto, diverge dos resultados encontrados em relação à captação de recursos junto à festividade, rifas e APM sugerindo que a captação destes recursos não influencia o desempenho dos alunos.

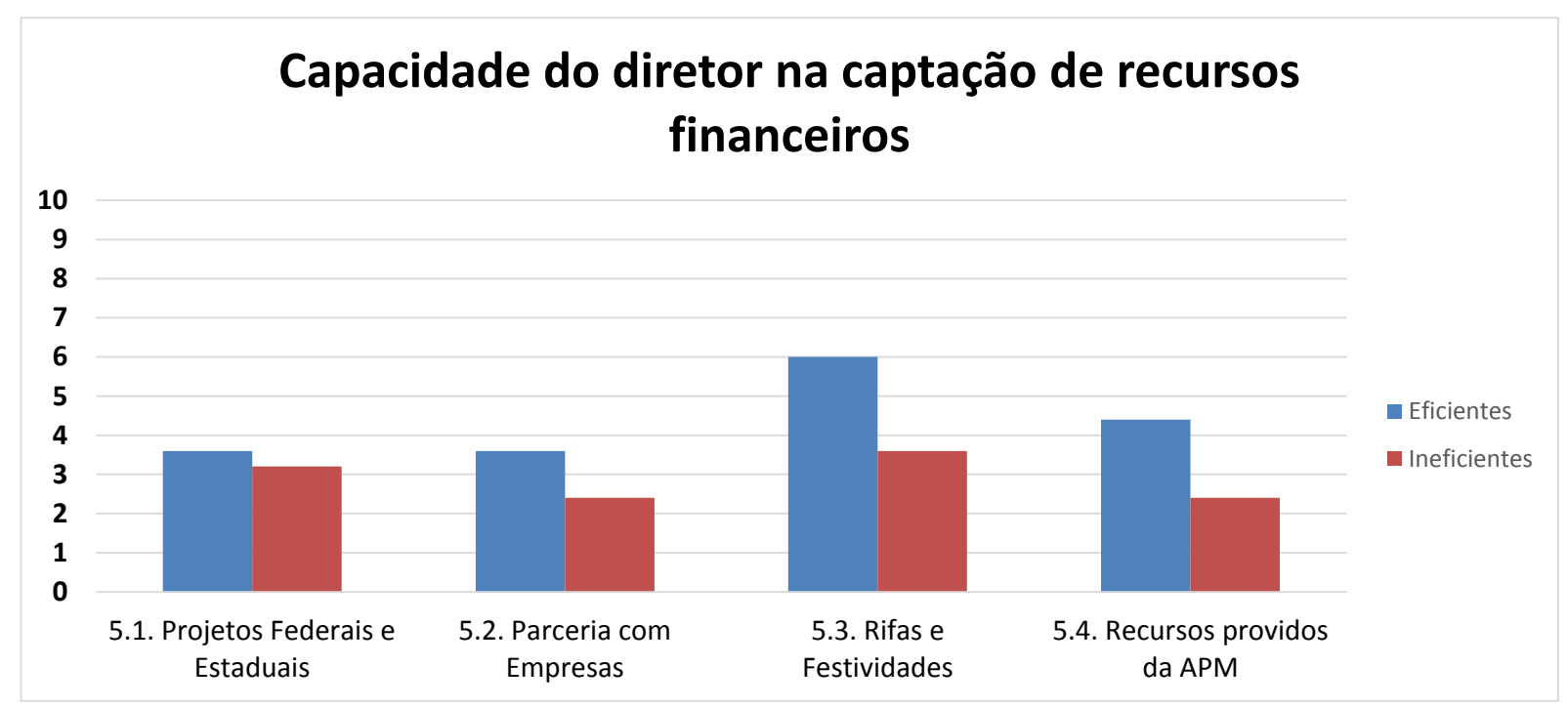

Gráfico 14 - Capacidade do Diretor na captação de recursos financeiros

Fonte: Elaborado pelo autor, com base nos resultados dos estudos de caso 
Não foi possível realizar a análise comparativa das práticas relacionadas ao indicador 6 (Destinação do Recurso Financeiro Descentralizado e Centralizado) pois a destinação dos recursos financeiros centralizados e descentralizados não são monitorados ou medidos quantitativamente para que fosse possível efetuar a comparação das diferenças entre as escolas eficientes e ineficientes.

O Quadro 18 apresenta a relação de autores que corroboram ou divergem dos resultados encontrados nesta dissertação, referente a cada uma das atividades que compõe os indicadores do instrumento administrativo do Diretor. 


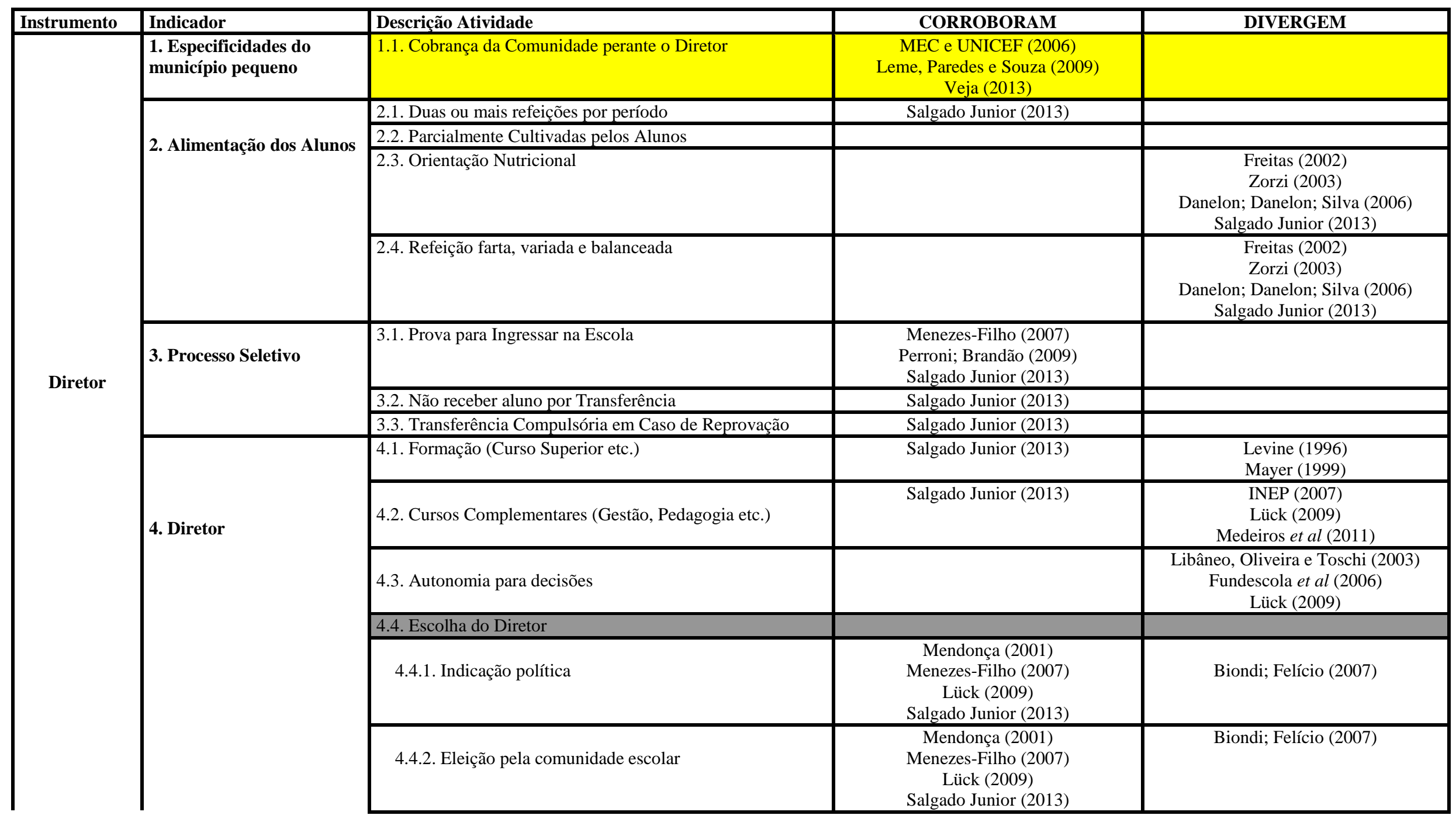




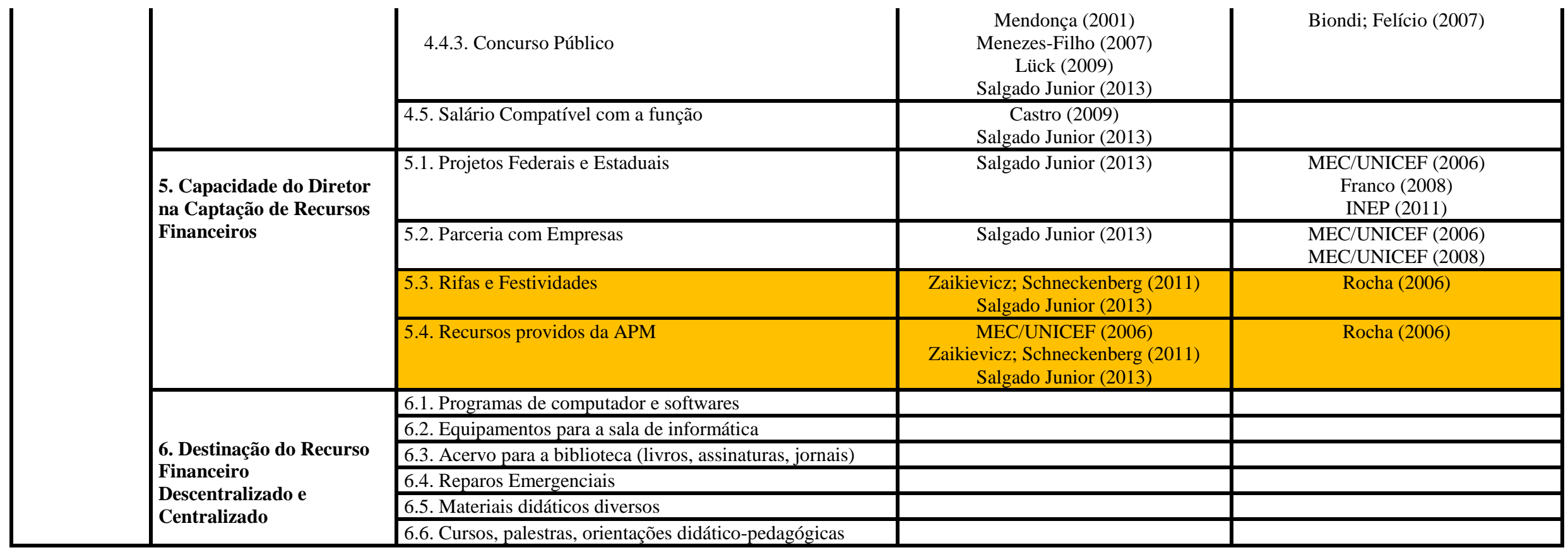

Quadro 18 - Autores que corroboram ou divergem dos resultados encontrados no estudo de caso em relação às práticas administrativas do Diretor

Fonte: Elaborado pelo autor 


\subsection{Análise comparativa das Práticas Pedagógicas entre as Escolas Eficientes e Ineficientes}

No Quadro 19 é possível verificar a frequência das atividades que caracteriza cada indicador do instrumento pedagógico aplicado aos atores que envolvem a escola (Professores, alunos e pais de alunos) nas escolas eficientes e ineficientes. Nos gráficos apresentados nesta seção será analisada a frequência de todas as atividades encontradas nas escolas eficientes e ineficientes, que colabora na formação de cada indicador.

Os resultados foram analisados de forma comparativa, objetivando destacar as atividades com diferença expressiva de frequência entre as escolas eficientes e ineficientes. Além disto, os resultados dos estudos de caso foram comparados à literatura, destacando-se para cada atividade as principais convergências e divergências entre os resultados encontrados e a percepção dos autores. 


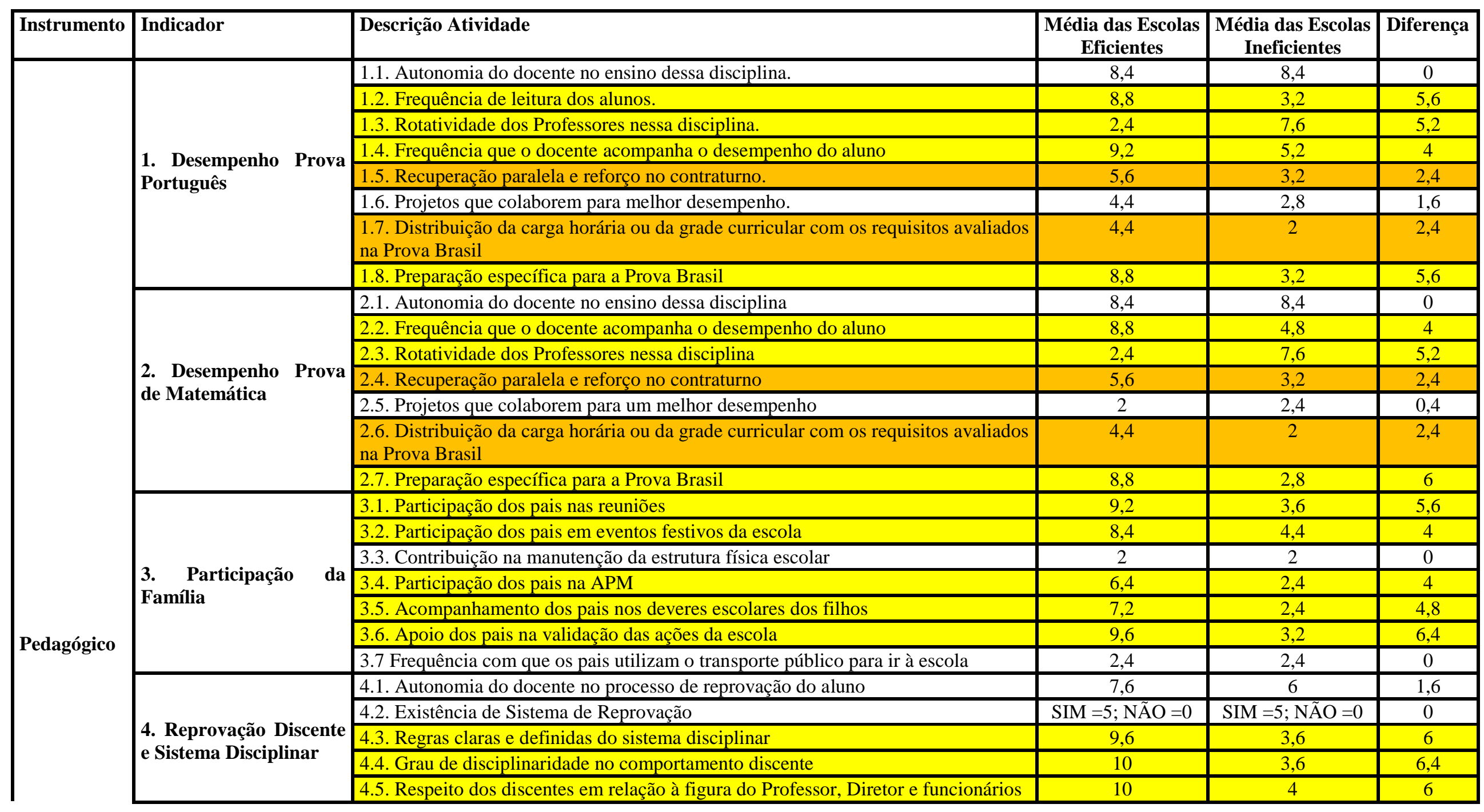




\begin{tabular}{|c|c|c|c|c|}
\hline \multirow{3}{*}{$\begin{array}{l}\text { 5. Laboratório de } \\
\text { Informática }\end{array}$} & 5.1 Existência de laboratório de informática na escola & $\mathrm{SIM}=2 ; \mathrm{NA} O \mathrm{O}=3$ & $\mathrm{SIM}=2 ; \mathrm{NÃO}=3$ & 0 \\
\hline & 5.2 Frequência das aulas de informática & 2 & 2 & 0 \\
\hline & 5.3 Número de computadores para cada 100 alunos & 3,384 & 4,124 & 0,74 \\
\hline \multirow[t]{2}{*}{ 6. Biblioteca } & 6.1 Tamanho do acervo da biblioteca & 8 & 6 & 2 \\
\hline & 6.2 Variedade do acervo da biblioteca & 7,2 & 6,4 & 0,8 \\
\hline \multirow[b]{2}{*}{ 7. Sala de Leitura } & 7.1 Existência de sala de leitura na escola & $\mathrm{SIM}=1 ; \mathrm{NÃO}=4$ & $\mathrm{SIM}=2 ; \mathrm{NÃO}=3$ & 1 \\
\hline & 7.2 Utilização da sala de leitura & 3,6 & 2,8 & 0,8 \\
\hline \multirow[t]{2}{*}{ 8. Transporte } & 8.1 Frequência com que os alunos utilizam o transporte público para ir à escola & 6 & 5,6 & $\overline{0,4}$ \\
\hline & 8.2 Número de matrículas & 466,6 & 476,8 & 10,2 \\
\hline \multirow{10}{*}{ 9. Docentes } & 9.1 Porcentagem de docentes pertencentes ao gênero feminino & 79,29 & 73,71 & 5,58 \\
\hline & 9.2 Porcentagem dos docentes tem o magistério concluído & 2,364 & 1,852 & 0,512 \\
\hline & 9.3 Porcentagem dos docentes que tem o curso de licenciatura concluído & 74,206 & 71,368 & 2,838 \\
\hline & 9.4 Porcentagem dos docentes que tem ensino superior concluído & 97,506 & 98,01 & 0,504 \\
\hline & 9.5 Porcentagem dos docentes que tem especialização concluída & 38,518 & 36,328 & 2,19 \\
\hline & 9.6 Número docentes para cada 100 alunos. & 7,5 & 7,2 & 0,3 \\
\hline & 9.7 Incentivo financeiro & $\mathrm{SIM}=3 ; \mathrm{NA \tilde {O }}=2$ & $\mathrm{SIM}=3 ; \mathrm{NÃO}=2$ & 0 \\
\hline & 9.7.1 Plano de carreira financeiramente atrativo & $\mathrm{SIM}=3 ; \mathrm{NA} \mathrm{O}=2$ & $\mathrm{SIM}=3 ; \mathrm{NÃO}=2$ & 0 \\
\hline & 9.7.2 Salários acima da média regional & $\mathrm{SIM}=3 ; \mathrm{NA \tilde {O } = 2}$ & $\mathrm{SIM}=3 ; \mathrm{N} \tilde{\mathrm{A} O}=2$ & 0 \\
\hline & 9.7.3 Progressão salarial & $\mathrm{SIM}=4 ; \mathrm{NÃO}=1$ & $\mathrm{SIM}=4 ; \mathrm{NÃO}=1$ & 0 \\
\hline 10. Funcionários & 10.1 Número de funcionários para cada 100 alunos & 9,836 & 10,742 & 0,906 \\
\hline
\end{tabular}

Quadro 19 - Comparação entre as escolas eficientes e ineficientes pelos indicadores pedagógicos

Fonte: Elaborado pelo autor com base nos resultados dos estudos de caso 
O Gráfico 15 e o Gráfico 16 apresentam a frequência das escolas eficientes e ineficientes de cada atividade que compõe o indicador desempenho prova de português por meio das atividades 1.1 a 1.8 .

De acordo com o Gráfico 15, não há diferença expressiva $(0,0)$ quando se compara sua frequência nas escolas eficientes e ineficientes relacionada à atividade 1.1. No caso desta atividade tanto nas escolas eficientes quanto nas ineficientes os Professores têm a mesma autonomia em sala de aula indicando que a autonomia não é explicativa no desempenho dos alunos. Os resultados encontrados por Setúbal (2010), no entanto, divergem do resultado encontrado nesta pesquisa.

A frequência de leitura dos alunos (atividade 1.2) mostrou-se relevante na análise. A atividade 1.2 apresenta diferença expressiva $(5,6)$ quando se compara sua frequência nas escolas eficientes e ineficientes, sugerindo que a frequência de leitura dos alunos pode influenciar o desempenho. Esta observação é corroborada por outros autores (BORUCHOVITCH, 2001; SOARES, 2004; MEC; UNICEF, 2006; OLIVEIRA; BORUCHOVITCH; SANTOS, 2008; DELMANTO, 2009; CURY, 2010; FARIAS, 2010; SOUZA; SOUZA; BONFIM, 2010; ZOGHBI; LOUZANO, 2012; SALGADO JUNIOR, 2013) que também relacionam a leitura ao desempenho dos alunos.

Um fator importante no desempenho dos alunos na prova de português foi a rotatividade dos Professores na disciplina, avaliado na atividade 1.3. A rotatividade nas escolas eficientes é menor que nas escolas ineficientes. Conforme apresentado no Gráfico 15, a atividade 1.3 apresenta diferença expressiva $(5,2)$ quando se compara sua frequência nas escolas eficientes e ineficientes. Os estudos de GAME (2002), Alves e Soares (2007), Biondi e Felício (2007), Vegas (2008) e Salgado Junior (2013) também corroboram com os resultados encontrados, sugerindo que a menor rotatividade do Professor pode indicar melhor desempenho para os alunos.

Outro ponto em destaque observado nesse mesmo gráfico é com relação à frequência com que o docente acompanha o desempenho do aluno (atividade 1.4). Também foi encontrada diferença expressiva $(4,0)$ nesta atividade quando comparadas as frequências nas escolas eficientes e ineficientes. Esse resultado é corroborado por Boruchovitch (2001), Oliveira; 
Boruchovitch e Santos (2008), MEC e UNICEF (2008), MEC e BID (2010), Setúbal (2010) e UNICEF (2010), sugerindo que o acompanhamento do docente tende a impactar positivamente o desempenho do aluno. Na literatura, contudo, foi encontrado um estudo (SALGADO JUNIOR, 2013) que diverge do resultado desta dissertação.

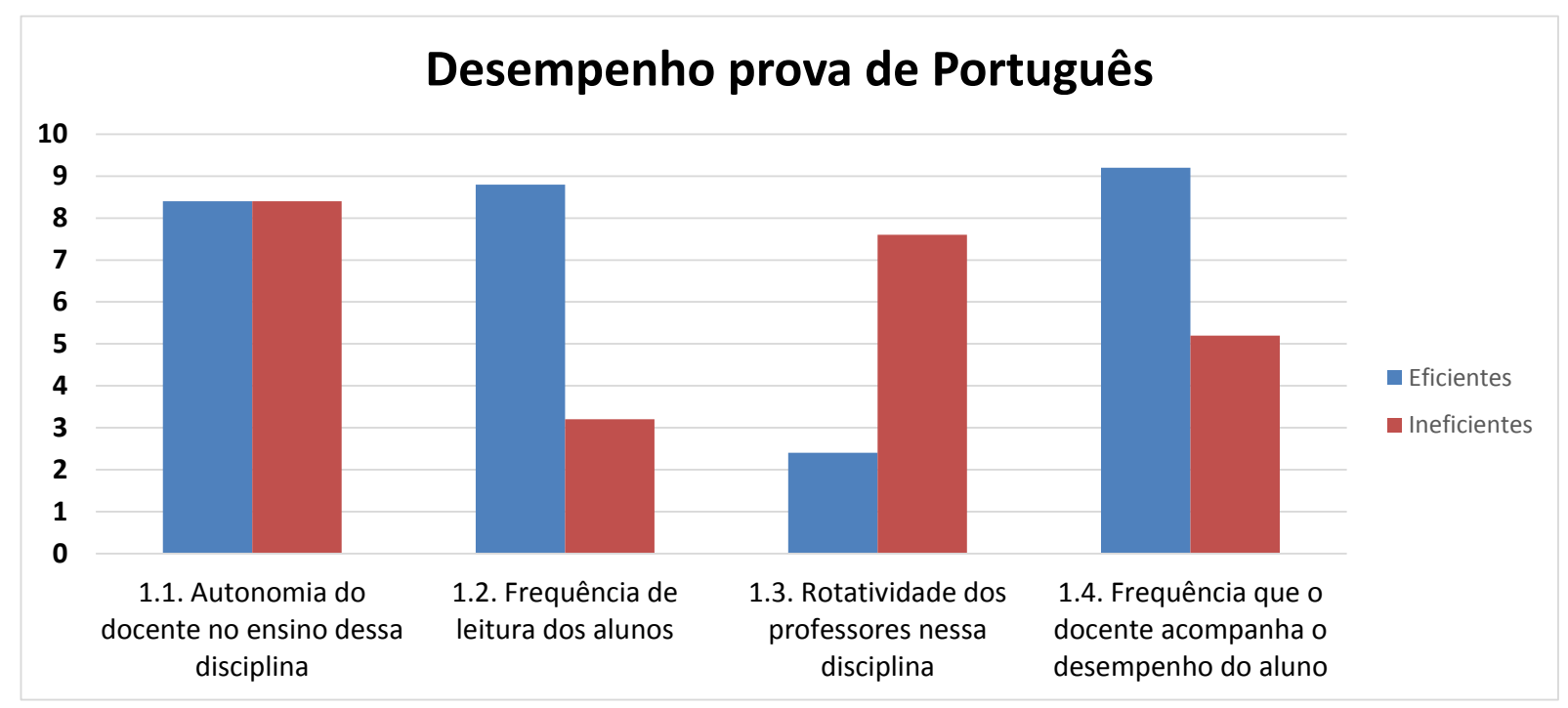

Gráfico 15 - Desempenho prova de português

Fonte: Elaborado pelo autor, com base nos resultados dos estudos de caso

No Gráfico 16 são apresentadas outras atividades comparando escolas eficientes e ineficientes. Com relação à recuperação paralela e aulas de reforço no contraturno, descritos pela atividade 1.5 , notou-se que há diferença pouco expressiva $(2,4)$ quando se compara sua frequência nas escolas eficientes e ineficientes. Vários autores identificam esta atividade como importante para melhoria no desempenho. Na literatura foram encontrados os trabalhos de MEC e UNICEF (2006), MEC e UNICEF (2008), Azevedo (2008), MEC e BID (2010), Setúbal (2010), UNICEF (2010), Palma Filho; Alves e Duran (2012) e Salgado Junior (2013) que corroboram os resultados encontrados nesta dissertação em relação a esta atividade.

A atividade 1.6, apresentada no mesmo gráfico, destaca a comparação entre as escolas em relação aos projetos que podem colaborar para melhorar o desempenho dos alunos. Não foi encontrada diferença expressiva $(1,6)$ quando se compara sua frequência nas escolas eficientes e ineficientes, sugerindo que esta atividade não é explicativa na determinação do desempenho dos alunos. Foram identificados na literatura estudos que divergem do resultado encontrado neste trabalho, sugerindo que a realização de projetos pode influenciar o 
desempenho dos alunos (MEC; UNICEF, 2006; SANTOS, 2008; DELMANTO, 2009; PINTO, 2013; SALGADO JUNIOR, 2013).

A distribuição da carga horária ou da grade curricular com os requisitos avaliados na Prova Brasil (atividade 1.7) apresentou diferença pouco expressiva $(2,4)$ quando comparada a frequência nas escolas eficientes e ineficientes. Ademais, identificou-se na literatura estudos que corroboram com o resultado encontrado sugerindo que a adequação da grade curricular ou da carga horária pode influenciar positivamente o desempenho na Prova Brasil (UNICEF, 2010; LEME et al, 2012; CENPEC, 2013).

A preparação específica para Prova Brasil, destacada pela atividade 1.8 no Gráfico 16, mostrou-se relevante e apresentou diferença expressiva $(5,6)$ quando comparada a frequência nas escolas eficientes e ineficientes. Ainda que esperado, esse resultado sugere que a preparação específica para a Prova Brasil tem relação direta com o desempenho dos alunos na avaliação. Esta atividade apresentou uma das maiores diferenças de frequência quando comparadas as escolas eficientes e ineficientes, fazendo com que a preparação específica para a prova Brasil tenha grande capacidade explicativa no desempenho dos alunos. Esse resultado é corroborado por vários autores, dentre eles UNICEF (2010), Oliveira (2011), CENPEC (2013) e Salgado Junior (2013).

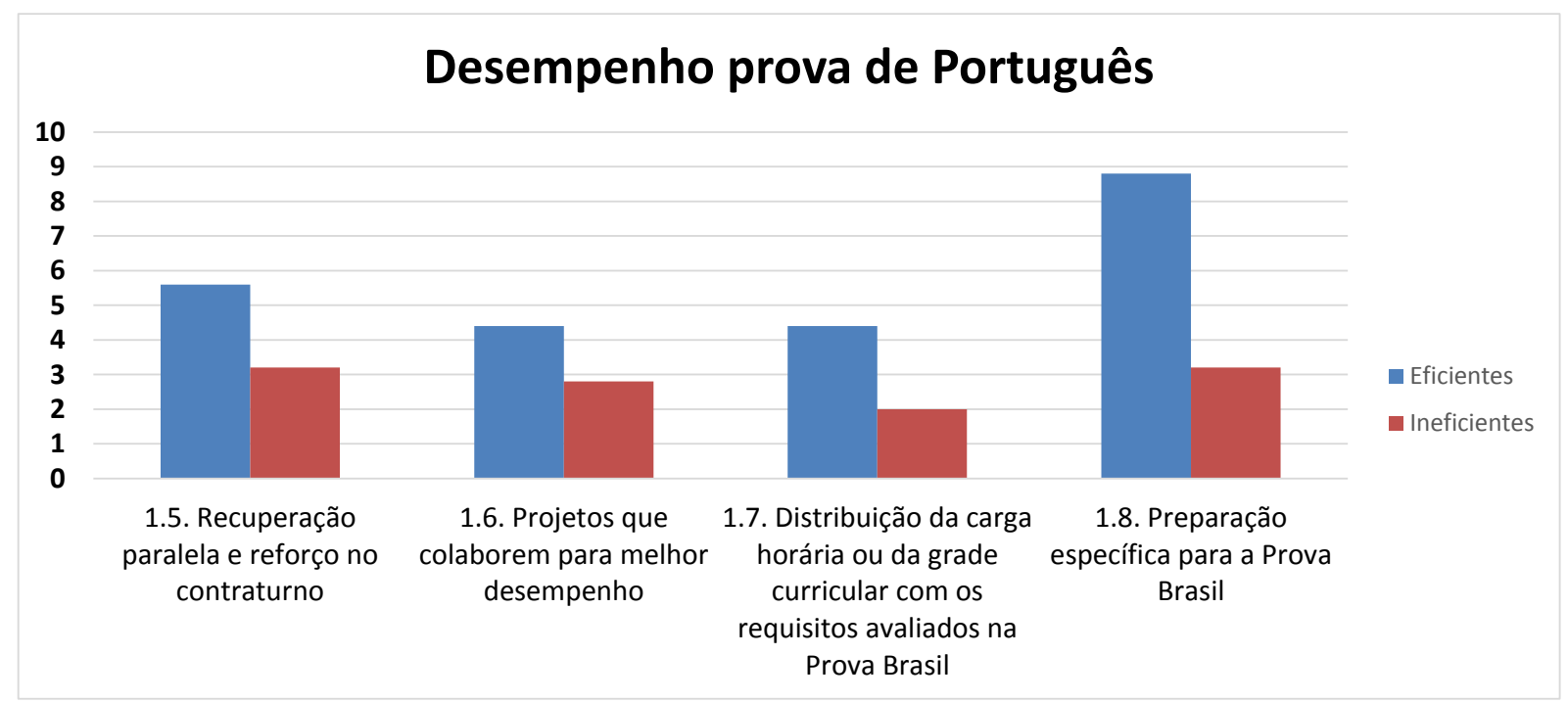

Gráfico 16 - Desempenho prova de português (outros)

Fonte: Elaborado pelo autor, com base nos resultados dos estudos de caso 
O Gráfico 17 e o Gráfico 18 apresentam a frequência das escolas eficientes e ineficientes de cada atividade que compõe o indicador desempenho prova de matemática por meio das atividades 2.1 a 2.8 .

De acordo com o Gráfico 17, a atividade 2.1 não apresenta diferença expressiva $(0,0)$ quando comparada a frequência nas escolas eficientes e ineficientes. Isso sugere que a autonomia do docente não é um fator explicativo no desempenho dos alunos. O resultado encontrado nesta pesquisa diverge da pesquisa de Setúbal (2010), que aponta a autonomia do docente como fator importante no desempenho.

Ainda no Gráfico 17, com diferença de 4,0 quando comparadas as escolas eficientes e ineficientes, a atividade 2.2 apresenta diferença expressiva em sua frequência. Esse resultado sugere que a frequência que o docente acompanha o aluno tem capacidade explicativa no desempenho dos alunos. Na literatura, Boruchovitch (2001), Oliveira; Boruchovitch e Santos (2008), MEC e UNICEF (2008), MEC e BID (2010), UNICEF (2010) e Setúbal (2010) corroboram com estes resultados. Os achados de Salgado Junior (2013), no entanto, divergem do resultado encontrado sugerindo que o acompanhamento frequente do docente não é relevante para o desempenho dos alunos.

Nesse mesmo gráfico, a rotatividade dos Professores, destacada pela atividade 2.3, também apresenta diferença expressiva na frequência de escolas eficientes e ineficientes sugerindo que a rotatividade do Professor (e os problemas derivados disto) também é um fator que influencia no desempenho dos estudantes, sendo que quanto menor for à rotatividade, melhor tende a ser o desempenho destes alunos. O trabalho de GAME (2002), Alves e Soares (2007), Biondi e Felício (2007), Vegas (2008) e de Salgado Junior (2013) corroboram com este resultado.

Por fim, com relação ao desempenho na prova de Matemática, apresentada no Gráfico 17, a atividade 2.4 apresenta diferença pouco expressiva quando se compara sua frequência nas escolas eficientes e ineficientes, indicando que a recuperação paralela e reforço no contraturno são atividades que influenciam o desempenho, porém com baixo capacidade explicativa na performance dos alunos. Neste sentido outros estudos também apontam a importância da recuperação paralela e do reforço no contraturno como fatores de melhoria no desempenho 
(MEC; UNICEF, 2006; AZEVEDO, 2008; MEC; UNICEF, 2008, MEC; BID, 2010; SETÚBAL, 2010; UNICEF, 2010; PALMA FILHO; ALVES; DURAN, 2012).

\section{Desempenho prova de Matemática}

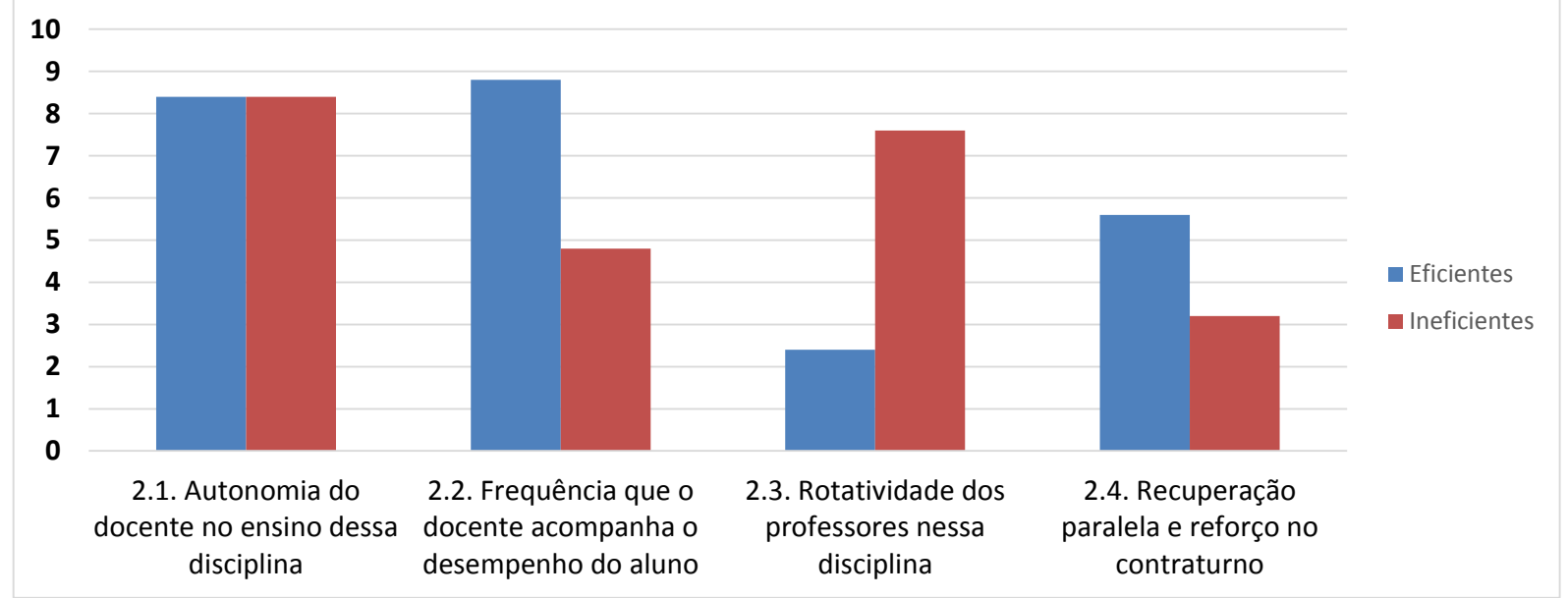

Gráfico 17 - Desempenho na prova de matemática

Fonte: Elaborado pelo autor, com base nos resultados dos estudos de caso

No Gráfico 18 são apresentadas as atividades 2.5, 2.6 e 2.7, também relacionadas ao desempenho na prova de Matemática. A atividade 2.5 não apresenta diferença expressiva quando se compara sua frequência nas escolas eficientes e ineficientes, sugerindo que projetos que colaborem para melhorar o desempenho não têm poder de explicação na diferença de desempenho. Os trabalhos de Zoghi e Louzano (2012) e Salgado Junior (2013) encontraram os mesmos resultados desta dissertação, contudo, para o MEC (2006), UNICEF (2006) e Veloso (2011), acreditam que projetos que colaborem para melhorar o desempenho podem influenciar a performance dos alunos.

A atividade 2.6 apresenta diferença pouco expressiva (diferença de 2,4) quando comparada a frequência nas escolas eficientes e ineficientes. Esse resultado sugere que a distribuição da carga horária ou grade curricular com os requisitos avaliados na Prova Brasil podem influenciar o desempenho, mas não tem forte poder explicativo para justificar a diferença no desempenho. Na literatura, as considerações da UNICEF (2010), Leme et al (2012) e CENPEC (2013) destacam a importância dos ajustes de distribuição da carga horária ou da grade curricular como forma de melhorar o desempenho e atingir melhores resultados. 
Nesse mesmo Gráfico 18, com diferença expressiva $(6,0)$ na comparação de frequência entre as escolas eficientes, a atividade 2.7 sugere que a preparação específica para a Prova Brasil é um forte fator explicativo na diferença do desempenho dos estudantes. Vários autores também destacam a preparação específica como forma de melhorar o desempenho, dentre eles o estudo da UNICEF (2010), Oliveira (2011), CENPEC (2013) e Salgado Junior (2013).

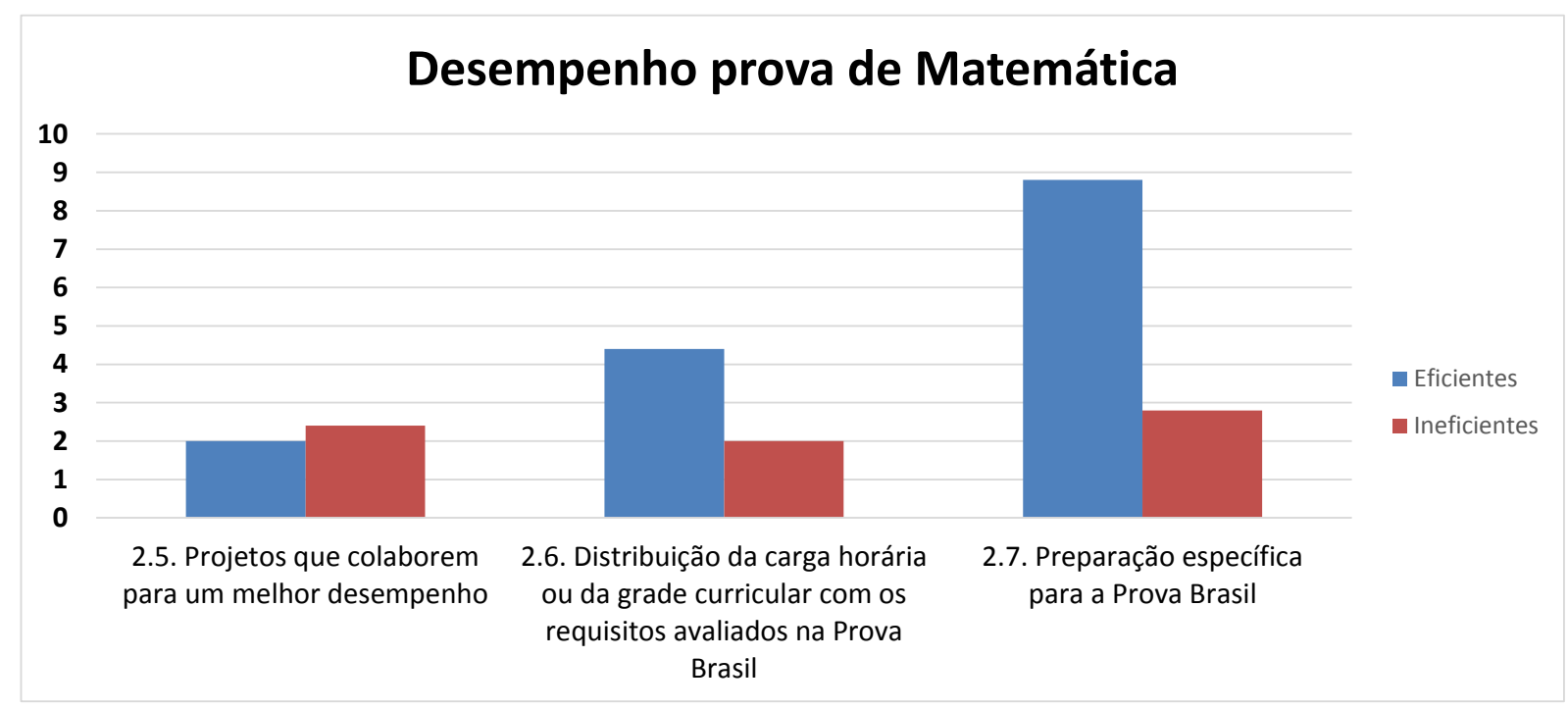

Gráfico 18 - Desempenho na prova de matemática

Fonte: Elaborado pelo autor, com base nos resultados dos estudos de caso

A seguir, o Gráfico 19 e o Gráfico 20 apresentam a frequência de cada atividade que compõe o indicador participação da família em escolas eficientes e ineficientes.

No Gráfico 19, a atividade 3.1, referente à participação de pais nas reuniões, apresenta diferença expressiva $(5,6)$ quando se compara sua frequência nas escolas eficientes e ineficientes. Esse resultado sugere que o acompanhamento mais próximo dos pais provoca uma melhora no desempenho dos alunos, seja por aumentar a cobrança em relação aos estudos ou correção de caminhos. Outros estudos na literatura também apontam que a participação dos pais junto aos Professores tende a impactar positivamente no desempenho destes alunos (LAREAU, 1987; GAME, 2002; UNESCO, 2004; MARTURANO, 2006; ALVES; SOARES, 2007; DOURADO; SANTOS; OLIVEIRA, 2007; MEC; UNICEF, 2008; LEME; PAREDES; SOUZA, 2009; FERREIRA; BARRERA, 2010; UNICEF, 2010; SALGADO JUNIOR, 2013; VEJA, 2013). 
A atividade 3.2, inserida neste mesmo gráfico, também apresenta diferença expressiva $(4,0)$ na frequência observada em escolas eficientes e ineficientes, ainda que em menor evidência que a atividade 3.1 (diferença de 5,6). Neste sentido, a participação dos pais em eventos festivos também pode ser um fator explicativo no desempenho dos alunos conforme também apontam GAME (2002), MEC e UNICEF (2006), Dourado, Santos e Oliveira (2007), MEC e UNICEF (2008) e UNICEF (2010). O resultado encontrado neste trabalho em relação à participação dos pais em eventos da escola diverge do resultado encontrado por Salgado Junior (2013) que pondera que a participação dos pais em eventos festivos não tem capacidade explicativa na comparação de desempenho entre escolas eficientes e ineficientes.

A contribuição na manutenção da estrutura física escolar, destacada pela atividade 3.3, não apresenta diferença expressiva $(0,0)$ entre as escolas, com baixa frequência tanto em escolas eficientes quanto ineficientes. Neste sentido, esta atividade não tem poder de explicação no desempenho das escolas. A atividade 3.4, no entanto, apresenta diferença expressiva $(4,0)$ quando se compara sua frequência nas escolas eficientes e ineficientes. Isso sugere que a participação dos pais na APM tende a impactar positivamente no desempenho dos alunos. Esse resultado não é consenso entre os pesquisadores. Por um lado, essa observação é corroborada pelos estudos de GAME (2002), MEC e UNICEF (2006), Dourado, Santos e Oliveira (2007), MEC e UNICEF (2008), Ferreira e Barrera (2010) e por considerações feitas pela revista Veja (VEJA 2013) e, no entanto, esse resultado diverge dos resultados encontrados por Salgado Junior (2013). Os dados são apresentados no Gráfico 19.

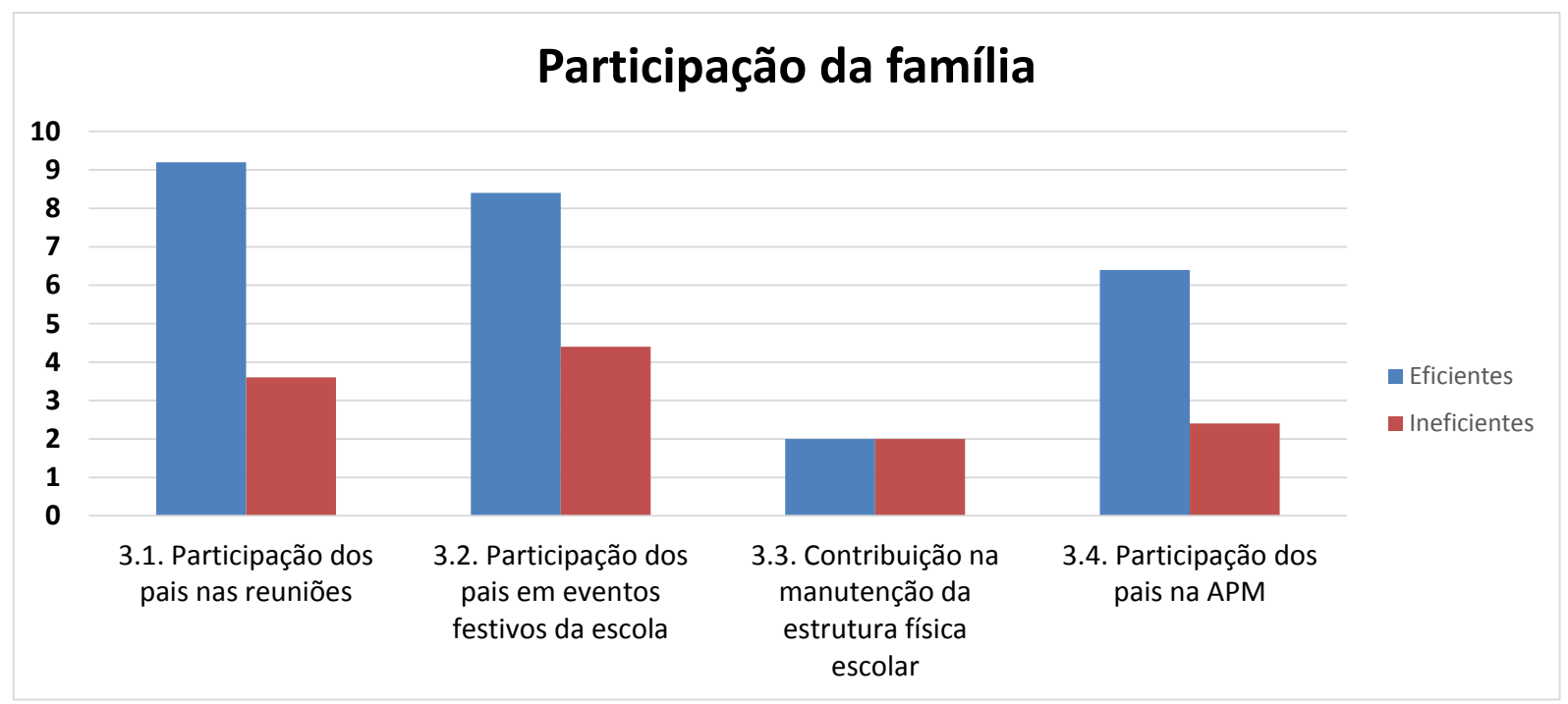

Gráfico 19 - Participação da família

Fonte: Elaborado pelo autor, com base nos resultados dos estudos de caso 
O Gráfico 20 também apresenta atividades relacionadas à participação da família nas atividades escolares. Neste sentido, o acompanhamento dos pais nos deveres escolares dos filhos, destacado pela atividade 3.5, pode ser um fator explicativo no desempenho dos alunos, uma vez que esta atividade apresenta diferença expressiva $(4,8)$ quando comparada a frequência nas escolas eficientes e ineficientes. Este resultado também foi encontrado nos trabalhos de Bezerra e Kassouf (2006), Menezes-Filho (2007), MEC e UNICEF (2008), UNICEF (2010), Ferreira e Barrera (2010) e Salgado Junior (2013). A atividade 3.6, destacada neste mesmo gráfico, também apresenta diferença expressiva $(6,4)$ quando comparada a frequência nas escolas eficientes e ineficientes. Esse resultado, em convergência com a UNESCO (2004), Marturano (2006), Dourado, Santos e Oliveira (2007), MEC e UNICEF (2008), Ferreira e Barrera (2010), UNICEF (2010) e Salgado Junior (2013), sugere que o apoio dos pais na validação das ações da escola pode ser fator explicativo no desempenho.

Por outro lado, a frequência com que os pais utilizam o transporte público para ir à escola, destacado na atividade 3.7, não apresenta diferença expressiva $(0,0)$ entre as escolas eficientes e ineficientes. Esse resultado diverge com os resultados encontrados por Soares, Alves e Oliveira (2001), Alves e Soares (2007) e Salgado Junior (2013).

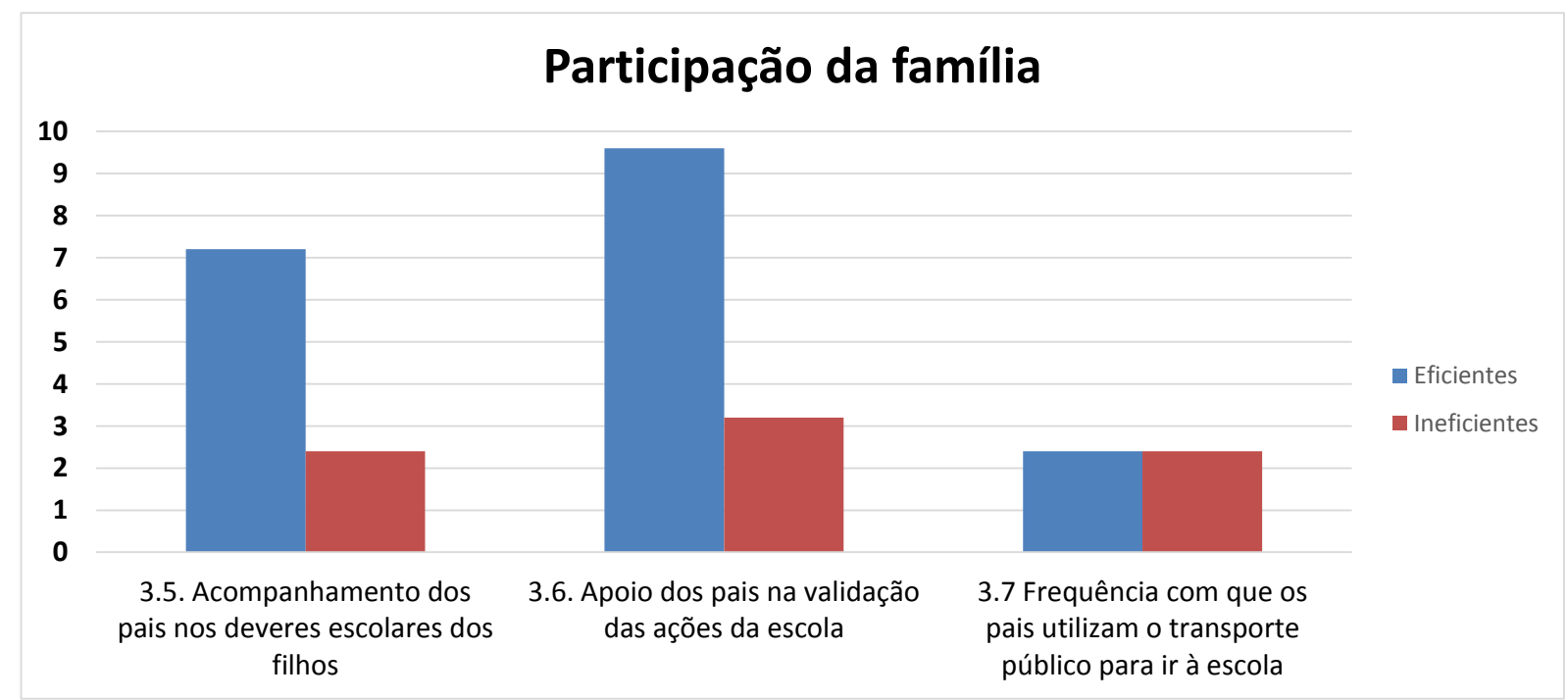

Gráfico 20 - Participação da família

Fonte: Elaborado pelo autor, com base nos resultados dos estudos de caso 
Os dois gráficos seguintes apresentam a frequência das escolas eficientes e ineficientes de cada atividade que compõe o indicador reprovação discente e sistema disciplinar, sendo que as atividades 4.1, 4.3, 4.4 e 4.5 são apresentadas no Gráfico 21 e a atividade 4.2 é apresentada no Gráfico 22.

No Gráfico 21, a autonomia do docente no processo de reprovação dos alunos, destacado pela atividade 4.1, não apresenta diferença expressiva quando comparada a frequência nas escolas eficientes e ineficientes. O resultado encontrado sugere que a autonomia do docente no processo de reprovação não é um fator explicativo no desempenho dos alunos, conforme também defende Fernandes (2007). Outros autores, no entanto, divergem deste resultado conforme apontam os estudos de GAME (2002), Cianflone e Andrade (2007) e Salgado Junior (2013).

Neste trabalho foi identificado que fatores relacionados à disciplina e respeito aos Professores, Diretores e funcionários, apresentaram diferenças importantes entre escolas eficientes e ineficientes, indicando um possível fator de explicação. Com uma diferença expressiva $(6,0)$ quando comparadas escolas eficientes e ineficientes, a definição de regras claras do sistema disciplinar (atividade 4.3) é apontada como um fator com poder de explicação da diferença de desempenho entre as escolas conforme mostra o Gráfico 21. Este resultado é corroborado pelos estudos de MEC e UNICEF (2006), Silva e Santana (2007), MEC e BID (2010), Leite e Tocornal (2012) e Salgado Junior (2013).

Neste mesmo sentido, o grau de disciplinaridade no comportamento do discente, destacado pela atividade 4.4, também apresenta uma diferença expressiva $(6,4)$ quando comparada a frequência nas escolas eficientes e ineficientes. Em convergência com os resultados encontrados por Pires (1999), UNESCO (2004), MEC e UNICEF (2006), Cianflone e Andrade (2007), Paro (2011), Leite e Tocornal (2012) e Salgado Junior (2013), esse resultado sugere que um maior grau de disciplinaridade pode estar relacionado com um melhor desempenho do aluno.

Ainda no Gráfico 21, foi identificada uma diferença expressiva $(6,0)$ na comparação de frequência entre escolas eficientes e ineficientes em relação à atividade 4.5. Esse resultado sugere que em escolas em que os discentes respeitam mais os Professores, funcionários e 
Diretor o desempenho tende a ser melhor. O mesmo resultado foi encontrado por Cotton (1996), MEC e UNICEF (2006), Dourado, Santos e Oliveira (2007), Leite e Tocornal (2012) e Salgado Junior (2013).

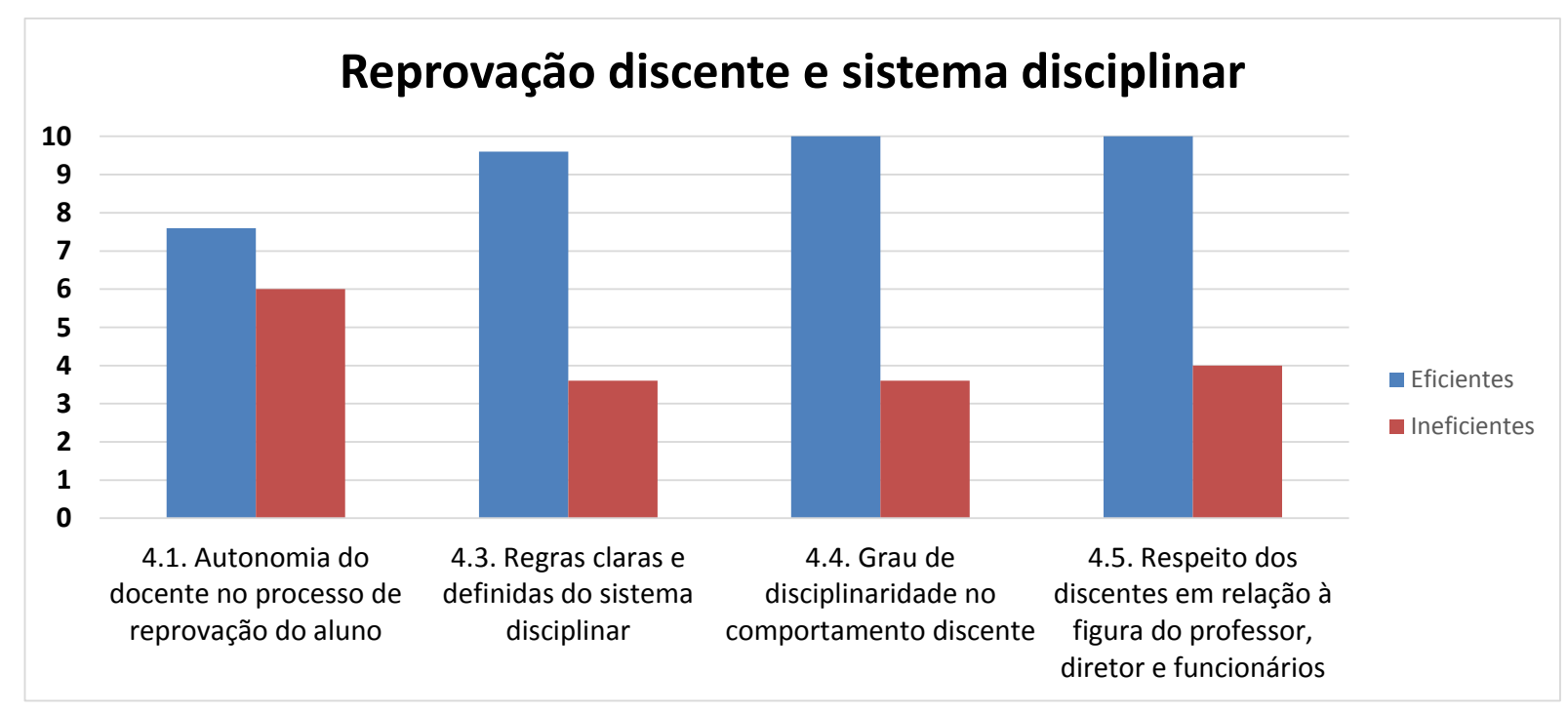

Gráfico 21 - Reprovação discente e sistema disciplinar

Fonte: Elaborado pelo autor, com base nos resultados dos estudos de caso

Em todas as escolas analisadas foram identificadas a existência de um sistema de reprovação. Desta forma, não foi encontrada diferença expressiva nas escolas eficientes e ineficientes nesta atividade (atividade 4.2) sugerindo que a existência de um sistema de reprovação não influencia no desempenho dos alunos. Fernandes (2007) e Vasconcelos (2008) concordam com os resultados encontrados neste trabalho ponderando que a performance dos alunos não é influenciada pela reprovação. Outros autores, no entanto, divergem deste resultado como destacam os estudos de Paro (2001), GAME (2002), Menezes-Filho (2007), Cianflone e Andre (2007) e Salgado Junior (2013) defendendo que a existência de um sistema de reprovação pode ser um fator explicativo no desempenho das escolas eficientes. Os dados desta atividade são apresentados no Gráfico 22. 


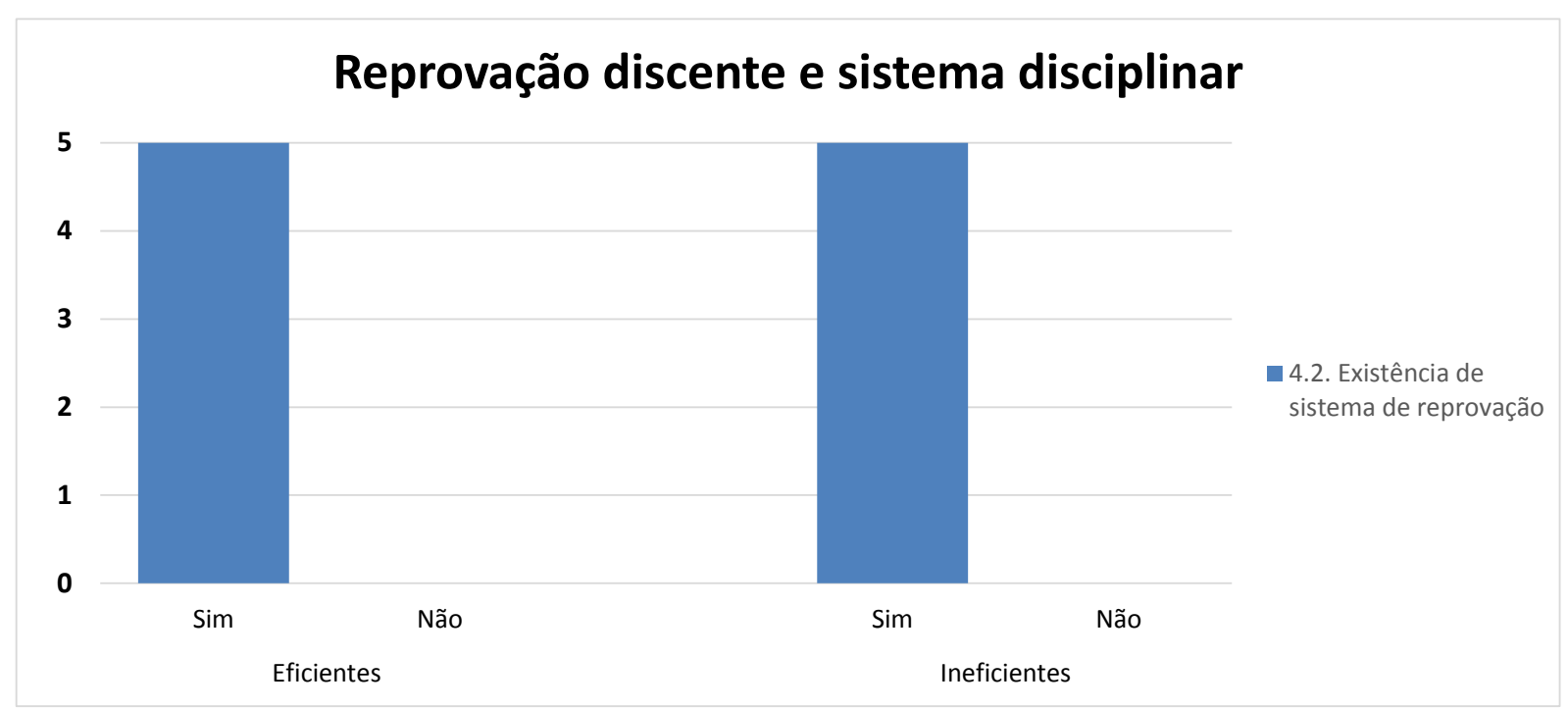

Gráfico 22 - Existência de sistema de reprovação

Fonte: Elaborado pelo autor, com base nos resultados dos estudos de caso

O Gráfico 23 e o Gráfico 24 apresentam a frequência das escolas eficientes e ineficientes de cada atividade que compõe o indicador laboratório de informática.

No Gráfico 23, a atividade 5.1 não apresenta diferença expressiva quando se compara sua frequência nas escolas eficientes e ineficientes. Em duas escolas eficientes e duas ineficientes foi constatada a existência de laboratório de informática. Desta forma, com base nestas escolas analisadas, essa atividade não tem capacidade explicativa no desempenho das escolas. Esse resultado também foi encontrado nos trabalhos de Kulik (2003) e Bionde e Felício (2007). Outros estudos, no entanto, apontam que a existência de laboratório de informática pode ser um fator positivo no desempenho dos alunos (GLADCHEFF; ZUFFI; SILVA, 2001; DOURADO; SANTOS; OLIVEIRA, 2007; FRANCO, 2008; SULIANO; OLIVEIRA, 2011; INEP, 2013). 


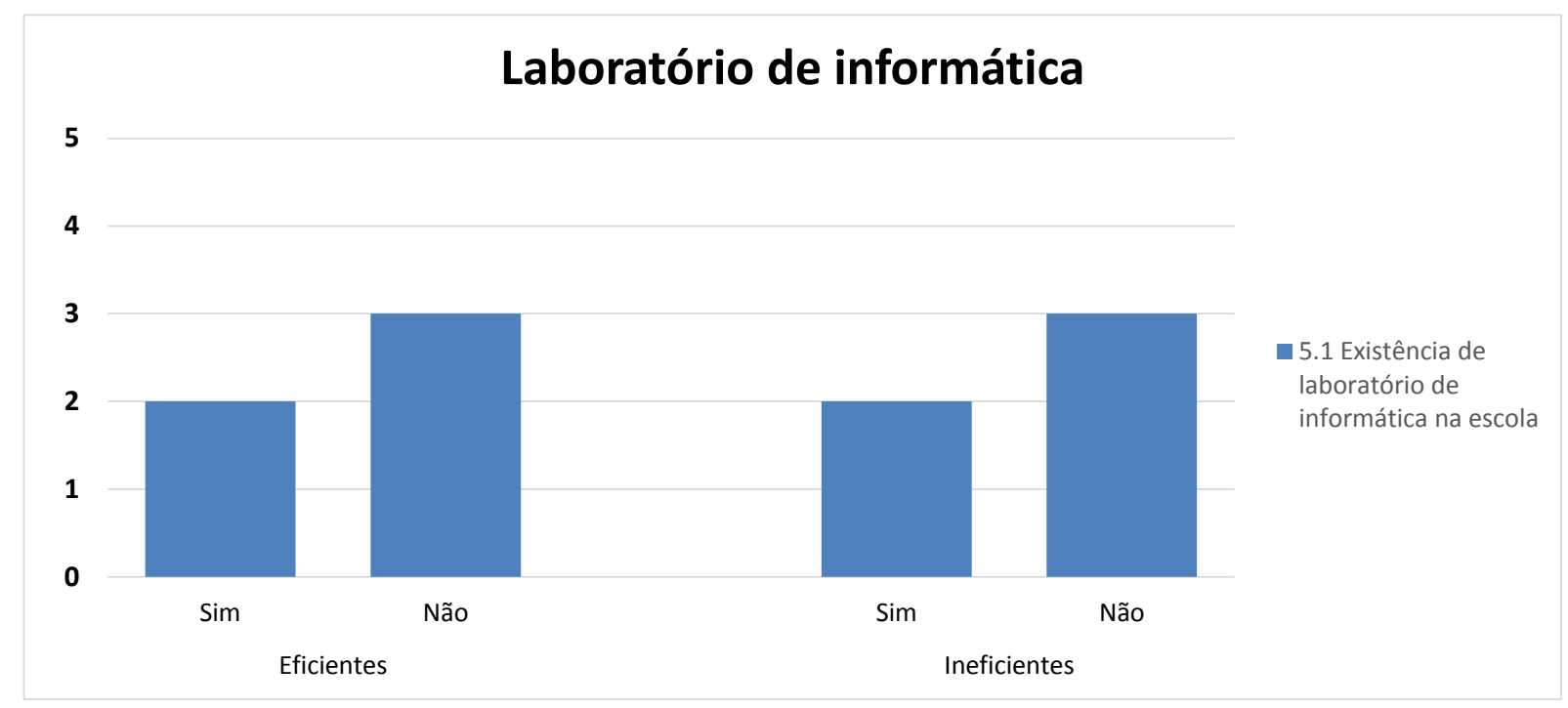

Gráfico 23 - Existência de laboratório de informática

Fonte: Elaborado pelo autor, com base nos resultados dos estudos de caso

Em congruência com os resultados encontrados na atividade anterior, o Gráfico 24, destaca as atividades 5.2 e 5.3 relacionadas ao laboratório de informática. De acordo com o gráfico, a atividade 5.2 não apresenta diferença expressiva $(0,0)$ quando se compara sua frequência nas escolas eficientes e ineficientes. Uma importante observação nesta atividade, contudo, é que em ambas as escolas eficientes e ineficientes a frequência das aulas de informática é baixa. Nesse mesmo gráfico, a atividade 5.3 não apresenta diferença expressiva quando comparada a frequência nas escolas eficientes e ineficientes, sugerindo que o número de computadores por aluno não influencia o desempenho. Na literatura, este resultado é corroborado pelo estudo de Menezes Filho (2007).

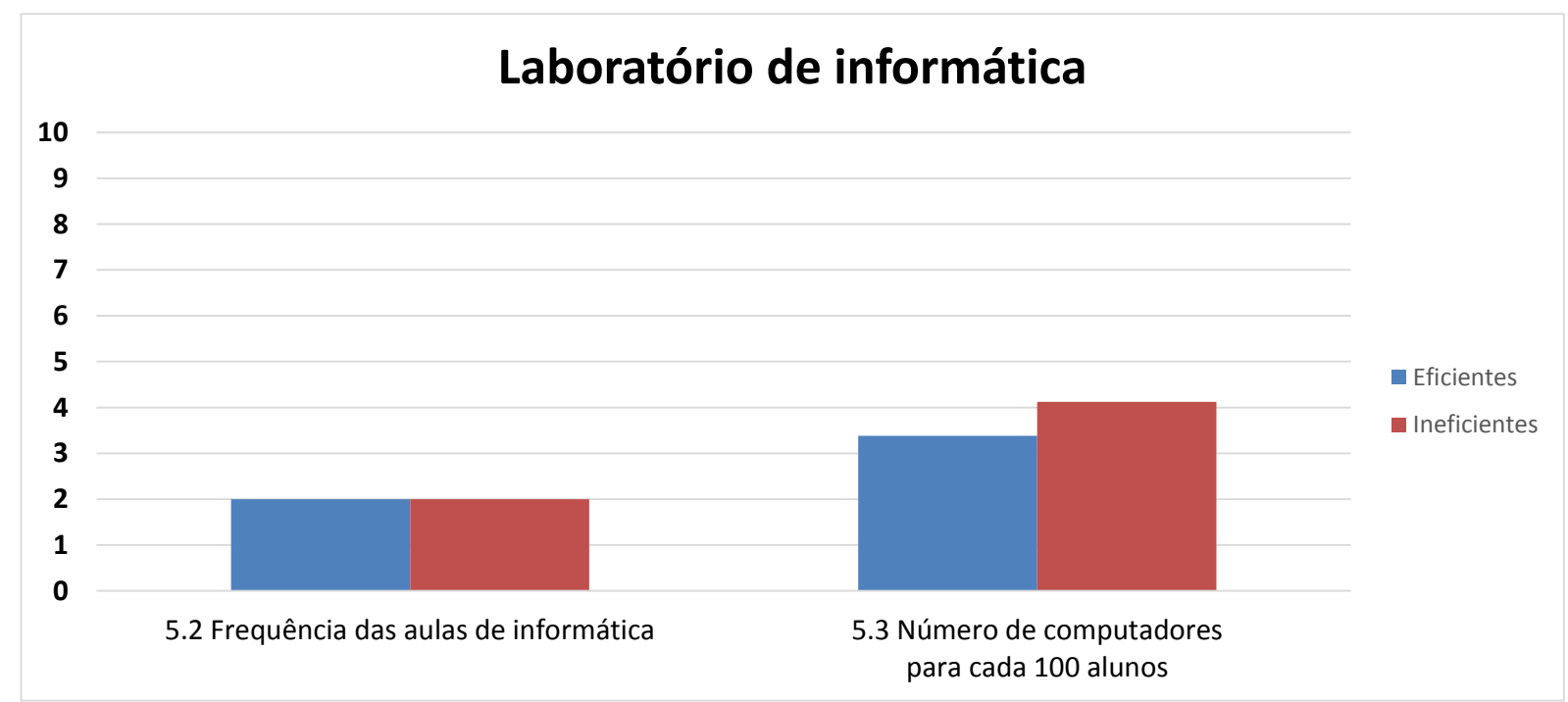

Gráfico 24 - Frequência de aulas e quantidade de computadores

Fonte: Elaborado pelo autor, com base nos resultados dos estudos de caso 
No Gráfico 25 são apresentadas as atividades relacionadas à biblioteca. Neste sentido, a atividade 6.1 apresenta diferença pouco expressiva $(2,0)$ quando comparado sua frequência nas escolas eficientes e ineficientes, o que sugere que o tamanho do acervo da biblioteca tem pouco poder de explicação no desempenho dos alunos. Esse resultado corrobora com o resultado encontrado por Quinhões (1999), Dourado, Santos e Oliveira (2007), Bezerra (2008), UNICEF (2010) e Salgado Junior (2013) que identificam o tamanho do acervo da biblioteca como fator que pode influenciar positivamente o desempenho.

A variedade do acervo da biblioteca, destacada pela atividade 6.2, não apresenta diferença expressiva $(0,8)$ quando comparada a frequência nas escolas eficientes e ineficientes sugerindo que a variedade do acervo da biblioteca não influencia no desempenho dos alunos. Esse resultado também foi encontrado por Salgado Junior (2013). Da mesma forma que na atividade anterior, alguns autores (QUINHÕES, 1999; SOARES, 2004; DOURADO; SANTOS; OLIVEIRA, 2007; BEZERRA, 2008) encontraram resultados que divergem dos resultados desta dissertação sugerindo que a variedade do acervo da biblioteca pode influenciar positivamente a performance dos alunos.

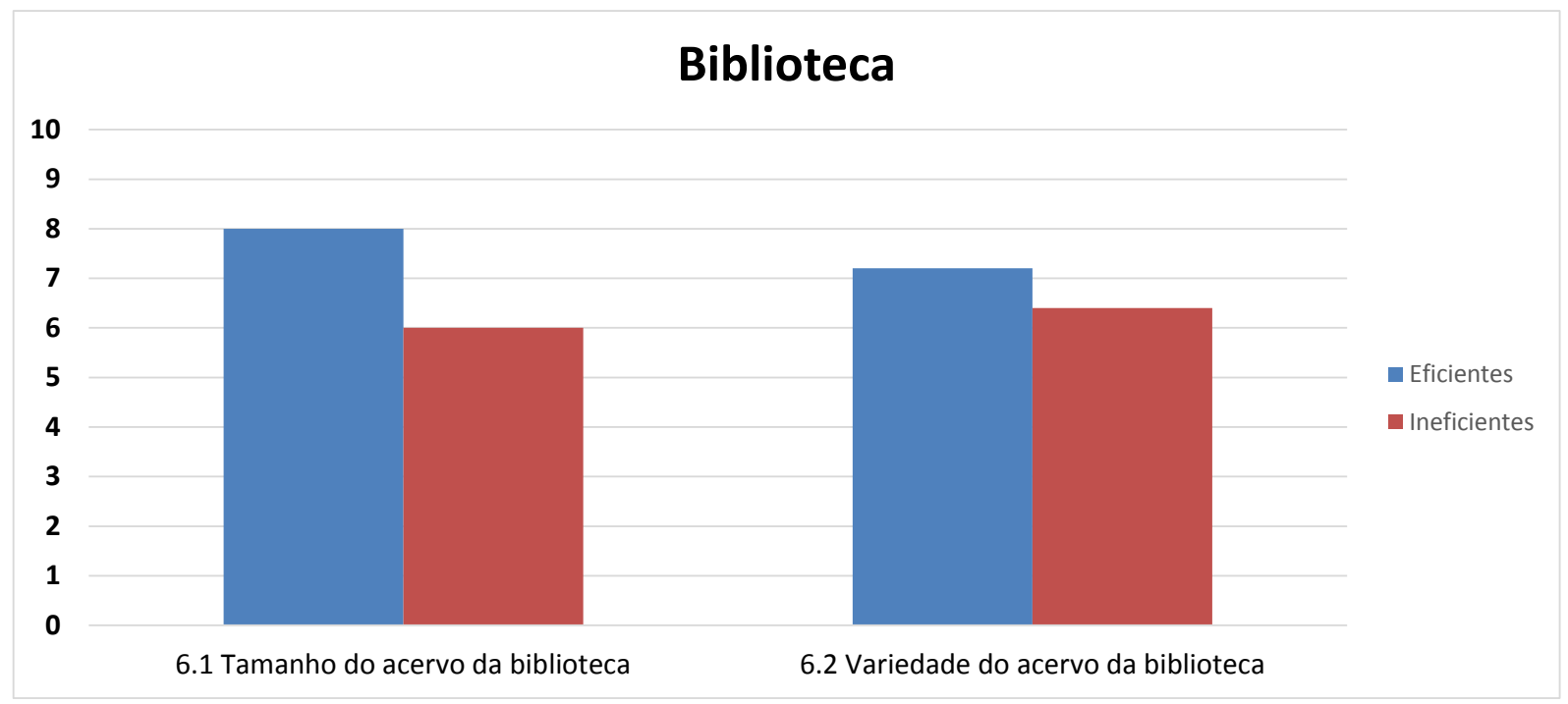

Gráfico 25 - Tamanho e variedade do acervo da biblioteca

Fonte: Elaborado pelo autor, com base nos resultados dos estudos de caso 
O Gráfico 26 e o Gráfico 27 apresentam a frequência das escolas eficientes e ineficientes de cada atividade que compõe o indicador sala de leitura.

No Gráfico 26, a atividade 7.1 não apresenta diferença expressiva quando se compara sua frequência nas escolas eficientes e ineficientes, sendo que nas escolas ineficientes foram identificadas duas escolas com sala de leitura enquanto nas escolas eficientes apenas uma sala de leitura. Com uma pequena diferença entre as escolas e também com uma pequena quantidade de salas (apenas três salas de leitura em dez escolas visitadas) não se pode afirmar que esta atividade tem poder de explicação no desempenho. Os estudos de Soares (2004) e Dourado, Santos e Oliveira (2007) apontam a direção contrária, sugerindo que a existência de salas de leitura pode influenciar positivamente no desempenho dos alunos.

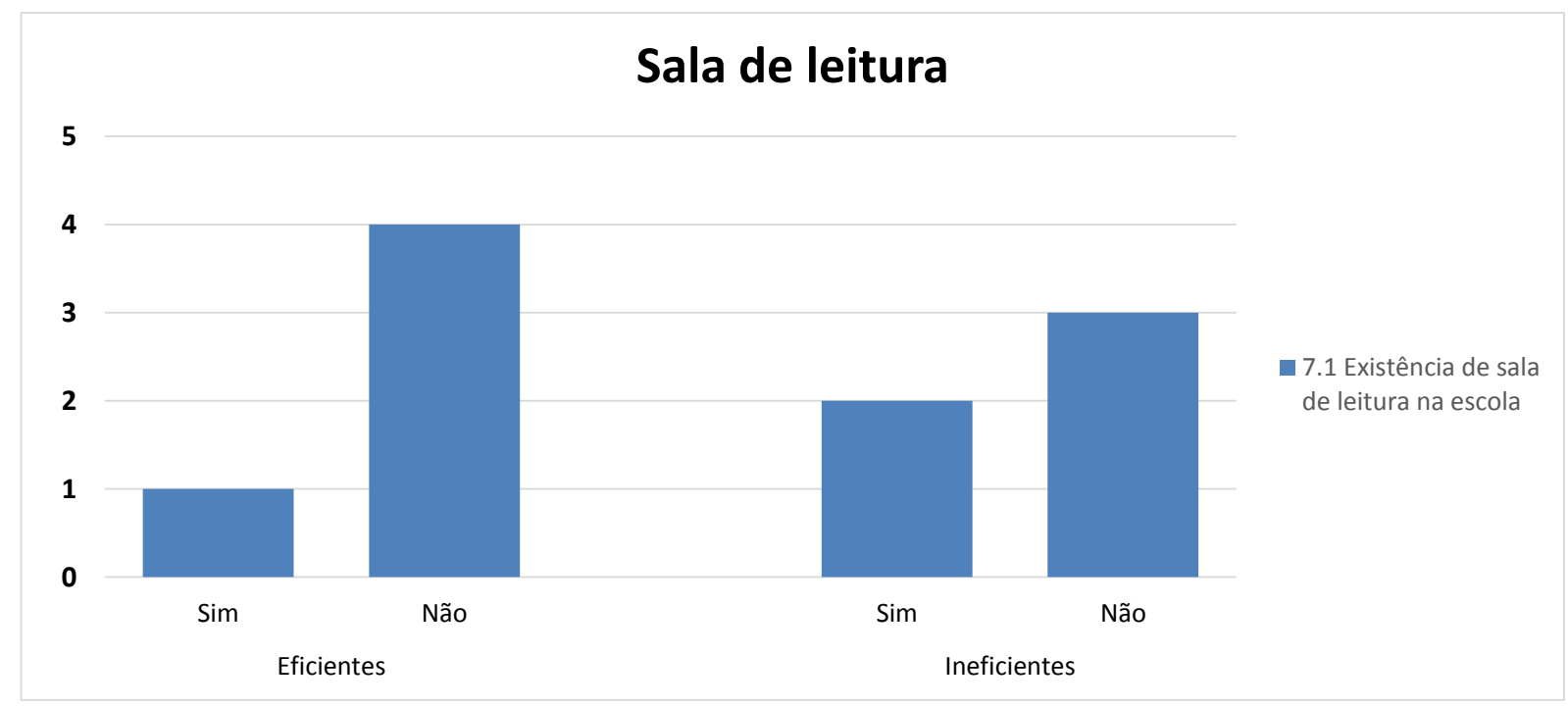

Gráfico 26 - Existência de sala de leitura

Fonte: Elaborado pelo autor, com base nos resultados dos estudos de caso

No Gráfico 27, a atividade 7.2 avalia a utilização da sala de leitura pelos alunos. Nesta atividade também não foi identificada diferença expressiva quando comparada a frequência nas escolas eficientes e ineficientes. Com baixa utilização em ambas as escolas, esse resultado sugere que a utilização da sala de leitura não tem poder de explicação no desempenho destas escolas. Soares (2004), no entanto, apresenta resultados divergentes do resultado encontrado nesta dissertação, considerando que a utilização de salas de leitura pode influenciar positivamente o desempenho dos estudantes. 


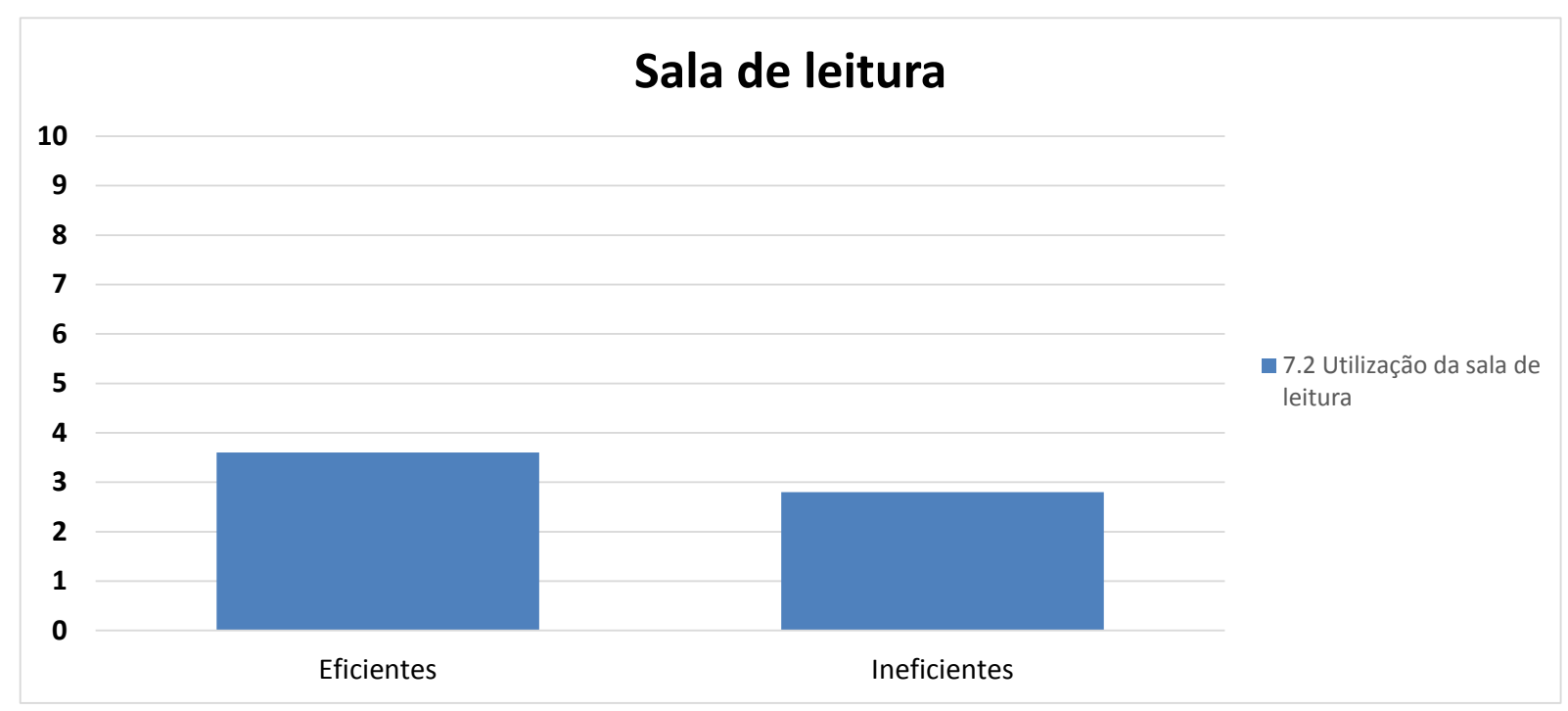

Gráfico 27 - Utilização da sala de leitura

Fonte: Elaborado pelo autor, com base nos resultados dos estudos de caso

O Gráfico 28 e o Gráfico 29 apresentam a frequência das escolas eficientes e ineficientes de atividades relacionadas ao transporte e ao número de matrículas nas escolas.

Segundo mostra o Gráfico 28, não há diferença expressiva entre a frequência de utilização do transporte público para ir à escola (atividade 8.1) nas escolas eficientes e ineficientes. Esse resultado sugere que a utilização do transporte público não é um fator explicativo para o desempenho. Outros estudos (BRASIL, 2006; SALGADO JUNIOR, 2013; MOURA; CRUZ, 2013), no entanto, divergem do resultado encontrado nesta dissertação.

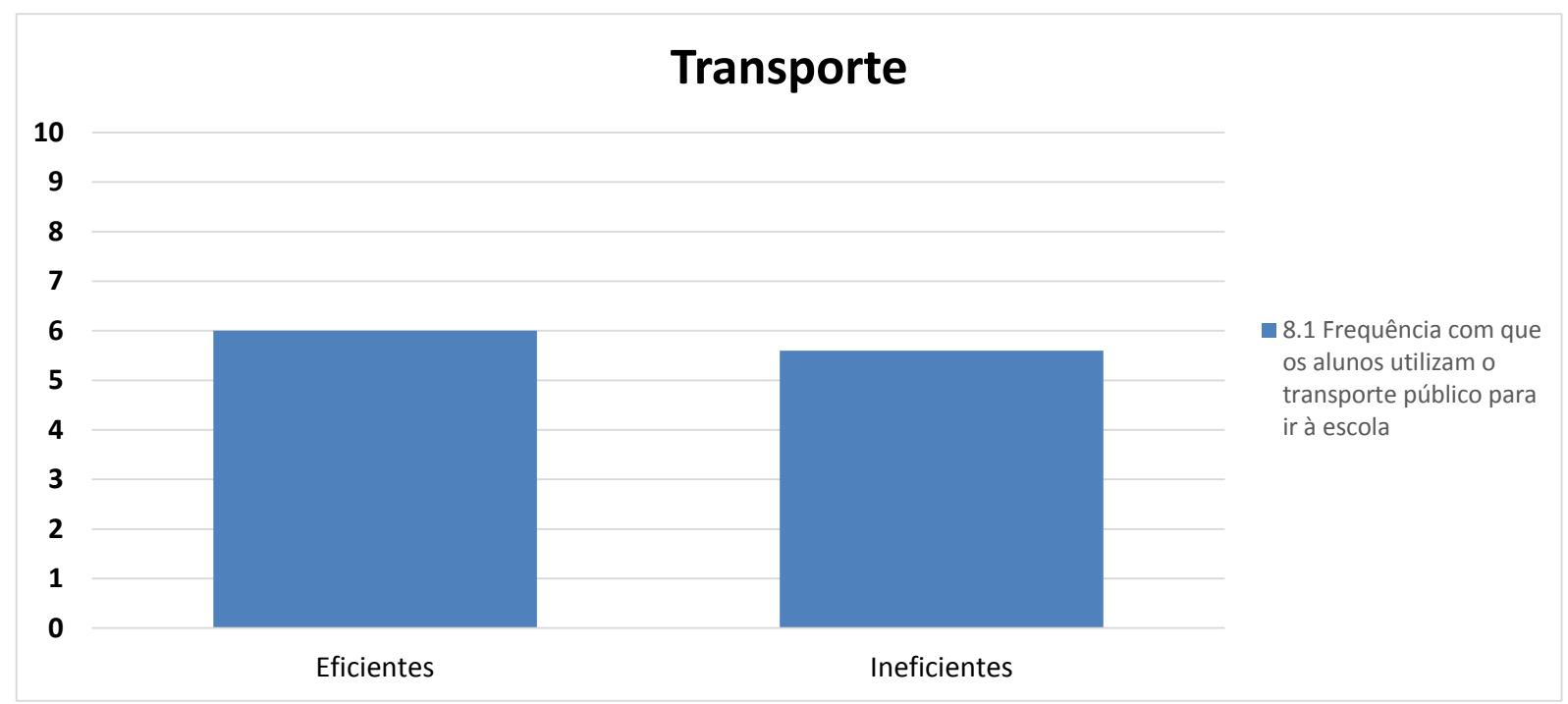

Gráfico 28 - Frequência de utilização do transporte público para ir à escola

Fonte: Elaborado pelo autor, com base nos resultados dos estudos de caso 
No Gráfico 29, a atividade 8.2 não apresentou diferença expressiva quando comparada sua frequência nas escolas eficientes e ineficientes. Tal resultado já era esperado, tendo em vista que o tamanho da escola, medido pelo número de matrículas, foi um dos critérios de seleção utilizados para escolha das escolas ineficientes (grupo de controle).

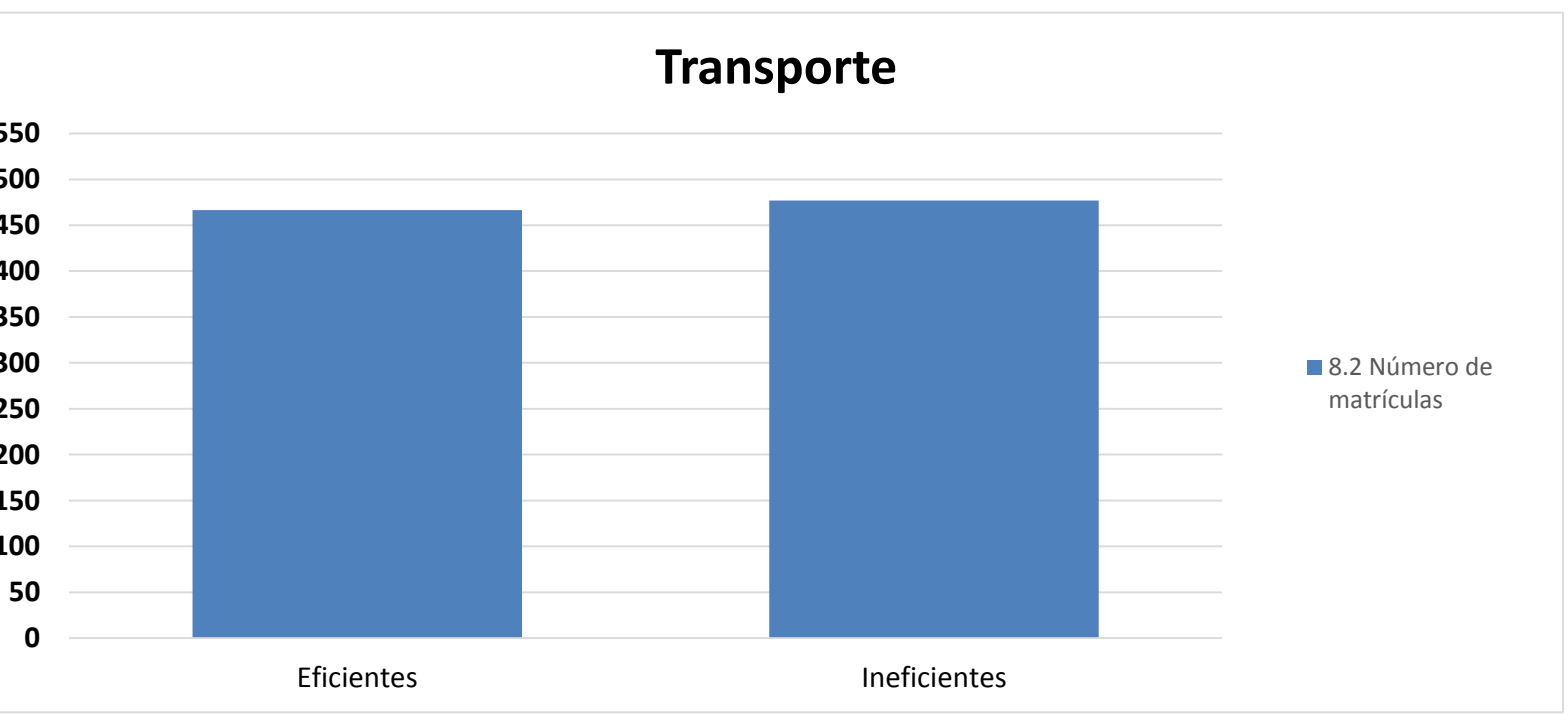

Gráfico 29 - Número de matrículas

Fonte: Elaborado pelo autor, com base nos resultados dos estudos de caso

Os gráficos 30, 31, 32 e 33 apresentam a frequência das escolas eficientes e ineficientes de cada atividade que compõe o indicador docente.

No Gráfico 30, a atividade 9.1 não apresenta diferença expressiva entre as escolas eficientes e ineficientes. Entretanto, na estatística descritiva apresentada na tabela 9 desta dissertação, é possível verificar que existe uma maior porcentagem de Professores do sexo feminino nas escolas eficientes, quando comparado às $10 \%$ das escolas com maior escore DEA, as $10 \%$ das escolas com menor escore DEA e a média de São Paulo. Nesse mesmo gráfico, a atividade 9.2 também não apresenta uma diferença expressiva quando comparada a frequência nas escolas eficientes e ineficientes. Entretanto, na estatística descritiva apresentada na tabela 9 desta dissertação, é possível verificar que há uma maior porcentagem de Professores com magistério concluido nas escolas eficientes, quando comparado a 10\% das escolas com menor escore DEA e as $10 \%$ das escolas com maior escore DEA. Por fim, não há diferença expressiva em relação ao percentual de docentes com curso de literatura concluído, destacado 
pela atividade 9.3, quando comparada sua frequência nas escolas eficientes e ineficientes. Entretanto, na estatística descritiva apresentada na tabela 9 desta dissertação, é possível verificar que há uma menor porcentagem de Professores com licenciatura concluída nas escolas eficientes quando comparado com as $10 \%$ das escolas com menor escore DEA.

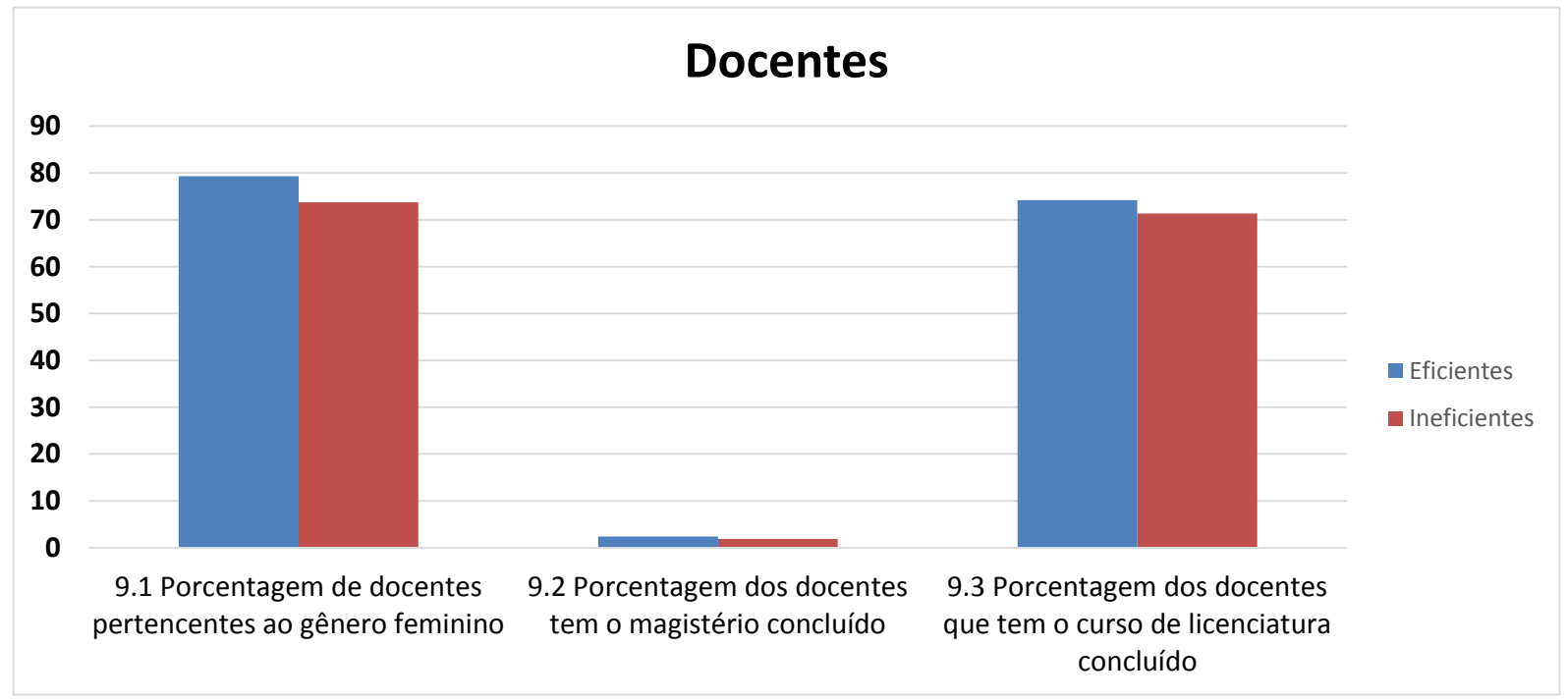

Gráfico 30 - Docentes por gênero, magistério e cursos de licenciatura

Fonte: Elaborado pelo autor, com base nos resultados dos estudos de caso

No Gráfico 31, a atividade 9.4 não apresenta uma diferença expressiva quando se compara sua frequência nas escolas eficientes e ineficientes. Entretanto, na estatística descritiva apresentada na tabela 9 desta dissertação, é possível verificar que há uma menor porcentagem de Professores com ensino superior concluido nas escolas eficientes quando comparado com as $10 \%$ das escolas com maior escore DEA, no entanto, essa porcentagem é maior quando comparada com as $10 \%$ das escolas com menor escore DEA e a média de São Paulo. Nesse mesmo gráfico, a atividade 9.5 não apresenta uma diferença expressiva quando se compara sua frequência nas escolas eficientes e ineficientes. Entretanto, na estatística descritiva apresentada na tabela 9 desta dissertação, é possível verificar que há uma maior porcentagem de Professores com especialização concluida nas escolas eficientes quando comparado com as $10 \%$ das escolas com maior escore DEA, as $10 \%$ das escolas com menor escore DEA e a mádia de São Paulo. 


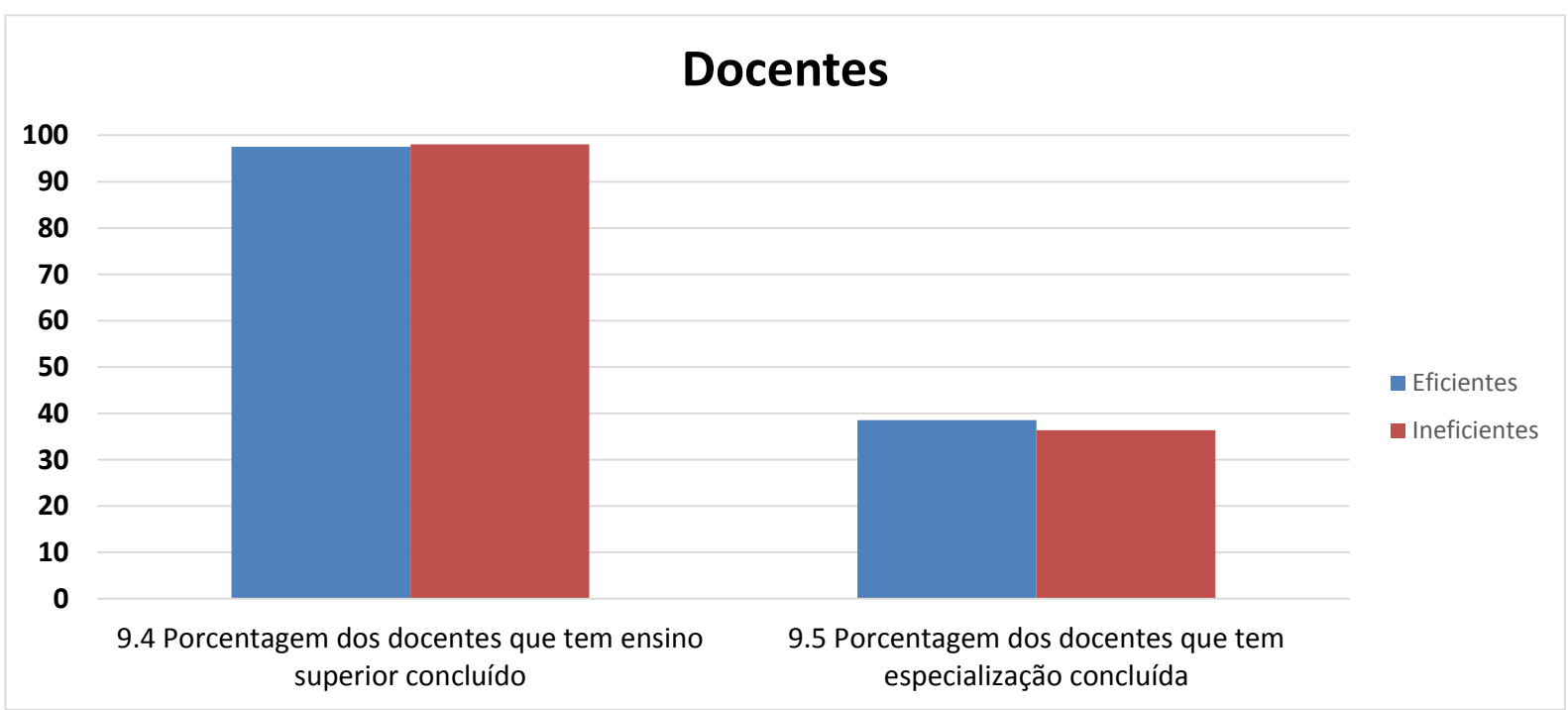

Gráfico 31 - Percentual de Docentes com curso superior e especialização

Fonte: Elaborado pelo autor, com base nos resultados dos estudos de caso

O Gráfico 32 mostra o número de docentes para cada 100 alunos destacado pela atividade 9.6. De acordo com o gráfico, não há diferença expressiva nesta atividade quando comparada as frequências nas escolas eficientes e ineficientes. Esse resultado era esperado uma vez que foram selecionadas escolas com características semelhantes em cada município.

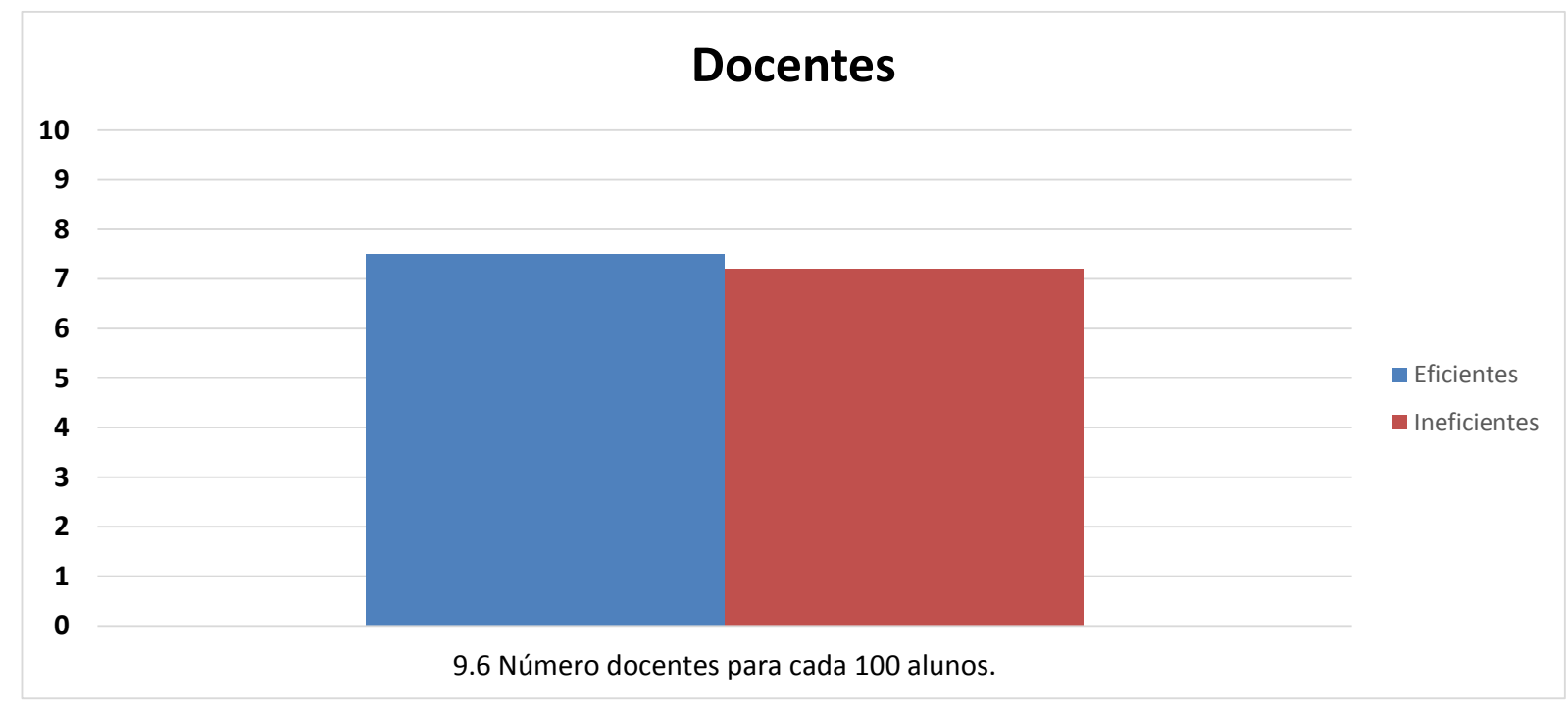

Gráfico 32 - Número de docentes para cada 100 alunos

Fonte: Elaborado pelo autor, com base nos resultados dos estudos de caso

O Gráfico 33 apresenta atividades relacionadas ao incentivo financeiro, plano de carreira e salário dos docentes e progressão salarial. Em nenhuma das atividades foi identificada 
diferença expressiva quando comparada a frequência nas escolas eficientes e ineficientes. Vegas (2008) e Setúbal (2010), no entanto, divergem do resultado encontrado em relação ao incentivo financeiro, destacando que o incentivo financeiro pode influenciar o desempenho dos Professores e, consequentemente, o desempenho dos alunos. Setúbal (2010) ainda aponta a importância do plano de carreira atrativo como forma de incentivo para melhorar o desempenho.

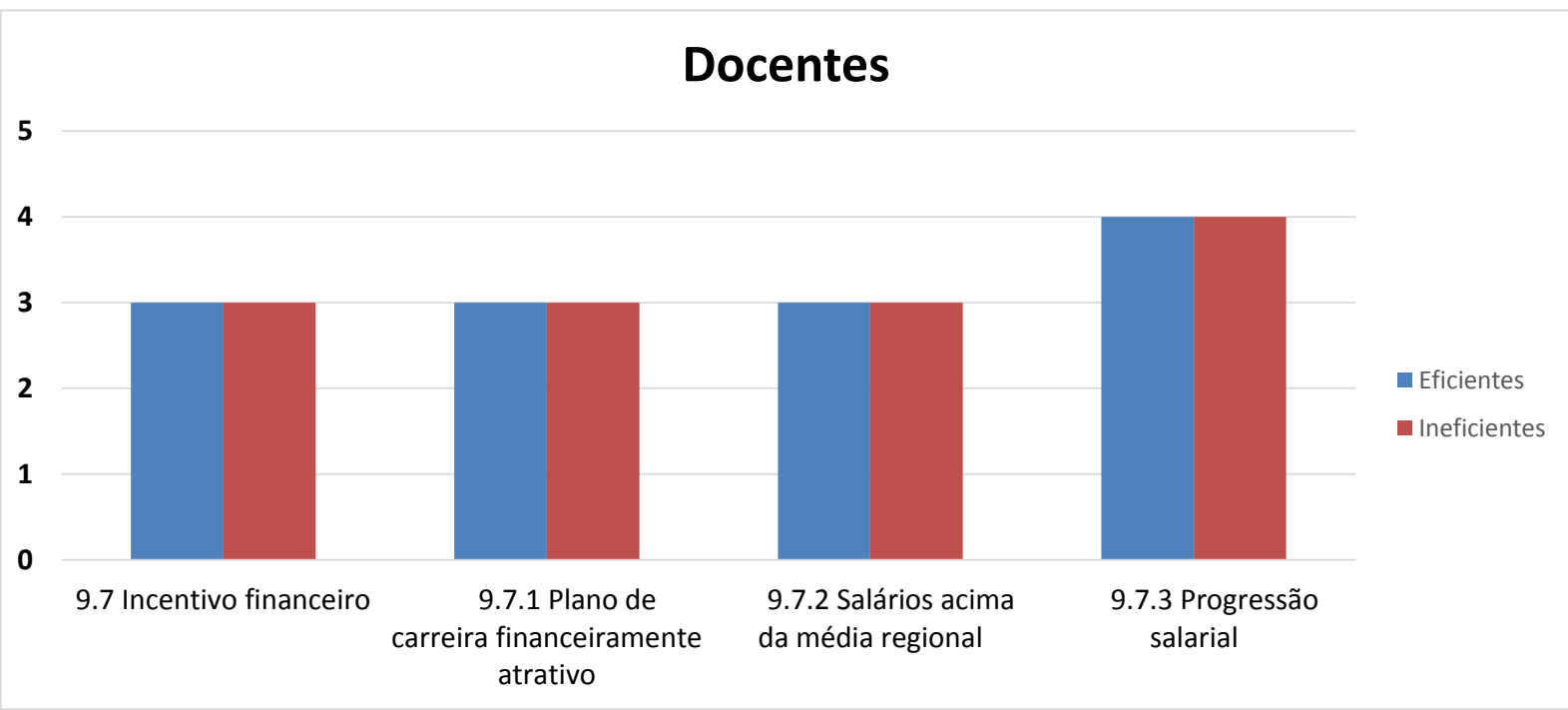

Gráfico 33 - Incentivo financeiro, plano de carreira e salário dos docentes

Fonte: Elaborado pelo autor, com base nos resultados dos estudos de caso

No Gráfico 34, a atividade 10.1 não apresenta diferença expressiva quando se compara sua frequência nas escolas eficientes e ineficientes. Entretanto, na estatística descritiva apresentada na tabela 9 desta dissertação, é possível verificar que há um maior número de alunos por funcionário nas escolas eficientes quando comparado com as $10 \%$ das escolas com maior escore DEA e com a média de São Paulo, no entanto, esse número é menor quando comparado com as $10 \%$ das escolas com menor escore DEA. 


\section{Funcionários}

12

10

6

4

2

0

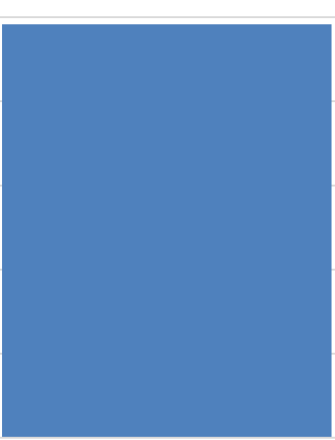

Eficientes

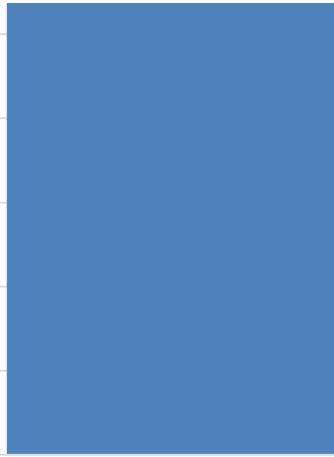

Ineficientes
10.1 Número de

funcionários para cada 100 alunos

Gráfico 34 - Número de funcionários para cada 100 alunos

Fonte: Elaborado pelo autor, com base nos resultados dos estudos de caso

O Quadro 20 apresenta a relação de autores que corroboram ou divergem dos resultados encontrados nesta dissertação, referente a cada uma das atividades que compõe os indicadores do instrumento pedagógico da escola. 


\begin{tabular}{|c|c|c|c|c|}
\hline Instrumento & Indicador & Descrição Atividade & CORROBORA & DIVERGE \\
\hline \multirow{7}{*}{ Pedagógico } & \multirow{7}{*}{$\begin{array}{l}\text { 1. Desempenho Prova } \\
\text { Português }\end{array}$} & 1.1. Autonomia do docente no ensino dessa disciplina. & & Setúbal (2010) \\
\hline & & 1.2. Frequência de leitura dos alunos. & $\begin{array}{c}\text { Boruchovitch (2001) } \\
\text { Soares (2004) } \\
\text { MEC/UNICEF (2006) } \\
\text { Oliveira; Boruchovitch e Santos (2008) } \\
\text { Delmanto (2009) } \\
\text { Cury (2010) } \\
\text { Farias (2010) } \\
\text { Souza; Souza e Bonfim (2010) } \\
\text { Zoghbi e Louzano (2012) } \\
\text { Salgado Junior (2013) } \\
\end{array}$ & \\
\hline & & 1.3. Rotatividade dos Professores nessa disciplina. & $\begin{array}{c}\text { Vegas (2008) } \\
\text { Biondi e Felício (2007) } \\
\text { Alves e Soares (2007) } \\
\text { GAME (2002) } \\
\text { Salgado Junior (2013) }\end{array}$ & \\
\hline & & $\begin{array}{l}\text { 1.4. Frequência que o docente acompanha o desempenho do } \\
\text { aluno }\end{array}$ & $\begin{array}{c}\text { Boruchovitch (2001) } \\
\text { MEC/UNICEF (2008) } \\
\text { Oliveira; Boruchovitch e Santos (2008) } \\
\text { MEC/BID (2010) } \\
\text { Setúbal (2010) } \\
\text { UNICEF (2010) } \\
\end{array}$ & Salgado Junior (2013) \\
\hline & & 1.5. Recuperação paralela e reforço no contraturno. & $\begin{array}{c}\text { MEC/UNICEF (2006) } \\
\text { MEC/UNICEF (2008) } \\
\text { Azevedo (2008) } \\
\text { MEC/BID (2010) } \\
\text { Setúbal (2010) } \\
\text { UNICEF (2010) } \\
\text { Palma Filho; Alves e Duran (2012) } \\
\text { Salgado Junior (2013) } \\
\end{array}$ & \\
\hline & & 1.6. Projetos que colaborem para melhor desempenho. & & $\begin{array}{l}\text { MEC/UNICEF (2006) } \\
\text { Santos (2008) } \\
\text { Delmanto (2009) } \\
\text { Pinto (2013) } \\
\text { Salgado Junior (2013) } \\
\end{array}$ \\
\hline & & $\begin{array}{l}\text { 1.7. Distribuição da carga horária ou da grade curricular com } \\
\text { os requisitos avaliados na Prova Brasil }\end{array}$ & $\begin{array}{l}\text { UNICEF (2010) } \\
\text { Leme et al (2012) } \\
\text { CENPEC (2013) }\end{array}$ & \\
\hline
\end{tabular}




\begin{tabular}{|c|c|c|c|}
\hline & 1.8. Preparação específica para a Prova Brasil & $\begin{array}{c}\text { UNICEF (2010) } \\
\text { Oliveira (2011) } \\
\text { CENPEC (2013) } \\
\text { Salgado Junior (2013) } \\
\end{array}$ & \\
\hline \multirow{7}{*}{$\begin{array}{l}\text { 2. Desempenho Prova de } \\
\text { Matemática }\end{array}$} & 2.1. Autonomia do docente no ensino dessa disciplina & & Setúbal (2010) \\
\hline & $\begin{array}{l}\text { 2.2. Frequência que o docente acompanha o desempenho do } \\
\text { aluno }\end{array}$ & $\begin{array}{c}\text { Boruchovitch (2001) } \\
\text { MEC/UNICEF (2008) } \\
\text { Oliveira; Boruchovitch e Santos (2008) } \\
\text { MEC/BID (2010) } \\
\text { Setúbal (2010) } \\
\text { UNICEF (2010) } \\
\end{array}$ & 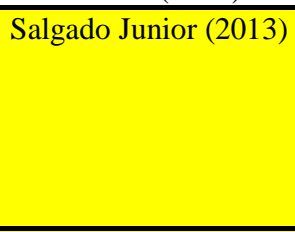 \\
\hline & 2.3. Rotatividade dos Professores nessa disciplina & $\begin{array}{c}\text { GAME (2002) } \\
\text { Alves e Soares (2007) } \\
\text { Biondi e Felício (2007) } \\
\text { Vegas (2008) } \\
\text { Salgado Junior (2013) }\end{array}$ & \\
\hline & 2.4. Recuperação paralela e reforço no contraturno & $\begin{array}{l}\text { MEC/UNICEF (2006) } \\
\text { MEC/UNICEF (2008) } \\
\text { Azevedo (2008) } \\
\text { MEC/BID (2010) } \\
\text { Setúbal (2010) } \\
\text { UNICEF (2010) } \\
\text { Palma Filho e Duran (2012) }\end{array}$ & \\
\hline & 2.5. Projetos que colaborem para um melhor desempenho & $\begin{array}{l}\text { Zoghbi e Louzano (2012) } \\
\text { Salgado Junior (2013) }\end{array}$ & $\begin{array}{l}\text { MEC/UNICEF (2006) } \\
\text { Veloso (2011) }\end{array}$ \\
\hline & $\begin{array}{l}\text { 2.6. Distribuição da carga horária ou da grade curricular com } \\
\text { os requisitos avaliados na Prova Brasil }\end{array}$ & $\begin{array}{l}\text { UNICEF (2010) } \\
\text { Leme et al (2012) } \\
\text { CENPEC (2013) }\end{array}$ & \\
\hline & 2.7. Preparação específica para a Prova Brasil & $\begin{array}{c}\text { UNICEF (2010) } \\
\text { Oliveira (2011) } \\
\text { CENPEC (2013) } \\
\text { Salgado Junior (2013) }\end{array}$ & \\
\hline
\end{tabular}




\begin{tabular}{|c|c|c|c|}
\hline \multirow[t]{7}{*}{ 3. Participação da Família } & 3.1. Participação dos pais nas reuniões & $\begin{array}{c}\text { Lareau (1987) } \\
\text { GAME (2002) } \\
\text { UNESCO (2004) } \\
\text { Marturano (2006) } \\
\text { Dourado, Santos e Oliveira (2007) } \\
\text { Alves e Soares (2007) } \\
\text { MEC/UNICEF (2008) } \\
\text { Leme, Paredes e Souza (2009) } \\
\text { Ferreira e Barrera (2010) } \\
\text { UNICEF (2010) } \\
\text { Salgado Junior (2013) } \\
\text { Veja (2013) }\end{array}$ & \\
\hline & 3.2. Participação dos pais em eventos festivos da escola & $\begin{array}{c}\text { GAME (2002) } \\
\text { MEC/UNICEF (2006) } \\
\text { Dourado; Santos e Oliveira (2007) } \\
\text { MEC/UNICEF (2008) } \\
\text { UNICEF (2010) }\end{array}$ & Salgado Junior (2013) \\
\hline & 3.3. Contribuição na manutenção da estrutura física escolar & & \\
\hline & 3.4. Participação dos pais na APM & $\begin{array}{c}\text { GAME (2002) } \\
\text { MEC/UNICEF (2006) } \\
\text { Dourado; Santos e Oliveira (2007) } \\
\text { MEC/UNICEF (2008) } \\
\text { Ferreira e Barrera (2010) } \\
\text { Veja (2013) } \\
\end{array}$ & Salgado Junior (2013) \\
\hline & $\begin{array}{l}\text { 3.5. Acompanhamento dos pais nos deveres escolares dos } \\
\text { filhos }\end{array}$ & $\begin{array}{l}\text { Bezerra e Kassouf (2006) } \\
\text { Menezes Filho (2007) } \\
\text { MEC/UNICEF (2008) } \\
\text { UNICEF (2010) } \\
\text { Ferreira e Barrera (2010) } \\
\text { Salgado Junior (2013) } \\
\end{array}$ & \\
\hline & 3.6. Apoio dos pais na validação das ações da escola & $\begin{array}{c}\text { UNESCO (2004) } \\
\text { Marturano (2006) } \\
\text { Dourado; Santos e Oliveira (2007) } \\
\text { MEC/UNICEF (2008) } \\
\text { UNICEF (2010) } \\
\text { Ferreira e Barrera (2010) } \\
\text { Salgado Junior (2013) } \\
\end{array}$ & \\
\hline & $\begin{array}{l}\text { 3.7 Frequência com que os pais utilizam o transporte público } \\
\text { para ir à escola }\end{array}$ & & $\begin{array}{l}\text { Soares, Alves e Oliveira (2001) } \\
\text { Alves, Soares (2007) } \\
\text { Salgado Junior (2013) }\end{array}$ \\
\hline
\end{tabular}




\begin{tabular}{|c|c|c|c|}
\hline \multirow{5}{*}{$\begin{array}{l}\text { 4. Reprovação Discente e } \\
\text { Sistema Disciplinar }\end{array}$} & $\begin{array}{l}\text { 4.1. Autonomia do docente no processo de reprovação do } \\
\text { aluno }\end{array}$ & Fernandes (2007) & $\begin{array}{c}\text { GAME (2002) } \\
\text { Cianflone e Andrade (2007) } \\
\text { Salgado Junior (2013) }\end{array}$ \\
\hline & 4.2. Existência de Sistema de Reprovação & $\begin{array}{c}\text { Fernandes (2007) } \\
\text { Vasconcelos (2008) }\end{array}$ & $\begin{array}{c}\text { Paro (2001) } \\
\text { GAME (2002) } \\
\text { Menezes-Filho (2007) } \\
\text { Cianflone e Andrade (2007) } \\
\text { Salgado Junior (2013) }\end{array}$ \\
\hline & 4.3. Regras claras e definidas do sistema disciplinar & $\begin{array}{c}\text { MEC/UNICEF (2006) } \\
\text { Silva e Santana (2007) } \\
\text { MEC/BID (2010) } \\
\text { Leite e Tocornal (2012) } \\
\text { Salgado Junior (2013) } \\
\end{array}$ & \\
\hline & 4.4. Grau de disciplinaridade no comportamento discente & $\begin{array}{c}\text { Libâneo (1985) } \\
\text { Pires (1999) } \\
\text { UNESCO (2004) } \\
\text { MEC/UNICEF (2006) } \\
\text { Cianflone e Andrade (2007) } \\
\text { Paro (2011) } \\
\text { Leite e Tocornal (2012) } \\
\text { Salgado Junior (2013) } \\
\end{array}$ & \\
\hline & $\begin{array}{l}\text { 4.5. Respeito dos discentes em relação à figura do Professor, } \\
\text { Diretor e funcionários }\end{array}$ & $\begin{array}{c}\text { Cotton (1996) } \\
\text { MEC/UNICEF (2006) } \\
\text { Dourado; Santos e Oliveira (2007) } \\
\text { Leite e Tocornal (2012) } \\
\text { Salgado Junior (2013) } \\
\end{array}$ & \\
\hline \multirow[t]{3}{*}{$\begin{array}{l}\text { 5. Laboratório de } \\
\text { Informática }\end{array}$} & 5.1 Existência de laboratório de informática na escola & $\begin{array}{c}\text { Kulik (2003) } \\
\text { Bionde e Felício (2007) }\end{array}$ & $\begin{array}{c}\text { Gladdchef, Zuffi e Silva (2001) } \\
\text { Dourado, Santos e Oliveira (2007) } \\
\text { Franco (2008) } \\
\text { Suliano e Oliveira (2011) } \\
\text { INEP (2013) } \\
\end{array}$ \\
\hline & 5.2 Frequência das aulas de informática & & \\
\hline & 5.3 Número de computadores para cada 100 alunos & Menezes Filho (2007) & \\
\hline 6. Biblioteca & 6.1 Tamanho do acervo da biblioteca & $\begin{array}{c}\text { Quinhões (1999) } \\
\text { Dourado, Santos e Oliveira (2007) } \\
\text { Bezerra (2008) } \\
\text { UNICEF (2010) } \\
\text { Salgado Junior (2013) }\end{array}$ & \\
\hline
\end{tabular}




\begin{tabular}{|c|c|c|c|}
\hline & 6.2 Variedade do acervo da biblioteca & Salgado Junior (2013) & $\begin{array}{c}\text { Quinhões (1999) } \\
\text { Soares (2004) } \\
\text { Dourado, Santos e Oliveira (2007) } \\
\text { Bezerra (2008) }\end{array}$ \\
\hline \multirow[t]{2}{*}{ 7. Sala de Leitura } & 7.1 Existência de sala de leitura na escola & & $\begin{array}{c}\text { Soares (2004) } \\
\text { Dourado, Santos e Oliveira (2007) }\end{array}$ \\
\hline & \begin{tabular}{|l|}
7.2 Utilização da sala de leitura \\
\end{tabular} & & Soares (2004) \\
\hline \multirow[t]{2}{*}{ 8. Transporte } & $\begin{array}{l}8.1 \text { Frequência com que os alunos utilizam o transporte } \\
\text { público para ir à escola }\end{array}$ & & $\begin{array}{c}\text { BRASIL (2006) } \\
\text { Salgado Junior (2013) } \\
\text { Moura e Cruz (2013) }\end{array}$ \\
\hline & 8.2 Número de matrículas & & \\
\hline \multirow{10}{*}{ 9. Docentes } & $\begin{array}{l}9.1 \text { Porcentagem de docentes pertencentes ao gênero } \\
\text { feminino }\end{array}$ & & \\
\hline & 9.2 Porcentagem dos docentes tem o magistério concluído & & \\
\hline & $\begin{array}{l}9.3 \text { Porcentagem dos docentes que tem o curso de licenciatura } \\
\text { concluído }\end{array}$ & & \\
\hline & $\begin{array}{l}\begin{array}{l}9.4 \text { Porcentagem dos docentes que tem ensino superior } \\
\text { concluído }\end{array} \\
\end{array}$ & & \\
\hline & $\begin{array}{l}\begin{array}{l}9.5 \text { Porcentagem dos docentes que tem especialização } \\
\text { concluída }\end{array} \\
\end{array}$ & & \\
\hline & 9.6 Número docentes para cada 100 alunos. & & \\
\hline & 9.7 Incentivo financeiro & & \\
\hline & 9.7.1 Plano de carreira financeiramente atrativo & & $\begin{array}{l}\text { Vegas (2008) } \\
\text { Setúbal (2010) }\end{array}$ \\
\hline & 9.7.2 Salários acima da média regional & & $\begin{array}{l}\text { Vegas (2008) } \\
\text { Setúbal (2010) }\end{array}$ \\
\hline & 9.7.3 Progressão salarial & & $\begin{array}{l}\text { Vegas (2008) } \\
\text { Setúbal (2010) } \\
\end{array}$ \\
\hline 10. Funcionários & 10.1 Número de funcionários para cada 100 alunos & & \\
\hline
\end{tabular}

Quadro 20 - Autores que corroboram ou divergem dos resultados encontrados no estudo de caso em relação às práticas pedagógicas da escola

Fonte: Elaborado pelo autor 


\subsection{Análise das Práticas Administrativas dos SMEs nos cinco municípios}

Como as escolas eficientes e ineficientes estão localizadas no mesmo município e sobre a gestão da mesma SME, não foi possível identificar a influência da SME no desempenho das escolas (eficientes e ineficientes), no entanto, para fim de análise das boas práticas de gestão, foi realizada uma análise de frequência das principais práticas desenvolvidas pelas cinco SMEs dos municípios visitados.

No Quadro 21 é possível verificar a frequência das atividades que caracteriza cada indicador do instrumento administrativo aplicado aos SMEs. Nos gráficos apresentados nesta seção foram analisadas a frequência de todas as atividades encontradas nas SMEs, que colabora na formação de cada indicador.

Os resultados foram analisados e comparados à literatura, destacando-se para cada atividade as principais convergências e divergências entre os resultados encontrados e a percepção dos autores. 


\begin{tabular}{|c|c|c|c|c|c|c|c|c|}
\hline Instrumento & Indicador & & Mairinque & SãoJoséCampos & Dois Córregos & Tuiuti & Cerquilho & Frequência/Média \\
\hline \multirow{32}{*}{ SME } & \multirow{6}{*}{ 1. Constituição da SME } & 1.1. Todo corpo administrativo por indicação política & SIM & NÃO & SIM & SIM & SIM & $\mathrm{SIM}=4 ; \mathrm{N} \tilde{\mathrm{A} O}=1$ \\
\hline & & 1.2. Parte concursada e parte por indicação política & NÃO & SIM & $\mathrm{NA \tilde {O }}$ & NÃO & NÃO & $\mathrm{SIM}=1 ; \mathrm{NA \tilde {O }}=4$ \\
\hline & & \begin{tabular}{|l|} 
1.3. Escolha do Diretor \\
\end{tabular} & & & & & & \\
\hline & & 1.3.1. Indicação política & SIM & SIM & SIM & NÃO & SIM & $\mathrm{SIM}=4 ; \mathrm{N} \tilde{\mathrm{A} O}=1$ \\
\hline & & 1.3.2. Eleição pela comunidade escolar & NÃO & $\mathrm{NÃO}$ & NÃO & NÃO & NÃ̃ & $\mathrm{SIM}=0 ; \mathrm{NA \tilde {O }}=5$ \\
\hline & & 1.3.3. Concurso público & NÃO & NÃO & $\mathrm{NA \tilde {O }}$ & $\overline{S I M}$ & NÃO & $\mathrm{SIM}=1 ; \mathrm{NA \tilde {O } = 4}$ \\
\hline & \multirow{3}{*}{ 2. Organização Secretaria } & 2.1. Organograma & & & & & & \\
\hline & & 2.2. Governança & & & & & & \\
\hline & & 2.3. Organização de projetos (área de captação) & $\mathrm{NÃO}$ & $\mathrm{NÃO}$ & $\mathrm{NÃO}$ & NÃO & NÃO & $\mathrm{SIM}=0 ; \mathrm{NA \tilde {O }}=5$ \\
\hline & \multirow{9}{*}{ 3. Secretário } & 3.1. Formação (curso superior etc.) & SIM & SIM & SIM & SIM & SIM & $\mathrm{SIM}=5 ; \mathrm{NA} O=0$ \\
\hline & & \begin{tabular}{|l} 
3.2. Cursos complementares em Gestão \\
\end{tabular} & SIM & NÃO & $\mathrm{NA \tilde {O }}$ & NÃO & SIM & $\mathrm{SIM}=2 ; \mathrm{NA \tilde {O }}=3$ \\
\hline & & 3.3. Pré-requisitos para se tornar Secretário & & & & & & \\
\hline & & 3.3.1. Formação em pedagogia & SIM & $\mathrm{NA \tilde {O }}$ & $\mathrm{NÃO}$ & NÃO & NÃO & 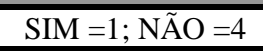 \\
\hline & & 3.3.2. Curso superior completo & $\mathrm{NÃO}$ & $\mathrm{NÃO}$ & NÃO & NÃO & SIM & $\mathrm{SIM}=1 ; \mathrm{NA \tilde {O } = 4}$ \\
\hline & & 3.3.3. Não há pré-requisitos & $\mathrm{NA \tilde {O }}$ & SIM & SIM & SIM & NÃO & $\mathrm{SIM}=3 ; \mathrm{NA} O=2$ \\
\hline & & 3.4. Autonomia para criação/alteração de políticas educacionais & 6 & 8 & 10 & 2 & 4 & 6,0 \\
\hline & & 3.5. Análise crítica da situação do município & 2 & 6 & 10 & 2 & 8 & 5,6 \\
\hline & & 3.6. Autonomia para decisões financeiras & 4 & 8 & 6 & 4 & 4 & 5,2 \\
\hline & \multirow{4}{*}{$\begin{array}{l}\text { 4. Capacidade da SME na } \\
\text { Captação de } \\
\text { Financeiros }\end{array}$} & 4.1. Projetos federais e estaduais & 2 & 2 & 6 & 2 & 4 & 3,2 \\
\hline & & 4.2. Parceria com empresas & 2 & 4 & 4 & 2 & 2 & 2,8 \\
\hline & & 4.3. Grau de conhecimento dos indicadores financeiros municipais & 2 & 6 & 2 & 4 & 2 & 3,2 \\
\hline & & \begin{tabular}{|l|} 
4.4. Recursos providos da APM \\
\end{tabular} & 2 & 2 & 8 & 2 & 2 & 3,2 \\
\hline & \multirow{3}{*}{$\begin{array}{l}\text { 5. Destinação do Recurso } \\
\text { Financeiro Descentralizado } \\
\text { e Centralizado }\end{array}$} & 5.1. Reparos emergenciais & 2 & 2 & 2 & 2 & 6 & 2,8 \\
\hline & & 5.2. Transporte & 10 & 4 & 2 & 10 & 8 & 6,8 \\
\hline & & 5.3. Cursos, palestras, orientações didático-pedagógicas & 4 & 10 & 4 & 2 & 8 & 5,6 \\
\hline & $\begin{array}{l}\text { 6. Transição de novo } \\
\text { Secretário e nova equipe }\end{array}$ & $\begin{array}{l}\text { 6.1. Grau de alteração do quadro de funcionários ao fim de cada gestão da } \\
\text { prefeitura ( } 4 \text { anos) }\end{array}$ & 8 & 4 & 10 & 8 & 10 & 8,0 \\
\hline & \multirow{2}{*}{$\begin{array}{l}\text { 7. Critério para matrícula } \\
\text { de alunos } \\
\end{array}$} & 7.1. Por zoneamento & SIM & SIM & SIM & SIM & SIM & $\mathrm{SIM}=5 ; \mathrm{NA} \tilde{\mathrm{O}}=0$ \\
\hline & & 7.2. Por escolha da família & NÃO & $\mathrm{NA \tilde {O }}$ & NÃO & NÃO & NÃO & $\mathrm{SIM}=0 ; \mathrm{NA \tilde {O }}=5$ \\
\hline & 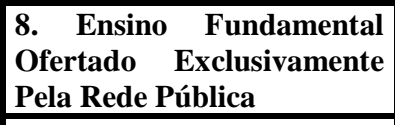 & 8.1 Exclusividade da oferta do ensino fundamental pela rede pública & SIM & NÃO & NÃO & SIM & NÃO & $\mathrm{SIM}=2 ; \mathrm{NÃO}=3$ \\
\hline & \multirow[t]{3}{*}{ 9. Informações Adicionais } & 9.1. Percentual de escolas rurais no município & 19,05 & 0,0 & 0,0 & 50,0 & 0,0 & 13,81 \\
\hline & & 9.2. Existência de política de progressão continuada & SIM & $\mathrm{NA \tilde {O }}$ & $\mathrm{NÃO}$ & NÃO & $\mathrm{NÃO}$ & $\mathrm{SIM}=1 ; \mathrm{NA \tilde {O } = 4}$ \\
\hline & & 9.3. Incentivos para participação em olímpiadas custeadas pelo Município & 4 & 8 & 8 & 4 & 6 & 6 \\
\hline
\end{tabular}

Quadro 21 - Comparação entre as práticas administrativas do SMEs dos cinco municípios

Fonte: Elaborado pelo autor com base nos resultados dos estudos de caso 
O Gráfico 35 e o Gráfico 36, apresentam a frequência das atividades desenvolvidas pelas cinco SMEs que compõe o indicador constituição da SME. No Gráfico 35, identificou-se que a atividade 1.1 é uma prática adotada por quatro das cinco SMEs visitadas, enquanto a atividade 1.2 foi adotada por apenas uma das cinco SMEs visitadas. Foram encontrados na literatura estudos que divergem da escolha do Secretário e do restante do corpo administrativo ser feita por meio de indicação política como forma de melhorar o desempenho dos alunos (MENDONÇA, 2001; SALGADO JUNIOR, 2013).

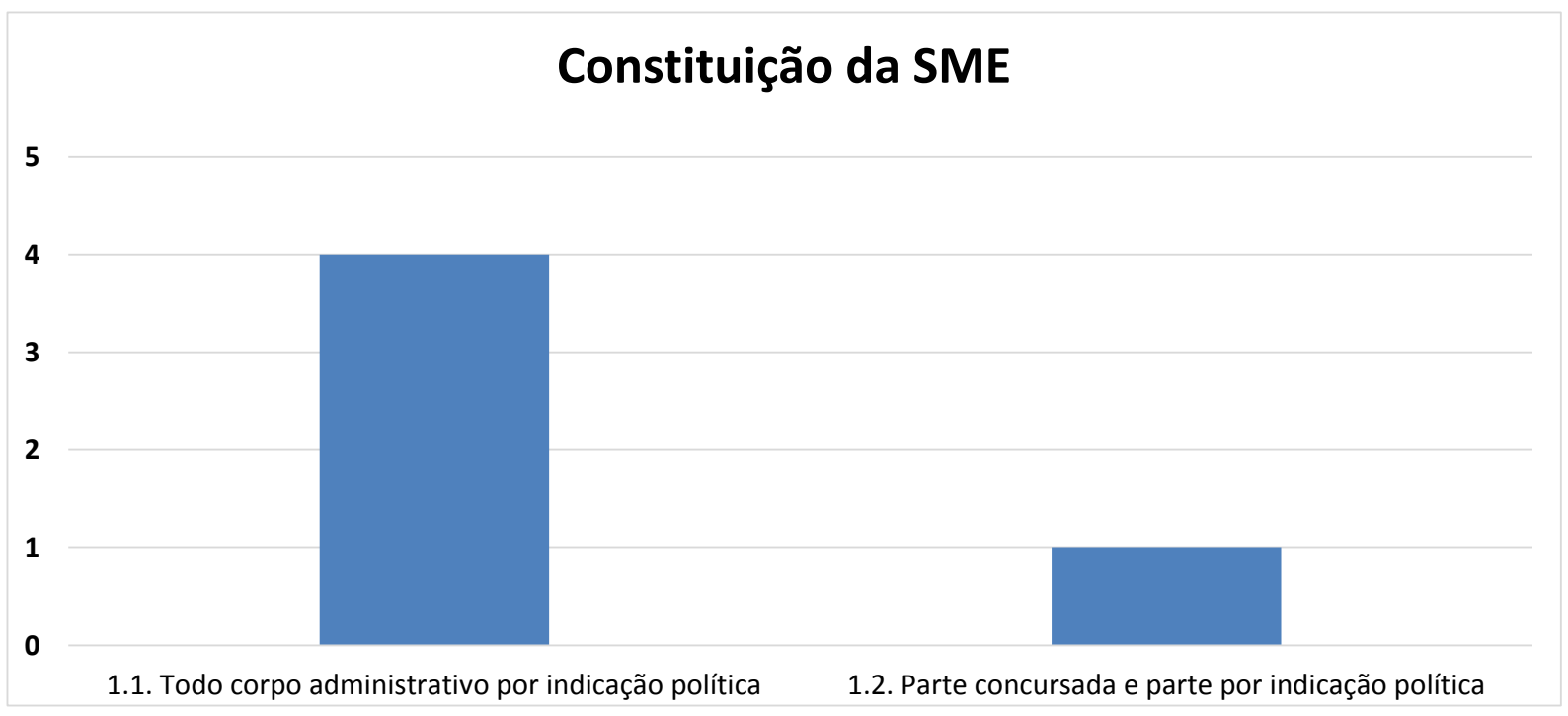

Gráfico 35 - Constituição da Secretaria Municipal de Educação

Fonte: Elaborado pelo autor, com base nos resultados dos estudos de caso

No Gráfico 36, identificou-se que a atividade 1.3.1 é uma prática adotada por quatro das cinco SMEs visitadas, enquanto a atividade 1.3 .3 foi adotada por apenas uma das cinco SMEs visitadas. Mendonça (2001) e Lück (2009) defendem que a escolha do Diretor não deve ser feita por meio de indicação política, pois deve levar em consideração a competência e o conhecimento profissional e não os interesses partidários, que demonstra constituir-se em um elemento desvirtuador do princípio de que a educação está acima dos interesses de grupos específicos. 


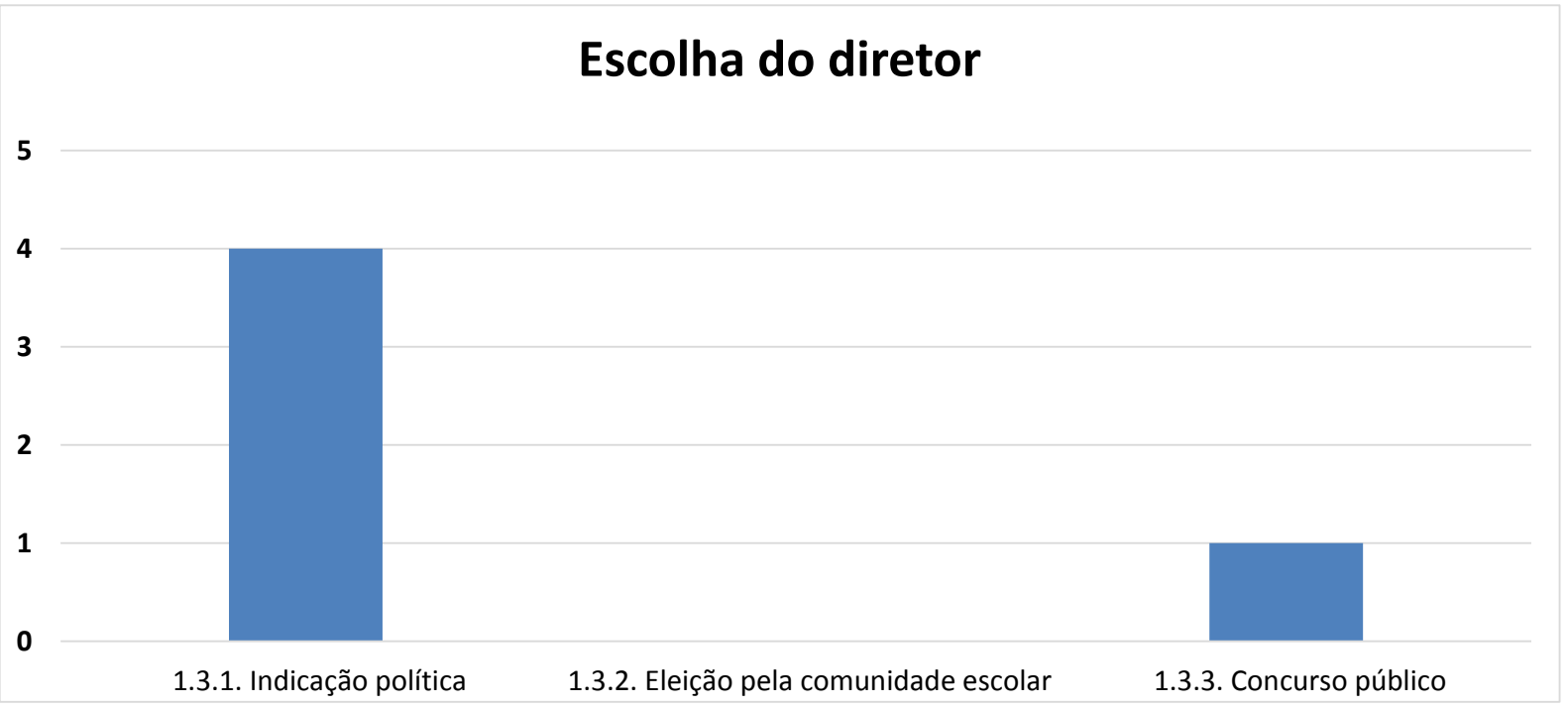

Gráfico 36 - Escolha do Diretor

Fonte: Elaborado pelo autor, com base nos resultados dos estudos de caso

Os gráficos 37, 38, 39 e 40, apresentam a frequência das atividades desenvolvidas pelas cinco SMEs que compõe o indicador Secretário.

No Gráfico 37, é possível verificar que a atividade 3.1 é uma prática adotada pelas cinco SMEs visitadas. Segundo o INEP (2011), a formação em curso superior dos SMEs é um fator que influencia positivamente o desempenho das escolas. Neste sentido, ao realizar uma pesquisa a fim de identificar a característica dos Secretários municipais de educação, o INEP (2011) identificou que mais de 90\% dos Secretários entrevistados possuem formação em nível superior. Outros autores também destacam a importância dos Secretários possuírem formação superior (LÜCK, 2009; UNDIME, 2012). Nesse mesmo gráfico, é possível verificar que a atividade 3.2 (cursos complementares em gestão) foi adotada por apenas duas das cinco SMEs visitadas.

Neste sentido, Lück (2000) identificou que em geral os Secretários não possuem formação em gestão. Ainda que parte dos Secretários não tenha cursos complementares de gestão, a literatura destaca a importância da formação em gestão pelos Secretários como forma de melhorar o desempenho das escolas (LÜCK, 2000; LÜCK, 2009; UNDIME, 2012). 


\section{Formação dos SMEs}

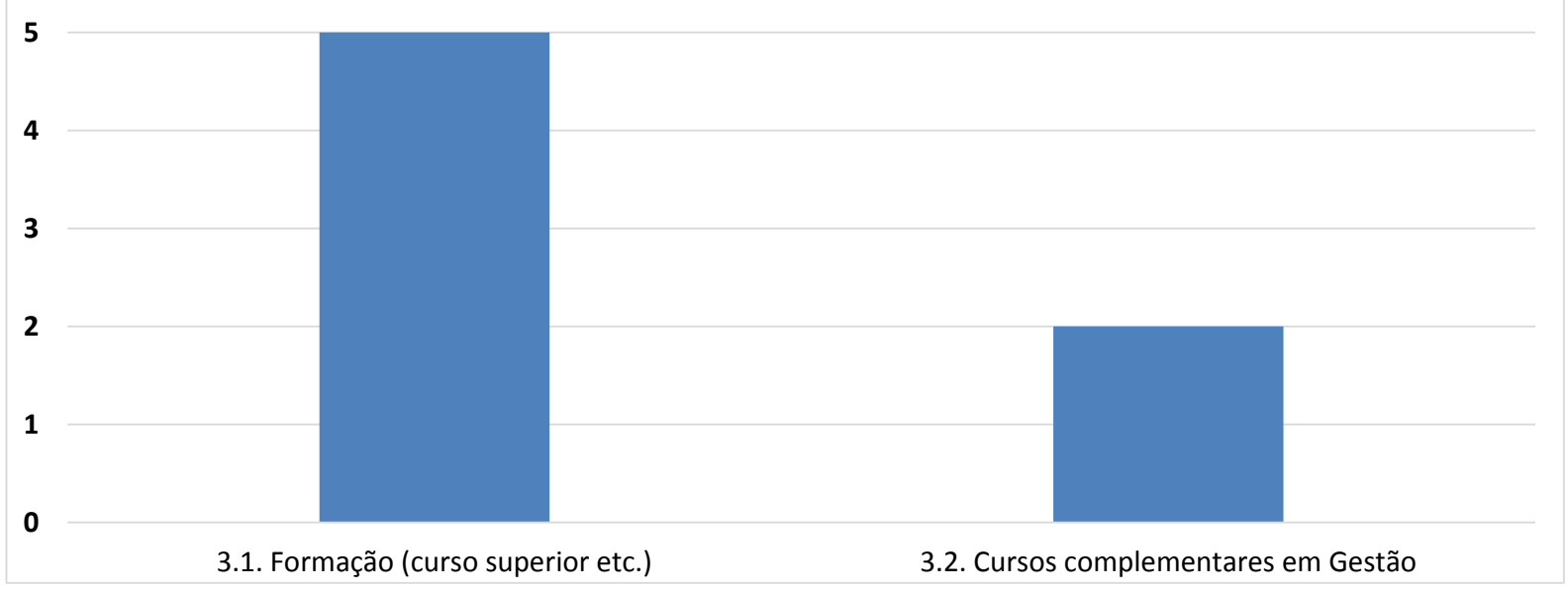

Gráfico 37 - Formação do Secretário Municipal de Educação

Fonte: Elaborado pelo autor, com base nos resultados dos estudos de caso

No gráfico 38, é possível verificar a área de formação dos Secretários entrevistados, lembrando que cada Secretário pode possuir mais do que uma graduação. Deste modo, identificou-se que nas cinco SMEs visitadas quatro Secretários possuem formação em pedagogia, três em letras, um em matemática, dois em administração e dois em outras áreas de conhecimento. Em pesquisa realizada em 2011, o Instituto de Estudos e Pesquisas Educacionais Anísio Teixeira (INEP, 2011) destacou que 44,9\% do total de Secretários entrevistados possuem formação em pedagogia.

\section{Cursos de formação dos SMEs}

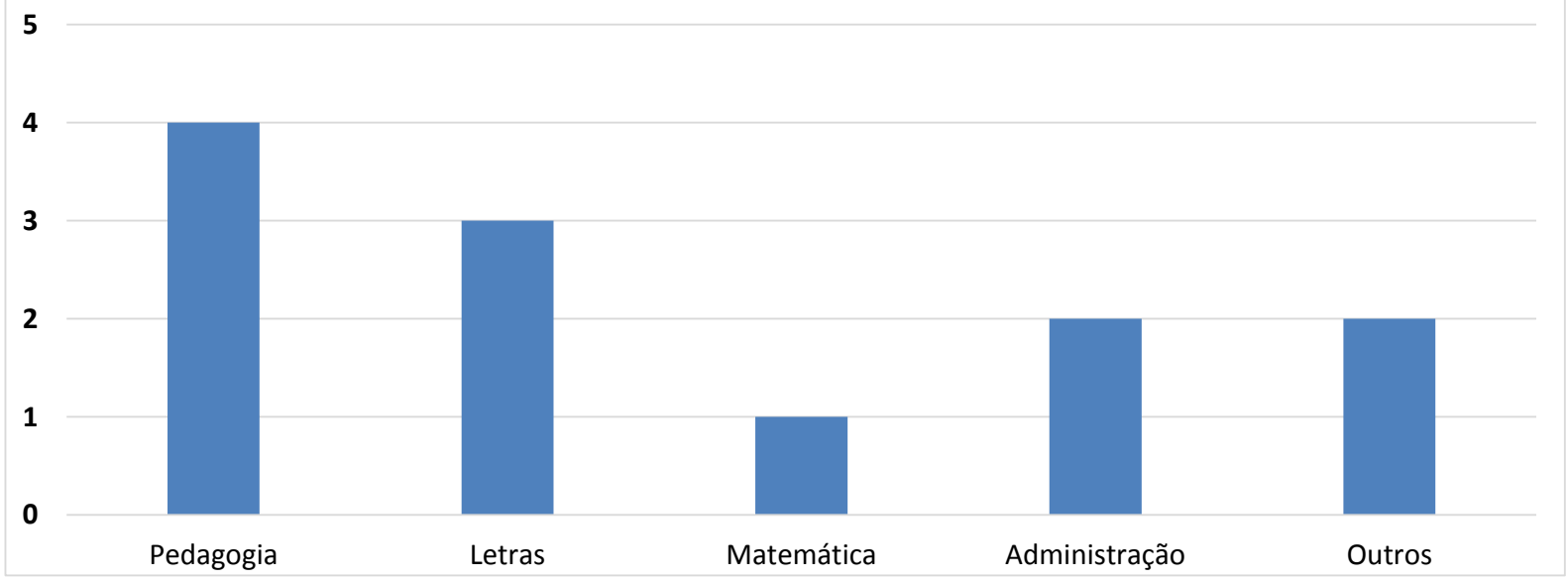

Gráfico 38 - Cursos de formação dos SMEs

Fonte: Elaborado pelo autor, com base nos resultados dos estudos de caso 
No gráfico 39, identificou-se que a atividade 3.3.1 é uma prática adotada por uma das cinco SMEs visitadas, enquanto a atividade 3.3.2 foi adotada por apenas uma das cinco SMEs visitadas, já a atividade 3.3.3 foi adotada por três das cinco SMEs visitadas. Com relação à atividade 3.3.3, a Undime (2012) defende que a qualificação técnica e a formação adequada do candidato a Secretário municipal de educação são um pré-requisito indispensável para o desenvolvimento de sua função.

\section{Pré-requisitos para se tornar SME}

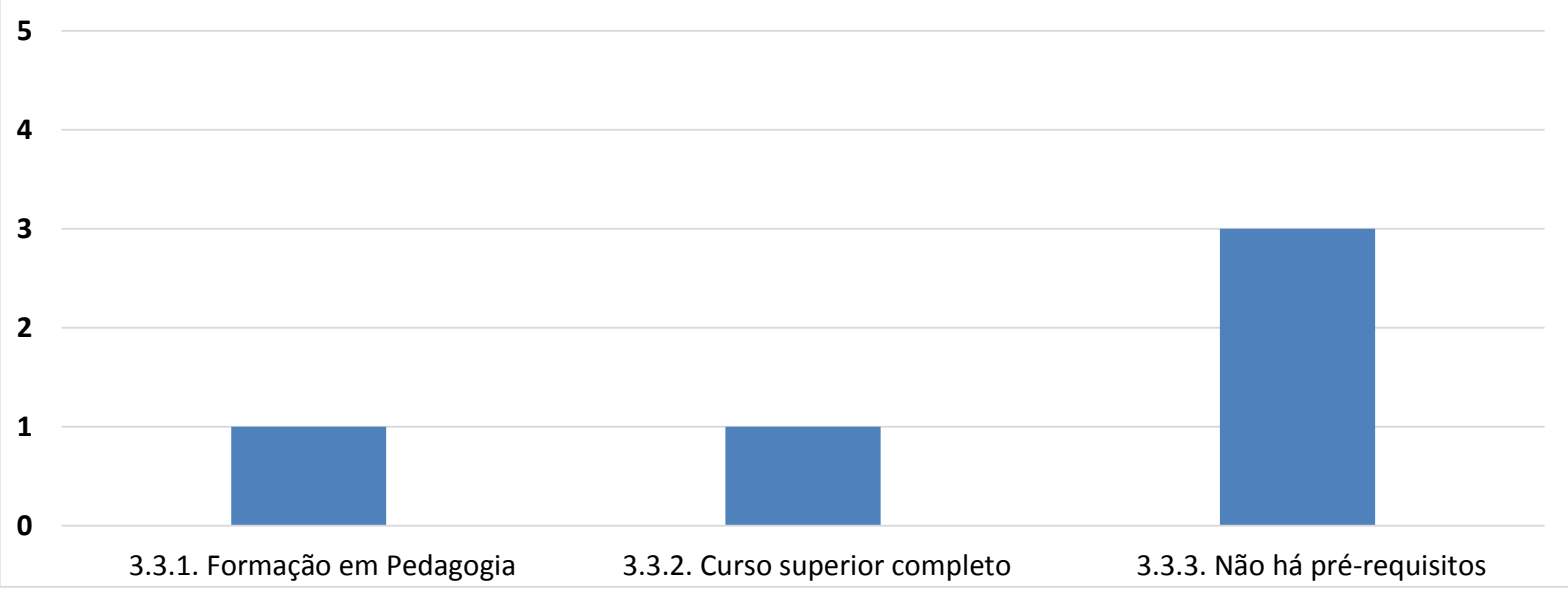

Gráfico 39 - Pré-requisitos para se tornar SME

Fonte: Elaborado pelo autor, com base nos resultados dos estudos de caso

No gráfico 40, é possível verificar, em relação à atividade 3.4, que o município de Dois Córregos e São José dos Campos, acompanhado em terceiro lugar por Mairinque, possuem uma maior autonomia para a criação/alteração de políticas educacionais quando comparado com os demais municípios. Com relação a esta atividade, foram identificados estudos que destacam a importância da autonomia do Secretário sobre a criação ou alteração das políticas educacionais (INEP, 2011; UNDIME, 2012).

Neste mesmo gráfico, é possível verificar, em relação à atividade 3.5, que o município de Dois Córregos e Cerquilho, acompanhado em terceiro lugar por São José dos Campos, possuem uma maior análise crítica da situação do município quando comparado com os demais municípios. Neste sentido, a UNDIME (2012) destaca a importância de o Secretário possuir uma ampla análise crítica da situação do município como forma de otimizar recursos e adotar práticas que melhorem o desempenho da escola (UNDIME, 2012). 
Ainda no Gráfico 40, em relação à atividade 3.6, é possível verificar que o município de São José dos Campos e Dois Córregos, possuem uma maior autonomia para decisões financeiras quando comparado com os demais municípios.

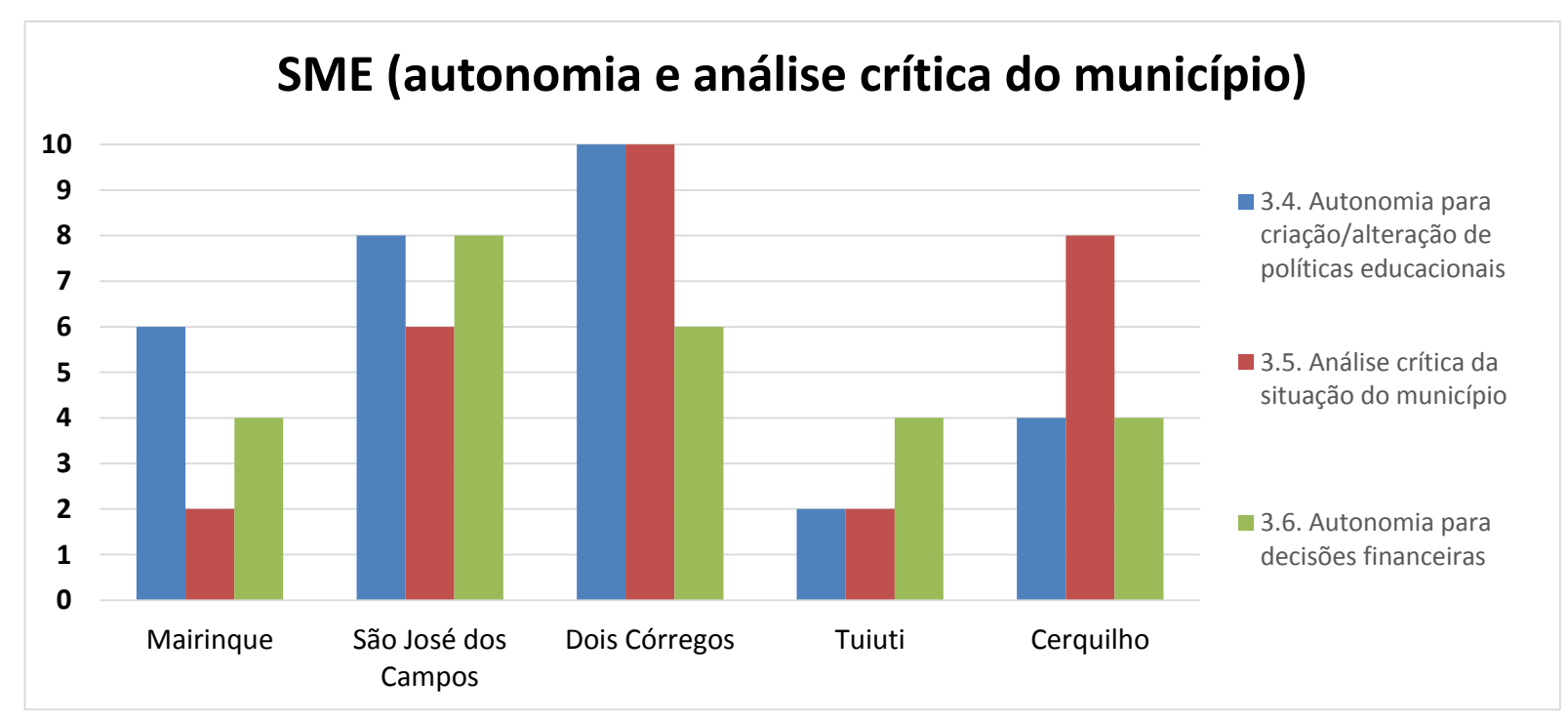

Gráfico 40 - Autonomia e análise crítica do município

Fonte: Elaborado pelo autor, com base nos resultados dos estudos de caso

No gráfico 41 é possível verificar em relação às atividades 4.1, 4.2 e 4.4, que as cinco SMEs visitadas possuem na média uma maior capacidade de captação de recursos financeiros em projetos federais e estaduais e recursos da APM do que em parceria com empresas. Soares (2004); Dourado, Santos e Oliveira (2007) e Marchelli (2010) destacam a importância da SME na captação de recursos financeiros como forma de melhorar o desempenho das escolas. Nesse mesmo gráfico, também é possível verificar em relação à atividade 4.3, na qual os Secretários demonstraram na média possuir um baixo nível de conhecimento sobre os indicadores financeiros municipais. 


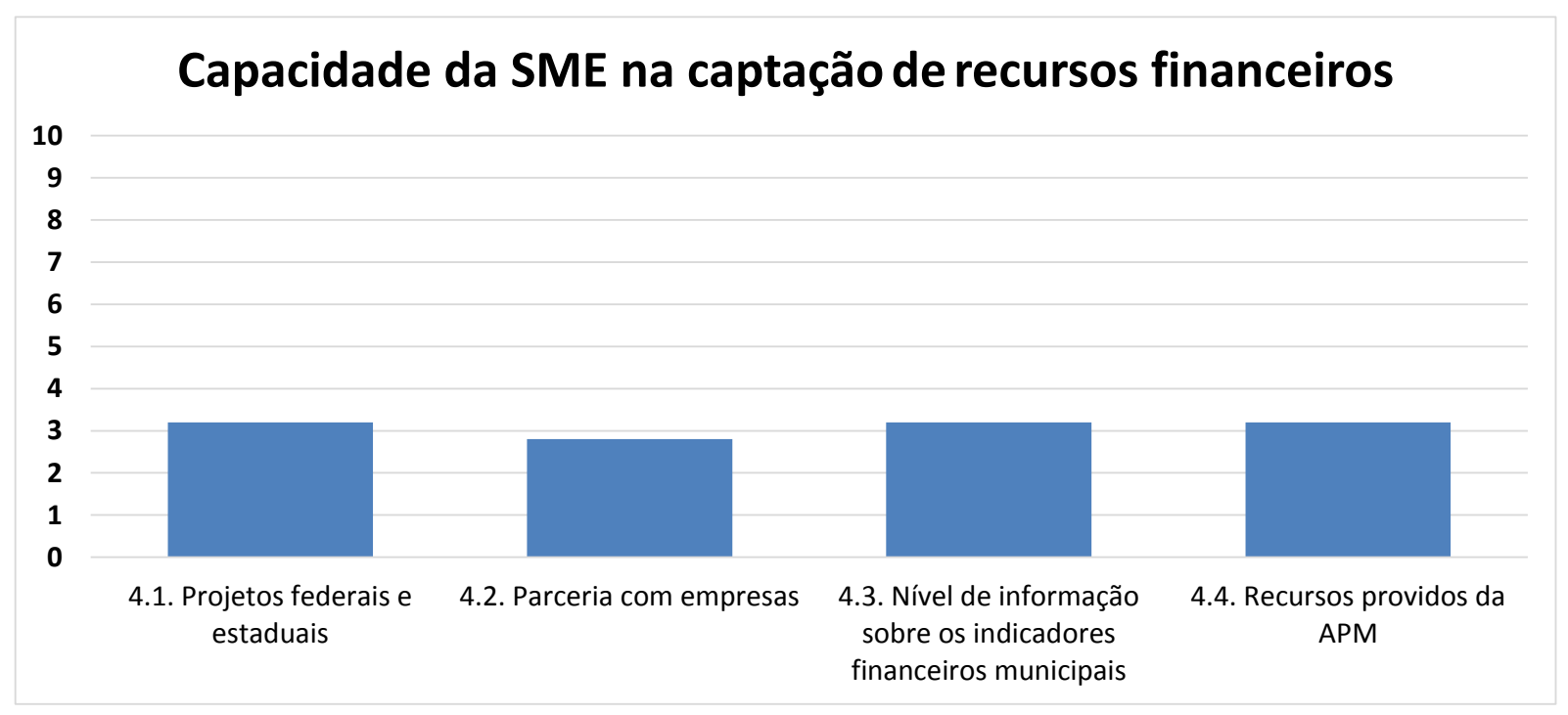

Gráfico 41 - Capacidade da SME na captação de recursos financeiros

Fonte: Elaborado pelo autor, com base nos resultados dos estudos de caso

No gráfico 42, identificou-se que a atividade 5.2 (destinação de recursos para transporte) foi a que mais recebeu recursos na média das cinco SMEs visitadas. Na literatura foram encontrados estudos que destacam a importância da destinação de recursos para o transporte escolar como forma de inclusão e garantia de educação (BRASIL, 2006; MOURA; CRUZ, 2013). Nesse mesmo gráfico, identificou-se que a atividade 5.3, relacionada ao aperfeiçoamento profissional, foi a segunda atividade que na média recebeu mais recursos das cinco SMEs visitadas. Com relação a esta atividade, vários autores destacam a importância da destinação de recursos ao aperfeiçoamento dos profissionais da educação como forma de melhorar o desempenho e qualidade de ensino nas escolas (BRASIL, 2006; BRASIL, 2007; VEGAS, 2008; BROOKE; SOARES, 2008; SETÚBAL, 2010; LEME et al, 2012).

Por fim, a atividade 5.1 (reparos emergenciais) foi a que menos recebeu recursos das três atividades destacadas nas cinco SMEs visitadas. A literatura destaca a importância da destinação de recursos a reparos emergenciais, principalmente em infraestrutura, que tem como objetivo proporcionar boas condições para que o aluno permaneça na escola (CEPAL, 2000; MEC; UNICEF, 2006; GAME, 2002). 


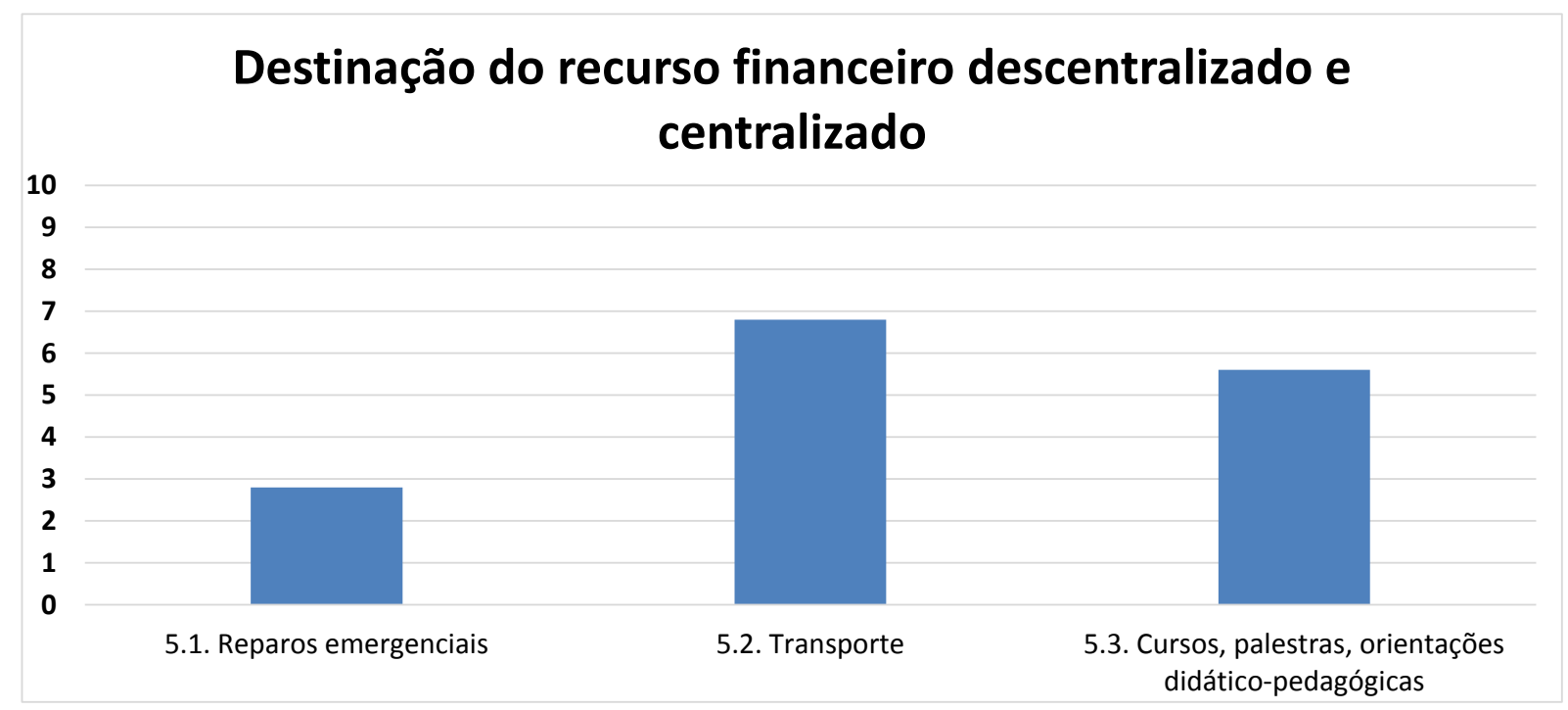

Gráfico 42 - Destinação do recurso financeiro descentralizado e centralizado

Fonte: Elaborado pelo autor, com base nos resultados dos estudos de caso

No gráfico 43, é possível verificar em relação à atividade 6.1, que o município de Dois Córregos e Cerquilho, empatados em primeiro lugar, são os que apresentam maior grau de alteração do quadro de funcionários da SME ao fim de cada gestão municipal (4 anos), acompanhado por Mairinque e Tuiuti, empatados em segundo lugar e por São José dos Campos em terceiro lugar. Lück (2009) e Mendonça (2001) apontam os efeitos negativos e o prejuízo causado à qualidade da educação pelas mudanças de gestão por prefeitos e Secretários de educação. Neste sentido, municípios com maior grau de alteração do quadro de funcionários a cada gestão da prefeitura tendem a ter maiores problemas em continuidade de projetos e adoção de políticas de ensino duradouras (VEJA, 2013).

\section{Transição de novo secretário e nova equipe}

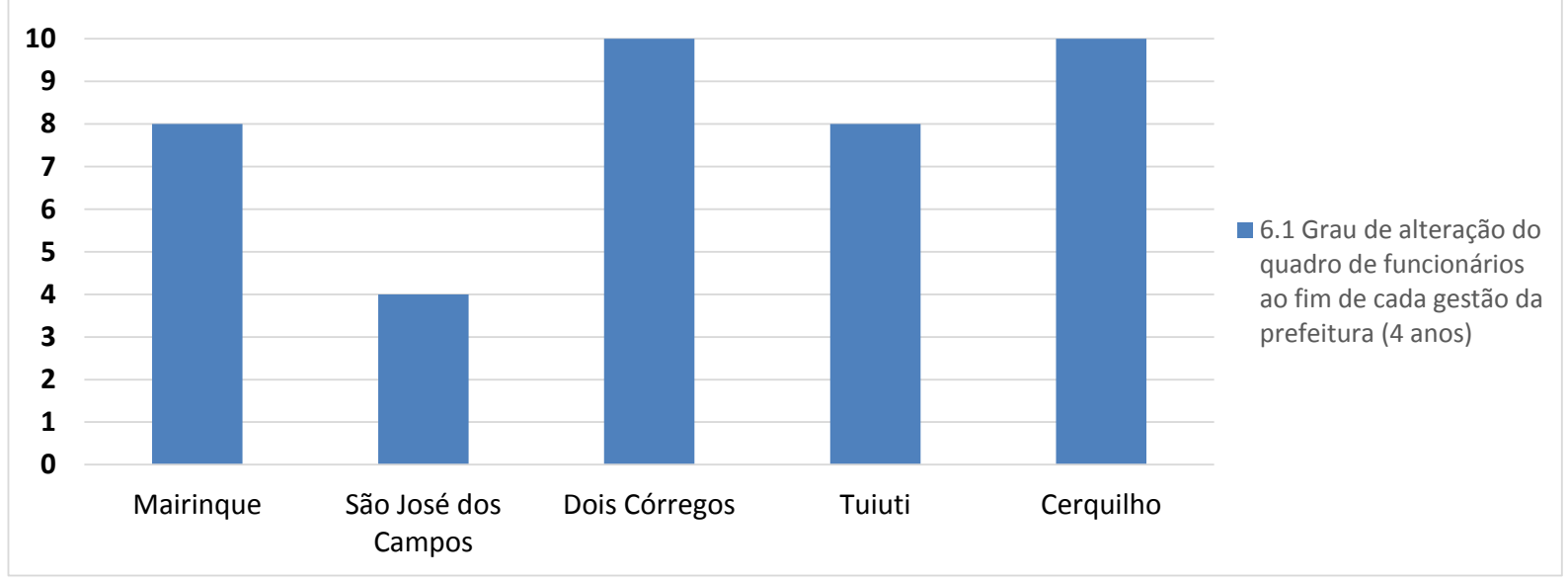

Gráfico 43 - Transição de novo Secretário e nova equipe

Fonte: Elaborado pelo autor, com base nos resultados dos estudos de caso 
No gráfico 44, é possível verificar em relação à atividade 7.1 e 7.2, que o critério para matrícula de alunos nas cinco SMEs visitadas é por zoneamento. Este modelo é o mais adotado nos municípios pela facilidade de acesso às escolas pelos estudantes (SOARES, 2004; DELGADO; MACHADO, 2007; SETUBAL, 2010)

\section{Critério para matrícula de alunos}
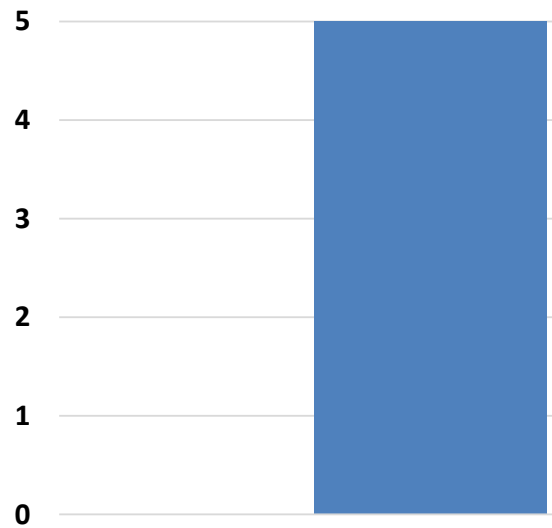

7.1. Por zoneamento

7.2. Por escolha da família

Gráfico 44 - Critério para matrícula dos alunos

Fonte: Elaborado pelo autor, com base nos resultados dos estudos de caso

No gráfico 45, é possível verificar em relação à atividade 8.1, que em duas das cinco SMEs visitadas o ensino fundamental é ofertado exclusivamente pela rede pública, sendo que as outras três foram encontrados ensino fundamental em escolas particulares.

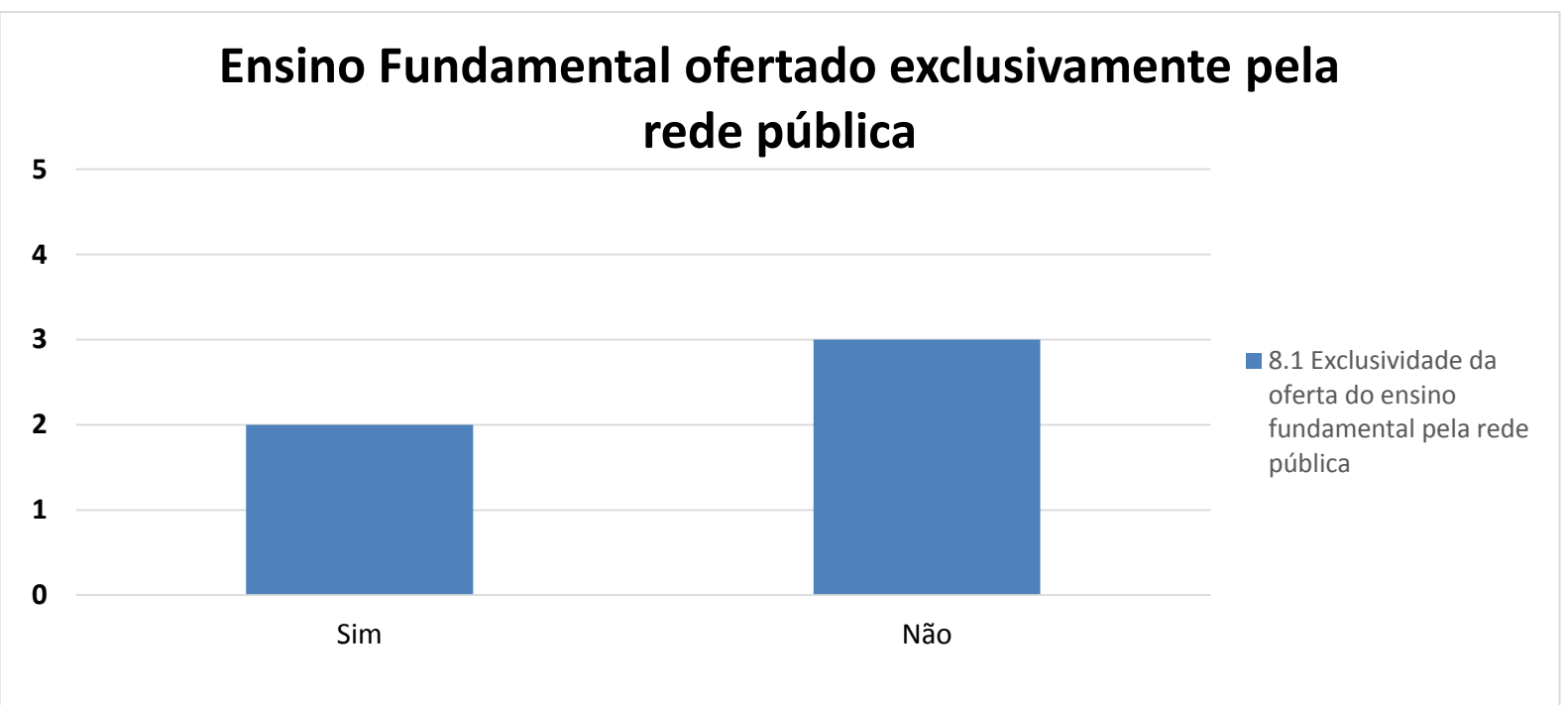

Gráfico 45 - Exclusividade da oferta do ensino fundamental pela rede pública Fonte: Elaborado pelo autor, com base nos resultados dos estudos de caso 
Os gráficos 46, 47 e 48, apresentam a frequência das atividades desenvolvidas pelas cinco SMEs que compõe o indicador informações adicionais. No gráfico 46, é possível verificar em relação à atividade 9.1, que no município de Tuiuti 50\% do total de escolas públicas municipais são rurais, enquanto no município de Mairinque esse percentual é de 19,05\%. Já o município de São José dos Campos, Dois Córregos e Cerquilho não possuem escolas rurais.

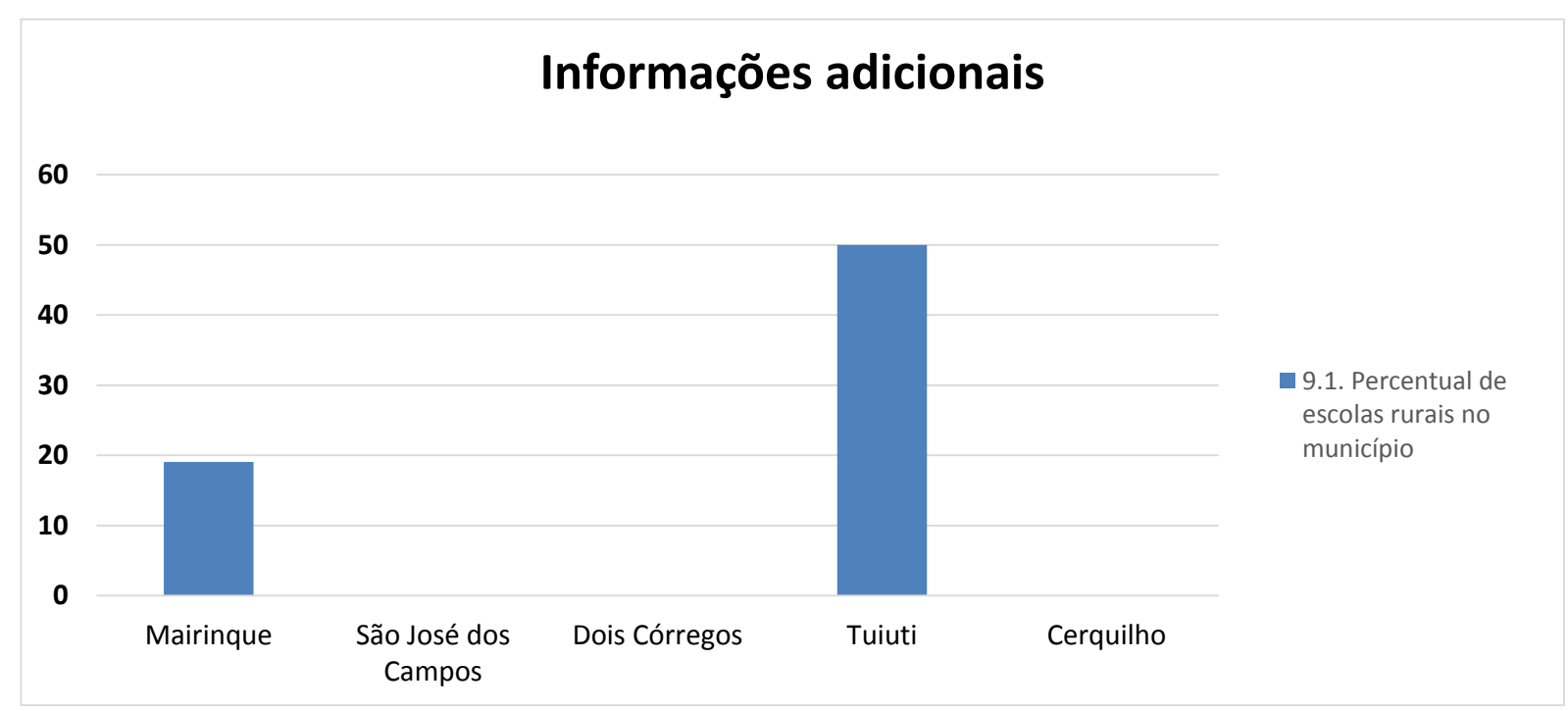

Gráfico 46 - Escolas rurais no município

Fonte: Elaborado pelo autor, com base nos resultados dos estudos de caso

No gráfico 47, é possível verificar em relação à atividade 9.2, que quatro das cinco SMEs visitadas não possuem política de progressão continuada. Segundo o MEC (2006) e Dourado, Santos e Oliveira (2007), a adoção de política de progressão continuada é utilizada como um mecanismo para evitar a evasão escolar. Esta prática, no entanto, pode permitir que alunos menos preparados passassem para séries superiores sem obter o nível mínimo de conhecimento para isso prejudicando o aprendizado de temas novos e, por vezes, atrasando o aprendizado da turma (uma vez que o docente possa direcionar mais tempo e atenção para os alunos com maior dificuldade de aprendizado). 


\section{Informações adicionais}

\section{5}

\section{4}

3

2

1

0

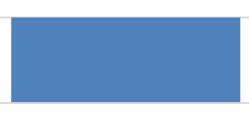

$\operatorname{Sim}$

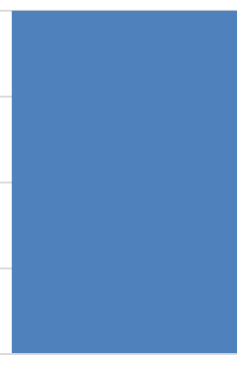

Não
9.2. Existência de política de progressão continuada

Gráfico 47 - Política de progressão continuada

Fonte: Elaborado pelo autor, com base nos resultados dos estudos de caso

No gráfico 48, é possível verificar em relação à atividade 9.3, que o município de São José dos Campos e Dois Córregos, empatados em primeiro lugar, são os que mais oferecem incentivos financeiros para os alunos participarem de olímpiadas, acompanhado por Cerquilho em segundo lugar, e por Mairinque e Tuiuti, empatados em terceiro lugar.

\section{Informações adicionais}

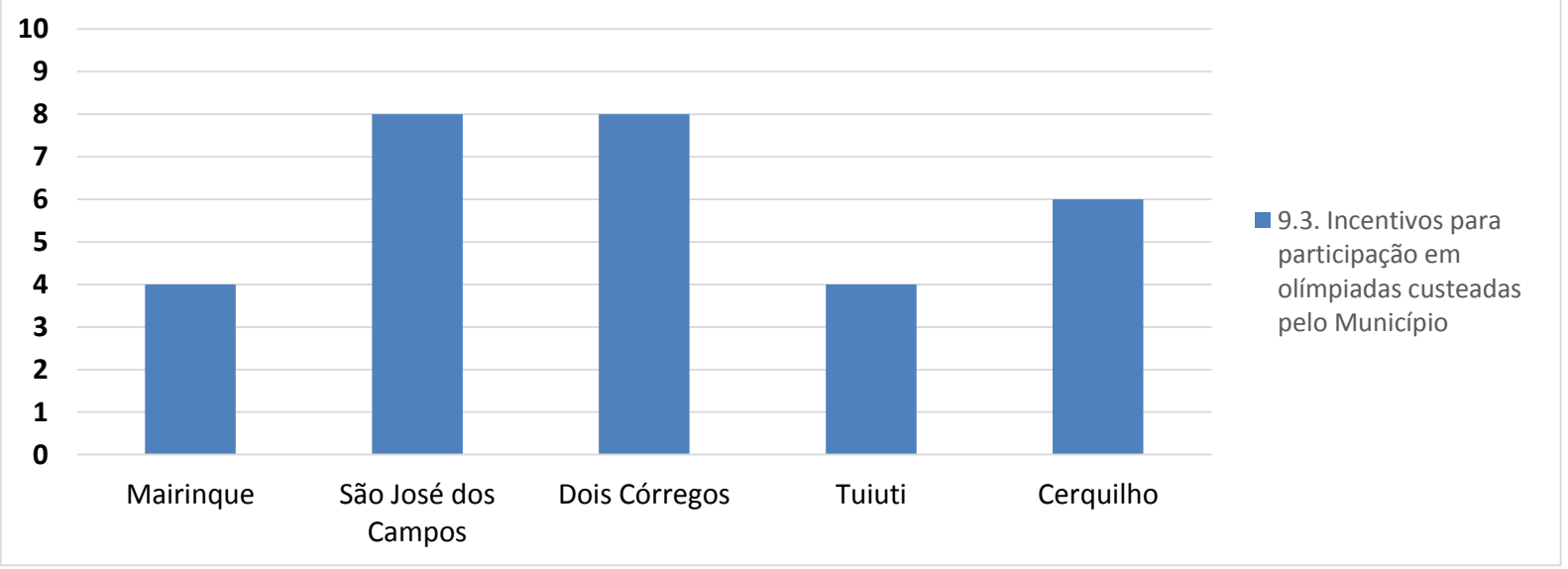

Gráfico 48 - Incentivos para participação em olimpíadas custeadas pelo município

Fonte: Elaborado pelo autor, com base nos resultados dos estudos de caso

A seguir são apresentadas as atividades com diferença expressiva (ou pouco expressiva) com capacidade explicativa no desempenho dos alunos. 


\subsection{Avaliação dos fatores identificados frente a estudos encontrados na literatura}

$\mathrm{Na}$ literatura foram identificados autores, cujos trabalhos corroboram ou divergem dos resultados encontrados nesta dissertação. Desta forma, esta seção apresenta as atividades com diferença expressiva (ou pouco expressiva) com capacidade explicativa no desempenho das escolas eficientes quando comparadas com as escolas ineficientes. Assim, as atividades são divididas nas subseções que avaliam as atividades com diferença expressiva medida pelo instrumento administrativo aplicado ao Diretor e as atividades com diferença expressiva medida pelo instrumento pedagógico aplicado aos principais atores que envolvem a escola (Professor, aluno e pais de alunos). No caso das SMEs não há destaque de atividades com diferença expressiva (ou pouco expressiva) entre escolas eficientes e ineficientes uma vez que ambas as escolas estão localizadas em um mesmo município e sob responsabilidade da mesma SME (e desta forma uma atividade da SME não pode influenciar positivamente uma escola e negativamente outra).

\subsubsection{Atividades com diferença expressiva (e pouco expressiva) relacionada ao instrumento administrativo do Diretor}

Foram identificadas três atividades com capacidade explicativa relacionada ao instrumento administrativo do Diretor, sendo que uma delas foi considerada como diferença expressiva (Atividade 1.1) e outras duas atividades (Atividade 5.3 e Atividade 5.4) consideradas pouco expressivas quando comparado o desempenho entre escolas eficientes e ineficientes. As demais atividades do instrumento administrativo do Diretor não apresentam diferenças expressivas e, desta forma, não tem capacidade explicativa na diferença do desempenho entre as escolas deste estudo de caso. As principais atividades são apresentadas a seguir.

\section{Atividade 1.1. Cobrança da Comunidade perante o Diretor}

A cobrança da comunidade perante o Diretor, neste instrumento, foi a atividade com maior diferença (diferença expressiva) quando comparadas as escolas eficientes e ineficientes. Esse resultado sugere que a participação, envolvimento e cobrança da comunidade junto ao Diretor por melhor ensino e desempenho tende a ser um fator que provoca melhoria de desempenho. Em escolas em que não há cobrança do Diretor ou não há participação ou envolvimento da comunidade o desempenho tende a ser menor. 
Este resultado é corroborado por Leme, Paredes e Souza (2009) que destacam que um sistema descentralizado torna a gestão mais flexível e transparente, aprimorando sua governança e, desta forma, promovendo a participação da família e comunidade no processo educativo dos seus filhos. Segundo o MEC e UNICEF (2006, p. 27), a participação da comunidade é fundamental para o bom desempenho dos alunos nas escolas, sendo que esta participação pode se dar por meio de três formas: gestão participativa e democrática da escola; o envolvimento e a presença dos pais das crianças e dos adolescentes; e as parcerias externas com empresas, associações de moradores e ONGs. Relatos da revista Veja (VEJA, 2013) também apontam para a participação e cobrança da comunidade como forma de melhorar o desempenho. Segundo a revista, as razões do bom desempenho de Novo Horizonte (município que possuía em 2013 a melhor rede municipal de ensino fundamental segundo a Prova Brasil) são relacionados ao comprometimento de gestores, pais e Professores, sendo que a participação da família e a cobrança da comunidade são destacadas na reportagem.

\section{Atividade 5.3. Rifas e Festividades}

Esta atividade, também com diferença pouco expressiva entre escolas eficientes e ineficientes, busca relacionar a realização de rifas e festividades no desempenho dos alunos. Segundo Zaikievicz e Schneckenber (2011), estas atividades, na maioria das vezes, voltam-se para realização de eventos a fim de angariar lucros para a escola, lucros esses revertidos na compra de materiais e modernização da escola que, segundo os autores, seria função dos órgãos públicos. Assim, esta atividade pode ser importante por ser direcionada na escola de forma descentralizada (sem ter um encaminhamento previamente determinado) podendo atender às necessidades específicas da escola, envolvendo necessidade de infraestrutura e dos alunos.

Apesar dos argumentos de defesa desta atividade como recurso complementar para melhoria no desempenho, Rocha (2006, p 7) aponta que a realização de rifas, festividades, bingos e outras atividades de caráter de arrecadação de recursos pode não ser efetivo na melhoria do desempenho. Segundo o autor, essas ações não representam os desejos comunitários e estes recursos podem ser utilizados de maneira pouco efetiva nas escolas. 


\section{Atividade 5.4. Recursos providos da APM}

Os recursos providos pela APM também tiveram diferença pouca expressiva na comparação entre escolas eficientes e ineficientes. Estes recursos, assim como os recursos oriundos de rifas, festividades e bingos são descentralizados. Desta forma, estes recursos podem ser utilizados de maneira mais objetiva em casos de necessidades imediatas da escola ou na carência de infraestrutura. Segundo o MEC e UNICEF (2006, p. 62), em algumas escolas os laboratórios de informática e ciências, assim como quadras poliesportivas e bibliotecas são mantidas pelos pais e comunidades, destacando a importância dos recursos providos pela associação de pais e mestres, além da própria comunidade. Além disto, em muitos casos os pais têm fortes laços e vínculos com a escola, fazendo com que eles participem ativamente dos interesses dos alunos e da escola.

De uma maneira geral, Zaikievicz e Schneckenber (2011) destacam que a APM tem uma importante participação na organização de festas e eventos como forma de arrecadação de recursos, como foi apontada pela atividade anterior. Rocha (2006) critica as APMs pela preocupação ser voltada principalmente aos recursos financeiros e, segundo o autor, quase nunca voltada para assuntos pedagógicos.

\subsubsection{Atividades com diferença expressiva (e pouco expressiva) relacionada ao instrumento pedagógico}

Com relação ao instrumento pedagógico, foram identificadas 20 atividades com capacidade explicativa, segmentadas no desempenho das provas de Português, desempenho das provas de Matemática, participação da família no processo de educação, reprovação discente e sistema disciplinar e biblioteca. Estas atividades podem estar mais fortemente relacionadas ao desempenho (atividades com diferença expressiva entre escolas eficientes e ineficientes) ou apenas com indícios de relacionamento com o desempenho (atividades com diferença pouco expressiva). As atividades são apresentadas a seguir. 


\section{Atividade 1.2. Frequência de leitura dos alunos}

A frequência de leitura dos alunos, juntamente com a preparação para a Prova Brasil, é a atividade com maior diferença expressiva entre escolas eficientes e ineficientes no desempenho em Português. Esse resultado sugere que a maior frequência de leitura dos alunos tende a promover ganhos de desempenho destes alunos nas escolas.

Boruchovitch (2001) e Zoghbi e Louzano (2012) destacam a necessidade de uma atuação conjunta entre a escola e a família, uma vez que a competência em leitura é influenciada por fatores motivacionais, cognitivos e contextuais como os familiares e escolares. Para Delmanto (2009), no entanto, o simples fato do aluno saber ler ou escrever (estar apenas alfabetizado) não é suficiente para melhorar o desempenho, pois para que a leitura tenha impacto no desempenho é necessário que o aluno tenha capacidade de compreensão de textos mais complexos. Além disso, Farias (2010) aponta que o indivíduo precisa praticar a leitura de forma correta, interagindo com o texto lido, de forma que o mesmo obtenha sentido, desvelando, analisando e contextualizando o texto, para estabelecer as suas inter-relações criticamente na realidade social. Para Oliveira, Boruchovitch e Santos (2008), sob este aspecto,

[...] é possível fomentar que quanto mais contato se tem com a leitura, isto é, quanto mais se lê, mais aprimorada se torna a habilidade de compreensão, em razão do desenvolvimento e ampliação dos conhecimentos prévios que servirão de base para a compreensão de novas informações (OLIVEIRA; BORUCHOVITCH; SANTOS, 2008, pp. 532-533)

De acordo com Souza, Souza e Bonfim (2010), o ato de ler frequentemente aumenta a capacidade crítica e o desenvolvimento intelectual permitindo ganhos diversos como capacidade de defender argumentos ou pontos de vista; desenvolvimento de pensamentos, ideias, imaginação e capacidade de discussão de textos.

\section{Atividade 1.3. Rotatividade dos Professores na disciplina de Português}

A rotatividade dos Professores na disciplina de Português também foi uma atividade com diferença expressiva entre as escolas eficientes e ineficientes. Neste sentido, foi identificado neste trabalho um melhor desempenho em escolas com baixa rotatividade de Professores. Esse resultado também foi encontrado no trabalho de Biondi e Felício (2007) que destacam a baixa rotatividade como fator de melhoria na performance dos alunos. Com base nesta 
observação pode-se inferir que o aumento da rotatividade do Professor impede que a sala de aula siga uma sequência didática de ensino, fazendo com o que o conhecimento seja passado para os alunos de maneira desestruturada. Outro fator relacionado à rotatividade é o tempo de reposição do Professor na escola, sendo que o período entre a saída de um Professor e a recolocação de outro pode prejudicar os alunos. Esse resultado também foi encontrado por Alves e Soares (2007) que relacionam a ausência do Professor com o baixo desempenho dos alunos.

De acordo com GAME (2002), a rotatividade pode ser explicada pela forma com que os Professores são designados pela Secretaria Municipal de Ensino. Segundo o grupo (GAME, 2002), além das escolas não poderem selecionar os seus Professores e da demora com que o processo vem sendo feito, as designações fazem com que exista nas escolas uma grande rotatividade de Professores, afetando seu funcionamento. Além destes fatores a causa da rotatividade também pode ser levada em questão, pois é difícil afirmar se o Professor deixou a escola por conta das condições de ensino (salário incompatível com suas necessidades ou salas de aula de difícil controle) ou pela formação deficitária do Professor.

Vegas (2008) ainda destaca que o impacto de um Professor sobre os resultados de aprendizagem dos alunos é cumulativo e duradouro, de modo que um Professor ineficaz reduz potencialmente o desempenho do aluno durante anos. Assim, para minimizar os impactos negativos dos Professores no desempenho dos alunos o autor sugere a adoção de duas políticas eficientes na gestão dos Professores: (1) os incentivos que buscam atrair, motivar e reter Professores de alta qualidade e (2) as políticas que buscam melhorar as habilidades e os conhecimentos dos Professores, através de treinamento e capacitação.

\section{Atividade 1.4. Frequência que o docente acompanha o desempenho do aluno na disciplina de Português}

A frequência que o docente acompanha o desempenho do aluno também foi considerada uma atividade com diferença expressiva entre escolas eficientes e ineficientes. Desta forma, o acompanhamento do aluno permite ganhos de desempenho, pois essa atividade promove o engajamento do aluno com o aprendizado do conteúdo uma vez que ele sabe que é monitorado de perto. Essa atividade como forma de melhorar o desempenho também foi abordada em diversos trabalhos e estão estabelecidas no Plano de Desenvolvimento da 
Educação (PDE) do Ministério da Educação (OLIVEIRA, BORUCHOVITCH, SANTOS; 2008; MEC; UNICEF, 2008; MEC; BID, 2010; UNICEF, 2010).

Para Boruchovitch (2001), o monitoramento no processo de aprendizado é essencial para o bom desempenho acadêmico dos alunos. Segundo o autor, as estratégias de monitoramento da compreensão implicam que o indivíduo esteja constantemente com a consciência realista do quanto ele está sendo capaz de captar e absorver do conteúdo que está sendo ensinado e, neste sentido, tomar alguma providência de correção no processo de aprendizado. De acordo com o Ministério da Educação e a UNICEF,

[...] o monitoramento atento da evolução do aluno permite, mais do que a mensuração de seu desempenho, um diagnóstico precoce da razão das dificuldades de aprendizagem. Identificar os problemas de cada criança tão logo eles apareçam é um modo de garantir uma aprendizagem efetiva, no tempo desejável (MEC; UNICEF, 2008, p. 56).

Setúbal (2010) aponta que o acompanhamento e monitoramento dos alunos é uma forma de não aumentar a desigualdade entre as escolas e por consequência deixar para trás uma grande parcela de alunos. Segundo o autor, estratégias para este fim seriam dar apoio pedagógico e acompanhamento próximo para os alunos com maiores dificuldades e colocar o Professor no centro da educação de qualidade. De acordo com Setúbal (2010), ao analisar as boas práticas de municípios que garantem o direito de aprender, o Fundo das Nações Unidas para a Infância (UNICEF) ressalta que educar a todos implica acompanhar de perto a evolução de cada criança, garantindo a aprendizagem.

\section{Atividade 1.5. Recuperação paralela e reforço no contraturno}

A recuperação paralela e reforço no contraturno é uma atividade pouco expressiva na comparação entre escolas eficientes e ineficientes para determinação do desempenho. Apesar disto, vários autores apontam que esta atividade tem efeitos positivos na performance dos alunos (MEC; UNICEF, 2006; MEC; BID, 2010; PALMA FILHO; ALVES; DURAN, 2012).

Azevedo (2008) destaca que um programa de reforço e recuperação contínua é um dos fatores que permite que as instituições de ensino obtenham bons resultados no desempenho uma vez que ajudam a suprir as necessidades e carências educacionais dos alunos. Segundo o MEC e UNICEF (2010), há uma preocupação generalizada para que esta atividade não seja vista 
como forma de punição ao aluno com baixo desempenho, mas uma oportunidade de aprendizado assim como uma atividade prazerosa.

Setúbal (2010) também destaca atividades de reforço como boas práticas adotadas por municípios, sendo apontado pela UNICEF como uma importante metodologia de promover melhoria de desempenho e aprendizagem. De acordo com a instituição, a adoção de aulas de reforço no turno oposto para alunos com dificuldades, a realização de atividades incentivo à leitura e à escrita, o acompanhamento da frequência, do desempenho e do trabalho desenvolvido em sala de aula aluno a aluno também foram algumas das iniciativas concretas adotadas pelos municípios que registraram grande avanço no IDEB (UNICEF, 2010).

\section{Atividade 1.7. Distribuição da carga horária ou da grade curricular com os requisitos avaliados na Prova Brasil}

A distribuição da carga horária ou da grade curricular com os requisitos avaliados na Prova Brasil também apresentou diferença pouco expressiva na comparação entre escolas eficientes e ineficientes. Desta forma, pode-se inferir que esta atividade tem pouca capacidade explicativa na diferença do desempenho entre as escolas.

Na literatura foram encontrados autores que defendem que a distribuição da carga horária ou da grade curricular pode influenciar positivamente o desempenho dos alunos. Segundo Leme et al (2012) e CENPEC (2013, p. 7), a abordagem metodológica e os conteúdos da formação partem da perspectiva de que as informações produzidas pelas avaliações externas contribuem para o diagnóstico de necessidades dos sistemas de ensino e escolas e podem induzir à formulação de políticas com efeitos positivos na prática pedagógica e na aprendizagem. A Prova Brasil ainda serve para direcionar foco em leitura, escrita nas escolas (fator fundamental para o aprendizado dos alunos) em razão da ênfase na avaliação de competências de leitura escrita.

\section{Atividade 1.8. Preparação específica para a Prova Brasil na disciplina de Português}

No instrumento pedagógico, a preparação para a Prova Brasil foi uma das atividades com maior diferença expressiva na comparação entre as escolas eficientes e ineficientes. Assim, 
como era de se esperar, a preparação específica para a prova permite que os alunos se capacitem de maneira mais apropriada para os testes, refletindo no seu desempenho.

Esta observação é corroborada por vários autores que apontam que a preparação adequada dos alunos tende a refletir em notas maiores, dentre eles UNICEF (2010), Oliveira (2011), CENPEC (2013) e Salgado Junior (2013). Segundo o Fundo das Nações Unidas para a Infância (UNICEF, 2010), mesmo ações simples de preparação para a Prova Brasil como a realização de provas discursivas e reflexivas similares à Prova Brasil, além do uso de gabaritos, surtem resultados positivo no desempenho dos alunos. Oliveira (2011) aponta que com o objetivo de melhorar o desempenho das escolas, Diretores e Coordenadores Pedagógicos (das escolas analisadas em seu estudo) têm adotado meios de preparação dos alunos para realização da Prova Brasil em diversas séries, com resultado positivo. Para o CENPEC (2013, p.7), o ponto de partida para a preparação dos alunos é a interpretação e compreensão dos resultados das avaliações padronizadas, que possibilita um "diálogo entre essas avaliações e as práticas de ensino e de gestão".

\section{Atividade 2.2. Frequência que o docente acompanha o desempenho do aluno na disciplina de Matemática}

A frequência que o docente acompanha o aluno também foi considerada uma atividade com diferença expressiva e, desta forma, com capacidade explicativa no desempenho comparado entre escolas eficientes e ineficientes. Isso sugere que o acompanhamento do docente tende a ser um fator que influencia no desempenho do aluno, uma vez que o Professor pode perceber mais prontamente as falhas do aluno e corrigi-las. Além disto, a simples presença de um Professor acompanhando o aluno tende a motivar o aluno ou, em determinados casos, fazer com que ele se dedique mais, especialmente os pontos falhos. Neste sentido, o Plano de Desenvolvimento da Educação (PDE) estabelece que o acompanhamento de cada aluno deve ser realizado periodicamente (MEC; UNICEF, 2008) com o objetivo de reduzir problemas de desempenho por falta de compreensão ou entendimento das disciplinas.

$\mathrm{Na}$ literatura foram encontrados diversos estudos que corroboram com o resultado encontrado neste trabalho. Para Boruchovitch (2001), o monitoramento do próprio processo de aprender é essencial para o bom desempenho acadêmico dos alunos. Segundo a autora, as estratégias de monitoramento da compreensão implicam que o indivíduo esteja constantemente com a 
consciência realista do quanto ele está sendo capaz de captar e absorver do conteúdo que está sendo ensinado. Oliveira; Boruchovitch e Santos (2008, p. 537) destacam os resultados e a importância do acompanhamento dos Professores no desempenho, em especial aos alunos do ensino público oriundo de classe socioeconômica desfavorecida. O Fundo das Nações Unidas para Infância destaca que o acompanhamento dos alunos é uma das iniciativas adotadas pelos municípios que registraram avanços no Ideb (UNICEF, 2010). De acordo com o MEC e BID (2010), o senso de responsabilidade dos docentes em relação ao desempenho dos alunos e com o desenvolvimento de competências e habilidades são práticas identificadas na literatura características de escolas eficazes. Setúbal (2010) coloca o Professor no centro da educação de qualidade e aponta o apoio pedagógico e acompanhamento próximo dos alunos com maiores dificuldades como forma de evitar desigualdades de aprendizado entre os alunos e garantir melhor aprendizagem do conteúdo.

\section{Atividade 2.3. Rotatividade dos Professores na disciplina de Matemática}

A rotatividade dos Professores na disciplina de matemática é um fator explicativo na comparação do desempenho dos alunos de escolas eficientes e ineficientes, uma vez que houve diferença expressiva entre as escolas. Esse resultado sugere que quanto maior a rotatividade dos Professores, pior tende a ser o desempenho dos alunos. A explicação para isso pode ser relacionada ao tempo de reposição do Professor que deixou a turma ou mesmo problemas de didática do novo Professor, diferente dos Professores anteriores. Assim, a falta de continuidade e padrão de ensino pode influenciar negativamente o aprendizado e consequente desempenho dos alunos.

Segundo GAME (2002), a rotatividade dos Professores afeta o ensino e aprendizagem do aluno, tanto pela demora nas designações dos Professores quanto pela limitação e falta de opção de escolha dos Professores pela escola, uma vez que são designados pela SME. Biondi e Felício (2007) destacam em seu estudo que turmas que tiveram aulas com o mesmo Professor de Matemática durante o ano letivo tiveram desempenho superior às turmas com rotatividade de Professores. Alves e Soares (2007) apontam que a ausência dos Professores nas salas de aula (seja por rotatividade ou faltas com ou sem justificativas) impacta negativamente o desempenho dos alunos. Para Vegas (2008), o impacto de um Professor sobre os resultados de aprendizagem dos alunos é cumulativo e duradouro favorecendo o 
desempenho dos alunos. Desta forma, com a rotatividade, o impacto de um Professor ruim reduz potencialmente o desempenho destes alunos por anos afetando seu aprendizado.

\section{Atividade 2.4. Recuperação paralela e reforço no contraturno}

A atividade recuperação paralela e reforço no contraturno mostrou-se pouco expressiva na comparação entre escolas eficientes e ineficientes para avaliação do desempenho. Desta forma, ainda que haja diferença expressiva, esta atividade tem pouca capacidade explicativa na performance das escolas.

Vários autores na literatura, no entanto, apontam que a recuperação paralela e o reforço dos alunos no contraturno é um fator importante no desempenho dos estudantes. Segundo o MEC e UNICEF (2006) e Setúbal (2010), as boas práticas de aprendizagem envolvem os processos de recuperação dos alunos, com aulas de reforço para os alunos com mais dificuldade, garantindo o aprendizado dos alunos e melhoria de desempenho (UNICEF, 2010). Azevedo (2008) e Palma Filho e Duran (2012) corroboram com esta observação destacando que o programa de recuperação contínuo e paralelo, juntamente com a adoção de um processo de avaliação contínua, é imprescindível para que as organizações de ensino produzam bons resultados. De acordo com o MEC e UNICEF (2008), as aulas de reforço deveriam ser vistas como uma oportunidade e não como uma forma de punição para os alunos com mais dificuldades e que, desta forma, deveria haver um esforço por parte das escolas para que isso fosse implementado corretamente.

\section{Atividade 2.6. Distribuição da carga horária ou da grade curricular com os requisitos avaliados na Prova Brasil}

A atividade de distribuição da carga horária ou da grade curricular também se apresentou pouco expressiva na determinação do desempenho das escolas quando comparadas escolas eficientes e ineficientes. Isso sugere que, apesar de haver indícios de que a distribuição da carga horária ou grade curricular possam influenciar positivamente o desempenho dos alunos, não é possível afirmar com segurança que estes fatores foram responsáveis ou tiveram capacidade explicativa na comparação do desempenho das escolas. 
$\mathrm{Na}$ literatura foram encontrados autores que apontam uma relação positiva entre esta atividade e o desempenho dos alunos. Segundo Leme et al (2012) e CENPEC (2013), as informações e interpretações dos resultados das avaliações externas permitem uma adequação dos programas de ensino e, desta forma, as escolas podem adotar práticas pedagógicas que melhorem a aprendizagem e consequente performance.

\section{Atividade 2.7. Preparação específica para a Prova Brasil na disciplina de Matemática}

A preparação específica para a Prova Brasil na disciplina de Matemática é uma atividade com diferença expressiva entre escolas eficientes e ineficientes na avaliação do desempenho. Essa constatação sugere que escolas que adotam métodos de preparação específica para a Prova Brasil tendem a ter resultados melhores do que escolas com pouca ou nenhuma preparação.

Assim como na atividade 1.8 (preparação específica para a Prova Brasil na disciplina de Português), na literatura foram encontrados autores que corroboram com este resultado. Os autores apontam que, com base nas avaliações padronizadas, é possível adequar melhores práticas pedagógicas como forma de preparação dos alunos para a Prova Brasil em diversas séries, pois ainda que sejam práticas simples, produzem resultados positivos (UNICEF, 2010; OLIVEIRA, 2011; CENPEC, 2013).

\section{Atividade 3.1. Participação dos pais nas reuniões}

A participação dos pais nas reuniões constitui uma das práticas encontradas nesse trabalho que apresenta diferença expressiva entre as escolas eficientes e ineficientes e possui maior capacidade de explicar o desempenho dos alunos no IDEB. O estudo de Alves e Soares (2007) também aponta a participação dos pais como fator determinante para o desempenho dos filhos. Segundo os autores, a participação dos pais nas reuniões e suas expectativas em relação ao futuro dos filhos são comportamentos encontrados com alta frequência no grupo dos pais cujos filhos possuem melhor desempenho. Em contrapartida, no outro grupo (filhos que possuem pior desempenho) é frequente o comportamento desinteressado dos pais em relação à vida escolar dos filhos. 
Para Dourado, Santos e Oliveira (2007), a participação ativa dos pais nas reuniões escolares é de fundamental importância para a produção de uma escola de qualidade que apresenta resultados positivos em termos de aprendizagem. Os autores finalizam afirmando que a participação dos pais na vida escolar dos filhos interfere significativamente no desempenho escolar dos alunos. Ferreira e Barrera (2010) corroboram com os autores acima ao afirmar que os alunos de alto rendimento escolar dispõem de um ambiente mais rico em termos de materiais e estímulos para desenvolvimento, sendo que as mães participam mais das reuniões escolares.

Segundo o GAME (2002), há um consenso entre os pesquisadores e educadores no que diz respeito à importância da participação dos pais e da comunidade nas atividades escolares. De acordo com o grupo, é unânime a opinião das lideranças administrativas e pedagógicas acerca do fato de que a participação dos pais nas reuniões interfere de maneira positiva no desempenho dos alunos e que sua ausência acarreta malefícios para os alunos.

De acordo com Marturano (2006), o benefício proporcionado pela participação dos pais no desempenho escolar dos filhos, ocorre principalmente por eles serem capazes de direcionar positivamente o aprendizado escolar, a motivação do filho para os estudos e o desenvolvimento de competências interpessoais que garantem um bom relacionamento com Professores e colegas. Deste modo, Ferreira e Barreira (2010) aponta que é necessário incentivar o trabalho conjunto entre família e escola, buscando uma maior aproximação desses contextos educacionais, com vistas à obtenção de uma educação de melhor qualidade que efetivamente promova a aprendizagem dos alunos.

\section{Atividade 3.2. Participação dos pais em eventos festivos da escola}

A participação dos pais em eventos festivos da escola consiste em uma prática com diferença expressiva quando comparada sua frequência entre as escolas eficientes e ineficientes. Deste modo, ela é considerada um fator relevante para explicar o desempenho dos alunos no IDEB. Assim como a participação dos pais nas reuniões, a sua participação em eventos festivos da escola é fundamental para despertar no aluno o interesse e o comprometimento com a escola e com seu desempenho, pois saber que os pais estarão presentes para apreciar seu trabalho na apresentação de artes, apresentação teatral e demais eventos que contam com a sua 
participação, serve como motivação para eles se dedicarem a fazer o melhor e se envolverem com seu aprendizado, pois para preparar as festas e demais eventos os alunos são estimulados a ler, pesquisar e planejar os eventos (MEC; UNICEF, 2006).

Segundo Dourado, Santos e Oliveira (2007), a realização de festas e demais eventos promovidos pela escola, constitui em uma estratégia adotada a fim de motivar os pais a estarem mais próximos da vida escolar de seus filhos. Nesse mesmo sentido o MEC e UNICEF (2008), afirmam que a realização de palestras, promoção de festas e demais eventos que conta com a participação dos pais, consiste em uma estratégia das escolas que têm como finalidade promover a aproximação dos pais com a escola e com os alunos.

De acordo com Dourado, Santos e Oliveira (2007), as pesquisas atuais têm ressaltado a importância da presença dos pais nos eventos festivos realizados pela escola. Segundo os autores, esses mecanismos de participação representa um forte impacto na melhoria dos processos ensino-aprendizagem das escolas.

\section{Atividade 3.4. Participação dos pais na APM}

A participação dos pais na APM (Associação de Pais e Mestres), também representa uma atividade com diferença expressiva entre as escolas eficientes e ineficientes. A importância da participação dos pais na APM para o desempenho dos alunos no IDEB é explicada, dentre outros fatores, pela importância que a APM possui para as escolas. Segundo o MEC e UNICEF (2008), as APM são associações civis, independentes da escola, que têm tradicionalmente como missão aproximar os pais do cotidiano escolar e arrecadar recursos complementares para a escola. Os autores ainda destacam que em algumas redes a APM também é responsável pelo recebimento e gestão de recursos do poder público.

Segundo o GAME (2002), a APM é fundamental na aquisição de recursos que poderão ser utilizados na escola de forma descentralizada, como a aquisição de livros didáticos, equipamentos de informática, reparos emergenciais na infraestrutura da escola dentre outros. A importância da APM é destacada pelo MEC e UNICEF (2008) ao afirmar que as escolas que têm APM contam com uma participação maior ainda da comunidade. De acordo com os autores, os pais que participam da APM zelam muito mais pela escola e contribuem imensamente para a melhoria da qualidade da direção escolar. 
Para o MEC e UNICEF (2006), a APM se resume no trabalho conjunto entre escola, família e comunidade, de interação e participação em processos de decisão, elaboração do planejamento escolar, união da comunidade escolar em torno de objetivos comuns e formulação conjunta de regras e acordos.

\section{Atividade 3.5. Acompanhamento dos pais nos deveres escolares dos filhos}

O acompanhamento dos pais nos deveres escolares dos filhos é uma prática que possui diferença expressiva quando se compara sua frequência entre as escolas eficientes e ineficientes deste estudo.

A relevância desta atividade para o bom desempenho dos alunos no IDEB é corroborada por Ferreira e Barrera (2010), ao afirmar que tal prática pode incidir diretamente em um bom rendimento escolar do aluno. De acordo com os autores, é importante que o aluno sinta que os pais valorizam e se preocupam com a sua aprendizagem, estimulando-o na realização das demandas escolares, como a frequência à escola e a realização dos deveres de casa. Os resultados encontrados por Bezerra e Kassouf (2006) também apontam que o bom desempenho dos alunos em português é consequência da competência dos pais em ajudar os filhos nos deveres de casa. Segundo Ferreira e Barrera (2010), é característico das famílias brasileiras valorizarem os deveres escolares e sempre buscar auxiliar os seus filhos nessas tarefas.

Deste modo, acompanhar os filhos nos deveres escolares é fundamental pelo fato de os pais poderem demonstrar para os filhos que estão presentes e interessados no que eles estão aprendendo na escola, além de esclarecer prontamente as possíveis dúvidas que irão surgir com a realização das tarefas.

\section{Atividade 3.6. Apoio dos pais na validação das ações da escola}

O apoio dos pais na validação das ações da escola também é uma prática com diferença expressiva quando comparada sua frequência entre as escolas eficientes e ineficientes deste estudo. A importância desta prática para explicar o desempenho dos alunos no IDEB é justificada pelo apoio dos pais as regras, projetos e demais ações estabelecidas pela escola, o 
que cria um ambiente coeso, de disciplina e respeito a todos os atores escolares (Diretor, Professores, funcionários, alunos, etc.), propício ao desenvolvimento da aprendizagem.

Para Ferreira e Barrera (2010), um bom diálogo entre os pais e a escola, contribui para que se estabeleçam melhores relações entre esses contextos, proporcionando maior interesse, valorização e significação dos mesmos. Tanto os pais quanto os Professores devem estar conscientes da importância de se relacionar em tais ambientes (FERREIRA; BARRERA, (2010). Segundo os resultados encontrados no trabalho de Ferreira e Barrera (2010), uma das práticas que contribui para o bom desempenho dos alunos são a presença e o apoio constante dos pais no trabalho desenvolvido pela escola.

Os resultados encontrados por MEC e UNICEF (2008) corroboram com tais resultados ao afirmar que uma grande parte das redes de ensino pesquisada em seu trabalho destacaram a interação e o apoio dos pais as ações da escola como fatores de melhor desempenho dos alunos. Segundo os autores, o bom relacionamento entre pais e escola passa pela participação dos pais na elaboração do guia das práticas pedagógicas que será desenvolvido pela escola.

Dentro deste contexto, fica evidente que o alinhamento de ideias entre pais e escola é fundamental no desenvolvimento de um relacionamento de confiança e apoio mútuo entre as partes, que contribuirá positivamente para a melhoria da educação oferecida pelas escolas.

\section{Atividade 4.3. Regras claras e definidas do sistema disciplinar}

O estabelecimento de regras claras e definidas do sistema disciplinar é uma das práticas encontradas nesse trabalho que apresenta diferença expressiva quando comparada sua frequência entre as escolas eficientes e ineficientes. Este resultado sugere que quando as regras escolares são claras e conhecidas por toda comunidade escolar (pais, alunos, Professores, funcionários, etc.) tende a haver um maior respeito por elas, o que cria um ambiente favorável ao desenvolvimento da aprendizagem, e contribui para o melhor desempenho dos alunos. O MEC e BID (2010) corroboram com tal observação ao afirmar que a existência de normas de convivência claras, conhecidas e acordadas por todos garante um ambiente disciplinado, propício à atenção, à reflexão, ao debate, ou seja, proporciona as condições tidas como imprescindíveis ao ensino-aprendizagem dos alunos. 
Para Leite e Tocornal (2012), o estabelecimento de regras claras e conhecidas por toda comunidade escolar constitui um fator indispensável para a melhoria da convivência escolar. Segundo os autores, a maioria dos conflitos ocorridos no interior das escolas apenas reflete a falta de clareza e compreensão das regras que são em sua maioria impostas pela escola. De acordo com pesquisa realizada pelos autores, Professores e alunos concordam que o estabelecimento de regras claras, objetivas e conhecidas por todos pode ser o caminho para a superação dos problemas de relação conflituosa entre alunos e Professores. O MEC e UNICEF (2006) destacam a importância do bom relacionamento entre alunos e Professores como sendo um fator fundamental para o bom desempenho dos alunos em teste de avaliação em larga escala.

Deste modo, a construção de um ambiente escolar favorável à aprendizagem dos alunos passa pelo estabelecimento de regras claras, que são discutidas previamente ou construídas com a participação de toda a comunidade escolar (MEC, UNICEF 2006).

\section{Atividade 4.4. Grau de disciplinaridade no comportamento discente}

O grau de disciplinaridade no comportamento discente está entre as práticas que apresentou maior diferença expressiva entre os grupos das escolas eficientes e ineficientes deste trabalho. Isso indica que o comportamento disciplinar dos alunos no ambiente escolar contribui para que eles tenham um melhor desempenho no IDEB.

A influência deste fator no desempenho dos alunos, também é destacada por Cianflone e Andrade (2007), que após realizar um estudo de caso em três escolas de ensino fundamental da rede estadual paulista, destaca como resultado, que o desempenho dos alunos tende a piorar a medida que ocorre um aumento nos casos de indisciplina nas escolas. Pires (1999) corrobora com este resultado ao destacar que sem um comportamento disciplinado dos alunos não se pode fazer nenhum trabalho pedagógico significativo.

Para a UNESCO (2004), a disciplina dos alunos remete a ordem em sala de aula, necessária para que se alcancem os objetivos educacionais. Segundo Pires (1999), a disciplina ideal dos alunos deve ser consciente e interativa, marcada por participação, respeito, responsabilidade, construção do conhecimento, formação do caráter e da cidadania. Libâneo (1985) corrobora tal constatação ao afirmar que o aluno disciplinado é aquele que é solidário, participante e 
respeitador das regras escolares. Pires (1999) aponta que a disciplina dos alunos tornou-se um grande desafio, que cada vez mais tem sido alvo de preocupação das escolas, da direção, dos pais e Professores, devido sua relevância na concretização de uma educação de qualidade.

\section{Atividade 4.5. Respeito dos discentes em relação à figura do Professor, Diretor e funcionários}

Esta prática também apresentou uma diferença expressiva quando comparada a sua frequência entre as escolas eficientes e ineficientes. Este resultado indica que o respeito dos discentes em relação à figura do Professor, Diretor e demais funcionários pode ser um fator que contribui para o melhor desempenho dos alunos no IDEB.

Dourado, Santos e Oliveira (2007) corroboram com tal resultado ao apontar em seu trabalho que nas escolas de boa qualidade (aquelas em que os alunos possuem bom desempenho) os alunos reconhecem e valorizam o trabalho dos Professores e dos demais trabalhadores da educação e, também, por essa razão, se envolvem mais no processo de aprendizagem. $\mathrm{O}$ envolvimento dos alunos com a sua aprendizagem é fruto do bom relacionamento criado com os Professores, Diretores e funcionários, devido principalmente ao respeito e em muitos casos pela admiração que os alunos demonstram ter por eles.

\section{Atividade 6.1 Tamanho do acervo da biblioteca}

O tamanho do acervo da biblioteca apresentou diferença pouco expressiva quando comparada a sua frequência entre as escolas eficientes e ineficientes nesse trabalho, ou seja, ela possui apenas uma pequena capacidade explicativa no desempenho dos alunos no IDEB. Entretanto, é possível identificar na literatura estudos que destacam a importância de se possuir um bom acervo na biblioteca da escola.

Dentre esses estudos destaca-se Bezerra (2008), que aponta em seu trabalho que o acervo da biblioteca escolar deve conter materiais bibliográficos de autores diversificados, em uma quantidade que dê suporte ao seu corpo discente e docente. Segundo Dourado, Santos e Oliveira (2007), o acervo da biblioteca deve possuir quantidade e qualidade para atender ao trabalho pedagógico e ao número de alunos existentes na escola. Já Quinhões (1999) conclui em seu trabalho que um bom acervo é capaz de enriquecer o processo de ensinoaprendizagem e, deste modo, fomentar a aprendizagem dos alunos. 


\section{Considerações Finais}

Este trabalho se propôs, como objetivo geral, compreender a influência das práticas administrativo-pedagógicas no desempenho dos alunos de escolas públicas municipais do ensino fundamental do estado de São Paulo no IDEB.

Para atingir esse objetivo, a metodologia adotada neste trabalho consistiu em uma adaptação da metodologia proposta por Salgado Junior (2013), que envolveu a realização de uma pesquisa de abordagem quali-quantitativa dividida em duas etapas, sendo a primeira a aplicação da técnica DEA em 1.298 escolas públicas municipais do estado de São Paulo para identificar as escolas eficientes e a segunda na escolha das escolas ineficientes nos mesmos municípios com características semelhantes, além da realização de um estudo de múltiplos casos, onde foi possível comparar a frequência das práticas no grupo das escolas eficientes com as escolas ineficientes. Como resultado foi identificado um conjunto de 23 práticas, sendo 3 administrativas e 20 pedagógicas, que podem contribuir para o melhor desempenho dos alunos de escolas públicas municipais no IDEB.

Dentre as práticas administrativas, a atividade com maior capacidade explicativa no desempenho dos alunos foi relacionada ao Diretor da escola. Neste sentido, a cobrança da comunidade perante o Diretor mostrou-se uma prática que pode colaborar para o melhor desempenho dos alunos, pois a participação ativa da comunidade no dia-dia da escola é fundamental para acompanhar e fiscalizar as decisões tomadas pelo Diretor. Percebe-se que em municípios pequenos a cobrança da comunidade sobre o Diretor é ainda maior devido a um contato mais próximo e constante entre os pais, Professores e o Diretor no convívio da comunidade em igreja, padarias, restaurantes, supermercados, bares e ambientes de convívio social compartilhado.

É importante ressaltar que o Diretor possui um papel imprescindível na construção de uma escola de qualidade, pois é ele o principal responsável por trazer toda a comunidade para dentro da escola. $\mathrm{O}$ envolvimento da comunidade pode trazer inúmeros benefícios para a escola e colaborar de modo significativo para uma boa gestão do Diretor e aprendizagem dos alunos. A comunidade pode contribuir no sentido de levantar recursos descentralizados, por meio da elaboração de eventos festivos ou rifas ou por meio da APM, que podem ser aplicados naquilo que a escola mais necessita no momento, pode colaborar com a elaboração 
e apoio a criação de regras escolares claras que sejam respeitadas por todos, a fim de criar um ambiente escolar propício à aprendizagem dos alunos, além de poder exercer maior pressão sobre o Secretário e o Prefeito para promover possíveis melhorias na escola.

Dentre o conjunto de práticas pedagógicas, destaca-se a participação da família na vida escolar do filho, seja por meio da participação em reuniões de pais, em eventos festivos realizados pela escola, participação na APM, no acompanhamento dos deveres escolares dos filhos ou mesmo na validação das ações da escola. A participação da família na vida escolar do filho funciona como um fator de motivação aos alunos, pois saber que os pais sempre estão presentes, ajudando a resolver os deveres escolares em caso de dúvidas, nas reuniões de pais ou para assistir a alguma apresentação em algum evento festivo realizado pela escola, faz com que o aluno valorize a educação e se envolva ainda mais com sua aprendizagem, a fim de apresentar bons resultados para os pais. Já a ausência da família na vida escolar do filho desestimula o envolvimento do aluno com a escola, pois em alguns casos, além do aluno se sentir envergonhado perante seus colegas pela ausência de seus pais, ele pode concluir que se os seus pais não valorizam a educação e passam a questionar se deveriam valorizar os estudos e dedicar para obter um bom desempenho.

Também merecem destaque as práticas relacionadas ao desempenho nas provas de Português e Matemática. A alta rotatividade dos Professores também constitui uma prática que pode prejudicar o desempenho dos alunos, pois a troca constante de Professores promove a interrupção de trabalhos, metodologias de ensino além de ocasionar muitas vezes a ausência do Professor em sala de aula (pela demora de designação do Professor pela SME). Deste modo, a descontinuidade de Professores compromete a aprendizagem dos alunos e sua respectiva performance. A frequência que o docente acompanha o desempenho do aluno também constitui um fator determinante para o desempenho, pois o Professor que acompanha constantemente o desempenho dos alunos consegue detectar, logo no início, que o aluno possui dificuldade de aprendizagem em determinado tema, podendo assim retomar o assunto com o aluno, evitando assim acúmulo de dúvidas e de matérias.

Outro ponto que contribui para a melhoria do desempenho dos alunos está relacionado com a preparação específica para a Prova Brasil. Tal fato pode ser justificado pela familiarização antecipada dos alunos com os tipos de questões exigidas na prova. Esta atividade, tanto na 
análise de desempenho da prova de Português como na prova de Matemática, apresentou grande diferença expressiva quando comparado o desempenho entre as escolas eficientes e ineficientes sugerindo grande capacidade explicativa na performance dos alunos. Foi identificado que em escolas com iniciativas e práticas de preparação para a Prova Brasil, seja pela realização de simulados, adequação de carga horária ou grade curricular ou mesmo aulas de reforço, o desempenho dos alunos é superior. Assim, pode-se inferir que a adoção de metodologias formais de preparação para a Prova Brasil é imprescindível para a obtenção de melhores resultados nas escolas.

No caso do desempenho na prova de Português foi identificado que a frequência de leitura tem grande relação com o desempenho dos alunos, pois a leitura aprimora a habilidade de compreensão, em razão do desenvolvimento e ampliação dos conhecimentos prévios, além de aumentar a capacidade crítica e o desenvolvimento intelectual do aluno. Neste sentido, o tamanho do acervo da biblioteca também foi destacado nesta pesquisa como fator relevante, ainda que pouco expressivo na comparação entre escolas eficientes e ineficientes na avaliação do desempenho.

Por fim, o sistema disciplinar também se mostrou relevante no desempenho dos alunos. De acordo com os resultados encontrados nesta dissertação, o estabelecimento de regras claras e definidas do sistema disciplinar cria um ambiente de envolvimento e respeito (aos Professores, Diretor e demais funcionários), favorável ao desenvolvimento da aprendizagem, contribuindo para um melhor desempenho dos alunos. Também foi identificado que o comportamento disciplinar dos alunos no ambiente escolar contribui para um melhor aprendizado e consequentemente para que eles tenham um melhor desempenho no IDEB.

Desta forma, os resultados encontrados nessa pesquisa podem contribuir na orientação da SME sobre a destinação dos recursos financeiros, e dos Diretores na gestão dos processos administrativo-pedagógico da escola, a fim de promover uma melhoria no desempenho dos alunos no IDEB. Entretanto, por se tratar de estudo de caso, os resultados não devem ser generalizados. 


\subsection{Limitações da pesquisa}

A escolha por estudar o grupo das escolas eficientes e ineficientes no mesmo município foi importante para minimizar as diferenças de nível socioeconômico e demais características locais entre as escolas. Entretanto, tal escolha possibilitou apenas a identificação de práticas relacionadas ao instrumento pedagógico e ao instrumento administrativo aplicado ao Diretor. As práticas relacionadas ao instrumento administrativo do Secretário ficaram comprometidas, pois ambos os grupos das escolas (eficientes e ineficientes) estão localizados no mesmo município e sobre a gestão da mesma SME.

\subsection{Sugestão para trabalhos futuros}

Este trabalho pode ser replicado em escolas eficientes e ineficientes, localizadas em municípios diferentes a fim de identificar, com maior precisão, os efeitos da Secretaria Municipal de Educação sobre o desempenho dos alunos. 


\section{Referencial Bibliográfico}

AKKARI, A. J. Desigualdades educativas estruturais no Brasil: entre Estado, privatização e descentralização. Educação \& Sociedade. Ano XXII, n.74, abr.2001.

ALMEIDA, M. Infraestrutura produtiva: uma sistematização dos métodos, técnicas e modelos para análise de desempenho. Dissertação apresentada à Escola de Engenharia de São Carlos da Universidade de São Paulo (EESC-USP), 2007

ALVES, M. T. G.; SOARES, J. F. As pesquisas sobre o efeito das escolas: contribuições metodológicas para a Sociologia da Educação. Sociedade e Estado, Brasília, v. 22, n; 2, mai/ago, 2007, pp. 435-473

ALVES, M. T. G.; SOARES, J. F. Medidas de nível socioeconômico em pesquisas sociais: uma aplicação aos dados de uma pesquisa educacional. Opinião Pública, Campinas, v. 15, n. 1, jun, 2009, pp. 1-30

ALVES, M. T. G.; SOARES, J. F. O efeito das escolas no aprendizado dos alunos: Um estudo com dados longitudinais no ensino fundamental. Educação e Pesquisa, São Paulo, v. 34, n.3, p. 527-544, set./dez. 2008.

ALVES, M. T. G.; SOARES, J. F. O nível socioeconômico das escolas de educação básica brasileiras. Relatório do Projeto de Pesquisa realizado pelo Grupo de Avaliação e Medidas Educacionais (GAME) da UFMG, com intermediação da Fundação de Amparo a Pesquisa da Universidade Federal de Minas Gerais, 2012

ALVES, Maria Teresa G.; SOARES, José Francisco; XAVIER, Flávia P. Índice do Nível Socioeconômico (NSE) das Escolas de Educação Básica Brasileiras: Banco de Dados - versão 3. Belo Horizonte: Núcleo de Pesquisa em Desigualdades Escolares (Nupede)/Grupo de Avaliação e Medidas Educacionais (GAME)-Universidade Federal de Minas Gerais, 2014.

AMARAL, L.; MENEZES FILHO, N. A Relação entre Gastos e Desempenho

Educacional. In XXXVI Encontro Nacional de Economia, 2008, Salvador. Anais do XXXVI Encontro Nacional de Economia, 2008.

AMARAL, N. C. O novo PNE e o financiamento da educação no Brasil: os recursos como um percentual do PIB. In: Ivany Rodrigues Pino e Dirce H=Djanira Pacheco Zan. (org.).

Plano Nacional de Educação (PNE); questões desafiadoras e questões emblemáticas.. 1ed.:, 2013, v., p. 85-101.

ANDRADE, E. C. Rankings em educação: Tipos, problemas, informações e mudanças:

Análise dos principais rankings oficiais brasileiros. Estudos Econômicos, v. 41, n. 2, p. 323 343, 2011.

ANDRADE, M. M. Como preparar trabalhos para cursos de pós-graduação: noções práticas. 5. Ed. São Paulo: Atlas, 2002.

APPOLINÁRIO, F. Dicionário de metodologia científica: um guia para a produção do conhecimento cientifico. São Paulo: Atlas, 2004. 
AZEVEDO, A. J. A organização do ensino em ciclos e o regime de progressão continuada. Revista Científica Eletrônica de Pedagogia, v. 5, n. p, jan. 2008.

BANKER, R. D.. CHARNES, A.; COOPER, W. W. Some Models for Estimating Technical and Scale Inefficiencies in Data Envelopment Analysis. Managemente Science, v. 30, n. 9, sep, 1984

BARBOSA, A. Salários Docentes, Financiamento e Qualidade da Educação no Brasil. Educação \& Realidade, Porto Alegre, v. 39, n. 2, p. 511-532, abr./jun. 2014.

BARDIN, L. Análise de conteúdo. São Paulo: Edições 70, 2011

BARRO, R. J. Human capital and growth in cross-country grow regressions. Swedish Economic Policy Review, v. 6, n. 2, 1999

BARRO, R. J.; LEE, J. A new data set of educational attainment in the world, 1950-2010. National Bureau of Economic Research, NBER Working Paper Series, Working Paper 15902, 2010

BARROS, A.J.S e LEHFELD, N.A.S. Fundamentos de Metodologia: um guia para a iniciação científica. 2 Ed. São Paulo: Makron Books, 2000.

BARROS, R. P.; LAM, D. Income and education inequality and children's schooling attainment in Brazil. In: BIRDSALL, N.; SABOT, R.H. (Eds.). Opportunity forgone: education in Brazil. Washington, DC.: Inter-American Development Bank, 1996.

BARROS, R. P.; MENDONÇA, R. S. Investimento em educação e desenvolvimento econômico. A economia brasileira em perspectiva. RJ: IPEA, 1998, v., p. 605-614

BATALHA, C.; MIRANDA, M.; LIRIO, V. Investimento em educação e seu efeito na qualidade do ensino nas escolas municipais em Minas Gerais. In X Encontro Nacional da Associação Brasileira de Estudos Regionais e Urbanos, 2012.

BENEVIDES, M. V. M. Educação para a democracia. Lua Nova, n.38, 1996, pp. 223-237

BEZERRA, M. O papel da biblioteca escolar: importância do setor no contexto educacional. São Paulo: CRB-8 Digital, v. 1, n. 2, out. 2008.

BEZERRA, M.; KASSOUF, A. L. Análise dos fatores que afetam o desempenho escolar nas escolas das áreas urbanas e rurais do Brasil. In: SOBER, Fortaleza, CE, 2006.

BILBAO-OSORIO, B.; DUTTA, S.; LANVIN, B. The Global Information Technology Report 2013: Growth and Jobs in a Hyperconnected World. World Economic Forum and INSEAD, 2013

BIONDI, R. L.; FELÍCIO, F. Atributos escolares e o desempenho dos estudantes: uma análise em painel dos dados Saeb. Brasília: Instituto Nacional de Estudos e Pesquisas Educacionais Anísio Teixeira (Inep), 2007.

BLÖMEKE, S.; SUHL, U., KAISER, G., DÖHRMANN, M. Corrigendum to Family background, entry selectivity and opportunities to learn: What matters in primary teacher education? An international comparison of fifteen countries. Teaching Educ. 28 
(1), 2011, pp. 44-55 Disponível em

http://www.sciencedirect.com/science/article/pii/S0742051X11001004

BORUCHOVITCH, E. Algumas estratégias de compreensão em leitura de alunos do ensino fundamental. Psicologia Escolar e Educacional, v. 5, n. 1, jun. 2001.

BOTH, I. J. Municipalização da educação. Uma contribuição para um novo paradigma de gestão do ensino fundamental. Campinas: Papirus, 1997.

BRASIL Portaria nº 931, de 21 de março de 2005. Instituir o Sistema de Avaliação da Educação Básica - SAEB, que será composto por dois processos de avaliação: a Avaliação Nacional da Educação Básica - ANEB, e a Avaliação Nacional do Rendimento Escolar ANRESC. Diário da União, Brasília, Seção 1, p. 17, n. 55, 22 mar. 2005 e.

BRASIL. Constituição da República Federativa do Brasil. Brasília: Senado, 1988

BRASIL. Decreto 5.800, de 8 de junho de 2006. Sistema Universidade Aberta do Brasil UAB. Congresso Nacional, 2006. Disponível em

http://www.planalto.gov.br/ccivil_03/_ato2004-2006/2006/decreto/d5800.htm, acesso em $23 / 04 / 2014$

BRASIL. Lei 11.502, de 11 de julho de 2007. Modifica as competências e a estrutura organizacional da fundação Coordenação de Aperfeiçoamento de Pessoal de Nível Superior - CAPES. Congresso Nacional, 2007. Disponível em http://www.planalto.gov.br/ccivil_03/_Ato2007-2010/2007/Lei/L11502.htm, acesso em $14 / 04 / 2014$

BRASIL. Lei 13.005, de 25 junho de 2014. Plano Nacional de Educação (PNE 2014-2024). Congresso Nacional, 2014. D disponível em http://presrepublica.jusbrasil.com.br/legislacao/125099097/lei-13005-14, acesso em $15 / 08 / 2014$

BRASIL. Lei 4.024, de 20 de dezembro 1961. Lei de Diretrizes e Bases da Educação Nacional. Congresso Nacional, 1961. Disponível em http://www.planalto.gov.br/ccivil_03/leis/14024.htm, acesso em 10/02/2014

BRASIL. Lei 5.692, de 11 de agosto de 1971. Lei de Diretrizes e Bases para o ensino de $1^{\circ}$ e $2^{\circ}$ graus. Congresso Nacional, 1971. Disponível em http://www.planalto.gov.br/ccivil_03/leis/15692.htm, acesso em 12/02/2014

BRASIL. Lei 9.394, de 20 de dezembro de 1996. Lei de Diretrizes e Bases da Educação Nacional. Congresso Nacional, 1996. Disponível em http://www.planalto.gov.br/ccivil_03/leis/L9394.htm\#art92, acesso em 12/02/2014

BRASIL. Ministério Público Federal. Transporte escolar: via legal para uma educação de qualidade. set. 2006.

BRASIL. Projeto de Lei da Câmara, ${ }^{\circ} 41$ de 2013. Brasília, DF: Câmara dos Deputados, 2013 
BRASIL. Secretaria do Tesouro Nacional. Estados e Municípios. Dados do FINBRA, STN, 2013. Disponível em http://www3.tesouro.fazenda.gov.br/estados_municipios/index.asp. Acesso em 11/08/2013

BRASIL. Sistema educacional: Educação Básica. Disponível em: http://www.brasil.gov.br/sobre/educacao//sistema-educacional/educacao-basica. Acesso em 27 dez. 2012.

BROOKE, N.; SOARES, J. F. Pesquisa em eficácia escolar: origens e trajetórias. Belo Horizonte: Ed. UFMG, 2008.

BRUNET, J. F. G.; BERTÊ, A. M. A.; BORGES, C. B. Qualidade do Gasto Público em Educação nas Redes Públicas Estaduais e Municipais. XIII Prêmio Tesouro Nacional, 2008

BURKE, A. M. Making a big school smaller: the school-within-a-school arrangement for middle level school.- Orting, WA: Orting Middle School, 1987.

CADAVAL, A. Qualidade da educação fundamental e sua relação com o crescimento econômico. Tese de Doutorado apresentada ao Programa de Pós-Graduação em Economia da Faculdade de Ciências Econômicas da UFRGS, 2010.

CALlEJA, J. M. R. Os Professores deste século. Algumas reflexões. Revista Institucional Universidad Tecnológica del Chocó, v.27, n. 1, p. 109-117, 2008.

CAMPOMAR, M. C. Do uso do "Estudo de Caso" em Pesquisas para Dissertação e Teses em Administração. Revista de Administração, v. 26, n. 3, p. 95-97, 1991.

CAPPELE, M.; MELO, M.; GONÇALVES, C. Análise de conteúdo e análise de discurso nas Ciências Sociais. Organizações Rurais e Agroindustriais, v.5, n. 1, 2003

CARIA, T. H. L. Perspectiva sociológica sobre o conceito de educação e a diversidade das pedagogias. Sociologia - Problemas e Práticas. N. 12, p. 171-184, 1992.

CARVALHO, J. S. F. O declínio do sentido público da educação. Revista Brasileira de Estudos Pedagógicos, Brasília, DF, v. 89, n. 223, p. 411-424, set./dez. 2008

CASTRO, J.; DUARTE, B. Descentralização da Educação Pública no Brasil Trajetória dos Gastos e das Matrículas. Textos para Discussão, nº 1352, Ipea, pp. 1-33, 2008.

CASTRO, M. H. G. Avaliação do sistema educacional brasileiro: tendências e perspectivas. Brasília: Ministério da Educação, Instituto Nacional de Estudos e Pesquisas Educacionais, 1998.

CASTRO, M. L. S. de. Formação do Diretor de escola do estado do Rio Grande do Sul: implicações para a prática. Educação, v. 32, n. 2, p. 114-121, maio/ago. 2009.

CENPEC. Avaliação e Aprendizagem: Avaliações externas: perspectivas para a ação pedagógica e a gestão do ensino/[textos] Eloisa de Blasis, Ana Maria Falsarella, Ocimar Munhoz Alavarse; coordenação Eloisa de Blasis, Patricia Mota Guedes.- São Paulo: CENPEC: Fundação Itaú Social, 2013. 
CEPAL Equidad, desarrollo y ciudadanía. Comissão Econômica para a América Latina e Caribe (Cepal). Documento de 2000., México, 2000.

CERQUEIRA, A. G.; CERQUEIRA, A. C.; MENDES, P. A.; SOUZA, T. C. A trajetória histórica da LDB: um estudo crítico frente à realiade brasileira. 2009.

CHARNES, A.; COOPER, W. W.; LEWIN, A.; SEIFORD, L. Data Envelopment Analysis: Theory, Methodology, and Applications. Boston: Kluwer Academic Publishers, 1997

CHARNES, A.; COOPER, W. W.; RHODES, E. Measuring the efficiency of decision making units. European Journal of Operational Research, v. 2, n. 6, 1978, pp. 429-444

CHARNES, A.; COOPER, W. W.; SEIFORD, L.; STUTZ, J. A multiplicative model for efficiency analysis. Socio-Economic Planning Sciences, v. 16, n. 5, 1982, pp. 223-224

CHARNES, A.; COOPER, W.W.; GOLANY, B.; SEIFORD, L.M.; STUTZ, J. Foundations of data envelopment analysis for Pareto-Koopmans efficient empirical production functions. Journal of Econometrics, v. 30, p. 91-107, 1985.

CHAUDHARY, L. MUSACCHIO, A.; NAFZIGE, S.; YAN, S. Big BRICs, weak foundations: The beginning of public elementary education in Brazil, Russia, India, and China. Explorations in Economic History, n. 49, 2012, pp. 221-240

CHIAVENATO, I. Introdução à Teoria Geral Da Administração: uma visão abrangente da moderna administração das organizações. 7. ed. Rio de Janeiro: Elsevier, 2003.

CIANFLONE, A. R. L.; ANDRADE, E. N. F. de. Práticas avaliativas no ensino fundamental e cultura escolar. Paideia, v. 17, n. 38, 2007, p. 389-402.

COELLI, T.J., RAO, P., BATTESE, G.E. An introduction to efficiency and productivity analysis. Dordrecht: Kluwer Academic, 1998.

COLEMAN, J. S.; CAMPBELL, E. Q.; HOBSON, C. J.; MCPARTLAND, F.; MOOD, A. M.; WEINFELD, F. D; YORK, R. L. Equality of educational opportunity. Washington, DC: US, 1966. Disponível em: http://www.icpsr.umich.edu/icpsrweb/ICPSR/studies/06389, Acesso em: 07 dez. 2013

CONTE, N.; DONIN, S. Um Estudo do Investimento Público em Educação Básica e o Desempenho dos Alunos em Avaliações Nacionais nos Municípios Pertencentes à Associação dos Municípios da Encosta Superior do Nordeste do Rio Grande do Sul AMESNE. XIV Convenção de Contabilidade do Rio Grande do Sul, 2013.

COOPER, W.; LI, S.; SEIFORD, L.; TONE, K.; THRALL, R. ZHU, J. Sensitivity and Stability Analysis in DEA: Some Recent Developments. Journal of Productivity Analysis, v. 15, n.3, 2001, pp. 217-246

COOPER, W.; SEIFORD, L.; TONE, K., Data Envelopment Analysis: A Comprehensive Text with Models, Applications, References and DEA-Solver Software. Kluwer Academic Publishers, Boston, 2007 (originalmente publicado em 2000)

CORSEUIL, C.; SANTOS, D. D.; FOGUEL, M. N. Decisões críticas em idades críticas: a escolha de jovens entre estudo e trabalho em seis países da América Latina. ENCONTRO 
NACIONAL DE ESTUDOS POPULACIONAIS, 12, Caxambu, 2000. Anais... Belo Horizonte: Abep, 2000

COSTA, R. D. O Aspecto Sócioeconômico e Sua Influência na Qualidade no Ensino Fundamental Público no Brasil. Dissertação apresentada ao corpo docente da escola brasileira de Administração Pública - EBAPE da Fundação Getulio Vargas como parte dos requisitos necessários a obtenção do grau de Mestre em Administração de Empresas. Rio de Janeiro - RJ 2010.

COTTON, K. School size, school climate, and student performance. School Improvement Research Series, NREL, 1996.

CRUZ, P.; MONTEIRO, L. Anuário Brasileiro da Educação Básica 2013. Organizadores Priscila Cruz e Luciano Monteiro. Editora Moderna, 2014

CUNHA, J. M.; JIMENEZC, M. A., PEREZD, J. R. R.; ANDRADE, C. Y. Social segregation and academic achievement in state-run elementary schools in the municipality of Campinas, Brazil. Geoforum, v. 40, n. 5, set, 2009, pp. 873-883. Disponível em http://www.sciencedirect.com/science/article/pii/S0016718509000736

CURY, C. R. J., Qualidade em Educação. Nuances (UNESP Presidente Prudente), v. 17, p. 17-34, 2010.

CURY, C. R. M. A educação básica no Brasil. Educ. Soc. v. 23, n. 80, p. 168-200, set.2002.

DANELON, M. A. S.; DANELON, M. S.; SILVA, M. V. da. Serviços de alimentação destinados ao público escolar: análise da convivência do Programa de Alimentação Escolar nas cantinas. Segurança Alimentar Nutricional, v. 13, n.1, p. 85-94, 2006.

DE PRINS, D.; SIMAR, L.; TULKENS, H. Measuring Labor Efficiency in Post Offices. The Performance of Public Enterprises: Concepts and Measurements. M. Marchand, P. Pestieau, and H. Tulkens, Eds., Amsterdam: North Holland, 1984, pp. 243-268

DELGADO, V. M. S.; MACHADO, A. F. , Eficiência das Escolas Públicas de Minas Gerais: Considerações Acerca da Qualidade do Ensino. Apresentação XXXV Encontro Nacional de Economia-ANPEC, 2007.

DELMANTO, D. A leitura em sala de aula. Almanaque do Programa Escrevendo o Futuro, n. 7, 2009.

DELORS, J. Educação um tesouro a descobrir. Relatório para a UNESCO da Comissão Internacional sobre Educação para o Século XXI. UNESCO; 2010, disponível em http://unesdoc.unesco.org/images/0010/001095/109590por.pdf, acesso em 29/03/2014

DENISON, E. F. Accounting for United States economic growth, 1929-1969. Washington: Brookings Institution, 1974.

DIAZ, M. D. M. . Qualidade do gasto público municipal em ensino fundamental no Brasil. Revista de Economia Política (Impresso), v. 32, p. 128-141, 2012.

DOURADO, L. F.; SANTOS, C. A.; OLIVEIRA, J. F. . A qualidade da educação: conceitos e definições. Série Documental (INEP), Brasilia, v. 24, n.22, p. 05-34, 2007. 
DURKHEIM, Emile. Sociologia, educação e moral. Porto: Rés Editora, 1984, 398 pp.

FARIAS, M. P. de. Refletindo a prática de leitura no ensino superior. Revista Multidisciplinar IESC, v. 1, n. 2, 2010.

FARRELL, M. J. The Measurement of Productive Efficiency. Journal of the Royal Statistical Society. Series A (General), v. 120, n. 3, 1957, pp.253-290

FELÍCIO, F; FERNANDES, R.. O efeito da Qualidade da Escola sobre o Desempenho Escolar: uma Avaliação do Ensino Fundamental no Estado de São Paulo. Anais do XXXIII Encontro Nacional de Economia, 2005

FERNANDES, C. O.; NAZARETH, H. D. G. . A retórica por uma educação de qualidade e a avaliação de larga escala. Impulso (Piracicaba), v. 51, p. 63-72, 2011.

FERNANDES, R.; GREMAUD, A. P. Qualidade da Educação: avaliação, indicadores e metas. In: Veloso, F. et al. (Orgs.). Educação básica no Brasil: construindo um país do futuro. Rio de Janeiro: Elsevier, 2009.

FERNANDES, R. Índice de Desenvolvimento da Educação Básica (IDEB). Texto para discussão n. 26, 2007. Disponível em: http://www.publicacoes.inep.gov.br/detalhes.asp?pub=4121 >.Acesso em: 09. Set 2013.

FERRAZ, J; POLENA, A.; QUIRINO, S. R.. Finbra e Siop, o que os dados nos dizem. In: XXVI Simpósio Brasileiro de Política e Administração da educação, 2013, Recife. XXVI Simpósio Brasileiro de Política e Administração da educação, 2013.

FERREIRA, C. M. C.; GOMES, A. P. Introdução à Análise Envoltória de Dados: Teoria, Modelos e Aplicações. Viçosa: Editora UFV, 2012

FERREIRA, S. BARRERA, S. Ambiente familiar e aprendizagem escolar em alunos da educação infantil. Revista Psico, v. 41, n. 4, pp. 462-472, 2010.

FIPE. Qualidade do gasto público no Brasil: sugestões para melhorar os resultados das políticas públicas, sem aumento de impostos. Fundação Instituto de Pesquisa Econômica (FIPE) e Instituto brasileiro de ética concorrencial (ETCO) e Fundação Instituto de Pesquisa Econômica. 2007

FLICK, U. Introdução à pesquisa qualitativa. 3ª Edição, São Paulo: Artmed., 2009

FRANCO, A. M. de P. Os determinantes da qualidade da educação no Brasil. 2008. 146 f. Tese (Doutorado em Economia) - Universidade de São Paulo, São Paulo, 2008.

FREITAS, Pâmela Félix. Escolas com Alto e Baixo Rendimento no IDEB: Estudo Comparativo Entre Quatro Escolas no Interior do Ceará. In: III Congresso Ibero Americano de Política e Administração da Educação, 2012, Zaragoza, Espanha, Cadernos ANPAE, 2012.

FREITAS, P. G. Saúde em estilo de vida. Baseado no equilíbrio dos quatro pilares. São Paulo: IBRASA, 2002). 
FRIGOTTO, G. Educação e trabalho Bases para debater a educação profissional emancipadora. Perspectiva, Florianópolis, v.19, n.1, jan.-jun. 2001, p. 71-87.

FUNDESCOLA, DIPRO, FND e MEC. Como elaborar o Plano de Desenvolvimento da Escola; aumentando o desempenho da escolar por meio do planejamento eficaz. $3^{\mathrm{a}} \mathrm{ed}$. Brasília, 2006.

GALEGO, C.; GOMES, A. A. Emancipação, rupture e inovação: o focus group como instrument de investigação. Rev. Lusófona de Educação [online]. 2005, n.5, pp. 173-184. ISSN 1645-7250.

GAME. Escola Eficaz: um estudo de caso em três escolas da rede pública de ensino do Estado de Minas Gerais. Grupo de Avaliação e Medidas Educacionais. Belo Horizonte, 2002, 114 p.

GAMORAN, A.; LONG, D. Equality of Educational Opportunity: a 40-Year

Retrospective. Wisconsin Center for Education Research Working Paper, 2006.

GIL, A. C. Como elaborar projetos de pesquisa. 4ª Edição, São Paulo: Atlas, 2009.

GIL, A. C. Métodos e Técnicas de Pesquisa Social. 5a Edição, São Paulo: Atlas, 2006.

GIVISIEZ, G.; OLIVEIRA, E. Royalties do petróleo e educação - análise da eficiência da alocação. RBPG, Brasília, supl. 1, v. 8, p. 31 - 54, dezembro 2011.

GLADCHEFF, A. P. ; ZUFFI, E. M. ; SILVA, D. M. . Um instrumento para avaliação da qualidade de softwares educacionais de matemática para o ensino fundamental. In: Workshop de Informática na Escola, 2001, Fortaleza. VII Workshop de Informática na Escola, 2001.

GOLANY, B.; ROLL, Y. An application procedure for DEA. Omega International Journal of Management Science, v. 17, n. 3, 1989, pp. 237-1250

GOMES, C. A. A escola de qualidade para todos: abrindo as camadas da cebola. Ensaio. Avaliação e Políticas Públicas em Educação, Rio, v.13, n.47, p. 281-306, 2005.

GREMAUD, A. P.; FELICIO, F.; BIONDI, R. L. Indicador de Efeito Escola: uma metodologia para a identificação dos sucessos escolares a partir dos dados da Prova Brasil. Brasília: Instituto Nacional de Estudos e Pesquisas Educacionais Anísio Teixeira, 2007.

GREMAUD, A. P.; FERNANDES, Reynaldo; ULYSSEA, Gabriel. A alocação de recursos para a educação básica: o caso do Fundef. Pesquisa e Planejamento Econômico (Rio de Janeiro), Rio de Janeiro, v. 36, n. 1, 2006.

GUSMÃO, J. B. . A construção da noção de qualidade da educação. Ensaio (Fundação Cesgranrio. Impresso), 2012.

HADDAD, F. O Plano de desenvolvimento da educação: razões, princípios e programas. Brasília: Instituto Nacional de Estudos e Pesquisas Educacionais Anísio Teixeira, 2008.

HAIR JR., J. F.; BABIN, B.; MONEY, A. H.; SAMOUEL, L. P. Fundamentos de método de pesquisa em administração. Porto Alegre: Bookman, 2005. 
HANUSHEK, E. A. Economic growth in developing countries: The role of human capital. Economics of Education Review, n. 37, 2013, pp. 204-212

HANUSHEK, E., School and academic achievement. Econometrica. v.73, n.2, p.417-458, mar 2005.

HANUSHEK, Eric. Teacher Quality. In: IZUMI, L.T; EVERS W. M. (Ed.). Teacher Quality. Stanford: Hoover Institution Press, p. 1-12, 2002.

HÖFFE, O. Valores em Instituições Democráticas de Ensino. Educação e Sociedade, v.25 n.87, 2004

HOLANDA, M. C.; PETTERINI, F. C.; BARBOSA. Marcelo Ponte. TEXTO PARA DISCUSSÃO N ${ }^{\circ}$ 24- Existiria um Tamanho ideal de escolar?. 2006.

HORTA NETO, João Luiz. Um olhar retrospectivo sobre a avaliação externa no Brasil: das primeiras medições em educação até o SAEB de 2005. Revista Iberoamericana de Educación, n42/5. Abr. 2007.

INEP. Conheça o Inep, 2011. Disponível em: http://portal.inep.gov.br/conheca-o-inep>. Acesso em: 16. jun 2014.

INEP. Descrição dos níveis da escala de desempenho de língua portuguesa-saeb, 2011. Disponível em:

<http://download.inep.gov.br/educacao_basica/prova_brasil_saeb/escala/2011/escala_desemp enho_portugues_fundamental.pdf > Acesso em: 04 set. 2013.

INEP. Descrição dos níveis da escala de desempenho de matemática-saeb, 2011.

Disponível em:

http://download.inep.gov.br/educacao_basica/prova_brasil_saeb/escala/2011/escala_desempe nho_matematica_fundamental.pdf >Acesso em: 04 set. 2013.

INEP. Instituto de Estudos e Pesquisas Educacionais Anísio Teixeira. Investimentos Públicos em Educação. 2011 Disponível em <http://portal.inep.gov.br/estatisticasgastoseducacao> Acesso em: 28. Mar 2014.

INEP. Instituto Nacional de Estudos e Pesquisas Educacionais Anísio Teixeira. Censo da educação básica 2012. Brasília Instituto Nacional de Estudos e Pesquisas Educacionais Anísio Teixeira, 2013, Disponível em http://portal.inep.gov.br/basica-censo, Acesso em 20. ago., 2014

INEP. Nota Técnica: Cálculo das Taxas de Rendimento Escolar - Censo da Educação Básica, 2011. Disponível em: http://download.inep.gov.br/download/censo/2011/NT_indicadores_rendimento2011.pdf $>$. Acesso em 10. Ago 2013.

INEP. Nota Técnica: Índice de Desenvolvimento da Educação Básica- IDEB, 2011. Disponível em: http://download.inep.gov.br/educacao_basica/portal_ideb/metodologias/Nota_Tecnica_n1_co ncepcaoIDEB.pdf> Acesso em: 04. set 2013. 
INEP. O Que São as Metas, 2011. Disponível em: http://portal.inep.gov.br/web/portalideb/o-que-sao-as-metas>. Acesso em: 10. set 2013.

INEP. Perfil dos dirigentes municipais de educação 2010/ Instituto Nacional de Estudos e Pesquisas Educacionais Anísio Teixeira, Diretoria de Estudos Educacionais (Dired), Brasília: O instituto, 2011.

INEP. Projeto Piloto: Escola de Gestores da Educação Básica: Relato de uma Experiência. Brasilia: Intituto Nacional de Pesquisas Educacionais Anísio Teixeira, 2007.

INEP. Relatório Nacional da Pesquisa: Levantamento do Custo-aluno-ano em escolas de Educação Básica que oferecem condições de oferta para um ensino de qualidade-2a Etapa. Salvador-Bahia, 2005.

INEP. Resultados da participação do Brasil no PISA. Brasilia: Instituto Nacional de Estudos e Pesquisas Educacionais Anísio Teixeira, 2014. Disponível em http://portal.inep.gov.br/internacional-novo-pisa-resultados, Acesso em 11/05/2014

INEP. Taxas de Rendimento Escolar, 2013. Disponível em: http://download.inep.gov.br/educação_basica/educacenso/situação_aluno/documentos/2013/ta xas_rendimento.pdf $>$. Acesso em 10. Set 2013.

IOSCHPE, Gustavo. A Ignorância Custa Um Mundo: o valor da educação no desenvolvimento do Brasil. São Paulo: Francis, 2004.

JUBRAN, A. J. Modelo de análise de eficiência na administração pública: estudo aplicado às prefeituras brasileiras usando a análise envoltória de dados. Tese de Doutorado apresentada à Escola Politécnica da Universidade de São Paulo, 2006

KASSOUF, A. L. O efeito do trabalho infantil para os rendimentos dos jovens, controlando o background familiar. In: XIII ENCONTRO NACIONAL DE ESTUDOS POPULACIONAIS, 2002, Ouro Preto - MG. Violências, o Estado e a Qualidade de Vida da População Brasileira, 2002

KNIGHT, F. The Economic Organization. Chicago: University of Chicago, 1933 (original de 1933, republicado em 1951 como Knight, F. H. The Economic Organization: with an Article, "Notes on Cost and Utility". New York: A. M. Kelley, 1951)

KRUEGER, R. A. Focus groups: a practical guide for applied research. 2. Ed. Thousand Oaks, SAGE Publications, 1994.

KULIK, J. A. Effects of instructional technology in elementary and secundary schools: what controlled evaluation studies say? Arlington: SRI International, 2003.

KUSIAK, S. M. Uma análise da prova Brasil com enfoque nos processos de leitura e escrita. Cadernos ANPED, v.1, p. 1-10, 2012.

LAREAU, A. Social class differences in family-school relationships: the importance of cultural capital. Sociology of education, v. 60, 1987.

LEE, V. E. Using hierarchical linear modeling to study social contexts: the case of school effects. Educational Psychologist, London, n.35, p. 125-141, 2000. 
LEE, V.E; SMITH, J.B. High school size: Which works best, and for whom?. Educational Evaluation and Policy Analysis,19(3), p. 205-227, 1997.

LEITE, C. R.; TOCORNAL, P. V. Convivência Escolar: uma reflexão a partir do ponto de vista do Professor e do aluno. Imagens da Educação, v. 2, n. 3, p. 45-53, 2012.

LEME, M. C. S.; WAJNMAN, S. A alocação do tempo dos adolescentes brasileiros entre o trabalho e a escola. ENCONTRO NACIONAL DE ESTUDOS POPULACIONAIS, 12, Caxambu, 2000. Anais... Belo Horizonte: Abep, 2000

LEME, M. C.; LOUZANOC, P.; PONCZEKA, V.; SOUZA, A. P. The impact of structured teaching methods on the quality of education in Brazil. Economics of Education Review. Volume 31, Issue 5, October 2012, Pages 850-860. Disponível em http://www.sciencedirect.com/science/article/pii/S0272775712000660

LEME, M. C.; PAREDES, R.; SOUZA, A. A municipalização do ensino fundamental e seu impacto sobre a proficiência no Brasil. In: VELOSO, F; PESSÔA, S; HENRIQUES, R; GIAMBIAGI, F. Educação básica no Brasil - construindo o país do futuro. Rio, Elsevier: 2009.

LEVINE, D. U. An interpretative review of US research and practice dealing with unusually effective schools. In: School effectiveness. Londres: Cassell, 1996.

LIBÂNEO, J. C; OLIVEIRA, J. F; TOSCHI, M. S. Educação Escolar: políticas, estrutura e organização. São Paulo: Cortez, 2003.

LIBÂNEO, J. C., Pedagogia e pedagogos: inquietações e buscas. Educar em Revista, v. 17, p. 153-176, 2001.

LIBÂNEO, J. C. Tendências pedagógicas na prática social. Democratização da escola pública. São Paulo: Loyola, 1985.

LÜCK, H. Dimensões de gestão escolar e suas competências. Curitiba, Editora Positivo, 2009.

LÜCK, H. Perspectivas da Gestão Escolar e Implicações quanto a Formação de seus Gestores. Em Aberto, Brasília, v. 17, n. 72, p. 11-33, fev./jun. 2000.

LÜCK, Heloísa. Planejamento em orientação educacional. 17. Ed. Petrópolis: Vozes, 2008.

MACHADO, N. Educação: projetos e valores. São Paulo: Escrituras, 2000.

MARCHELLI, P. S. Expansão e qualidade da educação básica no Brasil. Cadernos de Pesquisa, v.40, n. 140, p. 561-585, maio/ago. 2010.

MARIANO, E. B. Sistematização e comparação de técnicas, modelos e perspectivas nãoparamétricas de análise de eficiência produtiva. Dissertação de Mestrado apresentada à Escola de Engenharia de São Carlos, EESC USP, São Carlos, 2008

MARTINEZ-FRITSCHER, A. C., MUSACCHIO, A., VIARENGO, M., The great leap forward: the political economy of Education in Brazil, 1889-1930. Harvard Business School Working Paper, Mar, 2010 
MARTURANO, E.M. O inventário de recursos do ambiente familiar. Psicologia: Reflexão e Critica, 19, 3, 498-506. 2006.

MAYER, D. P. Measuring Instructional Practice: can policymakers trust survey data? Educational evaluation and policy analysis. V. 21, n. 1, 1999.

MEC; UNICEF. Aprova Brasil: O direito de aprender. Estudos de boas práticas de educação pública em escolas avaliadas pelo Prova Brasil: caderno de campo - orientações e instrumentos de trabalho para os pesquisadores. Ministério da Educação e Cultura (MEC) e Fundo das Nações Unidas para a Infância (UNICEF), Brasília, 2006.

MEC; UNICEF. Redes de aprendizagem: boas práticas de municípios que garantem o direito de aprender. Brasília: Ministério da Educação e Cultura, 2008.

MEC História do Ministério da Educação. Ministério da Educação e Cultura, 2014. Disponível em http://portal.mec.gov.br/index.php?option=com_content\&view=article\&id=2\&Itemid=1164, Acesso em 18/04/2014

MEC Melhores práticas em escolas de ensino médio no Brasil. Ministério da Educação e Cultura (MEC) e Banco Interamericano de Desenvolvimento (BID), Brasília: Instituto Nacional de Estudos e Pesquisas Educacionais Anísio Teixeira, 2010.

MEC Prova Brasil: Apresentação. Ministério da Educação e Cultura, 2008, acesso em 02/05/2014, disponível em http://portal.mec.gov.br/index.php?option=com_content\&view=article\&id=210\&Item $\underline{\mathrm{id}=324}$

MEDEIROS, M.L.; ARTONI, C.B.; PASSADOR, João Luiz; PASSADOR, C. S. Diretor de Escola Pública: Da Totalidade a Centralidade?. In: XXV Simpósio Brasileiro e II Congresso Ibero-Americano de Política e Administração da Educação, 2011, São Paulo. Cadernos ANPAE. São Paulo: ANPAE, 2011.

MELLO, J. C.; GOMES, E.; BIONDI NETO, L.; LINS, M. Suavização da Fronteira DEA: o Caso BCC Tridimensional. Associação Portuguesa de Investigação Operacional, n. 24, 2004, pp. 89-107

MENDES, Marcelo Simões. Da inclusão à evasão escolar: o papel da motivação no ensino médio. Estud. psicol. (Campinas) [online]. 2013, vol.30, n.2, pp. 261-265

MENDONÇA, E.F. Estado Patrimonial e Gestão Democrática do Ensino Público no Brasil. Educação \& Sociedade, Campinas, v. 22, n. 75, p. 84-108, ago 2001.

MENEZES FILHO, N. A. A evolução da educação no Brasil e seu Impacto no mercado de trabalho. Instituto Futuro Brasil, mar. 2001.

MENEZES FILHO, N. A. Os Determinantes do Desempenho Escolar no Brasil. Instituto Futuro Brasil, São Paulo, Ibmec - SP, 2007.

MIGUEL, P. A. C. Estudo de caso na engenharia de produção: estruturação e recomendações para sua condução. Produção, v. 17, n. 1, p. 216-229, Jan./Abr. 2007 
MINAYO, M. O desafio do conhecimento: pesquisa qualitativa em saúde. 7. ed. São Paulo: Hucitec, 2000. 269 p.

MIZUKAMI, Maria da Graça Nicoletti. Ensino: as abordagens do processo. São Paulo: Editora Pedagógica e Universitária, 1986.

MORAN, J. M. A educação que desejamos. Novos desafios e como chegar lá. Campinas-SP: Papirus, 2007.

MOREIRA, A, F, B; KRAMER, S. Contemporaneidade, educação e tecnologia. Educ.

Soc., Campinas, v.28, n. 100, Out. 2007. Disponível em

http://www.scielo.br/pdf/es/v28n100/a1928100.pdf. Acesso em 27. Ago. 2014.

MOTTA, D. Biblioteca escolar: orientações básicas para organização e funcionamento. Revista do Professor, Porto Alegre, v. 15, n. 58, p. 21-24, abr./jun. 1999.

MOURA, A. P. M; CRUZ, R. E. A política do transporte escolar no Brasil. In: XXVI Simpósio Brasileiro de Políticas e Administração da Educação sobre Políticas, Planos e Gestão da Educação: democratização e qualidade social, 2013, pp. 1-13.

MUSACCHIO, A.; MARTINEZ-FRITSCHER, A.; VIARENGO, M. Colonial Institutions, Trade Shocks, and the Diffusion of Elementary Education in Brazil, 1889-1930. Harvard Business School Working Paper, Dez, 2012

NIEDERAUER, C. A. P. Avaliação dos bolsistas de Produtividade em Pesquisa da Engenharia da Produção utilizando Data Envelopment Analysis. Dissertação de Mestrado apresentada ao Programa de Pós-Graduação em Engenharia de Produção da Universidade Federal de Santa Catarina. Florianópolis: UFSC, 1998

NIEDERAUER, C. A. P. Ethos: um modelo para medir a produtividade relativa de pesquisadores baseado na análise por envoltória de dados. Tese de Doutorado. Apresentada à Universidade Federal de Santa Catarina: Florianópolis, UFSC, 2002.

NOGUEIRA, L.; RAMOS, F. Uma proposta de distribuição dos royalties do petróleo introduzindo critérios de eficiência - uma abordagem DEA. in XV Encontro Regional de Economia, 2010, Fortaleza. XVI Fórum BNB de Desenvolvimento, 2010

NUNES, S. M. L.; VIEIRA, G. M. O desempenho de matemática dos brasileiros no PISA. IV Congresso Nacional/ III Encuentro Internacional de Estudios Comparados em educación. Buenos Aires, 16-17 jun. 2011.

OECD. Education at a Glance 2007: OECD Indicators. Programme for International Student Assessment. Organization for Economic Co-operation and Development, 2007

OECD. PISA 2009 Results: What Students Know and Can Do - Student Performance in Reading, Mathematics and Science. Programme for International Student Assessment. Organization for Economic Co-operation and Development, 2010

OLIVEIRA, A.P.M. A Prova Brasil Como Política de Regulação da Rede Pública do Distrito Federal, 2011. Disponível em: http://repositorio.unb.br/bitstream/10482/9334/1/2011_AnaPauladeMatosOliveira.pdf $>$. Acesso em 10. Set 2013. 
OLIVEIRA, K. L. de; BORUCHOVITCH, E.; SANTOS, A. A. A. dos. Leitura e desempenho escolar em português e matemática no ensino fundamental. Paidéia, v. 18, n 41, p. 531-540, 2008.

OLIVEIRA, M.; FREITAS, Henrique. Focus group, pesquisa qualitativa: resgatando a teoria, instrumentalizando o seu planejamento. RAUSP. Revista de Administração, São Paulo, v.33, n.3, p.83-91, 1998.

OLIVEIRA, P. R.; BELLUZO, W.; PAZELLO, E. T. The public-private test score gap in Brazil. Economics of Education Review, Volume 35, August 2013, Pages 120-133. Disponível em http://www.sciencedirect.com/science/article/pii/S0272775713000538

OLIVEIRA, R. Da universalização do ensino fundamental ao desafio da qualidade: uma análise histórica. Educ. Soc., Campinas, vol. 28, n. 100 - Especial, p. 661-690, out. 2007

OLIVEIRA, R. P. Estado e politica educacional no Brasil: desafios do século XXI. 2006. 161 f. Tese (Livre-docência)-Faculdade de Educação, Universidade de São Paulo, São Paulo, 2006.

OLIVEIRA, R. P.; ARAUJO, G. C. Qualidade do ensino: uma nova dimensão da luta pelo direito à educação. Revista Brasileira de Educação, n. 28, 2005.

ORAIR, R. et al. Uma metodologia de construção de series de alta frequência das finanças municipais no Brasil com aplicação para IPTU e o ISS: 2004-2010. Pesquisa e Planejamento Econômico (PPE), v. 41, n. 3, dez. 2011

PADILHA, Frederica; ÉRNICA, Maurício; BATISTA, Antonio Augusto Gomes; PUDENZI, Luciana. As regularidades e exceções no desempenho no IDEB dos municípios. Estudos em Avaliação Educacional (Impresso), v. 23, p. 58-81, 2012.

PALMA FILHO, J. C.; ALVES, M. L; DURAN, M. C. G. A reorganização do ensino fundamental em ciclos: trajetória dos últimos trinta anos no estado de São Paulo. Educação e Linguagem, v. 15, n. 26, p. 169-191, 2012.

PARO, V. H. Administração Escolar - introdução crítica. 9 ed. São Paulo: Cortez, 2005.

PARO, V. H. Democratização da Gestão Escolar, FÓRUM NACIONAL DA EDUCAÇÃO, 2., 2002, Santa Cruz do Sul. Anais: humanizando teoria e prática. Santa Cruz do Sul: Edunisc, 2002, p. 60-64.

PARO, V. H. Progressão continuada, supervisão escolar e avaliação externa: implicações para a qualidade do ensino. Revista Brasileira de Educação, v. 16, n. 48, dez. 2011. Disponível em:http://www.scielo.br/scielo.php?script=sci_arttext\&pid=S141324782011000300009\&lng=en\&nrm=iso. Acesso em: 22 nov. 2013.

PARO, V. H. Reprovação escolar: Renúncia à educação. In: Escritos sobre educação. São Paulo: Xamã, 2001. P. 33-47.

PEREIRA, J.; ALBYN, M. What level of education matters most for growth?: Evidence from Portugal. Economics of Education Review, v. 28, n. 1, 2009, pp. 67-73. 
PERRONI, J.; BRANDÃO, A. Seleção ou exclusão: difícil acesso a instituições públicas de ensino. Educação e Realidade, v. 34, n. 1, p. 65-81, 2009.

PIMENTEL, L. A. S. O impacto na variação da matriz energética e da área das florestas na eficiência relativa entre os países membros do G20 na emissão de gases de efeito estufa: uma análise envoltória de dados (DEA) nos anos 1990, 2000 e 2010. 2014. Tese (Doutorado em Administração de Organizações) - Faculdade de Economia, Administração e Contabilidade de Ribeirão Preto, Universidade de São Paulo, Ribeirão Preto, 2014. Disponível em: http://www.teses.usp.br/teses/disponiveis/96/96132/tde-17072014-171326/. Acesso em: 2014-07-18.

PINTO, J. M. R. Novas fontes de financiamento e o custo aluno-qualidade (CAQ). In: Justiça pela qualidade na educação. ABMP, todos pela educação (org). São Paulo: Saraiva, 2013. P. 288-311.

PIRES, D. B. Disciplina: construção da disciplina consciente e interativa em sala de aula e na escola. Educação \& Sociedade, v. 20, n. 66, 1999.

PLOWDEN, L. B. et al. Children and their primary school: A report of the central advisory council for education. London: HMSO, 1967. Disponível em:

http://www.educationengland.org.uk/documents/plowden/. Acesso em: 20 out. 2013.

PNUD Desenvolvimento Humano e IDH. Programa das Nações Unidas para o

Desenvolvimento, 2014. Disponível em http://www.pnud.org.br/IDH/DH.aspx\#, Acesso em08/04/2014

PORTILHO, G. Entenda as Taxas de Transição Escolar e de Rendimento dos Alunos, 2013. Disponível em: http://revistaescola.abril.com.br/politicas-publicas/entenda-taxastransicao-escolar-rendimento-alunos-689317.shtml >. Acesso em: 11. Set 2013.

PSACHARAPOULOS, G. Returns to education: A further international updated and implications. The Journal of Human Resources, v. 20, n. 4, 1985, p. 583-604

PSACHARAPOULOS, G. Returns to education: an updated international comparison. Comparative Education, 1981, p. 321-341

PUCCINELLI, F. G. ; SLOMSKI, V. . Um estudo do investimento público em educação básica no Brasil e do desempenho dos alunos em avaliações nacionais por unidade federativa no período de 1998 a 2007. In: $7^{\circ}$ Congresso USP de Iniciação Científica em Contabilidade, 2010, São Paulo: Êxito Editora, v. 1. 2010

QUINHÕES, M. E. T. Biblioteca escolar: sua importância e seu espaço no sistema educacional do Estado do Rio de Janeiro. In: VIANNA, M. M.; CAMPELLO, B.; MOURA, V. H. V. Biblioteca escolar: espaço de ação pedagógica. Belo Horizonte: EB/UFMG, p. 178-182, 1999.

RAYWID, M.A. Current literature on small schools. Charlestown: Eric Clearinghouse on Rural and Small Schools, 1999.

RESENDE, M.; WYLLIE, R. Retornos para educação no Brasil: evidências empíricas adicionais. Econ. aplic. São Paulo, v. 10, n.3, p. 349-365, jul./set. 2006. 
RESENDE, Tânia F.; NOGUEIRA, Cláudio M, ; NOGUEIRA, M, A,. Escolha do estabelecimento de ensino e perfid familiares: uma faceta a mais das desigualdades escolares. Educação \& Sociedade (Impresso), v. 32, p. 953-970, 2011.

RIANI, J.; RIOS NETO, E. Background familiar versus perfil escolar do município qual possui maior impacto no resultado educacional dos alunos brasileiros. Revista Brasileira de Estudos da População, v. 25, p. 251-269, 2008.

RIBEIRO, P. R. M. História da educação escolar no Brasil: Notas para uma reflexão. Paideia, FFCLRP-USP, fev-jul, 1993

RICHARDSON, R. J. Pesquisa Social: métodos e técnicas. J. A. et al. (Colab.), 3. ed. 7. reimpr. São Paulo: Atlas, 2007.

ROCHA, M. J. F. A Associação de Professores e a gestão democrática na escola pública. UNIrevista, v. 1, n. 2, 2006.

RODRIGUES, A. Impacto da educação no rendimento salarial no Brasil de. 2001 a 2008. Dissertação apresentada ao Programa de Pós-Graduação da UFRGS, 2010.

RUMBERGER, R. W. Why students drop out of school. In G. Orfield (Ed.), Dropouts in America: Confronting the graduation rate crisis. Cambridge: Harvard Education Press., 2006, pp.131-155

RUTTER, M.; MAUGHAN, B.; MORTIMORE, P.; OUSTON, J. Fifteen Thousand hours: secondary schools and their effects on children. Cambridge: Harvard University Press, 1979

SACAVINO, S. Direito humano a educação no Brasil. XIII Encontro Nacional de didática e Prática de Ensino, abr. 2006, Recife.

SALGADO JUNIOR, A. P. Proposta de metodologia para identificação de fatores que possam influenciar no desempenho de alunos de escolas municipais do ensino fundamental em testes padronizados de avaliação em larga escala. 2013. $340 \mathrm{f}$. Tese (Livre-docência - Área de concentração: Produção) - Faculdade de Economia, Administração e Contabilidade de Ribeirão Preto, Universidade de São Paulo, Ribeirão Preto, 2013.

Disponível em: <https://www.dropbox.com/sh/v3wvb57bazfzu91/098HU44lsw>

SALGADO JUNIOR, A. P.; BONACIM, C. A. G.; PACAGNELLA JUNIOR, A. Aplicação da Análise Envoltória de Dados (DEA) para avaliação de eficiência de usinas de açúcar e álcool da região nordeste do estado de São Paulo. Organizações Rurais \& Agroindustriais, Lavras, v.11, n.3, 2009, pp. 494-513

SANTOS, L. S. G. (2008). Fatores associados ao sucesso escolar em matemática: um estudo comparativo entre duas escolas públicas do DF a partir dos dados da Prova Brasil. Disponível em: http://www.ucb.br/sites/100/103/TCC/12008/LarissaSampaioGurgeldosSantos.pdf >.

Acesso em: 10. Ago 2013.

SARAFIDIS, V. An Assessment of Comparative Efficiency Measurement Techniques. London: European Economics, 2002, Disponível em http://www.europeeconomics.com/download/eeeff.pdf 
SAVIAN, M.; BEZERRA, F.; MELO, C.. Análise de Eficiência dos Gastos Públicos com Educação no Ensino Fundamental nos Municípios do Estado do Paraná Evidências para os anos de 2005 e 2009. In X ENABER, 2012, Recife. X ENABER, 2012.

SCHULTZ, T. Investment in Human Capital. The American Economic Review, v. 51, n. 1, mar, 1961, pp. 1-17

SCHWARTZMAN, S.; BROCK, C. (Ed.). Os desafios da educação no Brasil. Rio de Janeiro: Nova Fronteira, 2005.

SEDU Regimento da Secretaria da Educação do Estado do Espirito Santo. Secretaria da Educação (SEDU) do Estado do Espírito Santo, 2010.

SEN, A.A Decade of Human Development. Journal of Human Development, v. 1, n. 1, 2000

SENRA, L.; NANCI, L.; ANGULO MEZA, L. Revisão dos métodos totais de seleção de variáveis em DEA. XXXVII Simpósio Brasileiro de Pesquisa Operacional. Pesquisa Operacional e o Desenvolvimento Sustentável, 2005

SENRA, L.; NANCI, L.; SOARES DE MELLO, J. C.; ANGULO MEZA, L. Estudo sobre métodos de seleção de variáveis em DEA. Pesquisa Operacional, v.27, n.2, 2007, p.191-207

SETÚBAL, M. A. Equidade e Desempenho Escolar É possível alcançar uma educação de qualidade para todos, Revista Brasileira de Estudos Pedagógicos, v.91, n.228, mai-ago, p. 345-366, 2010.

SILVA, D. G.; SANTANA, M. S. R., As Teorias da Educação e suas Contribuições na Consolidação do Conceito de Educação. In: IV SCIENCULT, 2007, Paranaíba. Sujeito, História e Cultura, 2007. V.01.

SILVA, E. P. A importância do Gestor Educacional na Instituição Escolar, Revista Conteúdo, Capivari, v.1, jul./dez. 2009 - ISSN 1807-9539.

SILVA, Nelson Do Valle ; HASENBALG, C. . Recursos Familiares e Transições Educacionais. Cadernos de Saúde Pública, Rio de Janeiro, v. 18, n.suplemento, p. 67-76, 2002.

SILVA, V. G. Por um sentido público da qualidade da educação. 120 f. 2008. Tese (Doutorado)-Faculdade de Educação, Universidade de São Paulo, São Paulo, 2008.

SOARES, J. F. Measuring cognitive achievement gaps and inequalities: The case of Brazil. International Journal of Educational Research, v. 45, n. 3, 2006, Pages 176-187. . Disponível em http://www.sciencedirect.com/science/article/pii/S0883035506001248

SOARES, J. F. Melhoria do desempenho cognitivo dos alunos do ensino fundamental. Cadernos de Pesquisa (Fundação Carlos Chagas), v. 37, p. 135-160, 2007

SOARES, J. F. O efeito da escola no desempenho cognitivo de seus alunos. REICE-Revista Electrónica Iberoamericana sobre Calidad, Eficacia y Cambio en Educación. v. 2, n. 2. 2004.

SOARES, J. F.; ALVES, M. T. G. Desigualdades Raciais no Sistema Brasileiro de Educação Básica. Educação e Pesquisa (USP), São Paulo, v. 29, p. 147-165, 2003. 
SOARES; J. F.; ANDRADE, R. J. Nível socioeconômico, qualidade e equidade das escolas de Belo Horizonte. Ensaio: Avaliação de Políticas Públicas em Educação, Rio de Janeiro, v. 14, n. 50, jan-mar, 2006, pp. 107-126.

SOARES, J. F.; ALVES, M. T. G.; OLIVEIRA, R. M. O efeito de 248 escolas de nível médio no vestibular da UFMG nos anos de 1998, 1999 e 2000. Estudos em Avaliação

Educacional, n. 24, p. 69-117, 2001.

SOLMON, L. Quality of Education and Economic Growth. Economics of Education Review, v. 4, n. 4, 1985 pp. 279-290

SOUSA, A. M.; CASTRO, S. U. Fundos de financiamento para a educação pública e o investimento em capital humano. Marcas educativas, Piauí, v. 1, n. 2, 2012.

SOUZA, L. V. A. de; SOUZA, I. M. A. de; BONFIM, E. C. Leitura no ambiente escolar: do incentivo à Prática. In: Colóquio Internacional Educação e Contemporaneidade, 4., 22 a 24 set., 2010. Anais...São Cristivão: NPGED, 2010.

SOUSA, S. Z.; OLIVEIRA, R. P. Sistemas estaduais de avaliação: uso dos resultados, implicações e tendências. Cadernos de Pesquisa, v. 40, n. 141, p. 793-822, set./dez.2010.

SULIANO, D. C. ; OLIVEIRA, J. L. Desempenho Escolar, Violência e Background Familiar nas Escolas Públicas do Estado do Ceará. Texto para Discussão - IPECE, Fortaleza 2011.

TEDDIE, C,; Reynolds, D. (2000). The international handbook of schoolneffectiveness research. London; New York: Falmer Press.

TEIXEIRA, R. A. Espaços, recursos escolares e habilidades de leitura de estudantes da rede pública municipal do Rio de Janeiro: estudo exploratório. Revista Brasileira de Educação, v. 14, n. 41, p. 232-390, 2009.

THANASSOULIS, E. Introduction to the theory and application of data envelopment analysis: a foundation text with integrated software. 2. ed. Springer, 2003.

TOBING, E. Taxation, human capital formation, and long-run growth with private investment in education. Journal of Asian Economics. Volume 22, Issue 1, February 2011, Pages 48-60. Disponível em

http://www.sciencedirect.com/science/article/pii/S1049007810000813

TRAGTENBERG, M. Sobre educação, política e sindicalismo. São Paulo: Autores Associados, 1982.

TRIVIÑOS, A. N. S. Introdução à pesquisaem ciências sociais: a pesquisa qualitativa em educação. São Paulo: Atlas, 1987.

UNDIME - União Nacional dos Dirigentes Municipais de Educação - Orientações ao dirigente municipal de educação: fundamentos, políticas e práticas. São Paulo: Fundação Santillana, 2012. 
UNESCO. Proyetcto Regional de Indicadores Educativos. Alcanzando las metas educativas: Informe Regional, Organização das Nações Unidas para a Educação, Ciência e Cultura, Santiago de Chile, 2003.

UNESCO. O Perfil dos Professores brasileiros: o que fazem, o que pensam, o que almejam/Pesquisa Nacional UNESCO, - São Paulo: Moderna, 2004.

UNESCO; OREALC. Cumbre de Las Américas. Panorama Educativo De Las Americas. Informe Regional, Proyecto regional de indicadores educativos. Oficina Regional de Educación para América Latina y el Caribe de la UNESCO, UNESCO, Santiago - Chile, Enero 2002. Disponível em:

http://www.prie.oas.org/espanol/documentos/panorama\%20educativo\%20sp.pdf. Acesso 27 de agosto de 2013

UNICEF. Caminhos do Direito de Aprender: Boas Práticas de 26 Municípios Que Melhoraram a Qualidade da Educação/Coordenação UNICEF.- Brasília, DF: UNICEF, 2010.

VASCONCELOS, M. L. M. C. Progressão continuada: por que a revisão dos ciclos? Revista Lusófona de Educação, v. 2, p. 77-84, 2008.

VEGAS, E. Raising student learning in Latin America : the challenge for the 21st century. Emiliana Vegas and Jenny Petrow. The International Bank for Reconstruction and Development. The World Bank, 2008 Disponível em http://siteresources.worldbank.org/INTLAC/Resources/Raising_Student_Learning_in_LAC_ Document.pdf

VEJA, As razões do sucesso da melhor rede municipal de ensino fundamental do Brasil. 2013. Disponível em: http://veja.abril.com.br/noticia/educacao/as-razoes-do-sucesso-damelhor-rede-municipal-de-ensino-fundamentaldo-brasil. Acesso em 18 de julho de 2013

VELOSO, F. A evolução recente e proposta para a melhoria da educação no Brasil. In: BACHA, E.; SCHWARTZMAN, S. (Orgs.), Brasil: A Nova Agenda Social. Riode Janeiro, LTC, p. 215-253, 2011.

VELOSO, F. Experiências de reforma educacional nas últimas duas décadas: o que podemos aprender? In: VELOSO, Fernando et al. (Orgs.). Educação básica no Brasil: construindo o país do futuro. Rio de Janeiro: Elsevier, 2009b. p. 191-211.

VERAS DA SILVA, V. E., Gestão educacional democrática na escola municipal Governador Carlos Lacerda, 2007. (Apresentação de Trabalho/Comunicação).

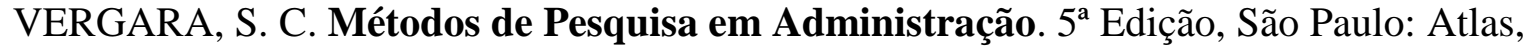
2012

VIDAL, Eloisa Maia; FARIAS, Isabel Maria Sabino. Saeb no Ceará: o desafio de definir o foco na aprendizagem. In. (Org.). Gestão para o sucesso escolar. Fortaleza: Edições SEDUC, 2005.

VILELA, D. L. Utilização do método Análise Envoltório de Dados Para Avaliação do Desempenho Econômico de Coorporativas de Crédito. Dissertação (Mestrado) da Escola de Engenharia de São Carlos, Universidade de São Paulo, 2004 
VIRGINIO, A. S. Educação e sociedade democrática: interpretações sociológicas e desafios à formação política do educador. Sociologias, vol.14, n.29, 2012, pp. 176-212

WAISELFISZ, Jacobo (a). Tamanho da escolar, ambientes escolares e qualidade do ensino. In: Série Estudos. Brasília: FUNDESCOLA/MEC, n. 11, 2000

WALTENBERG, F. D.; VANDENBERGHE, V. What does it take to achieve equality of opportunity in education?: An empirical investigation based on Brazilian data. Economics of Education Review. Volume 26, Issue 6, December 2007, Pages 709-723. . Disponível em http://www.sciencedirect.com/science/article/pii/S0272775707000805

ZAIKIEVICZ, A.P.; SCHNECKENBERG, M. A participação da comunidade nas escolas públicas municipais de Irati - desafios e possibilidades. In: Simpósio Brasileiro II congresso Íbero-Americano de Política de Administração da Educação Jubileu de Ouro da ANPAE, 35. 26 a 29 abril, 2011, São Paulo, Anais...São Paulo: ANPAE, 2011.

ZOGHBI, A. C. P. et al. Mensurando o desempenho e a eficiência dos gastos estaduais em educação fundamental e média. Est. Econ., São Paulo, v. 39, n. 4, p. 785-809, out./dez. 2009.

ZOGHBI, A. C.; LOUZANO, P. Avaliando o impacto do Caderno de Apoio e Aprendizagem na Rede de Ensino Municipal de São Paulo: Efeitos Médios e Heterogêneos. Anpec, 2012. Disponível em: $<$ http://www.anpec.org.br/encontro/2012/inscricao/files_I/i113c2842f66401ef4e218880b3b79a8232.pdf > . Acesso em: 25 dez. 2013.

ZORZI, J. L. Aprendizagem e distúrbios da linguagem escrita. Questões clínicas e educacionais. Porto Alegre: Artmes, 2003.

YIN, R. K. Estudo de caso: planejamento e métodos. 4. ed. Porto Alegre: Bookman, 2010. 
Apêndice A - Roteiro de entrevista - Secretário(a) Municipal de Educação

Informações sobre o Município

\begin{tabular}{|c|c|c|c|c|c|c|c|c|}
\hline \multicolumn{9}{|c|}{ Município/UF/Região: } \\
\hline \multirow[b]{3}{*}{ IDI } & \multirow[b]{3}{*}{ IDH } & \multirow[b]{3}{*}{ População } & \multicolumn{4}{|c|}{ Número de escolas (EF) } & \multirow{3}{*}{$\begin{array}{c}\text { Número } \\
\text { de Inst. de } \\
\text { Educação } \\
\text { Superior - } \\
\text { IES }\end{array}$} & \multirow{3}{*}{$\begin{array}{c}\text { Taxa de } \\
\text { analfabetismo }\end{array}$} \\
\hline & & & \multirow[b]{2}{*}{ Privadas } & \multicolumn{2}{|c|}{ Públicas } & \multirow[b]{2}{*}{ Total } & & \\
\hline & & & & Mun & Est & & & \\
\hline & & & & & & & & \\
\hline
\end{tabular}

Informações da rede/escola

Nome Secretário(a) da Educação:

1. Sexo:

$\square$ Feminino $\square$ Masculino

2. Qual seu nível de escolaridade:

( ) Ensino Médio

( ) Ensino Superior Completo

Qual área?

( ) Licenciatura em Pedagogia

( ) Pós-Graduação (Especialização, Mestrado, Doutorado).

Qual área?

( ) Outras.

Qual área?

3. Já foi Diretor(a) de escola municipal? Por quanto tempo?

4. Existem pré-requisitos para se tornar Secretário?

5. A formação exigida para o cargo é suficiente? Seria importante que houvesse a formação em outras áreas de conhecimento para exercer a função?

6. O Secretário tem autonomia para criação ou alteração de novas políticas educacionais?

7. O Secretário tem autonomia para tomada de decisões financeiras com recursos centralizados (destinos previamente estipulados)? Existe uma folga para atuar na escolha de como investir esse recurso (cadernos, borrachas, materiais escolares etc.)?

8. Como a equipe de funcionários da SME e os Diretores são selecionados: concurso ou indicação para preenchimento do(s) cargo(s)? No caso de indicação para o cargo, comentar sobre a transição política, de forma geral. 
9. Quais os principais desafios do seu município na área da Educação?

10. Em qual(is) área(s) a SME apresenta maior necessidade de melhorias:

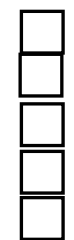
Financeira.

Planejamento.

Recursos Humanos.

Captação de projetos

Administrativa.

Infraestrutura

Compras e Aquisições.

Avaliação e Monitoramento.

Apoio pedagógico.

Comentários:

11. Qual é o organograma da secretaria? Existe uma área exclusiva de captação de recursos?

12. Como funciona a governança dentro da secretaria?

13. Em quais fontes a secretaria busca recursos para financiar a educação do município (arrecadações municipais, programas estaduais, programas federais)? Comente sobre cada um dos métodos utilizados.

14. A APM auxilia a secretaria de alguma maneira para melhoria do ensino no município (financeiramente, apoio em eventos etc.)?

15. Investimentos percentuais da secretaria com educação:

\begin{tabular}{|c|c|l|l|l|l|l|}
\hline \multirow{2}{*}{ FONTE } & \multirow{2}{*}{$\begin{array}{c}\text { Folha de } \\
\text { Funcionários }\end{array}$} & $\begin{array}{c}\text { Aperfeiçoame } \\
\text { nto de pessoal }\end{array}$ & $\begin{array}{c}\text { Materiais } \\
\text { Consumo }\end{array}$ & $\begin{array}{c}\text { Materiais } \\
\text { Permanentes }\end{array}$ & Manutenção & Outros \\
\hline $\begin{array}{c}\text { Secretaria de } \\
\text { Educação }\end{array}$ & & & & & & \\
\hline$\%$ & & & & & & \\
\hline & & & & & & \\
\hline
\end{tabular}

16. Especifique quais os programas (federais, estaduais e municipais) são implementados pela SME (Secretaria Municipal de Educação) nas escolas:

17. Existe alguma parceria da Secretaria da Educação com empresas da região?

18. A secretaria municipal descentraliza recursos para suas escolas?

Caso sua resposta seja "Sim" especifique: qual é a frequência, valor, percentual e a sua destinação: 
19. Os recursos descentralizados, geralmente vêm sendo utilizados para:

\begin{tabular}{|l|l|l|}
\hline \multicolumn{1}{|c|}{ Utilização dos recursos descentralizados } & sim & \multicolumn{1}{|c|}{ não } \\
\hline A. Programas de computador e softwares & (A) & (B) \\
\hline B. Equipamentos para a sala de informática & (A) & (B) \\
\hline C. Acervo para a biblioteca (livro, assinatura, jornais) & (A) & (B) \\
\hline $\begin{array}{l}\text { D. Mobiliário em geral (mesas, cadeiras) } \\
\text { E. Materiais didáticos diversos }\end{array}$ & (A) & (B) \\
\hline $\begin{array}{l}\text { F. Equipamentos de uso geral (copiadora, vídeo, TV, máquina fotográfica, } \\
\text { específicos para os alunos) }\end{array}$ & (A) & (B) \\
\hline $\begin{array}{l}\text { G. Cursos, palestras, orientações didático-pedagógica } \\
\text { H. Contratação de funcionários de apoio }\end{array}$ & (A) & (B) \\
\hline $\begin{array}{l}\text { I. Serviços e materiais para manutenção geral das dependências da escola e e } \\
\text { mobiliário }\end{array}$ & (A) & (B) \\
\hline \begin{tabular}{l} 
J. Outro. Especifique: \\
\hline
\end{tabular} & \\
\hline
\end{tabular}

20. Quais índices do município vocês acompanham em avaliações externas?

21. Qual custo por aluno do município?

22. Qual a média salarial do cargo de Diretor? O salário é atrativo? Qual o salário pago pelas outras escolas da região?

23. O ensino fundamental é ofertado exclusivamente pela rede pública?

24. Com relação ao critério para admissão (matrícula) de alunos:

$\square$ por zoneamento $\square$ por escolha da família

25. Existe uma política de aprovação automática?

26. Existe uma adequação das grades horárias das escolas voltadas para os requisitos da Prova Brasil?

27. Existem incentivos financeiros para as escolas participarem de campeonatos e olimpíadas (matemática, português etc.)?

28. Qual a quantidade de escolas urbanas e rurais no município?

29. Qual o percentual de empregados trocados ao fim de cada gestão na Secretaria?

30. Existem cursos de formação continuada para os Professores do município?

31. Existe algum incentivo financeiro para os Professores participarem dos cursos de formação continuada? E para evolução na carreira?

32. Como são os benefícios para os Professores? (salário, vale refeição etc.)

33. O salário dos Professores deste município está acima da média regional? Em qual porcentagem? 


\section{Apêndice B - Roteiro de entrevista com Diretor}

\section{Informações da escola}

Endereço da escola:

Telefone:

e-mail:

Localização:
( ) área urbana
( ) área rural
( ) área urbana periférica

2. Nível e modalidade de ensino ministrado na escola:

( ) educação infantil
( ) ensino fundamental $-1^{\circ}$ ao $5^{\circ}$ ano
( ) ensino fundamental $-6^{\circ}$ ao $9^{\circ}$ ano
( ) ensino fundamental $-1^{a}$ a $9^{\circ}$ ano
( ) educação de jovens e adultos
( ) ensino médio

\section{Nome do Diretor:}

5. Sexo: $\square$ Feminino $\square$ Masculino

6. Qual seu nível de escolaridade?

( ) Ensino Superior Completo

Qual área?

( ) Licenciatura em Pedagogia

( ) Pós-Graduação (Especialização, Mestrado, Doutorado).

Qual área?

( ) Outras.

Qual área?

\section{Existem requisitos para se tornar Diretor da escola?}

\section{A formação exigida para o cargo é suficiente?}

9. Seria importante que houvesse a formação em outras áreas de conhecimento para exercer a função? Quais seriam?

10. Você assumiu a direção desta escola por:

Concurso.

Eleição.
Indicação.

Seleção e Eleição.

11. Quais são as atribuições do cargo de Diretor? 
12. O Diretor tem autonomia para tomada de decisões financeiras com recursos centralizados (destinos previamente estipulados)? Existe uma folga para atuar na escolha de como investir esse recurso (cadernos, borrachas, materiais escolares etc.)?

13. Referente às condições para o exercício do cargo de Diretor(a):

a) Há interferências externas a sua gestão?

b) Há apoio de instâncias superiores?

c) Há troca de informações com outros Diretores?

d) Há apoio da comunidade na sua gestão? Existe algum tipo de cobrança?

e) Existe alguma resistência contra quem está no cargo caso seja indicado pelo prefeito ao invés de concurso elou eleição?

f) Há alguma reunião periódica com o Secretário da Educação?

14. Qual é a média salarial do cargo de Diretor da escola?

15. A dificuldade do cargo de Diretor está:

\begin{tabular}{|l|c|c|}
\hline \multicolumn{1}{|c|}{ Tipos de dificuldades } & Não & Sim \\
\hline No salário. & & \\
\hline Na longa jornada de trabalho. & & \\
\hline Na falta de suporte. & & \\
\hline No perfil dos alunos e de suas famílias. & & \\
\hline Na falta de infraestrutura da escola. & & \\
\hline Nos relacionamentos interpessoais com os Professores & & \\
\hline Nos relacionamentos interpessoais com os pais dos alunos & & \\
\hline Nos relacionamentos interpessoais com alunos & & \\
\hline Nos relacionamentos interpessoais com a equipe da SME & & \\
\hline
\end{tabular}

Outros itens citados durante a entrevista: Comente os principais resultados.

\section{Perfil e Funcionamento da Escola}

16. Qual o número total de alunos matriculados nesta escola?

17. Com relação ao critério para admissão (matrícula) de alunos:

$\square$ por zoneamento $\square$ por escolha da família

18. Existe sistema de reprovação na escola? Como ele funciona?

19. A escola realiza algum tipo de processo seletivo para ingresso do aluno? Como ele é realizado?

20. A escola recebe alunos de outras escolas por transferência? Existe alguma restrição para que isso aconteça?

21. A escola realiza transferência compulsória caso o aluno reprove em alguma disciplina? 
22. A rotatividade dos Professores e funcionários, nos últimos três anos, tem afetado o desempenho da escola?

23. A escola adota sistema padronizado de ensino?

24. Qual o critério de escolha para o material escolar?

25. Existe um sistema de reforço escolar? Como é feito?

26. A escola tem projetos voltados para Matemática e Português?

27. Existe uma adequação da grade horária de ensino ou preparação específica visando a Prova Brasil?

28. Medidas e Projetos pedagógicos

a. Há medidas e projetos implantados pela Secretaria Municipal da Educação? Listar.

b. Há resultados mensurados de algum projeto implantado?

c. Há projetos que dão atenção especial aos alunos com dificuldades de aprendizagem?

d. No caso de não haver projetos, descrever os motivos ou dificuldades.

29. Há parcerias de Projetos subsidiados por ONGs, empresas, sindicatos, etc.?

30. Existe arrecadação de recursos descentralizados? (Rifas, festas juninas etc.)

31. Como a APM auxilia a gestão do Diretor?

32. Pais e Comunidade

a. A escola promove eventos que permitam contato entre pais e Professores?

( ) frequentemente ( ) quase sempre ( ) às vezes ( ) raramente ( ) nunca

b. Os pais comparecem e participam das reuniões para as quais são convidados?

( ) frequentemente ( ) quase sempre ( ) às vezes ( ) raramente ( ) nunca

c. Os pais participam de eventos festivos que acontecem nas escolas?

( ) frequentemente ( ) quase sempre ( ) às vezes ( ) raramente ( ) nunca

33. Como é a oferta de transporte gratuito para pais de alunos quando convidados a comparecer na escola?

34. Existem Professores com magistério?

35. A escola promove cursos de formação continuada para Professores?

( ) $\operatorname{sim}$ ( ) não

36. Liste os cursos oferecidos nos últimos 2 anos. 
37. Existe algum incentivo para os Professores participarem dos cursos de formação continuada?

38. Em relação à Alimentação dos alunos, a escola:

a) Recebe orientação de nutricionista $\square$ Sim $\square$ Não

b) Promove a participação dos alunos no cultivo de hortifruti para consumo $\square \operatorname{Sim} \square$ Não

c) São oferecidas __ refeição(ões) ao dia.

39. Em relação à biblioteca e/ou sala de leitura:

a) Possui acervo diversificado para o incentivo à leitura.

b) Possui espaço para estudos coletivos.

c) A comunidade pode usar os espaços e os livros.

d) Recebe recursos para investimento periodicamente.

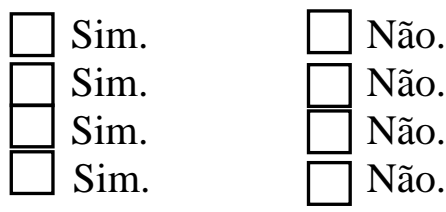

40. Em relação à informática:

a) A escola possui um laboratório próprio para aulas. $\square$ Sim. $\square$ Não.

b) A escola recebe recursos para investimentos periódicos. $\square$ Sim. $\square$ Não

41. Qual a quantia aproximada de recursos financeiros descentralizados que sua escola recebe anualmente da $\mathrm{SME}$ ?
a. Até $\mathrm{R} \$ 5.000,00$.
b. $\quad$ De R $\$ 5.001,00$ a $\mathrm{R} \$ 10.000,00$.
c. De $\mathrm{R} \$ 10.001,00$ a $\mathrm{R} \$ 15.000,00$.
d. De R $\$ 15.001,00$ a $\mathrm{R} \$ 20.000,00$.
e. Mais de $\mathrm{R} \$ 20.001,00$.
f. Não recebe.

42. Os recursos descentralizados, geralmente vêm sendo utilizados para:

\begin{tabular}{|l|c|c|}
\hline \multicolumn{1}{|c|}{ Utilização dos recursos descentralizados } & sim & não \\
\hline A. Programas de computador e softwares & (A) & (B) \\
\hline B. Equipamentos para a sala de informática & (A) & (B) \\
\hline $\begin{array}{l}\text { C. Acervo para a biblioteca (livro, assinatura, jornais) } \\
\text { D. Mobiliário em geral (mesas, cadeiras) }\end{array}$ & (B) \\
\hline $\begin{array}{l}\text { E. Materiais didáticos diversos } \\
\text { F. Equipamentos de uso geral (copiadora, vídeo, TV, máquina fotográfica, }\end{array}$ & (B) \\
\hline $\begin{array}{l}\text { específicos para os alunos) } \\
\text { G. Cursos, palestras, orientações didático-pedagógica }\end{array}$ & (A) & (B) \\
\hline $\begin{array}{l}\text { H. Contratação de funcionários de apoio } \\
\text { I. Serviços e materiais para manutenção geral das dependências da escola e e } \\
\text { mobiliário }\end{array}$ & (A) & (B) \\
\hline $\begin{array}{l}\text { J. Outro. Especifique: } \\
\text { (B) }\end{array}$ \\
\hline
\end{tabular}

43. O salário dos Professores deste município está acima da média regional? Em qual porcentagem? 


\section{Apêndice C - Roteiro de entrevista com os Professores}

1. Nome da Escola:

2. Gênero: $\square$ Feminino $\square$ Masculino

3. Qual seu nível de escolaridade?
( ) Ensino Médio
( ) Ensino Superior Completo
( ) Licenciatura em Pedagogia
( ) Outras. Especificar
( ) Pós-Graduação (Especialização, Mestrado, Doutorado)

4. Há quanto tempo você atua como Professor?

5. Quais são as disciplinas que você ministra atualmente?

6. Como você avalia a sua autonomia no ensino (formas de avaliação, atividades em sala, reprovação)?

7. Você tem autonomia em relação a escolha do material didático? Na sua percepção qual é a qualidade do material atualmente utilizado?

8. No seu entendimento, como é a frequência de leitura dos alunos? Se possível quantifique.

9. Como é a rotatividade dos docentes responsáveis pelas disciplinas de matemática e português?

10. Com que frequência você faz o acompanhamento do desempenho dos alunos na sua disciplina? Como ele é feito?

11. Na escola existe recuperação paralela e reforço no contraturno? Em caso positivo, de quais disciplinas e como isso ocorre?

12. Existem projetos que colaborem para o melhor desempenho do aluno nas disciplinas de matemática e português? Quais?

13. Você sabe se a distribuição de carga horária ou grade curricular é influenciada pelos requisitos avaliados na Prova Brasil?

14. Existe alguma preparação específica em relação à Prova Brasil? Em caso positivo, como ela ocorre?

15. Qual é a frequência dos pais nas reuniões de pais e mestres?

16. Qual é a frequência dos pais em eventos festivos da escola?

17. Os pais contribuem com a manutenção da estrutura física da escola? Como?

18. Existe associação de pais de mestres (APM)? Como é a participação dos pais?

19. Com qual intensidade os pais apoiam as ações da escola? 
20. Existe sistema de reprovação na escola?

\begin{tabular}{|l|l|}
\hline Sim & Não \\
\hline & \\
\hline
\end{tabular}

21. As regras do Sistema Disciplinar são claras e bem definidas? Você as conhece? Os alunos as conhecem?

22. Como é a disciplina comportamental dos alunos no transcorrer das aulas?

23. Como é o respeito dos discentes em relação à figura do Professor, Diretor e funcionários?

24. Existe laboratório de informática na escola?

\begin{tabular}{|l|l|}
\hline Sim & Não \\
\hline & \\
\hline
\end{tabular}

25. Em caso positivo, com qual frequência ocorrem as aulas? Qual é o número de computadores?

26. Como você classifica o tamanho do acervo da biblioteca?

\begin{tabular}{|l|l|l|l|l|}
\hline 1 & 2 & 3 & 4 & 5 \\
\hline & & & & \\
\hline
\end{tabular}

27. Como você classifica a variedade de livros existentes na biblioteca?

\begin{tabular}{|l|l|l|l|l|}
\hline 1 & 2 & 3 & 4 & 5 \\
\hline & & & & \\
\hline
\end{tabular}

28. Como você classifica a frequência da retirada de livros da biblioteca por parte dos alunos?

\begin{tabular}{|l|l|l|l|l|}
\hline $\mathbf{1}$ & $\mathbf{2}$ & $\mathbf{3}$ & $\mathbf{4}$ & $\mathbf{5}$ \\
\hline & & & & \\
\hline
\end{tabular}

29. Existe sala de leitura?

\begin{tabular}{|l|l|}
\hline Sim & Não \\
\hline & \\
\hline
\end{tabular}

30. Em caso positivo, com que frequência ela é utilizada pelos alunos?

31. A escola realiza algum tipo de processo seletivo para ingresso do aluno? Como ele é realizado? 
32. Em caso positivo, os alunos valorizam a vaga conquistada através do processo seletivo?

33. Com que frequência os alunos utilizam o transporte público para ir à escola?

34. Em relação à questão financeira, existe plano de carreira? Ele é atrativo financeiramente (possui salários acima da média regional)?

35. Existe progressão salarial, como ela funciona? Quais são os critérios levados em consideração?

36. A secretaria municipal de educação promove cursos, palestras ou orientações didático-pedagógicas para os Professores? 


\section{Apêndice D - Roteiro de Entrevista com os alunos}

Nome da escola:

Idade

Série/ciclo

1. Sexo

( ) Masculino ( ) Feminino

2. Você reside na área:

( ) Rural ( ) Urbana

3. Você utiliza o transporte público para ir à escola? Em caso positivo, com qual frequência?

4. Como são suas aulas de português?

5. O que você acha da forma como o Professor de português aborda os conteúdos na sala?

6. O Professor de português acompanha o seu desempenho na disciplina? Em caso positivo, como ele é feito?

7. Existe recuperação paralela e reforço no contraturno na disciplina de Português? Em caso positivo, como isso ocorre?

8. Existem projetos que colaboram para um melhor desempenho em português? Em caso positivo, quais são?

9. Existe alguma preparação específica para a Prova Brasil na disciplina de Português? Em caso positivo, como ele ocorre?

10. Você gosta de ler? Qual sua frequência de leitura?

11. Você costuma frequentar a biblioteca da escola?

12. Como você classifica o tamanho do acervo da Biblioteca?
(1) (2)
(3)
(4)
(5)

13. Como você classifica a variedade do acervo da Biblioteca?
(1) (2)
(2)
(3) (4)
(5) 
14. A escola possui sala de Leitura? Em caso positivo, ela é adequada para leitura?

15. Você utiliza a sala de Leitura? Com qual frequência?

16. Você costuma levar livros para casa? Em caso positivo, eles são indicados pelos Professores ou são de seu próprio interesse?

17. Como são suas aulas de matemática?

18. O que você acha da forma como o Professor de matemática aborda os conteúdos na sala?

19. O Professor de matemática acompanha o seu desempenho na disciplina? Em caso positivo, como ele é feito?

20. Existe recuperação paralela e reforço no contraturno na disciplina de matemática? Em caso positivo, como isso ocorre?

21. Existem projetos que colaboram para um melhor desempenho em matemática? Em caso positivo, quais são?

22. Existe preparação específica para a Prova Brasil na disciplina de matemática? Em caso positivo, como ela é?

23. Sua escola costuma realizar atividades extra escolares? Em caso positivo, Quais são?

24. A escola possui laboratório de informática?

( ) Sim. ( ) Não

25. Qual a frequência das aulas de informática?

( ) Diariamente ( ) Semanalmente ( ) Mensalmente

26. Você possui interesse pelas aulas de informática? Como elas são?

27. As aulas de informática se relacionam com as outras disciplinas? Em caso positivo, com quais?

28. A escola oferece refeição para os alunos?

( ) $\operatorname{Sim}$ ( ) Não 
29. Quantas refeições por período a escola oferece?

30. O que você acha das refeições oferecidas pela escola?

31. Existe alguma atividade que envolva o cultivo de alimentos para consumo na escola? Em caso positivo, quais são?

32. As regras do sistema disciplinar são claras, conhecidas e respeitadas pelos alunos?

33. Os alunos da escola possuem respeito pela figura do Professor, Diretor e funcionários?

34. Seus pais/responsáveis concordam com as regras estipuladas pela escola?

35. Seus pais/responsáveis participam da APM?

36. Seus pais/responsáveis participam dos eventos festivos da escola?

37. Seus pais/responsáveis frequentam as demais reuniões realizadas pela escola?

38. Seus pais/responsáveis participam de suas tarefas de casa?

39. Seus pais/responsáveis utilizam o transporte público para ir à escola?

40. Como é a disciplina comportamental de seus colegas no transcorrer das aulas?

41. Os alunos com baixo desempenho reprovam nas disciplinas?

42. Você sente orgulho de estudar nesta escola?

43. Quais mudanças você faria em sua escola? 


\section{Apêndice E - Roteiro de Entrevista com os pais}

Nome da escola:

1. Seu (s) Filho (a) reside na área:

\section{( ) Rural ( ) Urbana}

2. Você costuma participar da vida da escolar de seu filho? Em caso positivo, comente como?

3. Você acompanha os deveres escolares de seu filho? Em caso positivo, com qual frequência?

4. Você frequenta a Associação de Pais e Mestres? Em caso positivo, com qual frequência?

5. Você participa dos eventos festivos da escola? Em caso positivo, com qual frequência?

6. Você costuma frequentar as demais reuniões realizadas pela escola? Em caso positivo, com qual frequência?

7. Você utiliza transporte público para ir à escola?

8. Você conhece o Diretor (a) da escola? Como é a sua relação com ele (a)?

9. O Diretor se mostra disponível para atender os pais individualmente?

10. Seu (s) filho (a) utiliza transporte público para ir à escola? Com qual frequência?

11. Você contribui ou já contribuiu de alguma maneira para a manutenção da estrutura física da escola? Em caso positivo, comente como?

12. O que você acha das regras estipuladas pela escola?

13. As regras do sistema disciplinar são claras, conhecidas e respeitadas pela comunidade escolar?

14. A escola oferece recuperação paralela e reforço no contraturno na disciplina de português para o seu filho (a)? Em caso positivo, como isso ocorre?

15. A escola oferece projetos que colaboram para um melhor desempenho do seu filho (a) em português? Em caso positivo, quais? 
16. No seu entendimento, qual é a frequência de leitura do seu filho (a)? Se possível quantifique.

17. Seu (s) filho (a) costuma levar livros para casa?

18. Existe sala de leitura na escola de seu filho (a)?

( ) Sim. ( ) Não.

19. A escola oferece recuperação paralela e reforço no contraturno na disciplina de matemática para seu filho (a)? Em caso positivo, como isso ocorre?

20. A escola oferece projetos que colaboram para um melhor desempenho do seu filho (a) em matemática? Em caso positivo, quais?

21. Existe sala de informática na escola de seu filho (a)?

( ) Sim. ( ) Não.

22. Você conhece as propostas pedagógicas que a escola vai desenvolver ao longo do ano? Em caso positivo, como você ficou sabendo?

23. Você percebe avanço na aprendizagem de seu (a) filho (a) em função de atividades escolares?

24. Em que áreas/ disciplinas você percebe maior evolução?

25. Qual é os pontos fortes e fracos dessa escola? 


\section{Apêndice F - Roteiro de entrevista sobre Infraestrutura}

\section{Nome da escola:}

2. Nível e modalidade de ensino ministrado na escola:

( ) educação infantil

( ) ensino fundamental $-1^{\circ}$ ao $5^{\circ}$ ano

( ) ensino fundamental $-6^{\circ}$ ao $9^{\circ}$ ano

( ) ensino fundamental $-1^{\mathrm{a}}$ a $9^{\circ}$ ano

( ) educação de jovens e adultos

( ) ensino médio

\section{Avalie o estado de conservação dos itens e equipamentos do prédio escolar:}

\begin{tabular}{|l|l|l|l|l|l|}
\hline Item & $\mathbf{1}$ & $\mathbf{2}$ & $\mathbf{3}$ & $\mathbf{4}$ & $\mathbf{5}$ \\
\hline Telhado & & & & & \\
\hline Paredes & & & & & \\
\hline Piso & & & & & \\
\hline Entrada da escola & & & & & \\
\hline Pátio & & & & & \\
\hline Salas de Aula & & & & & \\
\hline Banheiros & & & & & \\
\hline Cozinha & & & & & \\
\hline Instalações hidráulicas & & & & & \\
\hline Instalações elétricas & & & & & \\
\hline Portões & & & & & \\
\hline Muros/cercas & & & & & \\
\hline Grades de segurança & & & & & \\
\hline Acesso à Internet & & & & & \\
\hline DVD & & & & & \\
\hline Projetor de slides & & & & \\
\hline Quadra de Esportes & & & & \\
\hline Laboratório de Ciências & & & & \\
\hline
\end{tabular}

4. Em relação à biblioteca:

a) Possui acervo diversificado para o incentivo à leitura? Qual a quantidade?

\begin{tabular}{|l|l|}
\hline Sim & Não \\
\hline & \\
\hline & \\
\hline
\end{tabular}

b) Possui espaço para estudos coletivos? É capaz de atender à quantos alunos simultaneamente? 


\begin{tabular}{|l|l|}
\hline Sim & Não \\
\hline & \\
\hline & \\
\hline
\end{tabular}

c) Os livros podem ser manuseados ou emprestados? Existe registro de retirada dos livros?

\begin{tabular}{|l|l|}
\hline Sim & Não \\
\hline & \\
\hline
\end{tabular}

d) A comunidade pode usar os espaços e os livros?

\begin{tabular}{|l|l|}
\hline Sim & Não \\
\hline & \\
\hline
\end{tabular}

e) O espaço é bem iluminado e arejado?

f) Existe fluxo de alunos na biblioteca? Há uma mensuração dessa movimentação?

\begin{tabular}{|l|l|}
\hline Sim & Não \\
\hline & \\
\hline & \\
\hline
\end{tabular}

g) Quantas obras distintas atualmente compõe o acervo?

5. Existe laboratório de informática? Qual é o número de computadores disponíveis?

6. Existe sala de leitura na escola? Em caso positivo, trata-se de um ambiente bem iluminado e arejado? Quantos alunos podem utilizá-la simultaneamente?

7. Há alguma parte da infraestrutura da escola que tenha sido construída ou reformada por pais de alunos? 


\section{Apêndice G - Correlação de Spearman das variáveis do instrumento de pesquisa}

\section{Tabela 13 - Correlação de Spearman para identificar as variáveis que formam o instrumento de pesquisa}

\begin{tabular}{|c|c|c|c|c|c|c|c|c|c|c|c|c|c|c|c|c|c|c|c|c|c|c|c|c|c|c|c|c|c|c|c|c|c|c|c|c|c|c|}
\hline & EB & in & 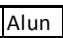 & 71 & lun & 11 & 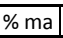 & B & ret & Pard & $\mathrm{ar}$ & Indí & isc & Medi & si & Ensi & Ensi & Ensi & Espe & Mest & :Dout & Educ & Ensi & fo & ala & Sala & \begin{tabular}{|l|l|} 
Labo \\
\end{tabular} & Labo & Sala & ibl & ala & Inte & NSE & Popu & Tota & ort & hate & nve \\
\hline$E B$ & 1 & $\mid-, 079^{\prime \prime}$ & 098" & ,093" & $088^{\prime \prime}$ &,- 025 & $-0,066$ & ,494" & 362 & $4{ }^{4}$ & \begin{tabular}{|c|}
, 047 \\
\end{tabular} &,$- 157^{\prime \prime}$ &,- 030 & \begin{tabular}{|l|}
,- 068 \\
\end{tabular} &,- 031 & \begin{tabular}{|c|}
1,013 \\
\end{tabular} & \begin{tabular}{|l|}
,- 034 \\
\end{tabular} & \begin{tabular}{|l|}
, 039 \\
\end{tabular} & , & \begin{tabular}{|c|}
, 033 \\
,
\end{tabular} & \begin{tabular}{|l|l|}
3 & 042 \\
\end{tabular} & $280^{\circ}$ & 994 & $15^{\prime \prime}$ &, 006 & ,010 & \begin{tabular}{|l|}
,- 025 \\
\end{tabular} & \begin{tabular}{|l|}
, 063 \\
\end{tabular} &,- 022 & .086 & 081 & $077^{7}$ & 392 & 232 & -215 & $846^{\prime \prime}$ & $840^{\circ}$ & \\
\hline ccentes & $-0,079^{\prime \prime}$ & 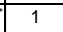 & , & $64^{\prime \prime}$ & 304 & $484^{\prime \prime}$ & $=, 0$ & $16 "$ & 138" & $101^{\prime \prime}$ & $060^{\circ}$ & ,027 &,- 029 & 176 & ,047 & ,044 & .030 & $158^{\circ}$ & $\overline{00}$ & .093" & ,027 & 290 & $\overline{111}$ & 037 & $\overline{011}$ &,- 024 & ,040 & ,046 & 145 &, 009 &, $04 \mathrm{~s}$ & 022 & 120 & 357 & 413 & 077 & 125 & $129^{\prime \prime}$ \\
\hline uno & $098^{\circ}$ & 379" & 1 & , $311{ }^{-1}$ & ,470" & ,023 & $-0,094^{*}$ & $223^{\prime \prime}$ & ,201" & ,222" & $136^{\prime \prime}$ & ,152" & $31^{\prime \prime}$ & ,260" & - & \begin{tabular}{|l|l|}
5 &,- 020 \\
\end{tabular} & $0,00^{\circ}$ & $136^{\circ}$ &, $135^{*}$ & 137 & 09 &,- 359 & 236 & , $310^{\prime \prime}$ &,- 006 & ,029 & 122 & ,019 &, 089 & , 194" &, $254^{\circ}$ & ,069 & 089 & 454 & .575 & 134 & 08 & 41 \\
\hline ador & $93^{3}$ & $264^{4}$ & $11^{\prime \prime}$ & - & $-390^{\circ}$ & 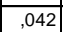 & ,041 & $268^{\circ}$ &,- 035 &,- 074 & 12 & $060^{\circ}$ & ,004 &,- 045 & \begin{tabular}{|c|}
, 017 \\
\end{tabular} & ,027 & 018 & $\overline{012}$ & -.024 &,- 025 &,- 042 &, $152^{\prime}$ &, 035 & ,043 &,- 030 &,- 042 & $128^{\circ}$ & $04 \mathrm{0}$ & 077 & 053 &, $04 c$ &,- 003 &, 00 & $078^{\circ}$ & 388 & 100 & 01 & \\
\hline luno: &,$- 088^{\prime \prime}$ & 304 & $70^{\circ \prime}$ & $\mid-390^{\prime \prime}$ & & ,013 &, 04 & $072^{\prime \prime}$ & ,038 & 120 & 035 & $088^{\circ}$ & |014 &,- 036 & ,001 & -012 & ,009 & \begin{tabular}{|l}
, $064^{\circ}$ \\
\end{tabular} &, $0 c$ &, 053 & $-0,014$ & \begin{tabular}{|l|}
,- 129 \\
\end{tabular} &, 004 & \begin{tabular}{|l|}
, $068^{\prime}$ \\
\end{tabular} & ,002 & ,031 &, 105 & ,045 & 058 & $111^{1}$ &, $105^{\circ}$ & ,021 & ,024 & 118 & 444 & 111 & 113 & 774 \\
\hline & $-0,025$ & $484^{4}$ &,- 023 & ,042 & ,013 & 1 & ,065 & $61^{\circ}$ & ,075" &, 066 & ,041 & ,013 & \begin{tabular}{|l|l}
, $076^{\circ}$ \\
\end{tabular} &,- 038 & ,040 &, 022 &, 073 & $200^{\circ}$ & ,073" &,- 012 & ,037 & 222 & ,086 & $144^{\prime \prime}$ &, 032 & $=001$ & 084 & ,078" & 148 & ,018. & 123 &,- 037 &, 00 & 286 & 18 & 072 & $108^{\circ}$ & \\
\hline $\mathrm{ma}$ & \begin{tabular}{|c|}
-0666 \\
\end{tabular} &, 046 & 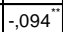 & ,041 & -,044 & ,065" & & \begin{tabular}{|l|}
, 017 \\
\end{tabular} &,- 048 & 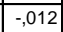 &,- 003 & ,039 & ,026 &,- 044 &,- 002 & 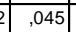 & ,012 & ,014 & ,040 & $-0,038$ & ,010 & \begin{tabular}{|l}
, 047 \\
\end{tabular} & ,030 & 061 & 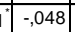 & \begin{tabular}{|c|}
3 \\
\end{tabular} & \begin{tabular}{|c|}
, 014 \\
\end{tabular} & ,025 & -,034 & ,046 & \begin{tabular}{|l|}
-044 \\
\end{tabular} & $=, 007$ &,- 033 & .086 &,$- 077^{\prime}$ &, $061^{\circ}$ & $=016$ & \\
\hline & $494^{\circ}$ & $16^{\prime \prime}$ & $23^{\circ}$ & $68^{\circ}$ & 072 & ,061. & ,017 & \begin{tabular}{l|l} 
\\
\end{tabular} & - & $350^{\circ}$ & ,046 &,$- 213^{\prime \prime}$ & - & ,130" & ,011 & 1,006 &, 022 & ,015 & ,261" & ,028 & - & $303^{\circ}$ & $2,210^{\circ}$ & $313^{\circ}$ & ,007 & ,023 & ,025 & ,015 &, $070^{\circ}$ & ,038 &, $102^{\circ}$ & ,013 & $2,239^{\circ}$ & $-366^{\prime \prime}$ &,$- 282^{\circ}$ & $483^{\prime \prime}$ & 534 & 145 \\
\hline et & $-362^{\circ}$ & $138^{\prime \prime}$ & , 201" & - & ,038 & ,075" & -,048 & - & 1 & ,620" & | & | & , 102" & , 279" & - & $7 \mid-, 043$ & ,006 & , 041. & | & ,094" & ,024 &,$- 331^{\prime}$ &,$- 251^{\prime \prime}$ & |,287" & ,038 & | & \begin{tabular}{|l|l}
, $097^{\prime \prime}$ \\
\end{tabular} & \begin{tabular}{|l|l|}
, $080^{\circ}$ \\
\end{tabular} & ,073" &,$- 090^{\prime \prime}$ & "152" & , 050 & \begin{tabular}{|l|}
-055 \\
\end{tabular} & $449^{\circ}$ & ,304" & ,332" & $389^{\circ}$ & $250^{\circ}$ \\
\hline$r d$ &,- 4 & $01 "$ & & 074 & ,120" &,$- 066^{\circ}$ & $-0,012$ & $\cdots$ & ,620" & & $\begin{array}{l}, 022 \\
,\end{array}$ & ,246" & $-0,054$ & \begin{tabular}{|l|l}
, $139^{\prime \prime}$ \\
\end{tabular} & ,030 & \begin{tabular}{|c|}
0,043 \\
\end{tabular} & \begin{tabular}{|c|}
, 023 \\
\end{tabular} & . & 178" & ,011 & , 016 &, $310^{\circ}$ & 221 & \begin{tabular}{|l|l|}
, $295^{\prime \prime}$ \\
\end{tabular} & .080" &, $057^{\prime}$ & , $064^{\circ}$ & ,047 & ,004 &,$- 126^{\prime \prime}$ & , 180" & ,026 &,- 257 & 336 & & 406 & 48 & \\
\hline & 47 &, $060^{\circ}$ & 36 & -027 & ,035 & ,041 & \begin{tabular}{|c|}
,- 003 \\
\end{tabular} & 46 & , $085^{\prime \prime}$ & ,022 & 1 & | & ,080" & ,187" & , 040 & \begin{tabular}{|c|}
0 \\
\end{tabular} & -024 & ,048 & \begin{tabular}{|l|l|} 
&,- 011 \\
\end{tabular} & 123" & $0,05^{\circ}$ & "|,-099" &,$- 097^{7}$ & , 121" & 24 &,- 032 & $\mid$ & ,057 & ,036 &,$- 068^{\circ}$ & ,050 & \begin{tabular}{|l|} 
\\
, 048
\end{tabular} & , 132" & 174 & , 157" & , & ,042 & $1111^{11}$ \\
\hline & & ,027 & & $060^{\circ}$ & ,088" &,- 013 & ,039 & $13^{*}$ & 8 & 246" & ,169" & 1 & \begin{tabular}{|l|}
,- 006 \\
\end{tabular} & (158" & $\begin{array}{l}, 036 \\
,\end{array}$ & 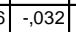 & ,007 & ,033. &,- 121 & ,093" & ,015 &,$- 219^{\prime \prime}$ &,$- 157^{7}$ & & $-0,004$ & -,003 & ,039 & ,008 & ,019 &,$- 097^{\circ}$ & ,120" & ,039 & $\begin{array}{l}-, 062 \\
\end{array}$ & 256 & & 131 & $173^{\prime \prime}$ & \\
\hline lascu & 30 &,- 029 &,$- 081^{\prime \prime}$ & ,004 & ,014 & \begin{tabular}{|l|l|}
, $076^{\prime \prime}$ \\
\end{tabular} & ,026 & 51 & , 102" & 8,054 &,$- 080^{\prime \prime}$ & \begin{tabular}{|c|}
,- 006 \\
\end{tabular} & 1 & $235^{\prime \prime}$ & ,011 & \begin{tabular}{|c|}
$1-009$ \\
\end{tabular} & $085^{\circ}$ & ,112" & , & 24 & \begin{tabular}{|c|}
, 007 \\
\end{tabular} & , 212, & $115^{\circ}$ & 90 & $-0,054$ & ,019 &,$- 073^{\prime \prime}$ & ,004 &,- 050 & 114" &, $181^{\circ}$ &,- 020 &,$- 078^{\circ}$ & $200^{\circ}$ &,- 14 &, 00 & ,030 & $083^{\prime \prime}$ \\
\hline & $88^{\circ}$ & $176^{\prime \prime}$ & & -,045 & ,036 &,- 038 & -,044 & . & , $279^{\prime}$ & $139^{\circ}$ & - & $\mid$ & $235^{\circ}$ & & -044 & \begin{tabular}{|l|l|}
4 &,- 039 \\
\end{tabular} & 138 & , 232" &,- 045 & $25^{\circ}$ & ,097" &,$- 396^{\circ}$ &,$- 218^{\prime \prime}$ & & ,020 & $\begin{array}{l}-0,029 \\
\end{array}$ & , 122" & $128^{\prime \prime}$ & 182 & 102 &, 233 & ,032 & 201 & & .40 & -040 & 141 & \\
\hline $1 \sin 0$ & 31 &,- 047 &,- 0 & \begin{tabular}{|l|}
, 017 \\
\end{tabular} & ,001 & r &,- 002 & 14 & \begin{tabular}{|l|}
,- 0 \\
\end{tabular} & ,030 & 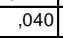 & \begin{tabular}{|l|}
, 036 \\
\end{tabular} & 011 & \begin{tabular}{|l}
,- 044 \\
\end{tabular} & & $-0,002$ & |,071, & 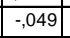 &,- 031 &,- 020 &,- 006 & \begin{tabular}{|c|c|}
, 020 \\
\end{tabular} & \begin{tabular}{|l|}
, $059^{\circ}$ \\
\end{tabular} &,- 030 & ,005 & , & ,008 & $-0,016$ & $-0,017$ & -016 & ,018 & $\begin{array}{l}, 004 \\
\end{array}$ &,- 031 & -048 &,- 027 &,- 03 &,- 031 & .02 \\
\hline & 0013 &,- 044 & -020 & ,027 &,- 012 & ,022 & ,045 & 4 &,- 043 & $-0,043$ & ,014 & -032 &,- 009 &,- 039 & -,002 & 1 &, 009 & $92 "$ & ,039 & ,012 & ,054 & \begin{tabular}{|l|l}
, 046 \\
\end{tabular} & ,045 & - ,005 &, 065 & - & -,026 & -,035 & -,039 & ,022 &,$- 070^{\circ}$ & ,008 & -025 & 06 &,- 063 & -015 & 5 & \\
\hline ssing & $\begin{array}{l}-0,034 \\
\end{array}$ & 30 & $60^{\circ}$ & -018 & | & $-073^{*}$ & ,012 & 22 & ,006 & ,023 &,- 0 & ,007 & $35^{\circ}$ & $138^{\circ}$ & . $071{ }^{\circ}$ & | & 1 & $483^{\prime \prime}$ & , 115" & -048 &, 008 & $\left.\right|^{\prime \prime}$ & ,017 &,$- 088^{\prime \prime}$ & ,002 & $-0,067$ & $=041$ &, 030 & ,025 & $120^{\circ}$ & $138^{\circ}$ & ,028 & $=028$ & $143^{\circ}$ & $-055^{\circ}$ & 010 & 032 & 063 \\
\hline & ,039 & & & 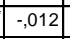 & ,064 & & ,014 & 15 & ,041 & ,045 & \begin{tabular}{|c|}
, 048 \\
\end{tabular} & ,033 & 2 & & 49 & \begin{tabular}{|c|}
$-092^{\prime}$ \\
\end{tabular} & 483 & 1 &,- 066 & 33 & 01 & \begin{tabular}{|l|l|}
,- 181 \\
\end{tabular} &,- 017 & & 666 & 0,085 & ,096 & ,061 & ,008 & -201 & ,24 & 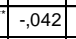 & ,049 & & &,- 023 & 3 & 119 \\
\hline & , $143^{\prime \prime}$ & .005 & $135^{\circ}$ & -,024 & , 002 & , $073^{* \prime \prime}$ & ,040 & $261^{\prime \prime}$ & , 171" & $178^{\circ}$ & $-0,011$ & $21 "$ & $79^{\prime \prime}$ & - & -031 & $\mid \begin{array}{cc}1,0 \\
\end{array}$ & $115^{\circ}$ & .066 & & , & , 054 & \begin{tabular}{|l|l|} 
& 358 \\
\end{tabular} & $2,230^{\circ}$ & $-403^{*}$ & | & $\mid \begin{array}{l}\mid c 0 \\
-, 040\end{array}$ & \begin{tabular}{|l|}
,- 039 \\
-5
\end{tabular} & \begin{tabular}{|l|}
,- 006 \\
\end{tabular} &,- 013 & , 196" & -226" & , & 104 & $349^{\circ}$ & , 186 & 16 & $246^{\circ}$ & 166 \\
\hline & & | $093^{\prime}$ & , &,- 025 & ,053 & \begin{tabular}{|l|}
,- 012 \\
\end{tabular} & \begin{tabular}{|l|}
,- 038 \\
\end{tabular} & \begin{tabular}{|c|} 
\\
\end{tabular} & \begin{tabular}{|l|} 
\\
\end{tabular} & 011 &, $123^{*}$ & \begin{tabular}{|l|}
, $0933^{\prime}$ \\
\end{tabular} & \begin{tabular}{|l|}
,- 024 \\
\end{tabular} & \begin{tabular}{|l|l}
, $225^{\prime \prime}$ \\
\end{tabular} & $=020$ & \begin{tabular}{|l|l}
5,012 \\
\end{tabular} & \begin{tabular}{|l|}
,- 048 \\
\end{tabular} & \begin{tabular}{|l|}
, $083^{\prime}$ \\
\end{tabular} & ,024 & 1 & $249^{\prime \prime}$ & | & \begin{tabular}{|l|}
-204 \\
,- 045
\end{tabular} & $\left.\right|^{, 055^{\circ}}$ & $=050$ & \begin{tabular}{|c|}
, 011 \\
\end{tabular} & ,043 & \begin{tabular}{|l|l|}
, 044 \\
\end{tabular} & \begin{tabular}{|l|}
$4,075^{\circ}$ \\
\end{tabular} & ,050 & $\mid-, 016$ & ,051 & |, 138 & & . & , $056^{\circ}$ & , & 166 \\
\hline & 42 & 027 & ,009 & \begin{tabular}{|c|}
,- 042 \\
\end{tabular} & 4 & $\begin{array}{l}, 037 \\
\end{array}$ & , 010 & 15 & 024 & ,016 & 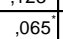 & 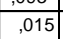 & ,007 & \begin{tabular}{|l|}
, $097^{\prime}$ \\
\end{tabular} &,- 006 & \begin{tabular}{|l|l|}
5 &, 054 \\
\end{tabular} & $\mid$ & 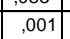 & ,054 & 249 & 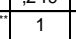 & \begin{tabular}{|c|} 
\\
, 024
\end{tabular} & \begin{tabular}{|c|}
,- 016 \\
\end{tabular} & $\mid-, 077^{\prime \prime}$ &,- 039 & $\mid-, 018$ &,- 013 & ,054 & \begin{tabular}{|l|l|}
4 &, 026 \\
\end{tabular} &, $090^{\circ}$ &,$- 067^{\circ}$ & $\begin{array}{l}, 026 \\
\end{array}$ & 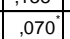 & , & 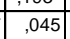 & , & $666^{6}$ & $=01$ \\
\hline & ,280" &, $290^{\circ}$ & $359^{\prime \prime}$ & , 152" &,$- 129^{\prime \prime}$ & , $222^{\prime \prime}$ & ,047 & & {$[-331 "$} &,$- 310^{-}$ & "-099" & $-219^{\prime}$ & $\mid$ & 66 & ,020 & \begin{tabular}{|l|l|}
5 & 046 \\
\end{tabular} & , $119^{\prime \prime}$ &,$- 181^{\prime \prime}$ & , & $30^{\circ}$ & ,024 & 1 & $\mid, 299^{\prime}$ & $17^{\prime \prime}$ & 38 & $3-0,057$ &,$- 186^{\prime \prime}$ &,$- 112^{\prime \prime}$ & $77^{-1}$ & $94^{4}$ & $-406^{\prime \prime}$ &,- 007 & \begin{tabular}{|c|} 
\\
\end{tabular} & $696^{\circ}$ &., $588^{-\|}$ & , $338^{\prime \prime}$ & $445^{\prime}$ & , 262, \\
\hline & , $094^{4}$ & 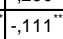 & $66^{\prime \prime}$ &,- 035 & , 004 & , &, 030 & $210^{\circ}$ & $251^{\prime \prime}$ & 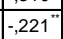 & - & 57 & 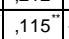 & -218 & $0,059^{\circ}$ & \begin{tabular}{|l|l|} 
& 045 \\
\end{tabular} & 017 & $=017$ & $30^{\circ}$ & $\mid$ &,- 016 & $\mid 299^{\circ}$ & 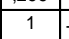 & 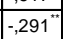 & ,009 & $\mid-, 029$ & \begin{tabular}{|c|}
,$- 063^{\prime}$ \\
\end{tabular} & 021 & \begin{tabular}{|c|}
, 014 \\
\end{tabular} & $116^{\prime \prime}$ & $-0,097^{\prime \prime}$ & ,008 &,- 020 & 347 & -,192" & , 080 & $171^{1}$ & 167 \\
\hline & &,- 037 & 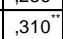 & ,043 & $\mid$ & 4 & \begin{tabular}{|c|}
-061 \\
\end{tabular} & & 28 &, $2 \mathrm{~s}$ & , 12 & $\mid, 216^{\prime \prime}$ &,$- 190^{\circ}$ & 3 & 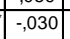 & $\mid$\begin{tabular}{|c|}
5 \\
5
\end{tabular} &,$- 088^{\prime \prime}$ & $1,157^{\circ}$ & $03^{\prime \prime}$ & $55^{\circ}$ & $\mid-, 077^{\prime}$ &,$- 617^{\prime}$ &,- 29 & & ,053 & 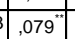 & \begin{tabular}{|l|}
, $255^{\circ}$ \\
\end{tabular} & \begin{tabular}{|l|}
, $058^{\prime}$ \\
\end{tabular} & \begin{tabular}{|l|l|} 
\\
\end{tabular} & 22 & , $428^{\prime \prime}$ &,- 004 &,- 022 & 83 & &, 286 & & ,230 \\
\hline &, 006 & 10 &,- 006 & $=0$ & -1 & 032 & \begin{tabular}{|c|}
,- 048 \\
\end{tabular} & \begin{tabular}{|l|}
, 007 \\
\end{tabular} & ,038 & \begin{tabular}{|l|}
, 08 \\
\end{tabular} & \begin{tabular}{|c|}
,- 024 \\
\end{tabular} & \begin{tabular}{|l|l|}
,- 004 \\
\end{tabular} & \begin{tabular}{|l|}
,- 054 \\
\end{tabular} & \begin{tabular}{|l|l}
, 020 \\
\end{tabular} & , 005 &, $065^{\circ}$ & \begin{tabular}{|l|}
, 002 \\
\end{tabular} & \begin{tabular}{|l|l|} 
& $066^{\circ}$ \\
\end{tabular} & \begin{tabular}{l|l|}
, 035 \\
\end{tabular} & $-0,050$ &,- 039 & $-0,038$ & ,009 & ,053 & & 384 & 204" & $\mid 074^{\prime \prime}$ & ,022 & 002 & , &, $090^{\circ}$ & , 016 & ,027 & , $068^{\circ}$ &,- 012 &,- 02 & -064 \\
\hline & ,010 & 24 & 29 & \begin{tabular}{|l|}
,- 042 \\
\end{tabular} & \begin{tabular}{|l|l|}
, 031 \\
\end{tabular} &,- 001 & \begin{tabular}{|l|}
-015 \\
\end{tabular} & \begin{tabular}{|l|}
, 023 \\
\end{tabular} & ,011 & \begin{tabular}{|l|}
, 05 \\
\end{tabular} & -032 & \begin{tabular}{|l|}
,- 003 \\
\end{tabular} & \begin{tabular}{l|l|}
19 \\
\end{tabular} & - & 05 & &,- 067 & $85^{\prime \prime}$ &,- 040 & 11 &,- 018 & $-0,057$ & ,029 & "9." & $84^{4}$ & & $1,178^{\circ}$ & \begin{tabular}{|l|}
, 037 \\
\end{tabular} & \begin{tabular}{|c|}
, 027 \\
\end{tabular} & \begin{tabular}{|c|}
, 018 \\
\end{tabular} & , 130" & $094^{\circ}$ & -,031 & |045 & &,- 020 &,- 033 & $\overline{03}$ \\
\hline &,- 025 &, 040 & "122" & 128 & $105^{\circ}$ & .084" & ,014 & 25 & , 09 & , 064 & "099" & \begin{tabular}{|l|l|}
, 039 \\
\end{tabular} &,$- 073^{\prime}$ & , 122" & ,008 & \begin{tabular}{|l|l}
8 &,- 026 \\
\end{tabular} & -041 & 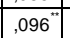 &,- 039 & , 043 &,- 013 &,- 186 &,- 063 & $55^{\circ}$ & $04 "$ & 178 & & $139^{\circ}$ & 133 & $\begin{array}{l}, 035 \\
\end{array}$ & "184, &, 006 & 059 & $259^{\circ}$ & ,258" & $.080^{\circ}$ & $108^{\circ}$ & 102 \\
\hline & & 16 & 19 & & &,$- 078^{\prime \prime}$ & 0 & 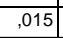 & & ,047 & & 808 & 004 & & $-0,016$ & & 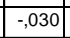 & & -,006 & 44 & 54 &,- 1 & ton & & & & "139", & & , 138" & 441 & & ,002 & 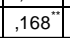 & & & 037 & $\mid 19$ & 30 \\
\hline & $\begin{array}{l}-, 022 \\
-02\end{array}$ & , 145" & ,089" &,$- 077^{\prime \prime}$ & 05 & , 148" &,- 034 & 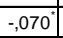 & , 073 & ,004 &, 036 & ,019 & 550 & & -,017 & , & ,025 & \begin{tabular}{l|l|}
088 \\
\end{tabular} & ,013 & $75^{\circ}$ & ,026 & $\begin{array}{l}8-177 \\
\end{array}$ & .014 & $094^{\prime \prime}$ &, 022 & . & $133^{\circ}$ & $138^{\circ}$ & &,- 019 &, $126^{\circ}$ &,- 001 & $0,066^{\circ}$ & 227 & & 02 & 555 & 190 \\
\hline & $36^{\circ}$ & , & &, 053 & &, 018 & 0 & 38 & & 126 &,- 0 & "דים & 14 & & 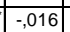 & \begin{tabular}{|l|l|}
6 &, 022
\end{tabular} & 12 & $\because$ & t & & $\mid$ & |, $294^{\circ}$ & $116^{\prime \prime}$ & & 002 &,- 018 & 035 & &, 019 & &,$- 585^{\circ}$ & \begin{tabular}{|l|}
, 045 \\
\end{tabular} & $\mid 098$ & & & $159^{\prime \prime}$ & $97^{\prime \prime}$ & \\
\hline & 81 & 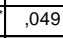 & $54^{\prime \prime}$ & $\begin{array}{l}, 040 \\
.04\end{array}$ & 001 & $123^{\prime \prime}$ & \begin{tabular}{|l|}
,- 044 \\
\end{tabular} & inc & 152 & $180^{\circ}$ & , 050 & \begin{tabular}{|l|l|}
, $120^{\circ}$ \\
\end{tabular} & 181 &, 233 & $\begin{array}{l}, 018 \\
,\end{array}$ & $3-, 070^{-1}$ & $138^{\prime \prime}$ & $33^{\prime \prime}$ & ;226 & 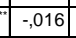 & 0,067 & $-406^{\circ}$ & ;097 & ,428" &, $089^{\circ}$ & 30 & 84 & .082" & $126^{\circ}$ & $585^{\prime \prime}$ & $\dot{r}$ &,- 014 & -,026 & $429^{\circ}$ & , 355" & 150 & $209^{\circ}$ & 149 \\
\hline & & 0,022 & &,- 003 & , & - & \begin{tabular}{|c|}
,- 007 \\
\end{tabular} & 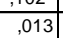 & & ,026 & 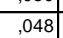 & \begin{tabular}{|l|}
, 039 \\
\end{tabular} & 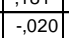 & & ,004 & & & \begin{tabular}{|l|}
$-0,042$ \\
,- 03
\end{tabular} & 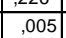 & 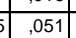 & 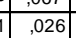 & \begin{tabular}{|l|l|l|}
,- 007 \\
\end{tabular} & $\frac{1008}{1008}$ & & $\mid$ & & & & 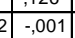 & 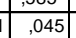 & \begin{tabular}{|l|}
$-0,01$ \\
\end{tabular} & &, 033 & 007 & & "099. & & \\
\hline & $392^{\prime \prime}$ & , 120" & , $089^{\prime \prime}$ & \begin{tabular}{|c|} 
\\
\end{tabular} & , & \begin{tabular}{|l|}
, 007 \\
\end{tabular} & $\mid$ & 9 & $-055^{\circ}$ & ,257" & , & \begin{tabular}{|c|}
,- 062 \\
\end{tabular} & $78^{*}$ & 201 & | & \begin{tabular}{|l|l|}
1 &,- 025 \\
\end{tabular} & \begin{tabular}{|c|}
,- 028 \\
\end{tabular} & | & | $104^{\mid}$ & , $138^{\prime}$ & , $070^{\circ}$ & | & - & \begin{tabular}{|l|l|} 
& -022 \\
\end{tabular} & 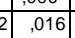 & $\mid \begin{array}{l}\mid c 00 \\
--, 031\end{array}$ & , $059^{\prime}$ & , $168^{-1}$ & 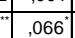 & , & -026 & \begin{tabular}{|l} 
\\
\end{tabular} & 1 & | & ,09 & , $432 "$ & $368^{\circ}$ & ,205 \\
\hline & & $357^{\prime \prime}$ & & $078^{\prime \prime}$ & $118^{\circ}$ & 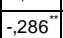 & $086^{\circ}$ & & , $449^{\prime \prime}$ & \begin{tabular}{|l|l|}
, $336^{\prime}$ \\
\end{tabular} & 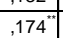 & 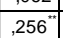 & & &,- 048 & $\theta$ & 4 & & . & 4 & , &,- 696 & 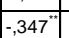 & - & $\mid, 027$ & ,045 & & 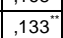 & 0 & 年, & 4 & ,007 & $1,187^{\circ}$ & & 672 & $268^{\prime \prime}$ & 17 & 463 \\
\hline & -215 & , $413^{\prime \prime}$ & , $575^{\prime \prime}$ & $\mid-388^{-1}$ & , $444^{\prime}$ & | & ") &,$- 282^{2}$ & , 304" & $277^{\prime \prime}$ & , 157 & $\mid$ & | & , 404 &,- 027 & 7 & $-0,055^{\mid}$ & . & $\mid-186^{\prime}$ & , 193 & , 045 & "',588 & , 192 & , $480^{\circ}$ & , 068 & $\mid$ & , $258^{\prime}$ & $\mid$ & ,288" & -202 &, $355^{\prime \prime}$ & , $082 "$ & $\mid, 0911^{\mid}$ & ,672" & 1 & - 229 & 325 & ,232, \\
\hline & $846^{\circ}$ & , & 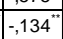 & , $100^{\circ}$ & 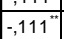 & $\mid$ & $\mid-061$ & & "-332" & -40 & , & 131 &,- 004 & 年 &,- 038 & & 年 & 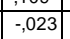 & , 169 & 056 & . & $\mid, 338^{\circ}$ & , $080^{\prime \prime}$ & -286" & & & & ,037 &,- 023 & $59^{\circ}$ & , 150 & 199 & 32 & 88 & ,229" & 1 & $03^{\prime \prime}$ & \\
\hline &, 8 & $25 "$ & 208 & 101" & $113^{3}$ & 108 & \begin{tabular}{|c|}
,- 016 \\
\end{tabular} &, $534^{4}$ & $389^{\prime \prime}$ & 448 & ,042 & $-173^{-1}$ & 030 &,$- 141^{\prime \prime}$ &,- 031 & ,000 & ,032 &,$- 055^{\circ}$ & , 246" & 035 & 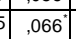 & $445^{\circ}$ & \begin{tabular}{|l|l|}
, $171^{\prime}$ \\
\end{tabular} & $\mid-384$ & -024 &,- 033 & , 108 & ,019 & -055 & 97 & ,209" & 0 & $68^{\circ}$ & 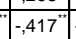 & 325 & $903^{\prime \prime}$ & 1 & 098 \\
\hline vestir & 00 & 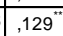 & & ,044 & & $125^{*}$ & -033 & & 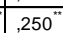 & & & $80^{\circ}$ & 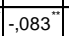 & & & & & & & & 000 & & & & & & & & & & & & & & & & & \\
\hline
\end{tabular}

Fonte: Elaborado pelo autor. 


\section{Apêndice H - Correlação de Pearson das variáveis do instrumento de pesquisa}

\section{Tabela 14 - Correlação de Pearson para identificar as variáveis que formam o instrumento de pesquisa}

\begin{tabular}{|c|c|c|c|c|c|c|c|c|c|c|c|c|c|c|c|c|c|c|c|c|c|c|c|c|c|c|c|c|c|c|c|c|c|c|c|c|c|c|}
\hline & EEB & & un & un & \begin{tabular}{|l|} 
Alun \\
\end{tabular} & di & $\mathrm{ma}$ & Bran & et & & nar & |lndi & $\begin{array}{lll}\mathrm{sc} & \mathrm{N}\end{array}$ & $\mid$ Medi & Ensi & Ensi & & & & $\mathrm{st} \mid \mathrm{L}$ & & Eau & & & & & & 踏 & & & sala & te & & ove & Tota & 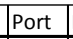 & ate & \\
\hline & 1 & 17 & $09^{\prime \prime}$ & 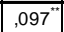 & 30 & .001 & 68 & $490^{\circ}$ & $46^{\prime \prime}$ & $13^{3}$ & 067 & 112 & $\begin{array}{l}037 \\
037\end{array}$ & $\overline{047}$ &, 026 &, 009 & 011 & \begin{tabular}{|l|l|}
, 033 \\
\end{tabular} & $167^{\circ}$ & .019 & , 009 & $1,247^{\circ}$ & $\begin{array}{l}, 081 \\
\end{array}$ & $222^{\prime \prime}$ & $\overline{0.016}$ & .003 &, 011 & .074 & .010 & ,090" &, $075^{\prime \prime}$ & $073^{\circ}$ & 414 & $270^{\circ}$ & & 848 & $846^{\circ}$ & \\
\hline unos & 17 & 7 & ,327" & $34^{4}$ & 311 & $457^{\prime \prime}$ & 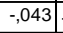 & 772" & $106^{\prime \prime}$ & D73" & ,010 & 000 & \begin{tabular}{l|l|}
, 025 \\
\end{tabular} & \begin{tabular}{|l|l|}
, $133^{*}$ \\
\end{tabular} & \begin{tabular}{l|l|}
,- 053 &
\end{tabular} & $\begin{array}{l}-, 030 \\
-5\end{array}$ & 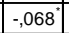 & 064 & ,044 & $060^{\circ}$ & ,028- &,$- 176^{\circ}$ & $\begin{array}{l}-, 022 \\
, 02\end{array}$ & $101^{\prime \prime}$ & 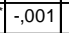 & 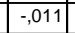 & \begin{tabular}{|l|l|}
, 030 \\
\end{tabular} & ,046 & , 114" &, 024 & \begin{tabular}{|l|}
, 019 \\
\end{tabular} & ,025 & 24 & $086^{\prime \prime}$ & 314 & 029 & |58 & 27 \\
\hline & $9^{\circ}$ & $27^{\prime \prime}$ & 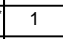 &,$- 147^{\prime \prime}$ & $466^{\prime \prime}$ & 0,018 & $44^{4}$ & ,203" & $149^{\circ}$ & 198 & $\begin{array}{l}, 022 \\
\end{array}$ & .052 & 084" & , $230^{\circ}$ & 0,031 & 0,015 &, $085^{\circ}$ & $130^{\circ}$ & $06^{\prime \prime}$ & $70^{\circ}$ & 00 & $-307^{7}$ & , 138" & $70^{\circ}$ & 012 & $\mid .013$ & 1111 & $\overline{010}$ & \begin{tabular}{|l|l}
, 070 \\
\end{tabular} & $177^{\prime \prime}$ & 20 & $074^{4}$ & $777^{\circ}$ & 357 & ,573" & $134^{\circ}$ & 91 & 107 \\
\hline & $97^{\circ}$ & $94 "$ & $147^{\prime \prime}$ & & $148^{\prime \prime}$ & 44 & ,033 & ,045 & 50 & 100 & 06 & 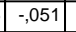 & . & $\mid-, 079^{\prime \prime}$ & - 001 & $-0,002$ & ,001 & 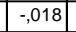 & ,002 &,- 013 &,- 018 & , $089^{\circ}$ & \begin{tabular}{|l|l|}
-016 & \\
\end{tabular} & \begin{tabular}{|l|}
,- 040 \\
\end{tabular} & \begin{tabular}{l|l|}
, 010 \\
\end{tabular} & 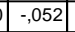 & 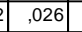 & 0,050 & \begin{tabular}{|l|l|} 
\\
\end{tabular} & ,052 & -1115 &, 010 & $115^{\circ}$ & 0,098 & 127 & 181 & $179^{\circ}$ & 106 \\
\hline & $30^{\circ}$ & $281^{\prime \prime}$ & $466^{\circ}$ & $148^{\prime \prime}$ & & ,051 & $59^{\circ}$ & -,050 & 02. & &,- 015 & ,007 & 21 & 0,051 &,- 001 & \begin{tabular}{|l|l|}
, 027 \\
\end{tabular} & - & ,094" & ,030 & 0016 & $00 \leqq$ & 4069 & \begin{tabular}{l|l|}
, 026 \\
\end{tabular} & 54 & 002 & $\begin{array}{l}, 032 \\
\end{array}$ & 01 & \begin{tabular}{|c|}
, 028 \\
\end{tabular} & 043 & 107 & $090^{\circ}$ & ,029 & 017 & 064 & 437 & 00 & & \\
\hline & $\overline{001}$ & $57^{\circ}$ & 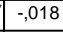 &, 04 & 051 & 1 & , & $6 "$ & & & $=005$ &,- 039 & 114 & 128 & $055^{\circ}$ & ,047 & ,030 & 112 & 142 & -,047 & 0,007 & $.300^{\circ}$ & $\begin{array}{l}, 067 \\
\end{array}$ & 46 & $=0,010$ & $=007$ & 120 & 0,028 &,- 158 & ,032 & 13 & 059 & .07 & 35 & 27. & 062 & , 116 & 85 \\
\hline & 68 & 3 & 684" & .03 & &, $062^{\circ}$ & & ,010 & & &, 05 & ,028 & & 24 & ,003 &, 00 & $=005$ & & 809 &, 021 & $\overline{012}$ & \begin{tabular}{|l|l|}
, 057 \\
\end{tabular} & ,013 & 64 & & $\begin{array}{l} \\
\end{array}$ & ,017 & ,038 & & 560 & & & & & B0" &,- 05 & & \\
\hline & $90^{\circ}$ & $72^{2}$ & $203^{\prime \prime}$ &, 04 & 50 & ,076" & \begin{tabular}{|c|}
, 010 \\
\end{tabular} & 1 & 2 & 322 & 042 & $149^{\circ}$ & $60^{\circ}$ & 13 & , 008 & $-0,051$ & ,020 & 0,033 & $260^{\circ}$ & 019 & 0,013 &, $274^{\circ}$ &, $140^{\circ}$ & $286^{\prime \prime}$ & 003 & 0,018 & $\begin{array}{l}, 036 \\
\end{array}$ & 0,017 & -062 & ,024 & -086 & .003 & 216 & 33 & 27 & 474 & 522 & 778 \\
\hline & $46^{\circ}$ & $106^{\prime \prime}$ & $149^{\prime \prime}$ &, 05 & 21 & & $\begin{array}{l}-027 \\
-5\end{array}$ & 272 & & & & & ,087" & ,245" & $-0,015$ & -030 & 1 & . & & ,046 & .004 & 294 &,- 167 & $236 "$ & 03 & 01 & 088 & 064 & & & & & & & & & & \\
\hline & $13^{\circ}$ & ,073" & 198 & $\overline{00}$ & & $071^{1}$ & $\begin{array}{l}-007 \\
-5\end{array}$ &,- 322 & 63" & & 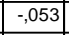 & $166^{\circ}$ & 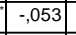 & 118 & ,024 & 05 & 63 & $077^{\prime \prime}$ & $162^{2}$ &,- 024 & , 00 &,- 282 &,$- 178^{\circ}$ & $269^{\circ}$ & 078 & ,055 &, 055 & 038 &,- 00 & $115^{\circ}$ & ,180" & ,028 & & 337 & 261 & 398 & & 06 \\
\hline & ,067 & 7 & $=$ & & & 005 & ,053 & ,042 & & & &, 0 &, 003 &, $060^{\circ}$ & \begin{tabular}{l|l}
, 016 &
\end{tabular} & $-0,011$ & 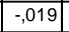 & \begin{tabular}{|l|l|}
, 027 \\
\end{tabular} & 保, & 62 & , & &,- 025 & ,007 & & & & .00 & & & & 0 & & & & 85 & & \\
\hline & 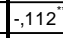 & ,000 & ,052 &, 051 & ,007 & - & $\begin{array}{l}, 028 \\
\end{array}$ & $\mid-149^{-1}$ & $21^{10}$ & $166^{\circ}$ & & & \begin{tabular}{|c|}
,- 003 \\
-1
\end{tabular} &, 112 & $\begin{array}{l}, 026 \\
,\end{array}$ & -, & 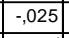 & $\begin{array}{l}, 036 \\
, 06\end{array}$ &,$- 092^{\prime \prime}$ & ,082" & $118^{\circ}$ &,$- 165^{\circ}$ & $096^{\circ}$ & , 154" & ,011 & ,007 & \begin{tabular}{|l|l|} 
\\
\end{tabular} & 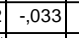 & \begin{tabular}{|l|}
,- 005 \\
\end{tabular} & 076 &, 081 & 036 & -0,07 & 176 & $099^{\circ}$ & .086 & 112 & , 03. \\
\hline & & -025 & & 018 & 021 & , 114" & \begin{tabular}{|c|}
, 039 \\
\end{tabular} & \begin{tabular}{|c|}
,- 060 \\
\end{tabular} & & & &,- 003 & 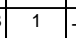 & $-236^{\prime \prime}$ & $\begin{array}{l}, 006 \\
,\end{array}$ & ,041 & , & 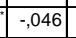 & $077^{\circ}$ & ,008 &, 029 & \begin{tabular}{|l|}
, 223 \\
\end{tabular} &, $085^{\circ}$ &,$- 185^{\circ}$ &,$- 065^{-}$ & ,003 &,- 076 & 001 & & $106^{\circ}$ & $-180^{\circ}$ & & &, 240 & & , 000 & & \\
\hline & 47 & 7 & $30^{\circ}$ & 79" & 51 & $28^{2}$ & \begin{tabular}{|c|}
,- 024 \\
-5
\end{tabular} &,$- 113^{-1}$ & & , 118 & & , 112" & $236 "$ & 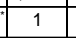 & |-047 &,- 026 & , 161" & , 168" &,- 025 & , 182 & - &,$- 394^{\prime \prime}$ &,$- 102^{\prime \prime}$ & $\left.\right|^{2}, 292^{\prime}$ & , &,- 031 & $120^{\circ}$ &, $126 "$ & $183^{\circ}$ & 096 & ,230" &, 036 & & $499^{\circ}$ & $368^{-1}$ & \begin{tabular}{|c|}
,- 033 \\
\end{tabular} & 121 & 306 \\
\hline & 26 & & & & 01 & & \begin{tabular}{|c|}
,- 003 \\
-5
\end{tabular} & ,008 & & & & 826 & ( &,- 047 & 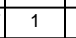 & $\begin{array}{l}-0,01 \\
\end{array}$ & & $-127^{\prime \prime}$ &,- 025 &,- 014 &,- 004 & \begin{tabular}{|c|}
, 019 \\
\end{tabular} & ,025 & \begin{tabular}{|l|}
,- 030 \\
\end{tabular} & ,005 & , & \begin{tabular}{|l|l}
5,008 \\
\end{tabular} &,- 016 & & -016 & $\begin{array}{l}, 018 \\
\end{array}$ & & & & & \begin{tabular}{l|l|}
,- 035 \\
\end{tabular} & & \\
\hline &,- 009 & \begin{tabular}{|l|l|}
9 & -030 \\
\end{tabular} & ,015 &,- 002 & \begin{tabular}{|l|}
, 027 \\
,
\end{tabular} & , & $\begin{array}{l}, 005 \\
\end{array}$ & \begin{tabular}{|l|}
,- 051 \\
\end{tabular} & \begin{tabular}{l|l|}
030 \\
\end{tabular} &,- 053 &,- 011 &,- 025 & ,041 & \begin{tabular}{|l|}
,- 026 \\
\end{tabular} &,- 001 & 1 & , 004 & $078^{\circ}$ & $-0,004$ &,- 005 & \begin{tabular}{|l|l|}
, 010 \\
\end{tabular} & \begin{tabular}{|l|}
, 026 \\
\end{tabular} & \begin{tabular}{|l|}
, 009 \\
\end{tabular} & ,020 & \begin{tabular}{|l|}
-012 \\
\end{tabular} & 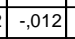 & \begin{tabular}{|l}
, 001 \\
\end{tabular} &,- 021 &,- 023 & - & \begin{tabular}{l|l|}
9 &,$- 055^{\mid}$ \\
\end{tabular} & ,005 &, 028 & $\begin{array}{l}-, 031 \\
\end{array}$ & -038 & \begin{tabular}{|c|}
-028 \\
-10
\end{tabular} & \begin{tabular}{|l|l|}
8 & -025 \\
\end{tabular} & , 01 \\
\hline & 011 & 1 & & ,001 & ,039 & 030 & $\begin{array}{l}-0,055 \\
-5\end{array}$ & ,020 & $80^{\circ}$ & & &,- 025 & , $069^{\circ}$. & -161 & 88 & ,004 & 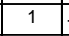 &,$- 522^{\circ}$ & ,023 & -,042 & ,044 &., $120^{\circ}$ & $\begin{array}{l}, 006 \\
\end{array}$ & $-0,017$ & 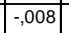 & , & \begin{tabular}{|l|l|} 
& -010 \\
\end{tabular} & ,001 & \begin{tabular}{|l}
,- 019 \\
\end{tabular} & , $060^{\circ}$ &,- 107 & , & &, 152 &,$- 123^{\prime \prime}$ & ,039 & 052 & 060 \\
\hline & ,033 & $64^{\circ}$ & $30^{\circ}$ & .018 & $44^{4}$ & 2 & \begin{tabular}{|c|}
, 018 \\
\end{tabular} & ,033 & $58^{\circ}$ & & ,027 & $\begin{array}{l}, 036 \\
\end{array}$ & $\begin{array}{l}, 046 \\
\end{array}$ & | & -127 & -,078. & 522 & & $-0,018$ & \begin{tabular}{|l|}
, 045 \\
\end{tabular} & \begin{tabular}{|l|}
,- 001 \\
\end{tabular} &,$- 146^{\prime \prime}$ & \begin{tabular}{|l|} 
\\
\end{tabular} & , 102" & ,051 & \begin{tabular}{|c|c|}
, $070^{\circ}$ \\
\end{tabular} & \begin{tabular}{|l|l} 
\\
\end{tabular} &, 055 & . 034 . & $143^{\circ}$ & , 195" &,- 034 & ,031 & 191 & 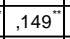 & $=006$ & 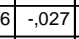 & \\
\hline & & \begin{tabular}{r|r|}
, 044 \\
\end{tabular} & & ,002 & ( & & \begin{tabular}{|l|}
, 009 \\
\end{tabular} & ,2 & & & & 2 & 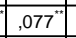 & \begin{tabular}{l|l|}
-025 \\
\end{tabular} & -025 & $\begin{array}{l}-, 004 \\
-5\end{array}$ & \begin{tabular}{|l|l|}
, 023 \\
\end{tabular} & 18 & \begin{tabular}{l|l}
1 \\
\end{tabular} & \begin{tabular}{|c|}
, 019 \\
\end{tabular} & ,022 & \begin{tabular}{|l|}
, 364 \\
\end{tabular} & ,192" & - & , & 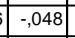 & \begin{tabular}{|l|l|}
3,044 \\
\end{tabular} & ,019 & & , 193 &,- 21 & in & & $-445^{\prime \prime}$ & 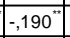 & $66^{\circ}$ & 37 & , \\
\hline & 9 & $60^{\circ}$ & $\frac{70^{\circ}}{}$ & & 016 & $\begin{array}{l}-, 047 \\
-5\end{array}$ & \begin{tabular}{|c|}
,- 021 \\
-5
\end{tabular} & ,019 & 46 & & & \begin{tabular}{|l|l}
, 082 \\
\end{tabular} & \begin{tabular}{l|l|}
008 & \\
\end{tabular} & $\mid, 182^{\prime \prime}$ & ,014 &,- 005 & 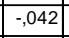 & 45 & ,019 & - & $287^{\circ}$ & $\begin{array}{l}-, 032 \\
-\end{array}$ & $\begin{array}{l}, 004 \\
\end{array}$ & ,001 & -069 & 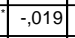 & \begin{tabular}{|c|}
, 013 \\
\end{tabular} & ,032 & , & , $074^{\prime \prime}$ &,- 056 & 05 & & 33 & ,066 & 037 & (30) & 0.097 \\
\hline & 59 & 028 &,- 003 & & 09 & -007 & \begin{tabular}{|l|}
, 012 \\
\end{tabular} & 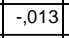 & n & & & & \begin{tabular}{|l|}
, 029 \\
\end{tabular} & 061 & 04 & .010 & $\begin{array}{l}, 044 \\
,\end{array}$ & $-\frac{-0}{-, 0}$ & ,022 & & & \begin{tabular}{|l|l|}
, 022 \\
\end{tabular} & $\begin{array}{l}-, 018 \\
-0,\end{array}$ &,- 063 &,- 02 & $\begin{array}{l}-, 022 \\
\end{array}$ & 014 & 040 & & & -031 & & & -,041 & ,010 & 031 & 4 & 02 \\
\hline & 7 & 176 & $307^{\circ}$ & & $69^{\circ}$ & ,300" & 57 & 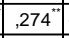 & $94^{4}$ & & ,009 &,$- 165^{\prime \prime}$ & 23 & 84 & \begin{tabular}{l|l|}
19 \\
\end{tabular} & \begin{tabular}{|l|l|}
, 026 \\
\end{tabular} & ,120" & $46^{\prime \prime}$ & 364" & 032 & \begin{tabular}{|l}
, 022 \\
\end{tabular} & 1 & ,240" & $637^{\prime \prime}$ & 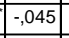 & 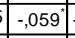 & $203^{*}$ & 131 &,$- 156^{\prime \prime}$ & ,290" & $420^{\circ}$ &, 00 & $, 0,010$ & 817 & 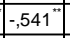 & $314^{\prime \prime}$ & $409^{\circ}$ &,- 05 \\
\hline & & -,022 & 8 & & .02 & 06 & ,0 & & & & &,- 09 & $085^{\circ}$ & $02^{\prime \prime}$ &, 02 &, 00 & 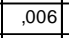 & .0 & 2 & ,004 &,- 018 & $.240^{\circ}$ & 1 & 180 & 02 & ,033 & 09 &,- 005 & \begin{tabular}{|l|l|}
, 066 \\
\end{tabular} & 114 &,- 057 ] & , &, $059^{\circ}$ & -286 &, 127 & 88 & 144 & 143 \\
\hline & & 101 & 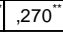 & -04 & $\mid$ &,- 246 & . & $86^{\circ}$ & & & ,007 & & $-185^{\prime \prime}$ & ,292" & 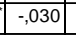 & \begin{tabular}{|c|}
, 020 \\
\end{tabular} & - & , 102" & $3^{3}$ & ,001 &, $063^{\circ}$ &,$- 637^{-1}$ &,$- 180^{\circ}$ & & 051 & $80^{\circ}$ & $258^{\prime \prime}$ & , & ,091 & $18^{\circ}$ & $422^{2}$ & \begin{tabular}{|l|l|}
-006 \\
\end{tabular} & 039 & $779^{\prime \prime}$ & $459^{\circ}$ & $294^{4}$ & 84 & \\
\hline & & &,- 012 & &, 002 & & 41 & 0 & & & & ,0 & 0,065 & 02 &, 00 &,- 01 &,- 008 & 051 &,- 036 & -06 &,- 02 &,- 04 & -,02 & 551 & & , & , 204 & .074" & 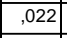 &, 00 & ,089 & & , & . 057 & ,064 &, 0 & , & .06c \\
\hline & 3 &,- 011 & ,013 & - & ,032 & - -007 & 16 & ,018 & 018 & & & ,007 & ,003 &,- 031 & \begin{tabular}{l|l}
05 \\
\end{tabular} & \begin{tabular}{|l|l|} 
&,- 012 \\
\end{tabular} &,- 037 & ,070 & | & .015 & $=0$ &,- 05 &,- 033 & $\mid$ & ,384" & 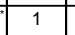 & ,178" & .03 &, 02 &, 018 & & & .008 & ,082" & $077^{\prime \prime}$ & ,025 & $\overline{03}$ & \\
\hline & 111 & .030 & & 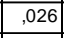 & &,- 12 & \begin{tabular}{|c|}
, 017 \\
\end{tabular} & $\begin{array}{l}, 036 \\
\end{array}$ & & & , & -,002 &,$- 076^{*}$ & $20^{\circ}$ & \begin{tabular}{l|l|}
, 008 \\
\end{tabular} & , &,- 010 &, 1 & -,044 & \begin{tabular}{|l|l|}
, 013 \\
\end{tabular} & $=, 01$ &,- 203 & 194 & 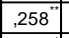 & ,204" & $178^{\circ}$ & & , 139 & 133 & , & |184" & & 066 & $251^{\prime \prime}$ & ,245 & 073 & 090 & 02 \\
\hline & $4^{4}$ & ,046 & 010 & 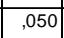 & \begin{tabular}{|l|}
, 028 \\
\end{tabular} &,- 02 & ,038 & 17 & & & &,- 033 & $\mid-001$ & $26^{\prime \prime}$ & ,016 & 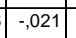 & ,001 & & \begin{tabular}{|l|}
, 019 \\
\end{tabular} & \begin{tabular}{|l}
, 032 \\
\end{tabular} &, 04 & & -,005 & & , & ,037 & , & & &, 04 & & , & & & & ,050 & & \\
\hline &,- 010 & 0,114 & ,070 &, 073 & ,043 & 158 & \begin{tabular}{|c|}
,- 028 \\
-1
\end{tabular} & 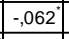 & ,070 & -,002 & 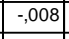 & -,005 & -,054 & , 183" & 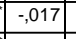 & -,023 & 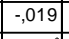 & ,034 & -,023 & $\begin{array}{l}, 046 \\
\end{array}$ & \begin{tabular}{|c|}
, 025 \\
\end{tabular} &,$- 156^{\circ}$ & , $066^{\circ}$ & ,091" & \begin{tabular}{|l|}
, 022 \\
\end{tabular} & , 027 & , 133" & , 138 & & 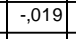 & ,126" & \begin{tabular}{|c|} 
\\
\end{tabular} & , 071 & , 175" & ,282" & 027 & 056 & 170 \\
\hline & 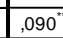 & 024 & & & & 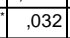 & 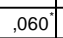 & 024 & & & & na" & & & \begin{tabular}{|l|l|}
16 & \\
\end{tabular} & 0 & & & 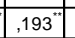 & & & $290^{\circ}$ & & & & $\mid$ & \begin{tabular}{|l|l} 
& -035 \\
\end{tabular} & & .01 & &,$- 585^{\circ}$ & 045 & & & & & & 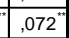 \\
\hline & 5 & |019 & , & 115 & | & $138^{\circ}$ & - &,$- 086^{\prime \prime}$ & & &,- 01 & | & | & , 230 & $\begin{array}{l}, 018 \\
\end{array}$ &,$- 055^{-}$ &,+ 107 & - &,$- 214^{\prime \prime}$ &,- 056 &,- 031 & $-420^{\circ}$ & -, 057 | & , 422 & , 089 & , $130^{\circ}$ & , 184 & $\mid 082$ & | 126 & 85 & 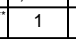 & \begin{tabular}{|l|}
-014 \\
-0
\end{tabular} & \begin{tabular}{|l|}
-019 \\
\end{tabular} & ,511, & , 339 & 154 & 202 & \\
\hline & & ,025 & & & 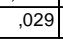 & & $\mid$\begin{tabular}{c|}
-028 \\
-5
\end{tabular} & 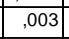 & 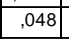 & & & 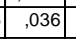 & \begin{tabular}{|c|} 
\\
\end{tabular} & 它 & $\begin{array}{l}, 004 \\
\end{array}$ & 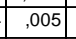 & 025 &,- 034 & \begin{tabular}{|l|}
012 \\
\end{tabular} & 051 & \begin{tabular}{|l|l|}
, 020 \\
\end{tabular} & $\begin{array}{l}, 003 \\
\end{array}$ & \begin{tabular}{|l|}
011 \\
\end{tabular} & \begin{tabular}{|l|}
,- 006 \\
\end{tabular} & $\mid$ & & 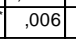 & & 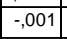 & & \begin{tabular}{|c|}
,- 014 \\
-5
\end{tabular} & & ,050 & & 08 & & & \\
\hline & 4 & 124 & , & , 115 & ,017 &,$- 070^{\circ}$ & -, 020 & $\left|, 216^{\mid}\right|$ & 55 &, $252^{\prime}$ & $073^{\prime}$ &, $070^{\circ}$ &, $062^{2}$ &, $222^{2}$ & $-0,026$ & \begin{tabular}{|l|l|}
-028 \\
\end{tabular} & -,045 & ] & , $106^{\prime \prime}$ & $103^{\prime \prime}$ & \begin{tabular}{|l|l|}
, 018 \\
\end{tabular} & \begin{tabular}{|l|}
,- 010 \\
\end{tabular} &, $059^{\prime}$ & | & \begin{tabular}{|l|}
, 015 \\
\end{tabular} & - -008 & , $060^{\circ}$ & $170^{\circ}$ & $\mid$ & $102^{\prime}$ & ] & ,050 & 1 & . & | & ,456 & $403^{\circ}$ & ,222 \\
\hline & & & & & & & $75^{\circ}$ & & & & & & & & -024 & \begin{tabular}{|l|l|}
,- 031 \\
\end{tabular} & & & & & -044 &,$- 817^{\circ}$ & 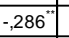 & & & & & & & & & 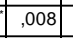 & ,045 & & 012 & 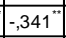 & & 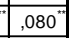 \\
\hline &,- 214 & 314 &, $573^{\prime \prime}$ & , & \begin{tabular}{|l|l|}
, $437^{\prime}$ \\
\end{tabular} & 274 &,$- 080^{\circ}$ &,$- 270^{-}$ & 43 & , $261^{\prime}$ &., 00 & " & , 147" & $368^{\prime \prime}$ & - &,- 038 & 123 & , 149 & , $190^{\prime}$ & ,066 & ,010- &,$- 541^{\prime \prime}$ &,- 127 & , $459^{\circ}$ & ] & \begin{tabular}{|l|l|}
, $077^{\circ}$ \\
\end{tabular} & \begin{tabular}{|l|l|}
, $245^{\prime}$ \\
\end{tabular} & 137 & $\left|, 282^{\mid}\right|$ & , & ,339" &, 083 & ,071 & ,612" & 1 & $233^{\prime}$ & 305 & 064 \\
\hline & & 0 & 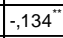 & & & - & $\begin{array}{l}-054 \\
-5\end{array}$ & \begin{tabular}{|l|l|}
, $474^{\prime}$ \\
\end{tabular} & & , & 08 &,$- 086^{\prime \prime}$ & \begin{tabular}{|l|}
, 000 \\
\end{tabular} & - & -,035 & \begin{tabular}{|l|}
,- 02 \\
\end{tabular} & & & , 166" & . & & 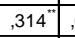 & , 088, & -294" & & & + & & 8077 & , 166" &,$- 154^{\prime \prime}$ & , $095^{\prime \prime}$ & ,456" &,$- 341^{\prime \prime}$ &, $233^{\prime \prime}$ & 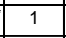 & 3" & 996 \\
\hline & 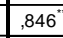 & $0,058^{-10}$ & $191^{\prime \prime}$ & $179^{\circ}$ &,$- 094^{\prime \prime}$ & $116^{\prime \prime}$ & \begin{tabular}{|c|}
,- 013 \\
\end{tabular} & ,522" & 363 & $433^{\prime \prime}$ & 081 & , 1112" & , 024. &,- 121 &,- 026 & $\begin{array}{l}-, 025 \\
\end{array}$ & ,052 & -027 & $237^{\prime}$ & \begin{tabular}{|c|}
, 030 \\
\end{tabular} & ,044 & , 409" & ,144" &,$- 384^{4}$ & 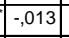 &,- 031 &,$- 090^{\circ}$ & ,038 &,- 056 & , 199 & $-202^{\prime \prime}$ & , 071 & 03". & $465^{\circ}$ & $305^{\prime \prime}$ & 113" & 1 & ,05 \\
\hline stimert &, $085^{\circ}$ & 127 & "107" & 更, & 144" & $085^{\prime \prime}$ & ,024 &, 078 & , & . &, 02 & &, 002 & 306 & 012 & & 000 & 041 & & & 025 & & & & 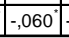 & ]-0,072 & & - & 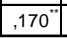 & & - & & $\angle 2$ & 080 & A & t & 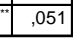 & \\
\hline
\end{tabular}

Fonte: Elaborado pelo autor. 


\section{Apêndice I - Escala de frequência de avaliação dos indicadores administrativos da SME}

\begin{tabular}{|c|c|c|c|c|c|c|c|c|c|}
\hline Indicador & Descrição Atividade & 1 & 2 & 3 & 45 & 6 & 7 & 8 & \begin{tabular}{l|l}
9 & 10
\end{tabular} \\
\hline \multirow{6}{*}{ 1. Constituição da SME } & 1.1. Todo corpo administrativo por indicação política & & & & & & & & \\
\hline & 1.2. Parte concursada e parte por indicação política & & & & & & & & \\
\hline & 1.3. Escolha do Diretor & & & & & & & & \\
\hline & 1.3.1. Indicação política & & & & & & & & \\
\hline & 1.3.2. Eleição pela comunidade escolar & & & & & & & & \\
\hline & 1.3.3. Concurso público & & & & & & & & \\
\hline \multirow{3}{*}{ 2. Organização Secretaria } & 2.1. Organograma & & & & & & & & \\
\hline & 2.2. Governança & & & & & & & & \\
\hline & 2.3. Organização de projetos (área de captação) & & & & & & & & \\
\hline \multirow{9}{*}{ 3. Secretário } & 3.1. Formação (curso superior etc.) & & & & & & & & \\
\hline & 3.2. Cursos complementares em Gestão & & & & & & & & \\
\hline & 3.3. Pré-requisitos para se tornar Secretário & & & & & & & & \\
\hline & 3.3.1. Formação em Pedagogia & & & & & & & & \\
\hline & 3.3.2. Curso superior & & & & & & & & \\
\hline & 3.3.3. Não há pré-requisitos & & & & & & & & \\
\hline & 3.4. Autonomia para criação/alteração de políticas educacionais & & & & & & & & \\
\hline & 3.5. Análise crítica da situação do município & & & & & & & & \\
\hline & 3.6. Autonomia para decisões financeiras & & & & & & & & \\
\hline \multirow{4}{*}{$\begin{array}{l}\text { 4. Capacidade da SME na } \\
\text { captação de recursos } \\
\text { financeiros }\end{array}$} & 4.1. Projetos federais e estaduais & & & & & & & & \\
\hline & 4.2. Parceria com empresas & & & & & & & & \\
\hline & 4.3. Grau de conhecimento dos indicadores financeiros municipais & & & & & & & & \\
\hline & 4.4. Recursos providos da APM & & & & & & & & \\
\hline \multirow{3}{*}{$\begin{array}{l}\text { 5. Destinação do recurso } \\
\text { financeiro } \\
\text { descentralizado e } \\
\text { centralizado }\end{array}$} & 5.1. Reparos emergenciais & & & & & & & & \\
\hline & 5.2. Transporte & & & & & & & & \\
\hline & 5.3. Cursos, palestras, orientações didático-pedagógicas & & & & & & & & \\
\hline $\begin{array}{l}\text { 6. Transição de novo } \\
\text { Secretário e nova equipe }\end{array}$ & $\begin{array}{l}\text { 6.1. Grau de alteração do quadro de funcionários ao fim de cada } \\
\text { gestão da prefeitura ( } 4 \text { anos) }\end{array}$ & & & & & & & & \\
\hline \multirow{2}{*}{$\begin{array}{l}\text { 7. Critério para matrícula } \\
\text { de alunos }\end{array}$} & 7.1. Por zoneamento & & & & & & & & \\
\hline & 7.2. Por escolha da família & & & & & & & & \\
\hline 8. Ensino Fundamental & 8.1. Exclusividade da oferta do Ensino Fundamental pela rede & & & & & & & & \\
\hline pela rede pública & pública & & & & & & & & \\
\hline \multirow{3}{*}{ 9. Informações adicionais } & 9.1. Percentual de escolas rurais no município & & & & & & & & \\
\hline & 9.2. Existência de política de progressão continuada & & & & & & & & \\
\hline & $\begin{array}{l}\text { 9.3. Incentivos para participação em olímpiadas custeadas pelo } \\
\text { município }\end{array}$ & & & & & & & & \\
\hline
\end{tabular}

Quadro 22 - Escala de frequência de avaliação dos indicadores administrativos da SME

Fonte: Elaborado pelo autor 


\section{Apêndice J - Escala de frequência de avaliação dos indicadores administrativos do Diretor}

\begin{tabular}{|c|c|c|c|c|c|c|c|c|c|}
\hline Indicador & Descrição Atividade & 1 & \begin{tabular}{l|l}
2 & 3 \\
\end{tabular} & $3 \mid 4$ & 5 & $6 \mathbf{6}^{7}$ & $7 \mid 8$ & 89 & 10 \\
\hline $\begin{array}{l}\text { 1. Especificades } \\
\text { do município } \\
\text { pequeno } \\
\end{array}$ & 1.1. Cobrança da comunidade perante o Diretor & & & & & & & & \\
\hline \multirow{4}{*}{$\begin{array}{l}\text { 2. Alimentação } \\
\text { dos alunos }\end{array}$} & 2.1. Duas ou mais refeições por período & & & & & & & & \\
\hline & 2.2. Parcialmente cultivadas pelos alunos & & & & & & & & \\
\hline & 2.3. Orientação nutricional & & & & & & & & \\
\hline & 2.4. Refeição farta, variada e balanceada & & & & & & & & \\
\hline \multirow{3}{*}{$\begin{array}{l}\text { 3. Processo } \\
\text { Seletivo }\end{array}$} & 3.1. Prova para ingressar na escola & & & & & & & & \\
\hline & 3.2. Não receber aluno por transferência & & & & & & & & \\
\hline & 3.3. Transferência compulsória em caso de reprovação & & & & & & & & \\
\hline \multirow{8}{*}{ 4. Diretor } & 4.1. Formação (curso superior etc.) & & & & & & & & \\
\hline & 4.2. Cursos complementares (Gestão, Pedagogia etc.) & & & & & & & & \\
\hline & 4.3. Autonomia para decisões & & & & & & & & \\
\hline & 4.4. Escolha do Diretor & & & & & & & & \\
\hline & 4.4.1. Indicação política & & & & & & & & \\
\hline & 4.4.2. Eleição pela comunidade escolar & & & & & & & & \\
\hline & 4.4.3. Concurso público & & & & & & & & \\
\hline & 4.4. Salário Compatível com a função & & & & & & & & \\
\hline \multirow{4}{*}{$\begin{array}{l}\text { 5. Capacidade } \\
\text { do Diretor na } \\
\text { captação de } \\
\text { recursos } \\
\text { financeiros }\end{array}$} & 5.1. Projetos federais e estaduais & & & & & & & & \\
\hline & 5.2. Parceria com empresas & & & & & & & & \\
\hline & 5.3. Rifas e festividades & & & & & & & & \\
\hline & 5.4. Recursos providos da APM & & & & & & & & \\
\hline \multirow{6}{*}{$\begin{array}{l}\text { 6. Destinação do } \\
\text { recurso } \\
\text { financeiro } \\
\text { descentralizado } \\
\text { e centralizado }\end{array}$} & 6.1. Programas de computador e softwares & & & & & & & & \\
\hline & 6.2. Equipamentos para a sala de informática & & & & & & & & \\
\hline & 6.3. Acervo para a biblioteca (livros, assinaturas, jornais) & & & & & & & & \\
\hline & 6.4. Reparos emergenciais & & & & & & & & \\
\hline & 6.5. Materiais didáticos diversos & & & & & & & & \\
\hline & 6.6. Cursos, palestras, orientações didático-pedagógicas & & & & & & & & \\
\hline
\end{tabular}

Quadro 23 - Escala de frequência de avaliação dos indicadores administrativos do Diretor

Fonte: Elaborado pelo autor. 


\section{Apêndice $K$ - Escala de frequência de avaliação dos indicadores pedagógicos da escola}

\begin{tabular}{|c|c|c|c|c|c|c|c|c|c|c|c|}
\hline Indicador & Descrição Atividade & 1 & 2 & 3 & 4 & 5 & 6 & 7 & 8 & 9 & 10 \\
\hline \multirow{8}{*}{$\begin{array}{l}\text { 1. Desempenho } \\
\text { Prova } \\
\text { Português }\end{array}$} & 1.1. Autonomia do docente no ensino dessa disciplina. & & & & & & & & & & \\
\hline & 1.2. Frequência de leitura dos alunos. & & & & & & & & & & \\
\hline & 1.3. Rotatividade dos Professores nessa disciplina. & & & & & & & & & & \\
\hline & $\begin{array}{l}\text { 1.4. Frequência que o docente acompanha o } \\
\text { desempenho do aluno. }\end{array}$ & & & & & & & & & & \\
\hline & 1.5. Recuperação paralela e reforço no contraturno. & & & & & & & & & & \\
\hline & 1.6. Projetos que colaborem para melhor desempenho. & & & & & & & & & & \\
\hline & $\begin{array}{l}\text { 1.7. Distribuição da carga horária ou da grade } \\
\text { curricular com os requisitos avaliados na Prova Brasil }\end{array}$ & & & & & & & & & & \\
\hline & 1.8. Preparação específica para a Prova Brasil. & & & & & & & & & & \\
\hline \multirow{7}{*}{$\begin{array}{l}\text { 2. Desempenho } \\
\text { Prova de } \\
\text { Matemática }\end{array}$} & 2.1. Autonomia do docente no ensino dessa disciplina. & & & & & & & & & & \\
\hline & $\begin{array}{l}\text { 2.2. Frequência que o docente acompanha o } \\
\text { desempenho do aluno. }\end{array}$ & & & & & & & & & & \\
\hline & 2.3. Rotatividade dos Professores nessa disciplina. & & & & & & & & & & \\
\hline & 2.4. Recuperação paralela e reforço no contraturno. & & & & & & & & & & \\
\hline & $\begin{array}{l}\text { 2.5. Projetos que colaborem para um melhor } \\
\text { desempenho. }\end{array}$ & & & & & & & & & & \\
\hline & $\begin{array}{l}\text { 2.6. Distribuição da carga horária ou da grade } \\
\text { curricular com os requisitos avaliados na Prova Brasil }\end{array}$ & & & & & & & & & & \\
\hline & 2.7. Preparação específica para a Prova Brasil. & & & & & & & & & & \\
\hline \multirow{7}{*}{$\begin{array}{l}\text { 3. Participação } \\
\text { da família }\end{array}$} & 3.1. Participação dos pais nas reuniões. & & & & & & & & & & \\
\hline & $\begin{array}{l}\text { 3.2. Participação dos pais em eventos festivos da } \\
\text { escola. }\end{array}$ & & & & & & & & & & \\
\hline & $\begin{array}{l}\begin{array}{l}\text { 3.3. Contribuição na manutenção da estrutura física } \\
\text { escolar. }\end{array} \\
\end{array}$ & & & & & & & & & & \\
\hline & 3.4. Participação dos pais na APM. & & & & & & & & & & \\
\hline & $\begin{array}{l}\text { 3.5. Acompanhamento dos pais nos deveres escolares } \\
\text { dos filhos. }\end{array}$ & & & & & & & & & & \\
\hline & 3.6. Apoio dos pais na validação das ações da escola. & & & & & & & & & & \\
\hline & $\begin{array}{l}\text { 3.7. Frequência com que os pais utilizam o transporte } \\
\text { público para ir à escola. }\end{array}$ & & & & & & & & & & \\
\hline \multirow{5}{*}{$\begin{array}{l}\text { 4. Reprovação } \\
\text { discente e } \\
\text { sistema } \\
\text { disciplinar }\end{array}$} & $\begin{array}{l}\text { 4.1. Autonomia do docente no processo de reprovação } \\
\text { do aluno. }\end{array}$ & & & & & & & & & & \\
\hline & 4.2. Existência de sistema de reprovação. & & & & & & & & & & \\
\hline & 4.3. Regras claras e definidas do sistema disciplinar. & & & & & & & & & & \\
\hline & $\begin{array}{l}\text { 4.4. Grau de disciplinaridade no comportamento } \\
\text { discente. }\end{array}$ & & & & & & & & & & \\
\hline & $\begin{array}{l}\text { 4.5. Respeito dos discentes em relação à figura do } \\
\text { Professor, Diretor e funcionários. } \\
\end{array}$ & & & & & & & & & & \\
\hline \multirow{3}{*}{$\begin{array}{l}\text { 5. Laboratório } \\
\text { de Informática }\end{array}$} & 5.1. Existência de laboratório de informática na escola. & & & & & & & & & & \\
\hline & 5.2. Frequência das aulas de informática. & & & & & & & & & & \\
\hline & 5.3. Número de computadores para cada 100 alunos & & & & & & & & & & \\
\hline 6. Biblioteca & 6.1. Tamanho do acervo da biblioteca. & & & & & & & & & & \\
\hline
\end{tabular}




\begin{tabular}{|c|c|c|c|c|c|c|}
\hline & 6.2. Variedade do acervo da biblioteca. & & & & & \\
\hline \multirow{2}{*}{$\begin{array}{l}\text { 7. Sala de } \\
\text { leitura }\end{array}$} & 7.1. Existência de sala de leitura na escola. & & & & & \\
\hline & 7.2. Utilização da sala de leitura & & & & & \\
\hline \multirow{2}{*}{ 8. Transporte } & $\begin{array}{l}\text { 8.1. Frequência com que os alunos utilizam o } \\
\text { transporte público para ir à escola. }\end{array}$ & & & & & \\
\hline & 8.2. Número de matrículas & & & & & \\
\hline \multirow{10}{*}{ 9. Docentes } & $\begin{array}{l}\text { 9.1. Porcentagem de docentes pertencentes ao gênero } \\
\text { feminino. }\end{array}$ & & & & & \\
\hline & $\begin{array}{l}\text { 9.2. Porcentagem dos docentes tem o magistério } \\
\text { concluído. }\end{array}$ & & & & & \\
\hline & $\begin{array}{l}\text { 9.3. Porcentagem dos docentes que tem o curso de } \\
\text { licenciatura concluído. }\end{array}$ & & & & & \\
\hline & $\begin{array}{l}\text { 9.4. Porcentagem dos docentes que tem ensino } \\
\text { superior concluído. }\end{array}$ & & & & & \\
\hline & $\begin{array}{l}\text { 9.5. Porcentagem dos docentes que tem especialização } \\
\text { concluída. }\end{array}$ & & & & & \\
\hline & 9.6. Número de docentes para cada 100 alunos. & & & & & \\
\hline & 9.7. Incentivo financeiro & & & & & \\
\hline & 9.7.1. Plano de carreira financeiramente atrativo & & & & & \\
\hline & 9.7.2. Salário acima da média regional & & & & & \\
\hline & 9.7.3. Progressão salarial & & & & & \\
\hline 10. Funcionários & 10.1. Número de funcionários para cada 100 alunos & & & & & \\
\hline
\end{tabular}

Quadro 24 - Escala de frequência de avaliação dos indicadores pedagógicos da escola

Fonte: Elaborado pelo autor. 